\author{
Universität Göttingen
}

\title{
BETWEEN FAITH AND TRUTH: THE HISTORIOGRAPHY OF BUDDHISM IN MODERN CHINA (1902-1965)
}

Qinqin Peng

2021 


\title{
Between Faith and Truth: The Historiography of Buddhism in Modern China (1902-1965)
}

\author{
Thesis \\ in order to acquire the Doctoral Degree in Philosophy \\ at the Faculty of Humanities of the Georg-August-Universität Göttingen
}

\author{
Submitted by \\ Qinqin Peng \\ Sichuan, China
}

Göttingen, 2021 
Supervisors: Prof. Dr. Axel Schneider (University of Göttingen)

Prof. Dr. John Kieschnick (Stanford University) 


\section{Table of Contents}

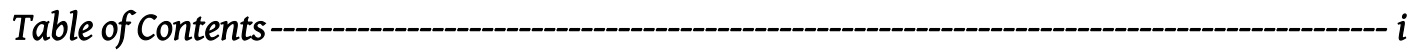

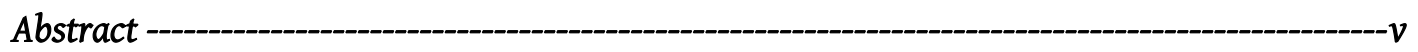

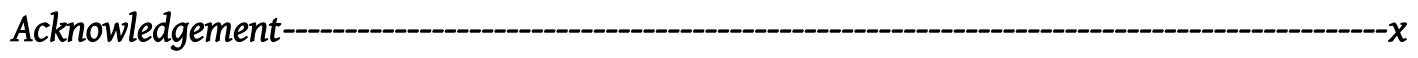

Abbreviation ---------------------------------------------------------------------------------------------xi

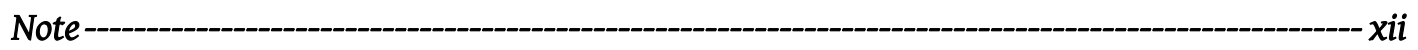

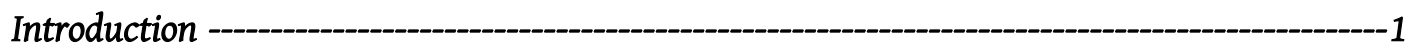

Buddhist Revival -- 5

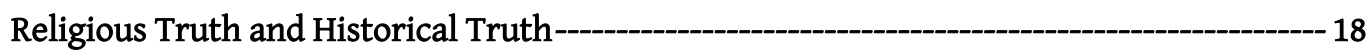

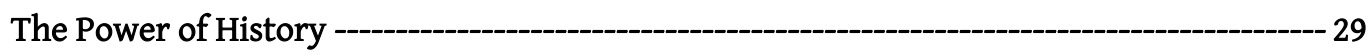

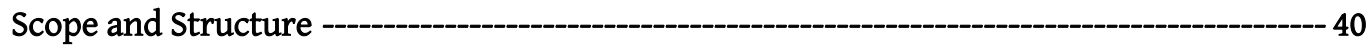

PART I: Transforming Discourses: History and Religion

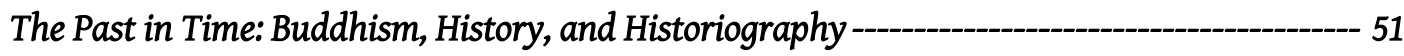

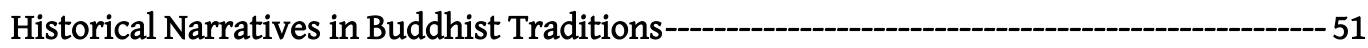

The Buddhist Concept of History ...................................................................................................52

Traditional Buddhist Historiography in PreModern China...........................................................56

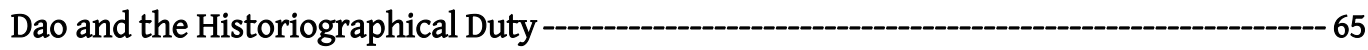

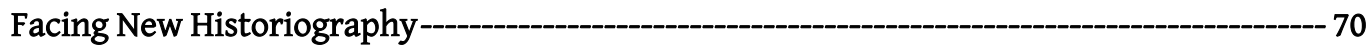

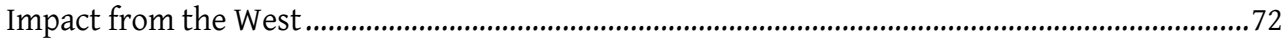

The Collapse of the Foundation of History.............................................................................. 74

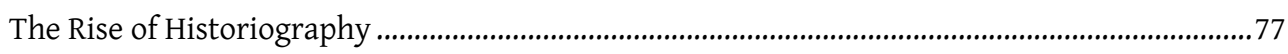

The Choice of Chinese Historiography - 82

Progressivism ............................................................................................................................. 84

Tradition, Nation, and Culture ................................................................................................ 88

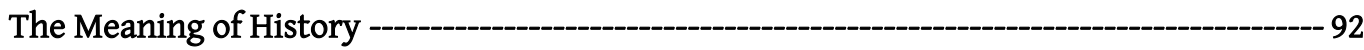

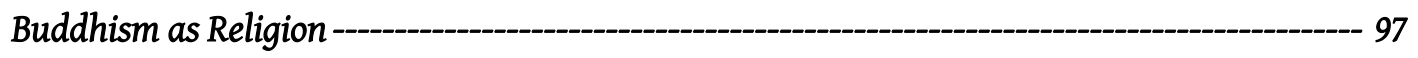

The Arrival of 'Religion' - 99 


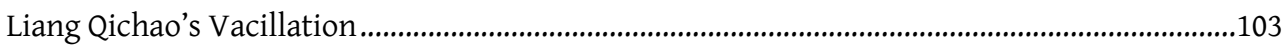

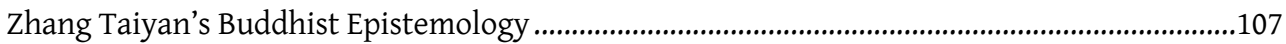

Response from Buddhism...............................................................................................................110

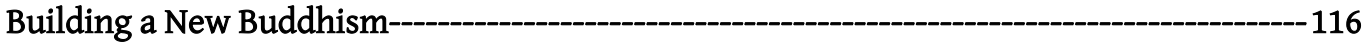

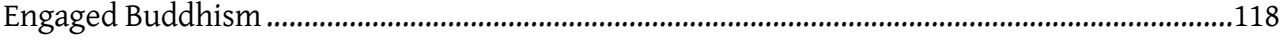

Genuine Buddhism 本真佛學 ...............................................................................................122

The Failure of Buddhist Nationalism -

\section{PART II: Towards the Modern Historiography of Buddhism}

Histories and Historians---_- 139

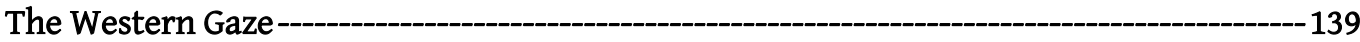

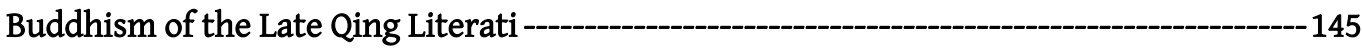

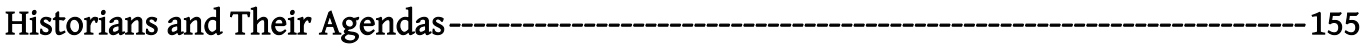

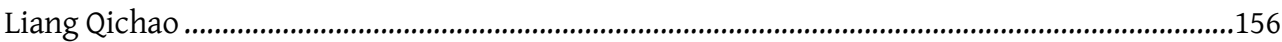

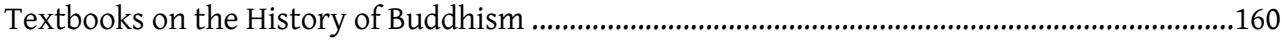

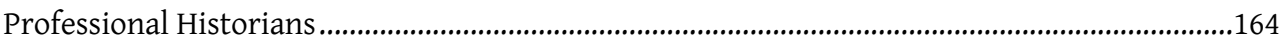

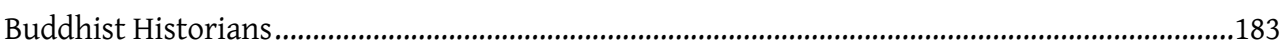

The General History of Chinese Buddhism - 191

The Consciousness of General History ---192

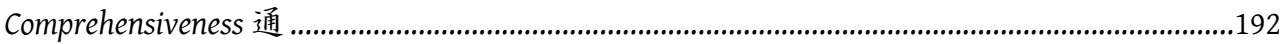

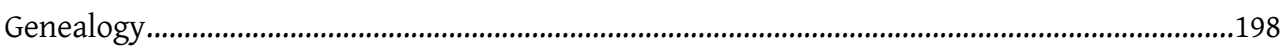

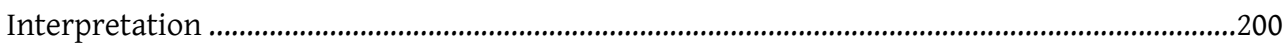

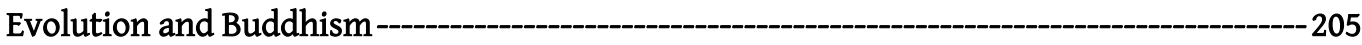

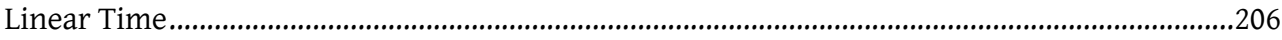

Reflections on Evolutional Theory ..........................................................................................212

Narrating the Evolution of Buddhism---12

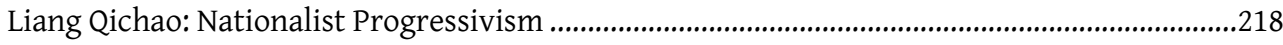

Taixu: Buddhist Evolutionism ...........................................................................................22

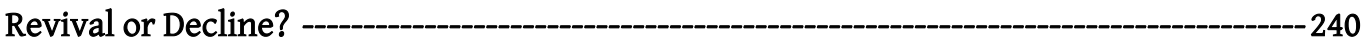

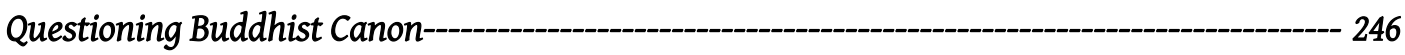

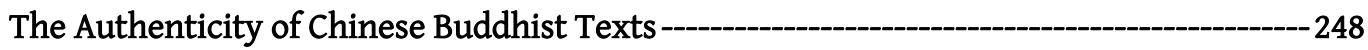




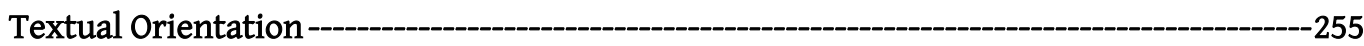

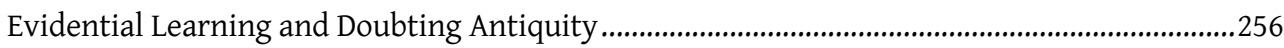

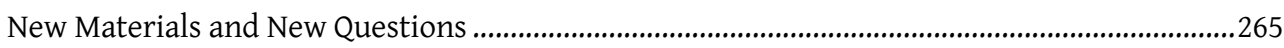

Apocryphal Canon? Debates on the Chinese Texts of Mahāyāna Buddhism----------------273

Debates on The Sūtra of Forty-Two Sections 四十二章經 ...................................................................24

Debates on the Treatise on Awakening Mahāyāna Faith 大乘起信論 ............................................28

Rewriting the History of Chan Buddhism---_---288

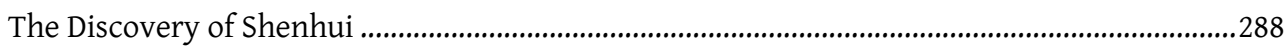

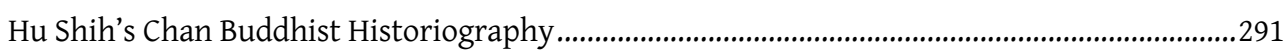

New Paradigm of the Historiography of Buddhism ...................................................................299

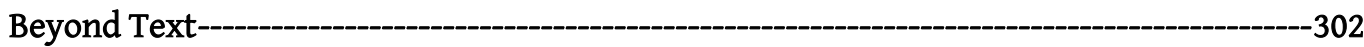

“The Scholarship of Truth” 真實之學 and “The Scholarship of Life” 為人之學 ........................304

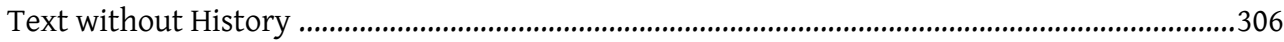

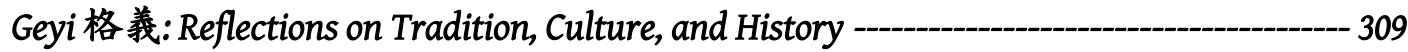

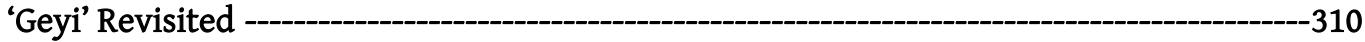

Geyi in Historical Context ........................................................................................................

The Modern Interpretations of Geyi ........................................................................................

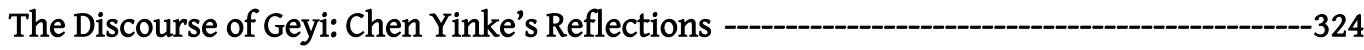

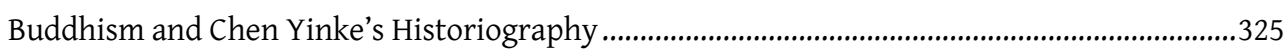

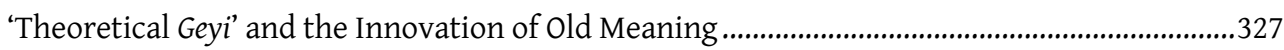

'Methodological Geyi and National Identity ..................................................................................338

The Lesson of Geyi -

Sinicization: A Modern Narrative of Chinese Buddhism - 361

The Anxiety of Origins--399

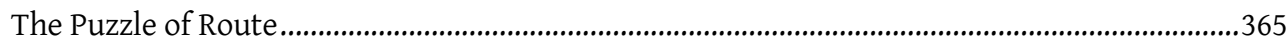

The Textual and Cultural Journey of Buddhism..........................................................................372

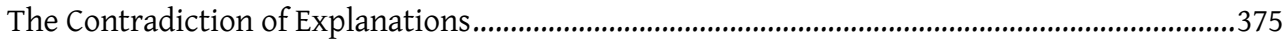

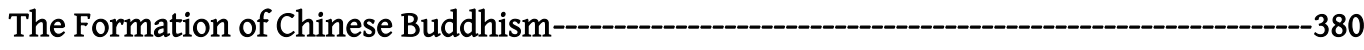

Chinese Buddhism in the West...................................................................................................380

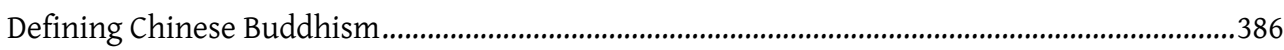

Sinicization and Indianization - -

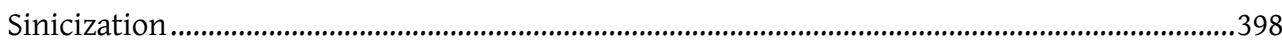




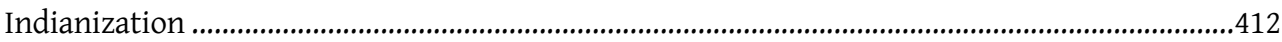

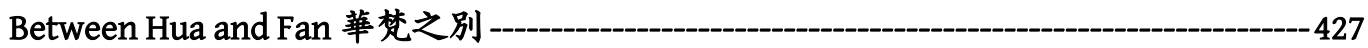

Conclusion: The Invention of Chinese Buddhism -

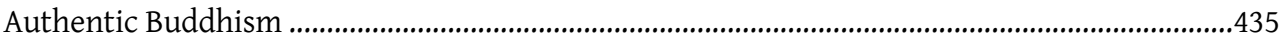

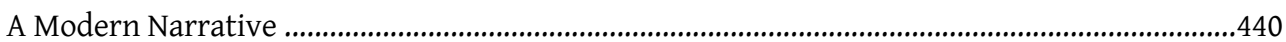

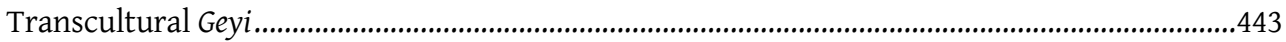

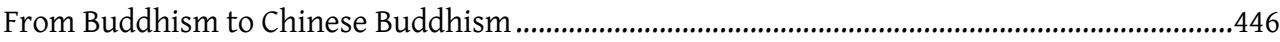

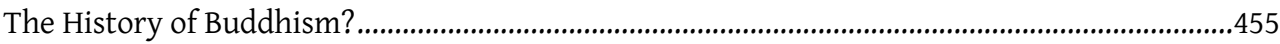

Bibliography-- 463 


\section{Abstract}

The historiography of Buddhism 佛教史學) in modern China develops under the influence of modernity and amidst dramatic transformations in the Chinese intellectual world. It combines the philological tradition of Evidential Learning with foreign intellectual trends in history, philosophy, and linguistics, and develops syncretistic methodologies of data collection, textual criticism, chronological arrangement, and historiographical interpretation. As one pivotal part of the so called "Buddhist revival," this research branch demonstrates the formation of modern Buddhist knowledge and introduced religious concerns into Chinese academia. It plays a cardinal role in the re-invention of Chinese Buddhist tradition, as well as the establishment of 'Chinese Buddhism'.

Most leading scholars of the modern period contributed to this field, including historians such as Liang Qichao, Hu Shi, Chen Yinke, Tang Yongtong, Chen Yuan; and scholarly monks and Lay Buddhists such as Taixu, Yinshun, Lü Cheng, and so on. Due to their different motivations and viewpoints, the writing of Buddhist history quickly grew in diversity and complexity, triggering debates, controversies, and discussions. Practices and phenomena related to this new research area not only reflect the general interdisciplinary character of the historiography of Buddhism as a border field but also show how it was constrained by specific contextual factors and two ontological concerns: what is 'Chinese Buddhism' and what is 'China'. Investigating how these two concerns were addressed by modern Chinese intellectuals will deepen our knowledge of the history of historiography in modern China and contribute to a more thorough understanding of how the field of religion has changed as well as how modern Chinese intellectuals in their studies of religion and history have tried to reunderstand themselves, China and the world.

Recently, the changes of Buddhism in China since the 1890s has been investigated by current scholarship. However, because of the current dominant discourse of secular modernity in historiography, as well as the prevailed research paradigm of "religion-state" in religious studies, issues like the modernization of 
Buddhist knowledge and the tension between faith and truth in the writings of the history of Buddhism remain unresearched. To examine the influence of historiography on modern Buddhist studies and the fundamental mechanism of the formation of Buddhism as new knowledge regime, my study focuses on the modern discourses of this religious tradition, with particular emphasis on the historiographical transition of Buddhist studies from the 1900s to the 1960s. By comparing different scholars with different backgrounds in faith and varying conceptual approaches, I investigate the general background of the historiography in modern China as well as several specific topics, including the construction of the general history of Chinese Buddhism, the authenticity of Buddhist textual tradition, the narrative of Buddhist sinicization, etc.

Using the methodology of academic history and discourse analysis, my study shed light on the genealogy of modern Chinese historiography of Buddhism. The emerging academic interest in writing the history of Buddhism engaged with the changing scholarly and religious situation in modern China. Historians and Buddhist organized, criticized, and interpretated the past of Buddhism through hermeneutic readings of Buddhist texts and through critically utilizing new theories. Their attempts of historizing Buddhism further led to the formation of a 'secularized' understanding of Buddhism. In this process, 'Chinese Buddhism' was constructed terminologically and discursively. The historiography of Buddhism reflects the relocation of Buddhism in the modernized constellation of Chinese traditions and the attempts of reshaping Buddhism as an alternative to Confucianism to be a national cultural identity. This textual-historiographical path (文史路徑), which has developed different research perspectives, became the dominant paradigm of modern Chinese religious scholarship. It influenced the defining of Buddhism as a 'religion' (discursively in parallel to science, and superstition) and participated in the multifaceted process of modernization.

Keywords: Buddhism, Modern China, historiography, religion 


\section{Zusammenfassung}

Die historiografischen Arbeiten über den Buddhismus im modernen China (佛教史 學) entstanden unter dem Einfluss der Moderne und den damit zusammenhängenden dramatischen Transformationsprozessen in der intellektuellen Landschaft in China. In der Historiografie des Buddhismus kamen Einflüsse von der philologisch geprägten textkritischen Tradition mit westlichen akademischen Strömungen aus der Geschichtswissenschaft, der Philosophie und der Linguistik zusammen und es wurden damit sowohl neue synkretistische Methoden der Datenerhebung und Textkritik als auch der chronologischen Zusammenstellung und historischen Deutung gewonnen.

Als ein zentraler Teil des sogenannten „Wiederauflebens des Buddhismus," zeigt diese Forschungsrichtung auf, wie das Wissen um den Buddhismus in der Moderne aufgebaut ist und führt auch religiöse Ansätze in den akademischen Diskurs in China ein._Die Historiografie des Buddhismus spielt eine tragende Rolle in der Neuerfindung der chinesischen buddhistischen Tradition und der Bildung eines „chinesischen Buddhismus.” Die meisten der führenden Intellektuellen in der modernen Epoche haben ihren Beitrag in diesem Forschungsfeld geleistet, darunter Historiker wie Liang Qichao, Hu Shih, Chen Yangtong und Chen Yuan, wie auch gelehrte Mönche und Laienbuddhisten wie Taixu, Yinshun, Lü Cheng und andere. Aufgrund der unterschiedlichen Motivationen und Standpunkte der Gelehrten, wuchs die Geschichtsschreibung über den Buddhismus in Komplexität und Diversität rasch an und entfachte Debatten und Kontroversen. Die unterschiedlichen Debatten, die in diesem neuen Forschungsfeld der Geschichtsschreibung über den Buddhismus geführt werden, deuten nicht nur auf dessen allgemeine interdisziplinäre Ausrichtung hin, sondern zeigen auch auf, wie dieses Forschungsfeld durch den spezifischen Kontext und zwei (definitorische) Fragen bestimmt und damit auch begrenzt wurden, nämlich: was bedeutet "Chinesischer Buddhismus" und was heißt „China“ in diesem Kontext. In meiner Arbeit untersuche ich, wie diese zwei Fragen von den modernen chinesischen Intellektuellen (unterschiedliche) beantwortet wurden, was uns neue Erkenntnisse über die Geschichte der Historiografie in China 
und ein tieferes Verständnis für den Wandel des Diskurses der Religion ermöglicht. Es gibt uns ebenfalls Aufschluss darüber, wie die chinesischen Intellektuellen der Moderne in ihren religionswissenschaftlichen und historischen Arbeiten sich selbst, China und die Welt neu verstanden haben.

Aufgrund der Dominanz, welche der Diskurs der Säkularisierten Moderne in dem Bereich der Geschichtsschreibung eingenommen hatte, und durch die bedeutende Stellung des Forschungsparadigmas „religion- state,” wurde die Historiografie des Buddhismus im modernen China sowohl in der Geschichtswissenschaft als auch in der Religionswissenschaft weitgehend vernachlässigt. Themen wie die Modernisierung des buddhistischen Wissens und die Spannung zwischen Glauben und Wahrheit in den Schriften der buddhistischen Geschichte sind in der Forschung noch nicht angemessen angegangen worden. Um den Einfluss der Geschichtsschreibung auf die moderne Gelehrsamkeit des Buddhismus und die Mechanismen hinter der Bildung des Buddhismus als ein neues Wissenssystem besser zu verstehen, wird in der vorliegenden Arbeit der Blickpunkt auf den Diskurs über die religiöse Tradition gelegt, und zwar unter besonderer Berücksichtigung des historiografischen Übergangs der Gelehrsamkeit über den Buddhismus in dem Zeitraum von 1900 bis in die 1960er Jahren. Durch einen Vergleich von Gelehrten unterschiedlichem Hintergrund in ihren Glaubensrichtungen und ihrem konzeptionellen Vorgehen, werde ich den allgemeinen Kontext der Geschichtsschreibung des modernen China zu ergründen suchen und auch auf mehrere stärker spezifische Themen wie die der Konstruktion einer allgemeinen Geschichte des chinesischen Buddhismus, der Authentizität der buddhistischen Texttradition und der Erzählung einer Sinisierung des Buddhismus näher eingehen und beleuchten.

Anhand der Methodologie der Diskursanalyse und der akademischen Geschichtsschreibung werden in dieser Arbeit die Genealogie der modernen chinesischen Geschichtsschreibung über den Buddhismus aufgezeigt. Das herausbildende akademische Interesse, die Geschichte des Buddhismus zu schreiben, bezieht sich auf die sich wandelnden Situation der Gelehrsamkeit und Religiosität im 
modernen China. Historiker und buddhistische Gelehrte organisierten, kritisierten und interpretierten die Vergangenheit des Buddhismus durch hermeneutische Lesart der buddhistischen Schriften und durch die kritische Nutzung neuer Theorien. Ihre Versuche, den Buddhismus zu historisieren, erzeugt ein säkularisiertes Verständnis des Buddhismus. In diesem Prozess wurde der "Chinesische Buddhismus" terminologisch und historiografisch konstruiert. Die Geschichtsschreibung des Buddhismus vorführt, wie der Buddhismus in die moderne Vorstellung von chinesischer Tradition integriert oder als eine Alternative zum Konfuzianismus als eine nationale-kulturelle Identität Chinas, gezeichnet wurde. Dieser textuell-historiographische Weg (文史路徑), der verschiedene Forschungsperspektiven entwickelt hat, wurde zum dominanten Paradigma der modernen chinesischen Religionswissenschaft. Dieser Weg beeinflusste die Definition des Buddhismus in Abgrenzung zur Wissenschaft und Aberglauben als eine „Religion“ und nahm an den facettenreichen Prozess der Modernisierung teil.

Schlagwörter: Buddhismus, Modernes China, Historiografie, Religion 


\section{Acknowledgement}

This dissertation is the result of the confluence of various yinyuan 因緣. In the process of conceiving and executing it, I have benefited from the support and inspiration of numerous individuals. My gratitude goes first to my advisor, Prof. Axel Schneider, for his stalwart support, critical eye, and generous enthusiasm. His intellectual influence helped shape the essential questions behind this research. I am also grateful to my second supervisor, Prof. John Kieschnick, for his astute comments and his wise guidance.

I have also gained important information, insights, and opportunities from scholars in Taiwan and mainland China. In particular, Prof. Li Yu-chen at the National Chen-chi University gave me the benefit of her long experience as a historian and as a female scholar. I also owe a debt of thank to Prof. Teng Wei-jen at the Dharma Drum Institute of Liberal Arts, for his generosity, resourcefulness, and his impeccable ability of host.

Many scholars have read, discussed, and steered this dissertation. They include Julia Schneider, Katja Triplett, Wang Fan-sen, Chen Huaiyu, Chen Jinhua, Pung Mingfei, Ge Zhaoguang, Chi Chih-Chang, Tsai Jung-Ting, Lin Pei-ying, Huang Yihsun, Xue Yu and the participants of the meetings and seminars I attended.

Grants from the Committee on Scholarly Communication with China funded the research of this dissertation, fellowships from the Sheng-yen Foundation and the GSGG enabled my several stays in China and Taiwan.

My thanks also to my friends and peers, for the nice conversations we had and our numerous coffee-gatherings. I would like particularly to thank Felix Ernst and Pan Xuan, who help me with the German translation; and Chiu Tzu-lun, for sharing with me her experience, joy, and effort.

Lastly, my heartfelt gratitude flows to my family, for their patience, support, and tough love. 


\section{Abbreviation}

YBSHJ Yinbing shi heji 飲冰室合集 [Collected works of the Ice Drinking Studio]

SBP Foxue yanjiu shiba pian 佛學研究十八篇

JMCB Jinmingguan conggao chubian 金明館叢稿初編 [First volume of the Jinmingguan Drafts].

JMEB Jinmingguan conggao chubian 金明館丵稿二編 [Second volume of the Jinmingguan Drafts]

HLTJ Hanliu tangji 寒柳堂集 [Collected works from the Cold Willow Hall]

Hanwei Hanwei liangjin nanbeichao fojiao shi 漢魏兩晉南北朝佛教史 [History of Buddhism in Han, Wei, Jin and Southern and Northern Dynasties]

Suitang Sui Tang fojiao shigao 隋唐佛教史稿 [Draft of Sui and Tang Buddhist History]

TYQJ Tang Yongtong Quanji 湯用䑣全集 [Complete Works of Tang Yongtong]

HSWJ Hu Shih Wenji 胡適文集 [Collected Works of Hu Shih]

LFLX Lü Cheng Foxue lunzhu xuanji 吕澂佛學論著選集 [A Selective Collection of the Published Works of Lü Cheng on Buddhism]

TXQS Taixu Dashi quanshu 太虚大師全書 [Complete Works of Master Taixu]

CYQJ Chen Yuan quanji 陳垣全集 [Complete Works of Chen Yuan]

MFQ Mingguo fojiao qikan wenxian jicheng 民國佛教期刊文獻集成 [Collection of Republican-Era Buddhist Periodical Literature]

MFQB Mingguo fojiao qikan wenxian jicheng bubian 民國佛教期刊文獻集成補編 [Supplement to the Collection of Republican-Era Buddhist Periodical Literature]

XFXCXiandai fojiao xueshu congkan 現代佛教學術叢刊 [Modern Buddhist Scholarship Series] 


\section{Note}

Chinese terms and names are transliterated according to the hanyu pinyin system, except in cases where alternate renderings are more commonly used (e.g. Hu Shih, Sun Yat-sen, Chiang Kai-shek), or when official names of existing organizations and places employ another romanization (Taipei, Peking.)

Traditional Chinese characters will be used in all cases, even when the original source was written in simplified characters.

Single quotation marks enclose terms used under consideration, to bring attention to the fact that they may not have the meaning commonly ascribed to them or they require emphasis in the context. Double quotation marks are used for direct quotations from sources. Original texts of translated sentences are provided where possible in footnote. 


\section{Introduction}

風雨如晦, 雞鳴不已。

詩經 Shijing, “Zhengfeng·Fengyu 鄭風·風雨”

江山重複爭供眼, 風雨緃横亂入樓。

Lu You 陸游, “Nanding Lou yu jiyu 南定樓遇急雨”

A few steps from Xuanwu Lake 玄武湖, in the heart of Nanjing, one comes upon the old Jiming Temple 雞鳴寺, small and elegant, shrouded by the cherry blossoms every spring. At the northeastern corner of the temple stands a charming building of three storeys, the Huomeng Lou 豁蒙樓. In 1904, Zhang Zhidong 張之洞 (1837-1909), the Viceroy of Liangjiang 雨江, donated to the temple to transform the old chanting hall into a building for sightseeing and literati assembly. He named it after a marvelous phrase from Du Fu's poem-“when sorrow comes, the perplexity in one's mind is dispelled" [youlai huo mengbi 憂來豁蒙蔽] -in memory of his student, Yang Rui 楊銳 (1855-1898), one of the six young men who had been executed by the Qing court after the failure of the Hundred Days Reform.

With Zhang Zhidong's portrait hanging in the main chamber and Liang Qichao's 梁啟超 (1873-1929) handwriting on the gateposts, this corner, although hidden deep in the temple, lost its religiosity and ritual function while it was secularized and culturized as a historical landmark. Literati ${ }^{2}$ like Huang Kan 黄㑆

\footnotetext{
${ }^{1}$ This phrase from the poem "Nandingkou yu jiyu" [Encountered with torrential rain in Nanding Lou] written by the famous Song poet Lu You, was what Liang transcribed on the gateposts of Huomeng lou, as mentioned below.

${ }^{2}$ In this dissertation, 'literati,' 'gentry,' and 'elite' are utilized differently. By 'gentry' [xiangshen 鄉紳] I mean a class that owned its property, was educated, and had a direct link with local, especially rural, culture. By 'literati,' I mean a group of elites who were well-educated and had a reputation for literature and scholarship but were not employed in the central bureaucracy. 'Elite' is more general; it has different sub-categories, for example, political elites, intellectual elites, and religious elites. See
} 
(1886-1935) and Chen Sanli 陳三立 (1853 -1937) $)^{3}$; historians, from Liu Yizheng 柳詒徵 (1880-1956) and Hu Shih 胡適 (1891-1962) to Guo Moruo 郭沫若 (1892-1978); religious elites, from Taixu 太虚 (1890-1947) and Lü Cheng 呂溦 (1896-1989) to Zhao Puchu 趙樸初 (1907-2000); and politicians, such as Cao Jingyuan 曹經沅 (1891-1946) and Wang Jingwei 汪精衛 (1883-1944), all visited this place, viewing the majestic scenery of Xuanwu Lake and the relic of the Taicheng 台城 and writing poems to express their nostalgia and emotions. Nowadays, serving as a tea house, this renovated building is typically crowded with pilgrims and tourists and is slightly contaminated with something of a commercial touch. The turbulence it witnessed in history has been forgotten; the implication of its name, 'enlightenment,' is also seldom mentioned. However, this building still silently recalls the vicissitude of Chinese society and the transformation of the Chinese religious landscape.

One hundred years ago, when Liang Qichao visited this holy place in 1922, China was still in the midst of a storm, as he lamented through Lu You's poem. This was Liang's first visit to Nanjing, while at that time he had more or less escaped from the political vortex. After witnessing the dramatic transformations in modern China, Buddhism appealed to him once again. He understood that China was still in turmoil and that there was no relief for people's suffering. The ideal pictured by the Western theories that had once given him hope was basically also an illusion. Under such circumstances, he felt that the claimed universal tenets, whether imported from the West or based on China's past experience, could not solve the problems China was encountering. What was more important, now he understood, was the particularity of China and the free will of each Chinese person. To him, the awakening of the individual could eventually become a collective enlightenment and later save the country.

Ping-Ti Ho, The Ladder of Success in Imperial China: Aspects of Social Mobility, 1368-1911 (New York, London: Columbia University Press, 1962), 37-41.

${ }^{3}$ Chen Sanli was Chen Yinke's 陳寅恪 father. He was the leading figure of the Late Qing literati. After the Marco Polo Bridge Incident, he is said to have committed suicide by starvation in protest of the Japanese invasion. 
This thinking about faith differed from Liang's earlier instrumental understanding of religion, but was closely related to his reading of Buddhism in his youth. After his failure in the Metropolitan Examination in Peking in 1895, he experienced a series of setbacks in both his personal career and political project. Perhaps it was due to the agony of the aborted revolution that Liang came into deep contact with Buddhism. When he was in Shanghai, he spent days with his friends, such as Tan Sitong 譚嗣同, Song Shu 宋恕, Wu Yanzhou 吴雁舟, and so on, reciting sūtras, discussing the relationship between Buddhism and science, and meditating. ${ }^{4}$ In one letter he sent to his friend Xia Suiqing 夏穗卿, he wrote, “even in an age that had been abandoned by the Buddha, peace and tranquility will finally arrive if people keep the Buddhist precepts strictly." As he indicated here, Buddhism might be able to play its role in a time of turmoil and transition if it could bring people together through the power of faith. He expressed this view more clearly in an essay he dedicated to his mentor, Kang Youwei 康有為. In this essay, Liang reflected on his past failures and his own shortcomings in scholarship: "I think my knowledge is still limited," he wrote, "[therefore] I am recently studying history and reading 'Inner Classics 內 典' (Buddhist texts). I seem to be making progress and realize that our faith 吾教, the teaching of 'Great Harmony' [datong 大同], is only something that the Buddha disdained to talk about." Liang then further persuaded Kang to assist the salvation of the world [jiushi 救世] by becoming a “missionary [chuanjiao 傳教]," as the Buddha did. He said: "Our mission is rather preaching our faith than managing state affairs, is rather saving the world and all sentient beings than saving one country." Due to such a religious enthusiasm for saving the world, Liang Qichao's reflections on the fate of China often returned to faith, a spiritual force that seemed to him both rooted in the past and echoing the present. He had noticed that the religious landscape and intellectual climate of China were altering dramatically; the

\footnotetext{
${ }^{4}$ Sun Baoxuan 孫寶瑄, Riyi zhai riji 日益齋日記, excerpted from Ding Wenjiang 丁文江, Liang Qichao nianpu changbian 梁啟超年譜長編 (Shanghai: Shanghai renmin chubanshe, 2009).

${ }^{5}$ Liang Qichao, “Yu Suifo shangzuo shu 與碎佛上座書," ibid.

${ }^{6}$ Zhongguo shixuehui 中國史學會, Zhongguojindaishi ziliao congkan·Wuxu bianfa 中國近代史資料丵刊· 戊戌變法, vol.2 (Shanghai: Shanghai renmin chubanshe, 2000), 544 .
} 
existing faith of the Chinese was challenged both by modern values and principles from the world outside and by the innate tension within tradition itself. For the sake of explaining and legitimatizing all the changes he observed, he ranged widely, often in a comparative manner, over ancient and modern Chinese and Western thought. In the Chinese field, although his first concern was Confucianism, he made a broad and generally sympathetic study of other traditions, in particular Buddhism. ${ }^{7}$ In the book On the Major Trends of the Changes in Chinese Scholarship and Thought [Lun Zhongguo xueshu sixiang bianqian zhi dashi 論中國學術思想變遷之大勢, below: Dashi], published in 1902, Liang for the first time incorporated Buddhism into the national history of China, locating this external tradition within the constellation of Chinese culture through historiography. ${ }^{8}$ By doing so, he framed his reading of Buddhism into his revolution in scholarship and thus pioneered the study of the historiography of Buddhism.

After Liang Qichao, more and more professional and Buddhist historians began to describe and interpret Buddhism from a historiographical angle. Their paths and perspectives triggered a profound shift in the modernization of the knowledge of Buddhism - the 'historiographical turn' of Buddhology in modern China. This research trend closely related to religious commitments, historical reflections, modern impacts, and political concerns. Beginning at the turn of the century, the impact of modernity ${ }^{9}$ profoundly changed people's understanding of history and religion: history was in search of new meanings and paradigms; religion, at the same time, was controlling or modifying its representations and resources to fit into the modern category of 'religion.' Witnessing and involved in such transformations, a new generation of historians and religious scholars began to re-establish the

\footnotetext{
${ }^{7}$ Liang Qichao, “Kang Nanhai xiansheng zhuan 康南海先生傳,” YBSHJ, Wenji, vol.3, 67-70.

${ }^{8}$ For details, see later chapters. In this dissertation, I considered this work by Liang as the first study of the history of Buddhism from a modern historiographical perspective.

${ }^{9}$ The term 'modernity,' as I use it in this dissertation, differs slightly from 'modernization.'

Modernization focuses on material and social changes, such as urbanisation, industrialization, technological innovations, modern medicine, mass media, the decline of social hierarchy, and the increasing commodification of goods and human labour. Modernity refers to discourses and concepts, for example, science, evolution, progress, and so on.
} 
legitimacy of religion through the discourse and methodology of historiography, describing religion as tradition and reflecting on its origin and composition, and further contemplating the premise of modernity as well as the interplay between civilizations through the example of religion. In this process, religion became part of national history, and history constructed new knowledge of religion.

The historiography of Buddhism, under this mechanism, not only intellectualized Buddhism through academic discourses, demarcating it from superstition, but also defined Buddhism in China's past based on the experience of Sinicization. These two dimensions echo the core issues of the transformation of Buddhism in modern China-namely, first, Buddhism, as a 'world religion,' underwent a process of modernization, not only on the doctrinal and institutional levels but also on a discursive level, in order to resist the onslaught of science and to reconcile itself with the material world; secondly, it was also legitimized by historythrough the narratives of Sinicization-as a 'Chinese' tradition that could help to support the newly established national identity of China. The historiography of Buddhism, therefore, eventually formed a 'historized Buddhism' that functioned both as the standard of the 'truth' of Buddhism and as the discursive basis of 'Chinese Buddhism.'

How did the historiography of Buddhism emerge in the early twentieth century? How did it change the knowledge about Buddhism and further lead to the formation of 'Chinese Buddhism'? These questions configure the broad framework of my research, insinuating themselves into my discussion of various individual cases. All these cases, which I wish to elaborate through comparative description, entwine to form a complicated, multifaceted field in which individuals with varying identities and habitus participate in debates and conversations on issues relevant to the past, present, and future of Buddhism and China.

\section{Buddhist Revival}


In the Late Qing dynasty, dramatic changes were in their embryonic stage. An intense pessimism prevailed throughout the whole Chinese nation, including among intellectuals and Buddhist elites. "The Buddhist chanting in the Mountain Fish had stopped, and the lion petal of the Buddha was covered by dust," as the eminent Monk Jichan 寄禪 (also known as Bazhi Toutuo 八指頭陀, 1852-1912) described rhetorically in his poem on the desperate situation he observed. ${ }^{10}$ Jichan, however, was not the only one who had great anxiety about the future of Chinese Buddhism and was worried about the arriving age of 'declining Dharma.' Although there was a brief Buddhist revival among the literati during the late Ming period, generally the scenario at the dawn of the modern age was alarming: Buddhism had gradually "fallen into quietude, neither showing knowledge of doctrine nor striving to accumulate it." ${ }^{11}$ Indeed, some members of the Qing royal family were devout Buddhists; ${ }^{12}$ the Qing emperors, in contrast, continually issued edicts to "make severe

\footnotetext{
${ }^{10}$ The original sentence is “魚山輟梵, 獅座蒙塺,” in Bazhi toutuo shiwenji 八指頭陀詩文集 (Changsha: Yuelu shushe, 1984), 471.

${ }^{11}$ In Japan, the academic discourse on the decadence of early modern Buddhist clergy is usually referred to as kinsei bukkyō darakuron 近世仏教值落論 and variants thereof. Tsuji asserted the "socalled Theory of Buddhist Decadence in the Edo Period [kinsei bukkyō darakuron]" (1979, 224-25). Expressions such as the "historical view of decadent Edo Buddhism" [Kinsei bukkyō daraku shikan 近世 仏教墮落史観], “the pejorative historical view of Edo Buddhism” [Kinsei bukkyō keishi no shikan 近世仏 教軽視の史観], or “historical view of Buddhist decline” [Bukkyō suitai no shikan 仏教衰退の史観] are also used by some authors. For more on this issue, see Orion Klautau, “近世仏教陸落論の近代的形 成：記憶と忘却の明治仏教をめぐる一考察,”Journal of Religious Studies 81, no. 3 (2007): 581-601; Orion Klautau, "Against the Ghosts of Recent Past: Meiji Scholarship and the Discourse on Edo-Period Buddhist Decadence," Japanese Journal of Religious Studies 35, no. 2 (2008): 263-303.

${ }^{12}$ Officially, the Manchu Qing dynasty valued the Buddhism of Mongolia and Tibet instead of Han Chinese Buddhism. For the relationship between the Qing Court and Tibetan Buddhism, see Zhang Yuxin 張羽新, Qing zhengfu yu Lama jiao 清政府與喇嘛教 (Lhasa: Xizang renmin chubanshe, 1988); Miaozhou 妙舟, Meng Zang Fojiao shi 蒙藏佛教史(Yangzhou: Jiangsu guangling guji keyinshe, 1997). Also, Yumiko Ishihama 石濱裕美子, Shinchō to Chibetto Bukkyō: bosatsuō to natta Kenryūtei 清朝とチベッ 卜仏教: 菩薩王となった乾隆帝 (Tokyo: Waseda University Press, 2013); Johan Elverskog, Our Great Qing: The Mongols, Buddhism, And the State in Late Imperial China (Hololulu: University of Hawai'i Press, 2006), chapter 4.
} 
regulation, so that [Buddhism] will not spread widely." ${ }^{13}$ In many regions, Buddhism continued to be practiced and retained its role in rituals and in people's daily lives, but the number of monasteries and the clergy population had dramatically shrunk; ${ }^{14}$ studies of Buddhist doctrines, although ongoing, remained a minor trend in scholarship. The space for Buddhism was extremely compressed, while suffering caused by foreign invasion and internal socio-political turmoil became more and more overwhelming.

In this deepening gloom, however, a glimmer of hope of Buddhist 'revival' sparkled. As the example of Huomeng Lou shows, Buddhist apologists began to build up new links with secular realms, seeking further participation in socio-political transformation and academic activities. Significantly, Liang connected Buddhism with the modern Chinese intelligentsia, who tried to promote the 'New Learning' [xinxue 新學] (Here Liang used 'the study of Buddhism' [foxue 佛學], instead of 'Buddhism as religion' [fojiao 佛教]). Buddhism, again, as Liang suggested here, engaged in the intellectual turn of the Chinese, constructing itself in accordance with the call of the age and re-interpreting itself with new discourses, just as it had coped two millennia before.

Liang's opinion directed later scholars to the prevailing, if not dominant, pattern of narrative, namely, a structure of 'decline-revival;' meanwhile, since Liang traced this revival back to Gong Zizhen 龔自珍 (1792-1841) and Wei Yuan 魏源 (17941857), it has been widely accepted that Gong and Wei were the key figures who led to widespread attention to Buddhism, for they encouraged people to use Buddhism against the shackles of Confucianism. ${ }^{15}$ However, as some scholars rightly have

\footnotetext{
13 “嚴其禁約,勿使滋蔓, ” in Qing Kangxi Huidian [清康熙會典], vol. 71: Buddhist and Daoist Monks; cf. Zenryū Tsukamoto 塚本善隆, Chügoku kinseibukkyōshi no shomondai 中国近世仏教史の諸問題, Tsukamoto Zenryū chosakushū 塚本善隆著作集, vol.5 (Tokyo: Daitō shuppansha, 1975).

${ }^{14}$ The Qing Court had placed restrictions on temple construction. See Yu Benyuan 于本源, Qing wangchao de zongjiao zhengce 清王朝的宗教政策 (Beijing: Zhongguo shehui kexue chubanshe,1999). For the activity of building temples, see Wolfram Eberhard, "Temple-Building Activities In Medieval And Modern China: An Experimental Study," Monumenta Serica 23 (1964): 264-318.

${ }^{15}$ For example, Guo Peng put Gong and Wei at the beginning of his second volume, indicating their role as forerunners. See Guo Peng 郭朋, Zhongguo jindai foxue sixiang shigao 中國近代佛學思想史稿
} 
pointed out, it was due to their rebelliousness as heretics rather than their contributions to Buddhist scholarship that Gong and Wei were admired. ${ }^{16}$ More scholars from the field of religious studies, following Holmes Welch, have tended to consider Yang Wenhui 楊文會 (1837-1911) as the 'father of modern Chinese Buddhism, ${ }^{17}$ not merely because of his endeavor to spread Dharma through distributing the Buddhist canon and promoting new-style education for laity and clergy, but, more generally, because of his concept of an 'institutionalized' religion that granted Yang several remarkable attributes of 'modern-ness. ${ }^{18}$

In both cases, the thesis of 'revival' seems to have been accepted without doubt. This revival has been perceived as a natural outcome of 'decline' and 'crisis.' According to this narrative, the intellectual elite in the early twentieth century China was pushed to respond to challenges from both inside and outside, reflecting on the built-in tension between the past and present of China and searching for a way out of the crisis by selectively transforming and reinterpreting Chinese cultural and religious heritages. ${ }^{19}$ Against this background, they turned to something unorthodox but familiar-Buddhism.

(Chengdu: Bashu shushe, 1989). Deng Zimei also considered Gong and Wei as "opening a new historical process of using Buddhism to fight against Confucianism”; see Deng Zimei 鄧子美, Chuantong fojiao yu Zhongguojindai hua 傳統佛教與中國近代化 (Shanghai: Shanghai Huazhong shifan daxue chubanshe, 1994). Ma Tianxiang, as well, labelled Gong and Wei as “vanguards”; see Ma Tianxiang 麻天祥, Wanqing foxue yu jindai shehui sichao 晚清佛學與近代社會思潮 (Taipei: wenjin chubanshe, 1992).

${ }^{16}$ Some scholars have noticed that Gong and Wei "were marginal figures whose historical importance has been determined largely by a consensus of twentieth-century scholars." See Benjamin Elman, A Classicism, Politics, and Kingship: the Chang-chou School of New Text Confucianism in Late Imperial China (Berkeley: University of Califonia Press, 1990), xxii; Ge Zhaoguang 葛兆光, “Guanyu jindai fojiao yanjiu de shuping 關於近代佛教研究述評,"Si yu Yan 思與言, 37, 2 (1999).

${ }^{17}$ Holmes Welch, The Buddhist Revival in China (Cambridge: Harvard University Press, 1965), 2.

${ }^{18}$ For studies on Yang Wenhui, see Welch, The Buddhist Revival in China.; Gabriele Goldfuss, Vers un bouddhisme du XXe siècle: Yang Wenhui (1837-1911), réformateur laïque et imprimeur, (Paris: Collège de France, Institut des Hautes Études Chinoises, 2001); also, Chen, Jidong 陳繼東, Shinmatsu bukkyō no kenkyū 清末仏教の研究--楊文会を中心として (Tokyo: sankibō busshorin, 2003).

${ }^{19}$ Justin Ritzinger labelled it as the “"push' model of modernity." See Justin R. Ritzinger, "Anarchy in the Pure Land: Tradition, modernity, and the reinvention of the cult of Maitreya in Republican China" (Ph.D Harvard University, 2010), 4-9. 
Once Buddhism was put on the table, however, it needed to regain its legitimacy by satisfying several principles set by modernity and relocating itself in the modernized constellation of 'national essence' [guocui 國粹]. First of all, it had to be shaped, categorized, and defined, to at least a certain degree, as a 'modern religion.' Then, it must meet the expectations of the modern Chinese. At times, Buddhism was expected to fill the vacuum of belief left by Confucianism and bring 'wakening' to the new citizens of China. At other times, it became a personal domain, or a shelter, in which the intellectuals, who were tired of the surrounding dissensions and sufferings, could escape the volatile situation into the peaceful world of Buddhism and gain some rest. These entangled and somewhat conflicting aspects of Buddhism present the current interpreter with a puzzle, namely, how can we understand the multiple facets of Buddhism and the roles it played in modern China? It acted as a foundation of faith, a force of revolution, a new domain of science, a medicine for mental illness, or a distinction, in Pierre Bourdieu's sense. ${ }^{20}$ Its multifacet character, as well as the contradiction in the modernization of it, made Buddhism one of the axes of the 'transitional' intelligentsia. ${ }^{21}$ If the intellectual elite that emerged after the Sino-Japanese war could be divided into 'conservatives' and 'reformists,' their moving trajectories often intersected in Buddhism. ${ }^{22}$ Eventually,

\footnotetext{
${ }^{20}$ Pierre Bourdieu, Distinction: A Social Critique of the Judgement of Taste (Cambridge: Harvard University Press, 1984).

${ }^{21}$ Chang, Hao, “Zhongguo jindai sixiangshi de zhuanxing shidai 中國近代思想史的轉型時代,” in Ershiyi Shiji 二十一世紀 [The Twenty-First Century] (1999): 29-39.

${ }^{22}$ However, intellectual conservatives/reformists and religious conservatives/reformists did not always coincide. In this dissertation, 'conservatives' mean a group of intellectuals who supported 'Chinese values' (not matter whether these values are particular or universal) instead of aiming at the preservation of the socio-political status quo. In this sense, my use of conservativism is closer to Mannheim's 'style of thought' than Burke's theory. See Edmund Burke, Reflections on the Revolution in France and on the Proceedings in Certain Societies in London Relative to that Event: In a Letter Intended to Have Been Sent to a Gentleman in Paris (London, 1790). Reprinted in Frank M. Turner, ed., Reflections on the Revolution in France (New Haven, London: Yale University Press, 2003) and Karl Mannheim, "Conservative Thought," in From Karl Mannheim, ed. Kurt H. Wolff, (New York: Oxford University Press, 1971), 132-222. For an overall discussion of studies on conservatism, see Panajotis Kondylis, Konservativismus: geschichtlicher Gehalt und Untergang (Stuttgart: Klett-Cotta, 1986). For different approaches to defining conservatism, see Klaus Epstein, The Genesis of German Conservatism (Princeton, NJ: Princeton University Press, 1966), 3-25; Jerry Z. Muller, "Introduction: What is Conservative Social
} 
Buddhism, more or less became not only a common topic for discussion but also a shared ground for conversations, similar to what Paul Cohen has called the "consensual Chinese agenda." ${ }^{23}$ Because of Buddhism's connecting role, some current scholars have placed Buddhism at the core of their understanding of modern Chinese history. ${ }^{24}$

Centered on the term 'revival,' the current scholarship on Chinese religion has devoted great endeavor to exploring the reasons behind this revival and its manifestations in various locales and times. Numerous studies in the past decades have focused on religious changes in modern China ${ }^{25}$ emphasizing the tension between religion and secular force, such as unstable social environments, policies, and regulations, the attitudes of government, and the whole project of 'making the state. ${ }^{26}$ Following the pattern of sociological history and focusing on the

and Political Thought?," in idem(ed.), Conservatism: An Anthology of Social and Political Thought from David Hume to the Present (Princeton, NJ: Princeton University Press, 1997), 3-31. For conservatism in China, see Charlotte Furth, "Culture and Politics in Modern Chinese Conservatism," in idem (ed.), The Limits of Change: Essays on Conservative Alternatives in Republican China (Cambridge, MA, London: Harvard University Press, 1976),22-53; and Benjamin I. Schwartz, "Notes on Conservatism in General and in China in Particular," in Charlotte Furth (ed.), The Limits of Change (q.v.), 3-21. There are also different tendencies within conservatism. Axel Schneider has made a distinction between a "classicist conservatism" that identifies timeless, universal norms and a "historicist conservatism" that leaves the question of universal standards unanswered and that stresses the particularity of traditions. See Axel Schneider, "The One and the Many: A Classicist Reading... and Its Role in the Modern World-An Attempt on Modern Chinese Conservatism," Procedia-Social and Behavioral Sciences 2, no. 5 (2010). ${ }^{23}$ Paul A Cohen, Discovering History in China: American Historical Writing on the Recent Chinese Past (New York: Columbia University Press, 1984), 132-133.

${ }^{24}$ See for example, Paul R. Katz, Religion in China and Its Modern Fate (Waltham: Brandeis University Press, 2014).

${ }^{25}$ Representative recent works include Vincent Goossaert and David A Palmer, The Religious Question in Modern China (Chicago: University of Chicago Press, 2011); Yoshiko Ashiwa and David L. Wank, Making Religion, Making the State: The Politics of Religion in Modern China, The Politics of Religion in Modern China (Stanford: Stanford University Press, 2009); Mayfair Mei-hui Yang, Chinese Religiosities, Afflictions of Modernity and State Formation (Berkeley: University of California Press, 2008); Adam Yuet Chau, Religion in Contemporary China: Revitalization and Innovation (London: Routledge, 2011).

${ }^{26}$ See Yoshiko Ashiwa, "Making Religion, Making the State: The Politics of Religion in Modern China," in Making Religion, Making the State: The Politics of Religion in Modern China, ed. Yoshiko Ashiwa and David L. Wank (Stanford: Stanford University Press, 2009). 43-73. 
'institutional' development of Buddhism as a 'modern religion" ${ }^{27}$ (evidenced by the modernization of samgha education, the growth of Buddhist publications, the transformation of Buddhist culture in urban and rural space, the restoration of Buddhist monasteries, and so on), ${ }^{28}$ a narrative of 'revival,' or in Vincent Goossaert's words, "the renewal paradigm," has been formulated and been used to describe a concrete, state-induced process of "revival-cum-institutionalization." ${ }^{29}$ Consequently, 'revival' has then been solidly linked to the discourse of 'reform' or 'revolution. ${ }^{30}$

Taixu and his slogan of "three revolutions of Buddhism" reinforced this link. ${ }^{31}$ The Buddhist revival has been depicted as a process of 'humanization,' 'secularization,' and 'politicization.' However, this impression begs some crucial questions. If a 'revival' of Buddhism did occur in modern history, the issue is not only why the revival emerged and what it looked like, but rather its very nature: was it an unwilling response to impacts from the outside, especially that of modernity, or a spontaneous reaction to save Buddhism from decline? Was it a progressive step towards a better future or a loss of Buddhism's essence and a betrayal of its tradition? Was it part of the project of globalization, or in contrast, a segment of

\footnotetext{
${ }^{27}$ Normally, Buddhism is considered a highly institutionalized religion. For the division of 'institutionalized' and 'diffused' religion, see C.K. Yang, Religion in Chinese Society: A Study of Contemporary Social Functions of Religion and Some of Their Historical Factors (Berkeley, Los Angles: University of California Press, 1961), chapter 12.

${ }^{28}$ For a discussion of some fundamental Buddhist institutional innovations since the end of the nineteenth century, see Ji Zhe, 'Buddhist Institutional Innovations', in V. Goossaert, J. Kiely \& J. Lagerwey ed., Modern Chinese Religion II: 1850-2015 (Leiden, Brill, 2006), 731-766.

${ }^{29}$ Vincent Goossaert, "State and Religion in Modern China: Religious Policies and Scholarly Paradigms," paper presented at Rethinking Modern Chinese History: An International Conference to Celebrate the $50^{\text {th }}$ Anniversary of the Institute of Modern History, Academia Sinica, Taipei, June 29-July 1. Goossaert considers Buddhism as one of the most outstanding cases of this paradigm.

${ }^{30}$ The discourse of revolution [geming 革命] is very dominant in studies of modern China. It was considered a 'symbolic capital'; see Chen Jianhua, 'Geming' de xiandaixing: Zhongguo geming huayu kaolun “革命”的現代性: 中國革命話語考論 (Shanghai: shanghai guji chubanshe, 2000); also, David Ernest Apter and Tony Saich, Revolutionary Discourse in Mao's Republic (Cambridge, MA: Harvard University Press, 1994); Xiaobo Liu, “That Holy Word, 'Revolution', in Popular Protest And Political Culture In Modern China, ed. Jeffrey N Wasserstrom, (New York: Routledge, 2018), 309-324.

${ }^{31}$ For studies on Taixu as a Buddhist reformist, see Don A. Pittman, Toward a Modern Chinese Buddhism: Taixu's Reforms (Honolulu: University of Hawai'i Press, 2001).
} 
nationalization? Was it an actualized occurrence in history, or did it remain a utopian plan imagined or designed by certain figures?

As some scholars have noticed, Taixu was actually a 'too-perfect ideal' or a "classical" religious figure, in Joachim Wach's sense..$^{32}$ His legacy and his Buddhism for the human world [renjian fojiao 人間佛教] represent a type of spirituality that exemplifies the trend of 'modern religion' identified by Joseph Kitawaga, John Randall, and others: an ethicized, protestant Buddhism with a this-worldly soteriology. ${ }^{33}$ However, the stunning case of Taixu, as well as other 'classical' figures, more or less has overshadowed the complexity of the 'religious issue' in modern China because it has established a simplified logic of causality—because Buddhism needed to overcome its decline, it had to be reformed; because Buddhism was reformed (although the reform was incomplete), it experienced a revival. This logical sequence, although still dominant, contains several pitfalls.

Influenced by the concept of 'declining Dharma' [mofa 末法], a sense of crisis has always haunted the minds of Chinese Buddhists. ${ }^{34}$ Fundamentally, this concept essentially has its root in Buddhist teaching. It is not only a prophecy, but rather a

\footnotetext{
${ }^{32}$ Joachim Wach, Types of Religious Experience. Christian and Non-Christian (Chicago: University of Chicago Press, 1972), 48-57.

${ }^{33}$ Joseph M. Kitagawa, "Primitive, Classical and Modern Religions: A Perspective on Understanding the History of Religions," in The History of Religions : Essays on the Problem of Understanding, ed. Joseph M. Kitagawa (Chicago: University of Chicago Press, 1967). 39-65; and John Herman Randall Jr, The Making of the Modern Mind: A Survey of the Intellectual Background of the Present Age (New York: Columbia University Press, 1926).

${ }^{34}$ The concept of mofa, which was interpreted by Erik Zürcher as a Messianism, describes the demise of Buddhist teachings in an era when the Buddha has long since entered nirvana and all semblances of the monastic community have disappeared. While references to the decline of Buddhism were present in Indian literature, the systematization of this concept was most likely articulated in medieval China. People of the Northern Dynasties (386-581) and Tang periods (618-907) had already been anxious about mofa and prepared for its coming. See Jan Nattier, Once upon a Future Time: Studies in a Buddhist Prophecy of Decline, vol. 1 (Fremont: Jain Publishing Company, 1991). Also Yūki Reimon, "Shina Bukkyō ni okeru mappō shisō no kōki” 支那佛教に於ける末法思想の興起 [The Rise of the Mofa Concept in Chinese Buddhism," Tōhō gakuhō 東方學報 [Journal of Oriental Studies] 6, no. 1 (1936). Foreboding of the destruction of Buddhist teachings can be found in Nakāya or Āgama scriptures; see Jamie Hubbard, "Salvation in the Final Period of the Dharma." Ph.D. Dissertation (University of Wisconsin, 1986), 15-24; David W. Chappell, "Early Forebodings of the Death of Buddhism," Numen 27 (1980): 124-127.
} 
tripartite scheme of periodization. After the two sequent ages of the 'correct Dharma' [zhengfa 正法] and the 'semblance Dharma' [xiangfa 像法], the final age of mofa will inevitably come. The decline and disappearance of the dharma have been viewed in Buddhist sources as automatic, simply resulting from the transitory nature of all conditional things. Therefore, in Chinese terms, the response to mofa has always focused on how to practice Buddhism in this prolonged, decadent final age, instead of how to stop the arrival of mofa. Historically, within monastic communities, the concept of mofa or 'decline' was utilized to reinforce monastic regulations and to stress self-examination among the samgha in order to react to external criticism and prevent further corruption from the inside. In the modern Chinese context, the intensifying attention to mofa or intensive vigilance towards the 'decline,' called a "we-try-harder response" by Jan Nattier, ${ }^{35}$ undoubtedly was caused by various factors, for example, the impulse to strengthen the internal management of the samgha against corruption, impacts from Christian missionaries, military invasions, criticism from Japanese Buddhism, and so on. ${ }^{36}$ However, these efforts meant it was impossible to legitimatize the 'reform' of Buddhism itself. In some cases, as Welch has indicated, the idea of 'decline' was a 'narrative' constructed on purpose by Buddhist reformers like Taixu. It was neither an established fact nor a real crisis that needed to be overcome by a certain kind of reform or revolution. ${ }^{37}$

Besides, the 'revival' model has overlooked the built-in strata within the modern transformation of Chinese Buddhism. Apart from the inner contradictions between Buddhists and non-Buddhists, which made the whole picture more

\footnotetext{
${ }^{35}$ Nattier, Once upon a Future Time: Studies in a Buddhist Prophecy of Decline, 137.

${ }^{36}$ For the narrative of mofa in modern times, see Erik Schicketanz, Daraku to fukkō no kindai Chūkoku Bukkyō: Nihon Bukkyō to no kaikō to so no rekishizō no kōchiku 值落と復興の近代中国仏教: 日本仏教との 邂逅とその歷史像の構筑 (Kyoto: Hozōkan, 2016). Also, Erik Schicketanz, “Narratives of Buddhist Decline and the Concept of the Sect (Zong) in Modern Chinese Buddhist Thought," Studies in Chinese Religions 3, no. 3 (2017), 281-300.

${ }^{37}$ Welch's attitude towards 'revival' made him special among all scholars who put 'revival' at the centre of their narrative. See Welch, The Buddhist Revival in China, 222-223.
} 
complicated, ${ }^{38}$ the modern Chinese Buddhist community, in general, was a layered, multidimensional, and hybrid edifice. Taking rituals and festivals into account, Paul A. Katz has pointed to "triangular networks of power," featuring three groups involved in management and regulation: officials, elites, and religious specialists. ${ }^{39}$ Prasenjit Duara, based on his study of religion in rural China, has also indicated a divided space of religious practice, separate from formal institutionalized religions, in which the masses of common believers lived. This localized, popularized facet of religion constituted the bottom structure of religious communities. ${ }^{40}$ Scholars beginning with Timothy Brook have noticed a 'connecting stratum. ${ }^{31}$ Their analysis has found that, in the urban space, the gentry and the elite played their roles as 'middlemen' between the populace and the governors, resisting the national apparatus of the government through supporting local monasteries and participating

\footnotetext{
${ }^{38}$ For example, although Taixu insisted on the purity of Buddhism and its distinction from superstition, he did not fully forbid 'superstitious activities' in his monastic communities and tacitly consented to such practices. See Kangbao, "Yige zhuming shanghai shangren yu cishanjia de zongjiao shenghuo --Wang Yiting 一個著名上海商人與慈善家的宗教生活一王一亭” in Cong chengshi kan Zhongguo de xiandaixing 從城市看中國的現代性, ed. Wu Renshu 巫仁恕, Lin, Meili 林美莉, and Paul Katz 康豹 (Taipei: Institute of Modern History, Academia Sinica), 275-296; studies of Buddhism and superstitious activities, for example, fuji, see Wang Jianchuan 王見川, “Jindai Zhongguo fuji cishan: yi Yinguang wenchao wei kaocha xiansuo 近代中國扶乩慈善與「迷信」一以印光文鈔為考查線索,” in Disijie guoji hanxue huiyi lunwenji: Xinyang, shijian, yu wenhua tiaoshi 第四屆國際漢學會議論文集: 信仰, 實踐, 與文化調適 (Taipei: Academia Sinica, June 2013), 525-562; Fan Chunwu 范純武, “Jindai Zhongguo fojiao yu fuji 近現代中國佛教與扶乩, ” in Yuanguang foxue xuebao 圓光佛學學報, 3 (1999), 261-291.

${ }^{39} \mathrm{Katz}$, Religion in China and Its Modern Fate, 6-7.

${ }^{40}$ Prasenjit Duara, "Knowledge and Power in the Discourse of Modernity: The Campaigns Against Popular Religion in Early Twentieth-Century China," in The Journal of Asian Studies 50, no. 1 (1991), 6783; also, Prasenjit Duara, Culture, Power, and the State: Rural North China, 1900-1942 (Stanford: Stanford University Press, 1991). Further studies on 'popular religion', Adam Yuet Chau, Miraculous Response: Doing Popular Religion in Contemporary China (Stanford: Stanford University Press, 2005); Philip Clart, "Chinese Popular Religion," in The Wiley-Blackwell Companion to Chinese Religions, ed. Randall Nadeau (Oxford: Wiley-Blackwell, 2012), 219-37; Adam Yuet Chau, "The Politics of Legitimation and the Revival of Popular Religion in Shaanbei, North-Central China," Modern China, 31,2 (2005): 236-78.

${ }^{41}$ Focusing on the late Ming period, Brook's study revealed the relationship between Buddhism and Ming gentry. See Timothy Brook, Praying for Power: Buddhism and the Formation of Gentry Society in LateMing China (Cambrige, MA: Council on East Asian Studies, Harvard University and Harvard-Yenching Institute, 1993).
} 
in religious practices. ${ }^{42}$ These inherent hierarchies and structures were very solid and did not really undergo a changing process of decline and revival.

This 'hybridity' of Buddhism that David McMahan (borrowing from Homi Bhaba) pointed out hints at the limitation of the 'reform-revival' narrative, demonstrating that the stories of religious leaders promoting reforms have only been the tip of the iceberg. ${ }^{43}$ This hybridity, as noted by many current scholars, also has made China an exception to the theory of secularism. ${ }^{44}$ The Buddhist 'revival' in modern China cannot be attributed to secularization but to a process of religious modernization, which had as its preconception the idea of 'progress' and emphasized the deeper engagement of religion in public affairs. However, the different scenario in modern China reveals that the narrative of the 'reform' of Buddhism was basically an unfulfilled dream that existing in the writings and sayings of some Buddhist leaders. The practice of Buddhist modernization in Republican China essentially failed, as many current Buddhist reformers have already realized ${ }^{45}$ Pressures from the inside and outside hindered any intensive, thorough attempts. China, during the first decades of the twentieth century, never fully established its own form of 'Buddhist modernism', as Japan did. ${ }^{46}$ The outcome of the Buddhist revival in China, as well, was something polyphonic, ambiguous, and paradoxical, which, as Welch has

\footnotetext{
${ }^{42}$ Many of the studies have taken Shanghai as their case. See James Brooks Jessup, "The House Holder Elite: Buddhist Activism in Shanghai, 1920-1956" (PhD University of California, Berkeley, 2010).; Tang Zhongmao 唐忠毛, Zhongguo fojiao jindai zhuanxing de shehui zhi wei: minguo Shanghai jushi fojiao zuzhi yu cishan yanjiu 中國佛教近代轉型的社會之維：民國上海居士佛教組織與慈善研究 (Guilin: Guangxi shifan daxue chubanshe, 2013).

${ }^{43}$ David McMahan, The Making of Buddhist Modernism (New York: Oxford University Press, 2008), 14, 19.

${ }^{44}$ For a discussion of China and secularization, see Karel Dobbelaere, "Secularization: A Multi-

Dimensional Concept," Current Sociology 29 (1981); Karel Dobbelaere, Secularization: An Analysis at Three Levels (New York: Peter Lang, 2002); Also, José Casanova, Public Religions in the Modern World (Chicago: University of Chicago Press, 1994).

${ }^{45}$ For example, Taixu outlined the reasons for the failure of his Buddhist reform in his essay "Wo de fojiao gaige shibai shi 我的佛教革命失敗史. TXQS, vol.31, 57.

${ }^{46}$ David McMahan has enumerated four features of Buddhist modernism; see David L. McMahan, The Making of Buddhist Modernism (Oxford: Oxford University Press, 2008).
} 
described, sometimes even "meant not a growing vitality for Buddhism but its eventual demise as a living religion., ${ }^{27}$

Meanwhile, the paradigm of 'reform-revival,' as analyzed above, always presupposed modernity, for it imagined that, through reform, Buddhism could become more progressive, more scientific, and more modern. However, if we look beyond the level of practice to some more theoretical reflections that emerged during the early twentieth century, we find that whether and how Buddhism could be modernized was sometimes irrelevant. To some Chinese, the route of modernization was either a dead end or thorny. As early as the 1910s, suspicion and rejection of Western modernity had arisen among many Chinese intellectual elites. Different voices also appeared inside the Buddhist circle. The 'conservative' group of monks, such as Xuyun 虚雲 (?-1959), Yinguang 印光 (1862-1940), Hongyi 弘一 (1880-1942), and so on, rejected the 'secular' presupposition of the reform of Buddhism from a stance of preserving monastic purity; ${ }^{48}$ also, lay Buddhists associated with the China Inner Learning Institute [Zhina Neixueyuan 支那內學院], such as Ouyang Jingwu 歐 陽竟無 (1871-1943), Lü Cheng, and Wang Enyang 王恩洋 (1897-1964), consciously dismissed the model of modernization and reflected on some of the essential concepts behind it, such as science and progress. ${ }^{49}$ The polarized voices speaking about reform scattered here and there in these people's works declared or implied a tendency of Buddhism to develop into other forms that were 'purer,' 'truer,' and more 'genuine.'

\footnotetext{
${ }^{47}$ Welch, The Buddhist Revival in China, 264.

${ }^{48}$ For Xuyun, see Daniela Campo, "Chan Master Xuyun: The Embodiment of an Ideal, The Transmission of a Model," in Making Saints in Modern China: Profiles in Religious Leadership, ed., D. Ownby, V. Goossaert \& Z. Ji (New York: Oxford University Press, 2016), 99-136; for Yinguang, see Jan Kiely, "The Charismatic Monk and the Chanting Masses: Master Yinguang and his Pure Land Revival Movement," in ibid, 30-77; for Hongyi, Raoul Birnbaum, "Master Hongyi Looks Back: A Modern Man Becomes a Monk in Twentieth-Century China," in Buddhism in the Modern World: Adaptations of an Ancient Tradition, ed. S.Heine \& C. Prebish, (New York: Oxford University Press, 2003), 75-124.

${ }^{49}$ For more information on studies of those Buddhist intellectuals, see the collected essays in John Makeham, ed., Transforming Consciousness: Yogācāra Thought in Modern China (Oxford: Oxford University Press, 2014).
} 
From Holmes Welch's groundbreaking research to most of the latest studies, the revival of Buddhism, whether it was only an unfulfilled blueprint or an actualized phenomenon in history, has normally been perceived as a practice-oriented Buddhist 'game.' It has either been connected with certain groups of believers located in a religious hierarchy, or linked to the triangular power system posited by Paul Katz; it was these Buddhists who expected, participated in, disturbed, or witnessed the 'revival' directly or indirectly, or at least were concerned about the 'modern fate' of Chinese Buddhism. In this process, no matter whether Buddhist apologists in modern China were trying to reform or to protect Buddhism, they all realized that they must firstly 'know' it: not simply know its doctrines, but rather know how this tradition was formed in China's past and how it responded to the call of the time. Writing the history of Buddhism, then, became very crucial to Buddhist believers. This is why Buddhist elites often engaged in or initiated discussions about the past of Buddhism. Meanwhile, their voices on this topic were shadowed by their intense concerns with reality and their calls for reform. Therefore, the historiography of Buddhism in modern China has been read as a relatively marginal theoretical practice of 'insiders.' However, if we return to Liang Qichao's paragraph cited previously, we will identify one missing piece of the puzzle. This project, as one part of the modern transformation of Buddhism at the discursive rather than the institutional level, was not driven solely by those within the Buddhist circle. There were still some figures who remained outside of the tradition or who alienated themselves from any kind of religious practices. Chen Yinke 陳寅恪 (1890-1969), Tang Yongtong 湯用粀 (18931964), and Hu Shih 胡適 belonged to this group. The changing of the religious landscape was definitely manifested in their personal and academic life; they always, however, kept a distance from religious life and maintained their identity as professional historians. This does not mean that these people were peripheral; quite the contrary, they were those who had the most comprehensive and perceptive understanding of Buddhism as well as of the West-'the modern world.' To them, the logic behind the 'revival' of Buddhism-Buddhism needed to change to become modern-was sometimes in opposition to the tenet of their historiography; what they were concerned about was not the historical development of Buddhism itself but 
how to define the Buddhism in Chinese history as 'Chinese Buddhism' and how to identify, maintain, and evaluate its 'Chinese-ness.' One aim of my study, then, is to bring those 'outsiders' - the 'side current' [fuliu 伏流] in Liang Qichao's words—into our vision. They have disappeared in most of the recent literature on modern Buddhist scholarship; however, their voices echoed the broader account of the invention of 'Chinese Buddhism' under the modern category of 'religion' and the reconstruction of the religious and historical truth of Chinese Buddhism, in the multifaceted modernization of the domains of both academy and belief.

\section{Religious Truth and Historical Truth}

Buddhism, as a religion, has its allegedly eternal, ahistorical 'truth' ${ }^{50}$ : the Dharma, although the Dharma had been ceaselessly redefined, reinterpreted, and recreated throughout history. In China, people have been preoccupied with record keeping and history making throughout the past two millennia. ${ }^{51}$ Under the influence of this local culture, records about Buddhism were written down mostly by clergy but also by History Officers [shiguan 史官] and literati. Chinese Buddhists, although often belonging to varying denominations, established their own historical narrative tradition, which contained varied forms of writing, including sectarian stories, doctrinal bibliographies, gazetteers, biographies of monks, and so on. ${ }^{52}$ Writing the

\footnotetext{
${ }^{50}$ In this Introduction, I make a distinction between religious truth and historical truth and will discuss the difference between these two truths. In the later part of this dissertation, however, if there is no special clarification, I use 'truth' from a phenomenological perspective, which is what the historian can observe from historical materials or summarize from some evidential facts, namely, the historical truth. Certainly, the term 'truth' [zhenli 真理] itself, which originated in the West, had been widely used in a religious context.

${ }^{51}$ For the main facets of the historiographical tradition in China, see Endymion Wilkinson, Chinese History: A Manual (Cambridge: Harvard University Asia Centre, 1998).

${ }^{52}$ This tradition of Buddhist historiography had been studied by several scholars, for example, John Kieschnick, The Eminent Monk. Buddhist Ideals in Medieval Chinese Hagiography (Honolulu: University of Hawaii Press, 1997) and Song Daofa, Fojiao shiguan yanjiu 佛教史觀研究 (Beijing: Zongjiao wenhua chubenshe, 2009).
} 
history of Buddhism was one means for the believers to approach and reproduce the 'real' teaching of the Buddha.

The historiography of Buddhism that emerged in twentieth century China, however, was not a continuation of the previous tradition of Buddhist historiography. ${ }^{53}$ Several profound transformations can be observed. For example, new studies of the history of Buddhism surpassed sectarian boundaries and often organized the Buddhist past by referring to more general frameworks of periodization. Also, writing the history of Buddhism was no longer the privilege of Buddhist communities; the practices of professional historians challenged the monastic monopoly of Buddhist knowledge. Meanwhile, this new branch of Buddhology as an independent and highly institutionalized discipline imported numerous terms, concepts, and methods to describe and explain the changes in Buddhism throughout history according to new theoretical paradigms. More importantly, there was always a concern behind all these concrete and complex phenomena: what is 'Chinese Buddhism,' or what makes Buddhism 'Chinese'? Such questions were never asked by premodern Buddhist historians.

Reflections on these questions revolved around the rethinking and redefinition of 'truth' in two dimensions: religious truth, which determines that Chinese Buddhism is 'Buddhism,' and historical truth, which identifies Chinese Buddhism as 'Chinese.' As an interdisciplinary field, the historiography of Buddhism, in this sense, unites these two tendencies by, firstly, historicizing religious truth and, secondly, narrating Buddhism as part of the national history of China. This dual logic reveals what I see as the two cores of this historiographical turn - 'faith' and 'truth,' as indicated in the title of this dissertation.

Historiographical Buddhism indicates, in a broad sense, that teachings, ideas, and religious experience, and the criticism and narration about them, are actually

\footnotetext{
${ }^{53}$ I divide 'Buddhist historiography' and the 'historiography of Buddhism.' The former refers to historical writings produced by Buddhists, for example, scholarly monks, laymen, and so on. The 'historiography of Buddhism' refers to all writings about the history of Buddhism, no matter whether these writings come from professional or monastic historians.
} 
historized and can express their own historicity. The historiography of Buddhism in modern China presented and reinforced the historicity of Buddhism by setting up a textually oriented methodological paradigm. By critically reading Buddhist scriptures as historical material and questioning their authenticity and legitimacy, historians converted Buddhist doctrines into historical sources that could be dubious, disorderly, and even false. On the one hand, because of this stand of textual orientation, historians turned to a body of data that had been overlooked or deliberately ignored by former Chinese researchers and also their Western counterparts - the extra-canonical texts. Some of these texts were carefully preserved and heavily edited or commentated upon but seldom had drawn wide attention within academia. Others were unedited or even 'unread' before the rise of modern Buddhist historiography, such as some manuscripts discovered in the caves of Dunhuang. Historians dated, translated, and interpreted these materials. To them, all these texts, no matter whether canonical or not, were fundamentally equal. Without sectarian prejudice, they treated the texts as a database of information. On the other hand, these historians believed that texts were produced under certain historical circumstances by certain groups of people with special expectations and biases. Therefore, although Buddhism is a canon-based religion, its doctrinal foundation actually is not stable. To Buddhist historians, texts, despite their varying contents and styles, are, or at least were when they were produced, 'normative' expressions aimed at setting ideals, establishing doctrinal and sectarian orthodoxy, or responding to other practical concerns.

Because Buddhist scriptures was critically read by historians without faith, the tension between historical facts and the Buddhist 'essence' arose, and further caused the historicization of Buddhism..$^{54}$ As we will see in this dissertation, the believers in

\footnotetext{
${ }^{54}$ Discovering the essence of Buddhism remained the main task of Buddhist studies for a long time. This intention can be observed in the works of C.A.F. Rhys Davids, Hermann Oldenburg and later Theodor Stcherbatsky and so on. See Rhys Davids, Sakya, Or Buddhist Origins (London: Kegan Paul, Trench, Trubner and Co., Ltd., 1931); Hermann Oldenburg, Buddha, sein Leben, seine Lehre, seine Gemeinde (Berlin: Verlag von Wilhelm Hertz, 1881); and Theodor Stcherbatsky, The Conception of Buddhist Nirvana (London: Mouton \& Co, 1965).
} 
the Dharma and the proponents of historical fact both claimed, although in a careful and friendly manner, that the other side's approach would miss the 'real' truth. For Buddhist scholars, the underlying logical structure behind their rhetoric of 'genuine Buddhism' involved positing a distinction between the 'essence' of a religious tradition and its 'cultural manifestations.' As Robert Sharf has remarked, these scholars believed that "while the cultural manifestations of religion are invariably shaped by social, institutional, and economic contingencies, the essence is an ahistorical truth logically prior to, and thus unsullied by, the cultural forms through which it is made known." ${ }^{55}$ However, historians have rejected this position by criticizing that this attitude of fundamentalism fails to realize the historicity of truth itself. ${ }^{56}$ Sometimes, the terrain between these two camps has been so wide that voices from both sides have engaged in monologues.

In the context of religion, truth is often equated with faith. Such truth consists of a set of sacred doctrines, embodying itself through the activities of sages and ritual performances. It is often timeless, providential, and transcendent. Remarkably, religious truth indicates not merely worship and devotion, but also 'tradition,' namely, something, in Gadamer's sense, that one can never escape from. ${ }^{57}$ This inescapability does not mean that tradition is not questionable; on the contrary, as Gadamer has noted, tradition hands down certain interests, prejudices, questions, and problems that have the potential to incite critique and reform. ${ }^{58}$ The Buddhist reform conducted by Taixu, for example, was incited by the faith in Buddhist doctrines and monastic traditions. Similarly, for those who claimed themselves to be

\footnotetext{
${ }^{55}$ R. H. Sharf, “Whose Zen? Zen Nationalism Revisited," in Rude Awakenings: Zen, the Kyoto School and the Question of Nationalism (1995): 44.

${ }^{56}$ Faure Bernard, Chan Insight and Oversight (Princeton, NJ: Princeton University Press, 1993), 90

${ }^{57}$ Tradition literally implies (in both its Latin form 'tradition' and its Chinese form 'chuantong' 傳統) continuity and orthodoxy. However, as some scholars have pointed out, while tradition is usually seen as the opposite of modernity, yet it is much loved by modernity. Traditions are continually being created, not in some past time immemorial, but during modernity. For studies on this issue, see Eric Hobsbawm and Terence Ranger, The Invention of Tradition (Cambridge, New York: Cambridge University Press, 1983).

${ }^{58}$ Hans-Georg Gadamer, Truth and Method (London: Bloomsbury, 2013), 289-96.
} 
'atheists', like Hu Shih, 'faith' or 'tradition' still underlay their writings in certain forms. Through 'faith,' individuals produce symbols, stories, and memories that give them both identity and status. In a society that changes slowly, 'faith' may be solidly attached to powers - religious, political or ideological—and the stability maintained by the structure of power; however, in a time full of changes, I will suggest, faith is not so strong as to dominate one's behavior but is something that can be selected, discussed, and questioned. It often defines itself as an intellectual resource, a way of life, or one alternative: should one pick from (one's) previous faiths or should one go along with something more modern and form a new faith? In this sense, in the modern context, faith is a 'reservoir,' instead of an authority; that is, it is a strength to draw upon, a device for forming identity, and a source of a sense of safety, specialness, or difference.

In the context of history, truth, which is evidence-based, is also not ideologyfree. It always turns out to be "a mobile army of metaphors," as in Nietzsche's phrase, that sometimes goes against certain stands or faith. ${ }^{59}$ That is why sometimes the writing of Buddhist history became a deconstructive power to the monasteries. Meanwhile, once it was proved that a given system could not be reduced to its original form or the circumstances of its emergence, the overwhelming historicity then encouraged this system to resist against or even interfere with historical changes. That is why the protagonists of Buddhism persistently emphasized the 'genuineness' of the Dharma through history. This tendency echoes the view of Ernst Troeltsch. When discussing the "essence of Christianity," Troeltsch pointed out that the 'essence' of religious teaching incorporates not only an abstract ideal but also a critical judgment "which measures the manifestations against this ideal essence." That is to say, religious essence is irreplaceable and inescapable, for it is the criterion

\footnotetext{
${ }^{59}$ Nietzsche, "On Truth and Falsity in their Ultra Moral Sense" in The Complete Works of Frederick Nietzsche, ed. Oscar Levy (New York: Gordon, [1873]1974).

${ }^{60}$ See Michael Pye, "Comparative Hermeneutics in Religion," in The Cardinal Meaning: Essays in Comparative Hermeneutics, Buddhism and Christianity, ed. Michael Pye and Robert Morgan (The Hague: Mouton, 1973), 14. For a discussion of Ernest Troeltsch's notion of 'essence', see Mark Chapman, Ernest Troeltsch and Liberal Theology: Religion and Cultural synthesis in Wilhelmine Germany (Oxford: Oxford University Press, 2001).
} 
by which other truths are judged to be true. The 'historical essence' of Buddhism, although largely rejected by the recent trend of 'de-essentialization' in Buddhology, which Donald Lopez has called "a new historiography," ${ }^{11}$ had haunted many Western Orientalists and Buddhologists. ${ }^{62}$ In modern China, a similar intention was also repeatedly presented in the works of Lü Cheng and other lay Buddhist scholars from the China Institute of Inner Studies. Unlike both the scholastic monks and professional historians, these lay scholars made unique endeavors to safeguard the essence of Buddhism - the foundation of their faith - through provocative historiographical statements.

Different understandings of the truth led to the ambiguous role of historiography in Buddhology. The dilemma of historized Buddhism, as I will show in this dissertation, is that Buddhism can be depicted as the product of history, but only at the risk of opening up questions about its sacred past; meanwhile, although history tried to search for hard facts and to construct a 'historically real' Buddhism, history further separated Buddhism from its religious truth - the 'genuine' Buddhism. Also, it cannot be ignored that the writing of Buddhist history itself can also be historized and find itself captive by temporal discourses like science and progress. This point was particularly evident in modern China.But, if there is always a gap between religious truth (faith) and historical truth, how did writing the history of Buddhism become so active and important in early twentieth-century China, when both 'history' and 'religion' were undergoing dramatic transformations?

One significant inner transformation that might have inspired the inclination to write a national history of Buddhism was the widespread reflection on tradition among Chinese intellectuals after 1900. Tradition, a "white metaphor" in Derrida's

\footnotetext{
${ }^{61}$ See Lopez's foreword to Gregory Schopen's Bones, Stones, and Buddhist Monks, 1997, x. Here I need to add that Schopen's study provides a representative example of the trend that the 'real' Buddhism should be found in a distinctly unidealized reading based on a mélange of textual and extra-textual evidence, including epigraphic and archaeological materials. See his essays collected in the book. ${ }^{62}$ One response to this issue is the collected work edited by Roger R. Jackson and John J. Makransky, Buddhist Theology: Critical Reflections by Contemporary Buddhist Scholars (London: Cruzon, 2000). Also see C. W. Huntington Jr. "History, Traditon, and Truth," in History of Religions, 46, no.3 (2007): 187-227.
} 
sense, was selectively interpreted as the counterpart of 'modernity. ${ }^{63}$ The argument of tradition in the Chinese context was put forward by the historian Joseph Levenson. His argument of 'traditionalism'-the embrace of tradition in modern China as one response to the imbalance between history and value caused by the arrival of the West-is reminiscent of the same term used by Karl Manheim and Max Weber, which also emphasized the psychological clinging to tradition. As Levenson described, Chinese intellectuals, realizing the incompatibility of Confucianism with modern institutions, eventually "retired Confucius honorably into the silence of the museum. ${ }^{" 64}$ In this sense, the great tradition of Confucianism lost its voice in current affairs and was reduced to a symbol for national self-hood. After Levenson, his student Laurence Schneider complicated this paradigm by showing that Chinese intellectuals, such as Gu Jiegang 顧頡剛 (1893-1980), were still shaped by traditions and drew on classical resources as a means of redefining Chinese identity. ${ }^{65} \mathrm{Chang}$ Hao, as well, contended that, influenced by deep-rooted philosophies, Chinese intellectuals retained a sense of traditional values and attempted to seek universal meanings in traditions. ${ }^{66}$ Yü Ying-shih further suggested that Chinese modernity had its historical root in the inherent transformation of traditions, which, he pointed out

\footnotetext{
${ }^{63}$ The Chinese encounter with modernity was a double-edged sword: from the beginning, it was at the same time a project of anti-modernity-Wang Hui has referred to modern Chinese thought as marked by an "antimodern theory of modernization"-since modernity was perceived as belonging to the West. See Hui Wang, China's New Order: Society, Politics, and Economy in Transition, ed. Theodore Huters (Cambridge, MA: Harvard University Press, 2006), 150. A similar point was made by Arif Dirlik and Zhang Xudong, who raised the question of the experience of modernity for those "who were compelled into modernity by Euro-American coercion." Arif Dirlik and Xudong Zhang, "Introduction: Postmodernism and China," in Postmodernism and China, ed. Arif Dirlik and Xudong Zhang (Durham, London: Duke University Press, 2000), 2.

${ }^{64}$ Joseph R. Levenson, Confucian China and its Modern Fate: A Trilogy (Berkeley: University of California Press, 1968), vol.3, 79. For a discussion Levenson's point in relation to modernity, see Arif Dirlik, "Global Modernity?:Modernity in an Age of Global Capitalism," European Journal of Social Theory 6, no. 3 (2003), 278-279.

${ }^{65}$ Laurence A. Schneider, Ku Chieh-kang and China's New History: Nationalism and the Quest for Alternative Traditions (Berkeley: University of California Press, 1971).

${ }^{66}$ Chang Hao, Chinese Intellectuals in Crisis (Berkeley: University of California Press, 1987).
} 
rightly, included not only Confucianism but also other intellectual heritages, especially Buddhism. ${ }^{67}$

To modern historians, Buddhism is a special case, for, firstly, unlike other native religious traditions that may be categorized under the rubric of 'Chinese religion,' Buddhism is undisputedly a 'great religion' or 'world religion': it has profoundly influenced more than one large-scale civilization. As an illustrious tradition, Buddhism demonstrates how a vast, powerful metaphysical system can become dynamically ingrained in the social fabric of completely different contexts. Secondly, centered on several defining sectarian lineages and historical personagesfounders, masters, and reformers-Buddhism is a 'perfect' object for historical narration. As such, Buddhism offered modern Chinese scholars a comprehensive, representative, and comparative example to understand the mechanism through which an external system of thought entered China, became localized, and developed; they could study how this process functioned and what influences it caused. Answers to these questions further provoked reflections on the nature of Chinese civilization and the self-construction of Chinese national identity ${ }^{68}$

Another issue that affected concerns about the historical truth of Buddhism was the textualism of Buddhism. Compared to other folk beliefs, Buddhism was partly transformed into a written tradition based on readable records and data. Therefore, modern historians could locate Buddhism in a chrono-system (for example, the national history of (hina), and observe and understand it from the outside, without personally taking part in any ritual activities or having any religious experience. In this process, Buddhist scriptures were read and investigated as historical materials and were placed equally next to other materials. In many cases, it was curiosity about new materials and a propensity for antiquarianism that led historians into the field of

\footnotetext{
${ }^{67}$ Yu Ying-shih, “Wusi yundong yu Zhongguo chuantong 五四運動與中國傳統,” in Zhongguo sixiang chuantong jiqi xiandai bianqian 中國思想傳統及其現代變遷 (Guilin: Guangxi shifan daxue chubanshe, 2014), 82-91.

${ }^{68}$ For the formation of the concept of Chinese national identity [minzu xing 民族性], see Huang Xingtao, Chongsu zhonghua: Jindai Zhongguo 'zhonghua minzu' guannian yanjiu 重塑中華:近代中國“中華 民族”觀念研究 (Hong Kong: Sanlian shudian, 2017).
} 
Buddhist studies. Their first contacts with Buddhism came from the problems them encountered when studying other issues that were not directly related to Buddhism, or the new sources about Buddhism they discovered by accident. Chen Yuan and $\mathrm{Hu}$ Shih are two representative examples. Both of them had only limited connections with Buddhism and defined themselves as the outsiders of Buddhism but made their contributions to the historiography of Buddhism.

The textual orientation in the historiography of Buddhism, of course, does not mean that the past of Buddhism exists only on paper or that Buddhism should not be 'open' to the future. On the contrary, as I will argue in this dissertation through the cases of Chen Yinke, Hu Shih, and so on, the questions historians asked when they were writing the history of Buddhism in China pointed precisely to the future. When scholars began to focus on religious phenomena, ritual activities, and the changing relationship between religions and social-political forces in the Chinese historical context, connecting the historical material (Buddhist texts) with more general historical phenomena and principles, Buddhism then became more and more explained and interpreted by non-Buddhist discourses and theories, such as evolutionism and nationalism. In this process, the main agenda of the historical writing of Buddhism became the formation of 'Chinese Buddhism.' Replacing the essence of Buddhism with the particularity of Chinese Buddhism, the historiography of Buddhism in modern China established its own paradigm, responding to the dilemma of historicized Buddhism by creating Chinese Buddhism as a historical entity and combining the legitimation of its past with the choice for China's future. What modern Chinese historians of Buddhism wanted to understand about the religion, then, was not the doctrinal history of Buddhism or the Dharma itself but rather 'China' and the historical manifestations of Buddhism in China's past. In this sense, referring to the historical texts of Buddhism in ancient times, historians invented a Chinese Buddhism, or a Buddhist China.

Because the questions asked by historians went far beyond the doctrinal context of Buddhism, those historians were at times accused of misreading the 
Buddha's teachings or confusing and mixing up certain essential doctrinal terms. ${ }^{69}$ However, they had adequate reasons to do so, for what the Buddha said was not their concern. As Bernard Faure argued, in Maurice Merleau-Ponty's words, Chinese historians "do not have to choose from between those who think that the history of the individual or society holds the truth of the philosopher's symbolical constructions, and ...those who think on the contrary that the philosophical consciousness has as a matter of principle the keys to personal and social history"the tension is somewhat imaginary for "those who defend one of these resorts surreptitiously to the other." ${ }^{70}$ As we will see, in many cases, when historians were accused of distorting Buddhism, they were not unable, but rather unwilling, to respond to this criticism from Buddhists head on. What they concerned were the historical manifestations of Buddhism, which was dominated or determined by different socio-political systems and cultural landscapes. Even the Buddhists who were antagonistic towards 'superficial' history, ${ }^{71}$ such as Taixu and Lü Cheng, could not deny the historicity of Buddhism and also often resorted to historical terminology and methodology to prove their ideas. As Arthur Waley has remarked in relation to Suzuki and Hu Shih's case, those Buddhist scholars never felt that they were sinners when they dabbled in history; still less did they need to ask historians to join their 'peccavi,' for "if there were no $\mathrm{Hu}(\mathrm{s})$, there would be no Suzuki(s)."

All these aspects above have complicated the overall scenario of the modern transition of Chinese Buddhism. The questions faced by Chinese Buddhism, although concrete, pragmatic, and political, were related to two ontological concerns: what is 'Chinese Buddhism,' and what is 'China'? Clearly, the history of Chinese Buddhism or the history of China, as we understand them today, were one side; the history of the terms 'Chinese Buddhism' and 'China' themselves, which can be dated back to the late

\footnotetext{
${ }^{69}$ I provide more detail on the criticism they received in later chapters.

${ }^{70}$ Maurice Merleau-Ponty, Signs, Trans. Richard McCleary (Evanston: Northwestern University), 128-29.

${ }^{71}$ In Lü Cheng's commentary on Tang Yongtong's history of Buddhism, he criticized Tang's work as "superficial" [fan 泛]. For details, see the chapter 5 of this dissertation.

${ }^{72}$ Authur Waley, "History and Religion," in Philosophy East and West, 5, (1955): 75-78.
} 
nineteenth century, was another side. ${ }^{73}$ To be sure, the latter 'Begriffsgeschichte' is not separable from the former as a conceptual invention; the two are intertwined. Thus, the historiography of Buddhism in modern China was not only a historical writing of Buddhism, especially Buddhism in the Chinese context, but also a historical writing of the concept of 'Chinese Buddhism.' Behind the multifarious practices of the historiography of Buddhism during the modern Chinese period, the tension between the two truths-religious truth and historical truth-persisted and transformed into another question: should Buddhism or China be the focus of the modern Chinese historiography of Buddhism? As I will show in the following chapters, there was little consensus about the answer to this question. Accounts of Buddhist history swung between the two poles of 'Buddhism' and 'China,' sometimes overlapping, sometimes opposing or ignoring each other. Debates between historians and Buddhist scholars from the 1920s to the 1940s provided several concrete examples of the gap. Giving the conflicting standpoints behind their writings, their discussions were rather 'dialogues of the deaf.' However, such discussions, as I wish to explicate in this dissertation, appertained precisely to the validity of the premises of each interlocutor and, more generally, to their claims to legitimacy based either on the doctrinal supremacy of Buddhism as metaphysics, or on its value as a cultural factor and tradition presented by historiography. So, is Buddhism the business of historians? ${ }^{74}$ To what extent is Buddhism amenable to the historiographical approach, if indeed it is? Can Buddhism, which essentially rejects the concept of history, really be historicized? Or is Buddhism threatened by the result of historiographical inquiry, and how does

\footnotetext{
${ }^{73}$ Based on the Western experience, many scholars have pointed out that although many civilizations have had long histories, the stories of their respective religions are of recent pedigree. The establishment of ancient religions as objects of study coincided with the establishment of religion itself as a concept of the sixteenth and seventeenth centuries. See Brent Nongbri, Before Religion: A History of a Modern Concept (New Heaven: Yale University Press, 2013), 152; Peter Harrison, 'Religion' and the Religions in the English Enlightenment (Cambridge: Cambridge University Press, 2010), 1; and Tomoko Masuzawa, The Invention of World Religions: Or, How European Universalism was Preserved in the Language of Pluralism (Chicago: University of Chicago Press, 2005).

${ }^{74}$ This question is related to D.T. Suzuki. In the article "Zen: A Reply to Hu Shih," he stated that "it is not the business of historian to peer into [Zen in itself]." See D.T. Suzuki, “Zen: A Reply to Hu Shih," Philosophy East and West (1953), 3,1: 26.
} 
Buddhism respond to this threat? The complexity and intersection behind these questions determined the structure I employed in this dissertation: rather than advancing my investigation in a chronological fashion or ordering it in a biographical sequence, I purposely choose to cast a wide net in which the genealogy of the historiography of Buddhism is described as more layered than linear, more abrupt than cumulative, more paradoxical than tranquil. Behind the relatively sudden appearance of the new field of the historiography of Buddhism in modern China, I suppose, much of the logic and setting of this subject had already taken shape spontaneously underground but remained invisible until broader change suddenly stripped away all the topsoil and made everything apparent. It was not like a seedling growing into a tree, where we could log its development day by day, but rather like a flower bud suddenly bursting into full bloom.

\section{The Power of History}

Erik Zürich suggested that the history of Buddhism is not a "history of ideas" but a history of "a way of salvation, a way of life." ${ }^{75}$ His reflection emphasized a nondoctrinal perspective on Buddhist scholarship. After him, scholars went beyond the depository of Buddhist scriptures and began to understand Buddhism as a living tradition or a manifestation of several social phenomena that have changed throughout history. The practically and socially engaged aspects of Buddhism have received more and more attention and have been discussed under the rubric of religious studies, which was literally derived from the term 'science of religion' [G. Religionwissenschaft] but has concentrated on the cultural and historical phenomena of religion. ${ }^{76}$ Religious studies is an interdisciplinary area related to sociology and anthropology, as well as to history. Along with the establishment of religious studies as an independent discipline, Buddhism has been integrated into the constructed,

\footnotetext{
${ }^{75}$ Erik Zürcher, The Buddhist Conquest of China (Leiden: Brill, 1972). 1

${ }^{76}$ For the emergence of the 'study of religion' in the West, see Masuzawa, The Invention of World Religions: Or, How European Universalism was Preserved in the Language of Pluralism. In North American and Europe, it has become segregated into two institutional niches: religious studies and theology.
} 
discursive category of 'religion. ${ }^{, 77}$ The various cultural and social factors that contributed to the formation of Buddhism and its later development have been assigned as objects of religious studies.

In the contemporary academic system, the history of religion stands at the overlap between theology/philosophy and 'pragmatic' religious studies. ${ }^{78}$ This delimitation of this research area seems even more ambiguous if we look at the religious studies curricula in many American universities and colleges, which are taught by scholars representing a variety of disciplinary areas. 'History of religion,' in these institutions, has become a 'virtual code word' for any specialty other than Christianity and Judaism. ${ }^{79}$ More as a matter of convention and practical necessity than as a descriptor of a concrete 'discipline,' 'history' here means not 'writing the history of religion' but rather general studies of the non-Western religious traditions. In the studies of Chinese Buddhism, the gap between Buddhology and Sinology has also been conspicuous; the former has tended to look towards the textual tradition of Indian Buddhism, and the latter has focused on the literati culture related to Buddhism in China. Writing the history of Buddhism with conceptual reflections, as

\footnotetext{
${ }^{77}$ Some scholars have argued that the term 'religion', which emerged quite late, is an "essentially and increasingly contested category," see Roland Robertson, "Modernity and Religion: Towards the Comparative Genealogy of Religion in Global Perspective," Zen Buddhism Today, 6 (1988): 125-33; cf. Peter Beyer, "The Modern Emergence of Religions and Global Social System for Religion," International Sociology, 13 (1998): 151-72. For similar attempts in the history of the concept of 'religion', see Ernst Feil, Religio, 4 vol., (Göttingen: Vandenhoeck \& Ruprecht, 1986-2007); Jonathan Z. Smith, "Religion, Religions, Religious," in Mark C. Taylor (ed.), Critical Terms for Religious Studies (Chicago: University of Chicago Press, 1998).

${ }^{78}$ Several articles have discussed the impact of historical discourse on theology in Europe. For example, see Kurt Rudolph and Gregory D. Alles, "We Learn What Religion Is from History: On the Relation between the Study of History and the Study of Religions," Historical Reflections/Réflexions Historiques 20, no. 3 (1994): 357-76; John McIntyre, "The Uses of History in Theology," Studies in World Christianity 7.1 (2001): 1-20; Gordon E. Michalson, Jr., "Faith and History," in Alister E. McGrath ed., Modern Historical Thought (Oxford: Blackwell, 1993); R Kendall Soulen, "The Believer and the Historian: Theological Interpretation and Historical Investigation," Interpretation 53.2 (2003): 174-186. For a broader study on the discipline of the 'history of religion,' see Russell T. McCutcheon, The Discipline of Religion: Structure, Meaning, Rhetoric (London: Routledge, 2003).

${ }^{79}$ See Masuzawa, The Invention of World Religions: Or, How European Universalism was Preserved in the Language of Pluralism, 8.
} 
some scholars associated with the 'French school' have done, is one exception to this division of labor, or something in between these two types of scholarship. ${ }^{80}$ This hybrid approach of reading Buddhism historically as an intellectual system, which might be named the 'intellectual history of Buddhism,' however, has never been the mainstream in Buddhist scholarship. ${ }^{81}$

Although the rubric of 'the history of Buddhism' today is no more than an expedient name, in modern Chinese academia, writing the history of Buddhism marked the emergence of modern scholarship on Buddhism in China and the formation of a new paradigm for knowledge of Buddhism. Admittedly, Buddhist historiography had been practiced in premodern China for centuries. However, as the traditional systems of faith and history both were deconstructed and re-constructed again during the modern era, the old connection between Buddhism and historiography also profoundly changed. The new field of the historiography of Buddhism presented a unique and significant phenomenon. The new generation of historians showed preferences in its approach to Buddhism that neither directly originated from the Chinese historiographical tradition nor from the secular 'new historiography' of the West. Nor were they exclusively incited by religious commitment. Rather, this new historiographical approach was derived from the dual tasks of defining 'Chinese Buddhism': on one hand, Buddhism needed to gain its legitimacy as a 'modern,' global religion that fulfilled the requirements of modernity. It thus utilized the concepts and methodology of scientific historiography, such as progressivism and linear time. On the other hand, history treated Buddhism as an evidential historical experience through which historians could define the vitality

\footnotetext{
${ }^{80}$ Robert H. Sharf, Coming to Terms With Chinese Buddhism: A Reading of the Treasure Store Treatise (Honolulu: University of Hawai'i Press, 2002), 1.

${ }^{81}$ This situation may be changing, as attested in a number of recent English-language volumes on Chinese Buddhism that include contributions from both Buddhologists and Sinologists; see Peter N. Gregory, ed., Sudden and Gradual: Approaches to Enlightenment in Chinese Thought, vol. 5 (Honolulu: University of Hawai'i Press, 1991); Robert E. Buswell, Jr., ed., Chinese Buddhist Apocrypha (Honolulu: University of Hawai'i Press, 1990); and Peter N. Gregory, and Daniel A. Getz, Jr., ed., Buddhism in the Sung, vol. 13 (Honolulu: University of Hawai'i Press, 1999).
} 
and uniqueness of their tradition and fulfil their expectation of defending the value and independence of their own culture.

Undoubtedly, all the historians and scholars in modern China who wrote the history of Buddhism experienced a time full of turbulent and even violent changes. Being part of it, they observed and participated in the transformations that brought them both suffering and opportunities. One of the most famous theories about the transition China encountered in the modern period is what Joseph Levenson called a turn from "culturalism" to "nationalism." ${ }^{22}$ During this transition, the "universalistic pretension' of the Imperial Qing, namely, Chinese centrality, were entirely smashed. Chinese intellectuals then realized that there were other competing values that were not inferior variants of the Chinese ones but perhaps were something 'advanced.' Levenson described this scenario as a struggling process of 'alienation.' Levenson's thesis, which has been often read as a narrative of modernization, indicated an inevitable demise of 'Confucian China' in the face of Western modernity. However, the real situation was much more complicated. This transition, albeit in cases passive and painful, was also constructive, inspiring both radical self-critique and conservative entrenchment, as well as every position in between. The Chinese were not simply persuaded by the values of the West, they also tried to defend their own values, those they once thought were 'universal' but now appeared to be particular. In this process, they began to realize the particularity of China-the particularity of the terms they used to acquire and advance knowledge, the norms they enforced to construct the social system, the languages they uttered when telling the stories of their ancestors. The historical experience of Buddhism revealed that there never had been a monistic China; therefore, encountering the challenge of re-constructing a national identity, the Chinese intellectual elite could widely inspect the traditions that shaped them and make themselves open to different options. They did not have to choose between 'Confucian China' and the West: if Confucianism was a dead end,

\footnotetext{
${ }^{82}$ See Joseph R. Levenson, Liang Ch'i-ch'ao and the Mind of Modern China (Cambridge: Harvard University Press, 1953), 108-122 in particular; also, Levenson, Confucian China and Its Modern Fate: A Trilogy, vol. 1, 98-104.
} 
they still had other alternatives besides the path of the West—Buddhism was one of them.

New historical circumstances and options motivated historians to re-write history. In premodern China, historians, especially those in the official history system, showed less interest in non-Confucianist thoughts. The mission of traditional historiography, primarily, was actualizing the proper form of the Dao in the flux of time and rationalizing the 'Mandate of Heaven' [tianming 天命] through recording the activity of the rulers. ${ }^{83}$ Therefore, the nature of Buddhism as a belief and its ingredients of gods, demons, the next life, myth, and supernatural powers, determined that records about Buddhism could hardly be categorized as 'history.' Also, because of the intension to establish Confucian orthodoxy, many conceptual and theoretical resources, including Buddhism, were customarily excluded or deleted from the traditional system of scholarship. Outside the monasteries, the preservation and study of Buddhist scriptures was only stimulated by collectomania or antiquarianism among the literati, instead of by any historiographical interest.

When China entered into an age that was preponderantly characterized by modernity and concomitant discourses such as 'linear time' and 'secularization,' the old intellectual paradigm of China began collapsing under unprecedented pressure, both internal and external. At this stage, new ideas of history and religion which formed in the West became dominate. One of the influential theories was the progressive model, the narrative of gradual but steady progress from the lowest, the crudest, and the most primitive to the highest, the finest, and the most complex; this narrative also often described an upward spiral movement that started from a short stage of corruption and degeneration, followed by a precarious recovery and maturation, and finally culminating in the fulfillment of a certain ultimate goal. This narrative can be observed in Hume's Natural History of Religion (1756), Hegel's Philosophy of History (1830-1831), and many other accounts of the nineteenth century.

\footnotetext{
${ }^{83}$ Yves Chevrier, "Post-scriptum : La servante-maitresse : condition de la référence à l'histoire dans l'espace intellectuel chinois," Extrême-Orient, Extrême-Occident 9, no. La référence à l'histoire (1987). Also, Étienne Balázs, "Chinesische Geschichtswerke als Wegweiser zur Praxis der Bürokratie: Die Monographien, Enzyklopädien und Urkundensammlungen," Saeculum 8 ( 1957): 210-23.
} 
These works either suggested a universal form of religious development or, more frequently, a new, transcultural, objective worldview of science's conquest that wiped away the magical, religious concepts as obsolete and irrelevant.

By the time of Ranke, the metaphysical element within Hegel's history had also been largely eliminated. History became a time-honored ideographic, as opposed to a nomothetic study of human activities and was transformed into a scientific discipline. ${ }^{84}$ No longer a moral narration of edifying tales about bygone ages, history became essentially a work of 'research,' in the natural sciences' sense of the term, whose cardinal objective now was to establish certain facts about the past. Consequently, the construction of 'the science of history' resulted in a prevailing, if not dominant, secular paradigm of 'historiography.'

Even now, history scholarship is still profoundly influenced by the logic of 'historical secularism,' namely, the idea that historical processes are basically determined by secular forces. Current studies of modern Chinese history have paid little attention to the Buddhist presence in social, cultural, and political arenas. Whether their perspectives have leaned towards Western impact or Chinese responses, modernization or revolution, historians have focused primarily on political transformation, social structure, ideological shifts, or the lives of several representative individuals and have presumed a predominantly secular Chinese modernity. A politicalized and scientized view of history, which has been especially attributed to the tremendous impact of the May Fourth movement, has always been overriding in Chinese academia. This tendency has given later researchers the impression that modern Chinese intellectuals did not care about religion or even felt antipathy and hostility towards religion. Because of this impression, as well as a

\footnotetext{
${ }^{84}$ This concept of history comes from Dilthey. See Manfred Riedel "Einleitung (Introduction)," in Whilhelm Dilthey ed., Der Aufbau der geschichtlichen Welt in den Geisteswissenschaften (Frankfurt/Main: Suhrkamp, 1997), 9-80. Previously, the conception of the past, time, and history went through several changes. See R. Koselleck, Futures Past: On the Semantics of Historical Time (New York: Columbia University Press, 2004). On the development of views of history and the problem of historicity in nineteenth and twentieth century Europe, see Jeffery A. Barash, Martin Heidegger and the Problem of Historical Meaning (Dordrecht: Martinus Nijhoff, 1988).
} 
consistent marginalization of religion in the agenda for historical study, the most informative studies in the field of historiography have been undertaken on the Western roots of modern Chinese thought and the consequent response from the Confucianist tradition; the significance of other schools of thought, such as Buddhism, has been largely ignored. ${ }^{85}$

Benjamin Schwartz warned about the danger of considering the May FourthNew Culture Movement to be the key turning point in the history of modern China. ${ }^{86}$ The May Fourth model ${ }^{87}$ has been repeatedly criticized for privileging the antitraditional tendency as the shared paradigm of most modern historians and therefore losing sight of the contribution of historians who did not approve of the assumptions of the 'modern agenda. ${ }^{, 88}$ However, the 'May Fourth approach' is still influencing the

\footnotetext{
${ }^{85}$ Based on reflections on the modern landscape of Chinese religion and the deep links between religion and society, scholars such as Vincent Goossaert, David Palmer, Adam Chau, Daniel Bays, Rebecca Nedostup, Ji Zhe, and others have questioned the narrative of secular modernity and have tried to recover the very nature of Chinese religiosity through the historical manifestations of the changing religious landscape.

${ }^{86}$ Benjamin I. Schwartz, "Introduction," in Benjamin I. Schwartz (ed.), Reflections on the May Fourth Movement: A Symposium (Cambridge, MA: East Asian Research Centre, Harvard University Press, 1972), 1-13; also "Themes in Intellectual History: May Fourth and After," in John K. Fairbank (ed.), The Cambridge History of China, Republican China, 1912-1949, vol. 12 (Cambridge, UK: Cambridge University Press, 1983), 406-51.

${ }^{87}$ The historiographical approach has been depicted as one part of the 'intellectual revolution' of the May Fourth Movement. For this issue, see Chow, Tse-Tsung, The May-Fourth Movement: Intellectual Revolution in Modern China (Cambridge, MA: Harvard University Press, 1971); Lin, Yüsheng, The Crisis of Chinese Consciousness: Radical Antitraditionalism in the May Fourth Era (Madison: University of Wisconsin, 1979); Vera Schwarcz, The Chinese Enlightenment: Intellectuals and the Legacy of the May Fourth Movement of 1919 (Berkeley: University of California Press, 1986); For the impact of the May Fourth on modern Chinese historical methods, see Q. E. Wang, Inventing China through History: The May Fourth Approach to Historiography (Albany: State University of New York Press, 2001). Like Tang, Xiaobing, Wang used Liang's 'New Historiography' as the starting point for modern Chinese historical discourse. According to Wang, this 'new history' was shaped by two May Fourth notions: nation and science.

${ }^{88}$ Axel Schneider, "Reconciling History With The Nation? Historicity, National Particularity, And The Question Of Universals," Historiography East and West 1 (2003). Also see Hung-Yok Ip, Tze-Ki Hon, and Chiu-Chun Lee, "The Plurality of Chinese Modernity: A Review of Recent Scholarship on the May Fourth Movement," review of Fin-de-Siècle Splendor, David Der-wei Wang; Translingual Practice, Lydia Liu; Shanghai Modern, Leo Lee; Becoming Chinese, Yeh Wen-hsin, Modern China 29, no. 4 (2003): 490-509.
} 
writing of modern Chinese history. Scholars still tacitly acknowledge the antireligious tendencies of modern intellectuals, thus neglecting their historical interpretations of religion when exploring their attitudes towards tradition.

Indeed, modern scholars and historians, both from inside and outside Buddhist circles, more or less noticed that, as both political and scholarly discourse, the 'spirit of May Fourth' and its derivatives always urged religion to transform itself conceptually by taking 'science' as the yardstick. Science, at that time, was the dominant, if not the only, criterion of truth. Then, religion was resolved into components to fit into the scientific framework of modern knowledge in order to avoid being further exiled into 'superstition.' In some cases, it was divided and reproduced as 'social phenomena' that could be coped with using 'social science'; in other cases, it was read as 'textual heritage,' the object of the 'science' of history. This emphasis on science, however, did not mean that those modern historians had an anti-religious tendency, but rather was linked with the epistemological status of history at the time. By gathering data, texts, and archaeological materials comprehensibly within one intellectual system, history places more emphasis on objective evidence and demonstrates a 'will to truth' when it produces, manages, and authorizes our knowledge and memories. Objectivity in the spirit of science served as an important basis for this epistemological function of historiography. ${ }^{89}$

Meanwhile, modern historiography did not cut itself off from faith. The ethical standpoints of historians and their political ideals also played a significant role in historical writings. History was seen as having the potential to regulate conflicts and bring a sense of order in a variety of realms-political, intellectual, and cultural, as Gossmann described:

By making the past speak and restoring communication with it, it was believed, the historian could ward off potentially deconstructive conflicts produced by repression and exclusion; by revealing the continuity between remotest origins and the present, between the other and the self, he could ground the social and political order and demonstrate that the antagonism and rupture-notably the persistent social

${ }^{89}$ Edward W. Said, Orientalism, vol. 115 (New York: Vintage Books, 1978). 1-28, 201-84. 
antagonism-that seemed to threaten its legitimacy and stability were not absolute or beyond all mediation..$^{90}$

This expectation reinforced the power of history. Confucian Classists, philosophers, and Buddhist believers increasingly relied on history to expound and justify their own ideas, propositions, and world views.

Whether 'Six Classics is historiography' or 'Six Classics is historical materials,' these new slogans indicated that the status of historiography in the hierarchical system of Chinese scholarship had changed since the mid-Qing period. Traditionally, history was dominated by official historiography and constituted mostly of the imperial diaries [qijuzhu 起居注], veritable records [shilu 實錄] and dynastic histories [zhengshi 正史]. ${ }^{91}$ The collapse of the old order of the Imperial era, however, triggered the demise of the central pillars of this discursive structure. Instead, state support for the cultivation of historical knowledge shifted to professional historians and specialists who mainly worked in research institutes and universities. This new generation of historians drew extensively from the West in their attempts to establish modern historical practice, but meanwhile, they also tried to bridge the gap between new theories and the rich indigenous tradition of China. To them, historiography was unique among all the modern disciplines, since it had long been a defined and integral part of the traditional cultural fabric and was a deep reservoir that could be drawn on. ${ }^{92}$ Despite the existence of divergent views about traditional historical writing, modern historians saw some use in the insights and methodologies of historiography: historiography had at least some sort of 'hard ground' that was

\footnotetext{
${ }^{90}$ Lionel Gossman, "History as Decipherment: Romantic Historiography and the Discovery of the Other,"New Literary History 18, no. 1 (1986): 29.

${ }^{91}$ For a detailed discussion of the development of this official historiography and the system of the History Officer [shiguan 史官], see Denis Twitchett, The Writing of Official History Under the T'ang (Cambridge: Cambridge University Press, 2002).

${ }^{92}$ The attitude towards traditional historiography can be found, for example, in Liang Qichao's New Historiography in 1902. Liang argued that traditional historiography needs to be transformed, because China's survival depends on it. Other historians, on the contrary, believed that it was historiography, as an inherited tradition, that gave meaning to Chinese communities. See Brian Moloughney and Peter Zarrow, ed., Transforming History: The Making of a Modern Academic Discipline in Twentieth-Century China (Hong Kong: The Chinese University of Hong Kong Press, 2012).
} 
unquestionably written on paper, bones, and stones; it also had a power of explanation, which could help people understand the changes, ruptures, and discontinuities they faced; and, finally, history could always be re-written and reformulated to respond to the time. Not surprisingly, with the rising status of historiography during the modern period, history replaced the Classics to become one of the most important channels for the solution of conflicts and contradictions between different worldviews, belief standpoints, and value judgments.

Indeed, the 'whole concept of historical truth' has been called into question nowadays, especially in the Western discourse, and people are talking about the "lies in history ${ }^{93}$; however, even the most critical historian in modern China never doubted the epistemological status of history. The discovery of new materials and the debates on textual authenticity did not really undermine their confidence in historical objectivity and universal standards of truth, or result in their rejection of the variability in the process of searching for stable and determinate meanings. The practices of writing the history of Buddhism showed clearly that "the historicity of the criteria of truth" did not stop history from being utilized as a reliable and effective way of producing knowledge. ${ }^{94}$

Meanwhile, history helped modern Chinese people negotiate the "trauma of accommodation" caused by political turmoil and war, producing a sense of coherence and identity essential for nation-building. ${ }^{95}$ At the century's turn, China experienced a profound identity crisis, because of the collapse of the imperial powers and the

\footnotetext{
${ }^{93}$ Ellen Somakawa and Elizabeth E. Smith, "Theorizing the Writing of History or 'I Can't Think Why It Should Be So Dull," Journal of Social History 22.1 (1988): 149-161. There is an immense literature on the problem of historical knowledge, on historical objectivity, on the historians' construction of the past, and on the very conception of historical reality independent of contemporary discourse. See Lionel Gossman, "Towards a Rational Historiography," Transactions of the American Philosophical Society 79, no. 3 (1989): 1-68; Carol Ginzburg, "Checking the Evidence: The Judge and the Historian," Critical Inquiry 18 (1): 79-92; Joyce Oldham Appleby, Lynn Hunt, and Margaret J. Jacob, Telling the Truth about History (New York: W. W. Norton \& Company, 1994).

${ }^{94}$ Jeffrey Andrew Barash, "Martin Heidegger in the Perspective of the Twentieth Century: Reflections on the Heidegger Gesamtausgabe," The Journal of Modern History 64, no. 1 (1992): 76.

${ }^{95}$ See Theodore Huters, Bring the World Home: Appropriating the West in Late Qing and Early Republican China. (Honolulu: University of Hawai i University: 2005), 3.
} 
traditional worldview. The old world order, the All under Heaven [tianxia 天下], was-as the widely accepted tenet in modern historiography held-to be replaced by the nation state [guojia 國家]. In trying to determine Chinese-ness-what it meant to be Chinese and what should be excluded - the past was always considered to be a rich legacy that needed to be adapted to the current conditions of the nation in order to create a shared consciousness of belonging. ${ }^{96}$ Therefore, many intellectuals, scholars, and religious believers in modern China, regardless of how practically they were engaged in the present and how much of a utopia they imagined the future to be, always returned to history. To them, writing history was not a purely academic activity, but a choice, or a stand related to politics-to the enterprise of establishing the national identity of China. The reading of Buddhism's past thus had practical implications. Firstly, Buddhism, as an exogenous resource of ideas, was seen by modern Chinese historians as an informative example of indigenization, showing how to use new, non-local theories and concepts to rejuvenate and develop the national spirit. Secondly, the historical process of Buddhist Sinicization proved to be a triumph of Chinese indigenous civilization over foreign intellectual tradition, which could bring about a sense of national pride. Meanwhile, Buddhism was read not only as an active component of Chinese particularity but also as one potential power of social transformation, as the experience of modern Japan had shown. ${ }^{97}$

The political implications behind the modern Chinese historiography of Buddhism suggested a lasting historiographical consciousness - what came after bore the imprint of what went on before. Modern Chinese historians and the Buddhist elite, facing the same situation as their predecessors had faced two millennia before,

\footnotetext{
${ }^{96}$ Tze-ki Hon, "National Essence, National Learning, and Culture: Historical Writings in Guicui Xuebao, Xueheng and Guoxue jikan," in Historiography: East and West, 1.2 (2004), 240-287.

${ }^{97}$ In a recently published collected work on Japanese Buddhism and modern historiography, a group of representative scholars discussed that, in modern Japan, the agenda of the historiography of Buddhism has gone beyond the domain of 'academic historiography' [學術史學]. The same trend has also been observed in modern China. See Orion Klautau ed., Sengo rekishi-gaku to Nihon bukkyō 戦後歴史学と日本 仏教（Tokyo: Hozokan 法藏館, 2016). Also Orion Klautau, Kindainihon shisō to shite no bukkyō shigaku 近代日本思想としての仏教史学 [Buddhist History as Modern Japanese Thought] (Tokyo: Hozokan 法藏館, 2012).
} 
believed that Chinese Buddhism would provide answers about how China could participate in the global conversation between civilizations while maintaining its 'national essence.' Although many of the historians I investigate in this dissertation claimed no political commitments, they all devoted themselves to this enterprise. They were thus not as free as they pretended when thinking of the legacies that they consigned to the past. Based on these general observations, in this dissertation, I examine a few assumptions behind the 'historicized Buddhism' fashioned by modern historiography. However, current scholarship on modern Chinese Buddhism has not paid sufficient attention to the delicate influence of historiographical discourse on people's understanding of Buddhism. The processes by which Buddhism was narrated throughout history as one unit of China's national identity and the ways in which historiography challenged, shaped, and produced knowledge about religion (here Buddhism) still remain unclear. We need, as I propose in this dissertation, to realize that the alleged features of Chinese Buddhism on a doctrinal or practical level bear some resemblance to those features on the historical level. Our understanding of Buddhism can be biased or sectarian, and also can be historical, because all the claimed 'truth' (both religious and historical), which has been denied belonging to any specific place and time, has fundamentally arisen from somewhere at a certain moment. Therefore, Buddhism, whether for historians, clergy, students, or ordinary believers, has always been a tradition handed over from their ancestors but bearing some elements of the present.

\section{Scope and Structure}

The historiography of Buddhism is at the disposal of 'historians,' which literally means people who study and write histories. However, in this present case, further categorization is required. Professional historians and amateur historians would be a primary division; Buddhist scholars and non-Buddhist scholars would be another. Both of these divisions are clear enough but oversimplified. To avoid the pitfall of typology, some clarification of the variance among different research camps needs to be made. 
Certainly, history can be written by anyone: academics, dilettanti, storytellers, religious pundits, and so on. As many scholars have analyzed, historiography in modern China moved from the court or the emperor's study to universities and academic institutions, and from history officers to professors. ${ }^{98}$ Knowledge about Buddhism's past was previously exclusively kept by the monasteries. Historical sources were mainly preserved in the sutra repository of temples and only a few educated monks had the permission and ability to access them. However, because of the emergence of lay Buddhism, the monastic monopoly on religious knowledge was overcome as early as in the Late Ming era. ${ }^{99}$ In modern China, this trend became more intensive. Later, modern Buddhist scholarship emerged in Europe and was soon introduced into China, with methodologies designed to analyze religions by means that differed from prior Buddhist confessional, theological norms. ${ }^{100} \mathrm{~A}$ difference between the theology of Buddhism and the historiography of Buddhism gradually opened up.

\footnotetext{
${ }^{98}$ For a discussion of the formation of modern academic disciplines in China, see Luo, Zhitian 羅志田, “Xixue chongji xia jindai Zhongguo xueshu de yanbian 西學衝擊下近代中國學術的演變” Shehui kexue yanjiu 社會科學研究 1 (2003): 107-114; Hou, Yunhao 侯雲影, “20 shiji Zhongguo shixue de xuekehua jincheng 20 世紀中國史學的學科化進程”, in Shixue yuekan 史學月刊 5 (1999): 90-97.; Liu, Longxin 劉 龍心, Xueke yu zhidu: xueke tizhi yu xiandai Zhongguo shixue de jianli 學科與制度: 學科體制與現代中國史 學的建立 (Taipei: Yuanliu, 2002) and Essays in Moloughney and Zarrow, Transforming History: The Making of a Modern Academic Discipline in Twentieth-Century China.

${ }^{99}$ Goossaert and Palmer, The Religious Question in Modern China, 35-36. Liu Chengyou 劉成有 showed clearly the contributions made by committed lay believers to Buddhology in his Jinxiandai jushi foxue yanjiu 近現代居士佛學研究 (Chengdu, Bashu shushe, 2002). For the historical origins of Anticlericalism, see Ch'en Kenneth, “Anti-Buddhist Propaganda During the Nan-ch'ao," Harvard Journal of Asiatic Studies 15.1-2 (1952): 166-192; Zürcher, The Buddhist Conquest of China., 254-285; Sylvie Hureau, "L'apparition de thèmes anticléricaux dans la polémique anti-bouddhique médiévale," Extrême-Orient Extrême-Occident 24 (2002).17-29.

${ }^{100}$ An analogical example is eighteenth-century Germany, where the biblical criticism conducted by secular scholars horrified many churchmen. See T.A Howard, Protestant Theology and the Making of the Modern German University (New York: Oxford University Press, 2006); W. Clark, Academic Charisma and the Origins of the Research University (Chicago, University of Chicago Press, 2006), chap.7.
} 
The development of the modern historiography of Buddhism prompted the difference of "the insider/outsider," as pointed out by Russell McCutcheon. ${ }^{101}$ The 'outsider' is the academic scholar who studies another's religion or studies religion as an 'other,' while the 'insider' studies his/her 'own' religion. The personages discussed in this dissertation consist of both 'outsiders' and 'insiders.' In the outsiders, I include a group of professional historians who had no Buddhist faith and limited contact with Buddhist communities but demonstrated different historiographical stands-Liang Qichao, Hu Shih, Chen Yinke, Tang Yongtong, and Chen Yuan; the 'insiders' refer to scholarly samgha and lay Buddhists, especially Taixu and Lü Cheng, who represent two conflicting attitudes within Buddhist communities. In this study, more emphasis will be placed on the former group, for their contribution of providing challenging, controversial, and groundbreaking ideas to the historical writing of Buddhism. The latter group will also be analyzed as a valuable comparative reference.

There are, of course, atypical examples, such as Liang Qichao, who stood both outside and inside of religious belief, and there were also sub-camps within the believers, for example, those of clergy and laymen. However, the divergence between insiders and outsiders is significant. The insiders' history usually seems drawn to presenting a picture that is universally and eternally true and rejecting acknowledgment that the truth may vary from time to time or place to place. By contrast, a historian is accustomed to making relative statements. Doctrinal terms, such as karma, interdependence, causality, and the Vinaya codes are much less important for historians. Instead, 'relative' questions, such as the relationship between Buddhism and other cultural, political, and social factors, are more crucial for the academic historiography of Buddhism.

The issue, however, is not simply whether an outsider's critical findings accorded or should have accorded with the self-representations of the religious insider, but how this critical, secular, and othering interpretation of Buddhism

\footnotetext{
${ }^{101}$ Russell T. McCutcheon “'It is a Lie. There's No Truth in It! It's a Sin!" Journal of the American Academy of Religion, 74.3 (2006): 720-750; Also see José Ignacio Cabezón, "The Discipline and its Other: The Dialectic of Alterity in the Study of Religion," Journal of the American Academy of Religion 74, no. 1 (2006): 21-38.
} 
formed in a modern context and how this kind of interpretation should be understood. How can a 'secularized' history get into the world of Buddhism, a world cultivated by an 'ahistorical' religious worldview? Was the investigation of historiography valuable or provocative for the insiders? How did historical knowledge negotiate with religious commitments and how has this benefitted a modern understanding of Buddhism? And why were religious changes in China's past, as discovered and recovered by historians, so crucial for modern China? As Schleiermacher has stated, "history [is] always religious and religion [must] be essentially historical"102; these questions, therefore, generalize the historiography of Buddhism into a broad discursive field, bridging its two wings of the historiographical path and doctrinal concern.

My dissertation explores, albeit in a piecemeal fashion, the emergence of the modern historiography of Buddhism in early twentieth-century China and seeks to recover the half-forgotten venture towards a modernized Chinese Buddhology. Falling roughly in the purview of the 'modern age,' this study covers a more particular timespan: from 1902, when Liang Qichao discussed Buddhism in Chinese intellectual history for the first time in his booklet Dashi, to 1965, when the Seminar of Buddhism in Nanjing founded by Lü Cheng was closed down and other Buddhist academies stopped their teaching and research activities in succession. ${ }^{103}$ Focusing on how the historiography of Buddhism emerged in modern times and how it discursively shaped 'Chinese Buddhism,' the following chapters are divided into two parts: the first two chapters explore the intellectual background and conceptual context of the historiography of Buddhism: how modernity influenced both history and religion discursively in the early twentieth century and further incited the emergence of the historiography of Buddhism. The five chapters in the second part

\footnotetext{
${ }^{102}$ Friedrich Schleiermacher, Bruchstücke der unendlichen Menschheit, Fragmente, Aphorismen und Notate der frühromantischen Jahre, K. Nowak ed., (Berlin: Union Verlag Berlin, 1984), 51.

${ }^{103}$ This, not exactly in accordance with historians' convention of the 'modern age,' is defined by the actual development of the research agenda rather than a political based periodization. Some works published after 1965, for example, Lü Cheng's two general history of Indian and Chinese BuddhismZhongguo fojiao yuanliu luejiang 中國佛教源流略講 and Yindu fojiao yuanliu luejiang 印度佛教源流略講, would not be excluded from this study.
} 
investigate, firstly, the major content and achievements in, as well as some theoretical and methodological features of, this research area, and secondly, some core issues and tendencies behind the writing of the history of Buddhism. In the concluding part, I will discuss and evaluate the limitations and influence of the historiographical path in Buddhology.

The first part of my discussion refers to the transforming discursive space within which the new historical views and religious attitudes emerged. The dramatic changes in the domain of historiography and in the Chinese religious landscape laid the groundwork for the academic legitimization of interpretations of Buddhist history. In the first chapters, I contextualize the emergence and development of the historiography of Buddhism by laying out some historical movements and conceptual changes.

In Chapter 1, I discuss the changing conception of 'history' in the Chinese context-from the ahistorical cosmology of Buddhism to premodern Confucian historiography, and onwards to the modern historical view imported from the West. This reappraisal took place within a vastly expanding intellectual realm, one just like that of early medieval China when Buddhism entered the country. As the twentieth century began, the historiography of Chinese Buddhism saw a transformation caused by the Western framework for ordering the 'national past' as part of world history, especially through progressivism and historicism. Changes at three levels triggered the emergence of the historiography of Buddhism: methodologically, modern historiography maintained, or upgraded, history as an epistemological ground of knowledge; institutionally, historiography was professionalized and gained its independence as a modern discipline; conceptually, it provided new perspectives for re-shaping a continuity in traditions and establishing the national identity of China. These tendencies, as Partha Chatterjee has argued, were "for a regeneration of the national culture, adapted to the requirement of progress, but retaining at the same 
time its distinctiveness." ${ }^{104}$ In this way, Buddhism became an important object of historiography.

Chapter 2 focuses on the equally significant transformation of 'religion [zongjiao 宗教].' Assuming the narrative of the 'invention' of religion is correct (and it probably is), I begin this chapter by tracing how the combined neologism zongjiao was invented as a modern notion. In the modern Chinese intellectual realm, the term 'religion' was defined by the dual yardsticks of science and 'superstition' [mixin 迷 信]. Although Buddhism in premodern times used to be controlled or even banned as heterodoxy [yiduan 異端] by officialdom, beginning with the revival of Buddhism in the modern era, it gained its legitimacy both due to an engaged model of Buddhist modernization and to historiographical interpretations. As I will show in this part, a complex mechanism with particular socio-political conjunctions led to a failure of the engaged Buddhism and furthered the path of Buddhist nationalism; the historicization of Buddhism, however, provided the Chinese with a perspective for understanding the historical manifestations of Buddhism and reflecting on its future.

In the second part of this dissertation, I move to an empirical level, taking a closer look at the inner variance within the modern historiography of Buddhism. In the third chapter, I initially examine the scholarly environment of the emergence of the historiography of Buddhism, including the influence from Europe and Japan. Then I draw a few portraits of relevant personae across the modern/traditional spectrum, from their education background to their academic interests, and document their representative contributions.

Despite the apparent difference and temporal separation between history and religion, the transference of 'truth' and 'faith' and the reciprocal relationship between 'China' and 'Buddhism' will be discussed in Chapter 4 to Chapter 7 through four cases. Each case represents one facet of the overall framework consisting of modernity, identity, religion (faith), and history.

\footnotetext{
${ }^{104}$ Partha Chatterjee, Nationalist Thought and the Colonial World: A Derivative Discourse? (London: Zed Books, 1986), 2.
} 
It might be surmised that something fundamentally new emerged in the historiographical tradition of Buddhism, and this watershed was marked by modern signatures on the writing of Buddhist history. This turn, which occurred in the 1900s, is the subject of the fourth chapter-the encounter between modernity and the writing of Buddhism. The concepts of linear history and evolutionism were two of the significant factors that became the dominant logic for historical interpretations. However, this progressivist paradigm ${ }^{105}$ was criticized by several modern intellectuals who referred to the concepts of interdependence, graduality, and causation, which were based on Buddhist concepts such as karma. Liang Qichao and Taixu are two examples who represent how modern Chinese tried to construct the history of Buddhism by borrowing from evolutionary theory and how they responded to the paradoxes and dilemmas caused by the contradictions between this modern theory and Buddhism.

After examining the adoption and regeneration of the historiography of Buddhism on the level of historical concept, in the fifth chapter, I focus on the relationship between the historiography of Buddhism and people's understanding of Buddhism. Using historiographical methodology to break the canonical orthodoxy of Buddhist texts, the modern historiography of Buddhism, as I show, returned to the 'truth' of Buddhism, using historiographical methods to re-discover the facts about Buddhism from textual sources. Further, the textual criticism based on historical material went beyond the domain of methodology and demonstrated a deep conflict on the issue of 'objectivity,' touching upon the fundamental tension between ahistorical religious essence and historized truth. With this concern in mind, in this chapter I sketch the development of the renewed scholarship of textual criticism from the tradition of Evidential Learning in the Late Qing era to the Doubting Antiquity School, and further examine three examples-the modern reading of the Sūtra of Forty-Two Chapters [Sishier zhangjing 四十二章經], the debates surrounding the

\footnotetext{
${ }^{105}$ For other paradigms of modern Chinese historiography, see Huaiyin Li, Reinventing Modern China: Imagination and Authenticity in Chinese Historical Writing (Hololulu: University of Hawai' $i$ Press, 2013).
} 
Treatise on Awakening Mahāyāna Faith [Dasheng qixinlun 大乘起信論], and Hu Shih's interpretation of Chan Buddhism.

In Chapters 6 and 7, I explore how political concerns, especially the issue of identity, intertwined with historians' reflections on both history and religion through their writing of the history of Buddhism. I shed light upon the issue of the very nature of 'Chinese Buddhism' and a relevant and essential question: what is, fundamentally, the real relationship between Chinese Buddhism and its Indian origin? This question is what I see as a crucial concern behind the writing of the history of Buddhism in modern China. Instead of answering this question directly, I examine the responses that we can read from modern writing on the history of Buddhism and analyze these texts as 'the history of effects,' in Gadamer's sense. ${ }^{106}$ In Chapter 6, I focus on the side of historical truth, namely, how historians reconstructed Buddhism in China's past through re-narrating Buddhism into Chinese national history. Taking Chen Yinke and Tang Yongtong's critical interpretations of "matching concepts" [geyi 格義] as an example, I investigate how these two historians understood the influence of Buddhism on Chinese culture and scholarship from the perspective of intellectual history and how they reflected on transcultural communication in Chinese history through the history of Buddhism.

The plurality and estrangement embodied in the modern Chinese historiography of Buddhism is representatively shown in Chapter 7 in the divergent opinions on the issue of the Sinicization of Buddhism. In this part, I enumerate different opinions about the formation of 'Chinese Buddhism,' such as the early transmission of Buddhism into China, the definition and character of 'Chinese Buddhism,' the relationship between Buddhism and local culture, and the general influence of Buddhism on Chinese history. Based on these discussions, I suggest that historians and Buddhist scholars utilized historiography to discover the "Chineseness' of Buddhist tradition. This last chapter serves both to summarize this study and

\footnotetext{
${ }^{106}$ The term 'the effect of history' I use here is derived from Gadamer's 'effective history,' which involves a relationship of past and present in which the past constitutively determines the present through an interplay by bringing its tradition to bear upon it. See Gadamer, Truth and Method, 300.
} 
to sketch the beginning of a potential future inquiry into the question of how Chinese Buddhism could be understood and expressed in a time when almost all the models, paradigms, tracks, and claimed truth received by historians from both their ancestors and the West were turning out to be problematic.

In general, scholars involved in the academic trend of the historiography of Buddhism were encamped separately and loosely, due to the divergence of their professional orientations and religious tendencies. Also, the abstract presuppositions behind religion and history caused these scholars to reconsider their own positions constantly, although these presuppositions seldom allowed them to switch between camps (Liang Qichao might be an exception). ${ }^{107}$ Therefore, this study does not consist of a batch of academic biographies or a typological study of certain figures, but rather is a reflective narration of academic history that consists of several interrelated, contradictory voices; each voice presents one facet of the interwoven phenomenon that includes religious faith, historical knowledge, political orientation, and contemporary issues.

\footnotetext{
${ }^{107}$ As Chang Hao suggested when discussing the writing of the history of Buddhism, the instability of positions and camps indicates the 'transiting' characteristics of modern intellectuals.
} 


\section{PART I}

Transforming Discourses: History and Religion 


\section{CHAPTER 1}

\section{The Past in Time: Buddhism, History, and Historiography}

Buddhism has its history. This statement, which seems almost a truism, however, is very modern. Admittedly, in different Buddhist traditions, historical writings, not only in chronicle form but also in the form of sectarian stories, doctrinal bibliographies, gazetteers, biographies of monks, and so on, were created for centuries. ${ }^{108}$ However, due to the particularity of diverse genealogies, lineages, and differing spiritual authority, none of these historical writings became a universal pattern or was categorized under the rubric of 'history' in a modern sense. ${ }^{109}$ It is only at the beginning of the twentieth century under the influence of Qing learning and Western theories and methodologies, that historians began to narrate the history of Buddhism within the framework of modern scholarship.

\section{Historical Narratives in Buddhist Traditions}

A historical character, nevertheless, could be observed in these ancient practices, although 'secular,' dynastic historical time conflicts in some fundamental ways with the cosmological time of Buddhism. In most cases, traditional Chinese Buddhist historiography was a constructed narrative relying on local cultural forces-which might be shared by other religious or non-religious traditions-rather than an

\footnotetext{
${ }^{108}$ Timothy Barrett, "History," in Critical Terms for the Study of Buddhism, ed. Donald S. Lopez Jr. (Chicago: The University of Chicago Press, 2005), 124.

${ }^{109}$ According to the research of some scholars, given the strong Chinese penchant for historical studies, the Chinese word "history" occurs somewhere in some Buddhist texts; the dictionary yields no useful equivalent in an Indian language. See Hirakawa Akira, A Buddhist Chinese-Sanskrit Dictionary (Tokyo: The Reiyukai, 1997), 237.
} 
account based on the nature of Buddhism itself and its primary concerns with time and space.

\section{The Buddhist Concept of History}

In the worldview of Indian Buddhism, the condition of life and the essence of existence is ultimately transient, evanescent, and inconstant, and hence involves suffering [duhkha]. The Buddha, according to the early ägama canon, insisted that the beginning [ana-varāgra] of the world process [samsāra] is totally inconceivable [anamatagga]. ${ }^{110}$ Nevertheless, it is possible to see periods of evolution [vivatta] and dissolution [samvatta] following one another. ${ }^{111}$ These periods are reckoned in terms of aeons [kalpa], each of which is said to be of such immense duration that it can only be illustrated by means of a simile. One simile was Buddha's answer to the questions about the beginning and end of time posed by monk Mālunkyāputta:

Suppose there was a great mountain of rocks, seven miles across and seven miles high, a solid mass without any cracks. At the end of every hundred years, a man might brush it with a fine Benares cloth. That great mountain of rock would decay and come to an end sooner than ever the aeon. So long is an aeon. And of aeons of this length not just one has passed, not just a hundred, not just a thousand, not just a hundred thousand. ${ }^{112}$

This passage indicates that time is immense and out of the realm of the six senses. In the Abhidharma tradition, both Theravādins and Sarvāstivādins described the world as thrice-thousandfold world-spheres [cakra-vāda] driven by saṃsāra. It is a world

\footnotetext{
${ }^{110}$ For example, see Samyutta Nikāya, ed. Leon Feer (London: PTS, 1884-1904), i.178 ff; and Sāratthappakāsini, ed. F. L. woodward (London: PTS 1929-1937), ii. 156, anamattaggo aviditaggo. Later Mahāyāna disciples maintained that there is no beginning. See Mūlamadhyamakakārikās des Nāgârjuna, avec la prasannapadā commentaire de Candrakīrti, publié par Louis de la Villée Poussin (St. Petersburg: Academy of Sciences of USSR, 1903-1913), xi, 1. Also see David J. Kalupahana, “The Buddhist Conception of Time and Temporality," Philosophy East and West 24, no. 2 (1974): 181. ${ }^{111}$ The Dīgho Nikāya, ed. T. W. Rhys Davids and J. E. Carpenter (London: PTS, 1890-1911), iii.84-5; Taishō, i.37b-c.

${ }^{112}$ Taishō ii. 242a-243b. Translation quoted from the foundation of Buddhism, Rupert Gethin, The Foundations of Buddhism (Oxford: Oxford University Press, 1998), 113.
} 
without spatial limitation and is divided into a hierarchy consisting of thirty-one realms in which devas, Mara, Brahmas, human beings, and demons are living. In the world-spheres of human beings, the great mountain Meru or Sumeru is in the center, surrounded by seven concentric mountains and seas. Beyond those mountains and seas are four continents, among which the southern continent, Jambudvipa, is the place inhabited by ordinary human beings.

The world in Buddhism is not a static system but rather exists in ceaseless expansion and contraction. Cosmological time in Buddhism is measured by kalpa. According to the the Sarvāstivāda texts, time in the Buddhist world is moving in circles, going through a temporal and repeated progress of four stages: the nascent [jāti, cheng 成], the static [sthiti, zhu 住], the decaying [jarā, huai 壞], and the cessant [nāsa, kong 空] ${ }^{113}$ Every big kalpa will end with a universal destruction caused by the natural forces of fire, water, and wind that sweep across the lower realms of dhyāna. ${ }^{114}$ Only the devas and gods in superior world-spheres can escape from the destruction and finally enter into the process of nirvana. At the end of aeons, there is no 'Savior' or 'Messiah' who leads all the suffering beings to salvation, as promised by the JudeoChristian tradition, but a fire from hell that burns up everything; afterwards all beings are reborn in the ashes and the wheel of saṃsāra continually moves again.

The concepts of time and space in Buddhist thought went through several changes from early Buddhism to Abhidharmma scholasticism on to the Mādhyamikas. In the doctrines of early Buddhism, the recognition of time is derived from the finite segment grasped by the six senses. Time and causation, therefore, are empirical and relativistic; they exist in the immediate experience. ${ }^{115}$ However, after the Buddha passed away, Abhidharmma scholasticism developed a more metaphorical idea about time. In this tradition, time is analyzed into atomic units that are considered absolute

\footnotetext{
${ }^{113}$ Abhidharmadipa, ed. P. S. Jaini (Patna, K. P. Jayaswal Research Institute, 1959), 104. In other traditions, there are different divisions. For example, post-Buddhaghosan Theravāda recognized three: the nascent (uppāda), the static (thiti), and the cessant (bhaniga). See Sammohavinodani, ed. A. P. Buddhadatta Thero (London: PTS, 1923), 7.

${ }^{114}$ Robert E. Buswell, Encyclopedia of Buddhism (New York: Macmillan Reference USA, 2004), 185.

${ }^{115}$ see The Digha Nikāya, ed. T W Rhys Davids; J Estlin Carpenter (London, PTS, 1890-1911), iii 84-5.
} 
and real. These units move fleetingly from the future into the present and from the present into the past; only the very moment is real. In this view, the division between past, present, and future rests totally on the basis of moments [khanena paricchinna], which are isolated and discontinuous. ${ }^{116}$

The most influential theory about time in the Chinese Buddhist tradition comes from the Mādhyamika school. In the Mūlamadhyamakakārikā [Zhonglun 中論, Nāgārjuna 龍樹 (c.150 - c.250 CE) contested the Sarvāstivādā cosmological conception by denying reality and the existence of time. Based on the fundamental assumption that things are coexistent, dependent, and related, he argued that there is no past without a future, and there is also no future without a past. In the Mahāprajñāpāramitopadeśa [Dazhidu lun 大智度論], he argued:

If the three times each had their own characteristics [svalakșana], they would always be 'present' and there would be neither past nor future. If the future existed presently, it would not be called 'future' but indeed 'present'. ... If the past has 'passed,' it loses the nature of the past; if the past has not 'passed,' it does not have the nature of the past. ${ }^{117}$

According to Nāgārjuna, the recognition of the past, present and further are unjustified. Time is non-enduring, non-static, and unmeasurable. To clarify the misunderstandings in the thoughts expressed in the Upanisads and Jainism, he used the term samaye [sanmoye 三摩耶] instead of kāla [jialuo 迦羅] to criticize the conceptual realism of time and claimed that the term 'time' was just an expedient, or 'fake name' [prajbapti, jiaming 假名]. Further, he argued that other relevant categories of temporality are also just unwarranted interpretations based on language usages. Hence, in Nāgārjuna's concept, time does not exist [shifa wushi 時法 無實] ${ }^{118}$

\footnotetext{
${ }^{116}$ see Kalupahana, "The Buddhist Conception of Time and Temporality," 184-85.

${ }^{117}$ Mahāprajñāpāramitāśāstra, trans. Étienne, Lamotte, translated from French to English by Gelongma Karma Migme Chodron, 2001, chapter ii, p.82. In this treatise, Nāgārjuna dedicated one chapter to discussing the issue of time.

${ }^{118}$ Da zhidu lun, CBETA, T25, no. 1509. 65c11
} 
By criticizing time and causation in the phenomenal world as 'fallacies' [mithyā-drsti, xiejian 邪見], Nāgārjuna actually called into question the legitimacy of history. Because the past cannot exist without the present and the future, therefore, if the past is past, then it is always extinct; if it is not past, then it does not have the character of pastness. ${ }^{119}$ In this view, in the cycling round of rebirth-the uncertain, unstable, and unreal world without 'time'-history is fundamentally meaningless and illegitimate: it is neither the trustworthy record of the past nor the description of any cosmic order. The universe of Buddhism places its entirety totally in itself, without beginning and end, and thus has no history. The narrative of time only exists in conceivable experience as a matter of one single moment [kșana, shana 刹那], which is a microcosm of the cosmos at large. Human agency, trapped in the eternal suffering of samsāra, is also expelled from the passage of time. Hence, time itself, in the form of past, present, and future, cannot be understood, grasped, or recorded. ${ }^{120}$ The very format of the historical writing in Buddhist texts-the use of the term "when," which is mostly an equivalent to the conditional particle "if"-indicates that what happened in the past is unreachable, unpredictable, and indescribable; it is not even an absolute reality. ${ }^{121}$

\footnotetext{
${ }^{119} \mathrm{Ibid}$. See also K Venkata Ramanan, Nagarjuna's philosophy: as presented in the Maha-PrajnaparamitaSastra, vol. 6 (Motilal Banarsidass Publ., 1987), 197.

${ }^{120}$ In Buddhism, time is inherent in discrete factors that therefore must have a continuous essence (dravya), stretching from the past, over the present, to the future. In this sense, the 'temporality' of discrete factors is superimposed by a subjective observer. In Buddhist vocabulary, this is expressed in the concept of the "characteristic marks of the conditioned" (samskrta lakșana): birth (utpāda), change in continuance (sthityanyathātva), and passing away (vyaya). As Sinha $(1983,85)$ remarked, "It is not the reality of past, present, and future as three points of time that is posited by Mahāvibhāṣā; rather, it is the reality of things or dharmas as past, present, and future that is admitted here." Braj M. Sinha, Time and Temporality in SāmkhyaYoga and Abhidharma Buddhism (New Delhi: Munshiram Manoharlal Publishers Pvt. Ltd, 1983), 85; See also Kuala Lumpur Dhammajoti, Sarvāstivāda Abhidharma (Hong Kong: Centre of Buddhist Studies, the University of Hong Kong, 2009), 117-19.

${ }^{121}$ For further studies on the Buddhist concept of time, see Shoson Miyamoto, "Time and Eternity in Buddhism," Journal of the American Academy of Religion XXVII, no. 2 (1959): 118-26. Also, K. Inada Kenneth, “Time and Temporality, a Buddhist Approach." Philosophy East and West 24.2 (1974): 171-79; Bart Dessein, "Time, Temporality, and the Characteristic Marks of the Conditioned: Sarvāstivāda and Madhyamaka Buddhist Interpretations." Asian Philosophy 21.4 (2011): 341-60.
} 


\section{Traditional Buddhist Historiography in PreModern China}

Although Buddhism's understanding of history is complicated and ambiguous, narratives about the past were scattered throughout the early Buddhist literature in sūtras, monastic regulations, ritual descriptions, and doctrinal interpretations [jingjie 經解]. In particular, hagiographical accounts of Buddhist figures widely contributed to different Buddhist traditions. ${ }^{122}$ Terms meaning 'history' also appeared in places in Buddhist texts, although even inveterate recorders of history such as the Chinese have seldom considered these stories to be history.

In the Chinese tradition, the historical narratives about Buddhism, produced by monks, history officers, and some literati, were never categorized into the "branch of history' [shibu 史部] according to the traditional standard-'The Four-Branch Classification' [sibu fenlei fa 四部分類法] that divides literature into Classics [jing 經], History [shi 史] $]^{123}$, Master [zi 子], and Collections [ji 集]. Until the Late Qing dynasty, there was still no clear category for religious literature in any large collections of books. For example, in the Siku Qushu 四庫全書, edited during the period of Emperor Qianlong 乾隆, texts about Buddhism and Daoism were mainly collected into the group of 'masterworks'; in Huangchao jingshiwen bian 皇朝經世文編, edited by He Changling 賀長龄 (1785-1848) and Wei Yuan 魏源 (1794-1857), texts related to religious belief were classified as 'customary' [fengsu 風俗]. As shown by these examples, the traditional historical writing of Buddhism, although it sometimes presented itself in the form and style of 'history,' was still not strictly regarded in the traditional knowledge system as 'history. ${ }^{124}$

\footnotetext{
${ }^{122}$ For example, the biographies of Aśvaghosa, Nāgārguna, and Vasubanghu. See John Kieschnick, "Buddhism," in The Oxford history of Historical Writing (Oxford University Press, 2017), 535.

${ }^{123}$ Originally, the meaning of shi in the Chinese context refers to a history officer; lishi means 'the history of dynasties' [歷代之史]. In this sense, traditional historical writing on Buddhism can hardly fit this definition. For the change in the concept of history, see Masayuki Sato 佐藤正幸, Lishi renshi de shikong 歷史認識的時空 (Shanghai: Sanlian shudian, 2019), 4, footnote 1.

${ }^{124}$ In the Chinese traditional context, however, there was not a fixed definition of shi. As François Jullien argued, shi can be translated as 'position' or 'circumstances,' and at other times as 'power' or
} 
This absence of Buddhism in the 'branch of history' was attributed by some modern scholars to the innate deficiency of historical consciousness in Indian culture. For example, Liang Qichao mentioned in his article "A General Overview of Indian Buddhism" disappointedly that "Indian people are lacking in historical thinking, so that there is even not a single credible history to provide [us] any basis"; ${ }^{125}$ other scholars, such as Jiang Weiqiao 蔣維喬 (1873-1958) and Tang Yongtong, made similar statements. ${ }^{126}$ However, it should be acknowledged that a strong penchant for writing and recording the past had infiltrated the Chinese Buddhist tradition: the historicity in Chinese Buddhist accounts was indisputable; this tradition also encompassed a variety of historiographical formats, including histories of monasteries, the bibliographies of Buddhist scriptures, the stories of Buddhist figures, and the chronologies of events. Such historiographical touches in these traditional writings, although more or less in keeping with the genre of Indian Buddhist literature, owed much more to the native historiographical conventions of pre-Buddhist China in terms of style, content, framework, and the standard for the selection of historical materials. They were fundamentally the outcome of the local historiographical culture, especially the historiographical tradition of shi 史, which related to Confucian discourses. ${ }^{127}$

The earliest credible textual records of Buddhism in Chinese history can be found in the Hou Hanshu 後漢書 compiled by Fan Ye 范瞱 (398-445). He recorded two events that both happened in A.D 65 (the eighth year of Yongping 永平): the Buddhist worshipping of King Ying 英 of the Chu kingdom ${ }^{1}{ }^{128}$ and the famous story of the

\footnotetext{
'potential.' See François Jullien, The Propensity of Things: Toward a History of Efficacy in China, Janet Lloyd trans, (New York: Zone Books, 1999).

${ }^{125}$ Liang Liang Qichao, “Yindu fojiao gaiguan 印度佛教概觀, ” in Foxue yanjiu shibapian 佛學研究十八篇 [SBP] (Shanghai: Shanghai guji chubanshe, 2011), 40.

${ }^{126}$ Yongtong Tang, “Yindu zhexue jiangyi 印度哲學講義,” in TYQJ, (Shijiazhuang: Hebei renmin chubanshe, 1999), 189. Jiang Weiqiao, Zhongguo gojiao shi 中國佛教史 (Shanghai: Shanghai renmin chubanshe, 2007), 1.

${ }^{127}$ For an overall study on Chinese Buddhist historiography, see the unpublished work of John Kieschnick, Buddhist Historiography in China, forthcoming.

${ }^{128}$ Fan, Ye 范瞱, Hou Hanshu, vol.42.
} 
dream of Emperor Ming of the Later Han dynasty. ${ }^{129}$ These two stories were widely accepted and valued by Buddhist historians as authentic and credible descriptions of the beginning of Chinese Buddhism.

Stories about the earliest stage of Chinese Buddhism, which were originally vague and mythical, went through a process of 'narrativization.' They ceaselessly gained detail and were developed into coherent, embellished, plotted texts. The later Buddhist historical narratives, although produced in an era that was further away from the time the events they described actually happened, continued to accumulate detail in their content. This strategy was considered a solution to the problem of the inevitable loss of textual records and physical evidence. By adding detail, Buddhist historians were able to fill the gaps within the timeline of their narratives, compensating for the shortage of historical materials and making their writings easier to transmit and to be accepted by their audience. Therefore, these narratives were produced by intentional behavior that was motivated both by a religious imperative to persuade believers and a responsibility to tell the claimed 'true' version of a story.

To a large extent, traditional Buddhist narratives are a kind of literature that combines imagination with authentic facts, namely, a hybrid in which miracle tales, oral accounts, records of inscription, and archives were utilized without division. When compiling histories, Buddhist historians were accustomed to patching together different sources into a single narrative or account, and did not waver before the fragile balance between truth and faith like their modern counterparts. The 'histories' that they formulated about Buddhism's past were 'real' to them. The credibility of these traditional writings, however, seemed very tenuous under the scrutiny of modern scholarship. To modern readers, these writings were splendid sources of historical data but meanwhile were highly suspect because of their mixed content of facts filled in with imaginative deductions. Nevertheless, Chinese historical narratives of Buddhism still could be counted as the most systematic and

\footnotetext{
${ }^{129} \mathrm{Ibid}$, vol.2.
} 
advanced records in the premodern Buddhist world, not only because of their wideranging content but also because of their various formats and genres.

Most of the traditional historical writings are collected in the Xuzangjing 續藏 經, which contains around 200 volumes. The predominant form of these writings is biography, especially hagiographical accounts of eminent monks. ${ }^{130}$ However, texts about the history of Buddhism demonstrate diversity and flexibility and were composed to fulfill different requirements. This phenomenon caused huge difficulties in categorization when modern scholars tried to analyze them thoroughly and comparatively.

Some scholars arranged Chinese Buddhist historical literature into categories borrowed from Confucian historiographical tradition. ${ }^{131}$ However, this categorization sometimes led to overlapping sub-catagories and confused frameworks for quoting standards based on content and on format at the same time. Chen Yuan, the first scholar in modern China who conducted systematic studies of Buddhist literature, provided a comparatively reasonable classification by only referring to the contents of the texts ${ }^{132}:$ 1) biographies, including the biographies of monks, nuns, and other Buddhist figures ${ }^{133}$; 2) bibliographies, which focus on recording the origin, version, content, translation, and contribution process of Buddhist scriptures, as well as other

\footnotetext{
${ }^{130}$ See Kieschnick, “Buddhism,” 536.

${ }^{131}$ For example, Lan Jifu 藍吉富 classified Buddhist historical writings into nine categories: 1. biographies; 2. annuals; 3. histories in annual-biography form; 4. institutional history [會要]; 5. eventbased records [jishi benmo ti 紀事本末體]; 6. bibliographies; 7. histories of sects; 8. specialized history; 9. historical manual books; this catalogue, however, ignored the characteristic of Buddhist historical materials and overlooked the Buddhism-related texts in the official histories. See Lan Jifu. Fojiao shiliao xue 佛教史料學 (Taipei: Dongda tushu gufen youxian gongsi, 1997).

${ }^{132}$ Yuan Chen, Zhongguo fojiao shiji gailun 中國佛教史籍概論 (Shanghai: Shanghai shudian, 2005).This book was compiled based on Chen's early lecture notes and was published in 1962 by Zhonghua Shuju 中華書局. For a critical review of this book, see Cao Shibang 曹仕邦, “A Study Of Ch'en Yuan's Chungkuo fo-chiao shih-chi kai-lun 論陳垣中國佛教史籍概論, ” Chung-Hwa Buddhist Journal, no. 3 (1990): 261300 .

${ }^{133}$ The most representative works in this category are Huijiao's 慧皎 (497-554) Gaoseng Zhuan 高僧傳 and the two works that continued this tradition: the Xu Gaoseng Zhuan 續高僧傳 complied by Daoxuan 道宣 (596-667) in the seventh century and the Song Gaoseng Zhuan 宋高僧傳 compiled by Zanning 贊寜 (919-1001).
} 
general information, such the date, author, and volume $\left.{ }^{134} ; 3\right)$ histories of sects and lineages, which are dedicated to establishing the orthodoxy of particular schools or sects as well as recording the activities and sayings of the Buddhist masters properly according to a lineage of transmission ${ }^{135}$; 4) catalogues of collections of Buddhist historical texts ${ }^{136}$; 5) historical phono-semantic books, which trace the long-term historical development of certain language usages in Buddhist texts and provide references to the sounds and meanings of Buddhist terms by quoting numerous Buddhist allusions both from scriptures and other branches of Chinese literature. ${ }^{137}$

On the one hand, traditional Buddhist historical writings obviously often share features with the Chinese historiographical tradition, especially the genre and format of the official dynastic histories. The two general histories written by the monks of the Tiantai school, Shimen zhengtong 釋門正統 and Fozu tongji 佛祖統紀, for example, replicate the annual-biographical format of the official histories in their narratives. This framework consists of 'basic annuals' [benji 本紀], 'hereditary houses' [shijia 世家], 'ranked biographies' [liezhuan 列傳], 'treaties' [zhi 志], 'tables' [biao 表], etc. ${ }^{138}$ Other historical writings, such as the Gaosengzhuan, follow the style of earlier non-Buddhist historical works, especially Shiji 史記 and Hanshu 漢書, using commentaries-both eulogies [zan 贊] and disquisitions [lun 論]-at the end of each biography to praise and blame historical figures' behaviors and actions.

\footnotetext{
${ }^{134}$ The most valuable works contain the Chu sanzangjiji 出三藏記 complied by Seng You 僧祐 (445518); Lidai sanbao ji 歷代三寶記 complied by Fei Zhangfang 費長房 (?); and Kaiyuan shijiao lu 開元釋教 錄 compiled by Zhisheng 智昇(?).

${ }^{135}$ For example, Denglu 燈錄 compiled by the Chan school and Fozu tongji 釋門正統 and Shimen zhengtong 佛祖統紀 compiled by the Taitai school.

${ }^{136}$ The most important and well-known works are Hongming ji 弘明集, Daoxuan’s Guang Hongming ji 廣 弘明集 and Daoshi's 道世 (?-683) Fayuan Zhulin 法苑珠林.

${ }^{137}$ Two representative books in this group are Yiqiejing yinyi 一切經音義 by Hui Lin 慧琳 (733-817) and Xu yiqiejing yinyi 續一切經音義 by Xilin 希麟 (?).

${ }^{138}$ Shimen zhengtong recorded the Buddha and Nāgārjuna in basic annuals [benji 本紀] and later Chinese patriarchs in hereditary houses; it also imitated the style of Jinshu 晉書 to record the historical events of the other schools of Chinese Buddhism in the “Appended Records" [Zaiji 載記]. Fuzu tongji, followed the style of the Weishu 魏書, had nine treaties compiled at the end of the book, including a bibliographical record of the textual canons of the Taitai school, a record of the interactions between Buddhism and Taoism, and historical materials about Manichaeism and Zoroastrianism.
} 
On the other hand, these Buddhist narratives also profoundly influenced historical writings about non-Buddhist traditions as well. Two representative examples are the bibliographies of the canon [jinglu 經錄] and the Lamp records. Compared to Confucians or Daoists, Chinese Buddhists paid more attention to recording the origin, reception, and changes of their scriptures over a long-term spectrum. For example, in Chu sanzang jiji, the first systematic bibliography of Chinese Buddhist literature, Sengyou set up different categories (including a record of origins [yuanji 緣記], a list of terms [minglu 名錄], ${ }^{139}$ a brief introduction to the scripture [jingxu 經序], and biographies of the translators [liezhuan 列傳]) to record useful information about Buddhist literature, including translators, exegetes, and dates and locations of the translating activities, as well the social background of certain texts. ${ }^{140}$ Because the informative content of the Buddhist jinglu, this format of bibliography was not only maintained in later Buddhist works, such as Ouyi Zhixu's 蕅益智旭 Yuezang zhijin 閱藏知津, ${ }^{141}$ but also established a pattern for traditional bibliographical scholarship [mulu xue 目錄學], a special research field that reached its peak of development in the Ming and Qing dynasties. ${ }^{142}$

The genre of denglu was created by the Chan school. This kind of historical narrative customarily discussed the lives and teachings of a succession of individual masters. The status of the Chan school at any given time, therefore, could be defined by the biography of the reigning patriarch. Through this approach, the traditional orthodoxy of the Chan School could be established by sorting the lineal relations

\footnotetext{
${ }^{139}$ The sub-categories Sengyou applied included: translated canons of past dynasties [lidai chujing 歷代 出經], which had a determined title and date; scriptures based on same original Sanskrit text [yichu jing 異出經]; ancient scriptures based on same original text that did not exist anymore [guyijing 古異經]; translated scriptures without the name of the translator [shiyijing 失譯經] and Vinaya texts. See Sengyou, Chu sanzang jiji, CBETA, T55, no. 2145, 1a07

${ }^{140}$ The original sentence is “緣記撰, 則原始之本克昭; 名錄詮, 則年代之目不墜; 經序總, 則勝 集之時足徵; 列傳述, 則伊人之風可見.” See ibid.

${ }^{141}$ Other examples include Lidai sanbaoji and Kaiyuan shijiao lu.

${ }^{142}$ Buddhist bibliographies influenced works such as Chen Zhensun's Zhizhai shulu jieti 直齋書錄解題, Ma Duanlin 馬端臨's Wenxian tongkao 文獻通考, Zhu Yizun's 朱豖尊Jingyi kao 經義考, and so on. See Liang Qichao, “Fojia jinglu zai Zhongguo muluxue zhi weizhi 佛家經錄在中國目錄學之位置” (1926), in $S B P$.
} 
among Chan masters to show where individual masters belonged in the Chan 'clan,' which traced itself back to the 'grand ancestor,' Saakyamuni Buddha. ${ }^{143}$ One of the denglu, Jingde chuandenglu 景德傳燈錄, is regarded as the prototype for the way in which the multi-branched Chan tradition was formed and accepted in intellectual circles. ${ }^{144}$ Under its influence, similar historical writings recording Confucian lineage and transmission between Confucian masters were developed in the Song dynasty. For instance, Yiluo yuanyuan lu 伊洛淵緣錄 written by Zhu Xi 朱喜, the Mingru xuean 明儒學案 by Huang Lizhou 黄梨洲, and Ruling zongpai 儒林宗派 by Wan Jiye 萬季野 all followed the model of denglu and were considered an advanced form of recording the development of scholarship.

Besides, historical data related to Buddhism can also be found in official histories. Accounts of the activities of monks and nuns were scattered in the biographies of non-Buddhist figures, members of royal families with Buddhist beliefs, and elite lay Buddhists. Some historians organized or enumerated Buddhist literature in a bibliographical form and wrote brief introductions to these individual texts, as Fei Zhangfang did in his Jingji zhi 經籍志 in the Suishu 隋書. ${ }^{145}$ Records of events related to Buddhism or Buddhists had also been recorded by court documents about foreign affairs, records of diplomatic activities, and geographic reports ${ }^{146}$ Issues such as the debates around Buddhist doctrines and local thought, the persecution or promotion of Buddhism conducted by emperors, and so on, were also recorded by official historians with special attention. ${ }^{147}$

\footnotetext{
${ }^{143}$ For a detailed discussion about the 'transmission of the Lamp' histories, see John R. McRae, The Northern School and the Formation of Early Ch'an Buddhism (Honolulu: University of Hawaii Press, 1986), 72-97.

${ }^{144}$ The position of denglu among Chan transmission records is universally acknowledged; see, for example, Jan Yün-hua's entry, “Chan yü-lu” in William H. Nienhauser, ed., The Indiana Companion to Traditional Chinese Literature (Bloomington: Indiana University Press, 1986), 202.

${ }^{145}$ Other examples include the bibliography in Suishu jingji zhi 隋書經籍志.

${ }^{146}$ Both Weishu 魏書 and Yuanshi 元史 contain treaties titled shilao zhi 釋老志.

${ }^{147}$ For example, when compiling Liang shu 梁書, historian Yao Silian 姚思廉 (557-637) recored the entire text of Shenmie lun 神滅論 [On the extinguishment of spirit] written by Fan Zhen 范縝 (450-510), which attacked the philosophical thesis of Buddhism by rejecting the existence of spirit in the afterlife. In Fan Zhen's biography, Yao also recorded the Buddhist emperor Wu's response and criticism to Fan's
} 
These writings provided the historians and Buddhist scholars who re-wrote the history of Chinese Buddhism with important and reliable information, not because of the religious sacredness of these texts, but because of their abundant data and scholarly style. ${ }^{148}$ As early as the time of Sengyou and Huijiao, monastic historians had established a strict standard for selecting primary materials and emphasized the scholarly activities and pilgrimage of monks. By means of compiling biographies and bibliographies, the monastic historians attempted to establish supreme doctrinal principles and the moral ideal of the samgha through carefully arranging previous textual materials and seriously recording the activities of eminent figures. ${ }^{149}$ Sengyou, for example, clearly described this way of writing as "to produce reliable history" [cun xinshi 存信史] and “to select accurate records [qu shilu 取實錄]" in his Chu sanzang jijj. ${ }^{150} \mathrm{~A}$ sense of lineage and orthodoxy might exist in the writings of the early Buddhist historians like Sengyou and Huijiao but was somehow extremely dim. They were not interested in presenting a balanced assessment of the state of Buddhist monasticism over its first 400 years in China ${ }^{151}$ but composed their works as collections of exemplars-models of behavior for future monks-and as evidence for believers of the potentiality of perfection. ${ }^{152}$

Along with the Sinicization of Buddhism, a genealogical tendency to enumerate patriarchal generations - a way of defining Buddhist orthodoxybecame stronger in historical writings from the Tang dynasty onwards. ${ }^{153}$ This Chan

article. ${ }^{147}$ Another example is the records about Huilin 慧琳 (?). His biographical records and his famous article Baihei lun 白黑論 were recorded by Nan shi 南史 and Song shu 宋書. However, as a 'Buddhist heretic,' he was intendedly excluded by Hujiao in his Gaoseng zhuan.

${ }^{148}$ Kieschnick, "Buddhism," 543.

${ }^{149} \mathrm{Ibid}, 543$

${ }^{150}$ Chu sanzang jiji, 1b. Cf. Arthur E. Link, "Shih Seng-Yu and His Writings," Journal of the American Oriental Society 80, no. 1 (1960), 34-40, where the preface is translated in full, with annotation. Sengyou expressed similar sentiments in the preface to his now-lost collection of biographies of monks in the Sarvāstivāda tradition, in Chu sanzang jiji 12, 89a.

${ }^{151}$ Kieschnick, "Buddhism." 543.

${ }^{152} \mathrm{Ibid}, 543$.

${ }^{153}$ Hu Shih, "The Development of Zen Buddhism in China," in The Chinese Social and Political Science Review 15.4 (1932): 492. 
patriarchal tradition reflected a conventional type of "historical consciousness" and a fundamental aspect of the Chan monks' concept of time.${ }^{154}$ The historical writings after the Tang dynasty, although they demonstrated a fascination with a more literary voice, as shown in the Lamp records, should not be interpreted as examples of the degeneration of historicity but should rather be treated as examples of the contextual production of new ways of establishing sectarian identity and the independence of Buddhism. The denglu texts were retrospective in nature; they interpreted the past as a means to justify the present. These records were narratives that highlighted the ways the Chan tradition wished to remember their own champions. Thus, the biographical framework in denglu became the means to reveal the hallowed principles of a unique Chan identity. The need to affirm these principles drove the interpretation of monks' lives. In this sense denglu served the didactic purposes of Buddhism's own special version of hagiography, rather than actually approaching biography.

Taking into account their diverse genres and formats, modern scholars read the historical narratives of Buddhism in traditional China as layered recollections that encompass memories, imagination, legends, and textual records in formats such as inscriptions, scrolls, and so on. For example, to Hu Shih, the Lamp Records were forged to assert revisionist claims regarding Chan orthodoxy; ${ }^{155}$ they were best read as historical fiction rather than truly biographical records. ${ }^{156}$ However, although these traditional narratives were not 'perfect' histories, they actually represented the collective memory of Chinese Buddhists and expressed their most cherished aspirations. Through the filtered memory of successive generations and the exigencies associated with the rising prominence of a sect, recollections of the famed masters began to take on system of their own; the lineage of indigenous Buddhist sects also began to form. This historical construction, with a particular concern for

\footnotetext{
${ }^{154}$ Bernard, Chan Insight and Oversight,182-183.

${ }^{155}$ John R. McRae, "Religion as Revolution in Chinese Historiography: Hu Shih (1891-1962) on Shen-hui (684-758)," Cahiers d'Extrême-Asie 12, no. 1 (2001), 11-65.

${ }^{156}$ The notion that Chan records should be read as fiction was proposed by Yanagida Seizan; see, for example, “Shinzoku tōshi no keifu 新続灯史の系譜,” in Zengaku kenkyū 禪學研究 59 (1978): 5.
} 
the biographies of Chinese patriarchs and the genealogies of native schools, reflected the whole picture of the doctrines and practices of Chinese Buddhism according to the requisites of its newfound independence. Finally, along with Chinese Buddhist historiography reached its peak in the Song dynasty, Chinese Buddhism eventually established its sacred sites, canons, and ideals, as well as its own character. By recording and narrating its past, Chinese Buddhism revealed the hallowed principles of its unique identity and formed its orthodoxy; and consequently, Chinese Buddhism distanced itself from its Indian origin and moved further and further in a direction of indigenization or 'Sinicization.'

\section{Dao and the Historiographical Duty}

Buddhist historical writings in premodern China are not merely the annotation of the Dharma; rather, they demonstrate a religious function of establishing the sacredness of Chinese Buddhism and its ethical standards, behavior patterns, and lineage orthodoxy. Therefore, organizing and narrating Buddhist traditions in a historical form was one unique way through which the Chinese understood and interpreted the Buddha's teaching. This historical recording was deeply influenced by the tradition of Chinese historiography, as the Chinese always observed the Buddhist past through the Confucian 'spirit of history' and actualized the abstract Buddhist Dharma with authentic stories, real figures, and secular expressions.

When investigating the conceptual foundation of Buddhist historical narratives in premodern China, we cannot ignore the Chinese historiographical tradition. China has a long, stable structure of history called 'the official history' [zhengshi 正史]. According to Benjamin Schwartz, this historiographical structure is closely related to the "high-culture" constituted by the Six Arts [liuyi 六藝] in the Pre-Qin period. ${ }^{157}$ From the Han dynasty onwards, this knowledge system of the Six Arts had been gradually canonized to become the Confucian Five Classics and became

\footnotetext{
${ }^{157}$ Benjamin Schwartz, "History in Chinese Culture: Some Comparative Reflections," History and Theory 35, no. 4 (1996), 10
} 
the official scholarship [guanxue 官學]. Among these Five Classics, the Chunqiu 春秋, which are believed to have been written or edited by Confucius himself, set up the paradigm for traditional historiography.

This paradigm set by the Chunqiu, which was labelled by later historians the 'spirit of Chunqiu,' continued throughout the whole spectrum of Chinese history. The core of the spirit of Chunqiu is a normative order, the Dao 道. The Dao, in a traditional sense, does not point to an apocalyptic/eschatological destination but rather is an abstract ideal with potentiality, waiting to be actualized within the flux of history and embraced by all of entire civilized humankind. ${ }^{158}$ In history, the belief in the order of the Dao was paradigmatically expressed by the worship of ancestors or sages and the ritual enactment of sacrifices, coronations, and divine activities. Through rituals, religious and political elements, from devotion and sacrifice to oath and punishment, were closely intertwined. It was the function of history officers to witness and record those ritual events as well as the sacred behavior of the emperors, which was legitimatized by the Mandate of Heaven[tianming 天命]. ${ }^{159}$

Indeed, the Dao had its religious function and could be expressed by ritual enactment. ${ }^{160}$ By rationalizing the legitimacy of the ruling clan as the actualization of the Mandate of Heaven, religion and politics were closely combined and mixed in historical writings. ${ }^{161}$ In this way, the historiographer derived his or her eminently powerful ethic-political position. This position was further reinforced because the normative order in Chinese culture was not perceived as accessible to humans through divine revelation but was posited as once having been actualized in real

\footnotetext{
${ }^{158}$ Schwartz, "History in Chinese Culture: Some Comparative Reflections," 27.

${ }^{159}$ For a study of history officers in premodern China, see Denis Twitchett, The Writing of Official History Under the T'ang (New York, Cambridge University Press, 1992).

${ }^{160}$ Religious elements can be observed in Chinese historiographical traditions, such as the Gonyang tradition 公羊. See Joachim Gentz, “Language Of Heaven, Exegetical Skepticism And The Re-Insertion Of Religious Concepts In The Gongyang Tradition," in Early Chinese Religion: Part One: Shang through Han (1250 BC-220 AD) (Leiden, The Netherlands: Brill, 2009).

${ }^{161}$ Axel Schneider, "Nation, History and Ethics: The Choices of Post-Imperial Historiography in China," in Transforming History: The Making of a Modern Academic Discipline in Twentieth-Century China, ed. Peter Zarrow Brian Moloughney (Hong Kong: The Chinese University Press, 2012), 274.
} 
history during the Three Dynasties. ${ }^{162}$ Unlike the history of the premodern West, the Dao, the essential principle represented by shi, was not conceptualized as a preordained given. but rather had to be represented through sacred rituals or moral examples. To traditional historians, the Dao was the principle of the world and the abstract norms of society and human affairs. It provided the 'standards' [li 理] for changes and individual behavior. Therefore, traditional historiography was a hybrid of recording and evaluating; it had as well the dual characteristics of reliability and sanctity, and was profoundly involved in the Chinese epistemological and sociopolitical systems. ${ }^{163}$ Shi thus acquired a quasi-absolute status in the field of human activity, providing privileged, if not exclusive, access to heavenly truth. ${ }^{164}$ In this sense, history in China sometime took on the sacred role of religion and became the proper expression of ultimate order and the principle of value judgment. ${ }^{165}$ As we can see in the many official histories, deviant behaviors would be condemned by history instead of by 'God'; history also established moral and ethical models. ${ }^{166}$

Exemplary historical writings such as the Chunqiu and the Shiji established this long-lasting tradition of Chinese historiography, which has been usually called 'history as mirror [yishi weijian 以史為鑒]', alluding to the metaphor of the "mirror" that historian Sima Guang 司馬光 (1019-1086) used in the title of his masterpiece, Zizhi tongjian 資治通鑑. Writing history, accordingly, ultimately fulfilled two complementary functions, closely linked but not without internal tension: written history chronicled what had happened in the past by critically examining and analyzing records of past times as truthful as possible; yet it also manifested the

\footnotetext{
${ }^{162}$ Erich Haenisch, “Das Ethos der chinesischen Geschichtschreibung," Saeculum 1, no. 1 (1950), 111-23.

${ }^{163}$ Yves Chevrier, "La servante-maitresse : condition de la référence à l'histoire dans l'espace intellectuel chinois," 137.

${ }^{164}$ Masayuki Sato, "The Archetype of History in the Confucian Ecumene," History and Theory 46, no. 2 (2007), 218-23.

${ }^{165}$ Stefan Tanaka and Axel Schneider, "Chinese and Japanese Historiography," in Oxford History of Historical Writing, ed. Stuart MacIntyre Daniel Woolf (Oxford: Oxford University Press, 2011). ${ }^{166}$ Chinese rulers normally were highly self-conscious about their historical legacy. They were extremely concerned about how their behaviours would be recorded in history and considered 'the man of historical guilt' [lishi de zuiren 歷史的罪人] as the most negative epithet.
} 
cosmic order by expressing praise and blame [baobian 偯貶] ${ }^{167}$ In this sense, the truth in Chinese history was formed based on 'real' facts, as revealed by witnesses and records; ${ }^{168}$ Meanwhile, this kind of truth was not 'scientific' but was profoundly mixed with the normative judgments of the historians. Therefore, the truth in traditional Chinese history was also a selected and constructed reality. When this truth conflicted with the historians' values, they then expressed their confusion and criticism through blame. ${ }^{169}$ These two tendencies were deeply intertwined in traditional Chinese historiography and played pivotal roles in the mission of bridging 'truth' and 'values. ${ }^{170}$

Chinese traditional historiography, in general, was based on the Confucian worldview. Certainly, this historiographical tradition was conceptually far away from the Buddhist understanding of time and space. ${ }^{171}$ However, we can still imagine how this Confucian historiographical tradition influenced Buddhist historians for centuries. Without doubt, they must have felt some parallels between the two

\footnotetext{
${ }^{167}$ Yang Lien-sheng 楊聯陸, “The Organization of Chinese of Chinese Official Historiography: Principles and Methods of the Standard Histories from T'ang through the Ming Dynasty," in W. G. Beasley and E. G. Pulleyblank (eds.), Historians of China and Japan (London: Oxford University Press, 1961), 44-59. ${ }^{168}$ The historians' attitude can be seen in Sima Qian's writing: In the first sentence of the 'Arrayed Traditions' [Liezhuan 列傳] section of the Shiji, Sima Qian clarified how he determined reliability in the face of an abundance of historical material: "The records and texts of scholars are extremely extensive, but we still test reliability in the six arts” [夫學者載籍極博, 猶考信於六藝].

${ }^{169}$ One example is Sima Qian's comment on Boyi 伯夷 and Shuqi 叔齊, who were both people with immoral behaviours but who experienced success lives. He said, "I am so confused with the Dao of Heaven”[余甚惑焉, 儻所謂天道, 是邪非邪? ]. See “Boyi, Shuqi liezhuan 伯夷叔齊列傳, ” in Shiji, vol.61.

${ }^{170}$ E.G. Pulleyblank, "Chinese Historical Criticism: Liu Chin-chi and Ssu-ma Kuang,", in Historians of China and Japan, ed. W. G. Beasley and E. G. Pulleyblank (London: Oxford University Press, 1961), 2-3, 135-166.

${ }^{171}$ For example, Wolfgang Bauer has argued that the Buddhist concept of time differs from the traditional Chinese cyclic concept of time in that the latter lacks an aspect of progress (in a karmic way). See Bauer, Geschichte der chinesischen Philosophie (München: C. H. Beck, 2006), 37-8. Kurita Naomi 栗田直躬 has documented how Chinese time is timeliness, cosmic, natural, or sociopolitical, in his Chûgoku Shisô ni okeru Shizen to Ningen 中國思想におけみ自然と人間 [Nature and the human in Chinese thought] (Tokyo: Iwanami Shoten, 1996), 149-187. For studies of the concept of time and space in Chinese history, see also the essays collected in Chun-chieh Huang and John B. Henderson (ed.), Notions of Time in Chinese Historical Thinking, (Hong Kong: The Chinese University Press, 2006).
} 
traditions: the sages in Confucianism and Śākyamuni and his eighteen Arhats in Buddhism; the three golden ages in ancient China and the Buddha's land; the cyclical time of wuxing and the movement of samsāra; the actualization of the Dao and the appearance of the Maitreya Buddhas; and so on. ${ }^{172}$ The form, content, and style of the traditional Buddhist historical writings presented the local influence. The biographies of monks, the Lamp Records, and the genealogical narrative of Buddhist lineages and sects not only filled the 'emptiness' [Śūnyatā, 空] of Buddhist time with some continuums (although these were not strictly in chronological order) but also were burdened with a similar historiographical duty to the official histories-these Buddhist texts were intended to elevate ethical paragons and monastic ideals through baobian. ${ }^{173}$

What should be underscored here is the very nature of Chinese traditional Buddhist historiography: it tells religious stories with a 'secular' tone. For example, when rendered into the Chinese language, the Buddhist term for 'prophecy' [vyākarnana], was translated as 'records' [zaiji 載記], which had a strong historical implication. ${ }^{174}$ Most importantly, however, the Chinese historical writing of Buddhism accepted the presupposition of the Chinese historiographical tradition that there is a setting of the Dao and a group of moral archetypes - the sages, who represent the proper forms of Buddhist perfection and the bodhisattva path. Entangled with moral standards and ethical considerations, the Chinese historical writing of Buddhism provided guidance for monastic life, arranged and valued the authentic doctrines, formed 'orthodoxy' 正統 by establishing the lineage of the transmission of Dharma,

\footnotetext{
${ }^{172}$ In early medieval Chinese discourse, dao-one of the multiple 'ways' or 'paths' - was used as a ubiquitous way of nominalizing 'religion.' This term can be found in many Buddhist texts. See Robert Ford Campany, "On the Very Idea of Religions (In the Modern West and in Early Medieval China)," History of Religions 42, no. 4 (2003): 300-06. For the relationship between Buddhism, Taoism, and Confucianism on a language level, also see Shi Zhiru, "Contextualizing Buddhist Approaches to Religious Diversity," in Religious Diversity in Chinese Thought, ed. Perry Schmidt-Leukel and Joachim Gentz (New York: Palgrave Macmillan, 2013).

${ }^{173}$ Kieschnick, "Buddhism."

174 'Prophecy' [shouji 授記/受記] means a buddha predicts that the vow-making bodhisattva in his presence will become such-and-such a buddha in the future. However, its Chinese translation contains the word 'ji,' which originally meant 'record.'
} 
and functioned as an important means for solving the belief crisis and sectarian conflict. ${ }^{175}$ To traditional Buddhist historians, searching for the real successor of the Buddha and building the legitimacy of the genealogies of masters were extremely important. ${ }^{176}$ Therefore, Buddhist historians in premodern times paid great attention to recording the mysterious rituals of 'transmission' and were extremely sensitive about the pedigrees of sects or schools. Especially in some more indigenized traditions, such as Chan Buddhism, it was very palpable that the loose constellation of Indian Buddhism was replaced by a historicized, exclusive system of lineage, which was worshiped just like the kinship in the Confucianist tradition.

\section{Facing New Historiography}

As the imperial age came to an end, Buddhism, like other traditions, was faced with the task of re-constructing its intellectual foundation based on a new order of discourse. In this process, Buddhism began to create its 'history' (in the modern sense) by adopting new historiographical theories and gradually re-established the knowledge about its past. Therefore, the question would be why writing the history of Buddhism became meaningful and possible at this time, and what kind of history really arose from this process.

The emergence of the modern historiography of Buddhism is one facet of the so-called "revolution of historiography" [shijie geming 史界革命] advocated firstly by the leading intellectual Liang Qichao. ${ }^{177}$ This revolution was dramatic. Modern historiography, although sometimes it did not fundamentally change the existing system of scholarship or any substructure in people's ideas, behaviors, or faith,

\footnotetext{
${ }^{175}$ Kieschnick, "Buddhism," 543.

${ }^{176}$ John Jorgensen, “The 'Imperial' Lineage of Ch'an Buddhism: The Role of Confucian Ritual and Ancestor Worship in Ch'an's Search for Legitimation in the Mid-T'ang Dynasty," Papers on Far Eastern History 35 (1987): 89-133.

${ }^{177}$ For the contribution of Liang Qichao to historiography, see Tang Xiaobing, Global Space and the Nationalist Discourse of Modernity: The Historical Thinking of Liang Qichao (Stanford: Stanford University Press, 1996).
} 
evolved along different trajectories to form a modern understanding of China's past, developing new standards, using new vocabulary, and breaking into new domains. ${ }^{178}$

Similar to other new historiographical themes that appeared, the core of the historiography of Buddhism was the idea of 'tradition'-namely how historians defined the content and boundaries of tradition, looking for its position in a changing cultural environment, addressing its relationship with modernity, and responding to the built-in tensions. From the perspective of modern Chinese historians, their practices of writing the history of Buddhism were motivated by divergent strands of inquiry: the recognition of the importance of Buddhism as a form of traditional culture, the intellectual conviction of the philosophical and logical assertions contained in Buddhism, and many other private or localized factors. Whether they were professional historians or believers, their interests in this field can neither be simply attributed to religious zeal nor to emotional ties nor to pure academic curiosity. Instead, this research trend was closely influenced by internal and external forces, such as the passion for defending traditions or beliefs, nationalist sentiments, the sense of instability and anxiety caused by the changing environment, and so on. Different positions and purposes could be observed within this trend: the desire to build a new identity other than Confucianism as an ideological pattern for the coming age; or the drive to encompass religious traditions into domains labeled as 'the history of ideas' or 'the history of philosophy' so they could be incorporated into a modern knowledge system; or a wish to resist the impacts of modernity and fundamentally question its presuppositions and promises from the stances of Conservatism or Classicism [fugu zhuyi 復古主義]; and so forth.

\footnotetext{
${ }^{178}$ A useful discussion on this issue can be found in Achim Mittag, "Chinas Modernisierung und die Transformation des chinesischen Geschichtsdenkens unter westlichem Kultureinfluß-Drei Thesen," in Geschichtesdiskurs: vol.4: Krisenbeweßstein, Katastrophenerfahrungen und Innovationen 1880-1945, ed. Wolfgang Kuttler, Jörn Rüsen, and Ernst Schulin (Frankfurt am Main: Fischer Taschenbuch Verlag, 1997). General studies on the history of Modern Chinese historiography, see, for example, Xu Guansan 許冠三, Xin shixue jiushi nian 1900- 新史學九十年 1900- (Hong Kong: Chinese University Press, 1986).
} 


\section{Impact from the West}

In the late nineteenth century, China's traditional historiography was challenged by new concepts of history coming from the West, at the levels of both epistemology and methodology. ${ }^{179}$

In the West, the new, modern understanding of history as one important segment of modernity was deeply rooted in a 'disenchanted' worldview. After the Enlightenment, the old biblical timeline in historical writing, which promised divine revelation and eschatological hope, was replaced by a linear model of movement towards a secularized future. The notion of time was neutralized and transformed into an abstract, homogeneous, and empty mechanism, in line with the principles of modern science. In this process, as Heidegger described, humankind was removed from its past and could only gaze at or observe its object: the world. ${ }^{180}$

Corresponding to the 'new (modern) age', history, in Hegel's notion, no longer entailed the collection of stories (histories, in Koselleck's term) or led towards divine salvation, but pointed to a teleological end-a metaphysical, universal spirit of the world. ${ }^{181}$ As Koselleck argued, this historical consciousness opened up the future as "the horizon of expectations" in a utopian fashion while cutting off its link with the "space of experience" in the past. ${ }^{182}$ The meaning of history then was not the recollection of memories of the past, but the construction of the experience of

\footnotetext{
${ }^{179}$ For the transformation of Western historiography, see Ernst Breisach, Historiography: Ancient, Medieval \& Modern, 2nd ed. (Chicago: University of Chicago Press, 1994). Chapter 15-16. Also, Donald R. Kelley, Fortunes of History: Historical Inquiry from Herder to Huizinga (New Heaven, CT: Yale University Press, 2003), chapter 7.

${ }^{180}$ Martin Heidegger, "The Age of the World View," Boundary 2 4, no. 2 (1976).

${ }^{181}$ Reinhart Koselleck, "Historia Magistra Vitae: The Discourse of the Topos into the Perspective of A Modernized Historical Process," in Futures Past: on the Semantics of Historical Time (New York: Columbia University Press, 2004).

${ }^{182}$ For the philosophy of history in Hegel's style, see Otto Pöggeler, Eine Ende der Geschichte? Von Hegel zu Fukuyama (Opladen: Westdeutscher Verlag, 1995); Joe McCarney, Hegel on History (London: Routledge, 2000). Jörg Baberowski, Der Sinn der Geschichte. Geschichtstheorien von Hegel bis Foucault (Munich: C. H. Beck, 2005).
} 
progress, which contained a "historically new quality, constantly subject to being overlaid with utopian conceptions." 183

This consciousness of time and history dramatically expanded the differentiation between the future and the past, intensifying the dilemma of modernity: as Habermas wrote, "modernity can and will no longer borrow the criteria by which it takes its orientation from the models supplied by another epoch; it has to create its normatively out of itself." ${ }^{184}$ According to Jürgen Habermas, to solve the dilemma of self-assurance and to reconcile the gap between past and future, two conceptions consequently emerged: on the one hand, "the stubborn belief in progress" of evolutionism and the philosophy of history based on subjectivity; ${ }^{185}$ on the other hand, the neutralization of all standards fostered by historicism, as they imprison history in the museum and tell the events "like the beads of a rosary." 186

From Nietzsche to Ranke down to Heidegger, Hegel's constructive concept of a universal and singular, capitalized 'History' and progressivism's historical-political understanding of the "modern age" were contested, because this concept promised constant improvements and developments in all fields of human life, regardless of the particularity of actions and ideas. To this extent, Hegel's 'History' failed to reconcile historical relativity with universal norms. The philosophy of history and the concept of progress behind this view of history were replaced by more objectivist and fact-based historicism in the middle of the nineteenth century. ${ }^{187}$ However, this

\footnotetext{
${ }^{183}$ Reinhart Koselleck, Futures Past: On the Semantics of Historical Time, trans. and with an introduction by Keith Tribe (New York: Columbia University Press 2004), 266.

${ }^{184}$ Jürgen Habermas, The Philosophical Discourse of Modernity: Twelve Lectures, trans. Frederick Lawrence (Cambridge, MA: The MIT Press, 1987), 7.

${ }^{185}$ In Hegel's notion, 'subjectivity' refers to a) individualism; b) the right to criticism; c) autonomy of action; d) idealistic philosophy. See Habermas, The Philosophical Discourse of Modernity: Twelve Lectures. 711

${ }^{186}$ Habermas, The Philosophical Discourse of Modernity: Twelve Lectures. 11

${ }^{187}$ Jörn Rüsen, “Konfigurationen des Historismus," in Geschichte des Historismus. Eine Einführung, ed. Friedrich Jaeger and Jörn Rüsen (Munich: C.H. Beck, 1992).18-113; Georg G Iggers and James M. Powell, ed., Leopold von Ranke and the Shaping of the Historical Discipline (Syracuse, NY: Syracuse University Press, 1990).
} 
new concept of history was soon criticized as well. ${ }^{188}$ In Walter Benjamin's view, historicism was merely a functional equivalent of progressivism and the philosophy of history ${ }^{189}$ By historicizing all standards and ideas, and even the notion of history itself, studies on history only demonstrated the relativity of values and revealed the meaninglessness of existence. This 'crisis of historicism,' as it was called by Ernst Troeltsch and Karl Löwith, would lead to a tragic corruption of history: they lamented that "the scholarship of history, so central to the formation of the national and social identity in the nineteenth century, has lost its relevance." ${ }^{190}$

As the nineteenth century ran its course, the Western concepts of historiography travelled globally. The advances in the natural science supported the progressive view of history; Ranke's critical history gained its persuasive power; and, later, the increasing challenge to the existing social order gave strength to the Marxist idea of history. ${ }^{191}$ Those currents, nevertheless, profoundly influenced the historical understanding of the Chinese.

\section{The Collapse of the Foundation of History}

Modern historiography in China, which was profoundly influenced by both the Chinese historiographical tradition and Western theories such as progressivism and historicism, was full of controversies. ${ }^{192}$ Because of constant external stimulus, from

\footnotetext{
${ }^{188}$ Charles R. Bambach, Heidegger, Dilthey, and the Crisis of Historicism (Ithaca, NY: Cornell University Press, 1995).

${ }^{189}$ Walter Benjamin, Selected Writings, volume Four: 1938- 1940, E. Jephcott (trans.). H. Eiland and M.W. Jennings (ed.), (Cambridge, MA: The Belknap Press of Harvard University Press, 2003). Cf. Andrew Benjamin (ed.), Walter Benjamin and History (New York: Continuum, 2005).

${ }^{190}$ Georg G. Iggers, Historiography in the Twentieth Century: From Scientific Objectivity to the Postmodern Challenge (Middletown, CT: Wesleyan University Press, 2012).

${ }^{191}$ Ernst Breisach, Historiography (Chicago: University of Chicago Press, 1994), 319. For an overall investigation of these historiographical trends, see chapters 16,18 , and 19.

${ }^{192}$ For the transformation of Chinese Historiography in the nineteenth century to the twentieth century, see Axel Schneider, Wahrheit und Geschichte: Zwei chinesische Historiker anf der Suche nach einer modernen Identität für China (Wiesbaden: Harrassowitz Verlag, 1997); Edward Q. Wang, Inventing China through History: the May Fourth Approach to Historiography (Albany: State University of New York Press, 2001).
} 
the Opium War of 1840 to Japan's imperialistic aggression during the Second World War, the traditional Sino-centric self-image of China fell apart. It was a painful experience for the Chinese people, and this experience became even more bitter when some insightful intellectuals realized that tradition, which used to be coherent and stable (albeit with inner contradictions), was hopelessly left behind in the past and no value judgment could rely on it. Regardless of whether they saw traditional Chinese views of history as cyclical, linear, or regressive, old histories failed to explain the changes they observed and experienced and could not help them to understand the new modern world. As the Chinese learned more about the way that Western imperialism was helping to entrench the nation-state system around the globe, they were forced to rethink their own systems and their knowledge about the past.

This desperate situation led some pioneers to question the 'old order' and to pursue a new worldview. ${ }^{193}$ They realized that truth and value had been torn apart; these two dimensions could not be unified in the writing of history, as they used to be. Joseph Levenson described this situation as a feeling of "alienation":

History and value are worlds apart, but men are drawn to both, with an emotional commitment to the first and an intellectual commitment to the second; they need to ask the two incompatible questions, and they yearn to be able to answer "Mine" and "True."194

Levenson considered this dilemma a fundamental intellectual change during the modern China period that marked the change from a "culturalist" China to a nationalist China. He insightfully noticed the rupture between 'truth' and 'value,' and he described modern Chinese intellectuals as "emotionally tied to but intellectually alienated from Chinese cultural tradition." ${ }^{195}$ In other words, the modern

\footnotetext{
${ }^{193}$ John K. Fairbank, "Introduction: the Old Order," in The Cambridge History of China, ed. John K. Fairbank (Cambridge: Cambridge University Press, 1987), 2.

${ }^{194}$ J. R. Levenson, “'History' and 'Value': Tensions of Intellectual Choice in Modern China," in Studies in Chinese Thought, ed. Arthur Wright (Chicago: Univesity of Chicago Press, 1953), 150.

${ }^{195}$ Levenson, Confucian China and its Modern Fate: A Trilogy, 98.
} 
intellectuals' respect for the resources in Chinese tradition was in opposition to their new recognition of the universal values represented by the West.

Other scholars, like Yu Ying-shih 余英時, placed more emphasis on the builtin tensions within tradition, which led to an internal impulse for self-evolution. This critique of tradition was not stimulated by outside impact, but rather began from the inside. Traditional China did collapse at the "hardware" level-the level of politics and economy-but survived and continued on the level of culture ${ }^{196}$ through a kind of autonomous "inner logic." 197

Both Levenson and Yü Ying-shih have tackled the 'gap problem' and added different facets to the overall picture of the conflicts in the intellectual world of modern China. Their explanations both basically admit the crucial discontinuity of the Chinese tradition in the conceptual dimension and suppose an inevitable separation of 'truth' and 'value,' but their arguments are based on their observations of 'Confucian China.' Moreover, neither the theory of 'challenge-response' nor the theory of 'inner logic' can answer one crucial question: if Chinese tradition needed to be changed and modern Chinese intellectuals were forced to fill the gap between past and future and between truth and value in order to respond to the challenge of modernity during the nineteenth century, why did the Westernization movement and the putative success of modernity quickly lose its attraction for some intellectuals, such as Zhang Taiyan, Wang Guowei, Liu Yizheng, Chen Yinke, Qian Mu, and even Liang Qichao (in his later years)? ${ }^{198}$

One of the reasons why the dilemma of the 'gap' in this transition age seemed so severe probably was that most of the initial concerns and questions that had prompted the intellectuals to venture into the storehouse of traditions-for example, which indigenous factors had caused the marginalization of Confucianism in the intellectual life of the Chinese? Which cultural elements in Chinese history could help

\footnotetext{
${ }^{196}$ Yü Ying-shih, Fang Yizhi wanjie kao 方以智晚節考 (Beijing: Sanlian, 2004), preface, 9.

${ }^{197}$ Yü Ying-shih, “Qingdai sixiang shi de yige xinjie shi 清代思想史的一個新解釋, " in Lishi yu sixiang 歷史與思想 (Taipei: Lianjing, 1976), 124-25.

${ }^{198}$ For a discuss of these allegedly 'conservative' historians, see Schneider, "Nation, History and Ethics: The Choices of Post-Imperial Historiography in China."
} 
to save China from its descent and crisis?-were still highly dependent on value judgment and belief. ${ }^{199}$ Although at that moment judgments were beginning to refer to new standards and beliefs were starting to be expressed in the new terminology, these two dimensions, which once constituted the central concern of traditional Chinese historiography, were still crucial, or even more crucial than before, because they were related to some critical challenges China was encountering, such as the reorientation of national identity, the reassurance of Chinese cultural heritage, the reestablishment of the historical continuity of China as a cultural entity, the reformation of China's relationship with the world, and so on. ${ }^{200}$ These historical issues went beyond the domain of the traditional chinese world of all-under-heaven and were therefore less relevant to the old cosmic order and ethical questions. ${ }^{201}$ Because of its potential for solving these issues, history was able to maintain its responsibility for making evaluations, forming patterns, and resolving the conflicts between the old and the new. Therefore, although the foundation of traditional history nearly collapsed in the modern period, China's efforts to understand the changing world were constantly transformed into an impulse to read the past again. ${ }^{202}$

\section{The Rise of Historiography}

\footnotetext{
${ }^{199}$ History was unique among the other modern disciplines in at least one respect: history had long been a clearly defined and integral part of the traditional cultural fabric. Most academic disciplines were creations of the modern era. See Moloughney and Zarrow, Transforming History: The Making of a Modern Academic Discipline in Twentieth-Century China, 2.

${ }^{200}$ See Achim Mittag, Chinas Modernisierung und die Transformation des chinesischen Geschichtesdenkens und westlichem Kultureinfluß," in Geschichtsdiskurs: vol.4: Krisenbeweßtsein, Katastrophenerfahrungen und Innovationen 1880-1945, ed. Wolfgang Kuttler, Jörn Rüsen, and Enrst Schulin (Frankfurt: Fischer Taschenbuch Verlag, 1997), 355-79.

${ }^{201}$ See Schneider, "Nation, History and Ethics: The Choices of Post-Imperial Historiography in China," $275-28$.

${ }^{202} \mathrm{Hu}$ Chang-tze, "On the Transformation of Historical Thinking in Modern China," in Chun-chieh Huang, Jörn Rüsen ed., Chinese Historical Thinking: An Intercultural Discussion (Göttingen: V\&R unipress $\mathrm{GmbH}, 2015), 65-71$.
} 
Before Zhang Xuecheng 章學誠 (1738-1801) uttered his famous slogan “the six Classics are all history" [liujing jieshi 六經皆史], the Qing scholarship was generally “lowering history while raising the Classics" [loushi rongjing 婳史榮經] ${ }^{203}$ However, this situation changed with Zhang and Zhao Yi 趙翼(1727-1814). 'Historiography' [shixue 史學], which had been treated as an appendage of Classical Learning, began to be promoted as the core branch of scholarship. ${ }^{204}$ After Hui Dong 惠棟 (1697-1758) and Dai Zhen 戴震 (1727-1777), historians emphasized more and more the texts that had been long ignored by former Classical Learning. ${ }^{205}$ To these Qing scholars, the Six Classics were no longer sacred doctrines, but rather textual records about the past. The Dao itself, which used to be fixed in the Classics, could or should be temporalized/historized. ${ }^{206}$

From the Mid-Qing onwards, mainstream Qing scholarship went further in the direction of the "historicization of the Classics. ${ }^{207}$ This re-construction of jing and shi, namely the tendency to treat the Classics as the object of history, was widely accepted by the next generation of historians ${ }^{208}$ When Zhang Taiyan re-proposed the slogan "the Six Classics are history," he further elevated the status of history and

\footnotetext{
${ }^{203}$ See Chen Yinke, “Chen Yuan ‘Yuan Xiyu Ren Huahua Kao’ Xu 陳垣「元西域人華化考」序,” in JMEB, 238-39.

${ }^{204}$ Yü Ying-shih, Lun Dai Zhen yu Zhang Xuecheng: Qingdai zhongqi xueshu xixiang shi yanjiu 論戴震與章學 誠:清代中期學術思想史研究 (Hong Kong: Longmen shudian, 1976).

${ }^{205}$ For example, after the mid-Qing period, scholars like Gong Zizhen 龔自珍, Wei Yuan 魏源, Liao Ping 廖平, and Kang Youwei 康有為 paid more attention to Gongyang 公羊 instead of to the Chunqiu [春秋]; their studies further promoted the revival of New-Text Confucianism [Jinwen Jingxue 今文經學], which emphasized practical solutions to the crisis of Chinese society. A. Elman, Classicism, Politics, and Kingship: the Chang-chou School of New Text Confucianism in Late Imperial China, 114.

${ }^{206}$ See Yü Ying-shih, “Zhang Xuecheng vesus Dai Zheng," in Chinese History and Culture: Seventeenth Century Through Twentieth Century (New York: Columbia University Press, 2016), 109. Kang Youwei's Kongzi gaizhikao 孔子改制考 was one example of historicizing the Dao.

${ }^{207}$ For the historicization of the Classics, see Benjamin A. Elman, "The Historicization of Classical Learning in Ming-Qing," in Turning Points in Historiography: A Cross-Cultural Perspective (Rochester: The University of Rochester Press, 2012).

${ }^{208}$ Both Liang Qichao and Hu Shih accepted Zhang Xuecheng's "Six Classics are history," emphasizing that the texts of the Six Classics are all historical materials. See Liang, Qichao, "Zhi Guoxue De Liangtiao Dalu 治國學的兩條大路,” in YBSHJ: Wenji 39, 111; Shi Hu, Zhang Shizhai xiansheng nianpu 章實 齋先生年譜 (Taipei: Yuanliu, 1986), 158.
} 
claimed that history is about the whole of society, about the condition of humans. In this sense, “ancient histories are also Classics" [gushi jiejing 古史皆經]. ${ }^{209}$ Confucius himself, as Zhang Taiyan provocatively remarked, was not a sage, but a historian. ${ }^{210}$

These bold and 'deconstructive' claims changed the basic principle of historiography and thus opened the space for non-canonical materials that had long been ignored. ${ }^{211}$ Traditional textual sources then were equally read as problematic data and were labeled as 'national heritage' waiting to be arranged via historiographical methods and techniques. ${ }^{212}$ As Fu Sinian 傅斯年 once claimed:

The national heritage is material, not concept. 國故是材料, 不是主義. ${ }^{213}$

Basically, the new generation of Chinese historians no longer regarded classics, histories, masters, and collected writings as a taxonomy to categorize knowledge but

\footnotetext{
${ }^{209}$ Taiyan Zhang, “Qiushu 訄書 [The Book of Urgency],” in Zhang Taiyan Quanji 章太炎全集 (Shanghai: Shanghai renmin chubanshe, 1984 [1900]), vol.3. 154.

${ }^{210}$ Ibid. For Zhang's evaluation of Confucius, also see Chen Bisheng 陳壁生, “㜾子'形象的現代轉折一 章太炎的孔子觀, Zhongguo Renmin daxue xuebao 中國人民大學學報, 3 (2015): 154-162.

${ }^{211}$ For the raising of the status of historiography during the Late Qing period, see Luo Zhitian, "Qingmo mingchu jingxue de bianyuanhua yu shixue de zouxiang zhongxin 清末民初經學的邊緣化與史學的 走向中心," Hanxue yanjiu 漢學研究 15.2 (1997): 1-35.

${ }^{212}$ Before 1900, the term 'historical data/materials' [shiliao 史料], which had seldom appeared in texts, was not clearly defined or widely used. For example, in the late Ming dynasty, scholar Wang Shizhen 王世貞 and Dong Fubiao 董復表 compiled a book titled Yanzhou shijiao 弇州史料. However, shiliao here means collected materials in text form. Perhaps because the Japanese used the term shiliao to translate the concept of 'the materials of historiography,' this term was introduced into China as a neologism. Liang Qichao first discussed this in his New Historiography. See Max k.W. Huang, Liang Qichao yu Zhongguo xiandai shixue zhi zhuixun 梁啟超與中國現代史學之追寻, in Jindaishi yanjiu suo jikan, Academia Sinica 中研院近代史研究所集刊, 41 (2002): 183. Traditionally, there is actually huge difference between 'history' and 'historical materials.' See Yü, Lun Dai Zhen yu Zhang Xuecheng: Qingdai zhongqi xueshu xixiang shi yanjiu 論戴震與章學誠:清代中期學術思想史研究. Fansen Wang, “The New Historiograohy and its Critics in the Republic," in Zhongguo jindai sixiang yu xueshu de xipu 中國近代思 想與學術的系譜 (Taipei: Lianjing, 2003), 377-462.

${ }^{213} \mathrm{Fu}$ Sinian, Mao Zishui “Guogu yu kexue jingshen’ shiyu 毛子水「國故與科學精神」識語,” in Fu Sinian quanji 傅斯年全集 (Taipei: Lianjing 聯經, 1980), 4: 1258-60. Further discussion see Sang Bing, “Fu Sinian “shixue zhishi shiliao xue’ zaixi 傅斯年「史學只是史料學」再析, Jindai shi yanjiu 近代史研究, no. 5 (2007): 26-41.
} 
rather regarded them as a source providing the basic historical materials for scholarly research. ${ }^{214}$

But meanwhile, when the 'orthodoxy' conveyed by the Six Classics was exposed to suspicion and criticism, history kept its cognitive value, even as it lost its normative function and its concern for ethics. Historiography became somewhat more 'useful' [tongshi zhiyong 通史之用] due to its epistemological function. This transformation, in general, led to three phenomena: firstly, because all the historical data were considered equal, historians paid more and more attention to new resources, including newly discovered textual or archaeological materials and long reachable but less-read texts in the categories of religion, literature, art, folklore, and so on. The horizon of history thus became broader. Secondly, since history somehow had escaped from its former burden of Confucian ethics, it became more specialized and professional, developing into an independent discipline that relied on a large body of evidence and sophisticated methodology and techniques. ${ }^{215}$ Third, as a wave of translated sociological and anthropological books introduced from the West, the idea that history was about people, the nation, and society as a whole was reinforced. Although this idea had begun to take root in Chinese soil before the demise of imperial historiography, it became more powerful in conjunction with the new emphasis on the scientific nature of historical research and its social implications. ${ }^{216}$

\footnotetext{
${ }^{214}$ Liu Longxin, Xueshu yu zhidu: Xueke tizhi yu xiandai Zhongguo shixue de jianli 學術與制度: 學科體制與 現代中國史學的建立 (Taipei: Yuanliu, 2002), 163.

${ }^{215}$ One related development was the emergence of private historiography. Huang Zongxi, Gu Yanwu, Wang Fuzhi, and the later Kaozheng school are all representative examples. See Ng, On-cho. 'Private Historiography in Late Imperial China,' in José Rabasa, Masayuki Sato, Edoardo Tortarolo, and Daniel Woolf (ed.), The Oxford History of Historical Writing: Volume 3: 1400-1800 (Oxford, 2012; pubd online Mar. 2015). Also see On Cho Ng and Q. Edward Wang, Mirroring the Past: The Writing And Use of History in Imperial China (Honolulu: University of Hawai'i Press, 2005), chapter 8.

${ }^{216}$ Some scholars made efforts to group historians into separate schools, each defined by the distinctive positions from which they approached the business of researching and writing about the past. See Sang Bing “Zhongguo jindai xueshushi shang de daotong yu liupai 中國近代學術史上的道統 與學派,” in Xinyin houchuang yu bupo buli:jindai Zhongguo xueshu liupai yanjiu 先因後創與不破不立: 近 代中國學術流派研究, ed. Sang Bing and Guan Xiaohong (Bejing; Sanlian shudian, 2007), 1-42.
} 
Along with the expansion of the historical materials under study, Chinese scholarship also entered into a new stage of what Wang Guowei 王國維 (1877-1927) called “New Learning” [xinxue 新學]. The 'newness' of this trend comprised new research perspectives:

Those who talked about the Classics discussed New Text Confucianism, those who studied history discussed the Liao, Jin and Yuan dynasties, and those who studied geography brought the four barbarians into their scope. 言經者及今文、考史者兼 遼金元、治地理者逮四裔. ${ }^{217}$

As Wang observed, a tendency of "changing everything" [biange yiqie 變革一切] had widely emerged in academia. Instead of following "the existing path of scholarship" [weixue zhi chengfa 為學之成法], scholars of the new generation "committed to doing what no one has done before" [wuwei qianren suo buwei 務為前人所不為]. ${ }^{218}$ New patterns of scholarship, which Hu Shih described as "the revival of heterodoxy [yijun de fuhuo 異軍的復活], ${ }^{219}$ had inspired Chinese scholars to understand the Chinese cultural heritage from new angles. ${ }^{220}$

To the intellectuals who had said farewell to 'Confucian China', history bridged the new world they were longing for and their cultural home where they had grown up. This was the starting point of Liang Qichao's reformation of Chinese historiography. He noted that:

\footnotetext{
${ }^{217}$ Wang Guowei, “Shen Yian xiansheng qishi shouxu 沈乙庵先生七十壽序,” in Guantang jilin 觀堂集林 in Wang Guowei yishu 王國維遺書 (Shanghai: Shanghai guji chubanshe, 1983).

${ }^{218}$ Ibid. See Luo Zhitian, “"New Learning' in Daoguang and Xianfeng Period and Studies on the History of Learning in Qing Dynasty: An Introduction to On China's History of Learning in Recent 300 Years," in Journal of Sichuan University (Social Science Edition), 146 (2006), 8-14.

${ }^{219} \mathrm{Hu}$ Shih, “Hu Shih to Qian Xuantong [ 胡適致錢玄同] (1932. 5. 10)," cf. Geng Yunzhi 耿云志, Hu Shih nianpu 胡適年譜 (Chengdu: Sichuan renmin chubanshe, 1989), 198.

${ }^{220}$ Here, Hu Shih had summarized an important paradigm of research, namely, the study of zhuanshi 專史. The history of religion can be categorized into this paradigm. See Tang Degang, Hu Shih Koushu zizhuan 胡適口述自傳. Chapter 10, “Guogu jikan faxing zongzhi 國故季刊發行宗旨.”
} 
Among all the disciplines currently practiced in the West, the only one already present in China is historiography. 於今日泰西通行諸學科中，為中國所固有者， 為史學. ${ }^{221}$

Liang underscored both the revolution and continuity of historiography: he felt there were some useful insights and methodologies in traditional historiography, but it could and should be re-made-China's survival depended on this. Writing, or rewriting, history, he claimed, was the first step in renovating Chinese scholarship and thus the first step of rejuvenating the Chinese nation. ${ }^{22}$ This New Historiography 新史學 ${ }^{223}$ would help Chinese scholarship recover its “most supreme status, and become the leader of the world's academia." 224 Through the discursive, revolutionary power of historiography, as conceived by Liang and his peers, the morale of the Chinese would be boosted, the nation would be saved from crisis, and China's supremacy in the global order would be recovered. ${ }^{225}$

\section{The Choice of Chinese Historiography}

\footnotetext{
${ }^{221}$ Liang, Qichao, “Xin Shixue 新史學," in YBSHJ, Wenji: 9, 1.

${ }^{222}$ See Huang Jinxing 黄進興, “Zhongguo jindai shixue de shuangchong weiji: shilun 'Xinshixue' de dansheng ji qisuo minlin de kunjing 中國近代史學的雙重危機：試論「新史學」的誕生及其所面臨 的困境," in Journal of Chinese Studies 中國文化研究所學報 6 (1997): 263-284.

${ }^{223}$ For details and background on Liang's "New Historiography," see Tang Xiaobing, Global Space and the Nationalist Discourse of Modernity: The Historical Thinking of Liang Qichao (Stanford: Stanford University Press, 1996) and Edward Q. Wang, Inventing China through History: the May Fourth Approach to Historiography.

224 “最高尚最榮譽之位置, 而更執牛耳於全世界之學術思想.” Liang Qichao, “Lun Zhongguo Xueshu Sixiang Bianqian Zhi Dashi 論中國學術思想變遷之大勢,”YBSHJ, Wenji: 7, 2.

${ }^{225}$ For the political background of Liang's historiography, see Huang Minlan 黄敏蘭, “Liang Qichao 'Xin shixue' de zhenshi yiyi ji lishixue de wujie” 梁啟超《新史學》的真實意義及歷史學的誤解, in Jindaishi yanjiu 近代史研究 80.2 (1994): 219-35; Wang Fansen 王汎森, “Wan Qing de zhengzhi gainian yu 'Xinshi xue”” 晚清的政治概念與 “新史學”, in Ershi shiji de Zhongguo: xueshu yu shehui - shixuejuan 20 世紀的中國: 學術與社會-史學卷, ed., Luo Zhitian 羅志田, vol. 1, pp. 1-30; Yoshihiro Ishikawa 石川禎 浩 “Ryō Keichō to bunmei no shiza” 梁啓超と文明の視座 [Liang Qichao and the view of civilization] Buddhism and Japan), in Kyōdō kenkyū Ryō Keichō: Seiyō kindai shisō Juyō to Meiji Nihon 共同研究梁啓超— 西洋近代思想受容と明治日本, ed. Hazama Naoki 陝間直樹 (Tokyo: Misuzu shobô 1999), 106-131.
} 
Facing formidable, rapid, and often violent changes, historians, both in the West or in China realized that the old concept of time, no matter whether cyclical or regressive, could no longer serve as the framework for the writing of history; it also became powerless to depict the changes in a systematic, coherent way. ${ }^{226}$ The situation of China at the turning point of the modern age seemed more complicated due to the country's escalating conflicts with foreign powers. China had to Westernize itself by utilizing the new conceptual and technical tools from the West, but it also needed to construct its own path that met the special requirements of its local conditions. Chinese intellectuals, therefore, needed to overcome the rupture between the horizon of expectation and the space of experience; they also needed to recover the continuity of their culture in order to establish a national identity once again and, moreover, to allow the heritage of Chinese civilization to compete in the global 'free market' of ideas alongside other thoughts. Because of all these tasks, writing history in modern China can be better understood as a discursive activity through which its authors tried to form new understandings about their nation, identity, and culture, corresponding to the notions of science, rationality, progress, and so on. History, then, found itself at the center of the arena where discourses and worldview(s) battled. $^{227}$

One widely used but somewhat oversimplified classification of modern Chinese historiography was a threefold division between the traditionalists, the

\footnotetext{
${ }^{226}$ There are plenty of books and articles on the crisis of history, for example, Jacob Burckhardt, "Die geschichtlichen Krisen," in Jacob Burckhardt, Weltgeschichtliche Betrachtungen. Über geschichtliches Studium. Historische Fragmente (Leipzig: Dieterich, 1985), 155-197; Gerhard Masur, "Crisis in History," Dictionary of the History of Ideas, 4 vols., ed. Philip P. Wiener (New York: Scribner, 1968), vol. 1, 589-596; Martin Jänicke, "Krisenbegriff und Krisenforschung," in Herrschaft und Krise. Beiträge zur politikwissenschaftlichen Krisenforschung, ed. Martin Jänicke (Opladen: Westdeutscher Verlag, 1973), 1025; Rudolf Vierhaus, “Zum Problem historischer Krisen,” in Historische Prozesse, Beiträge zur Historik, ed. Karl-Georg Faber and Christian Meier (Munich: dtv, 1978), vol. 2, 313-329; Randolph Starn, "Historians and 'Crisis'," Past and Present 52 (1971): 3-22.

${ }^{227}$ See Axel Schneider, Wahrheit und Geschichte: Zwei chinesische Historiker auf der Suche nach einer modernen Identität für China (Wiesbaden: Harrassowitz, 1997), chapter 2.
} 
liberals, and later, the Marxists. ${ }^{228}$ This division, basically, rested on the different attitudes of each camp towards tradition. However, there were always overlaps and contradictions between, or within, these three camps. The traditionalists like Wang Guowei, Qian $\mathrm{Mu}$, and Chen Yinke, for example, were engaged in restoring the primary status of tradition but were not clones of the ancient dynastic historians; the liberals, such as Hu Shih and Fu Sinian, were often iconoclastic and modernists, but they were not intent on totally abandoning tradition; and the Marxists, like Guo Moruo, Tao Xisheng 陶希聖, etc., seemed to have a purer stand but also filtered Chinese tradition very carefully, rather than just ignoring it. ${ }^{229}$ Behind their different stances and practices, two sometimes contradictory but sometimes entangled trends shaped or even determined the modern Chinese historians' understanding of history: first, a progressive mode, which accepted the linear, mechanic concept of time and narrated histories according a universal framework or paradigm; second, a somewhat conservative mode, which emphasized empirical facts and evidence, and respected the particularity of every tradition.

\section{Progressivism}

The concepts of progressivism fundamentally changed the Chinese understanding of the past. The golden age, in which the Dao perfectly manifested itself, no longer maintained its superior, normative status, but was transformed into merely an early stage of history. It was Kang Youwei 康有為 who first switched the 'expectation' from the old ideal of the Three Dynasties [sandai 三代] to a future characterized by the Great Harmony. By adopting a periodizing pattern of the 'three ages' [sanshi 三世],

\footnotetext{
${ }^{228}$ This divination can be found in Levenson, Confucian China and its Modern Fate: A Trilogy., vol.3, chapter 4, 106-09. Also, Wang, Inventing China through History: the May Fourth Approach to Historiography, 7.

${ }^{229}$ For an introductory study on modern historians, see Axel Schneider, "Chinese and Japanese Historiography," in Oxford History of Historical Writing, ed. Stuart Macintyre and Daniel Woolf (Oxford: Oxford University Press, 2011), 506-17.
} 
he broke with the cyclical flux of time and reinterpreted China's past according to the Western idea of linear and teleological time. ${ }^{230}$

It was Yan Fu who introduced the Western evolutionary concepts of society and history into the intellectual world of modern China. ${ }^{231}$ Soon, Liang Qichao became one of the most influential and active propagators of those concepts. Combining New Text scholarship and Western concepts of historiography, Liang firmly rooted his early writing of history in a nationalistic and social Darwinist worldview, defining the task of historiography as arousing national consciousness among the population. ${ }^{232}$ In line with this view, Liang Qichao sketched a scheme of periodization for Chinese history that closely resembled Western examples and tried to implicitly place Chinese history into the same framework. ${ }^{233} \mathrm{He}$ posited that the progressive historiogeographical pattern he adopted was a sequential process of transformation in which no civilization could leap over any particular historical stages. ${ }^{234}$

According to Liang's understanding, "history is the description of the phenomenon of evolution." ${ }^{235}$ It should depict the past of China as a linear, law-like

\footnotetext{
${ }^{230}$ Based on New Text Confucianism, Kang interpreted history as a procession from 'the age of disunity' [juluan shi 據亂世], through 'the age of age of rising peace' [shengping shi 界平世], to 'the age of great peace' [taiping shi 太平世]. For Kang's historical-political views, see Ze Wu, “Kang Youwei gongyang sanshi shuo de lishi jinhua guandian yanjiu: Kang Youwei shixue yanjiu zhiyi," Zhonghua wenshi luncong 中華文史論叢, 1 (1962): 229-74. Also, Kung-chuan Hsiao, A Modern China and a New World: Kang Yu-wei, Reformer and Utopian, 1858-1927 (Seattle: University of Washington Press, 1975), chapter 3-4.

${ }^{231}$ Yan Fu's idea of evolutionism does not exactly follow the theories of Darwin and Huxley. For the difference between them, see Max K. W. Huang, "What is Tianyan? The Meaning and Significance of Yan Fu's Theory of Natural Evolution," Bulletin of the Institute of Modern History, Academia Sinica 中央研究 院近代史研究所集刊, no. 85 (2014): 129-87.

${ }^{232}$ See Liang “Xin shixue 新史學," 1-11, especially 1-4. He explicitly refers to the New Text School and its political engagement, Ibid. 26-29. For a brief summary of Liang's early historiographical theory, see Axel Schneider, "Shijie lishi yu lishi xiangdui zhuyi de wenti- 1919 nian yihou liangqichao de shixue 世 界歷史與歷史相對主義的問題 - 1919 年以后梁啟超的史學, ” in Zhenli yu lishi: Fu Sinian, Chen Yinke de shixue sixiang yu minzu rentong 真理與歷史:傅斯年、陳寅恪的史學思想與民族認同 (Beijing: Social Sciences Documentation Publishing House, 2008), 238-259

${ }^{233}$ Liang, Qichao, “Zhongguo Shi Xulun 中國史敘論,” in YBSHJ: Wenji, 6, 11-12

${ }^{234} \mathrm{Ibid}, 9$.

235 “歷史者, 敘述進化之現象也.”Ibid, 9.
} 
progress concomitant with a periodization based on universal experience. ${ }^{236}$ With enthusiasm, Liang introduced this progressive view of history in his New Historiography, in which he blamed traditional historiography for lacking a consciousness about the nation and state and for serving only the needs of the ruling clan. A 'new historiography,' he proclaimed, would write about people and nations, recording and explaining "the prosperity and competition" of the human race. ${ }^{237}$ This concept of history based on universal principles of evolution [Jinhua zhi gongli 進化 之公理] and causality [yinguo 因果] was embraced by other intellectuals who were eager to transform Chinese historical scholarship into a modern, scientific system, especially after the May Fourth movement in $1919 .{ }^{238}$ This trend also reached the Buddhist community.

The attitude of modern Chinese Buddhists towards progressivism and evolutionism was somewhat hesitant. However, most Buddhist modernists attempted to respond to this dominant discourse and mediate it with Buddhist doctrines. The Buddhist reformer Taixu, for example, was clearly aware of the influence of evolutionary theory. In one lecture, which he delivered at the Wuchuan Buddhist Institute 武昌佛學院, he mentioned that

in the past one hundred years, the most popular and influential [theory] is the theory of evolution. 近百年來, 風行一世, 而影響於世界人心最巨者, 厥為進化論. ${ }^{239}$

He named the theory of evolution the “Tianyan School 天演宗” and claimed that "there is a profound and significant relationship between this school and politics and scholarship as well as the way of the world and the heart of human beings." ${ }^{240}$

\footnotetext{
${ }^{236} \mathrm{Ibid}, 1-12$.

237 “人種之發達與其競爭.” Liang, Liang, “Xin Shixue 新史學,” 7.

${ }^{238}$ For the reception of the modern linear view of time and its influence upon Chinese historiography, see Fansen Wang, "The Impact of the Linear Model of History on Modern Chinese Historiography," in Transforming History: the Making of a Modern Academic Discipline in Twentieth-Century China, ed. Brain Moloughney and Peter Zarrow (Hongkong: The Chinese University Press, 2011), 135-68.

${ }^{239}$ Taixu, “Shijian wanyou wei Jinhua yi wei tuihua 世間萬有為進化抑為退化,” TXQS, vol.23, 332. 240 “此宗與政教學術世道人心關係之深且大也.” Taixu, “Lun tianyan zong 論天演宗,” TXQS, vol. 23, 297.
} 
As a Buddhist modernist, as Don Pittman described him, Taixu could not ignore the tension between Buddhism and modernity, especially the values conveyed by progressivism and science. To a certain degree, he accepted the logic of "natural selection" [wujing tianze 物競天擇] and applied the term 'evolution' to describe the process of escaping the six realms of samsära and the fulfillment of the Buddhahood. He tried to negotiate the conflicts between Buddhism and progressivism by claiming that the path of the Bodhisattva is the ultimate form of progress and by equating progressivist causality with the Buddhist concept of 'cause and fruitions' [hetu-phala, yinguo 因果]. When describing the principle behind the movement of the world, Taixu claimed that Buddhism and evolutionism are the same, just as Shi Shanyin 釋善 因 (?- 1947) argued in an article published in 1932:

Dharmas get together unanimously; to Laozi, this is nature; to Darwin, this is evolution [tianyan]; in Buddhist doctrines, this is the Dharma. 諸法際然會合時, 在 老子為自然, 在達氏為天演, 在佛經目為法爾. ${ }^{241}$

The understandings of progressivism among modern Chinese Buddhists were vague and changing. ${ }^{242}$ Their acceptance of this theory seldom derived from their interest in sketching the developmental stages of Buddhism throughout the past millennia. Neiter it derived from the challenge progressivism brought to their views of time and history. Rather, their utilization of progressivism was driven by their willingness to accomplish the modernization of Buddhism. In this sense, Buddhist believers tried to identify parallels between Buddhism and science, progress, and other modern concepts, although they often ignored to a great degree the Western (and often Eurocentric) presuppositions behind these modern ideas and the anti-religious hypotheses in the overall design of modernity. With a very pragmatic attitude, they used these theories to justify the modernness of Buddhism and its position in the development of human civilization, from the past to the present.

\footnotetext{
${ }^{241}$ Zhuju zhongsheng 竺居眾生( Shanyin 善因), “Lun ziran tianyan faer zhi yitong 論自然天演法爾之 異同," Haichaoyin 海潮音, 12 (1932): 1317-320.

${ }^{242}$ For the Buddhist response to evolutionary theory and Darwinism, see Justin R. Ritzinger, "Dependent Co-evolution: Kropotkin's Theory of Mutual Aid and Its Appropriation by Chinese Buddhists," in Chung-Hwa Buddhist Journal 26 (2013): 96-106.
} 


\section{Tradition, Nation, and Culture}

Ironically, although Buddhist modernists like Taixu, kept an open attitude towards progressivism and attempted to testify that Buddhism could promise a supreme 'progress,' some intellectuals began to question this discourse and its presuppositions, using Buddhism as their weapon. On the one hand, these intellectuals (most of whom had direct contact with the West) observed that the legend of modernity went up in smoke during the tragedy of World War I, making them question the 'bright future' promised by progress. On the other hand, many of these intellectuals held a very sympathetic feeling towards Chinese cultural heritage; therefore, they were uncomfortable with the concept of evolution because it constituted an attack on China's 'golden age' and even destroyed it in both material and moral terms. ${ }^{243}$ They also felt upset because this progressivist concept of history undermined the historiographical responsibility of historians: if history was predetermined and followed the principles of Darwinism, the subjectivity in the action of writing history would lose its meaning.

As early as in the 1910s, Liang Qichao, an important propagator of progressivism, became aware of the pitfalls of the linear concept of history and embarked consciously on the search for a historiography better suited to the needs of modern China. ${ }^{244}$ Only one year after the publication of New Historiography, Liang confessed in various places that Chinese history could hardly fit into the Western model. ${ }^{245}$ The importation of a pattern from the West was unable to create

\footnotetext{
${ }^{243}$ For a fuller discussion, see Fansen Wang, “Jindai Zhongguo de xianxing lishiguan: yi shehui jinhualun wei zhongxin de taolun 近代中國的線型歷史觀: 以社會進化論為中心的討論, ” Xin shixue 新史學 19, no. 2 (2008): 1-46.

${ }^{244}$ For the transition in Liang's views on historiography in his later career, see Axel Schneider, "Shijie lishi yu lishi xiangdui zhuyi de wenti - 1919 nian yihou Liang Qichao de shixue 世界歷史與歷史相對 主義的問題--1919 年以后梁啟超的史學,”238-259.

${ }^{245}$ For example, see Liang Qichao “Lun Zhongguo xueshu sixiang bianqian zhi dashi 論中國學術思想變 遷之大勢” in YBSHJ: Wenji: 7, 1-103. He discussed how the tripartite periodization that divided general history into three stages of the ancient age, the Middle Age, and the modern age was not fully able to explain the decline of the Chinese empire beginning in the mid-Qing dynasty.
} 
subcategories that fitted Chinese history specifically and even produced more confusion by introducing more controversial terms and notions. In Liang's later works, he further softened some of his early convictions. For example, in the article “What is Culture" [Shenme shi wenhua 什麼是文化] published in 1925, Liang asked whether the social Darwinist model could really describe the Chinese historical situation. Notions such as "universal principle" [gongli 公理] or "general precedents" [gongli 公例] were also partly questioned by him. Instead, he underscored emotion, reason, and human will as the agents of history and using Buddhist ideas of karma [ye 業] and interdependence [huyuan 互緣] to circumscribe 'culture' as a concept that did not exist by nature and necessity but depended on human norms and actions. ${ }^{246}$

From their practices of rewriting Chinese history, more historians had realized that, firstly, on a practical level, the adoption of Western schemes of periodization as well as other historical categories ('semi-feudal' or 'semi-colonial', for example) failed to neatly fit the factual situation of Chinese history; secondly, blindly borrowing external patterns based on experiences that shared little in common with the historical and local conditions in China could threaten Chinese cultural and historical particularity, and hence hinder the establishment of Chinese national identity; and, thirdly, the Eurocentric presupposition behind the Western view of history would lead to the judgement of China's eternal backwardness as a nation in the forming global order. A strong and modern China could not be envisaged and established by interpreting its history using Western terms and patterns. Ironically, the expectation of making China strong and modern was what encouraged Chinese scholars to learn from the West and accept the theory of progress and evolution in the first place.

Realizing the shortcomings of progressivism, some historians, such as Zhang Taiyan, Liu Yizheng ${ }^{247}$, and so on, partly or totally abandoned their expectations for

\footnotetext{
${ }^{246}$ Liang, “Yanjiu wenhuashi de jige zhongyao wenti 研究文化史的幾個重要問題 (1922), in YBSHJ: Wenji 40, 1-7

${ }^{247}$ Referring to the notions of change, permanence, cyclicality, and so on derived from the Yijing 易經, Liu Yizhang argued that evolutionism, which is based on brutal competition, cannot lead to a better
} 
the progressivist model of historiography. They began to criticize the concepts of progress and evolution based on Chinese historical experience or from a philosophical perspective. For example, Zhang Taiyan contested not only the concept of progressivism but also the discourse of modernity itself. ${ }^{248}$ Although he promoted linear time in his early historical works, he soon abandoned this 'hypnosis' due to his reading of Yogācāra Buddhism. Deely influenced by the Buddhist concept of samsāra he even claimed that time-what we experience as the flux from the past to the future-is only an illusion. ${ }^{249}$

Some other scholars, although they did not often directly criticize the concepts of evolution or progress, were never persuaded by the modern/Western idea that history moves linearly towards further modernization and unification of the world. Chen Yinke, Tang Yongtong, and Chen Yuan belonged to this group. Although they were unable and unwilling to distance themselves totally from the influence of modernity, they made efforts to avoid blindly embracing the 'universality' promised by the Western model and persisted in protecting their own cultural tenets. ${ }^{250}$

One of the strategies adopted by these intellectuals was to return to the ancient world of China and treat it as something special and unique. They believed that China's past was unique but had some universal principles that did not contradict modern values. The historical entity of ancient China was fundamentally not one piece of the overall puzzle of the presupposed universalism depicted by modern theories, but rather a representation that contrasted with that of Western

future. He then advocated for grounding Chinese history again in Confucian morality and called for reestablishing the 'virtue of the historians' [shide 史德].

${ }^{248}$ For the further for Zhang's critique on modernity and its Buddhist background, see Viren Murthy, The Political Philosophy of Zhang Taiyan (Leiden: Brill, 2011).

${ }^{249}$ Viren Murthy, “Transfiguring Modern Temporality: Zhang Taiyan's Yogācāra Critique of Evolutionary History," Modern China 38, no. 5 (2012), 482-522.

${ }^{250}$ The concept of 'universality' within Confucianism had profound influence on late Qing reformers, such as Kang Youwei. For a discussion on this concept and its parallel to the West's claims to universality, see Young-tsu Wong, "The Ideal of Universality in Late Ch'ing Reformism," in Reform in Nineteenth-Century China, ed. Paul A. Cohen and John E. Schrecker (Cambridge: East Asian Research Center, Harvard University, 1976), 150-54. 
civilization. Through this comparison, China could further understand both itself and the West.

Before opening itself to the rest of the world, China knew little about the outside; at the same time, to the Chinese, China's self-image was also invisible: lacking external representation and a sense of confinement, the Chinese would not have been able to recognize that they were Chinese. Therefore, looking to the outside world did not necessarily entail copying or following its external patterns, but could mean gaining a more complete picture of China itself..$^{251}$ In this way, unlike the liberal and leftist historians, these 'conservative' historians (including Liang Qichao in his later life) emphasized an empathetic understanding of China's past ('sympathy with understanding [liaojie zhi tongqing 了解之同情] in Chen Yinke's words ${ }^{252}$ or 'empathy with tacit resonance' [tongqing zhi moying 同情之默應] in Tang Yongtong's words $]^{253}$, instead of resonance with Western voices. This was also what Tang Yongtong meant when he cited the clichéd metaphor of the mirror from Shiji 史 記 to describe his historiography. Being a historian, as he quoted, means "living in this world, following the old way and reading the past as a mirror of self." 254 To them, History, as a mirror, was intended to illuminate the image of China itself so that all Chinese people could recognize themselves and their own culture. Some Buddhist scholars demonstrated a similar tendency. Historically, as a non-Chinese conceptual system, Buddhism was once an 'other' that reflected Confucian Han China. However, the emergence of the 'sinicized' version of Buddhism transformed it from a 'mirror of China' into a 'mirror of India.' During the first half of the twentieth century, scholars returned to Buddhism's past and tried to find its historical image through a mirrorlike comparison between Chinese Buddhist traditions and the original form of

\footnotetext{
${ }^{251}$ The relationship between self and other, particularity and universalism, has been addressed by many scholars; see, for example, Naoki Sakai, Translation and Subjectivity: On "Japan" and Cultural Nationalism (Minneapolis: University of Minnesota Press, 1997), chapter 5.

${ }^{252}$ See Chen Yinke, “Feng Youlan Zhongguo zhexue shi shangce shencha baogao 馮友蘭中國哲學史上 冊審查報告, in JMEB, 280 .

${ }^{253}$ Tang Yongtong, TYQJ, 655.

${ }^{254}$ Tang, “Wenhua sixiang zhi chongtu yu tiaohe 文化思想之衝突與調和, ” in TYQJ, vol.5, 281.
} 
Buddhism in India. This is what Yang Wenhui called as "aiming at renaissance" [zhizai fugu 志在复古].255

Carefully avoiding the dangers of applying a Western framework to China's particular historical reality, these historians nevertheless encountered the pitfall of relativism. ${ }^{256}$ Relativism had already caused the crisis of historiography in the West. ${ }^{257}$ Similarly, modern Chinese historians needed to overcome the feeling of meaninglessness caused by relativism when they questioned the unity and continuity of Chinese culture. It was challenging and somewhat ironic for them, because what they discovered in historical materials demonstrated that there was no cultural entity that could be called 'China.' This dilemma also led to the 'crisis of Chinese Buddhism'-modern historiography revealed that the history of Chinese Buddhism was full of falsifications, misunderstandings, and distortions. Chinese Buddhism was thus in danger of losing its legitimacy.

\section{The Meaning of History}

In the first decade of the twentieth century, whether premodern China had a history or not became an issue that provoked debate and controversy. Liang Qichao was one of the historians who held the view that China had no history. This idea derived from the concept of 'state-building'. By criticizing the old historiography as comprehending "only imperial courts but no nations" [you chaoting er wu guojia 有 朝廷而無國家], Liang proposed that the mission of history was “writing the nation, writing the citizen, writing the communities, and writing the society" [xie guojia xie

\footnotetext{
${ }^{255}$ For the difference between fugu and shoujiu, see Fansen Wang, "Cong chuantong dao Fan chuantong 一 Liangge sixiang mailuo de fenxi 從傳統到反傳統一兩個思想脈絡的分析, " in Zhongguo jindai sixiang yu xueshu de xipu 中國近代思想與學術的系譜 (Taipei: Linking, 2003), 111-32.

${ }^{256}$ For Chen's “universality of abstract ideals," see Axel Schneider, "Between Dao and History: Two Chinese Historians in Search of a Modern Identity for China," History and Theory 35, no. 4 (1996).

${ }^{257}$ See Georg G. Iggers, "Historicism: The History and Meaning of the Term." Journal of the History of Ideas 56, no. 1 (1995): 129-52. One influential book on this issue is Charles R. Bambach, Heidegger, Dilthey, and the Crisis of Historicism (New Heaven: Connell University Press, 1995).
} 
guomin xiequn xie shehui 寫國家寫國民寫群寫社會]; without the modern concept of the nation-state, it was impossible to consider any writing of 'history' as real history ${ }^{258}$ The propositions of national history are closely related to notions such as civil rights, citizenship, equality, and so on. ${ }^{259}$ From this standpoint, Liang advocated a historical writing of 'nationalism' for the first time. In his New Historiography, he claimed that "the reason why European nationalism is so developed, and countries are so civilized, must largely be attributed to their accomplishments in historiography." 260

However, there often was a tension between 'historical truth' and nationalist devotion. Sometimes, the truth discovered by historical studies failed to prove the credibility or 'innocence' of previously recorded ancient history [gushi 古史], but rather provided a fragmentary picture of China's past. Sometimes, the new historiography was not only powerless to build up the Chinese national identity but even harmed the recovery of the lost pride and glory of China. ${ }^{261}$ For example, the historian Zhu Xizu 朱希祖 once pointed out that Fu Sinian's study, which claimed that the Cheng Emperor of the Ming dynasty 明成祖 was not Han Chinese but was in fact the adopted son of the Shun Emperor of the Yuan dynasty 元順帝, proved the weakness of Han China and deeply hurt the confidence and self-respect of the Chinese. Such contradictions exemplified how modern Chinese historiography inescapably struggled over its dual identity as both protector and destroyer. When

\footnotetext{
${ }^{258}$ See Liang Qichao, “Lun guojia sixiang 論國家思想, in “Xinmin shuo 新民說,” YBSHJ: Zhuanji 4, 16-23; and “Xin shixue 新史學."

${ }^{259}$ The idea of civil rights was introduced into China in the late imperial era. Liang Qichao tried to promote the establishment the awareness of civil rights among the Chinese. See "Jinshi guomin jingzheng zhi dashi yu Zhongguo qiantu 近世國民競爭之大勢與中國前途,” in YBSHJ: Wenji 4, 56-67; “Liang Qichao, “Aiguo lun 愛國論," in YBSHJ: WenJi 3, 47.

260 “今日歐洲民族主義所以發達, 列國所以日進文明, 史學之功具其半焉.” Liang, “Xin Shixue 新史 學.”

${ }^{261}$ According to Peter Zarrow, Liang transferred the sage-kings to the nation itself. In this sense the sage-kings were desacralized, demoted from their positions as culture heroes and founders of civilization to representatives of stages of historical development. By doing so, Liang actually destroyed the myth of a golden age but valorized the evolution of the Chinese nation. See Peter Zarrow, “Old Myth into New History: The Building Blocks of Liang Qichao's 'New History', Historiography East and West 1, no. 2 (2003): 204-41.
} 
intellectuals like $\mathrm{Gu}$ Jiegang turned their eyes to the past, what they found was primarily not constructive, but deconstructive: the traditional accounts about China's past were revealed as 'hodgepodges' composed of fallacies, mysteries, and fabrications, and were thus no longer reliable. The new historiography hence became a job of “muckraking” [pafen 耙糞] in Hu Shih's word. ${ }^{262}$

The crisis of historiography also related to the emergence of the tendency to construct history as science. In the past, historians and Confucians had sometimes been uniformly identified as the 'literati', namely the shi \pm . To the Chinese literati, the dual responsibilities of historiography-recording historical facts and blaming/praising-made their works meaningful and noble. Model historians, like Sima Qian and Ban $\mathrm{Gu}$, were considered to be the ideal primarily because they were 'Confucian literati' [wenru 文儒] and only secondarily because of their outstanding historical writings. Even in the Mid-Qing dynasty, specialized historical studies without reference to the Classics, such as Zhao Yi's Nianershi zhaji 廿二史笭記, were under harsh critique. Following the trajectory of the modernization of history, the new generation of scholars, such as Fu Sinian and Gu Jiegang, no longer emphasized the ethical role of history but became producers of historical knowledge. They formed a new research community, the "professional historians," whose research purpose was to gain an accurate, scientific understanding of what had happened in the past. ${ }^{263}$ These group of historians switched their focuses from abstract theory and 'a priori rational argumentation [yili lunzheng 義理論爭] to historical data, empirical facts, and variable truth. Hence the moral discourse behind traditional historiography was replaced by a positivist attitude that was more 'scientific,' 'skeptical,' and secular. ${ }^{264}$

\footnotetext{
${ }^{262}$ See Reminiscences of Shih Hu : Oral History, ed. Te-kong Tong (Taipei: Yuanliu, 2010).

${ }^{263} \mathrm{Fu}$ Sinian, “Lishi yuyan yanjiusuo gongzuo zhi zhiqu 歷史語言研究所工作之旨趣” in Lishi yuyan yanjiusuo jikan [Bulletin of the Institute for History and Philology] 1: 1 (1928), in Fu Sinian quanji 傅斯年 全集 1980, vol.4, 1314.

${ }^{264}$ Benjamin Elman, "Philology of the Early Modern or the Late Imperial: The Crisis of Chinese Classical Learning in the 18th Century," Frontiers of History in China 6, no.1 (2011):3-25; Elman, "Philology of the Early Modern or the Late Imperial: The Crisis of Chinese Classical Learning in the 18th Century."
} 
This view required that historians should 'study' instead of 'practice' the national heritage. This research research intention was explained by Hu Shih in two aspects: firstly, a historical vision; secondly, an academic attitude ${ }^{265}$ He summarized with a metaphor: "a concept is just like a cheque." ${ }^{266}$ What the historian should pay attention to was not the tradition itself but its historical effects:

For a certain thought or religion, we should study the real influence it caused .......for example, what kind of etiquette system did it produce? What effect did this etiquette system have. 我們對於一種學說或一種宗教, 應該研究它實際發生了什麼影響…… （如）它產生了什麼樣的禮法制度? 它所產生的禮法制度發生了什麼效果. ${ }^{267}$

From the Movement of Arranging the National Essence to the Doubting Antiquity School, 'scholarship' [xuewen 學問] had become the equivalent of 'knowledge.' Traditional learning, to a certain degree, was "de-valorized, demoralized, de-mentalized," ${ }^{268}$ and was hence institutionalized and professionalized as a branch of pure research. The epistemological turn in historical studies and the knowledge-orientation of historiography clearly indicated that faith or other subjective, ethical issues were no longer some of the main foci of historiography. In some cases, the impulse to reconceptualize China's past into a narrative of progress further secularized 'faith' in historical processes. ${ }^{269}$ This tendency was also remarkable in the scholarship on Buddhism. Historians focused on a corpus of religious texts that they read for evidence and data; they swept away its 'Dharmic' implications and ignored the fact that these texts had been used in rituals, monastic life, and other religious practices for centuries. Buddhism then was understood within its social-political-economic-cultural setting and thereby tended to be treated

\footnotetext{
${ }^{265} \mathrm{Hu}$ Shi, “Lun Guogu xue 論國故學,” HSWJ, Original published on Xinchao 新潮, vol.1, issue 1 (1919); “Guoxue Jikan fakan xuanyan 國學季刊發刊宣言,” in HSWJ. Original published on Sinological Studies Quarterly, vol.1, issue 1 (1923).

266 “一個觀念就像一張支票.” Hu Shih, “Shiyan zhuyi 實驗主義, ” in Hu Shih zhexue sixiang ziliao 胡適哲 學思想資料 (Shanghai: Huadong shifan daxue chubanshe, 1981), 58.

${ }^{267} \mathrm{Hu}$ Shih, “Wu Yu wenlu xu 吳虞文錄序," HSWJ, vol.2.

${ }^{268}$ Wang Fansen, “Shishi yu jiazhi de fenli: minguo xinshixue jiqi pipingzhe 事實與價值的分離:民國新 史學及其批評者,” in Zhongguo jindai sixiang yu xueshu de xipu 中國近代思想與學術的系譜.

${ }^{269}$ Zarrow, “Old Myth into New History: The Building Blocks of Liang Qichao's “New History'.”
} 
strictly as a subcategory of the social sciences and historiography. This switch reinforced the division of factual knowledge from understandings related to faith commitment and moral commentary; and further led to "narrow and deep" research as an apparatus of knowledge production. ${ }^{270}$

${ }^{270}$ This tendency reached its peak in thethe Doubting Antiquity school movement and later research conducted by Academia Sinica. See Wang, “Shishi yu jiazhi de fenli: minguo xinshixue jiqi pipingzhe 事 實與價值的分離:民國新史學及其批評者.” 


\section{CHAPTER 2}

\section{Buddhism as Religion}

China had its religious traditions but lacked the lexical equivalent of the concept of 'religion' [zongjiao 宗教]. ${ }^{271}$ There was a deep gap, both conceptual and practical, between the traditional Chinese structure of belief and the Western notion of 'religion' that only entered china at the end of the imperial age. This gap became more noticeable in recent decades as sociologists began to question the universality of the term "religion" and the hypothesis of secularism linked with modernity. ${ }^{272}$ Scholars like Talal Asad warned that religion was not an innocent analytical category but was colored by the connotations of Western ideology. ${ }^{273}$ However, neither the questionability of the term "religion" itself nor the absence of an equivalent word in Chinese can lead to the conclusion that religion was absent from China or that the Chinese people lacked religious experiences.

The usage of 'zong 宗' and 'jiao 教,' can be dated back to the first Chinese writing system, the oracle bone script of the Shang Dynasty (1250-1200 BCE). The first Chinese dictionary, the Shuowen jiezi 說文解字, written during the Eastern Han dynasty, already contained entries for zong and jiao. ${ }^{274}$ Jiao was depicted as a combination of 'yao 爻'一a divine act—on the left with a student as well as a teacher's

\footnotetext{
${ }^{271}$ On the characteristic of 'modern religions,' see Joseph M. Kitagawa, "Primitive, Classical, and Modern Religions," in The History of Religion: Essays on Problems of Understanding, ed. Mircea Eliade Joseph Kitagawa, Charles Long (Chicago: University of Chicago Press, 1967), 39-65.

${ }^{272}$ Smith, Wilfrid Cantwell, The Meaning and End of Religion (1963; rpt. Minneapolis: Fortress Press, 1991), 12; Jonathan Z Smith, Imagining Religion: from Babylon to Jonestown (Chicago: University of Chicago Press, 1982), xi.

${ }^{273}$ Talal Asad, Genealogies of Religion: Discipline and Reasons of Power in Christianity and Islam (Baltimore: The Johns Hopkins University Press, 1993); see also Timothy Fitzgerald, “A Critique of "Religion" as a Cross-cultural Category," Method \& Theory in the Study of Religion 9, no. 2 (1997): 91-110.

${ }^{274}$ Shuowen jiezi used the traditional writing system of the 'small seal script' [xiaozhuan 小管], which well preserved the presumed origins of Chinese characters as pictographs.
} 
pointer on the right. This pictographic character was explained by the author of the Shuowen jiezi as “acting above and following below 上所施, 下所效也," which indicates a clear connotation of 'teaching' and 'education.' The item zong, with the components of 'worship' [shi 示] and 'house' [wu 屋], showed a more straightforward image of a rite performed in a holy space, and meant "worshipping at the temple of ancestors" [zun zumiao 尊祖廟也].

It is obvious that the earliest usages of zong and jiao had already embodied a strong religious sense, including ritual practices and some kind of spiritual transmission. Historically, jiao and zong were used in various traditions in the Chinese context ${ }^{275}$ and sometimes were combined with the term 'straight 正' to refer to the establishment of orthodoxy [zhengjiao 正教 or zhengzong 正宗].

However, these two words indeed fundamentally pointed in different directions. Jiao was somewhat culture-neutral and could be more appropriately perceived as 'teachings' or 'a set of principles,' while zong gradually came to connote regulation exclusively and emphasized the 'kinship' or 'lineage' serving as the basis for worship. When Zhizhuan 智顓 (538-597) formulated his classification system for Buddhism in the Sui dynasty, he used jiao to describe the different traditions of Buddhism; specifically, jiao was rendered by Zhizhuan as schools with different interpretations of the Dharma. After the Tang dynasty, however, the term zong gradually replaced jiao, as shown by the examples of the Chan school, the Tiantai school, and so on. This transition revealed an intensified sensitivity to lineage and authority. Although the combination of zongjiao and an ad hoc collocation of jiaozong appeared in Tang and later texts-in the works of Fazang 法藏 (643-714) as well as his follower Zongmi 宗密 (784-841), for example—zongjiao was not yet firmly established

\footnotetext{
${ }^{275}$ For example, Sanjiao 三教, or 'three teachings,' dating from the Tang dynasty, is an indigenous term referring to three different traditions (rujiao, daojiao, fojiao) belonging to one category. See Robert Ford Campany, "On the Very Idea of Religions (In the Modern West and in Early Medieval China)," History of Religions 42, no. 4 (2003): 287-319.
} 
as a fixed term. ${ }^{276}$ These characters only rarely occurred together in the premodern period in Buddhist texts. ${ }^{277}$

Nevertheless, to the Chinese, the continuity between the usage of premodern terminology and the modern concept of religion is relatively apparent. ${ }^{278}$ Both correspond to the long-existing realm of Chinese spiritual life, a space of idols, ancestors, rituals, and devotion. The pre-modern usage of jiao and zong, which both existed in Buddhist texts implied a rhetoric of the complex religious experience of the Chinese. 'Zong-jiao', taken together, embodies a loose collection of several ideas, secular or non-secular, political or philosophical, sometimes related to knowledge and sometimes meaning orthodoxy. These two separate but somewhat intertwined terms represented both the fundamental form of Chinese faith tradition and also implied the potential difficulties Chinese people encountered when the concept of religion traveled to China. ${ }^{279}$

\section{The Arrival of 'Religion'}

\footnotetext{
${ }^{276}$ Tim H. Barrett and Francesca Tarocco, “Terminology and Religious Identity: Buddhism and the Genealogy of the Term Zongjiao," in Dynamics in the History of Religions between Asia and Europe, ed. Volkhard Krech and Marion Steinicke (Leiden: Brill, 2012), 311-12; and Rebecca Nedostup, "Religion, Superstition and Governing Society in Nationalist China" (PhD Dissertation, Columbia University, 2001).

${ }^{277}$ In Japan's case: Natamura Hajime has argued that the Sino-Japanese technical language, shū (Chinese Zong) functioned as a translation of the Sanskrit siddhānta, meaning ineffable ultimate principle, while kyō translated the Sankrit deśanā, meaning provision verbal explanation. Thus, in its premodern Buddhist usage shūkyō referred to a linguistic expression of the ultimate principle of the dharma Hajime Nakamura, “Shūkyō to iu yakugo [宗教]という訳語, Nihon gakushi' in kiyō日本学士院 紀要 46, no. 2 (1991): 64-68, 146.

${ }^{278}$ Argument on the continuity and discontinuity in regarding to the concept of religion in china, see Ford Campany, "On the Very Idea of Religions (In the Modern West and in Early Medieval China)"; Vincent Goossaert, "Le concept de religion en Chine et l'Occident," Diogène 205, no. 1 (2004), 11. and Hans Martin Krämer, “Introduction: 'Religion'and 'Heresy' in East Asia between Continuity and Discontinuity," Bochumer Jahrbuch zur Ostasienforschung 33 (2009): 5-16.

${ }^{279}$ For the changes in the concept of zongjiao in modern China and its relationship with Confucianism, see Chen Hsi-yuan, “'Zongjiao” - yige Zhongguo jindai wenhuashi shang de guanjian ci 宗教——個中 國近代文化史上的關鍵詞, in Xin Shixue 新史學 13 (2004): 37-66.
} 
The term 'religion' was one of the neologisms that flooded China from the West via Japan around 1900. It was first translated by the intellectuals in Meiji Japan as 'shūkyō' in the 1860s and was re-imported into China as a "return graphic loan," in Lydia Liu's words. ${ }^{280}$ The traditional use of zong and jiao did exist in the Chinese language and may have influenced Japanese translators when they tried to find a word that meant 'religion.' Remarkably, before the redefined term zongjiao became popular in China, the modern sense of religious belief as an evangelistic instrument or something related to national characteristics had crept into the minds of Chinese politicians and intellectuals such as Kang Youwei. (Rebecca Nodostup argued that the word jiao, in this case, had taken on the characteristics of zongjiao advant le nom). ${ }^{281}$ Starting in the 1910s, with the involvement of religion in public affairs, a clearer definition of the compound word zongjiao gradually formed. This new meaning corresponded to that of science, politics, and other new terms that, as Asad noted, belong to "the domain of power."

Fundamentally, the term 'religion' is a European expression, and it has always been modeled after Christianity. When the concept entered Japan, 'religion' was understood by the Japanese as a category of beliefs and rituals related to supernatural powers. ${ }^{283}$ During the nineteenth century, the term shūkyō took on the negative meaning of sectarianism and became associated with 'evil, foreign teachings' antagonistic to the local ideological environment and subversive of native authority. ${ }^{284}$ The Japanese understanding of 'religion' went through several

\footnotetext{
${ }^{280}$ Lydia He Liu, Translingual Practice: Literature, National Culture, and Translated Modernity--China, 1900-1937 (Stanford: Stanford University Press, 1995), 301.

${ }^{281}$ Rebecca Nedostup, Superstitious Regimes: Religion and the Politics of Chinese Modernity (Cambridge: Harvard University Asia Center, 2009), 8.

${ }^{282}$ Talal Asad, "The construction of religion as an anthropological category," Genealogies of Religion: Discipline and Reasons of Power in Christianity and Islam (London: The Hopkins University Press, 1993): 2729.

${ }^{283}$ Nedostup, "Religion, Superstition and Governing Society in Nationalist China," 23.

${ }^{284}$ In the context of the Meiji government's promotion of Shintoism and emperor worship, shūkyō took on a negative connotation of sectarianism, as opposed to state doctrine and other laudable philosophies. In addition, it defined itself through "opposition" to "all the other major conceptual fields." For negative image of the concept 'religion' in Modern Japan, see James Edward Ketelaar, of
} 
changes. ${ }^{285}$ In 1893, when the Parliament of the World's Religions was held in Chicago, the Japanese cultural notions of religion eventually shed their former prejudices and successfully became meshed with positive, instructional discourses. ${ }^{286}$

Religion, along with other essential neologisms such as science [kexue 科學] and superstition [mixin 迷信], finally landed on Chinese soil at the beginning of the new century after a long process of reception. The religious traditions of China, then, were faced with the task of reconfiguring themselves in light of this new category. As is well known, the Late Imperial period had been characterized by a plural orthodoxy overseen by a religiously legitimatized state that assumed the right to determine what was orthodox [zheng 正] and what was heterodox [xie 邪]. But the collapse of the imperial polity changed this landscape drastically. The orthodox/heterodox distinction was replaced with the neologisms of 'religion' and 'superstition.' This discursive shift was given legal force by the new nation-state. Institutionally, this meant attempts to establish nationwide organizations to represent particular religions and advance their interests; ideologically, this meant that these traditions had to present themselves as systems of spirituality, knowledge and ethics which dissociate from the "superstitions" of local temple cults. The new nation-state, hungry for resources and urgently pursuing its vision of modernity, often expropriated popular temples and suppressed local cults. While such selective interference by the state was nothing new, the category of superstition swept up a far

\footnotetext{
Heretics and Martyrs in Meiji Japan: Buddhism and its Persecution (Princeton, N.J.: Princeton University Press, 1993), 41. Also Jason Ānanda Josephson, The Invention of Religion in Japan (Chicago: University of Chicago Press, 2012), chapter 3; Jun'ichi Isomae, Religious Discourse in Modern Japan: Religion, State, and Shintō (Brill, 2014).

${ }^{285}$ Josephson, Jason Ānanda, The Invention of Religion in Japan (Chicago: University of Chicago Press, 2012).

${ }^{286}$ For more details of the Parliament of World Religions, see Lewis Pyle Mercer, Review of the World's Religious Congresses of the World's Congress Auxiliary of the World's Columbian Exposition: Chicago, 1893 (Chicago \& New York: Randy, Mcnally \& Company, 1893). It should be noticed that, as Diana L. Eck clearly pointed out, the predominant vision of the Parliament was not pluralism, but the dawning of a new era of unity and universalism. See her forward in Richard Hughes Seager, ed., The Dawn of Religious Pluralism: Voices from the World's Parliament of Religions, 1893, vol. 1893 (Illinois: Open Court Publishing, 1993).
} 
larger proportion of Chinese religiosity than the earlier category of heterodoxy ever had. ${ }^{287}$

In this process, the three notions of science, religion, and superstition discursively formed a closely linked triangle within which Chinese religious heritage could be relocated. This structure reflected the dual thrusts of the secularist calculus of religion: on the one hand, the intellectual aspect of religions should be rearranged and reconfirmed as cultural heritage, which should then be folded into the new formulation of religious knowledge and glossed with a different glossary; on the other hand, the empirical and ritual elements of religion that could be seen as idolatry or overly elaborate rites should be categorized as superstition and therefore be expelled from 'religion.'

With some hesitation and confusion, as Nedostup noted, the intellectuals and religious elites in modern China actually used the category of 'superstition, " the opposite of science," to replace the old aggregation of 'heterodoxy,' which had been used to define practices seen as illegal, improper, immoral, or impure. In this transition, the underpinning of these new categories of science, religion, and superstition became "rationality, instead of a sense of impurity." 288 Rationality, based on the putative image of Enlightenment, was believed to be the principle that would allow people to eradicate 'superstition' from 'religion.' This idea could be found in Liang Qichao's early works. In an essay he wrote in October 1902, he claimed that harmful superstitions can be eliminated from the 'true faith' of religion. This

\footnotetext{
${ }^{287}$ These shifts are the subject of a significant and growing body of scholarly work. For an overview of these issues in this period, see Goossaert and Palmer (2011, chapters two and three). Vincent Goossaert elsewhere offers more narrowly focused treatments of the establishment of national religious associations and Christianity's role in that process (2008) and of the continuities and critical discontinuities between Late Imperial Confucian fundamentalist and anticlerical discourse and the religion/superstition discourse that took shape in the early twentieth century (2006). Nedostup (2009) provides an in-depth examination of the Nationalists' religious policies and anti-superstition campaigns in Jiangsu during the Nanjing Decade, while Poon (2011) examines the negotiations over these issues between the common people and the state in Guangzhou.

${ }^{288}$ Steven. A. Smith, "Introduction: The Religion of Fools? Superstition Past and Present," Past \& Present 199, 3 (2008): 8.
} 
viewpoint "formed the key to the cultural reform of the century to come." ${ }^{289}$ It actually later became the main logic of the religious revolutions as well as the academicization of religion during the modern period. This process of eradicating superstitious elements from religion was often conducted through political means, ${ }^{290}$ for example, through the 'Switch Temple into School Campaign' [miaochan xingxue 廟產興學 ${ }^{291}$ or the 'Anti-Superstition Movement' [pochu mixin yundong 破除迷信運 動 ${ }^{292}$; Meanwhile, it also happened in intellectual world, when scholars examined and described religion as 'tradition', 'philosophy' or knowledge. All these attempts were fundamentally designed not to destroy religions but to control the irrational force within them and to strengthen the power of rationality. ${ }^{293}$

\section{Liang Qichao's Vacillation}

The indigenization of Western concepts, which Lydia Liu called "trans-lingualism," created a new intellectual realm in which people tried to transcend the origin of these concepts and struggled to assimilate them into the local context. Although Buddhism and Taoism were somewhat better able than Confucianism to fulfill the Western definition of religion with their independent doctrinal canon, institutionalized organizations and systematic rituals, they too paid the price of

\footnotetext{
${ }^{289}$ Nedostup, Superstitious Regimes: Religion and the Politics of Chinese Modernity, 8.

${ }^{290}$ Vincent Goossaert, “The Concept of Religion in China and the West,” Diogenes 52, no. 1 (2005): 14-17.

${ }^{291}$ For studies on these two movements, see Matita Tairyō 牧田諦亮, “Seimotsu irai ni okeru byōsan kōgaku清末认來に於ける廟產興學,” in Chūgoku bukkyōshi kenkyu 中國佛教史研究, vol.2, (Tokyo, Taito shuppansha, 1984), 290-318; Vincent Goossaert, “Détruire Les Temples Pour Construire Les écoles: Reconstitution D'un Objet Historique." Extrême-Orient Extrême-Occident, no. 33 (2011): 35-51.

${ }^{292}$ Studies on Anti-superstition Movement, see Nedostup, Superstitious Regimes: Religion and the Politics of Chinese Modernity.

${ }^{293}$ There were always social and political discourses behind the anti-religion movement. See Vincent Goossaert, "1898: The Beginning of the End for Chinese Religion?" in The Journal of Asian Studies 65, no. 2 (2016): 307-36.
} 
cutting links with the ritual practices in the local sphere and were forced to stand closer and closer by science and nationalism. ${ }^{294}$

The acceptance and propagation of zongjiao as a modern notion can be primarily attributed to Liang Qichao. ${ }^{295}$ Liang mentioned this concept as early as 1897 when he gave the lecture "On China's revolution of religion" [Lun zhina zongjiao gaige 論支那宗教改革] to Japanese audiences. At that time, however, Liang's understanding of religion was quite vague. He employed terms like jiao, xue, and zongjiao in his works indistinctly, and they often simply seemed to refer to an overall system of thought or ideology. Liang basically continued to treat zongjiao as equivalent to its traditional analogue jiao, or 'teaching,' while highlighting its political facet at the same time. ${ }^{296}$ Having studied for years under the guidance of his mentor Kang Youwei-a “religionist [zongjiao jia 宗教家]” like Martin Luther, as Liang called him in his biographical article "Biography of Mr. Kang"297_Liang investigated the possibility of creating a national faith based on Kang's fusion of New Text Confucianism with Buddhist sensibilities. He also advocated for 'proselytizing' Confucian teachings in the manner of Christian missionaries ${ }^{298}$ However, Liang did not fully agree with what Kang believed in-a Confucian China with rujiao

\footnotetext{
${ }^{294}$ Around 1900, there were many essays on the issue of the relationship between religion and nationalism, for example, Cai Yuanpei’s 蔡元培 “Fojiao huguo lun 佛教護國論” (1900); Zhang Taiyan's “Lun fofa yu zongjiao, zhexue yiji xianshi zhi guanxi 論佛法與宗教、哲學以及現實之關係” (1901); Liang Qichao's “Fojiao yu qun zhi zhi guanxi 佛教與群治之關係” (1902).

${ }^{295}$ However, evidently Liang Qichao was not the first Chinese scholar to employ the term zongjiao. As early as 1890, Huang Zunxian, who served as a secretary of legation in Japan from 1877 to 1882, had already utilized this term in his Treatise on Japan [Riben Guozhi 日本國志]. See Huang Zunxian, Treaties on Japan (Shanghai: Tushu jicheng, 1989) Reprint (Taipei: Wenhai, 1968) 32:11a. ${ }^{296}$ Marianne Bastid-Bruguière, “Liang Qichao yu zongjiao wenti 梁啟超與宗教問題 [Liang Qichao and the Religious Issue],” in Liang Qichao, Mingzhi Riben, Xifang 梁啟超·明治日本·西方, ed. Hazama Naoki (Beijing: Shehui kexue wenxian chubanshe, 2001), 414.

${ }^{297}$ Liang Qichao, “Kang nanhai xiansheng zhuan 康南海先生傳,” in YBSHJ Wenji 3, 67-70.

${ }^{315}$ Lionel. M. Jensen, Manufacturing Confucianism: Chinese Traditions \& Universal Civilization (Durham: Duke University Press, 1997), 178-79. See also Chūzō Ichiko, “Hokyō to hempō 保教と變法," in Kindai Chügoku no shakai to keizai 近代中國の政治と社會, ed. Niida Noboru (Tokyo: Toko Shoin, 1951), 115-38.
} 
[Confucianism] as its national 'religion. ${ }^{299}$ In this period, Liang's understanding of religion was full of paradoxes. He linked the traditional notion of 'teaching'-jiao, the power of cultivation - with religious belief; however, when he talked about Confucianism as jiao, he actually emphasized its non-religious features: its 'rationality' and educational function.

In 1901, the third year of his political exile in Japan, his concept of religion witnessed a sudden transition. He began to discuss this term in the modern sense, with its Western meaning as the counterpart of science and its connotation of Protestantism. In his essay "How 'Protecting the Faith' is Not the Way to Honor Confucius" published in 1902, Liang first rejected the components of ritual and eschatology in the notion of religion and called them "superstition" [mixin zongyang 迷信宗仰]. ${ }^{300}$ “Religious awakening” [qixin 起信], he argued, would imprison the free thought of human beings by taking advantage of sectarianism to suppress dissent. He accused 'superstitious-ness' of being an essential feature of Western 'religions,' arguing that those religions would harm the progress of society and could not politically function to build up a modern, secular state. ${ }^{301}$

Hesitating over religion as a concept-its definition, its subcategories, and so on, Liang formed a new intellectual view in which modern discourses like 'science' and 'progressivism' became the criterion for dividing 'religion' (scientific jiao) from 'superstition' (unscientific jiao). ${ }^{302}$ Based on this categorization, Liang refused to categorize Confucianism as 'religion. ${ }^{303}$ He understored the difference between

\footnotetext{
${ }^{299}$ Kang's idea of Confucianism provoked fierce attacks by many conservative Confucian scholars in the late 1890s. See, for example, Kung-ch'uan Hsiao, A Modern China and a New World: K'ang Yu-wei, Reformer and Utopian, 1858-1927 (Seattle \& London: University of Washington Press, 1975), chapter 4.

${ }^{300}$ Liang, Qichao, “Baojiao fei suoyi zun Kong lun 保教非所以尊孔論," in YBSHJ: Wenji 9, 52.

${ }^{301}$ Liang argued that "religion is not a tool to make progress; it would be useful in the first stage of the progress of human beings but the advantages it brings will not compensate for the disadvantages it causes. [故宗教者非使人進步之具也, 於人群進化之第一期, 雖有大功德, 其第二期以後, 則或 不足以償其弊也]. See Liang, Qichao, “Baojiao fei suoyi zun Kong lun 保教非所以尊孔論, ”ibid. 52.

${ }^{302}$ Vincent Goossaert and David A. Palmer, The Religious Question in Modern China, 50.

${ }^{303}$ See Liang, “Baojiao fei suoyi zun Kong lun 保教非所以尊孔論," 52. There have always been debates on the question of whether Confucianism is a religion or not, both in China and in the West. For a summarized discussion, see Hsi-Yuan Chen, "Confucianism Encounters Religion: the Formation of
} 
Buddhism as religion and Confucianism as teaching [kongjiao 孔教]: "I think the 'jiao' of Confucianism means education, instead of religion." He argued, "this teaching advocates practice, instead of faith." 304 At the same time, he suddenly realized that religion, as belief, has also a practical function for “civilization [jiaohua 教化]," only several months after deprecating religion as 'superstition.' In his essay "On the Strengths and Weaknesses of Philosophers and Religious Personages" published in October 1902, Liang argued for the necessity of religion. Religion could be maintained as an edifying power, he claimed, if one could identify the blind and irrational beliefs within it and distance oneself from them. ${ }^{305}$ This transition in attitude happened when Liang switched from Confucianism to Buddhism under the influence of the Japanese Buddhist reformers Masaharu Anesaki 姉崎正治 (1873-1949) and Inoue Enryō 井上円了 (1858-1919). ${ }^{306}$

In the same year of 1902, Liang soon published another essay, "On the Relationship between Buddhism and Governing Communities" [Fojiao yu qun zhi zhi guanxi 佛教與群治之關係] on the instrumental function of Buddhism. Favorably comparing elements of Mahāyāna Buddhism to the ideals of social Darwinism and Western democracy, he began to interpret Buddhism as a dignified and sophisticated

Religious Discourse and the Confucian Movement in Modern China" (PhD Dissertation, Harvard University, 1999), introduction. There have been several recent studies that have discussed the religiosity of Confucianism. For example, Nobuyuki Kaji 加地伸行 has argued in his book Jukyō to wa nani ga 儒教とは何か. [What is Confucianism] (Tokyo: Chuo kolun sha, 1990) that Confucianism fulfils the definition of religion for "it offers explanations about death and the hereafter" (p.33). A further discussion on this issue is presented in his Chinmoku no Shukyō: Jukyō 沈黑の宗教-儒教 [A Silent Religion: Confucianism] (Tokyo: Tsukuma Shobo, 1994). Julia Ching also emphasized the ritualistic dimension of Confucianism, translating lijiao as "ritual religion." See Julia Ching, Chinese Religion (Maryknoll, New York: Orbis Books, 1993), 51-65. See also Li Shen 李申, “Guanyu rujiao de jige wenti 關 於儒教的幾個問題” Shijie zongjiao yanjiu 世界宗教研究, 2 (1995): 1-10; Huang Chin-shing 黄進興, “Zuowei zongjiao de rujiao: yige bijiao zongjiao de chubu tantao 作為宗教的儒教: 一個比較宗教的初 步探討," in Yazhou yanjiu 亞洲研究 23 (1997): 184-223.

304 “吾以為孔教者, 教育之教也”; “其為教也, 主於實行, 不主於信仰.” Liang, “Lun fojiao yu qunzhi zhi guanxi 論佛教與群治之關係,” in YBSHJ: Wenji 10, 45.

${ }^{305}$ Liang, Lun zongjiao jia yu zhexuejia changduan deshi 論宗教家與哲學家長短得失.”

${ }^{306}$ for the Japanese influence, see Bastid-Bruguière, “Liang Qichao yu zongjiao wenti 梁啟超與宗教問 題," 429-32. 
religion that consisted of, according to his words, "not superstition but intellectual belief." 307

Over the next few months, Liang still vacillated repeatedly over the proper position of Buddhism. His book Dashi showed his swaying attitude clearly. In the introduction to this booklet, Liang named the absence of religion as a positive feature of Chinese civilization and cheered the 'non-religious' feature of Chinese scholarship while later, in the sixth chapter, “The age of Buddhism" [foxue shidai 佛學時代], he described Buddhism (here using the word “fojiao 佛教”) as a unique religion that "splendidly lit up China's history." 308 Afterwards, however, he soon clarified that it was the 'Buddhist philosophy' [fojiao zhexue 佛教哲學], instead of the religiosity of Buddhism, that had made valuable contributions to Chinese culture. His random usage of the terms 'fojiao' and 'foxue' in the same text and his self-contradictory statements indicated his ambiguous understanding of religion in general and of Buddhism in particular.

\section{Zhang Taiyan's Buddhist Epistemology}

Liang's paradoxical and eclectic understanding was echoed by his rival, Zhang Taiyan. Similarly, Zhang's conception of religion went through numerous changes. Before he went to prison following the Subao Case 蘇報案 and probed deeply into Buddhist classics, he constantly expressed his antagonism towards religion and criticized religious beliefs as demonic. However, after 1900, Zhang accepted the Western concept of religion as it had been filtered through Japanese thinkers, especially Anesaki Masaharu. Perhaps related to his experience in jail, he then began to think

\footnotetext{
307 “佛教是智信而非迷信,” in Liang, “Lun zongjiao jia yu zhexuejia changduan deshi 論宗教家與哲學 家長短得失.” For an analysis of Liang's interpretation of Buddhism and Western political ideas, see Joseph R. Levenson, Liang Ch'i-chao and the Mind of Modern China (Berkeley: University of California Press, 1959), 129-33.

308 “放萬丈光焰於歷史上.” Liang, “Lun Zhongguo Xueshu Sixiang Bianqian Zhi Dashi 論中國學術思想 變遷之大勢,” YBSHJ, Wenji: 7, 63.
} 
about issues related to the possibility of transcendence within Buddhist thought and gradually "understood the meaning of Mahāyāna Buddhism." 309

In "On Establishing Religion"310, his first essays on Yogācāra Buddhism, Zhang followed the theory of Yogācāra ${ }^{311}$ and its philosophical setting to establish the ontological ground of religious belief and criticized Kang Youwei's efforts to fashion a national religion of "Confucianity." 312 Unlike Liang Qichao's pragmatic view of religion, Zhang's conception went beyond explicit links to nation-saving and revolutionary morality. His more abstract reading of Buddhism, especially the Yogācāra teachings, ${ }^{313}$ rarely touched on political ideas such as society, nations, or civilization but related to epistemology.

\footnotetext{
${ }^{309}$ Tang Zhijun 湯志鈞, Zhang Taiyan nianpu changbian,189; Zhang, zishu sixiang qianbian zhi ji (自述 思想韆變之跡). See also John Jorgensen, “Indra's Network: Zhang Taiyan’s Sino-Japanese Personal Networks and the Rise of Yogācāra in Modern China.” In John Makeham, ed., Transforming Consciousness: Yogacara Thought in Modern China (New York: Oxford University Press, 2014), 64-99. ${ }^{310}$ Zhang, Taiyan, “On Establishing Religion [Jianli zongjiao lun 建立宗教論].”

${ }^{311}$ Yogācāra was of all the traditional Chinese philosophical systems, the one that most nearly matched the epistemological complexity and rigor of the Western systems, such as the Kantian and neo-Kantian systems that had become popular in Europe and Japan. For example, a number of scholars have drawn attention to similarities between the Yogācāra notion of vijñapti-mātra (nothing but mental construction) and Kant's Vorstellung ("representation"). See Dan Lusthaus, Buddhist Phenomenology: A Philosophical Investigation of Yogacara Buddhism and the Ch'eng Wei-shih Lun (New York: Routledge, 2003); also Kern Iso, "Object, Objective Phenomenon and Objectivating Act According to the 'Vijñaptimātratāsiddhi' of Xuanzang (600-664)." in Phenomenology and Indian Philosophy, ed. Debi Prasad Chattopadhyaya, Lester E. Embree \& Jitendranath Mohanty (Albany: State University of New York,1992), 262-69.

${ }^{312}$ Lionel M. Jensen, Manufacturing Confucianism: Chinese Tradition and Universal Civilization (Durham: Duke University Press, 1997), 187.

${ }^{313}$ The core concept of Zhang's epistemology is the Buddhist notion “three natures" [tri-svabhāva, 三自 性]. For a detailed analysis of Zhang's view of these three natures, see Viren Murthy, The Political Philosophy of Zhang Taiyan: The Resistance of Consciousness (Leiden: Brill, 2011), 113-17. Also, Wang Hui, “Zhang Taiyan's Concept of the Individual and Modern Chinese Identity," in Becoming Chinese: Passages to Modernity and Beyond, ed. Wen-hsin Yeh (Berkeley: University of California Press, 2000), 231-59.
} 
Based on his understanding of Yogācāra Buddhism, Zhang discussed the relationship between religion and knowledge. ${ }^{314}$ This idea was elaborated in his essay "On establishing religion":

One cannot determine whether a religion is a base or exalted a priori. I take as a standard that religion should not lose truth above, and it should help the people's morality below. 宗教之高下勝劣, 不容先論。要以上不失真, 下有益於生民之道 德為其准的]. ${ }^{315}$

Although, in the Qiushu 訄書, Zhang contended that all religions are equal, here, as shown by the two labels "above" and "below," he clearly indicated principles for judgment and defined the mission of religion at two levels. The 'higher' religion, for example, Buddhism, as he indicated, is oriented toward the search for truth. In the lecture "On the Relationship between Buddhist Dharma and Religion, Philosophy and Reality," which he delivered in Japan, he stated that Buddhism, without a belief in God or any other supernatural subjects, such as hell and demons, is not a religion but essentially an atheism engaged in seeking for "wisdom" or "truth." In this sense, he understood Buddhism as a 'science' based on evidence, and called it a "philosophical positivism" [zhexue zhi shizheng zhe 哲學之實證者]. ${ }^{316}$

Zhang's philosophical interpretation of Buddhism influenced modern Chinese intellectuals and Buddhists profoundly. ${ }^{317}$ It revealed that, besides its political functions, religion has an epistemological dimension: it is the domain of knowledge. Religion not only has the power to reveal delusion and seize truth, but also is able to demonstrate the truth in a way that impels one to action. It was critical, in Zhang's

\footnotetext{
${ }^{314}$ Young-tsu Wong, Search for modern nationalism: Zhang Binglin and revolutionary China, 1869-1936 (Hong Kong: Oxford University Press, 1989), 52-55.

${ }^{315}$ Zhang Taiyan, Mingbao, no. 9 (1906): 19.

${ }^{316}$ Zhang Taiyan, Lun fofa yu zongjiao, zhexue, yiji xianshi zhi guanxi 論佛法與宗教、哲學以及現實 之關係[On the Relationship between Buddhist Dharma and Religion, Philosophy and Reality]; C.f. Murthy, “Transfiguring Modern Temporality: Zhang Taiyan’s Yogācāra Critique of Evolutionary History," 112.

${ }^{317}$ Named by Gong Jun the "philosophy-type" of Buddhist study. See Gong Jun, "Jindai Zhongguo foxue yanjiu fangfa jiqi pipan 近代中國佛學研究方法及其批判, Ershiyi shiji二十一世紀, vol. 43 (1997): 11827.
} 
view, that people surrounded by constantly changing phenomena still had a tool for reasoning to approach truth. ${ }^{318}$ And Buddhism could respond to the discourse of modernity and could somehow replace the standards imposed by Western science. At this point, Buddhism divided itself from superstition and was considered to be able to provide answers to questions such as the nature of the noumenon, causality, time, space, and so on. ${ }^{319}$

\section{Response from Buddhism}

Zhang Taiyan's idea about the epistemology of Buddhism spread throughout the Buddhist community. Discussions on the mission of Buddhism and its position in the modernizing Chinese society soon expanded to broader debates on the nature of religion and the relationships between religion, superstition, philosophy, and science.

The concern of Buddhist epistemology within Chinese Buddhist community originated from the layman Yang Renshan, who advocated and practiced this epistemological Buddhism by revitalizing the translation of Buddhist scriptures, initiating modern Buddhist education, and developing the scriptural publication and circulation of Buddhist texts. ${ }^{320}$ Yang's efforts to recover the true knowledge of Buddhism led to the formation of a scholastic Buddhism; it introduced an academic approach to rebuilding Buddhism from its doctrinal level and resisting pressure from politics and society, as well as from monasteries.

\footnotetext{
${ }^{318}$ Wing-tsit Chan, Religious Trends in Modern China (New York: Columbia University Press, 1953), 106-18. ${ }^{319}$ On Yogācāra and science in modern period see Scott Pacey, "Taixu, Yogācāra, and the Buddhist Approach to Modernity" and Erik J. Hammerstrom, "Yogācāra and Science in the 1920s: The Wuchang School's Approach to Modern Mind Science" in Transforming Consciousness: Yogacara Thought in Modern China, 148-98.

${ }^{320}$ For details of Yang Renshan's career, see Welch, The Buddhist Revival in China, 2-10.; Yü Lingbo, ed., Xiandai fojiao renwu cidian 現代佛教人物辭典, 2 vols. (Taipei: Foguang, 2004), 297-321. See also He jianming, “Minchu fojiao gexin yindong shulun 民初佛教革新運動, Jindai shi yanjiu 近代史研究 2 (1992). Pan Guiming, Zhongguo jushi fojiao shi 中國居士佛教史 (Beijing: Zhongguo she hui ke xue chubanshe, 2000), 835-36.
} 
Yang's student Ouyang Jingwu 歐陽竟無 (1871-1943) continued the undertaking of his mentor. ${ }^{321}$ Ouyang and his followers in the Neixue yuan shared the standpoint that Buddhism provided a foundation for knowing and understanding the world. ${ }^{322}$ However, they categorized Buddhism neither as philosophy nor as religion. In Ouyang's essay "The Dharma is neither religion nor philosophy," he criticized that both 'religion' and 'philosophy' were concepts derived from the West and therefore should not be recklessly applied to Buddhism. ${ }^{323}$ To Ouyang, the Dharma was the ultimate wisdom that went far beyond the scope of philosophy and had nothing in common with religious beliefs. In a letter from 1925 , he further explained:

Religion has conclusions but no investigation, while philosophy has investigation but no conclusion. The teaching of Dharma, however, means studying the ultimate truth after the conclusion has been reached, instead of searching for the conclusions through study. Therefore, the Dharma is neither religion nor philosophy but another branch of scholarship. 宗教有結論無研究, 哲學有研究無結論, 佛法則於結論後 而大加研究以極其趣, 非待研究而希得其結論。是故, 佛法於宗教哲學外, 而別 為一學也. . $^{324}$

The analogy between academic research and Buddhism here indicates that Ouyang regarded Buddhism as a kind of scholarship, although he rarely used the ambitious term foxue 佛學. He devoted a good portion of the same letter to discuss epistemological issues in detail, from the essence and origin of knowledge to its impact and function. He admitted that there was overlap between Buddhism, science,

\footnotetext{
${ }^{321}$ For Ouyang's academic background, see Yu Lingbo, Xiandai fojiao renwu cidian 現代佛教人物辭典; Eyal Aviv, Ouyang Jingwu: From Yogācāra Scholasticism to Soteriology, Transforming Consciousness: Yogācāra Thought in Modern China, (Oxford: Oxford University Press, 2014), 287-294.

${ }^{322}$ Scholars including Zhang Taiyan, Xiong Shili, Liang Qichao, Tang Yongtong, Wang Enyang 王恩洋, Jing Changji 景昌極, Miao Fenglin 繆鳳林, and Zhang Junmai 張君勱 had studied or taught at Neixue yuan. For more details about the organization and activities of Neixue yuan, see "Nanjing zhina neixueyuan zhi shikuang 南京支那內學院之實况, "Shijie fojiao jushilin linkan 世界佛教居士林林刊, issue 5, Section of Zhuangjian, 1924, 1-4; “Nanfang weishixue xuefu zhina neixueyuan gailan 南方唯識 學學府支那內學院概覽,” Haichaoyin, vol. 12, issue 5 (1931), section Shicheng 史乘, 7-9.

${ }^{323}$ Ouyang, “Fofa fei zongjiao yifei zhexue 佛法非宗教非哲學.”

${ }^{324}$ Ouyang, “Yu Zhang Xingyan shu 與章行嚴書,” in Ouyang Dashi yiji 歐陽大師遺集 (Taipei: Xinwenfeng, 1976), 335
} 
and philosophy, ${ }^{325}$ but, comparing ideas of Yogācāra Buddhis with science and philosophy, he insisted that science was limited to the realm of phenomena based on sensation; philosophy was powerless to grasp truth except in the realms of logic and experience, and would therefore unavoidably fall into agnosticism. Only Yogācāra:

......is a sophisticated convenient means [upāya] and also an ultimate reasoning. ${ }^{326}$ [yukti] 唯識法相, 方便善巧, 道理究竟.

Here Ouyang stressed again that the foundation of Buddhist teaching is the notion of rectified views [samyagjñāna, zhengjian 正見]. This knowledge-centered fundamentalism led Ouyang Jingwu to consider Buddhism the prerequisite for human rationality, and superior to science and philosophy. ${ }^{327}$ For him, the first step toward this goal was somewhat deconstructive: we have to sweep away all prejudice and illusions, especially false knowledge of Buddhism itself. In his “Today's Buddhist studies," a lecture he gave at Neixue yuan in 1923, he clarified that there are two methodological keys to 'correct' Buddhist learning: first, "the principles of the development of Buddhism" [dishan zhili 遞嬗之理] need to be clarified; second, the truth needs to be recognized in “proper sequence” [zhengqi zhishi 正期之事]. ${ }^{328}$ What he advocated here was a critical and historical reading of Buddhist teachings through which the origin and nature of Buddhism would be deciphered. His disciple Lü Cheng further explained this statement as "from the truth within the development of Buddhism to the truth of practice and action" in his speech "Talk on the scholarship

\footnotetext{
${ }^{325}$ Further study on the relationship between Buddhism and science, especially the debates on this issue in the modern period, see Erik J Hammerstrom, The Science of Chinese Buddhism: Early TwentiethCentury Engagements (New York: Columbia University Press, 2015).

${ }^{326}$ Ouyang Jingwu 歐陽竟無, “weishi juezetan 唯識抉擇談,” Ouyang Dashi yiji 歐陽大師遺集 (Taipei: Xinwenfeng, 1976), 1360. In the context of Yogācāra, daoli 道理 has the meaning of correct, rational, logical; it refers to the correct theory (Skt. nyāya, yukta; Tib. rigs pa dang ldan pa) and reasoning, logic (Skt. yukti, artha, yoga; Tib. rigs pa). For example, the Samdhinirmocana-sütra lists four kinds of reasoning 四種道理; see Cheng weishi lun 成唯識論, T 1585.31.47a29.

${ }^{327}$ Ouyang Jingwu 歐陽竟無, “Yu Zhang Xingyan shu 與章行嚴書.”

${ }^{328}$ Ouyang Jingwu, “Jinri zhi fofa yanjiu” 今日之佛法研究, 30. See also Cheng Gongrang, Ouyang Jingwu foxue sixiang yanjiu 歐陽竟無佛學思想研究 (Taipei: Xinwenfeng, 2000); Li Guangliang 李廣良, Ouyang Jingwu de foxue fangfa lun 歐陽竟無的佛學方法論, in Journal of Yunnan Normal University 云南師范大 學學報, 5 (1999): 53-7.
} 
of the Institute." ${ }^{329}$ Ouyang and Lü's proposal was aimed at restoring the most historically authentic Buddhism, so that what they believed in could be restored and an authentic or 'genuine Buddhism' could be re-established. With this strong tone of scholasticism, ${ }^{330}$ lay Buddhists in modern China, especially those associated with the Neixue yuan, adopted a position that was both radical and conservative. ${ }^{331}$ In the name of reconstructing knowledge, they attempted to rectify fallacies in the interpretation of Buddhism, revealing its genuine meaning and preventing its 'original nature [benzhen 本真] from further deviation and distortion.

This intention of rectifying Dharma and the somewhat rebellious attitude of these lay Buddhist scholars profoundly challenged the monastic orthodoxy established as early as the Tang dynasty. ${ }^{332}$ Compared to monastic Buddhism, lay Buddhism paid more attention to Buddhism's philosophical and intellectual dimensions instead of its rituals and religious experiences. Issues related to the regulatory framework for the samgha and monastic community were less discussed. This attitude was labeled by Goossaert as "anticlericalism." 333 Targeting "the selfish monks" [chujia zili zhiren 出家自利之人], such anticlericalism, as Helen Hardacre summarized, not only resulted in more extensive participation in shaping the

\footnotetext{
329 “由言教變遷之實, 求觀行践證之真.” Lü Cheng, “Tan yuanxue”談院學,” LFLX, vol.1, 329.

${ }^{330}$ The category of scholasticism as outlined by José Cabezón in his Buddhism and Language. Some of the relevant characteristics of scholastic Buddhism mentioned by Cabezón include: (1) formal nature; (2) systematicity; (3) preoccupation with scriptures and their exegesis in commentaries; (4) rationalism and reliance on logic; (5) dialectics in defense of outlined tenets; (6) a penchant for lists; (7) classification and categorization; (8) a tendency toward abstraction. See José Ignacio Cabezón, Buddhism and Language: A Study of Indo-Tibetan Scholasticism (Albany, N.Y.: State University of New York Press, 1994), 15. Also see Eyal Aviv, "Differentiating the Pearl From the Fish Eye: Ouyang Jingwu (18711943) and the Revival of Scholastic Buddhism" (Ph.D Dissertation, Harvard University, 2008).

${ }^{331}$ Dan Lusthaus, “Lü Cheng, Epistemology, and Genuine Buddhism," in Transforming Consciousness: Yogacara Thought in Modern China, 322.

${ }^{332}$ For further studies of the role of laity in modern Chinese Buddhism, see Holmes Welch, The Practice of Chinese Buddhism, 1900-1950 (Cambridge, MA.: Harvard University Press, 1967).

${ }^{333}$ Goossaert and Palmer, The Religious Question in Modern China., 308.
} 
trajectory of Buddhist institutionalization, but also in a growing skepticism regarding monastic superiority in terms of doctrinal, philosophical, and historical knowledge. ${ }^{334}$

Ouyang's alienation from monastic practices exposed him and the Neixueyuan to censure and criticism from Buddhist clergy ${ }^{335}$ Compared to Ouyang, Taixu's understanding of religion, philosophy, and science were more unstable. Indeed, he was basically convinced that Buddhism was superior to all other thoughts; however, he constantly compared Buddhism with science and other modern philosophies and did not consider Buddhism to be a self-sufficient system that should be distinguished thoroughly from science and philosophy, as Ouyang did. In his essay "My View of Religion", he defined the term zongjiao:

Now I give a definition to the currently popular term 'religion' [zongjiao]. What we call 'religion' now, according to the meaning of traditional Chinese, should be named 'teaching' [jiao] - such as the three teachings of Confucianism, Daoism, and Buddhism, and so on. Teaching equals religion. Therefore, both Buddhism and Christianity and so forth can all be called religion. Religion has two dimensions: inner realization and public education; the inner cultivation of individuals is called the 'foundation' [zong]; educating others based on this foundation is called 'religion'. ...... So, religion means cultivating people with the experience of one's inner cultivation. 今且就流行之宗教一名, 下一定義, 現在所謂宗教, 本之中國原來之語意, 應可 但稱為教——如中國言需、釋、道三教等。教即宗教, 故佛教及耶教等皆為宗 教。而教皆有自心修證及教化他人者之兩方面, 個人自心修證之實際日宗, 而本 之以教化他人者日宗教。........則宗教者, 有内心修證之經驗為宗本而施設之教化 也. . $^{336}$

Taixu's definition of zongjiao here was broader and more positive. More like Liang Qichao than Zhang Taiyan or Ouyang Jingwu, he emphasized the political function

\footnotetext{
${ }^{334}$ Helen Hardacre, “Laity," in Robert E. Busswell ed. Encyclopedia of Buddhism (New York: Macmillan Reference, 2004).

${ }^{335}$ Welch, The Buddhist Revival in China, 117-120; For the first hand sources, see Lingbo, Xiandai fojiao renwu cidian 現代佛教人物辭典, “Ouyang Jian”; the influential debate between the Inner Institute and the Wuchang Academy included: 1) debate on 'the selfish monk'; 2) debate on the birth and death dates of Śakyamuni Buddha; 3) debate on Buddhist logic; 4) debate on the falsehood of The Treatise on the Awakening of Mahāyāna Faith and the Shuangama Sūtra [Lengyan jing 楞嚴經].

${ }^{336}$ Taixu, “Wo zhi zongjiao guan 我之宗教觀, TXQS, vol22, 220.
} 
and social responsibility of religion. Without hesitation, he categorized Buddhism (along with Confucianism and Taoism) as zongjiao, following the traditional classification of the "three teachings," while mixing this classification with the modern concept of 'religion'. Interestingly, Taixu used 'Dharma' [fofa 佛法] and 'Buddhist teaching' [foxue 佛學] to refer to Buddhist belief in most of his writings; only in the final year of his life did he return to the term 'Buddhist religion' [fojiao 佛 教]. ${ }^{337}$

Although, in Taixu's view, Buddhism belonged to the category of religion, ${ }^{338}$ Taixu believed that Buddhist teaching can be a valid response to modernity, as he tried to prove in his discussions of modern philosophies and science, from social Darwinism to psychology, biology, and the theory of relativity. ${ }^{339}$ Buddhist doctrines, he emphasized in different articles, have no conflicts with modern tenets, such as progress, equality and freedom ${ }^{340}$; the Buddhist Dharma can even represent the perfect 'pure science. ${ }^{341}$

Inspired by nationalists like Liang Qichao and Zhang Taiyan, Taixu believed that, as a modern religion, Buddhism could and should support the formation of a modern state and provide solutions to the social crisis China faced. This expectation was also what Taixu read from the past of Chinese Buddhism. He had discussed many times the heroic role of samgha had played in resisting invasions and defending their local community. Although Taixu's early interest in revolutionary theories had subsided by the 1920s, he retained his concern for Buddhism's social role throughout his life. His design of modern Buddhist society came in the form of his "Pure Land in the human world" [renjian jingtu 人間淨土] concept in 1926一the notion that, rather than focusing on attaining rebirth in the Pure Lands, one should believe that this

\footnotetext{
${ }^{337}$ Nedostup, "Religion, Superstition and Governing Society in Nationalist China," 35; Goossaert and Palmer, The Religious Question in Modern China.

${ }^{338}$ We should note that, on a few occasions, Taixu argued that religion and science are both one part of philosophy. See Taixu, Foxue Gailun: jielun 佛學概論: 結論, vol.1, 58

${ }^{339}$ For a detailed discussion on how Taixu used Yogācāra to discuss these topics, see Scott Pacey,

"Taixu, Yogācāra, and the Buddhist Approach to Modernity."

${ }^{340}$ See Taixu: ziyou shiguan 自由史觀 in TXQS, vol.24, 116-203

${ }^{341}$ Taixu, “Zhen xianshilun zongyilun (shang) 真現實論宗依論(上),” in TXQS, vol. 34, 159.
} 
world itself can be "purified" by making Buddhism the intellectual foundation of individual and social life. (Taixu developed this view under the rubric of "Buddhism for human life" [rensheng fojiao 人生佛教]; a term he introduced in $1928,{ }^{342}$ and later (from 1933), “Buddhism for the human world" [renjian fojiao 人間佛教]). ${ }^{343}$

\section{Building a New Buddhism}

Throughout the twentieth century, the struggle between religion and other ideological and political forces was fierce and ceaseless. From 1898 onwards, as Goossaert and Palmer showed, the suppression of religion through, for example, the confiscation and destruction of temples, was not just a side effect of socio-political modernization but the direct result of the general policies that determined the new relationship between the state and religious institutions. ${ }^{344}$ At the same time, however, a discursive change took place and somehow preserved the space left for religion. Religion was conceived as a moralizing and unifying power behind modernization. Modern Chinese intellectuals gained this impression largely from the history of the Protestant Reformation in Europe and the experience of Japan. If, as they believed, religion could prove its correspondence with science or reshape itself as a constructive power supporting the establishment of the nation state, then it would survive. What we should notice, however, is that there was a gap between the Chinese religious heritage - an integrated system consisting of salvation, spiritual techniques, kinship-based rites, communal cults, etc.-and the discourse of a

\footnotetext{
${ }^{342}$ See Taixu 太虛, “Duiyu Zhongguo Fojiao geming seng de xunci 對於中國佛教革命僧的訓詞,” in TXQS, 597.

${ }^{343}$ His design of modern Buddhist society came in the form of his "Pure Land in the human world" [renjian jingtu 人間淨土] concept in 1926-the notion that, rather than focusing on attaining rebirth in the Pure Lands, one should believe that this world itself can be "purified" by making Buddhism the intellectual foundation of individual and social life. (Taixu developed this view under the rubric of “Buddhism for human life" [rensheng fojiao 人生佛教]; a term he introduced in 1928, and later (from 1933), “Buddhism for the human world” [renjian fojiao 人間佛教]). See Taixu, “Jianshe renjian jingtu lun 建設人間淨土論,” in TXQS, vol. 24 (2005 [1926]), pp. 349-424. See also Taixu, “Zenyang lai jianshe renjian Fojiao 怎樣來建設人間佛教, in TXQS, vol. 47 [1933], 431.

${ }^{344}$ Goossaert and Palmer, The Religious Question in Modern China.
} 
'modern religion,' which was considered to produce intellectualization, moralization, privatization, urbanization, and other processes that related to the broader phenomenon of secularization. In this sense, 'religion,' as modern Chinese people understood it, would not be a unified entity but a layered structure with different hierarchies. This gap between traditional/modern religion, as well as the inherent tension inside religion, encouraged many outsiders (mostly historians and philosophers) to participate in the discussions on the historical and political functions of religion. Most of these discussions did not transform rational atheists into believers or vice versa; rather, they consisted of interpretations of different religious visions or portraits of different faces of religion. To these non-believers, religion was fundamentally an 'invention': they read it, talked about it, imagined it, but never lived it. Therefore, it was not surprising that many contemporary scholars were addicted to the expressions 'invented religion' and 'inventing religion. ${ }^{345}$ These phrases indicated that the religious 'reformation' or 'modernization,' as "an institutionally and ideologically independent formation," was basically again a process of "religionization," ${ }^{346}$ within which the religious tradition modified its discourses, representations, and resources to fit in the new definition of 'religion' and meet the requirements of the new knowledge system and modern nation-state.

The conceptual dilemma caused by this process of invention was intensified by the threat Buddhism faced from both outside and inside: social and political upheaval as well as the doldrums of Buddhism itself at both the doctrinal and practical levels. In Buddhist communities, Buddhist leaders and elites responded to critiques of the superstitious elements in Buddhism and the corruption of the samgha by advocating that Buddhism should change according to the needs of the time. ${ }^{347}$

\footnotetext{
${ }^{345}$ By 'invention,' Tomoko Masuzawa meant that "the modern discourse on religion and religions was from the very beginning ...clearly a discourse of "othering"” or a "secular enterprise." Masuzawa, The Invention of World Religions: Or, How European Universalism was Preserved in the Language of Pluralism. 20. ${ }^{346}$ Robert Weller, "Taiwan and Global Religious Trend" (The First World Congress of Taiwan Studies, Academia Sinica, Taipei, April 26-28 2012); see also Robert Weller, Alternate Civilities: Democracy and Culture in China and Taiwan (Boulder: Westview Press, 1999).

${ }^{347}$ The concept of mofa had appeared in many modern writings. For example, the reformist monk Yakun 亞髨 in his “The Foreword of Buddhism Monthly” [佛教月報發刊詞] stated that, in “the current
} 
Meanwhile, they also insisted that the corruption of Buddhism solely indicated the degree to which Buddhism had deviated from its spiritual roots. The crisis was not caused by Buddhism itself, but rather by the institutional and sectarian misuse of the Buddha's teaching. This attitude has motivated these individuals to continually examine and rethink the Buddhist tradition and, in doing so, to seek the possibility of understanding and assessing Buddhism again with modern discourses.

The influence of modern religious scholarship can be discerned in this defensive strategy of utilizing the 'Zeitgeist' to protect Buddhist values and to sweep away doubts and critiques of this mixed, polluted religious tradition. ${ }^{348}$ In this process, the authenticity of the Chinese Buddhist canon became vulnerable under the scrutiny of modern Buddhology, which unveiled that what had been read as the Buddha's real words had in fact experienced ceaseless translation, editing, modification, and misreading. To solve this issue, Buddhist reformists and defenders in modern China envisaged two separate but not mutually exclusive paradigms: engaged Buddhism and genuine Buddhism. Despite their teleological and methodological differences, those paradigms both responded to the challenge of modernity and its components, such as rationality and science as well as the values of progress and secularization.

\section{Engaged Buddhism}

To establish Buddhism as an 'engaged' ${ }^{349}$ or 'socially engaged' religion was one of the strategies to re-organize its function based on secular values. Opposed to Weber's

age of mofa, Buddhism need to be reformed” [如今末法時代,.......即知宗教亦不得不因時而轉移]; Taixu also used this notion in his writings. See Taixu, “Jiren chengfo de zhen xianshi lun 即人成佛的 真現實論," in TXQS, vol. 47, 457

${ }^{348}$ The 'Western Zeitgeist' I refer here to includes (but is not limited to) the legacy of anti-clericism and anti-ritualism of the Reformation; the rationalism and empiricism of the Enlightenment; the romanticism of figures such as Schleiermacher and Dilthey; and the existentialism of Nietzsche. Robert H. Sharf, "The Zen of Japanese Nationalism," History of Religions 33, no. 1 (1993): 4.

${ }^{349}$ The concept of 'engaged Buddhism' or 'socially engaged Buddhism' is translated from 'le bouddhisme engage,' which was formulated by the Vietnamese Zen master Thích Nhất Hạnh. For 
idea that Buddhism is apolitical or even anti-political because of its rejection of "personality," those who supported the idea of "engaged religion" claimed that Buddhism would be an effective means to obtain human rights and build a civil society. ${ }^{350}$ Combining with the values of freedom, equality, democracy, and so on, Buddhism in the modern era became involved in public issues, such as the colonial crisis, political disputes, autocratic ruling, and economic inequality. ${ }^{351}$

In modern China, the 'politicization' of Buddhism was a significant trend among the proponents of Buddhist reformation. As a supporter of Buddhism, Liang Qichao argued in his 1902 article "On the Relationship Between Buddhism and Social Order" that religion was necessary for the progress of Chinese society. Affected by the theories of Johann Caspar Bluntschli and Japanese Spiritual Buddhism, Liang considered Buddhism to be a method of spiritual mobilization that could boost people's morale and awaken potential political powers. ${ }^{352}$

further study of 'engaged Buddhism,' see Christopher S. Queen and Sallie B. King, Engaged Buddhism: Buddhist Liberation Movements in Asia (Albany: SUNY Press, 1996). Also, K. Jones, The Social Face of Buddhism: an Approach to Political and Social Activism (London: Wisdom Publications, 1989), 271-76.

${ }^{350}$ There are already several works on this topic. See Sallie B King, Being Benevolence: The Social Ethics of Engaged Buddhism (Honolulu: University of Hawaii Press, 2005). Fred Eppsteiner ed., The Path of Compassion: Writings on Socially Engaged Buddhism (Berkeley: Paradax Press,1988); Kenneth Kraft, The Wheel of Engaged Buddhism: The Map of the Path (New York: Weatherhill, 1999); Christopher S. Queen, "Engaged Buddhism," in Charles S. Prebish, Martin Baumann,ed., Westward Dharma: Buddhism Beyond Asia (Berkeley: University of California Press, 2002); Charles Prebish, and Damien Keown, ed., Action Dharma: New Studies in Engaged Buddhism (London: Routledge Curzon, 2003).

${ }^{351}$ The historical records of the interaction between Buddhism and politics can be found in Buddhist scriptures. For example, Robert Thurman has argued that the political principles of the King Aśoka included transcendental individualism, nonviolence, educational evolutionism, social altruism, universal democracy, and so on. See Inner Revolution (New York: Riverhead Books, 1998), chapter 4. He also discussed the political ideas of Nāgārjuna based on these principles in his "Guidelines for Buddhist Social Activism Based on Nāgārjuna's Jewel Garland of Royal Counsels," in Fred Eppsteiner ed., the Path of Compassion: Writings on Socially Engaged Buddhism (Berkeley: Paradax Press,1988). Also, Ken Jones, the Social Face of Buddhism:An Approach to Political and Social Activism (London, Wisdom, 1989), 227-230; Tran Thanh Huang, "Buddhism and Politics in Southeast Asia" (Claremont Graduate School, University Centre, 1970), Ph.D diss., 11.

${ }^{352}$ Huang, Chi-shing 黄進興, Liang Qichao de zhongji guanhuai 梁啟超的終極關懷, Shixue pinglun 史學 評論, 2 (1980), 85-99. 
To invent a socially-politically engaged 'new Buddhism', ${ }^{353}$ people needed to re-interpretate its past and find in history the evidence that Buddhism can bring changes. Taixu, for example, attempted to "observe all the new cultures, including economy, politics and education, art and science through Buddhism-centric concepts. ${ }^{1354} \mathrm{He}$ believed that modern notions like equality and freedom, although Western and secular, could only be fully represented and decoded by Buddhism. Therefore, Buddhism "should be the foundation of all modern civilization." ${ }^{355}$ At many places, he investigated some of the core concepts of human society from a historical perspective, attempting to demonstrate that important processes in history can be explained and illustrated by Buddhism, and thus Buddhism can be involved in the future development of the world. He also advocated reflecting on many tenets in the history of Buddhism in light of the demands of the present. In the 1930s and the 1940s, Taixu severely criticized the traditional indifferent attitude towards politics as "a view which is out of touch with the trends of the time."356

This 'engaged Buddhism' is fundamentally conflicted to the historical image of Buddhism, which was retreated, self-limited and marginalized in political system. ${ }^{357}$ And partly because of this solid historical image and the long-lasting secular forces in

\footnotetext{
${ }^{353}$ According to Taixu, the goal of his Buddhist revolution was to "construct the original Buddhist into a new Buddhism which can adjust to the current Chinese environment" [建設原本釋迦佛遺教, 且適 合現時中國環境的新佛教]. See Taixu, “Wo de fojiao gaijin yundong lueshi 我的佛教改進運動略史,” in TXQS, vol.29, 114-115.

354 “是抱定以佛教為中心的觀念, 去觀察現代的一切新的經濟、政治、教育、文藝及科學、哲學 諸文化.” Taixu, “Xin yu rongguan 新與融貫,” in TXQS, vol.1, 375.

355 “近代文明當以佛為根據.” Taixu, “Dizhi yu shen minzhu yu fo zhi genju 帝制於神民主於佛之根 據, "Haichaoyin wenku 海潮音文庫, vol.1-11 (Taipei: Foxue shuju 佛學書局, 1930).

356 “不合時代潮流之論調.” Taixu, “Jianshe shiying shidai zhi Zhongguo fojiao 建設適應時代之中國佛 教.” C.f., He Jianming 何建明, Fofa guannian de jindai tiaoshi 佛法觀念的近代調適 (Guangzhou: Guangdong renmin chubanshe), 284.

${ }^{357}$ See Gong Jun 龔隽, “Tiaoshi yu fangkang - yi jindai dongya fojiao chuantong yu zhengzhi guanxi zhong de liangge gean wei zhongxin 調適與反抗一一以近代東亞佛教傳統與政治關係中的兩個案例 為中心," paper presented at Renjian fojiao, xinhuo xiangchuan: Di si jie Yinshun daoshi sixiang zhi lilun yu shijian xueshu yantaohui 人間佛教·薪火相傳: 第四屆印順導師思想之理論與實践學術研討 會, Taoyuan: Hongshi foxue yuan, 2003.
} 
China, the modernization of Buddhism processed slowing and remained unfinished. ${ }^{358}$ Buddhism in modern China, although engaged in society more and more deeply, still hardly fulfilled or safeguarded those voguish and powerful values that were propagated by science, nationalism, Marxism, and so on. Some scholars viewed this kind of modernism as 'reductive': the spiritual root of Buddhism had been deducted or compromised by the needs of secularization. ${ }^{359}$ To engage in such a modern world, Buddhist reformists like Taixu believed that Buddhism had to abandon the old rule that it should keep a distance from public life and should become 'humanized' [renjian hua 人間化]. However, ironically, both history and the current reality proved to the reformists that, once Buddhism interfered in the political sphere, it would be severely suppressed.

This path of engaged Buddhism in modern China, to a large degree, stucked on a theorical stage or confined to the narratives about Buddhism's past. Indeed, it still indicated a process that was the opposite of 'secularization'; ;60 it was not a simple separation of religiosity and secularity, but rather a new relationship between these two. ${ }^{361}$ As a core dimension of the classic theory of secularization, "differentiation," as Casanova summarized, underscored the "emancipation" of the secular spheres

\footnotetext{
${ }^{358}$ Taixu, “Wode fojiao yundong shibai shi 我的佛教運動失敗史," in TXQS, 19, 29. For the failure of Buddhist modernization, see Justin R. Ritzinger, Anarchy in the Pure Land: Reinventing the Cult of Maitreya in Modern Chinese Buddhism (New York, NY: Oxford University Press, 2017), 53-71.

${ }^{359}$ Ken Jones, The New Social Face of Buddhism (Wisdom Publications, 1992), 271-76.

${ }^{360}$ For the discussion on the theory of secularization, see Dobbelaere, "Secularization: A MultiDimensional Concept.” Dobbelaere, Secularization: An Analysis at Three Levels; Casanova, Public Religions in the Modern World; Danièle Hervieu-Léger, La religion pour mémoire (Paris: Cerf, 1993), 243 -59; Le pèlerin et le converti. La religion en mouvement (Paris: Flammarion, 1999), 36-37; "Pour une sociologie des 'modernités religieuses multiples': une autre approche de la 'religion invisible' des sociétés européennes." Social Compass 50, 3 (2003); Charles Taylor, Sources of the Self: The Making of the Modern Identity (Cambridge: Harvard University Press, 1989). For discussions on multiple secularities in non-western areas, see Matthias König, "Religion and the Nation-State in South Korea: A Case of Changing Interpretations of Modernity in a Global Context." Social Compass, 47, 4 (2000). Willfried Spohn, "Multiple Modernity, Nationalism and Religion: A Global Perspective." Current Sociology 51,3-4 (2003); Masoud Kamali, "Multiple Modernities and Islamism in Iran." Social Compass 54,3 (2007).

${ }^{361}$ Zhe 波喆, “Ruhe chaoyue jingdian shisuhua lilun? Ping zongiiao shehuixue de sanzhong houshisuhua lunshu 如何超越經典世俗化理論?評宗教社會學的三種後世俗化論述, ” Shehui kexue yanjiu 社會學研究 23.4 (2008): 55.
} 
(primarily the state, the economy, science) from the religious sphere and the "concomitant differentiation and specialization of religion within its own newly found religious sphere." ${ }^{362}$ Turning to modern China, it is evident that, at a certain level, differentiation and specification occurred. However, recent works on Chinese religion in modern times have shown that the distinction between religion and superstition in China complicated the differentiation thesis of secularization. ${ }^{363}$ In China, the invention of religion was intensely regulated and even tortured by ceaseless political campaigns and social movements as well as by the fixed, tough historical images of certain religion. The discourse of religion was surpassed, criticized, refuted, and promoted by varying policies and ideologies. The attempt to build engaged Buddhism indicated that institutionalized religions tried to negotiate with secular forces. However, religion was unable to maintain its power when colliding with political powers and when being alienate from its existing doctrines, systems and identities. Once the wheels of history had moved, religions, no matter how engaged they used to be, were facing the crisis of being abandoned or replaced.

\section{Genuine Buddhism 本真佛學}

The radical image of an engaged, this-worldly Buddhism caused the concern that Buddhism might lose its unique character and become less 'Buddhist.' When the reformation of Buddhism became more and more urgent, a crisis of legitimacy arose: if Buddhism was not 'good' enough, if it needed to be reformed to meet the requirements of the time, how could it be the 'perfect' teaching? How could it be the

\footnotetext{
${ }^{362}$ Casanova, Public Religions in the Modern World. 19

${ }^{363}$ Nedostup and Duara show that differentiation inevitably forced the state into the position of arbiter of religion. Nedostup, Superstitious Regimes: Religion and the Politics of Chinese Modernity. Duara, "Knowledge and Power in the Discourse of Modernity: The Campaigns Against Popular Religion in Early Twentieth-Century China." Goossaert and Poon show that intervention was a material as well as intellectual and political process, with the state, its agents, and local elites laying claim to temple property. See Vincent Goossaert, "State and Religion in Modern China: Religious Policy and Scholarly Paradigms" (Rethinking Modern Chinese History: An International Conference to Celebrate the 50th Anniversary of the Institute of Modern History, Academia Sinica, Taipei, 2005); Poon Shuk Wah, "Refashioning Festivals in Republican Guangzhou." Modern China 30,2 (2004): 199-227.
} 
basis of faith? Some Buddhist elites, often those with a scholastic background, adopted a more conservative position, advocating the removal of accumulated misconceptions about Buddhism and a return to the original essence of the Buddha's teachings, i.e. the Dharma. They attributed the crisis in Buddhism, its decline, and its lack of power in the modern world to a conceptual misreading of the Dharma, namely, an incoherent and distorted exegesis of the real tradition of Buddhism.

One of their responses to the crisis of Buddhist legitimacy was to position Buddhism as a transcending pure spiritual construction closely linked with the modern discipline of philosophy. As one form of 'Buddhist modernism,' David McMahan suggested, this pursuit of Buddhist spiritualization was a pivot towards the globalization of Buddhism during the twentieth century. ${ }^{364}$ The genesis of conceiving Buddhism as a transcendent or spiritual belief can be dated back to the Chan Buddhist tradition and to modern Western Buddhology initiated by French and German scholars in the eighteenth century. ${ }^{365}$ Modern Buddhology introduced Buddhist traditions into scholarship by editing, translating, and interpreting Buddhist scriptures from ancient Asian languages into a set of modern intellectual discourses. This process produced a wealth of textual studies on Buddhist doctrines and further supplemented them with in-depth field work in South Asia as well. This branch of scholarship interpreted Buddhism as an advanced intellectual activity based on profound, abstract philosophical reflection. Although it ignored the cultural and historical connotations of Buddhism in a particular locale, it pointed out a new direction for Chinese intellectuals and scholastic Buddhists, inspiring them to pay attention to 'genuine Buddhism' and the universal, unchangeable knowledge within it.

\footnotetext{
${ }^{364}$ See McMahan, The Making of Buddhist Modernism.The formation or 'invention' of Buddhism as a world religion has Western roots. For an insightful study on this issue, see Masuzawa, The Invention of World Religions: Or, How European Universalism was Preserved in the Language of Pluralism.See McMahan, The Making of Buddhist Modernism.

${ }^{365}$ On the history of Buddhist studies in the West, see: J.W. de Jong, A Brief History of Buddhist Studies in Europe and American; Philip C. Almond, The British Discovery of Buddhism (Cambridge: Cambridge University Press, 1988); Urs App, The Cult of Emptiness: The Western Discovery of Buddhist Thought and the Invention of Oriental Philosophy (Rorschach and Kyoto: University Media, 2012).
} 
Unlike engaged Buddhism, this tendency was an inward-looking transition that underscored the doctrinal basis of Buddhist texts and the inherent rationale within the texts. Therefore, it rarely touched the social stratum or tried to speak to the masses, as engaged Buddhism did. Rather, 'genuine Buddhism' was an elite discourse limited to intellectual circles. It represented how the educated elite controlled and transformed the discourses of religion with different forms of knowledge and how they used them to re-define Buddhism. ${ }^{366}$ This intellectual discourse of Buddhism was largely responsible for perpetuating the image of Buddhism as a rational, humanistic, contemplative creed that eschews magic and empty rituals. This tendency was often linked with the rising status of science and rationality. Similar changes had emerged in Europe in the eighteenth century as the outcome first of the Reformation and then of the Enlightenment, when modern theology was forming. ${ }^{367}$ In the same way, the 'genuine Buddhism' in modern China emphasized the unchanging truth in Buddhist doctrines, which could be more properly revealed through hermeneutical readings rather ritual practices that were controlled by temples.

One feature of this 'genuine Buddhism' pattern was the de-ritualization of Buddhism. Chinese Buddhism, although it had a long tradition of rituals, had to be

\footnotetext{
${ }^{366}$ The overall religious landscape of modern China indicated that the binary opposition of the elite/the masses was significant, even though this opposition was constructed and without a concrete historical base. The division between the elite and the masses may have existed before 1898, rooted in the Chinese religious tradition, as Goossaert and Palmer discussed in their book. Traditionally, the formation of cosmological and theological thinking was entrusted to clerical specialists who were invited by cult communities to write texts to legitimize the cults and place them in a large orthodox framework (for example, the Three Teachings). Such activities actually implied a gap between the elite and the masses. See Goossaert and Palmer, The Religious Question in Modern China. 21. Some scholars therefore have suggested that the 'Three Teachings' correspond to an 'elite religion,' in contrast to 'popular religion.' Two representative articles summarizing the debates on Chinese popular religion are: Stephen F Teiser, "Popular Religion,” The Journal of Asian Studies 54, no. 2 (1995): 387-95; Philip Clart, "The Concept of 'Popular Religion' in the Study of Chinese Religions: Retrospect and Prospects" (paper presented at the The Forth $\mathrm{Fu}$ Jen University International Sinological Symposium: Research on Religions in China: Status quo and Perspectives, Taipei, 2007).

${ }^{367}$ See T. A. Howard, Protestant Theology and the Making of the Modern German University (Oxford: Oxford University Press, 2006).
} 
"de-ritualized" to accord with notions of rationality. This discourse of de-ritualization might relate to the secularization thesis ${ }^{368}$ which indicated a tendency towards 'privatization' in which religions retreated from people's public lives into individuals' private realms. The social function of religious rites in traditional contexts-to transform collective experiences of religious practices performed in a sacred space into memories of individuals-was weakened and replaced by some abstract and intellectual expressions of religion that involved personal practices such as reading the canon, doing meditation, or participating in non-ritualized, scholastic activities. When the doctrinal orthodoxy was no longer tied to the monastic code as rigorously as in the past, ${ }^{369}$ a radically new force feeding the prosperity of Buddhist scholarship arose, showing that every person could acquire Buddhist truth and obtain his/her own salvation by 'probing into the Buddhist classics' [shenru jinglun 深入經論] instead of by participating in rituals or obeying the Vinaya principles.

After diluting the mysterious, ecstatic elements of Buddhist texts and practices, the religiosity of Buddhism was replaced with a new discourse of Buddhism that was neutral, objective, and trustworthy. This is what Buddhist scholars like Ouyang and Lü Cheng suggested: 'to return to the original texts' and form the 'genuine Buddhism'; in this way, a new Buddhist scholarship pursuing "the learning of truth" [zhenshi zhixue 真實之學] would be established. ${ }^{370}$

Basically, as Robert Sharf argued, the "logic structure" behind this modern interpretation of Buddhism was a fundamental distinction between the "essence" of the Buddhist tradition and its "cultural manifestations." 371 The real face of Buddhism,

\footnotetext{
${ }^{368}$ The privatization sub-theses have undergone numerous critiques and revisions in the last fifteen years. See José Cassanova, Public Religions in the Modern World (Chicago: University of Chicago Press, 1994), put into question the empirical as well as the normative validity of the privatization thesis.

${ }^{369}$ Robert H. Sharf, "Buddhist Modernism and the Rhetoric of Meditative Experience," Numen 42 (1995), 258.

${ }^{370}$ Lü Cheng, “Neixueyuan yanjiu gongzuo de zongjie he jihua 内學院研究工作的總結和計畫, in Jinxiandai zhuming xuezhe foxue wenji 近現代著名學者佛學文集, ed. Huang Xianian 黄夏年 (Beijing: Zhongguo shehui kexue chubanshe, 1995), 301.

${ }^{371}$ Robert Sharf, "Whose Zen? Zen Nationalism Revisited," Rude Awakenings: Zen the Kyoto School, and the Question of Nationalism (1995): 44.
} 
which should be an ahistorical truth logically prior to its superficial phenomena, was always covered or shaped by exterior contingencies. ${ }^{372}$ Behind this view was a timeless notion of 'pure origin,' presupposing that the original expression of Dharma most perfectly reflected its constant essence. ${ }^{373}$ The mission of 'genuine Buddhism,' was the same. Unlike the monastic scholars, these lay Buddhists who advocated 'genuine Buddhism' paid less attention to duhkha, karma, mokșa [emancipation, jietuo 解脱], and other soteriological or eschatological concepts. By contrast, it was more interested in the way in which Buddhist doctrines were or should be read or understood, and sought to change the declining status quo of Chinese Buddhism by critiquing and exposing its flaws and deviations from the original words of the Buddha. Although the delimitation of 'original' was often ambiguous and even arbitrary, 'genuine Buddhism' and its tendency of "perusing and respecting the truth" [cunzhen qiushi 存真求實] ${ }^{374}$ expanded the Buddhist 'communities' within which believers and non-believers could talk together about the Dharma instead of simply listening to sermons; it also lit up another path towards the 'revival' of the Chinese Buddhist tradition - the way of academization: namely, turning Buddhism into knowledge.

\section{The Failure of Buddhist Nationalism}

To the early twentieth century China at the century's turn, the power of modernity was irresistible; both engaged Buddhism, with its revolutionary standpoint, and 'genuine Buddhism,' with its more conservative, retrospective perspective, sought to understand and respond to the phenomena they faced. The former saw its goal as reforming Buddhism to address the pressing needs facing modern society. The latter,

\footnotetext{
${ }^{372}$ Ibid.

${ }^{373}$ Bernard Faure, The Rhetoric of Immediacy: A Cultural Critique of Chan/Zen Buddhism (Princeton, NJ: Princeton University Press, 1994).

${ }^{374}$ See the letter Lü wrote to Xiong Shili, in Lü Cheng xiansheng wenji 吕澂先生文集 (Taipei: Wenshu chubanshe 1988), 267. For further study of the discussions between Lü and Xiong, see Jiang Canteng 江 槡騰. “Lü Cheng yu Xiong Shili lunxue haogao pingyi 吕溦與熊十力論學函稿評議, ” Dongfang zongjiao yanjiu 東方宗教研究, 1 (1990): 219-261.
} 
maintaining the Buddhist 'other-worldly' principles and keeping a distance from 'reality,' also had an 'expected horizon' behind its interpretation of Buddhist tradition-a hermeneutic system that rested on modern discourses imported from the West (mainly through Japan). Its aim of returning to the Indian origins of Buddhism was also led, albeit well disguised, by modern inquiry. Meanwhile, besides the proponents of Western-style modernity, some other intellectuals, following their Japanese precursors, for example the Kyoto school philosophers like D.T Suzuki (1870-1966) and Nishida Kitarō (1870-1945), took the same standpoint as Zhang Taiyan and argued that Buddhism was immune to the accusation of superstition from Enlightenment secular-rationalism because it was not a religious belief but rather an epistemological base, a rational and empirical mode of inquiry into the true nature of the world. Although, at first glance, all these paths towards modernization were different or even contradictory to each other to a certain degree, they all showed the intention of establishing a Buddhism that belongs to China and respond to the needs of nationalism.

Robert Sharf offered a broad definition of nationalism when discussed Modern Japanese Buddhism: no matter whether it refers to a nation, a state, or an ethnic or racial group, nationalism can be defined as an ideology well expressed in the “collective past," a conceptual form of identity. ${ }^{375}$ A 'nation' [minzu 民族/guozu 國族], which has been defined as 'an imagined political community', often bounded together by an 'imagined' common history. ${ }^{376}$ In modern China, nationalism became a keyword, since, during that period, national identity surpassed all other identitieswhether racial, ethnic, or religious. The emergence of national identity in modern China was perceived as a natural outcome of globalization, because contact with other cultures and civilizations not only opens a window to the outside world but also

\footnotetext{
${ }^{375}$ Sharf, "The Zen of Japanese Nationalism.”

${ }^{376}$ Benedict Anderson, Imagined Communities: Reflections on the Origin and Spread of Nationalism (London: Verso. 1991), 6-7; Ernest Gellner, Nations and Nationalism (Ithaca, NY: Cornell University Press, 1983), 57; Adrian Hastings, The Construction of Nationhood: Ethnicity, Religion and Nationalism (New York, NY: Cambridge University Press, 1997), 3-4. For 'religious nationalism,' see Rogers Brubaker, Grounds for Difference (Cambridge, MA: Harvard University Press, 2015).
} 
to the inside so that one can recognize oneself through the 'other. ${ }^{1377}$ To 'semicolonial' China, globalization was always a rhetoric of 'Westernization' in realms from science and technology to values, disciplines, and habits. Nationalism, to China in crisis, was a promising alternative that would restore or preserve indigenous political, social, and moral norms in the face of the threat of foreign cultural 'hegemony. ${ }^{378}$

In modern China, religious identity was always bound up with national identity. As Holmes Welch pointed out, to choose Buddhism in the search for religious identity meant that one was choosing to be Chinese. It was an expression of cultural loyalism, a denial that things Chinese were inferior." ${ }^{\text {"I79 }}$ Influenced by the 'religious reformist' Kang Youwei but realizing his inevitable failure to establish Confucianism as the state religion, Liang Qichao and Zhang Taiyan turned to Buddhism and explored the possibility of establishing Buddhism as the base for a Chinese identity, either from an ethical or epistemological perspective. Soon, many of the Buddhist elites, who had remained sensitive to the 'national calamity' [guonan 國 難], began to explore the possibility of establishing a national identity via Buddhism.

In the first issue of the Buddhist Studies Magazine [Foxue congbao 佛學叢報], the famous lay Buddhist Pu Yicheng 锊一乘 argued for a 'nationalist Buddhism' in his article "The Buddhist view of the Republic of China":

Buddhism is the only national essence of the Republic of China; the special scholarship of the Republic of China; the supreme soul of the Republic of China 佛教 者, 中華民國唯一之國粹也, 中華民國特別之學術也, 中國民國無上之露魂也. 380

\footnotetext{
${ }^{377}$ Julia Schneider, Nation and Ethnicity: Chinese Discourses on History, Historiography and Nationalism (1990s-1920s) (Leiden: Brill, 2017), 13-61.

${ }^{378}$ For further studies on the mutual relationship between Buddhism and nationalism in a broader context, see Thomas Borchert, "Buddhism, Politics, and Nationalism in the Twentieth and Twenty-First Centuries," Religion Compass 1 (2007): 529-46; Matthew J. Walton, "Buddhism, Nationalism, and Governance " in The Oxford Handbook of Contemporary Buddhism (Oxford: Oxford University Press, 2017). ${ }^{379}$ Holmes Welch, The Revival of Chinese Buddhism, 261.

${ }^{380} \mathrm{Pu}$ Yicheng, “Zhonghua mingguo zhi Fojiao guan 中華民國之佛教觀,” MFQ, vol.1, 22.
} 
Buddhism, as he claimed in the latter part of this article, was the real 'value foundation' [jiazhi jichu 價直(值)基礎] of a modern, democratic, and free China. In the fourth issue of the same periodical, eminent monk Wumu Shanseng 鳥目山僧 (1865-1921) also claimed that Buddhism could serve as the moral and ethical base for Chinese civilization; Buddhism was not only the compensation for law and politics, he believed, but also the prerequisite to the natural rights of human beings. ${ }^{381}$

The expectation that Buddhism could become 'the Chinese spirituality' had been embodied distinctly in the writings of modern Chinese Buddhists. This phenomenon does not seem unusual if we consider the development of modern Buddhism in the overall context of East Asia. In Meiji Japan, the propagators of Buddhism also analogically advocated establishing Zen Buddhism as "Japanese spirituality." With the efforts of Shaku Sōen (1859-1919) and his disciples, like D.T. Suzuki, Nyogen Senzaki (1876-1958), and Nishida Kitarō (1870-1945), Zen was transformed into a modern religion, touting itself as "the very heart of Asian spirituality, the essence of Japanese culture, and the key to the unique qualities of the Japanese race." ${ }^{" 382}$ The military expansion of Japan in Asia from 1895 to $1905^{383}$ brought a sense of cultural and moral superiority to the Japanese. With the efforts of Shaku Sōen (1859-1919) and his disciples, like D.T. Suzuki, Nyogen Senzaki (1876-1958), and Nishida Kitarō (1870-1945), the Japanese began to combine Bushidō, the ancient "samurai code," with the spirituality of Zen Buddhism to build a 'Japaneseness' that later developed into the so-called 'nihonjinron,' an ideological expression of the national identity of modern Japan. ${ }^{384}$ This New Buddhism of Zen, on the one hand

\footnotetext{
${ }^{381}$ Zongyang had argured that Buddhism had the potential to become the 'national religion' of China or even a world belief that should stand alongside other universal creeds "in the competitive world of the $20^{\text {th }}$ century to restore civilization 標立於二十世紀競爭世界, 以光復文明.” Zongyang 宗仰, “Lun zunchong fojiao wei jinri zengjin guomin daode zhi qieyao 論尊崇佛教為今日增進國民道德之切要.” Fojiao congbao 佛教丵報 (1913.4), MFQ vol.2, 11 .

${ }^{382}$ Sharf, "The Zen of Japanese Nationalism," 6.

${ }^{383}$ Here this refers especially to the victories over the Qing dynasty in 1895 and the Russians in 1905 and to Japan's colonial activities in Korea, Manchuria, and Taiwan.

${ }^{384}$ Various scholars have tried to identify this basic core of Japanese self-identity. The anthropologist Robert. J. Smith has suggested Confucianism in his Japanese Society. Tradition, Self and the Social Order (Cambridge, Cambridge University Press, 1983, 37-38), as have R. S. Ellwood and R. Pilgrim [in Japanese
} 
promised the solidarity and modernity of Japanese culture; ${ }^{385}$ on the other hand, as an accomplice in the promulgation of Kokutai [national policy] ideology, it justified Japanese colonist power by claiming an 'Oriental ideal' that was exclusively transmitted by the essence of Japanese Zen. ${ }^{386}$

The nativist theme of 'nihonjinron' and its Buddhist background inspired modern Chinese intellectuals and Buddhists, especially those who had close official or personal relationships with Japan. ${ }^{387}$ The success of Japanese Zen Nationalism, in particular, gave them an impression (or illusion, as some scholars declared) that Buddhism would promote China's modernization and further make China prosperous and powerful. Chinese Buddhism, like Japanese Zen, could be transformed into the core of the Chinese spirit, morality, and aesthetics.

However, the project of building up Buddhism as a national religion that formed the 'soul of China' - 'Chineseness' based on Buddhist thought, equivalent to Zen in Japan-failed. Unlike Japan, the Chinese were always struggling with the colonial situation and had to firstly save the country from being destroyed.

Therefore, instead of declaring its cultural or moral superiority, China could hardly build up its 'confidence.' Chinese Buddhism, meanwhile, was always deployed from a very instrumental perspective and echoed political voices passively. No matter how it was packaged as scientific, democratic, or even communist, Buddhism in modern

Religion: A Cultural Perspective (Cliffs, NJ: Prentice-Hall 1985),130]. Jan Swyngedouw has argued that the basic religious value, and therefore the value that integrates the sociocultural order, is Japaneseness (kokutai). See Jan Swyngedouw, “Japanese Religiosity in an Age of Internationalization.” Japanese Journal of Religious Studies, 5 (1978): 92.

${ }^{385}$ Soyen Shaku, Sermons of A Buddhist Abbot [Zen for Americans], D.T. Suzuki trans., Sermons of a Buddhist Abbot (Chicago, the Open Court Publishing Company, 1906), 211-12. Also see Nukariya Kaiten, Religion of the Samurai: A study of Zen philosophy and Discipline I China and Japan (London: Luzac \& Co, 1913).

${ }^{386}$ For a historical investigation of the formation of Japan's 'Oriental ideal,' see Stefan Tanaka, Japan's Orient: Rendering Pasts into History (Berkeley: University of California Press, 1995).

${ }^{387}$ Ge Zhaoguang 葛兆光, “Kongjiao, Fojiao yihuo Yejiao: Yi jiu ling ling nian qianhou Zhongguo de xinli weiji yu zongjiao xingqu” 孔教、佛教抑或耶教——九零零年前後中國的心理危機與宗教興趣, in Zhongguo jindai sixiangshi de zhuanxing shidai 中國近代思想史的轉型時代, ed. Wang Fansen 王汎森 (Taipei: Lianjing, 2007), 201-240. 
China never reasserted itself at an ideological level and displayed itself as an independent theoretical entity.

The failure of Buddhist nationalism in China can also be attributed to the persistence of Confucianism. Despite the decline of Confucian authority, there was still an emotional reassurance to Confucian tradition among intellectuals. With a strong willingness to rebuild Confucianism again as the base of national ideology, some philosophers, such as Xiong Shili (1885-1968) and Liang Suming (1893-1988), who were known as the "New Confucianists," borrowed conceptual resources from Buddhism to establish a new philosophized Confucianism with ontological and epistemological dimensions. ${ }^{388}$ To these philosophers, Confucianism was always the prior choice, although their interpretations of Confucianism were heavily based on their critical readings of Buddhism. ${ }^{389}$

Moreover, because of the 'secular' character of Confucian tradition, the attitude of the Chinese towards religion was very ambivalent and hesitant. After the concept of religion entered China, debates on whether the traditional three teachings-Confucianism, Buddhism, and Daoism-were religions never ceased. These debates even evolved into a widespread suspicion that China might not have religion at all. ${ }^{390}$ One well-cited story is that when the Japanese monk Sōen preached

\footnotetext{
${ }^{388}$ For the philosophy of Neo-Confucianism, see John Makeham: Lost Soul: Confucianism. Contemporary Chinese Academic Discourse (Cambridge, MA.: Harvard University Press, 2008); Also. John Makeham ed. New Confucianism: A Critical Examination (New York: Palgrave Macmillan, 2003). Umberto Bresciani, Reinventing Confucianism: The New Confucian Movement (Taipei: The Taipei Ricci Institute for Chinese Studies, 2001).

${ }^{389}$ For the influence of Buddhism on Xiong Shili and Liang Shuming, see Thierry Meynard, The Religious Philosophy of Liang Shuming, The Hidden Buddhist (Leiden: Brill, 2011); John J. Hanafin, "The 'Last Buddhist': The Philosophy of Liang Shuming," in New Confucianism: A Critical Examination, ed. John Makeham (New York: Palgrave, 2003), 187-218. Lin, Chen-kuo 林鎮國, “Hsiung Shih-li’s Hermeneutics of Self: Making a Confucian Identity in Buddhist Words." NCCU Philosophical Journal 8 (2002): 69-90; John Makeham, "Xiong Shili's Critique of Yogācāra Thought in the Context of His Constructive Philosophy," in Transforming Consciousness: Yogacara Thought in Modern China, 242-282; Takahiro Nakajima, "New Confucianism and Buddhism: Liang Shuming, Xiong Shili, and Mou Zongsan," in Shiso no.9 (2007): 80 104.

${ }^{390}$ See Chen Hsi-yuan, “Confucianism Encounters Religion: the Formation of Religious Discourse and the Confucian Movement in Modern China."
} 
Buddhism as a "universal religion" in harmony with other religions as well as science and philosophy at the Parliament of the World's Religions in Chicago in $1893^{391}$, Peng Guangyu 彭光譽, a diplomat representing Confucianism, became opposed to portraying Confucianism as a 'religion' and claimed that the proper Chinese equivalent of 'religion' would be ' $w u$ 巫', a term associated with Shamanism. ${ }^{392}$ Not surprisingly, modern Chinese Buddhism, no matter how active and engaged it might be in political and social life, was never able to escape the censorship that classified it as 'superstition'; it was always struggling to distance itself from negative impressions and to survive under the pressure of changing social conditions and policies. Although it experienced a 'revival' in Republican times, Buddhism went through a very tough period when the May Fourth discourses and Communist ideology became stronger and dominant.

Nationalism, therefore, was not a 'intentional' choice for modern Chinese Buddhism, but fundamentally a compelled, desperate option. The 'sanjie reformation' [sanjie geming 三界革命] conducted by Taixu, Yuanying 圓瑶 (1878-1953), and other Buddhist leaders, while visionary and far-reaching, was extremely vulnerable, always struggling to maintain a shaky balance between monasteries, the government, and other social forces. None of these Buddhist modernists clearly realized that a modernized Buddhism could and should be an expression of the 'self-ness' of Buddhism itself, rather than only the annotation of a Western ideal. Under the pressure to subsist in a colonial society, there were no Chinese monks who could, like Sōen, clearly state that Buddhism was a universal religion before all other religions;

\footnotetext{
${ }^{391}$ For the activities of Japanese Buddhists in the Parliament in Chicago, see Shokin Furuta, "Shaku Soen: The Footsteps of a Modern Japanese Zen Master." Philosophical Studies of Japan 8 (1967):80. For details about this congress, see Richard Hughes Seager ed., The Dawn of Religious Pluralism: Voices from the World's Parliament of Religions, 1893 (Illinois: Open Court, 1993), xiv. All the conference papers were compiled in John Henry Barrows ed., The World's Parliament of Religions (Chicago: The Parliament Publishing Company, 1893). For the general program of this Congress and a detailed list of the issues discussed and the participants who came from all over the world, see The World's Religious Congresses of 1893: General Programme (Chicago \& New York: Randy, Mcnally \& Company, 1983), 23-33.

${ }^{392}$ Chen His-yuan, "Confucianism Encounters Religion: the Formation of Religious Discourse and the Confucian Movement in Modern China” (PhD dissertation, Harvard University, 1999), 28.
} 
there were also few Chinese Buddhists who could, like Suzuki and Nishida, successfully promote Buddhism as an Oriental wisdom to the West and further convert Buddhism into the core of 'Chinese-ness.' In most cases, modern Chinese interpretations of Buddhism were full of home-grown connotations, yet, at the same time, awkward attempts to use crude comparisons to appeal to Western audiences.

In 1928, as the representative of Chinese Buddhism, Taixu was invited by Sylvain Levi (1863-1935) to deliver a lecture in Paris ${ }^{393}$ His speech on the affinity between Buddhism and science did not sound impressive to his audience. The response Chinese Buddhism received was somewhat of a disappointment, especially in comparison with Japanese Zen, which had successfully touted itself as the essence of Oriental culture and had influenced several Western thinkers, such as Heidegger. The success of Japanese Buddhism indicated that what the West needed from Buddhism was something exotic and unfamiliar through which the West could define itself as 'the West.' This tendency was one of the reasons why Suzuki's empirical, spiritual Zen was embraced by the rationalized West, while Chinese Buddhism was not.

Under the 'sea tide' of Buddhist modernization, however, the real question might have been obscured: why did Chinese Buddhism have to be accepted and welcomed by the West? And was there still any way out for Chinese Buddhism, if the Chinese abandoned the desire to propagate Chinese Buddhism to the rest of the world? And what Buddhist really mean to China? Those questions were noticed and raised the concerns of some 'outsiders': historians with little or no faith in Buddhism, such Hu Shih, Chen Yinke, Chen Yuan, and Tang Yongtong.

\footnotetext{
${ }^{393}$ The title of Taixu's talk was “Exposé concis des principes du Bouddhisme Chinois." Technically, the effectiveness of the talk was severely hampered by an ill-prepared translation; the content of his talk, as well, failed to engage the interest of the Western audience. The perception was that Taixu was more concerned with impressing Westerners with his knowledge of science and philosophy (which surely he was) than in discussing in detail, as they had hoped, the theoretical, cultic, and institutional dimensions of the revitalization of Buddhism in China. See the recollections of an informant in Bulletin de l'Association Française des Amis de l'Orient, no.7, 93-94, cited by Holmes Welch, The Buddhist Revival in China, 60-62.
} 
To Japanese Zen scholars, Buddhism in spirit is close to science but maintains its religious essence, which is transcendental, heuristic, aesthetic, and mindful. ${ }^{394}$ Chinese non-Buddhist historians, in contrast, never accepted this prerequisite. $\mathrm{Hu}$ Shih, for example, kept a distance from Buddhism and other religious traditions, such as Daoism, because of their irrational elements. Other scholars like Chen Yinke and Tang Yongtong, although more neutral or sympathetic to Buddhism, also tried to dilute its religiosity by treating Buddhism as one element of Chinese cultural heritage. To them, the dilemma Buddhism faced in modern times was similar to the condition of all other Chinese traditions, from literature to art, and from Daoism to Mohism. Their interests in Buddhism belonged to their broader concerns for the fate of Chinese culture rather than the project of Buddhist modernization. Therefore, they did not focus on philosophical dimension of Buddhism but on its various manifestations in the historical context.

Realizing that, without Buddhism, it would be impossible to reestablish the continuity of Chinese history, these scholars tried to position Buddhism in the historical panorama of China. The path these outsiders took was one of 'historicization'-converting Buddhism into the object of historiography and reading, reorganizing, and re-interpreting it through historical writings. ${ }^{395}$ As Hu Shih elaborated in 1919:

Toward the old learning and thought, we make positive only one proposal, which is 'reorganize the national past' ... Because ancient learning and thought until now has not been organized, had no starting point, and had no system; therefore, the first step is to organize a logical sequence. 我們對於舊有的學術思想, 積極的只有一個主張 - - 就是「整理國故」.因為古代的學術思想向來沒有條理，没有頭緒，沒有系 統, 故第一步是條理系統的整理. ${ }^{396}$

\footnotetext{
${ }^{394}$ see Paul Carus, The Religion of Science (Chicago: Open Court Publishing Company, 1893).

${ }^{395}$ Irene Eber, "Hu Shih and Chinese History: The Problem of Cheng-li Kuo-ku," Monumenta Serica 27, no. 1 (1968). 169-207.

${ }^{396} \mathrm{Hu}$ shih “Xin sichao de yiyi 新思潮的意義.” Xin Qingnian 新青年 7.1 (1919). Translation see Eber, "Hu Shih and Chinese History: The Problem of Cheng-li Kuo-ku." 172. Eber pointed out that, in 1917,
} 
The agenda of Hu Shih's studies on Buddhism summarized this new pattern of Buddhology - the historiography of Buddhism. Until today, this historiographical path still dominant the scholarship of Buddhism in China. As Ge Zhaoguang observerd, research on Buddhism in Chinese academia is still "walking on the extended line of Hu Shih." Scholars still maintain the presupposition that it is not the philosophical connotations of Buddhism, but the historical effects and impacts that Buddhism brought to China. The cultural accretions of Buddhism and its religious manifestations, which consisted of mystical, irrational, and supernatural components, should be re-depicted and valued based on textual or extra-textual evidence. This path makes the study of Buddhism in China different from both the Western model of religious anthropology and sociology and the Japanese model of philosophy. And in Ge's view, this is precisely the characteristic rather than the defect of Chinese Buddhology.

In general, Buddhism, as a tradition, needed to regain its legitimacy in a modern context. There were different ways to approach this goal, such as getting support from political forces, attracting more believers, reaching a consensus with science, and so on. Recent scholarship has discussed more about the socio-political background of Buddhist reformation and the relationship between the government and Buddhist communities. However, Buddhism's tendency to shift into scholarship [xueshu hua 學術化] has been comparatively overlooked. This change has indicated that there is a neglected dimension beyond the widely accepted discursive framework of the so-called 'reform' or 'revival' paradigm, a paradigm which is constructed based on a pyramid of the monks, elite laymen, and ordinary believers. It cannot be ignored that, besides all these 'insiders,' there was still a group of 'outsiders' who did not directly participate in the modernization of Chinese Buddhism but more or less formed our knowledge of Chinese Buddhism and our attitude towards it.

Hu Shih had used the English word "systematize” as an equivalent for 'zhengli' [整理], but that she uses "reorganize" throughout. 
PART II

Towards the Modern Historiography of Buddhism 


\section{CHAPTER 3}

\section{Histories and Historians}

As the modern scholarship of religion emerged in the latter decades of the nineteenth century, ${ }^{397}$ Buddhism became an important research subject. For modern

Buddhologists, Buddhism was presumed to be a specific, historically unique tradition and its history, which had previously relied on records of monastic activities such as scriptural translation, pilgrimage, Dharma transmission, and so on, was now seen as a field that should be re-narrated through new methodologies and discourses. From the beginning of the twentieth century, Chinese Buddhist scholars and historians also participated in the research trend of re-writing the history of Buddhism. This trend was influenced both by the modern religious scholarship that emerged in the West, and also by the Qing Learning as well as the ethos of the literati community of the time. Although this trend never formed any schools or professional organizations with a unified foundation of epistemology and methodology, it was rooted in a common historical awareness: Buddhism needed to be re-interpreted in the modern context, both historically and conceptually.

\section{The Western Gaze}

Although Asian countries had read, studied, and practiced the Dharma for a long time, 'Buddhism' as a 'religion' was newly 'discovered' in the West during the first half of the nineteenth century ${ }^{398}$ It cannot be denied that there had been periodic

\footnotetext{
${ }^{397}$ The 1870s are often regarded as the beginning of Religionwissenschaft, or the modern science of religion. See Guy G. Stroumas, A New Science: The Discovery of Religion in the Age of Reason (Cambridge, MA: Harvard University Press, 2010); also see Mazuzawa, The Invention of World Religion, 107-109.

${ }^{398}$ My arguments on the early understanding of and attitude towards Buddhism in the West rely heavily on the exposition of Philip C. Almond in his book The British Discovery of Buddhism, especially chapter 1, “The Discovery of Buddhism," 7-32. Also see Li Silong 李四龍, Oumei fojiao xueshu shi:
} 
encounters between the West and Asian Buddhist traditions. However, those early contacts left little impact on the Western understanding of Buddhism. ${ }^{399}$ It was only after the middle of the nineteenth century that the term 'Buddha' ('Buddoo', 'Bouddha', 'Boudhou', etc.) began to gain currency in the Western-language-speaking world. ${ }^{400}$ Gradually, 'Buddhism', as a term with philosophical implications (indicated by its suffix '-ism'), had been constructed and recognized as a diverse, diffused cultural-religious phenomenon shared by different civilizations throughout Asia. ${ }^{401}$

The religion of the Buddha or Buddhism entered into the purview of Western academia in the $1820 \mathrm{~s}^{402}$ Before this very early phase of the formation of Buddhism as a 'religion,' Buddhism had been an imagined 'other' that existed in the memoirs of travelers, diplomats, missionaries, and traders ${ }^{403}$ During the first four decades of the nineteenth century, this situation changed. Buddhism, which originally had existed 'out there,' gained a constructed tradition that was primarily located in 'the West,'

xifang de fojiao xingxiang yu xueshu yuanliu 歐美佛教學術史: 西方的佛教形象與學術源流 (Beijing: Beijing daxue chubanshe, 2009).

${ }^{399}$ From A.D. 1000, a version of the life of the Buddha in the form of the legend of Barlaam and Josaphat influenced the Western Christian ascetic ideal. Moreover, from the thirteenth to the eighteenth centuries, there had been a succession of contacts: Willian van Ruysbroeck, Macro Polo, John of Monte Corvino, and Dominican, Jesuit, Capuchin, and Franciscan missionaries to Japan, China, and Tibet, had all encountered Buddhism and reported their findings to a curious West.

${ }^{400}$ An entry for 'Buddha' or 'Buddhism' could be found in dictionaries and encyclopedia as early as in the 1810s. In the English Encyclopedia of 1802, the Buddha was explained as "one of the Ceylonese Gods." An entry for the Buddha also appeared in the Encyclopedia Perthensis, the Encyclopedia Britannica, the Pantologia, and the London Encyclopedia.

${ }^{401}$ The very term 'Buddhism' proves that, in the Western world, Buddhism was understood as a religion centred on the Buddha-namely, the Buddha's 'ism' rather than the Dharma's 'ism' - which indicates the influence of Christianity, a religion centred on 'Christ.' See Masuzawa, The Invention of World Religions: Or, How European Universalism was Preserved in the Language of Pluralism. 121-131.

${ }^{402}$ As early as in 1693, Simon de la Loubèré, an envoy of Louis XIV, described the origin of Chinese Buddhism as Siam (today Thailand) based on his experience there. Lieutenant-Colonel William Francklin of the East India Company saw Buddhism as having reached China and Japan from Ceylon via Ava; John Crawfurd and Horace H. Wilson, in contrast, concluded that Buddhism originated in Magadha, the modern Bihar. Only by 1854 was India basically established as the birthplace of Buddhism. See, p.11

${ }^{403}$ Almond, The British Discovery of Buddhism, 13; Also see Richard King, The Orientalism and Religion: Postcolonial Theory, India and "The Mystic East” (London: Routledge, 1999). 
where the amassed collection, translation, and publication of its textual past had been preserved. As Philip C. Almond discussed,

Buddhism, by 1860, had come to exist, not in the Orient, but in the Oriental libraries and institutes of the West, in its texts and manuscripts, at the desks of the Western savants who interpreted it. It had become a textual object, defined, classified, and interpreted through its own textuality. ${ }^{404}$

It is clear that because of its material possession of the texts and artifacts of Buddhism, the West largely controlled Buddhism's past and also dominated discourse about its essence. Based on this ownership, the scholarship about Buddhism was established within the Western setting of knowledge by the 1850 s.

The increasing presence of Buddhist textual materials in the centers of Orientalism scattered across Europe, especially in Germany, France, England, and Russia made possible significant works on the history of Buddhism. ${ }^{405}$ Achievements that appeared included the works of Kalparoth, Schmidt, Rémusat, and Landlesse on Chinese and Mongolian texts; of Hodgson on Sanskrit and Tibetan texts; and of Alexander Csoma of Körös on the Tibetan bkah-hgyur. All these studies showed that Buddhism, in the view of modern Western scholarship, was less a living religion but more a showcase for information and knowledge that had been discovered and recovered from manuscripts, inscriptions, and rubbings. ${ }^{406}$

\footnotetext{
${ }^{404}$ Almond, The British Discovery of Buddhism, 12-13

${ }^{405}$ The early achievements of Buddhist studies were concentrated on linguistics. The most influential work of the Early Modern period was Siddhānta-Kaumudī by Bhațtoji Dỉkșita (in the seventeenth century) and its various derivative versions by Varadarāja. European grammatical scholarship began in the eighteenth century with Jean François Pons and culminated in the exhaustive expositions by nineteenth-century scholars such as Otto Boehtlingk, William Dwight Whitney, Jacob Wackernagel, and others. In 1824 the first Pali grammar was published in Columbo by the Wesleyan missionary Benjamin Clough; more significant was Burnouf and Lassen's Essai sur le Pali, the first Pali grammar to be published in Europe.

${ }^{406} \mathrm{~J}$. W. De Jong, in his A Brief History of Buddhist Studies in Europe and America, has made it quite clear that there was a significant upsurge in the editing and publishing of many Pali and Sanskrit works from 1877 onwards, especially after the creation of the Pali Text Society by T. W. Rhys Davids in 1881 . See J.W. de Jong.
} 
From the middle of the nineteenth century, Western scholarship developed various hermeneutical approaches to sorting, classifying, and interpreting the artifacts and texts of Buddhism. Behind these endeavors was an impulse to elucidate and clarify the historical 'truth' of Buddhism. Alongside the process of the textualization of Buddhism, there was also a simultaneous movement of the historicization of Buddhism. This was first expressed in a search for or, more precisely, the creation of the historical Buddha (both as a hero and as a mentor) ${ }^{407}$, and then eventually took on an intense but controversial struggle for the essence of the Buddha's words. ${ }^{408}$

Around the 1880s, the first methodological manifestos of Buddhist studies appeared. In the introduction to the 1882 edition of his Essai sur la légende du Buddha, Émile Senart clarified his critical methodology of the interpretation of the biographical narrative of the Buddha. He followed biblical scholarship and considered the records of the life of the Buddha to be a mixture of legendary and historical elements that was waiting for a 'criticism' to sift the truth from the mythological accretions. He named his method 'historical methodology' in order to distinguish it from the prevailing 'comparative methodology' inherited from Max Müller. Later, related to but different from Senart's idea of Buddhism as mythology, T.W. Rhys Davids and Hermann Oldenburg undertook a method of textual archaeology to discover the historical truth of Buddhism and compose a historical biography for the Buddha through a 'scientific method' of textual criticism. ${ }^{409}$

\footnotetext{
${ }^{407}$ This can be found especially in the writing of C. A. F. Rhys Davids.

${ }^{408}$ This issue has been discussed by Michael Pye in his article "Comparative Hermeneutics in Religion" in the Cardinal Meaning: Essays in Comparative Hermeneutics, Buddhism and Christianity, ed. Michael Pye and Robert Morgan (The Hague: Mouton, 1973). Relying on Ernst Troelsch's argument on the 'essence of Christianity,' Pye argued that the objectivity of history existing purely in the texts was an illusion; the essence of Buddhism was defined by the interpreter of its past through what Troeltsch called a 'creative act' in which history and theology merge. Therefore, any efforts to provide meaning to the past would lead to irony.

${ }^{409}$ Hermann Oldenburg, Buddha, Sein Leben, seine Lehre, seine Gemeinde (Berlin: W. Hertz, 1881). This work was translated into English soon its original publication under the title of "Buddha: His Life, His Doctrine, His Order," (London: William and Norgate, 1882); T.W. Rhys Davids, Buddhism: Being a Sketch of the Life and Teachings of Gautama, the Buddha (London: Society for Promoting Christian Knowledge, 1899).
} 
At the heart of the effort to construct a credible biography of the Buddha and a history of early Buddhism, there was always a pre-imaged 'essence' of Buddhism. Scholars believe, that before the time of Aśoka, Buddhism had existed for a long time in some sort of pre-canonical form that was 'primary' or 'essential'; this primary Buddhism was gradually lost in the following centuries, after the death of the Buddha. This essence-the 'lost sutras,' as well as the lost fragments of the Buddha's life-was considered to be both the historical and ideological foundation for the Buddhist tradition. ${ }^{410}$ This predisposition towards 'essence' had a crucial impact on the entire history of Western Buddhist studies. On the one hand, it sustained several methodologies, from historiography to philology; on the other hand, it led to contempt for Chinese Buddhism or Buddhist texts written in Chinese. Chinese Buddhism was believed to have been contaminated by other local ideological traditions and largely lost its credibility and value.

Only near the beginning of the twentieth century did a new generation of scholars turn their view towards Chinese Buddhism and other Buddhist traditions in East Asia. ${ }^{411}$ The main change brought about by these scholars was the discovery of

\footnotetext{
${ }^{410}$ Western Buddhologists before the twentieth century, although they had different methodological standpoints, generally accepted the concept of 'essential/original Buddhism. ${ }^{410}$ For example, in C.A.F. Rhys Davids's book Sakya, or Buddhist Origins, she used textual criticism to classify and examine the ancient sūtra in the Pāli literture to search for the historical Buddha and his essential teaching. German Indologist Hermann Oldenburg as well set his sights on the 'more essential ideas' [die wesentlicheren unter den Gedanken]; in his most influential book, Buddha, sein Leben, seine Lehre, seine Gemeide, he sought the core of this essence in early Brahmanism and attempted to reveal this core through a comparison between Buddhist and non-Buddhist texts. Russian Buddhologist Theodor Stcherbatsky attempted to reconstruct the logic of Buddhism through a historical hermeneutic, as he 'rendered the philosophical meaning and not the literal sense. ${ }^{410} \mathrm{He}$ believed that the meaning of history was always maintained in the context in which the Buddhist terminology was originally developed and deployed. A useful taxonomic scheme of Western Buddhist scholarship was introduced by Constantin Regamey, who said that there were three schools: the Anglo-German school, the Russian school, and the Franco-Belgian school. The first one included C.A.F. Rhys Davids and Hermann Oldenburg. See also De Jong, A Brief History, 47

${ }^{411}$ According to de Jong, this generation of scholars included R. Otto Franke (1862-1928), Serge d'Oldenburg (1863-1934), Sylvain Levi (1863-1935), Th. Stcherbatsky (1866-1942), F. W. Thomas (18671956), E. J. Thomas (1869-1958), Louis de La Vallee Poussin (1869-1938), and Heinrich Lüders (18691943), p.40
} 
non-Indian Buddhist materials, including the Buddhist literature written in Chinese, Korean, and Japanese. ${ }^{412}$ Historical comparative linguistics gradually became the dominant methodology of Buddhist scholarship. One pioneer in this field was Sylvain Levi (1863-1935). Partly because of his Japanese monk students, Fujishima Ryōon 藤 島了棌 (1852-1918) and Fujieda Takutstū 藤枝沢通 (1861-1920), from the Nishi Hongganji 西本願寺, Levi soon realized the significance of Chinese Buddhism, not only for the study of Buddhism but also for the study of the history of India. Almost at the same time, studies on the history of Chinese Buddhism, such as J. Edkins's Chinese Buddhism, a Volume of Sketches, Historical and Critical (1880), Notices of the Chinese Buddhism (1885), and S. Beal's On Buddhist Literature in China (1884) and Buddhism in China (1886), emerged in Europe. ${ }^{413}$ These studies influenced Buddhologists such as Louis de La Vallée Poussin (1869-1938) ${ }^{414}$ and Jean Przyluski (1885-1944). ${ }^{415}$ However, compared to the efforts these Western scholars made on Indian Buddhism, their studies of Chinese Buddhism were still limited.

From the nineteenth century until the early twentieth century, the Western scholarship of Buddhism was an ongoing attempt to demythologize and historicize Buddhism. The history of Buddhism 'created' by modern scholars "criticized the tradition, it claims to represent the tradition, and it reshaped, extended and

\footnotetext{
${ }^{412}$ Even after the 1990s, when more and more scholars (such as Gregory Schopen, Paul Harrison, Seishi Karashima 辛嶋静志, Jan Nattier and so on) began paying attention to Chinese Buddhist texts and other sources, the gap between Buddhology (which mainly was based on Indian materials) and Sinology, however, continued to exist. See the critique of Sharf, Coming to Terms With Chinese Buddhism: A Reading of the Treasure Store Treatise.,1.

${ }^{413}$ These works were some of the few studies available to the Chinese in the modern period. See Lü Cheng, Fojiao Yanjiufa 佛教研究法, 51-52. However, Lü was not satisfied with them. Pye, “Comparative Hermeneutics in Religion."

${ }^{414}$ The main contribution of Poussin was his works on what he called "the philosophical school of Mahāyāna," especially his translation and editing of the Abhidharma texts. In his Buddhisme, which appeared in 1898, Poussin discussed many problems, such as the value of the Pāli sources, the nature of popular Buddhism, Buddhist yoga, etc.

${ }^{415}$ Jean Przyluski did excellent work in translating the Chinese texts concerning northwestern India, the Buddha's parinirvāna, the legend of Aśoka and the Council of Rājagrha. Przyluski attached much importance to geographical factors in the development of Buddhist schools. His work on the Council of Rajagrha was inspired by some rather wild sociological ideas.
} 
transmitted the tradition." ${ }^{416}$ Meanwhile, this history to certain extent neglected some elements of Buddhist tradition at the same time: These (for example, the Chinese Buddhist tradition) were selectively excluded from the scope of the Western Buddhist historiography according to the discourse of the 'essence'. ${ }^{417}$ Only as late as in the 1960s did this research paradigm begin to receive questioning from scholars such as Dumont, Gombrich, Schithausen, and Schopen. They realized that building up a definitive bridge between Western researchers' own world and their object, when it was an 'other' that was culturally and historically remote, could be much more difficult than one might imagine. It became more and more clear that "the Western conceptions of history are necessarily ethnocentric or socio-centric." ${ }^{418}$ Related to such methodological reflections, later studies on Buddhism discerned a 'major shift' from philology towards a kind of anthropological-sociology that largely acknowledged the diversity of the historical experiences in all the places Buddhism had reached and intended to understand the particularity of different Buddhist traditions in their own social and historical contexts.

\section{Buddhism of the Late Qing Literati}

The developments and achievements of modern Buddhist scholarship began to influence Chinese researchers beginning in the early twentieth century when academic exchanges between China and the world become more frequent. However, some domestic changes had emerged several decades earlier. From the mid-

\footnotetext{
${ }^{416}$ Pye, "Comparative Hermeneutics in Religion." 42. He here presented a brief but useful overview of orthodox Buddhist hermeneutical methods. Pye, "Comparative Hermeneutics in Religion."36-53

${ }^{417}$ It should be noted that, influenced by this discourse, Japanese scholars of Buddhism from the Meiji era made great endeavours to prove that the essence of Buddhism lay in Japan and that Japanese Buddhism persevered the most pure and ahistorical form of the Buddhist doctrine and the Dharma. See Kotatsu Fujita 藤田宏達, “原始仏教・初期仏教・根本仏教 [“Early” Buddhism, “Primitive” Buddhism or “Original” Buddhism].” Hokkaido journal of Indological and Buddhist Studies 印度哲学仏教 学, 2 (1987): 20-52.

${ }^{418}$ Louis Dumont, La civilisation indigenen et nous: Esquisse de sociologie comparée (Paris: Librairie Armand Colin, 1964).
} 
nineteenth century, reading, studying, and practicing Buddhism became a trend among Chinese literati. This phenomenon was caused not only by outside impacts (in particular from Japan) but also by an internal transformation that took place in the intellectual life of the elites and educated people.

First, related to the widening divergence between the elite and popular culture $^{419}$ as well as the emergence of a new intelligentsia, a scriptural/discursive (textual-based) modality of Buddhism saw an upsurge and developed into a discursive exegetical mode of reading, commenting, and interpreting a wide range of religious texts. ${ }^{420}$ This trend can be dated back to Late Qing literati such as Shen Zengzhi 沈增 植 $(1850-1922)^{421}$ and Yu Yue 俞樾 $(1821-1907)^{422}$ and the ethos of "following the

\footnotetext{
${ }^{80}$ Some scholars have taken the view that this divergence had already existed before the modern era. For example William Rowe, in his analysis of the attitude of the Mid-Qing upper officials, mentioned the 'great religious war waged by lixue 理學' [Neo-Confucianism] against the Buddhist and Taoist beliefs and practice" and the "more persistent assaults on popular culture." See William T. Rowe, Saving the World. Chen Hongmou and Elite Consciousness in Eighteenth-Century China (Stanford: Stanford University Press, 2001), 436. However, some other scholars have rejected this thesis. They have suggested that, rather like the elite in ancient-régime European societies, those Qing elite lived in a state of bi-culturality, managing to participate not only in a culture (including a religious culture) belonging to their own milieu but also to a culture belonging to the broader community. See Donald $\mathrm{S}$ Sutton, "From Credulity to Scorn: Confucians Confront the Spirit Mediums in Late Imperial China," Late Imperial China 21, no. 2 (2000): 23-24.

${ }^{420}$ The other four modalities are: the self-cultivational, the liturgical, the immediate practical, and the rational/organizational (organizing festivities, managing temples). See Adam Yuet Chau, "Modalities of Doing Religion and Ritual Polytropy: Evaluating the Religious Market Model from the Perspective of Chinese Religious History," Religion 41, no. 4 (2011): 549.

${ }^{421}$ Shen Zengzhi's research on Buddhism was mainly concentrated in the period from 1898 to 1907. In the last years of Guangxu, Shen travelled to Japan and "returned to China with the full collection of Buddhist scriptures and then he devoted himself to these scriptures." In his postscripts and notes, there are many historical sources related to Buddhism and ground-breaking insights about Chan history. Important inscriptions and postscripts include his "A Postscripts to the Platform Sutra" [Tanjing ba 壇經跋] (collected in the second episode of his Meisou tiba 蒋舅題跋); in his Hairilou 海日 樓 collection, there are also many Dunhuang scriptures. See Wang Juchang 王遽常, Qingmo Shen Meisou xiangsheng nianpu 清末沈寝舅先生年譜 (Taipei: Shangwu yinshuguan, 1982).

${ }^{422} \mathrm{Yu}$ Yue was known for his central status in the social network of the elite in Jiangnan district, and he also kept a close association with Buddhist communities, especially the Japanese monks from the Higashi Honganji. His commentary on Buddhist texts, for example, the Diamond Sūtra, was from the standpoint of a classicist. For example, he quoted Confucian terms to criticize Buddhist belief.
} 
Confucian manner on the outside while holding Buddhism on the inside." ${ }^{423}$ To be sure, Buddhist practices, such as worshiping the Buddha [baifo 拜佛], sitting meditation [zuochan 坐禪], prophecy 經驖 [jingchan], transcribing scriptures [chaojing 抄經], burning incense [shaoxiang 燒香] and so on, were widely welcomed by intellectuals, ${ }^{424}$ which indicated a particular 'religiosity' in Chinese society during this period. ${ }^{425}$ These intellectuals maintained contacts with the local religious communities and did not isolate themselves from rituals, although they consciously maintained their academic works 'religion-free.'

Admittedly, there were various strata within the 'elite' itself, as demonstrated in Barend Ter Haar's model. ${ }^{426}$ For the 'higher elite,' who were different from the 'gentry' that shared a more varied religious identity, their religious participation and concerns were carefully conserved within a private realm and small circles and were

However, some private writings have revealed that he followed the Buddhist lifestyle and had considerably understanding of the religious world of the common people. See Vincent Goossaert, "Yu Yue (1821-1906) Explores the Other World : Religious Culture of the Chinese Elites on the Eve of the Revolutions," in Religion in Taiwan and China, ed. Hsun Chang and Benjamin Penny (Institute of Ethnology Academia Sinica, Peter Lang AG, 2017).

423 “外襲儒風, 內宗梵行.” See Shen Zengzhi, Zajiayan: hairi lou zhacong 雜家言:海日樓札叢, vol. 4. This kind of scholar also included Wen Tingshi 文廷式, Chen Baozhen 陳寶筬, Song Shu 宋述, Peng Shaosheng 彭紹升, Yang Du 楊度 and so on. For a study on these lay Buddhists, see Jiang Haishu 蔣海 恕, Wanqing zhengzhi yu foxue 晚清政治與佛學 (Shanghai: shanghai guji chubanshe, 2012).

${ }^{424}$ For example, Kang Youwei, the leader of the "Confucian Learning reformation," "read numerous Buddhist canon" 讀佛典甚多 and had written about his own experience with Buddhist sitting meditation. Tan Sitong, one of the disciples of Kang, also had said that he "vowed to the Buddha again and held the Buddhist mantras day after night” 書夜精持佛咒，不少間斷.

${ }^{425}$ This religiosity included some 'superstitious' activities. See Vincent Goossaert on Yu Yue: Goossaert, "Yu Yue (1821-1906) Explores the Other World : Religious Culture of the Chinese Elites on the Eve of the Revolutions." 59-107. The concept of religiosity, Vincent Goossaert argued, could offer a more fruitful avenue of investigation.

${ }^{426}$ According to Ter Haar, the higher elite had the duty to maintain the rule of the empire, which was often severe on religious matters (though in practice, tolerance and negotiation were the ways the ruling agents dealt with local religion), while the gentry who were not state functionaries, on the other hand, had a looser definition of their vocation as teachers for their local communities. See Barend ter Haar, The White Lotus Teachings in Chinese Religious History (Leiden: Brill, 1992). 
expressed only in their personal literary works, such as diaries, poetry, and essays. ${ }^{427}$ However, near the beginning of the twentieth century, discussion on Buddhism became increasingly open and wide, but usually had a strong scholarly tone. The upper strata of the Buddhist clergy also became members of the elite group and began to speak out publicly. ${ }^{428}$ Religious reformists, officials, missionaries, educated monks, scholarly laymen, and professional scholars formed a Buddhist academic community and constructed intimate domestic and international scholarly associations. ${ }^{429}$ Although still limited, the concern for a 'scholastic' Buddhism had risen on a national scale and profoundly influenced the academic path of the next generation of the intellectual elite, such as Chen Yinke, Hu Shih, Tang Yongtong, Lü Cheng, and so on.

Second, Japanese Buddhism's experience of modernization was introduced into China. In 1873, when Ogurusu Kōchō 小栗棲香頂 (1831-1905), a Jōdo Shin monk of the Higashi Honganji 東本願寺, began his 'journey of seeking Dharma' [qiufa 求法] in Peking, Chinese Buddhism was reeling from the blow delivered by the Taiping Rebellion (1850-1864) and was experiencing the unprecedented impact of Christian proselytization. Some scholars believe that Ogurusu's journey marked the renewed beginning of contacts between Chinese and Japanese Buddhism. ${ }^{430}$ Previously, Japanese monks had traveled to China to learn Dharma, but now, they were more like

\footnotetext{
${ }^{427}$ Records show that some of them dedicated themselves to a moral or religious cause and expended much time and financial resources to improve the local religious environment. See Jessup, "The House Holder Elite: Buddhist Activism in Shanghai, 1920-1956."

${ }^{428}$ Stefania Travagnin, "Concepts and Institutions for a new Buddhist Education: Reforming the Samgha Between and within State Agencies," East Asian History 39 (2014).

${ }^{429}$ One case was that of the famous French sinologist Paul Pelliot 伯希和 (1878-1945), who visited Shen Zhengzhi and Shen's private library, Hairi lou 海日樓 in 1916. See Ye Changzhi 葉昌熾, Yuandu lu riji chao 緣督盧日記鈔 [Dairies of the Hall of Yuandu] (丙辰六月廿二日). For the relationship between Paul Pelliot and modern Chinese academia, see Bing Sang, “Boxihe yu Zhongguo jindai xueshujie 伯希 和與中國近代學術界 [Paul Pelliot and the Modern Chinese Academia],” Lishi yanjiu 歷史研究, no. 5 (1995): 115-38.

${ }^{430}$ Ogurusu's ideas concerning the need for mission work in China are outlined in detail in his Shina kaikyō mikomi 支那開教見込 [The Prospects for Mission Work in China]. See Chen Jidong, Ogurusu Kochō no Shin matsu Chūgoku taiken: Kindai Nitchū Bukkyō kōryū no kaitan 小栗栖香頂の清末中国体験: 近 代日中仏教交流の開端(Tokyo: Sankibo, 2016).
} 
missionaries and tried to introduce and preach Japanese Buddhist doctrine to Chinese people. Regardless of the motivation behind these efforts, ${ }^{431}$ this "repaying favors [fan'en 返恩]" or “flowing backward" [daoliu 倒流] ${ }^{432}$ did contribute to the Buddhist revival in modern China. Local elites built up a very close association with these Japanese missionaries. ${ }^{433}$ branch monasteries [bieyuan 別院] and study halls [xuetang 學堂] of Japanese sects were also founded in Shanghai, Hangzhou, Suzhou, and many other cities.

Indirect influence from Japanese Buddhist scholarship can be observed widely in the development of Chinese Buddhism. ${ }^{434}$ The large scale of the Buddhist scriptures

\footnotetext{
${ }^{431}$ The missionary motivation behind the activities of these Japanese Buddhists caught the attention of some Chinese Buddhists and was criticized by them. For example, Yang Wenhui wrote to 南條文雄 to criticize the interpretation of the Lotus Sütra by the Japanese monk 幻人 and also to express his concern about religious infiltration from Japan. See Yang Renshan, “Yu Shi Huanren shu 與釋幻人書," “Yu riben nantiao wenxiong shu 與日本南條文雄書, ” in Yang Renshan jushi yishu楊仁山居士遺書, CBETA, B28, no.0157 p.65b19, p.698a14. Lay Buddhist reformer Wang Kangnian 汪康年 also wrote an article criticizing and questioning the transmission of Japanese Buddhism. He complained, "I do not know what is the meaning of Japan's repeated requests for transmission Buddhism in our country" [吾 不知日本屡以在吾國傳播佛教為要求, 果何意也]. See Wang, Yinian 汪詒年, Wang Rangqing yizhu 汪穰卿遺著 (Taipei: Chaohua chubanshe, 2017), vol.3, 23-24.

${ }^{432} \mathrm{Ge}$, Zhaoguang, Xi chao que zi dongying lai-riben dong benyuan si yu Zhongguo jindai fojiao de yinyuan 西潮卻自東瀛來-日本東本願寺與中國近代佛教的因緣, in Xichao you dongfeng: wanqing minchu sixiang, zongjiao yu xueshu shilun 西潮又東風: 晚清民初思想宗教與學術十論(Shanghai: Shanghai guji chubanshe, 2006), 47-66; Ji, Xianlin, “Fojiao de daoliu 佛教的倒流” in Fojiao shiwu ti 佛 教十五題 (Beijing: zhonghua shuju, 2007).

${ }^{433}$ For the details of the activities of the monks of Higashi Honganji in China, see Takanishi, Kenshō 高 西賢正 (ed.), Higashi Honganji Shanghai kaikyō rokujūnen shi 東本願寺上海開教六十年史 (Shanghai: Higashi Honganji Shanghai Betsuin, 1937); Also, Kikanishi, Hiro 北西弘, “Meiji shoki ni okeru Higashi Honganji no Chūgoku kaikyō” 明治初期における東本願寺の中國開教, Bukkyō daigaku sōgō kenkyūjo kiyō 仏教大学総合研究所紀要,1 (1994): 331-49.Ge, Zhaoguang, “Kongjiao, fojiao yihuo yejiao? - 1900 nian qianhou Zhongguo de xinli weiji yu zongjiao xingqu 孔教、佛教抑或耶教? -1900 年前後中國的心理危機與宗教興趣, in Zhongguo jindai sixiangshi de zhuanxing shiqi 中國近代思想 史的轉型時期, Wang, Fansen 王沉森 (ed.), (Taipei: Lianjing chubanshiye youxian gongsi, 2007), 218 ${ }^{434}$ In 1878, only few months after Yang Wenhui wrote a letter to Nanjō Bunyū, the Buddhist priest of Jōdo Shin who currently lived in London and studied Sanskrit and Indian philosophy under the supervision of Max Müller, they met in person in London. Bunyū helped Yang to acquire three hundred volumes of Chinese Buddhist texts that had long been lost in China. Those texts later were reprinted at Yang's printing house in Nanjing,the Jingling Sūtra Press [Jinling Kejing Chu 金陵刻經處].
} 
rediscovered in Japan promoted the distribution of the Buddhist canon in China. At the end of the nineteenth century, dozens of works of Buddhism were introduced into China from Japan. ${ }^{435}$ Books such as the Jōsei indo shūkyōshi 上世印度佛教史 written by Masaharu Anesaki 姉崎正治 (1873-1949), and Bukkyō katsuron joron 仏教活 論序論 written by Inoue Enryō 井上円了 (1958-1919) were widely read by Chinese intellectuals and officials, such as Wen Tingshi 文廷式 (1856-1904) and educator Cai Yuanpei 蔡元培 (1868-1940).

Due to the success of the Meiji Restoration, Japan became an 'enlightened model' that perfectly combined modern advances with traditional 'Eastern values.' Japanese Buddhism bonded itself together with the larger aspiration of the formation of Japan as a modern nation and embarked on a series of movements to unify and coordinate the different sects into a new 'Buddhism. ${ }^{436}$ Buddhism then justified itself as a national religion of Japan in the process of forming a discursive order that could be called “Japan's Orient: [tōyō], as Stefan Tanaka has suggested. ${ }^{437}$ This modern image of Buddhism introduced a fresh understanding of Buddhism back into China, encouraging the Chinese to reform Buddhism through producing new knowledge, forming new organizations, and fulfilling new social and political roles.

Third, a series of institutional transformations and the more intensive academic engagement of Buddhism shaped the new form of knowledge production. ${ }^{438}$ The institutionalization of Buddhism as one branch of modern Chinese scholarship had two main implications: Buddhism's entry into the higher education system and

\footnotetext{
${ }^{435}$ See Ni Guanning 倪管寧, “日本近現代佛教歷史學的發展與反思, ” Shiyuan luntan 史原論壇 (2020.8.26), http://shi-yuan.blog.ntu.edu.tw/xuexunaug20/.

${ }^{436}$ For the development of Japanese Buddhism in Meiji, see Shigeyoshi Murakami 村上重良, Zongjiao yu riben xiandaihua 宗教與日本現代化 (Beijing: Jinri Zhongguo chubanshe, 1990), 2-3; Senjō Murakami 村上專精, Riben fojiao shigang 日本佛教史綱, in Lan Jifu 藍吉富(ed.), Shijie foxue mingzhu yicong 世界佛學名著譯叢, vol.53 (Taipei: Huayu chubanshe 1988), 359.

${ }^{437}$ Stefan Tanaka, Japan's Orient: Rendering Pasts into History (Berkeley: University of California Press, 1995): 1-28.

${ }^{438}$ Innovative production of religious knowledge is a crucial theme for the transformation of Chinese religion. See Paul R. Katz, “'Superstition' and its Discontents - On the Impact of Temple Destruction Campaigns in China, 1898-1948," in Disijie guoji hanxue huiyi lunwenji: Xinyang, shijian, yu wenhua tiaoshi 第四屆國際漢學會議論文集: 信仰, 實踐, 與文化調適 (Taipei: Academia Sinica, June 2013), 606.
} 
the emergence of forums and portals for academic discussion - publications and periodicals. ${ }^{439}$

After the Wuxu Reform and the breakdown of civil exams in the Late Qing era, ${ }^{440}$ China began to reform its education system using a Western model. ${ }^{441}$ Due to a national project of converting religion-related knowledge into disciplines, ${ }^{442}$ Buddhism then was shifted from its previous vague position in the traditional category of Chinese scholarship and was placed into the Western-style curriculum as an interdisciplinary branch of philosophy. ${ }^{443}$

As many scholars have analyzed, education reforms under slogans like "saving the country through education" [jiaoyu jiuguo 教育救國] played a vital role in the modernization of Chinese society. ${ }^{444} \mathrm{New}$ concepts in education brought significant changes to the curricula and structure of schools: scientific subjects were introduced in schools; Classical Learning was downgraded to a research subject; Western models of education took over the Confucian system; the old imperial examinations [keju 科 舉] were abolished in 1905; and the traditional literati gradually were replaced by the

\footnotetext{
${ }^{439}$ For the relationship between print culture and knowledge in a general sense, see Adrian Johns, The Making of the Book: Print and Knowledge in the Making (Chicago: The University of Chicago, 1998). Also, Cynthia J. Brokaw, and Kai-wing Chow (ed.), Printing and Book Culture in Late Imperial China (Berkeley, University of California Press, 2005); Philip Clart, and Gregory Adam Scott, ed. Religious Publishing and Print Culture in Modern China, 1800-2012 (Boston and Berlin: De Gruyter: 2015).

${ }^{440}$ For the role of the civil exams in Late Qing China, see Benjamin A Elman, A Cultural History of Civil Examinations in Late Imperial China (Berkeley: Univ of California Press, 2000).

${ }^{441}$ For the establishment of the modern university in Republican China, see Wen-hsin Yeh, The Alienated Academy: Culture and Politics in Republican China, 1919-1937, vol. 148 (Cambridge, MA: Harvard Univ Asia Center, 1990).

${ }^{442}$ For a detailed discussion on Zongjiao xue, see Christian Meyer, "The Emergence of "Religious Studies (zongjiaoxue) in Late Imperial and Republican China, 1890-1949." Numen, 62 (2015), 40-75.

${ }^{443}$ In the early establishment of the academic disciplines in modern China, the study of religion, including theology and religious history, was basically left out. See Michael Lackner, Iwo Amelung, and Joachim Kurtz, New Terms for New Ideas: Western Knowledge and Lexical Change in Late Imperial China, vol. 52 (Leiden: Brill, 2001). Also see Michael Lackner and Natascha Vittinghoff, Mapping Meanings: The Field of New Learning in Late Qing China, vol. 64 (Leiden: Brill, 2004). 25-30.

${ }^{444}$ R. P. Scott, 'The Boxer Indemnity in its Relation to Chinese Education,' Journal of the British Institute of international Affairs 2.4 (1923): 149-67
} 
new community-rooted in Western culture-of the intellectuals. ${ }^{445}$ In 1898 , the first Chinese university based on a Western model, Peking University, was established. ${ }^{446}$ The famous lay Buddhist Jiang Weiqiao 蔣維喬 (1873-1958), the Counselor of the Ministry of Education of the Republican government, wasthe crucial figure who promoted Buddhism's entry into the classrooms of Chinese universities. ${ }^{447}$

At the same time, there were educational reforms for Buddhists (monastics as well as laity) in the Buddhist community. ${ }^{448}$ In 1903 the Hunan Samgha Study Hall 湖 南僧學堂, the first new-style Buddhist study institute, was established. ${ }^{449}$ Later, institutes of Buddhist studies [foxue yuan 佛學院] 一 a new form of samgha education-were built nationwide. The emergence of these research institutes showed that modern Buddhist educational institutions had gradually replaced the previous monastic study seminars. Buddhist education and monastic education[seng jiaoyu 僧教育] became important slogans; a more Western-style and comprehensive pedagogy was also slowly established in monasteries. ${ }^{450}$

With the promotion of Yang Wenhui and Taixu, ${ }^{451}$ the years 1914 to 1944 saw the actual establishment of more than 30 Buddhist institutes, including the most important ones, the Wuchang Buddhist institute and the China Inner Learning

\footnotetext{
${ }_{445}$ Y. C. Wang, Chinese Intellectuals and the West 1872-1949 (Chapel Hill: University of North Carolina Press, 1966), vii-xiv

${ }^{446}$ For more details on education in this period, see Chiang Monlin, 'Chinese Education: Force for Democracy,' Far Eastern Survey 14.13 (1945): 181; Chen Qingzhi 陳青之, Zhongguo jiaoyu shi 中國教育 史 (Beijing: Zhongguo shehui kexue chubanshe, 2009), 503-94.

${ }^{447}$ The original text in Chinese is: “我國大學之有佛教課程, 蓋自此始.” See Jiang Weiqiao 蔣維喬, Yinshi xiansheng zizhuan 因是先生自傳, in Bian Xiaoxuan 市孝萱, Minguo renwu beizhuan ji 民國人物 碑傳集, vol.5 (Nanjing: Fenghuan chubanshe, 2011), 393.

${ }^{448}$ See Travagnin, "Concepts and Institutions for a new Buddhist Education: Reforming the Samgha Between and within State Agencies."

${ }^{449}$ Ding, Gang 丁 鋼, Zhongguo fojiao jiaoyu 中國佛教教育 (Chengdu: Sichuan jiaoyu chubanshe, 2010), 167.

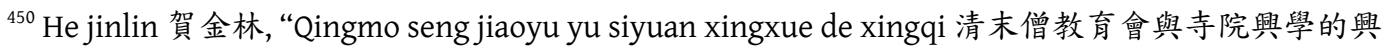
起,” Anhui shixue 安徽史學, 6 (2005): 28-64

${ }^{451}$ Taixu's highest ideal of education was the so-called “Buddhicized education" (Fohua jiaoyu 佛化教 育). It was the study of the ‘Buddhist five vehicles' (wu cheng 五乘). See Taixu: On education 論教育 (1924), TXQS, vol. 24, 340.
} 
Institute. ${ }^{452}$ This phenomenon represented a vital turning point in the history of samgha education, which Dongchu clarified as the shift from a sectarian-doctrinal form of education to a style based on the "school format" [xuexiaohua zhi seng jiaoyu 學校化之僧教育]. This transformation consequentially changed the knowledge discourse in the realm of Buddhist scholarship. ${ }^{453}$ If one considers the changes that occurred between the 'Switch temples into schools' movement in $1898^{454}$ and the rapid growth of Buddhist education or academic institutes, it is evident that the combination of Buddhism with secular education provided ample space for an upgrade of Buddhism's role in the hypothetical 'Chinese Renaissance' - the encounter with modern scientific thought, or the establishment of identities.

Meanwhile, the appearance of Buddhist periodicals and publications produced in movable type by modern commercial publishing houses formed new platform for knowledge production and communication. This phenomenon was termed by scholar Gregory Adam Scott a "publishing revolution" with dual meanings: firstly, this was a new means of publishing texts with new requirements of xylography; secondly, the content of these periodicals was often revolutionary in tone, calling for radical changes within the Buddhist world such as new forms of education and new types of religious organizations, and engaging in debates over intellectual and cultural issues unfolding in Chinese society. ${ }^{455}$

The first Chinese-language periodical specializing in Buddhist content was Foxue congbao, published in twelve issues between October 1912 and June $1914 .{ }^{456}$

\footnotetext{
${ }^{452}$ See Gong Jun 龔焦, “Jindai Zhongguo fojiao jingxue yanjiu: yi Neixueyuan yu Wuchang foxueyuan weili 近代中國佛教經學研究: 以内學院與武昌佛學院為例, ” Xuanzang foxue yanjiu 玄奖佛學研究, 24 (2015): 85-116.

${ }^{453}$ For the reinvention of the relations between religion and state starting from the end of the Qing era, see Goossaert and Palmer, The Religious Question in Modern China.; Nedostup, Superstitious Regimes: Religion and the Politics of Chinese Modernity.

${ }^{454}$ For more details on education in this period, see Chiang Monlin, "Chinese Education: Force for Democracy," Far Eastern Survey 14.13 (1945): 181.

${ }^{455}$ Gregory Adam Scott, "Conversion by the Book: Buddhist Print Culture in Early Republican China" (Ph.D Dissertation, Columbia University, 2013), 130.

${ }^{456}$ The term congbao [丵報] was coined by Liang Qichao as a translation of the Japanese zasshi 雜誌, meaning a weekly or monthly periodical. Several issues of Foxue congbao were published a month later
} 
Foxue congbao was not a temple-based publication; its format to a certain degree imitated secular periodicals, combining editorials, serialized scholarly works, news, poetry, biographies of eminent figures, and advertisements for publishers and scripture distributors. ${ }^{457}$ Although it was not fully academically oriented and only ran for a short period, Congbao set the standard for later Buddhist periodicals, in terms of both format and content. ${ }^{458}$ Around the 1920s, the second generation of Buddhist periodicals emerged. These Buddhist periodicals were produced and distributed through a network of local bookstores, lay associations, scriptural publishing houses, seminaries, and commercial presses. ${ }^{459}$ The most representative and influential one among them was the Voice of the See Tide [Haichaoyin 海潮音], a new monthly Buddhist periodical first published in 1919 under Taixu's leadership. It ran throughout the entire Republican period, with 352 issues published in total. Haichao yin had a significant impact on both scholarly and non-specialist views of Chinese Buddhism. A large group of eminent monks, intellectuals, and scholars contributed to this publication or were its readers, including Taixu, Zhang Taiyan, Liang Shuming, Tang Yongtong, and many more. ${ }^{460}$

than their scheduled publication date. Welch's book The Buddhist Revival in China (p. 100) has a brief mention of this title. Original printings can still be found in some libraries; the library of the Institute of Chinese Literature and Philosophy 中國文哲研究所 at Academia Sinica 中央研究院 has a set of original issues that were bound into volumes at some point, possibly after 1949 given the binder's imprint. The entirety of its print run is reprinted in the MFQ collection, volumes 1-4.

${ }^{457}$ Authors published in Congbao included Taixu, Dixian 諦閑 (1858-1932), Yuexian 月霞 (1858-1917), Zongyang 宗仰 (1865-1921), Jichan 寄禪, and lay Buddhists such as Pu Yicheng, Yang Renshan, Gao Henian 高鶴年(1872-1962), Ouyang Jingwu, Li Yizhuo 李翊灼 (1881-1952), Luo Jialing 羅迦陵 (19641941), and so on.

${ }^{458}$ Varying slightly from issue to issue, the basic structure of this periodical consisted of an 'editorial' section [lunshuo 論說], with political articles related to Buddhist cultivation; a ‘scholarship' section [xueli 學理], with research articles focused on questions of doctrine; a 'history' section [lishi 歷史], with research essays on the history of Buddhism; a 'special matters' section [zhuanjian 專件], with public statements or letters from nascent Buddhist associations; a 'news' section [jishi 紀事], with short pieces related to Buddhism from other print sources; and a 'miscellaneous' section [zazu 雜知], with recurring articles written by certain authors.

${ }^{459}$ Scott, "Conversion by the Book: Buddhist Print Culture in Early Republican China," 247-249.

${ }^{460}$ The original text was (in Chinese): 發揚大乗佛法真義, 應導現代人心正思. Haichao yin, no. 1, MFQ 147:7-12. 
From Congbao to Haichaoyin, these periodicals functioned as a platform for ideas concerning the transformation of Buddhism, a venue in which a new understanding of Buddhism could be critically discussed and reflected upon, a source of news on current events related to Buddhism, and a showcase for works of various genres, including translated texts and early drafts of works-in-progress. ${ }^{461}$ In addition to the periodicals, scholarly works on Buddhist history, biography, and philosophy in the forms of monographs or collections received support from commercial presses such as the Commercial Press 商務印書館 and Chunghwa Book Company 中華書局. These periodicals and publications not only provided a space in which scholars could communicate and make their voices available to other experts as well as a mass audience but also, pragmatically, they support these scholars' careers financially and helped them to maintain their livings as professional researchers. Although they took the form of commercial enterprises, most of these periodicals and publishing houses remained committed to a non-profit business model, gaining no profit from their publishing and often depending on donations to cover costs. This mechanism, to a large extent, maintained the independence of academic works and connected authors and readers together.

\section{Historians and Their Agendas}

The discovery of Buddhism in Western scholarship introduced new methodologiescomparative religious studies, linguistics, historical hermeneutics, and so on -into a tradition that existed 'out there. ${ }^{962}$ However, unlike their Western counterparts, Chinese scholars, due to their cultural background, more or less considered Buddhism

\footnotetext{
${ }^{461}$ Scott, "Conversion by the Book: Buddhist Print Culture in Early Republican China."265

${ }^{462}$ For a general study on the development of Chinese modern Buddhist scholarship, see Chen Bing and Deng Zimei, Ershi shiji Zhongguo gojiao 二十世紀中國佛教(Beijing: Minzu chubanshe 民族出版社). For a biographical study on the historians who wrote the history of Buddhism in the modern period, see Zhou Xia 周霞, Zhongguojindai fojiao shixue mingjia pingshu 中國近代佛教史學名家評述 (Shanghai: Shanghai shehui kexueyuan chubanshe, 2006).
} 
as something of their 'own' and maintained interpretations that were based on their own historical experience.

\section{Liang Qichao}

Along with the rising interest in Buddhism, there was a dramatic surge in popular writing about Buddhism aimed at non-expert readers in publication markets during the first decade of the twentieth century. Almost at the same time, writing on Buddhist history emerged on a larger scale under the dual influence of the domestic Chinese Buddhist revival as well as the flourishing trend of religious studies from the West and Japan. Issues related to the history of Buddhism soon attracted the attention of Chinese intellectuals, in particular those who were more sensitive about the encounter between the outside world and traditional China.

One pioneer who propagated a modern historiography of Buddhism was Liang Qichao. ${ }^{463}$ Although his study of Buddhism remained unfinished and was not systematic, he brought this theme into the scope of Chinese academia. In his 1902 article on the history of Chinese scholarship and thought, he, for the first time, described Buddhism from a historical viewpoint as a crucial element of Chinese culture by placing Buddhism into the pedigree of scholarship. This attempt announced the beginning of this new research domain. ${ }^{464}$

\footnotetext{
${ }^{463}$ Joseph R. Levenson's famous biographical study divided Liang's life into three stages: his youth as a reformist (1873-1898) ("Metamorphosis"); his exile in Japan (1898-1912) ("Bravo the new world"); and the years after he returned back to China (1912-1929) ("remembrance of things past"). His studies on Buddhist history mostly happened during the third stage. See Levenson, Liang Ch'i-ch'ao and the Mind of Modern China (Cambridge, Mass.: Harvard University Press, 1953).

${ }^{464}$ although in the first two decades of 20th century, there were already several studies on Buddhism history, mostly in article form. For example, Zhang Qiqin 張其勤’s Xizang zongjiao yuanliu 西藏宗教 源流; Li Yizhuo 李翊灼's Xizang Fojiao lueshi 西藏佛教略史; Chen Yuan 陳垣's “Ji Datong Wuzhoushan shikusi 記大同五州山石窟寺”; and Shen Zhenzhi's discussions on the history of Indian Buddhism, the origin of Tibetan Buddhism and so on, in his Hairilou zhaji 海日樓札記. However, these works are still very limited in length and content.
} 
Liang's interests in Buddhism started from a very early age when he was a young student at Kang Yuwei's Wanmu Caotang 萬木草堂 from 1891 to $1898 .{ }^{465} \mathrm{He}$ was impressed by the "comprehensiveness and profoundness" of Buddhist teaching when reading Buddhist canon under Kang's supervision. ${ }^{466}$ Although he said that he himself was unable to really grasp such great wisdom, he was fully convinced by the power of 'awakening' promised in Buddhist doctrines. ${ }^{467}$ Interrupted by the turmoil of Chinese politics and society, Liang's study of Buddhism stopped for a few years. Only in the last ten years of his life did he continue his writing on Buddhism.

Liang's impetus to writing the history of Buddhism was no doubt initially inspired in part by the popularity of reading and discussing Buddhist doctrines among Chinese intellectuals during this period. Besides Kang, Liang's personal interest in Buddhism was also directly influenced by his friends, such as Xia Zengyou 夏曾佑 (1863-1924) and Tan Sitong 譚嗣同 (1865-1898). After the failure of the Wuxu Reform, his reception and understanding of Buddhism was developed during his stay in Peking and later in Shanghai. At a certain moment, he even considered becoming a devoted Buddhist. However, because of the changing political situation, he soon returned to the harsh reality. In addition to his interest in some primary Buddhist texts, such as the Sutra on the Deeds of the Buddha [Abhiniskramanasutra 本行經], his empathy with Buddhism grew stronger and his attempts to "save the heart" [jiuxin 救心] and further "save the world" [jiushi 救世] through Buddhism never ceased.

The second stage of Liang's writing of Buddhist history was the 1920s, during which his attitude towards Chinese tradition became more sympathetic. When he was in Nanjing, he followed Ouyang Jingwu to study Buddhism, attending lectures at the China Inner Institute "with great endeavor [kewei pingming 可謂拼命]. ${ }^{468} \mathrm{After}$ learning the Treatise of the Establishment of Consciousness Only [Chengweishi lun 成唯識 論] from Ouyang, his interests in abstract Buddhist philosophy and terminology

\footnotetext{
${ }^{465}$ See Ding Wenjiang ed., Liang Qichao nianpu changbian 梁啟超年譜長編 (Shanghai: Shanghai Renmin chubanshe, 2009).

${ }^{466}$ Liang Qichao, “Sanshi zishu 三十自述,” in YBSHJ: Wenji 11, 17.

${ }^{467}$ Ibid.

${ }^{468}$ Ding Wenjiang ed., Liang Qichao nianpu changbian 梁啟超年譜長編, vol.10: 1922. 11.8
} 
developed; his opinion about religious 'truth' and its historical magnifications became deeper. It seems that after Liang abandoned his former political ideal, Buddhism filled up the intellectual vacuum in his mind. Especially after his visit to Europe, he returned to Buddhism and used it to reflect critically on the overall project of modernization. Buddhism, he remarked in the farewell talk he delivered at South-eastern University, defined his general view of life and the world. But until the 1920s, Liang had not really touched on the spiritual regime of Buddhism. He ceaselessly was rooted in the real world; only in the last years of his life did he start to “firmly believe in Buddhism" [duxin fojiao 篤信佛教]. Earlier, although he had had no faith in Buddhism, he behaved like a real Buddhist believer, placing many hopes of reformation and salvation in Buddhism; now, he 'detached' Buddhism from his political expectations and pragmatic criteria. Now he did not hope to establish Buddhism as a national religion, but only wished to keep its status as a valuable piece of cultural heritage.

In addition to his early introductory studies on Buddhist history that remained as chapters in his two monographs-The Outline of Chinese History [Zhongguoshi xulun 中國史敘論] and The Major Trend of the Changes in Chinese Scholarship and Thought - he wrote later works on Buddhism, most of which were compiled into a collection entitled Eighteen Essays on Buddhist Studies [Foxue yanjiu shibapian 佛學研究十八篇] ${ }^{469}$ Although these essays seemed isolated from each other and appeared in a random sequence, they were all part of Liang's unfinished general history of Buddhism. Claiming to use a modern "scientific methodology," these essays Liang provided several insightful but sometimes controversial ideas, for example, the sea route hypothesis of the import of Buddhism and the authenticity of

\footnotetext{
${ }^{469}$ For details about the compilation and publication of this collection, see Chen Shiqiang's introductory preface. Chen, Shiqiang, “Foxue yanjiu shibapian daodu 佛學研究十八篇導讀," in Liang Qichao, SBP, 4-7.

${ }^{470}$ Liang Qichao, “Dasheng qixinlun kaozheng xu 大乘起信論考證序,” in SBP, 388-92. In this article, Liang wrote: "The seven volumes of the Dazang Jing must be organized. And to organize, [we] must use the modern scientific method” 七千卷之大藏, 非大加一番整理, 不能發其光明, 而整理之功, 非 用近世科學方法不可], SBP, 392.
} 
Awakening of Mahāyāna Faith. ${ }^{471}$ Examining Buddhism from a historical perspective, he then suggested, was the first step of propagating Buddhism. ${ }^{472}$

As more of a cultural achievement rather than a philosophical ideal, Buddhism was considered by Liang to be one of the greatest achievements of human civilization ${ }^{473}$ and the most important "side-line" of Chinese scholarship. ${ }^{474}$ In the later phase of his life, writing the history of Buddhism became one of the key tasks in Liang's pursuit of constructing the history of Chinese scholarship. Liang's entire project about the history of Buddhism was centred on one core, yange 沿革, a notion containing two opposite sides: continuity and reform. As I will show in the next chapter, he was trying to construct a comprehensive narrative about Buddhism from a macroscopic view. Only the big events, or the milestones, caught his attention, such as the earliest contact between China and India, or the first Buddhist canon produced by the Chinese. In his proposal, the whole story of Buddhism could be divided into two stages, the Buddhism before Sinicization and the Buddhism after Sinicization. Articles like “General Survey of Indian Buddhism” [yindu fojiao gaiguan 印度佛教概 觀], and “Buddhism and Western regions” [fojiao yu xiyu 佛教與西域] clearly focus on the first stage; others, such as "The Early Import of Buddhism" [fojiao zhi chuchuanru 佛教之初傳入] and “The Outline of the Development of Chinese Buddhism" [Zhongguo fofa xingshuai yu yange shuolüe 中國佛法興衰沿革說略] belong to the second stage.

\footnotetext{
${ }^{471}$ Liang, “Dasheng qixinlun kaozheng xu 大乘起信論考證序,” ibid, 388-92

472 “今後而欲昌明佛法者, 其第一步當自歷史的研究始, ”ibid, 391.

${ }^{473}$ Liang, “Zhiguoxue de liangtiao dalu 治國學的兩條大路” in YBSHJ: Wenji 39, 199.

${ }^{474}$ Liang, “Zhongguo lishi yanjiu fa bubian 中國歷史研究法補編," in YBSHJ: Zhuanji 99: 144-148. In this article, he discussed how to write the history of “religion” [zongjiao shi 宗教史] and “the Chinese art of the Dao" [Zhongguo daoshu shi 中國道術史]. Daoshu, in Liang's view, meant actual scholarship. He considered the development from the teachings of the masters in the Pre-Qin era to the NeoConfucianism in the Song and Ming periods to be the mainstream history of Chinese scholarship. It should be noted that there have been discussions and critiques on the reduction of the traditional 'art of the Dao' to the academic discipline of 'philosophy' in the established institutional structures of the modern university. See Sébastien Billioud and Joël Thoraval, "The Contemporary Revival of Confucianism: Anshen liming or the Religious Dimension of Confucianism," China Perspectives, 3 (2008): 88-106.
} 
In general, Liang brought new paradigms and concepts to the scholarship of Buddhism. Firstly, he introduced a suite of discourses and methodologies based on modern science and historiography; secondly, he opened up the horizon of Chinese Buddhism and conceived of it as a 'world religion'; ${ }^{475}$ thirdly, he formed a Chinacentred narrative, which valued Chinese Buddhism as the superior outcome of the progress of Buddhism; and finally but most controversially, he highlighted the sequence of the historical developments of Buddhism and the thread that ran through them while largely overlooking the discontinuities, trivial factors and subtle changes. However, what Liang achieved through his more than thirty articles, was not promoting Buddhism as a cultural heritage, as he wished, but was something more deconstructive, namely, shaking the foundation of the old system of Buddhist knowledge.

\section{Textbooks on the History of Buddhism}

Since the 1910s, new-style educational organizations, institutes, and universities had emerged that made the compilation of modern, readable, and systematic introductory teaching materials highly important. ${ }^{476}$ The first batch of writings on the topic of Buddhist history intended for classroom use were introduced into China. ${ }^{477}$

These early works, in particular those on the general history of Chinese Buddhism, were produced by a group of Japanese scholars. The first work on this

\footnotetext{
${ }^{475}$ Liang Qichao was the first one (also probably the only one) who noticed the global academic trend centred on 'essential Buddhism' or the essence of Buddhism.' See Chen Huaiyu. Zaixifang faxian chenyinke 在西方發現陳寅恪.

${ }^{476}$ Another genre of didactic text that served for similar purpose is the introductory text or book for beginners [chuxue 初學 or rumen 入門], which has played a crucial role in the personal religious histories of many Chinese Buddhists. Dozens of such texts were produced from the late nineteenth century onwards and continue to occupy bookstore shelves today. See Gregory Scott, "The Publishing of Buddhist Books for Beginners in Modern China from Yang Wenhui to Master Sheng Yen," in Shengyan yanjiu 聖嚴研究 5 (2014): 51-107.

${ }^{477}$ See Xiao Ping 蕭平, Jindai Zhongguo fojiao de fuxing - Yu riben fojiaojie de jiaowanglu 近代中國佛教的復 興一一與日本佛教界的交往錄 (Guangzhou: Guangdong renmin chubanshe, 2003 ).
} 
topic was Sankoku Bukkyō ryakushi 三國佛教略史, originally published in 1890 by Jōdo shinshū Buddhist priests Shimaji Mokurai 島地墨雷 (1832-1911) and Oda Tokunō 生 田得能 (1860-1911). This article provided a neat summary of the historical development of Buddhism in India, China, and Japan. It was soon translated into Chinese by Li Yizhuo 李翊灼 and published in 1912 in the Foxue congbao, the first Buddhist periodical in modern China. Around a decade later, young Buddhist scholar Yo 吉永智海 published a book that, for the first time, generally outlined the history of Chinese Buddhism and used the term "Chinese Buddhist history" in its title. Before this book, the periodical Bukkyō Shirin 仏教史林, which was launched in 1894 by Murakami Senshō 村上專精 (1851-1929), Washio Junkei 熟尾順敬 (1868-1941), and Sakaino Satoru 境野哲 (1871-1933), as well as other works, such as Murakami Senshō's Nihon bukkyōshi kō日本仏教史綱 (1898) and Maeda Eun 前田慧雲 (18551930)'s Daijo Bukkyo shi ron 大乗仏教史論 (1904), introduced the perspective of 'new historicism' into Buddhology. In 1905, Sakaino Satoru published his model work on the general history of Chinese Buddhism titled Shina bukkyōshi kō 支那佛教史網. ${ }^{478}$ Satoru's book received wide attention in both Japanese and Chinese academia.

In 1923, lay Buddhist Shi Yiru 史一如(1876-1925), a professor of the Wuchang Buddhist Academy, compiled several textbooks on the history of Chinese Buddhism, such as The History of Chinese Buddhism [Zhonghua fojiaoshi 中華佛教史], The History of Indian Buddhism [Yindu fojiaoshi 印度佛教史] and The History of Buddhism in Several Countries [Geguo fojiaoshi 各國佛教史], based on Japanese textbooks. ${ }^{479}$ Also referring

\footnotetext{
${ }^{478}$ Sakaino Satoru was a priest in the Ōtani sect 大谷派 of the Jōdō Shinshu Japanese Buddhist tradition. As a child, he read Inoue Enryō 井上円了, which sparked his interest in Buddhism, and later in 1894 he was involved with the periodical Bukkyō Shirin 佛教史林 [Histories of Buddhism] published by Murakami Senshō 村上專精 (1851-1929). In 1900 he founded the periodical Shinbukkyō 新佛教 [New Buddhism], which was used as a platform for the Shin Bukkyō dōshikai 新佛教同志會 [New Buddhist Association], of which he was a member. His Shina bukkyōshi kō 支那佛教史網 [Outline History of Buddhism in China] was published in 1907 in Tokyo by Morie Shoten 森江書店.

${ }^{479}$ See Shi Dongchu 釋東初, “Jindai fojiao zhi chengjiu 近代中國佛教之成就," in Zhongguo fojiao jindai shi 中國佛教近代史 (Taipei: Zhongguo fojiao wenhua guan, 1974): 5-9
} 
to Japanese works, another scholar, translator Chen Binhe 陳彬和 (1897-1945), also published a small booklet on the history of Chinese Buddhism in 1927. ${ }^{480}$

In this early phase, the phenomenon of "borrowing from Eastern books" [jiezi yu dongji 借資於東籍] was very common. ${ }^{481}$ With the motivation of promoting Buddhist education in the newly established institutes, lay-Buddhist educator Jiang Weiqiao compiled his work on the general history of Chinese Buddhism, The History of Chinese Buddhism [Zhongguo fojiaoshi 中國佛教史], based on Sakaino Satoru's Shina bukkyōshi $k{ }^{4}{ }^{482}$ This book was considered to be the first general history of Chinese Buddhism in China that adopted a modern historiographical structure ${ }^{483}$ Exactly when Jiang saw Satoru's book remains uncertain; but there is no doubt that Jiang gained abundant materials and information about the latest research in this new scholarly branch of Buddhist history in Japan during his two visits in 1917 and $1926 .{ }^{484}$

\footnotetext{
${ }^{480}$ Chen Binhe 陳涁和, Zhongguo fojiao xiaoshi 中國佛教小史 (Shanghai: Shijie shuju, 1927).

${ }^{481}$ See Jiang Weiqiao 蔣維喬, Zhongguo fojiaoshi 中國佛教史(Shanghai: Shanghai guji chubanshe, 2005), Xuyan 敘言. For the phenomenon of "borrowing from Japan," see Ge, Zhaoguang, "Xi chao que zi dongying lai-riben dong benyuan si yu Zhongguo jindai fojiao de yinyuan 西潮卻自東瀛來-日本東本 願寺與中國近代佛教的因緣," in Xichao you dongfeng: wanqing minchu sixiang, zongjiao yu xueshu shilun 西潮又東風: 晚清民初思想宗教與學術十論 (Shanghai: Shanghai guji chubanshe, 2006), 47-66. ${ }^{482}$ Jiang's writing basically followed the outline of Satoru's book with two additional chapters, "Jinshi fojiao 近世佛教” [Buddhism in the contemporary period] and “Jinshi gezong 近世各宗” [the Buddhist sects in the contemporary period], extending the narrative of Chinese Buddhism from the Ming dynasty up to the modern age; Jiang also added a chapter about Buddhist statuary art and inscription.

${ }^{483}$ See the preface [敘言] and Editorial Guide [凡例] of Jiang Weiqiao's The History of Chinese Buddhism. See also Huang Canhua's comment in the preface of his The History of Chinese Buddhism. Huang Chanhua, Zhongguo fojiaoshi 中國佛教史 (Changsha: Shangwu yinshuguan, 1940), 1.

${ }^{484}$ Jiang Weiqiao visited Japan twice, in 1917 and 1926. According to Deng Zimei, Jiang saw Satoru's book in 1917, because Jiang wrote in the preface to the 'history' that he had made great efforts to search for books on Buddhism and had written to many temples during his investigation. See Deng Zimei, “Daodu 導讀," in Jiang Weixiao, Zhongguo fojiao shi 中國佛教史, 4-5; However, Zhou Xia has argued that, because during this short trip in 1917, the places Jiang visited were most primary and middle schools and Jiang was not yet a Buddhist, therefore, he probably got Satoru's book during his second visit to Japan in 1926. According to Jiang's autobiography, in 1926 he visited Japan again and he had many contacts with Japanese Buddhists this time. For example, on 1926-04-23, he met Takakusu Junjirō 高楠順次郎, the editor of the Taisho. He also visited Zojo Temple 增上寺 in Tokyo and Hōryū
} 
In the preface to this book, Jiang explicitly emphasized the importance of historiography in Buddhist studies. He wrote:

In all scholarship, there are two kinds of studies: doctrinal studies and historical studies; How can Buddhism be different? After its importation into China in the Han dynasty, Buddhism in China has become particularly advanced in terms of doctrine; there have been those [monks] who devoted themselves to thinking and absorbing the teachings from the West [India] to form its own sects, such Taitai and Huayan. On the history of Buddhism, however, there was still not any systematic literature available for reference in the past thousands of years due to the complexity of the historical facts; studying the history of Chinese Buddhism was like searching in the darkness, and it was hard to gain any progress...The reason for this is that Buddhists lack historical concepts, as is already the case in India, and our people are also under its influence. However, if the study of doctrine can be based on history, the results will be more precise. This is why the study of history is sufficient as an aid to doctrinal studies. How could it [history] be overlooked? 一切學問, 均有學理的研究 和歷史的研究雨種。於佛教何獨不然? 然我國佛教, 自漢代輸入以來, 與教理方 面, 特別發達, 且有潛心冥悟, 融合西來之義諦, 獨自成宗者, 如天台, 華嚴是 也。至於歷史, 則數千年來, 事實複雜, 向無有系統之典籍, 可供参考: 欲從而 研究之, 正如暗中索物, 不易獲得。此其故, 由佛教徒缺乏歷史觀念, 在印度已 然, 我國人亦承受其影響也。雖然, 研求教理, 若有歷史為依據, 則所得結果, 必益精確。是則歷史之研究, 實足為教理之輔助, 迄可忽哉? ${ }^{485}$

This passage indicates Jiang's judgment of the former Buddhist historical writings and his opinion about the relationship between Buddhist doctrine and Buddhist history. Considering history to be the basis for and companion to doctrinal understanding, he investigated the development of Buddhism from the Han dynasty onwards to the Republican era. In so doing, he attempted to shed light on the "general principles [tongli 通例] of history." ${ }^{486}$ Compared with Satoru's book, Jiang

\footnotetext{
Temple 法隆寺 in Nara. For the details of Jiang's visit in Japan, see Zhou Xia, Zhongguo jindai fojiao shixue mingjia pingshu 中國近代佛教史學名家評述, 86-87.

${ }^{485}$ Jiang Weiqiao 蔣維喬, Zhongguo fojiaoshi 中國佛教史(Shanghai: Shangwu yinshuguan, 1933), xuyan.

${ }^{486}$ As Jiang claimed, he wrote this history to compensate for traditional writings such as Feiying Tongrong 費隐通容's Wudeng zhengtong 五燈正統, Ji Yin 紀蔭’s Zongtong biannian 宗統編年, and so on. Ibid.
} 
added a chapter in his general history of Buddhism to discuss the development of Buddhism in the Qing dynasty, investigating the religious policies of the Qing court and analysing the impact of many deconstructive socio-political factors, such as the Taiping Rebellion, on Buddhism in a broader historical context. ${ }^{487}$ Besides his discussion of the degeneration of clerical Buddhism, he also expanded his research beyond the framework of sectarian classification, elaborating on the revival of lay Buddhism from the late Ming to the Qing dynasty.

Another influential general history of Buddhism was The General History of Chinese Buddhism [Zhongguo fojiaoshi 中國佛教史] written by lay Buddhist Huang Chanhua 黄懺華 and published in the early 1930s. Similar to Jiang's work, Huang's writing covers a wide time span, from the Wei-Jin dynasties to the early modern period. Before this book came out, Huang had already published several articles and books on the history of Chinese Buddhism, for example, The Drifts of Buddhist Sects [Fojiao gezong dayi 佛教各宗大意], An Introduction to Buddhism [Foxue gailun 佛學概 論], An Outline of the History of Indian Buddhism [Yindu fojiao shigang 印度佛教史網], and so on. Many of these works were selected as textbooks for the new-style Buddhist institutes and are in use today. The form of Huang's General History was influenced by Shina bukkyōshi 支那仏教史 written by Japanese scholar Hakuju Ui 宇井伯壽. ${ }^{488}$ Both of these two books divided the history of Chinese Buddhism into four stages (beginning, development, flourishing, and decay), and both their books emphasized "the transmission between sects and the sequence of lineage continuity." 489

\section{Professional Historians}

\footnotetext{
${ }^{487}$ Ibid, chapter 17 “Buddhism in Modern Time” [jinshi zhi fojiao 近世之佛教] and chapter 18 “Sects in Modern Time” [Jinshi gezong 近世各宗], 264-327. For further details see Jiang Weiqiao, Zhuweng ziding nianpu 竹翁自訂年譜, Shanghai Library, vol.3, 15-17. ${ }^{488}$ Lü Cheng, Zhongguo fojiao yuanliu luejiang 中國佛教源流略講, 18.

489 “學系的相承與師資的脈絡上.” Shigeo Kamada 鐮田茂雄, “Jindai Riben de Zhongguo fojiaoshi yanjiu 近代日本的中國佛教史研究," Shengkai 聖凱 trans. Fayin 法音 2,(2000): 25-29.
} 
Around the 1930s, a new generation of historians began their careers as professors in universities. Due to their vital, creative writings and teachings, studies on the history of Buddhism switched from an introductory, general level to a more detailed, microscopic level: the developments of Chinese Buddhism were thoroughly investigated as historical phenomena; Buddhist scriptures were read as historical materials critically and prudently; the concepts and linage of sects were examined, judged, and organized according to the standards of modern historiography. These studies provided new angles on this field that were innovative, thoughtful, severe, and sometimes challenging and controversial.

The reasons why these scholars became interested in Buddhism were varied and somewhat vague; however, the religious tradition of their families and their educational backgrounds always played a crucial role. Chen Yinke, for example, was born into an elite family with a solid Buddhist atmosphere and was raised by his grandfather Chen Baozhen 陳寶筬 (1831-1900), an upper official and a leading literatus, who maintained an extensive collection of Buddhist texts and kept close association with Buddhist circles. ${ }^{490}$ Before Chen was officially introduced to Buddhism, he had access to a voluminous Buddhist literature at a very young age through his family's book collection. ${ }^{491}$

\footnotetext{
${ }^{490}$ His grandfather, Chen Baozhen (1831-1900) was a famous politician and reformer in the late Qing period and was one of the main supporters of the Hundred-Days Reform. Partly for this reason, he had a close relationship with Kan Youwei, Liang Qichao, and other the reformers who were immersed in Buddhism.

${ }^{491}$ According to the memoirs of Chen Yinke's nephew Fengxiong 封雄, Chen Yinke started to read Buddhist canons collected by his great-grandfather before he was ten years old; "he felt those Buddhist canons were difficult to understand but he still was very interested in them" [覺其怪奥難懂，但頗感 興趣]. See Chen Fengxiong 陳封雄. “Shixuejie mianhuai yidai zongshi Chen Yinke-Canjia jinian Chen Yinke guoji xueshu yantaohui de ganxiang 史學界緬懷一代宗師陳寅恪一參加紀念陳寅恪國際學術 討論會的感想.”Renmin ribao Haiwaiban 人民日報海外版 (1988.6.21). Chen's niece Fenghuai 封懷 also recalled that, from Chen Yinke's teenage years until the period when he returned from Japan, he "buried himself in voluminous ancient Books and Buddhist texts day after day. He browsed through all of them” [他終日埋頭於浩如煙海的古籍以及佛書等等, 無不瀏覽]. See Bian Senghui 市僧慧, Chen Yinke xiansheng nianpu changbian 陳寅恪先生年譜長編 (Beijing: Zhonghua shuju, 2010), 47.
} 
It is also remarkable that Chen Yinke's father, Chen Sanli 陳三立 (1853-1937), was even more active in Buddhism-related activities and kept a close personal link with the Buddhist community in the Jiangnan area. After going into internal exile near Nanchang and later in Nanjing, he dedicated himself to rescuing the local Buddhist tradition and re-building Buddhist monasteries. He not only had studied Buddhism at Jinling Sūtra Press under the guidance of Yang Wenhui since 1899, but also donated to the establishment of the first Chinese Buddhist academies, including Jetavana Hermitage 祇洹精舍 and the Seminar of Buddhist studies 佛學研究會 in Nanjing. With his close friends Shen Zengzhi, Pu Yicheng, Mei Guangyi 梅光義 and so on, he sponsored the program of sending monk-students to India to study Dharma. ${ }^{492}$

However, Chen Yinke's own attitude towards Buddhism was complex and sometimes vague. Undoubtedly, he maintained a deep empathy towards Buddhism and valued it as a pivotal element of Chinese culture. However, the Dharma seemed never to convince him. He neither treated Buddhism as a religion that could provide solutions for Chinese society nor placed any practical expectations on it. Keeping a distance from ritual practices and monastic circles, he observed Buddhism only through the window of historiography. As his close friend, Yu Dawei 俞大維(18971993), noted in his commemorative article on Chen Yinke, Chen's interests in Buddhism focused only on its historical influences, instead of on its philosophical teachings, such as Buddhist logic and dialectics. ${ }^{493}$

One story may reveal Chen's stance. Chen's niece Fenghuai recalled in the essay "Chen Yinke had held the position as the secretary of Cai Songpo" [Chen Yinke ceng ren Cai Songpo mishu 陳寅恪曾任蔡松坡秘書] that, after the Marco Polo

\footnotetext{
${ }^{492}$ See Wu Zongci, 吴宗慈 “Chen Sanli zhuanlue 陳三立傳略, ” in Bian Senghui 市僧慧, Chen Yinke xiansheng nianpu changbian 陳寅恪先生年譜長編, 13. Shen Zengzhi was also a donator. ${ }^{493} \mathrm{Yu}$ also mentioned in another article that he once read Fyodor Shcherbatskoy's argument on the Indian Yogācāra canons of Dharmakriti 法稱 and the newly translated 藏文所譯龍樹迴猙論（梵文本 亦發現） to Chen, but Chen he did not show any special interest in them. However, in contemporary Western academia, studies on Dharmakriti were very popular, especially among the scholars of the Vienna School, such as Erich Frauwaller, Ernst Steinlellner and so on. See Chen Huaiyu 陳懷宇 Chen, Zai xifang faxian Chen Yinke: Zhongguo jindai renwenxue de dongfangxue yu xixue Beijing 在西方發現陳寅恪: 中國近代人文學的東方學與西學背景 (Beijing: Beijing Normal University Press, 2013). 110.
} 
Bridge Incident, Chen's father, Sanli, committed suicide by starvation in protest of the Japanese invasion. ${ }^{494}$ According to the family tradition, a group of Buddhist monks should have been invited to chant at the funeral. Chen Yinke opposed this plan firmly and said: "I have read numerous Buddhist doctrines; all of them were cheating." He then even refused to attend the funeral and left Peking immediately with the students of Tsinghua University. ${ }^{495}$

Clearly, Chen's approach to Buddhism rested basically on his academic intentions and his research background, instead of any religious commitment or feeling. Chen maintained his position as an 'outsider,' although he sometimes, especially in his later life, felt that his mind "went closer and closer to Chan Buddhism day by day [riru chanzong 日入禪宗]. ${ }^{496}$

During his early career, Chen Yinke's studies focused on the philological analysis of “the literature of the foreigners" [shuzu zhiwen 殊族之文]. ${ }^{497}$ By adopting a comparative linguistic method, Chen re-evaluated and reinterpreted many ancient religious texts from new perspectives for the sake of making them 'accessible' or 'readable' again. From 1925 to 1932, Chen reached the peak of his research career on the topic of the history of Buddhism when he was appointed to the Department of Chinese Literature at Tsinghua University. He taught several introductory courses on religious literature and methodology related to the historiography of Buddhism, including "The Bibliology of Oriental studies in the West," "498"Sanskrit Grammar,"

\footnotetext{
${ }^{494}$ Chen Yinke, “Diqici jiaodai gao 第七次交代底稿,” in Jiang Tianshu 蔣天樞, Chen Yinke xiansheng biannian shiji 陳寅恪先生編年事輯 (Shanghai: Shanghai guji chubanshe, 1981), 103.

${ }^{495}$ Bian Senghui 市僧慧, Chen Yinke xiansheng nianpu changbian 陳寅恪先生年譜長編, 179-80.

${ }^{496}$ See Wang Zhongmin 王重民's letter to Hu Shih, in Hu Shih wanglai shuxin xuan 胡適往來書信選 (Hong Kong: Zhonghua shuju, 1983), vol. 3, 110.

${ }^{497}$ See Yü Ying-shih 余英時, “Chen Yinke shixue sanbian 陳寅恪史學三變,” in Chen Yinke wannian shiwen shizheng 陳寅恪晚年詩文釋證 (Taipei: Dongda chuban gongsi, 1998), 331-377.

${ }^{498}$ For the academic background to Chen's interest in the bibliology of Oriental studies, see Chen Huaiyu, “Chen Yinke suowei zongfangxue zhi muluxue zhi yuanliu 陳寅恪所謂東方學之目錄學之源 流, in Chen, Zai xifang faxian Chen Yinke: Zhongguo jindai renwenxue de dongfangxue yu xixue Beijing 在西方 發現陳寅恪: 中國近代人文學的東方學與西學背景. 165-97.
} 
"Translated Buddhist Literature," "Studies on the Biographies of Eminent Monks," and "Chan Buddhist Literature." ${ }^{499}$

During the 1930s, Chen also published several articles on Buddhist history; most of them were short research essays and book reviews. These works covered a wide range of topics: 1) comparative studies on original Buddhist texts and their Chinese translation, ${ }^{500}$ 2) Chinese interpretations of Buddhist teaching and their cultural background, ${ }^{501}$ 3) the relationship between Buddhism and other local conventions and concepts; ${ }^{502} 4$ ) the influence of Buddhism on Chinese political and intellectual personalities. ${ }^{503}$ Mainly, he sketched several representative examples of how Chinese people translated, interpreted, and even misunderstood intellectual thought from the outside and how they utilized these external resources to strengthen the "position of the nation" [benminzu zhi diwei 本民族之地位]. ${ }^{504}$ Behind these seemingly independent studies, Chen's emphasis on the historical manifestation of China's cultural particularity was the thread that closely combined his ideological and methodological views. This historically formed particularity, in Chen' view, would not slip into relativism, as represented by Zhang Taiyan and his

\footnotetext{
${ }^{499}$ The term 'wenxue' Chen used here is actually 'philology' [yuwenxue 語文學] rather than 'literature.' Chen dealt with scriptures, inscriptions and other religious texts using a comparative linguistics method rather than literary criticism.

${ }^{500}$ For example, “An Epilogue to the Record of Retribution in Suvarṇaprabhāsôttama-sūtra” [懺悔滅罪 金光明經冥報傳跋], “Notes on the Story of the Ordination of the Bhikkhunī Uppalavanna Therī” [連花 色尼出家因緣跋], “Notes on the Dunhuang Version of Vimalakīrti-Nirdeça-Sūtra” [敦煌本維摩詰問疾 品演義書後], and so on.

${ }^{501}$ For example, “An Epilogue to the Essays on the Meanings of Mahāyāna Buddhism” [大乘義章書後], “An Analysis of the Dharma Transmission Verse of the Sixth Patriarch of Chan” [禪宗六祖傳法偈之分析], “An Epilogue of the Vow Established by the Great Dhyana Master from Southern Peak” [南获大師立誓 願文跋] and so on.

${ }^{502}$ Including “An Examination of Zhi Mindu's Work” [支慗度學說考], “Explorations into the Origins of Xiang Xiu, Guo Xiang and Zhidun's Commentaries on “Free and Easy Wandering' [Xiaoyao you]” [逍遙遊 向郭義與支遁義探源], and so on.

503 “Empress Wu and Buddhism” [武旺與佛教], Cui Hao and Kou Qianzhi [崔浩與寇謙之], “The Relationship between Bai Juyi's Thinking, Behavior and Buddhism/Taoism” [白樂天思想行為與佛道 關係], and so on.

${ }^{504}$ Chen Yinke, “Feng Youlan Zhongguo zhexue shi xiece shencha baogao 馮友蘭中國哲學史下冊審查 報告,” in JMEB, 282-85.
} 
concept of the 'national essence'. Chen made clear in several key texts that he regarded the history of the Chinese nation as a spatio-temporally special manifestation of 'abstract ideals.' Buddhism was one of the crucial elements that had influenced the establishment and development of these ideals-the Chinese "national spirit.' By depicting Buddhism as a dynamic element in the formation of this spirit, Chen combined his respect for traditional heritage, his value standard based on Confucian ethics, and his view of historiography together. ${ }^{505}$

After the Marco Polo Bridge Incident, Chen was forced to suspend and eventually give up his planned projects on Buddhism, in particular, on Gaoseng zhuan, because of the loss of primary resources and his bad health. ${ }^{506}$ In his later career, the political history of medieval China became the main theme of his research. ${ }^{507}$ However, the historical representation of religion, include Buddhism, remained a focus, as shown in his works such as the Comments on the Poems of Yuan Zhen and Bai Juyi [Yuanbai shi jianzheng gao 元白詩監證稿], and An Unofficial Biography of Liu Rushi [Liu Rushi bizhuan 柳如是別傳]. Switching between different objects and angles, Chen still paid close attention to the religious issues in Chinese history, especially the role religion had played in the formation of the Chinese 'national culture.'

Some other historians, also as 'outsiders,' developed their interests in Buddhist history from a perspective of trans-cultural comparison, which was stimulated by new theories rather than reflection on indigenous traditions. Tang Yongtong was one example. Born into a well-educated gentry family in Huangmei 黄

\footnotetext{
${ }^{505}$ For a detailed study on Chen's historiographical theory and concepts, see See Axel Schneider, Wahrheit und Geschichte: Zwei chinesische Historiker auf der Suche nach einer modernen Identität für China (Wiesbaden, Harrassowitz, 1997), 124-46.

${ }^{506}$ See Chen Yinke, “Chen shu liaoshi buzhu xu 陳述遼史補注序," in JMEB, 264.

${ }^{507}$ In two articles Chen wrote in 1942, he had discussed this switch in research direction. See his "Zhu Yanfeng Tujue tongkao xu 朱延豊突厥通考序," in HLTJ, 162-163, and “Chen shu liaoshi buzhu xu 陳述 遼史補注序." Several scholars have discussed the reasons for Chen's switch in his research foci. According to their investigations, the lack of primary Buddhist materials might be one important reason; see Ye Wenshin. There were also some deeper reasons related to Chen's fundamental concept of history; see Yü Ying-shih 余英時, “Chen Yinke shixue sanbian 陳寅恪史學三變, ” in Chen Yinke wannian shiwen shizheng 陳寅恪晚年詩文釋證 (Taipei: Dongda chuban gongsi, 1998), 331-377。
} 
梅 in the province of Hubei, Tang grew up in a town where a solid tradition of Buddhist faith was preserved (though there is no direct evidence showing that Tang in his early life had any personal contact with Buddhist believers and communities). ${ }^{508}$ During his childhood, he gained rich experience of reading histories under the influence of his family ${ }^{509}$ Later, he went into a family-based school with a very openminded environment and received a Confucian-Western mixed education during his schooldays.

In 1908, Tang was admitted to the Shuntian Learning Hall 順天學堂 in Beijing. ${ }^{510}$ As one of the earliest schools offering the new-style education, Shuantian Xuetang attracted many outstanding young students from all over the country, including Tang and Liang Shuming. Afterwards, Tang entered the Tsinghua school in 1911 and spent seven years there. In 1918, like his classmate Wu Mi, Tang was given the opportunity to study in the United States. Tang first went to Hamline University, where he received systematic training in Western philosophy, ${ }^{511}$ and then he pursued his studies further at Harvard, joining the new generation of Chinese philosophers alongside Wu Mi, Mei Guangyi 梅光義, Chen Yinke, and so on.

Before his Harvard period, there is no evidence to show that Tang had any particular interest in Buddhism. On the contrary, he held a Confucian standpoint and asserted that he himself was willing to 'beg for the medicine for saving the spiritual

\footnotetext{
${ }^{508}$ As early as in the Tang and Song dynasties, Huangmei was a sacred site of Chan Buddhism. The fourth patriarch, Daoxin 道信, and the fifth patriarch, Hongren 弘忍, of the Chan sect both established their ancestral temples in Huangmei; in legend, it was also in Huangmei that the sixth patriarch, Huineng 慧能, wrote his famous verse “Bodhi is not a tree” [puti ben wu shu 菩提本無樹] and became the authentic successor of the Chan lineage. Therefore, it was very possible that Tang had at a very young age an intuitive impression of the rituals and social functions of Buddhism in the local sphere. ${ }^{509}$ See Bian, Senghui 市僧慧. Chen Yinke xiansheng nianpu changbian 陳寅恪先生年譜長編, 46-7. ${ }^{510}$ Shuntian Learning Hall was a representative modern school that provided Western-style education. According to the memoirs of Tang's schoolmate Liang Shuming, Shuntian school offered courses in both Chinese and English, from Classical Learning to science. See Liang Shuming 梁漱溟. Yiwang tanjiu lu 憶往談舊錄 (Beijing: Zhongguo wenshi chubanshe 1987), 12- 14. Also, Zhao Jianyong ed., Tang Yongtong biannian shiji 湯用形編年事輯 (Beijing: zhonghua shuju, 2019).

${ }^{511}$ His courses included English writing, German, psychology, the history of philosophy, economics, and sociology. See Zhao Jianyong, Tang Yongtong biannian shiji 湯用形編年事輯 (Beijing: zhonghua shuju, 2019).
} 
weakness of China from the teaching of Zhuxi 朱喜. ${ }^{512}$ Partly based on this stance, he chose the "history of philosophy in China" as the topic of his study after he entered Harvard. Like his peers who had studied philosophy in Western universities, such as Hu Shih, Feng Youlan, and Chan Wing-tsit, Tang attempted to reinterpret Chinese philosophical thinking using a theoretical foundation borrowed from the West. By this means, he established his studies as 'comparative' with a transcultural background. Although a subject called Chinese Studies or Sinology had not yet appeared in Western universities at that time, professors in the departments of philosophy, history, literature, and language were curious about the traditions of the Far East and encouraged a research model of East-West comparison. This atmosphere further led Tang to turn his eyes back upon Chinese philosophical thinking, especially Buddhism.

Compared with Chen Yinke, Tang was more sensitive about the conceptual correspondence between Eastern and Western philosophies. To him, the constants of human nature in general were always accompanied by the particularities of time and place. This standpoint, which leaned towards the humanism of Tang's mentor, Irving Babbitt, ${ }^{513}$ later became the 'meaning' of his writing on Buddhist history, under his own rhetoric of "empathy with tacit resonance." 514

\footnotetext{
${ }^{512}$ Tang, Lixue chanyan 理學, in TYQJ, vol.5, 3.

${ }^{513}$ For a brief summary of the life and work of Irving Babbitt, see the "Minute on the Life and Services of Professor Irving Babbitt," which was placed on the records of the Harvard Faculty of Arts \& Sciences at its meeting of October 3, 1933. The first Chinese disciple of Professor Babbitt was May Kuang- ti 梅光 迪, who was educated the longest and most profoundly. Following him were $\mathrm{Wu} \mathrm{Mi}$, Tang Yongtong, Chang Hsin-hai 張歆海, Lin Yutang 林語堂, Liang Shih-ch'iu 梁實秋, and Kuo Pin-ho. See Wu Mi, “In Memory of Mr. Babbitt," Dagong Bao (Literature Supplement), (Dec. 25, 1933).

${ }^{514}$ There is no direct evidence of the extent to which Tang Yongtong was affected by Babbitt. Tang did not mention Babbitt and New Humanism specifically in his works. See Ma Tianxiang 麻天祥, Tang Yongtong pingzhuan 湯用䑣評傳 (Nanchang: Baihuazhou wenyi chubanshe, 1993), chapter 5.
} 
After finishing his study of oriental philosophy and Indian languages ${ }^{515}$ under the supervision of Sanskrit expert Professor Charles R. Lanman, ${ }^{516}$ Tang returned to China and began his own academic pursuits as a historian. ${ }^{517}$ During his first appointment as a professor in Nanjing, he not only taught several courses on philosophy, such as ethics and logistics, at Southeastern University, but also delivered lectures on Pali texts and Buddhist history at the China Inner Studies Institute. ${ }^{518}$ Before he fully turned to the study of the history of medieval Chinese Buddhism, he published several articles to introduce the basic concepts of Indian and Western philosophy and religion to both academic and general audiences ${ }^{519} \mathrm{He}$ also participated in discussions on the issue of 'reconciliation of cultures' with other scholars, as a member of Xueheng school 學衡派. ${ }^{520}$

\footnotetext{
${ }^{515}$ At Harvard, Tang took an elective course in "the system of Indian philosophy" provided by Prof. James H. Woods. This introductory course focused on the schools of Vedanta, Sankhya, and Yoga from a perspective of comparative philology. Prof. Woods was the student of Paul Deussen (1845-1919), one of the founders of Indic studies in Europe. After 1903, he was appointed to the Department of Philosophy as Instructor and then Professor of the Philosophical Systems of India. He taught several courses on Greek and Indian philosophy as well as Sanskrit.

${ }^{516}$ As recorded by Wu Mi, from 1919 to 1921 there were four Chinese students who took the Sanskrit course with Lanman: Yu Dawei, Chen Yinke, Tang Yongtong, and Li Ji. However, Yu and Li did not finish the entire curriculum. Impressed by their performance, Lanman mentioned in a letter to the president of Harvard University, Prof. Abbott Lowell, that Chen and Tangwere two 'outstanding' Chinese students; in another letter, he also commended Chen and Tang by saying they "have excellent wisdom." These two letters were translated by Zhao Jianyong 趙建永 and published in Zhongguo shehui kexue bao 中國社會科學報, 2013 .

${ }^{517}$ After he returned back China, Tang still kept close contact with Lanman. In 1922, he wrote a long letter to him from Nanjing. He called Lanman as "Old Guru" and introduced the China Inner Studies Institute in Nanjing to him.

${ }^{518}$ See his lecture notes: “Wendian changahan youxingjing yanxi 文典長阿含遊行經演習,” “Jin qishi lun jieshuo 金七十論解說,” and “Shijia shidai zhi waidao 釋迦時代之外道.”

${ }^{519}$ His articles on Indian religions and philosophy, such as "The Origin of Indian Philosophy [Yindu zhexue de qiyuan” [印度哲學之起源, “The non-Buddhist Teaching in the Age of Shakyamuni “Shijia shidai zhi waidao" [釋迦時代之外道] and so on, were published with some related lecture notes under the title of A Brief History of Indian Buddhism [Yindu fojiao shilue 印度佛教史略] by the Commercial Press. ${ }^{520}$ Tang Yongtong's son, Tang Yijie had said that his father was a member of Xueheng; see Tang Yijie, Women sandairen 我們三代人, 7,15. However, there is a disagreement among scholars as to whether Tang Yongtong belongs to the Xueheng school. See Sun Shangyang 孫尚揚, “Zai qimeng yu xueshu zhijian 在啟蒙與學術之間：重估學衡.” Ershiyi shiji 4 (1994). Tang published seven articles on
} 
Beginning in 1922, Tang became a professor of the Department of Philosophy at Peking University. During his stay Peking, especially in the 1930s, Tang published a dozen articles on Buddhist history from the Han to the Tang dynasties. Most of the articles were closely related to the draft of his masterpiece History of Buddhism in the Han, Wei, Jin, and Northern and Southern Dynasties [Hanwei liangjin nanbeichao fojiao shi 漢魏兩晉南北朝佛教史], which was the first and most systematic study of the history of Chinese Buddhism of the Pre-Sui era. This book, which was published in 1938, was just one part of his plan to write a comprehensive history of Chinese Buddhism. The second part of this project, the history of Buddhism from the Sui to the Tang dynasties, however, remained as two volumes of lecture notes. ${ }^{521}$ These notes, along with some of his published articles on related topics, were collected and compiled by his son, Tang Yijie 湯一介 (1927-2014), and published under the title of The Draft of the History of Buddhism in the Sui and Tang Dynasties [Suitang fojiao shigao 隋 唐佛教史稿].

Despite having a similar background to Tang, philosopher Hu Shih approached Buddhism with a different attitude. As a leading intellectual and famous philosopher, as well as an anti-traditionalist, $\mathrm{Hu}$ Shih was widely known as an ideologue behind the May Fourth Movement of 1919 and his several 'movements' of reforming Chinese tradition - which belonged to, in his words, the project of "Chinese Renaissance." Among all his academic activities, his subversive reading of the historical materials of the Chan school was the most 'fruitful' part of his entire scholarship, according to his self-evaluation. ${ }^{522}$

Growing up in a family with a strong atmosphere of Song-Ming rational idealism, Hu was inculcated deeply with the 'secular,' 'pragmatic' spirit of

\footnotetext{
Xueheng to criticize the "New Culture School." For the details of this debate and the activities of the Xueheng School, see Shen Sung-Chiao 沈松僑, “Xueheng Pai yu Wusi Shiqi de Fan Xinwenhua Yundong 學衡派與五四時期的反新文化運動," (Taipei: National Taiwan University, 1984); Lin Liyue 林麗月, “Xueheng yu xinwenhua yundong <學衡>與新文化運動, in Zhongguo xiandaishi lunji 中國現代 史論集, vol,6 (Taipei: Lianjing, 1980), 505-528.

${ }^{521}$ One volume of the mimeographed handout was printed at Central University 中央大學 in Nanjing; one volume of the stereotyped handout was printed at Peking University.

${ }^{522}$ Tang Degang 唐德剛, Hushi koushu zizhuan 胡適口述自傳, chapter 10, 12.
} 
Confucianism, which made him antagonistic to Buddhism and Daoism. ${ }^{523}$ More or less as a behaviorist performance, young Hu Shih smashed three Buddhist statues when he was fourteen, announcing his iconoclastic personality and his antipathy towards Buddhism. In his two autobiographical articles “My Faith" [Wo de xinyang 我的信仰] and "My Autography at Forty Years Old" [Sishi zishu 四十自述] , he repeatedly recalled one detail: above the front door of his uncle's house, there was a plaque with the characters for "No Affinity to Buddhism and Daoism" [sengdao wuyuan 僧道無 緣] on it. This slogan, in fact, described his overall attitude towards Buddhism.

It was history, especially, he claimed, the writings of Sima Guang 司馬光 and Fan Zhen 范縝, that triggered “a dramatic switch" in his "religious life," helping him "shake off the nightmare of causal determinism." ${ }^{24} \mathrm{He}$ then confirmed himself as an atheist and a stubborn rationalist, or in his own words, an "unconverted heretic" [weijing ganhua de yiduan 未經感化的異端]. ${ }^{525}$

With a strong suspicion of Chinese tradition, he entered into the realm of Chinese philosophy. Beginning in 1912, he went to study philosophy at Columbia University, where he was greatly influenced by his professor John Dewey. Hu became Dewey's translator and lifelong advocate. After finishing his doctoral studies, he returned to lecture at Peking University. There, he quickly gained much attention and became one of the leaders of the May Fourth Movement and later the New Culture Movement. His most important contribution to modern Chinese scholarship was the promotion of vernacular Chinese to make Chinese easier for ordinary people to read and write. As a result of this movement, as John Fairbank put it, "the tyranny

\footnotetext{
${ }^{523}$ According to Hu's own words, his father "was a classist, a man who insisted on the ethical principle of Neo-Confucianism and harshly opposed Buddhism and Taoism." Hu Shih, "Wo de Xinyang 我的信 仰," in HSWJ, 7.

524 “未經感化的異端,” in Hu Shih, “Sishi zishu 四十自述,” in Hu Shih Wenji 胡適文集 (Beijing: Beijing daxue chubanshe (2013) 1, 185.

${ }^{525}$ Ibid.
} 
of the Classics had been broken",526 in Hu's own case, his stress on folk literature led him to some Buddhist literature produced in medieval China.

As a 'cultural destroyer' but also a historian, Hu devoted a great deal of energy to applying his ideas to China's own background, rather than blindly relying on imports from the West. As his biographer Jerome Grieder put it, Hu's approach to China's "distinctive civilization" was "thoroughly critical but by no means contemptuous." ${ }^{527}$ Among Hu Shih's wide-ranging humanistic interests and expertise, writing the history of Chinese philosophy was one of his main research foci. His initial interest in Chan Buddhism originated from this monumental project of writing a comprehensive history of Chinese philosophy done according to a strictly modern methodological standard. After writing a ground-breaking dissertation at Columbia University on the patterns of thought shared by the ancient Chinese philosophers, ${ }^{528}$ Hu made plans to carry his project on through the medieval era as well. According to John R. McRae, his research was actually undertaken in two stages: during the years 1924-1935, he established his own methodological system and formulated his general theories and style of interpretation; in the second stage, from 1952 to 1962, he continued his early work by incorporating new implications and hypotheses. ${ }^{529}$

In the context of this general agenda, Hu decided to write a history of the Chan school. It was this juncture that he became fascinated by Shenhui 神會, a longforgotten Chan monk. As Hu himself described, his doubt about the identity and image of Huineng 慧能 and Shenhui in the historical texts of the Chan school arose in

\footnotetext{
${ }^{526}$ John K. Fairbank and Meler Goldman, China: A New History, Second Enlarged Edition ed. (Cambridge, MA: Harvard University Press, 2006), 266.

${ }^{527}$ Jerome B. Grieder, Hu Shih and the Chinese Renaissance Liberalism in the Chinese Revolution, 1917-1937 (Cambridge: Harvard University Press, 1970), 161-162.

${ }^{528}$ Title: The development of the Logical Method in Ancient China (Shanghai: Oriental Book Co., 1922; Reprinted New York: Paragon Book Reprint Co., 1963). This dissertation appeared in an extended form in Chinese in 1921 as the first volume of a projected multi-volume work: Outline of Chinese Philosophy [Zhongguo zhexueshi dagang 中國哲學史大綱] (Shanghai: The Commercial Press, 1921).

${ }^{529}$ The political turmoil surrounding World War II and the continuing Chinese revolution kept Hu Shih from serious scholarship on the Chan school for more than a decade. Only in the last ten years of his life did he returns to this area and write another dozen articles and letters to discuss the issue of the history of Chan Buddhism.
} 
1924 when he was attempting to write the draft of a history of the Chinese Chan school. New materials he collected in Europe, including three versions of Shenhui's recorded sayings in Paris and later Shenhui's Xianzong ji 顯宗記, confirmed his hypothesis. ${ }^{530}$

Based on these materials, Hu quickly finished his monograph The Lost Collection of Monk Shenhui [Shenhui heshang yiji 神會和尚遺集]. From the 1920s to the early 1930s, he published several articles relevant to this study, including analyses of the Buddhist meditation tradition prior or related to the Chan school, textual and biographical studies of Chan figures, and historical summaries of the development and lineage transmission of the early Chan school. ${ }^{531}$ Besides these articles, Hu also left dozens of letters to scholars in China and Japan in which he discussed many crucial issues related to the history of the Chan school. Some of the letters and disputes are arranged by Yanagida Seizan into a collection titled Hushi's Chan Study [Ko Teki zengaku an 胡適禪學案].

By making Shen Hui the key figure of the Chan school, $\mathrm{Hu}$ "almost thoroughly re-wrote the history of Chan Buddhism" and "exposed the falsification of the monks and Daoist priests," as he claimed. ${ }^{532}$ Hu's new narrative of the history of Chan Buddhism as well as his interpretation of the transformation of Chinese culture in the medieval period [Tang Song zhibian 唐宋之變] were rooted in his broader historical

\footnotetext{
${ }^{530} \mathrm{Hu}$ Shih, Lost Collection of Monk Shenhui [Shenhui he shang yiji 神會和尚遺集], 1-3, see John McRae, "Religion as Revolution in Chinese Historiography: Hu Shih (1891-1962) on Shen-hui (684-758)," 61. The original volume of the Yiji was published in 1930; all the references in this dissertation are to the second edition, 神會和尚遺集(附胡先生最後的研究) (Taipei: Hu Shih jinian guan 胡適紀念館), which includes copious handwritten annotations by Hu Shih reproduced with black, red, and green ink. The second edition contains what at the time were complete versions of all Shenhui's known works, edited by $\mathrm{Hu}$ in part on the basis of newly discovered manuscripts obtained through the efforts of Suzuki and Gernet. See John McRae, "Religion as Revolution in Chinese Historiography: Hu Shih (1891-1962) on Shen-hui (684-758)," 61.

${ }^{531}$ In his article "Religion as Revolution in Chinese Historiography: Hu Shih (1891-1962) on Shen-hui (684-758)," John R. McRae enumerated Hu Shih's works on the Chan school in detail. A list of Hu Shih's work on this topic can be found in the appendix of this dissertation.

${ }^{532}$ Original text: “我幾乎將一部禪宗史完全改䳆……揭穿認真作假的和尚道士.” Tang Degang 唐德 剛, Hushi koushu zizhuan 胡適口述自傳, chapter 10.
} 
theory of the "Chinese Renaissance." He tried to demonstrate that China was divested of its intellectual and religious domination by India and had reverted to the simple, humanistic rationalism of its native tradition during the Tang and Song dynasties. ${ }^{533}$ From a methodological perspective, Hu held to his historiographical method more rigorously and consciously than most of his peers. He remained extremely sceptical of Chinese traditional historical narratives and developed an analytical approach based on the combination of traditional textual criticism and modern scientific procedures. He insisted on this research path throughout his career. Compared with other scholars, he was willing to offer bold and fresh interpretations and then tried to expound and prove these interpretations inductively; in some circumstances, he seemed to indicate that the logical sequence between events and ideas could be established prior to their detailed investigation. This methodical strategy made his study a controversial hybrid with comprehensive, critical, and imaginative facets. ${ }^{534}$

However, no matter how controversial Hu's study was, in general, his persistence in searching for rare texts, as well as his important discoveries and subsequent publication of a detailed study of Chan figures' biographies, was the catalyst for the discovery of more Chinese Buddhist material throughout all of east Asia and was a major stimulus for the emergence of the field of Chan/Zen studies. ${ }^{535}$

Hu's strand of atheism formed the fundamental key to his interpretation of Buddhism; another historian, Chen Yuan, was, on the other hand, attempting to exclude the religious imprint from his research and to think and write neutrally.

\footnotetext{
${ }^{533}$ See Hu Shih, The Chinese Renaissance: the Haskell Lectures, 1933. Chicago: University of Chicago, 1934. Rep. with new introduction, New York: Paragon Book Reprint Corp., 1963. Other important literature on this topic include: "Religion and Philosophy in Chinese History," in Sophia H. Chen Zen ed., A Symposium on Chinese Culture, Shanghai: China institute of Pacific Relation, 1931, 31-58; and "The Indinization of China: A Case Study in Cultural Borrowing, in Independence Convergence and Borrowing in Institutions, Thought and Art," Harvard Tercentenary Publication (Cambridge, MA: Harvard University Press, 1937), 219-247.

${ }^{534} \mathrm{Hu}$ Shih and his attitude towards religion will be investigated in detail in Chapter 5 of my dissertation.

${ }^{535}$ Yanagida Seizan 柳田聖山, Goroku no rekishi - Zen bunken no seiritsu-teki kenkyū 語錄の歷史一 禪文獻の成立的研究. [A Historical Survey of the Recorded Saying of Chan Masters in view of the Formation of Chan Literature], Tōbō gakubō 東方學報 Kyoto 57 (1985): 365.
} 
Among all the historians in this field, Chen Yuan was the only one who had a religious background-a belief in Christianity. Against this background, his comparative standpoint rested on the opposing positions of Buddhism and Christianity, instead of the dichotomy between 'tradition/modern' or 'China/West.'

Chen Yuan was born into a family in the medicine business in Xinhui county 新會縣 in Guangdong 廣東. He received a classical Confucian education from his family, but he failed in the provincial examination. This failure, together with a realization that the old order was fast collapsing, made Chen subsequently give up the path to imperial officialdom but instead actively participate in social movements.

In his youth, Chen spent several years studying Western medicine at Boji Medical School 博濟醫學院, a Protestant missionary medical school in Guangzhou 廣 州, and later at Guanghua Medical School 光華醫學院, which he co-founded. His experience of studying medicine not only led to his conversion to Protestantism ${ }^{536}$ and his establishment of close ties with the missionary enterprises in China, but also trained him in his later academic life to observe and deal with his objects as meticulously as a surgeon.

Partly because of the influence from his schoolmate Sun Yat-sen, Chen was active in political activities. He later became a member of the National Assembly of the Republic of China after the success of the revolution in 1911 and was appointed as Deputy Minister of Education in 1921. However, he soon left the realm of politics to pursue an academic career. ${ }^{537}$

Chen Yuan's research focused on two themes: history and religion. Beginning in 1923, when he taught the course in "the history of Christianity in China"

\footnotetext{
${ }^{536}$ As Chen described, “for years I believed in Christianity and thought only it can save the world” [雨 年以來, 余篤信敬天愛人之學, 以為非此不能夠救世]. See Chen Yuan 陳垣. “Chongkan Duoshu xu” 重刊鐸書序 (1919). Chen became a Christian himself.

${ }^{537}$ After 1921, he became the second president of Fu Jen Catholic University 輔仁大學, a position he held from 1926 until the closure of the university in 1952 and the forced merger of its departments into other universities, notably Peking Normal University 北京師範大學, of which Chen Yuan continued to serve as president until his death in 1971.
} 
[zhonghua jidu jiaoshi 中華基督教史] at Yenching University, ${ }^{538}$ he devoted enormous energy to the field of religious history. Based on his reading of the Wenjing Ge 文津閣 version's Siku quanshu 四庫全書, he started his project of writing the history of Chinese Christianity and also planned to write a bibliographical work to organize the Chinese Christian literature, following the style of Zhu Yizun's 朱彝尊 Jingyi kao 經義考 and Xie Qikun's 謝啟昆 Xiaoxue kao 小學考. In 1916, Chen published one of his most influential works, A Study of Erkeun in Yuan Dynasty [Yuan yeli kewen jiao kao 元也里可溫考 $]^{539}$ - the one that launched his scholarly career - with materials from the private collection of Ying Lianzhi.

Due to his personal belief in Christianity, Chen Yuan's study on the history of religion brought new perspectives to this field. ${ }^{540}$ From 1917 to 1923, he published three other important articles on Manichaeism, Zoroastrianism, and Judaism. These works, with the abovementioned study on Christianity, became his famous "Four

\footnotetext{
${ }^{538}$ Yenching University was formed through the merger of four Christian schools. It was founded and directed by the famous missionary educator John Leighton Stuart 司徒雷登. Yenching Univeristy gained financial support from American foundations and maintained a close link with western academic institutes, such as Harvard University and Princeton University. Because of its Christian background, Yenching University gave major support to the School of Theology (which became the School of Religion in 1925), where Chen Yuan served as a professor in the Department of the History of Religions 宗教史學系. According to the Bulletin of The School of Religion, its aim was to "help in laying the foundation of Christian thought for China and in building up Christian life in China, .......with the historical sense and the scientific attitude and technique." Besides studies on the history of Christianity, the Department of the History of Religions also offered courses on Buddhist history and Sanskrit. See Bulletin: School of Religion, Yenching University (1929-1930) http://divinity.adhoc.library.yale.edu/UnitedBoard/Yenching_University/Box\%20315/RG011-3154819.pdf.

539 “Yelikewen 也里可溫” was an ambitious term derived from the Syriac term “arkagun," meaning "blessed people," and in Yuan times included Nestorianism as well as Catholic Christianity. Chen Yuan, Jidujiao ruhua shi 基督教入華史 [A history of Christianity's arrival in China], in Chen Yuan xueshu lunwen ji 陳垣學術論文集, vol.1 (Beijing: Zhonghua shuju, 1980), 102.

${ }^{540}$ Because Chen seldom talked about his religious belief openly, there is some discussion about his status as a Christian. See Wang Hao 王皓, “Chen Yuan shixue yu jiaohui yinyuan 陳垣史學與教會因 緣” [The Relationship between the Historical Studies of Chen Yuan and the Society of Jesus], Zhongyang yanjiu yuan jindaishi yanjiu suo jikan 中央研究院近代史研究所集刊, 97 (2017): 87-121; also Liu Xian 劉 賢, “Chen Yuan jidujiao xinyang kao 陳垣基督教信仰考,” Shixue yuekan 史學月刊, 10 (2006): 83-91.
} 
Studies on the Ancient Religions" [gujiao sikao 古教四考] ${ }^{541}$ Later he wrote his second monograph, The Sinicization of the Western Region people during the Yuan Dynasty [Yuan xiyuren huahua kao 元西域人華化考], which focused on the interaction between different religions and the changing social context surrounding them.

Chen Yuan's concern for Buddhist issues derived from his trans-religious and trans-disciplinary studies. His earliest study about Buddhism appeared in his investigation of Christianity in the Yuan period. He used two chapters in his Yuan Yekeliwenjiao Kao to discuss the relationship between Christianity and Buddhism and the influence of Buddhism on Christianity in a broad historical context. One year later, Chen published his first article on the history of Buddhism, "On the Grotto Temple in Mountain Wuzhou, Datong" [Ji Datong wuzhoushan shiku si 記大同武州山 石窟寺]. Other essays, such as “The Difference Between the Beliefs of Yelu Chu Cai and His Son” [Yelü Chucai fuzi 耶律楚材父子信仰之異趣], “The Translation of Scriptures in Yungang Temple and Liu Xiaobiao" [Yungang shikusi zhi yijing yu Liu Xiaobiao 雲崗石窟寺之譯經與劉孝標], “The Author of Great Tang Records on the Western Regions, Bianji” [Datang xiyuji zhuanren Bianji <大唐西域記>撰人辩機] and so on, were also published in the following years. In his works on other Chinese religions, he paid special attention to issues related to Buddhism; for example, in his monograph Yuan Xiyuren Huahua Kao, he dedicated one chapter, "Buddhism and Taoism," to investigating the beliefs and practices of Buddhism among foreign people in Yuan China and discussed the role Buddhism played in their process of Sinicization [huahua 華化]; in his article "The Life of Wu Yushan No. 5: Wu Yushan and His Chan Friends" [Wu Yushan shengping zhi wu: Wu Yushan yu Chanyou 吳漁山生平之五 :

\footnotetext{
${ }^{541}$ For Chen Yuan's achievements in the study of religious history, there are a couple of works (besides the ones mentioned above): see Liu Xian 劉賢, “On Chen Yuan's Study of Religions”, Diss. The Chinese University of Hong Kong, 2005; Niu Runzhen 牛潤珍, Chen Yuan xueshu sixiang pingzhuan 陳垣學術思想 評傳 (Beijing: Beijing tushuguan chubanshe, 1999). Articles: Xu Guansan 許冠三, Chen Yuan: tufa weiben yangfa weijian 陳垣:土法為本洋法為鑒,” in Xin shixue jiushi nisn 新史學九十年 (Changsha: Yuelu shushe, 2003) 118-146; Chen Lesu 陳樂素, “Chen Yuan tongzhi de shixue yanjiu 陳垣同志的史學 研究, Z Zhongguo shi yanjiu 中國史研究,4, (1980), 3-17; Ge Zhaoguang 葛兆光, “Xinshixue' zhihou 1929nian de Zhongguo lishi xuejie 《新史學》之後--1929 年的中國歷史學界, Lishiyanjiu 歷史研 究, 1, (2003), 82-97.
} 
吴漁山與禪友], he investigated the close contact between Wu Yushan, a Chinese Christian priest, and Buddhist monks in the Kangxi period of the Qing dynasty. He also discussed the so-called "Yuan fo ru ye 緣佛入耶” interpretation strategy-the use of Buddhist concepts and terms to explain the doctrines of Christianity-in his articles on Christianity. ${ }^{542}$

During the 1930s and 1940s, the history of Buddhism (especially Buddhism in the Yuan, Ming, and Qing dynasties) took up a remarkable portion of his study. In 1931, he arranged and catalogued the Dunhuang manuscripts in the Beijing Library and compiled a bibliographical work entitled Catalogue of Manuscripts from Dunhuang Remaining after the Theft [Dunhguang jieyu lu 敦煌劫余錄]; later, he published another bibliography of Buddhist literature, Introduction to Chinese Buddhist Historical Texts [Zhongguo fojiao shiji gailun 中國佛教史籍概論], in which he arranged some important Chinese Buddhist literature with his own summary and comments. In 1938, another reference book, titled Record of Dubious Dates of Buddhist Monks [Shishi yinian lu 釋世疑 年錄], was published; in this book, Chen examined and listed the biographical information of more than 2,000 Buddhist monks and nuns. All these works provided considerable information and materials for the scholarship of Chinese Buddhism.

More important are his two monographs on Ming-Qing Buddhism: A Study on Buddhism in Yunnan and Guizhou Provinces in Mid-Ming [Mingji dianqian fojiao kao 明季 滇黔佛教考] and Debates Between Monks in the Early Qing Dynasty [Qingchu sengzheng ji 清初僧猙記]. Both of these two studies were based on Buddhist literature he discovered in the archives of the Ming-Qing inner court. Instead of establishing a linear, meta-view of the development of Buddhism or providing historical interpretation based on any philosophical presuppositions, these studies aimed at constructing a narrative history of "events" or "phenomena" through reliable primary sources. Chen covered a wide range of topics in these two case studies, including the changing political background of Buddhism, the organization and

\footnotetext{
${ }^{542}$ Chen, Jidujiao renzi shiyi xu 基督教人子釋義序, CYQJ, vol. 7, 406-07.
} 
economy of monasteries, the conflicts among different Buddhist sects, and the relationship between monastic communities and the local literati.

As one of the 'old-fashioned' historians ${ }^{543}$ and a confessed Christian, Chen Yuan might not meet the criteria of a 'modern researcher.' Because of his alleged conservatism (e.g., writing in classical Chinese, emphasizing textual support, and avoiding popular theories ${ }^{54}$ ) and his rare expertise, Chen has been depicted more as a dispassionate scholar specializing in classical texts, non-native religions, and bibliography, instead of as a penetrating thinker. Mostly, he has been credited for his broad historical knowledge and his dedication to modern pedagogy as a successful educator ${ }^{545}$ Therefore, his contribution to the scholarship of Buddhism, especially his textual study of Buddhism, has been regarded as partly serving the purpose of teaching and has been overshadowed by his ground-breaking research on Christianity, Islam, Manichaeism, Zoroastrianism and the communication between Chinese/foreign religions. However, Chen was a distinguished historian of Buddhism, as well as a scholar who was "participating in the trend" [yuliu 預流] ${ }^{546}$ By offering

${ }^{543}$ During his whole life, Chen did not go abroad; however, he had some connection with Western and Japanese academia. For example, he built a close relationship with Paul Pelliot 伯希和 and Jitsuzō Kuwabara 桑原䉆蔵. See Sang Bing 桑兵, Boxihe yu jindai Zhongguo xueshujie 伯希和與近代中國學 術界," Lishi yanjiu 歷史研究, 5 (1997): 125-126; also see Masaaki Chikusa 䇥沙雅章, Chen yuan yu Sangyuan Wuzang 陳垣與桑原鹳藏, "Lishi yanjiu 歷史研究 1 (1991): 13-19. Chen also had direct contact with Western educational circles when he served as the president of Fu-Ren University. ${ }^{544}$ However, late in his career, he accepted the mainstream of historiography, Marxism. For details see Chen Zhichao 陳智超, Chen Yuan laiwang shuxin ji 陳垣來往書信集 (Shanghai: Shanghai guji chubanshe, 1990), 709-10; also see his letter to Hu Shih, in Chen Yuan laiwang shuxin ji 陳垣來往書信集, 192-94. For the context of this change, see Wang Fansen, “ 'zhuyi chongbai' yu jindai Zhongguo xueshe shehui de mingyun - Yi Chen Yinke wei zhongxin de kaocha," in Zhongguo Jindai Sixiang Yu Xueshu De Xipu 中國近代思想與學術的系譜, 471-77.

${ }^{545}$ For Chen's theory of pedagogy, see Chen Yuan xiansheng de shixue yanjiu yu jiaoyu shiye-jinian Chen Yuan xiansheng danchen 130 zhounian xueshu lunwenji 陳垣先生的史學研究與教育事業——紀念陳垣先 生誕辰 130 週年學術論文集 (Beijing: Beijing Normal University Press, 2010).

${ }^{546}$ The word 'yuliu' is originally a Buddhist term. In his article “Chen Yuan Dunhuang jieyu lux u 陳垣 敦煌劫餘錄序," in JMEB, 266. Chen Yinke used this term to summarize Chen Yuan's study. For a further discussion on this term in the context of modern Chinese scholarship, see Ge Zhaoguang 葛兆 光, “Yuliu de xuewen: chongfan xueshushi kan Chen Yinke de yiyi”預流的學問：重返學術史看陳寅 恪的意義,” Wenshizhe 文史哲, 5 (2015). 
informed accounts of Chinese religion, Chen created new themes, new vocabularies, and new perspectives for discussing religious traditions in a broader textual, historical, and political context. Equally important, he helped to bring Chinese scholarship on religious history into a global academic dialogue, joining the discussions and responding to the voices overseas directly and indirectly. ${ }^{547}$

\section{Buddhist Historians}

Along with the revival of Buddhism and the popularity of the consciousness-only school among modern Chinese intellectuals, a new trend in the historical studies of Buddhism emerged. This trend aimed to rebuild the doctrinal tradition, which had been long lost after Master Xuanzhang, and to re-link Chinese Buddhism with its Indian origin. The most representative Buddhist historian who pursued this direction was the lay Buddhist scholar Lü Cheng.

Lü Cheng was born in Danyang County, Jiangsu. ${ }^{548}$ It was under the influence of his elder brother, Lü Fengzi 吕鳳子 (1886-1959), a famous artist and lay Buddhist who learnt Buddhism from Yang Wenhui, that Lü Cheng became interested in both Buddhism and art. It was also through Fengzi that young Lü Cheng met Ouyang Jingwu in Nanjing and then became one of the first members of the Buddhist Seminary 佛學研究部 established by Ouyang as an affiliated institute of Jinling Sutra Press 金陵刻經處.

In 1917, Lü traveled to Japan to study language and art; however, due to the anti-Japanese sentiment in China, he returned to China in 1918. Although Lü's stay in Japan was comparatively short, his connection with Japan played an essential role in

\footnotetext{
${ }^{547}$ I discussed in detail Chen Yuan's study of Ming-Qing Buddhism, including the methods he used and the academic and religious standpoints behind his study, in the paper "Juwairen de shijiao: Chenyuan yu jindai mingqing fojiao lishi yanjiu" that I presented at the Conference of Early Modern Asian Buddhism held in Taiwan, May, 2021.

${ }^{548}$ Lü Cheng, "My Experience and the History of the China Institute of Inner Learning [wo de jingli yu neixue yuan fazhan licheng 我的經歷與內學院發展歷程].” This was a document written in 1959, when Lü worked at the Chinese Academy of Social Science.
} 
his academic career. Beginning in 1919, Lü worked with Ouyang in setting up the China Institute of Inner Learning. During the same period, Lü was also appointed as the dean of academic affairs at the Shanghai School of Art, teaching aesthetics and art history. In 1922, Lü became one of the leading figures of Neixueyuan when the institute was officially established. He then devoted himself entirely to the study of Buddhism and gave up his interests in art.

Throughout his entire career, Lü was highly influenced by his mentor Ouyang Jingwu. However, unlike Ouyang, who had never been trained in Sanskrit or Tibetan, Lü's language ability allowed him to deal with both Chinese and other language resources. He firstly studied Tibetan and Sanskrit with Huang Shuyin 黄樹因 (1898$1925)^{549}$, a young colleague who had learned Tibetan at Yonghe Lamasery 雍和宮 in Peking, and he continuously studied Sanskrit with Ferdinand Lessing (1882-1961), ${ }^{550} \mathrm{a}$ German linguist living in Shandong, and also with Baron Alexander von StäelHolstein (1877-1937), a Russian Sanskrit scholar who taught at Peking University from 1918 to $1929 .{ }^{551}$ Language training was a crucial skill that helped Lü complete the compilation of the Essentials of the Buddhist Cannon [Zangyao 藏要] ${ }^{552}$

\footnotetext{
${ }^{549}$ For the biography of Huang Shuyin, see Ouyang Jingwu, “Huang Jian shilue 黄建事略," Niexue I (1924): 179-180. See also the talks of Ouyang Jingwu and Lü Cheng given on the occasion of the opening of Shuyin Seminar: On the Opening of Shuyin Seminar [Shuyin yanjiu shi chengli ji 樹因研究室成立記], Neixue 3 (1926): 172-178.

${ }^{550}$ Lessing, who perhaps was best known for his works on Tibet, "Lamaism," and Tantra, came to China in 1907 and spent seventeen years there teaching languages and philology at various institutions.

${ }^{551}$ On Baron Stäel-Holstein, see Wang Qilong 王啟龍, Ganghetai xueshu nianpu jianbian 鋼和泰學術年譜 簡編 [A Brief Chronological Biography of Alexander von Stäel-Holstein] (Beijing: Zhonghua shuju, 2008), and a shorter English version, Wang Qilong, "A Brief Review of Alexander von Stael-Holstein: A Great Scholar in Asian Studies," Chinese Tibetology 1 (2008): 80-93. For examples of the Baron's scholarship, cf. Baron A. von Stael-Holstein, Kāśyapaparivarta (China: 1923) [correlated Sanskrit, Chinese and Tibetan editions of the text, with an English introduction]; "The Emperor Ch'ien-lung and The Larger Śūramgamasūtra," Harvard Journal of Asiatic Studies 1, no. 1 (1936): 136-146; "Avalokita and Apalokita," Harvard Journal of Asiatic Studies 1, no. 3 (1936): 350-362; and "On a Peking Edition of the Tibetan Kanjur which Seems to be Unknown in the West," edited and introduced by Jonathan Silk, Journal of the International Association of Buddhist Studies 22, 1 (1999): 215-249.

${ }^{552}$ Lü emphasized the mutual relationship between China and Tibet. See Lü, "Hanzang foxue gongtong de diyibu 漢藏佛學溝通的第一步," LFLX, 1402. Short summery see Zhou Xia, Zhongguo jindai fojiao shixue mingjia pingshu 中國近代佛教史學名家評述, 261-269.
} 
Lü's main contribution to modern Chinese Buddhology was that he built up the academic style and research standard for modern Buddhist education when he served as the dean of Neixueyuan. He noted in a work statement in 1950 that the mission of the institute was to restore 'genuine Buddhism' and to distinguish it from 'fake imitations' [xiangsi foxue 相似佛學]. To Lü, the Yogācāra tradition developed by Asanga, Vasubandhu, and others Indian masters, and promulgated in China by Xuanzang, Kuiji, etc., provided the necessary basis-doctrinally and methodologically-for the modernization of Buddhism. According to Lü, this mission would be accomplished in three steps: the first step was critically arranging and editing Buddhist texts referring to the Pali, Sanskrit, Tibetan, and credible Chinese versions of these texts; the second step was establishing accurate knowledge of Indian Buddhism and then using it as a criterion for re-evaluating Chinese Buddhism, especially the native sects, such as Chan and Huayan, from a historiographical perspective. The last step was establishing a comprehensive curriculum of Five Subjects [wuke 五科] ${ }^{553}$ as the structure of a new Buddhist education system. Lü expected the Neixueyuan model to embody the ideal of modern Buddhist education; this model also implied a revival of the traditions of Nālandā University, the premier Indian Buddhist institution where Xuanzang had studied.

Lü's studies focused on Buddhist epistemology and logic [hetuvidyā, 因明], especially the study of Ālambana-pariks $\bar{a}^{.54}$ His reading of Yogācāra texts made him suspect the sufficiency and authenticity of Chinese Buddhist resources. He believed that the 'genuine origin' of the Buddhist philosophical setting should be recovered through careful textual analysis of different translated and commentated versions of

\footnotetext{
${ }^{553}$ The Five Subjects include: Abhidharma [毗昙], Prajñā [般若], Yogācāra [瑜伽], Nirvāṇa Sūtra [涅槃], Vinaya [戒律].

${ }^{554}$ Ālambana-parikșā was superseded in India (and later Tibet) by more sophisticated and complex critiques of atomism, but none of those later works reached China and East Asia until the twentieth century.
} 
texts. This research model paved the way for subsequent studies, such as those by Yamaguchi Susumu 山口益 and Ui Hakuju 宇井伯壽. ${ }^{555}$

Based on his understanding of Buddhist doctrines, especially the Yogācāra teaching, Lü developed his historiographical concept from a similar 'fundamentalist' perspective on the development of Buddhism. In particular, he considered the emergence of its Chinese manifestations to be a deviation from its Indian origin. His studies of the history of Buddhism in general, with this presupposition in mind, focused on two divided but closely related themes: the critical textual analysis of Chinese Buddhist literature, and a retrospective, reconstructive narrative of the historical changes of Chinese Buddhism and their roots in Indian Buddhism. Beginning from his provocative study "One Hundred Things Wrong with the Śūrangama [sūtra]” [Lengyan bai wei 楞嚴百偽], he published several articles about 'spurious' Chinese Buddhist scriptures [weijing 偽經], including the Renwang jing 仁王 經,Brahmajāla-sūtra 梵網經, Dasheng qixin lun 大乘起信論, Yuanjuejing 圓覺經, and Zhancha yebao jing 占察業報經. His critique of these texts, especially some key terms in them, such as the 'inherent enlightenment' [benjue 本覺], demonstrated his tendency to read Chinese Buddhist texts more comparatively and more 'historically'. To Lü, all Buddhist texts, especially the Chinese ones, were productions of particular historical conditions and therefore could not fully demonstrate the teachings of the Buddha; the genuine truth of Buddhism, which presented itself differently or even sometimes distortedly in history, should be uncovered, deciphered, and extended, but not altered, changed, or developed.

\footnotetext{
${ }^{555}$ For example, Ui's study of Dignāga, Jinna chosaku no kenkyū 陳那著作の研究 (Tokyo: Iwanami shoten, 1958), includes his study of Ālambana-parikșā (pp. 24-130, with his Japanese translation of the Paramārtha, Xuanzang, and Yijing versions), and studies of three other Dignāga texts. This comparative study was conducted partially on the basis of Lü's contribution. Yamaguchi Susumu also acknowledged his indebtedness to Lü's exegetical reading of Dharmapāla's text. See Yamaguchi Susumu \& Josho Nozawa, Sesshin Yuishiki no Genten Kaimei 世親唯識の原典解明 (Kyoto: Hōzōkan. 1965): 413-414.
} 
Before his intellectual career was interrupted by the political turmoil during the Cultural Revolution (1966), ${ }^{556}$ Lü worked as a lecturer at the Seminar of Buddhist Study in Nanjing beginning in 1949. The notes for his two lectures on the history of Buddhism during this period were published with the keywords 'origin' and 'change' in their titles: The Origins and Changes of Indian Buddhism [Yindu fojiao yuanliu lüejiang 印度佛教源流略講] and The Origins and Changes of Chinese Buddhism [Zhongguo fojiao yuanliu lüejiang 中國佛教源流略講]. In these studies, Lü not only discussed the history of certain Buddhist texts-their translation, distribution, and acceptance in the Chinese context-but also clarified the traces of how these texts were used, understood, and misread by different Buddhist sects again and again based on their different intellectual backgrounds. Partly inheriting the 'traditional' pattern of classifying Buddhist teaching, namely the 'doctrinal classification' [panjiao 判教], he linked those 'local' or 'temporal' manifestations back to the 'reasoning of the sacred words' [shengyan liang 聖言量]—the essence of Buddhist Canon, as Lü indicated in the name of his collection of Buddhist classics, Zangyao.

During the early twentieth century, with the emergence of more and more educated monks, the Buddhist monastic circle began to 'organize Buddhist heritage' using the new academic discourse to establish the past of Buddhism. When the historical 'truth' contradicted their commitments to belief, these 'insiders' always had their own means of reconciling these different opinions and resolving the

\footnotetext{
${ }^{556}$ Most of Lü's manuscripts were lost during this political turmoil. Only in recent years have some of Lü Cheng's unpublished works been discovered and published. Here are some of the most important findings: (1) A Chinese draft translation of Dignāga's Ālambana-parīkșā from the Tibetan version, which was completed before the finalized version in Neixue 4 (1928). See Gao Shanshan 高山杉, “Zhina Neixue Yuan Foxue shiliao sanzhong 支那內學院佛學史料三種, ” in Shijie zhexue 世界哲學 3 (2012): 151-160. (2) A Chinese translation of Bhāvaviveka's (sixth century) Madhyamakahṛdaya, Chapter V, “Yogācāratattvaviniścaya” [中觀心論・入決擇瑜伽師真實品], which was completed in the 1950s, in Shijie zhexue 6 (2011): 72-91. (3) A modern Chinese translation of Vasubandhu's Vimśatika. See Lü Cheng, “Modern Chinese translation of Vimśatika“ [二十唯識白話譯本], in Shijie zhexue 1 (2009): 120133. (4) A lecture on the Diamond Sutra. See Lü Cheng, “Lecture on the Diamond Sutra” [金剛般若經講 義], in Zhongguo zhexue shi 4 (2008): 5-15, 24.
} 
'challenge' caused by history. Interesting enough, the customary tactic they used was still history, or historiography.

Taixu, one of the most important Chinese Buddhist monastics of the twentieth century, is known chiefly for his attempts to demonstrate Dharma's relevance to the modern intellectual landscape of Republican China. To underscore its resonance with contemporary scientific and ideological trends, Taixu presented his views on the Dharma under the rubric of "Buddhism for human life" [rensheng fojiao 人生佛教] (a term he introduced in 1928) (57 $^{55}$, and later (beginning in 1933), "Buddhism for the human worl" [renjian fojiao 人間佛教]. Compared to his vigorous activities in religious revolution, Taixu's academic activities were sometimes overlooked. Never labelling himself a 'scholastic monk' [xuewen seng 學問僧], Taixu, nevertheless devoted a great portion of his endeavour to historical and doctrinal studies of Buddhism. He also encouraged later Buddhist scholars, such as Yinshun and Shengyan, to enter the field of Buddhist studies.

Taixu was born in a small village in Haining county in northern Zhejiang province. As an orphan, he was raised by his maternal grandmother, a devout woman who had good reading and writing ability, and his uncle, a local schoolteacher but also an opium addict. Through them, Taixu received a passable primary education and was introduced to Buddhism via frequent visits to local temples and pilgrimages to some nearby sacred mountains ${ }^{558}$ Probably because of the need to sustain a living, Taixu chose to become a monk at a young age and undertook ritual service for the local community for years. As part of the generation that was born during the final years of Imperial China and came of age during a time of instability, revolution, and new possibilities, Taixu inevitably encountered the issue of whether the modernization of China could also bear Buddhist values or not. His inquiry into the fate of Chinese Buddhism intensified after he was introduced to the works of new modernizing intellectuals: Kang Youwei, Yan Fu, and Liang Qichao. All these

\footnotetext{
${ }^{557}$ See Taixu 太虚, “Duiyu Zhongguo Fojiao geming seng de xunci 對於中國佛教革命僧的訓詞,”in TXQS vol. 17 (2005 [1928]), 597.

${ }^{558}$ Yinshun 印順, Taixu Dashi nianpu 太虛大師年譜 (Taipei: 1973); originally published in Hong Kong in 1950, 24. Also see Taixu, “Taixu zizhuan 太虚自傳,” in TXQS, 19, 187.
} 
theoretical stimuli deepened his reflections and were eventually absorbed into his well-planned prospect of Buddhist revolution, from doctrinal updates to a new form of monastic economy.

As a crucial part of his reform, Taixu advocated a secular-style education among the samgha-a systematic curriculum that was resonant with the modern knowledge structure. History as a discipline, although not the ultimate goal of studying Buddhism, provided an overall picture of Buddhism's past and could help people better understand its current condition. Therefore, although he was a modernist and reformer who was staring at the future, Taixu began to describe his grand plan of reforming Chinese Buddhism by recalling its remote past. Basically, Taixu's writing maintained the traditional system of panjia $^{559}$ and the themes that could be found in pre-modern Buddhist historical writings, such as the lineages of different sects. Also, he uncritically used Chinese materials to reconstruct the history of Indian and Chinese Buddhism, even though those materials had already been questioned by scholars. He seemed less interested in newly discovered materials, such as the Dunhuang scriptures, and did not concern himself with the studies of his contemporaries from academia, such as the works of Hu Shih, Tang Yongtong, and Chen Yinke. He indeed read some of their works, but he seemed have not to have been influenced by any new trends in historiography. However, despite his limited interest in historiography, Taixu was one of the few Buddhists who intentionally pondered over the concept of history in his writings. When discussing the relationship between Buddhism and concepts from other disciplines, such as science and philosophy, he proposed a view of Buddhist history that was based on the key term of Buddhist teaching: independence [yuan 緣]. In the article "The DependentlyOriginated Conception of History" [yuancheng shiguan 緣成史觀], he used this concept to reach a balance between the modern idea of progressivism and Buddhist cosmology. History, as Taixu noted, was determined by a Buddhist causality and

\footnotetext{
${ }^{559}$ From 1908 to 1914, Taixu made a distinction between 'zong' ('lineage') and 'jiao' (school) when he discussed the issue of unity and diversity in the development of Buddhism [ fo fa de pan she 佛法的判攝] See Gao Yongxiao 高永霄, “Taixu dashi de sixiang tixi 太虚大師的思想體系, ” in Xianggang fojiao 香港 佛教, 286, (1960): 27.
} 
moved toward its teleological end: the actualization of the Pure Land through the Bodhisattava path. This is exactly what he pursued via his Buddhist reforms. ${ }^{560}$

Besides the historians and scholars mentioned above, there were still many individuals who participated in this research trend and contributed to the field of the historiography of Buddhism through their vigorous teaching and writing activities, for example, Zhou Shujia 周叔迦, Meng Wentong 蒙文通, Yinshun 印順, Tanxuan 談 玄, Fafang 法舫 and on on. ${ }^{561}$ Although this research trend一the historiography of Buddhism - remained a sub-branch of both historiography and Buddhist studies, it demonstrated a common historical awareness: Buddhism needed to be re-interpreted in the modern context, both historically and conceptually. This awareness led to the endeavour to reconstruct the past of Buddhism and changed our knowledge and understanding about Buddhism, whether through criticism, suspicion, comparison, or synthesis.

\footnotetext{
${ }^{560}$ Further discussion on this issue, see Chapter 4 of this dissertation.

${ }^{561}$ The total amount of articles about the history of Buddhism published on the periodicals is around 800.
} 


\section{CHAPTER 4}

\section{The General History of Chinese Buddhism}

China has a long tradition of recording, narrating, and commemorating events that happened in the past and has continually revered historical texts, archives, and antiquities. ${ }^{562}$ Over its two-millennia enterprise of record-keeping and history making, nuances in conceptions of time and space with varied temporalities have always coexisted. For example, Joseph Needham has argued that the Chinese concept of history is mainly linear, ${ }^{563}$ however, other interpretations have tended to see the traditional Chinese view of time as circular. ${ }^{564}$ Basically, as many current scholars believed, 'historical' time in China, represented by the social-political order centered on the activities of ruling clans and the worship of ancestors, reflected a cosmic time marked by the rhythms of yin-yang and the Five Elements 五 Mandate of the Heaven and provided legitimacy and a rationale for changes in dynasties. The historicity of time was reinforced by the fact that the ideal order, the Dao, would not be made accessible through an act of divine revelation, but could be

\footnotetext{
${ }^{562}$ See Endymion Wilkinson, Chinese History: A Manual, Harvard Yenching Institute Monograph Series, 52 (Cambridge, MA: Harvard University Asian Center, 2000).

${ }^{563}$ Joseph Needham, "Le temps et l'homme oriental," in La chinoise et l'Occident: le grand titrage, 1977, 201.

${ }^{564}$ For a strong argument favouring an understanding of traditional Chinese historiography as cyclical see Luke S. K. Kwong, "The Rise of the Linear Perspective on History and Time in Late Qing China c.1860-1911," Past and Present 173 (2001): 160-65. For further discussions of Chinese concepts of time see Chun-chieh Huang, “'Time' and 'Supertime' in Chinese Historical Thinking," in Notions of Time in Chinese Historical thinking, eds. Chun-chieh Huang and John Henderson (Hong Kong: The Chinese University Press, 2006), 19-41. Julius T. Fraser and Francis C. Haber, eds. Time, Science, and Society in China and the West (Amherst: University of Massachusetts Press, 1986); Liu Shu-hsien, "Time and Temporality: The Chinese Perspective," Philosophy East and West 24.2 (1974): 145-53; Edward Q. Wang, Time Perception in Ancient Chinese Historiography, in Storia della Storiografia 28 (1995): 69-86.

${ }^{565}$ For the Chinese 'correlative thinking' on time, see Marcel Granet, La penseé chinoise, (Paris, Albin Michel, 1968); Emile Durkheim and Marcel Mauss, Primitive Classification. (Chicago: University of Chicago Press, 1963 [1930]), 3.
} 
possibly measured through history. ${ }^{566}$ History, shi, in China, therefore, was entrusted with the power of providing access to divine truth. ${ }^{567}$ This concept of shi differed from the modern Western notion of history, which was conceived as contingent and irreversible." ${ }^{568}$

The encounter with the West from the nineteenth century challenged the declining traditional Chinese historiography with new concepts, methods, and patterns, which were labeled as 'modern' or 'civilized.' The old historiographical framework was contested since it failed to reveal the principles and logos behind changes and was unable to solve the real crisis China faced. The traditional historical writings were considered false and fabricated, mixed with myths, legends, stories, and other distorted narratives. As a result, a trend to organize past events in a coherent, scientific, chronicle-like manner emerged. ${ }^{569}$ Writing the general history of Buddhism was one important attempt in this trend.

\section{The Consciousness of General History}

\section{Comprehensiveness 通}

The term 'general history' [tongshi 通史] had its cultural roots in the Chinese historiographical tradition. As early as the Han dynasty, historian Sima Qian had described the mission of his masterpiece shiji as "to comprehensively penetrate the

\footnotetext{
${ }^{566}$ Axel Schneider and Stefan Tanaka, "Historical writings in China and Japan," in Stuart Macintyre, Juan Maiguashca, and Attila Pók ed., The Oxford History of Historical Writing: 1800-1945 (Oxford: University of Oxford Press, 2011), 492.

${ }^{567}$ Twitchett, The Writing of Official History Under the T'ang.

${ }^{568}$ Hayden White, Metahistory: The Historical Imagination in Nineteenth-Century Europe (Baltimore: Johns Hopkins University Press, 1975), 3

${ }^{569}$ Original text: 現時代之潮流. In Zhang Mantao 張曼濤 ed., “Bianji zhiqu 編輯旨趣,” in Xiandai fojiao xueshu congkan 現代佛教學術叢刊 [XFXC] (Taipei: Dasheng wenhua chubanshe, 1979), 1. Zhang Mantao named the study of Buddhist history one of "the three trends of the modern Chinese Buddhist studies." See Also Tan Xuan 談玄, “Fojiao lishi yanjiu fa 佛教歷史研究法.” XFXC, vol.41.
} 
changes of the past and present 通古今之變." ${ }^{570}$ Sima Qian's ideal of "comprehensiveness" in historical writing was held in high esteem by a significant number of Chinese historians, inspiring them to entitle their magnum opuses as 'comprehensive' [tong 通].$^{571}$ Zhang Xuecheng's wenshi tongyi 文史通義, for example, not only utilized tong as the name of the book but also dedicated one chapter to discussing the definition of 'tong' as well as the emergence and development of tongshi in the Chinese historiographical tradition. According to Zhang, the writing model of 'general history' derived from Ban Gu's 班固 Baihu Tongyi 白虎通義 and Ying Shao's 應劭 (140-206) Fengsu Tongyi 風俗通義; it grew under the promotion of the emperors of the Liang dynasty ${ }^{572}$ and reached its apogee in the works of Zheng Qiao 鄭樵(11041162), Sima Guang, Du You 杜佑(735-812), and Pei Lin 裴潾 (?-838). ${ }^{573}$ When Zhang Xuecheng listed the advantages and shortcomings of 'general history, ${ }^{574}$ he continued a line of thought already expressed by Song dynasty historian Zheng Qiao. ${ }^{575}$ Instead

\footnotetext{
${ }^{570}$ Sima Qian, “Bao Ren An sh u 報任安書,” translated by Burton Watson, in Ssu Ma Chien Grand Historian of China, 66.

${ }^{571}$ Shiji has also been considered a paradigm of general history, for it is a "whole corpus of a general history of several millennia." See Chen Shih-Hsiang, "An Innovation of Chinese Biographic Writing," Far Eastern Quarterly, 13, I (1953), 44-62. See also Watson, 122.

${ }^{572}$ According to Zhang, to overcome the shortage of dynastic history (Hanshu, Sanguo zhi, etc.), Emperor Liang Yuan commissioned his historians to compile a history covering a time span from the three dynasties to the Liang dynasty, titled 'tongshi' 通史 ['General history'], with 600 fascicles in its final version. Zhang Xuecheng, “Shi Tong 釋通,” Wenshi tongyi 文史通義 (Taipei: Huashi chubanshe, 1980), 133.

${ }^{573}$ The four works are Zheng Qiao's Tongzhi 通志; Simaguang's Tongjian 通鑑; Du You's Tongdian 通典; and Pei lin's Tongxuan 通選. Zhang commented that these four books "either maintain the principle of the Official Histories, or rectify the order of chronological histories, or using allusion as its outline, or preserving poems and literature. The comprehensiveness of history reaches its peak" [或存正史之 規，或正編年之的，或以典故為紀綱，或以詞章存文獻，史部之通，於斯為極盛也]. Ibid. ${ }^{574}$ Zhang listed several advantages of tongshi and praised it as a superior narrative technique. According to him, tongshi “avoids overlaps” [mian chongfu 免重複], “uses a wide variety of examples” [jun leili 均類例], “facilitates the classification of facts” [bian quanpei 便銓配], "balances rights and wrongs” [ping shifei 平是非], “ends contradictions” [去牴牾] and “gives detailed accounts of neighboring countries" [xiang linguo zhi shi 詳鄰國之事].Zhang Xuecheng, “Shi Tong 釋通," ibid, 133. ${ }^{575}$ See Zhang Xuecheng's 章學誠 inquiry into the concept of tong and his defence to Zheng Qiao: “Shi tong 釋通,”“Shen Zheng 申鄭,” and “Da ke wen, shang 答客問上,” in Wenshi tongyi 文史通義.
} 
of considering Ban $\mathrm{Gu}$ as the master-historian par excellence like his contemporaries, ${ }^{576}$ Zheng Qiao in his Tongzhi criticized that after Ban Gu's dynastic history ${ }^{577}$, the spirit of 'comprehensiveness' of Chunqiu and Shiji gradually was lost. ${ }^{578}$ He thus advocated a “synthetic comprehension" [huitong 會通] and “causal relations” [xiangyin 相因], emphasizing that history was the distillation, synthesis, and integration of the principles of the world, through which the pervasive Dao can be comprehended. ${ }^{579}$

In the modern context, the idea of 'comprehensiveness' was interpreted as an ability or 'historical insight' that could grasp, comprehend, and explain the changes across different times. It requires a focused, time-indexed approach with a deeper insight into the reception, adoption, and modification of Chinese historical views along the line of time from the past to the present. Following Zhang Xuecheng, ${ }^{580}$

\footnotetext{
${ }^{576}$ Some scholars have mentioned that, from a practical perspective, the dynastic history was the mainstream of traditional historical writing. See Achim Mittag, "Cultural Differences as an Inspirational Source of Historical Knowledge - Random Notes on Three Approaches to Chinese Comparative Historiography," in Chun-Chieh Huang, Jörn Rüsen ed., Chinese Historical Thinking: An Intercultural Discussion (Göttingen: V \& R Unipress, 2015), 89-93

${ }^{577}$ Zheng Qiao's Tongzhi is a general history of 200 fascicles, covering history from antiquity to the Tang dynasty. It is ambitiously modelled after Sima Qian's Shihji. The largest part of this book adopted the annals-biography (jizhuan) or composite style of the standard histories. See Thomas H. C Lee, "History, Erudition and Good Government: Cheng Ch'iao and Encyclopaedic Historical Thinking," in Thomas H. C. Lee ed., The New and the Multiple: Sung Senses of the Past (Hong Kong: The Chinese University Press, 2004), 163-71; Edwin G. Pulleyblank, "Chinese Historical Criticism: Liu Chih-chi and Ssu- ma Kuang," in W. G. Beasley and E. G. Pulleyblank ed. Historians of China and Japan (London: Oxford University Press, 1961), 150-151; Albert Mann, “Cheng Ch'iao: An Essay in Re-Evaluation," in D. C. Bauxbaum and F. W. Mote ed., Transition and Permanence in Chinese History and Culture: A Festschrift in Honour of Dr. Hsiao Kungch'üan (Hong Kong: Cathay Press, 1972), 23-57; Du Weiyun 杜維運, Zhongguo shixueshi 中國史學 史,vol. 3 (Taipei: Sanmin shuju. 2004), 99-102.

${ }^{578}$ See Zheng Qiao, “Zongxu 總序, ” in Tongzhi 通志, reprinted in 4 vols., (Taipei: Xinxing, 1965), 2.

${ }^{579}$ Thomas H. C Lee, "History, Erudition and Good Government: Cheng Ch'iao and Encyclopaedic Historical Thinking,” 172-179; Lin, Shimin 林時民, “Zheng Qiao de Tongzhi lüe ji qi shixue 鄭樵的通志 略及其史學”, Xingda lishi xuebao 5 (1995): 61-95; Pulleyblank, Edwin G, “The Historiographical Tradition."in Raymond Dawson ed., The Legacy of China (London: Oxford University Press, 1964); Tao Fanbing 陶惁炳. Zhongguo gudai shixueshi lue 中國古代史學史略 (Changsha: Hunan renmin chubanshe, 1987), 330-32, 335-37.

${ }^{580}$ Zhang Xuecheng may be the first one who advocated writing a 'real' general history. See Mary G. Mazur, "Discontinuous Continuity: The Beginning of a New Synthesis of 'General History' in $20^{\text {th }}$
} 
historian Liu Xianxin 劉咸炘 (1896-1932), for example, further interpreted the notion 'historical insight' as “observing trends in history” [guan shiji zhi fengshi 觀史 蹟之風勢], highlighting that a historian had to be able to cope with the underlying fabric of historical development [fazhan mailuo 發展脈絡] ${ }^{581}$ Liang Qichao 梁啟超, as well, understood historical 'comprehensiveness' as "capability of observation" [guancha nengli 觀察能力], namely, to "look at a thing and thoroughly examine its source and further development." ${ }^{582}$ By stressing the power of 'comprehension', modern historians actually further separated historical knowledge, which is descriptive and evidential, from the 'moral integrity of the historian' [shide 史德 ${ }^{583}$ and defined tongshi as an informative, neutral, and systematic narrative based on persuasive materials and scientific principles.

The term 'national history' was introduced from the West through Japan in the early years of the twentieth century. Toward the end of the nineteenth century, Japanese historians had already published many Western-style textbooks on Chinese history. Some of these works, such as A General History of China ${ }^{584}$ by Naka Michiyo (1851-1908) and Oriental History by Kuwabara Jitsuzo, ${ }^{585}$ exerted an inspiring influence on Chinese historians. Jitsuzo's work, which was published in 1898, was immediately translated into Chinese and enjoyed great success in the Chinese academic world. ${ }^{586}$

Century China," in Tze-ki Hon and Robert J. Culp eds., The Politics of Historical production in Late Qing and Republican China (Leiden: Brill, 2007), 112.

${ }^{581}$ Liu Xianxin 劉咸炘, Zhishi Xulun 治史緒論 (Taipei: Huashi Chuban 1980), 12.

${ }^{582}$ The original text is “看一件事情, 把來源去脈都要觀察清楚.” Here Liang Qichao adopted the idea of the four specialties of a historian 史家四長 - four essential abilities - discussed by Liu Zhiji as well as Zhang Xuecheng, in Liang, “Zhongguo lishi yanjiu fa bubian 中國歷史研究法補編,” YBSHJ, Zhuangji $73,22$.

${ }^{583}$ To Zhang Xuecheng, he never left the pattern of exemplary historical thinking. The concept of "a historian's moral integrity" merged completely with the concept of assessing historical examples “historical insight." See Zhang Xuecheng, “Shide," in: Wenshi Tongyi, Taipei: Shijie Shuju, 1962, 45-47. ${ }^{584}$ Naka Michiyo 那珂通世, Shina tsūshi 支那通史, (Tokyo: Iwanami Shoten, 1938-1941).

${ }^{585}$ In 1899 Shanghai Dongwen xueshe 東文學社 introduced and published this book for Chinese readers. It was translated by Fan Bingqing 樊炳清 with a preface by Wang Guowei 王國維 and was published under the title Dongyang shiyao 東洋史要.

${ }^{586}$ Zhu Weizheng 朱維鋝, ed., Zhou Yutong jingxueshi lunzhu xuanji 周予同經學史論著選集 (Shanghai: Shanghai renmin chubanshe, 1983), 534-536. 
Chinese intellectuals who took refuge in Japan, such as Liang Qichao, Zhang Taiyan, and Liu Shipei 劉師培 (1884-1919), were deeply influenced by the Japanese works on Western history and social sciences during their stay and thereby acquired a comparative perspective hitherto unknown in Chinese historiography. Although they held different, even opposing political standpoints, these intellectuals nevertheless joined hands in starting a revolution in historiography that led to the rise of "national history" as a new paradigm.

In July 1902, Zhang Taiyan returned from his second trip to Japan and planned to write a general rather than dynastic history of China, calling for understanding of the path of progressive developments. ${ }^{587}$ According to Yü Ying-shih, a 'general history' in Zhang's view had two meanings: first, it was to be a thorough history from remote antiquity to the recent past, thus cutting across all the boundaries of dynasties; and second, it was to be an interdisciplinary history focusing primarily on institutional, psychological, social, and religious developments. With both themes, Zhang clearly broke away from the 'clan-based' historiographical tradition. ${ }^{588} \mathrm{He}$ also wished to establish valid generalizations to explain the internal political changes in Chinese history and to revitalize the ethos of the people in order to inspire and guide China in its search for a viable future through his writing. ${ }^{589}$

Liang Qichao responded to Zhang's idea of a general history with great enthusiasm. He also moved in a very similar direction by compiling a 'general history of China.' In 1901, he published the outline of his planned project, namely, the “Prolegomena to Chinese History" [Zhongguoshi xulun 中國史敘論]. This trailblazing work "marks the beginning of the transition of Chinese historiography from traditional to modern." ${ }^{590}$ Through his writing, Liang tried to define China vis- à- vis

\footnotetext{
${ }^{587}$ Zhang Taiyan, “Zhonggguo tongshi lueli 中國通史略例”, in Qiushu (Taipei: Shijie shuju), 1971.

${ }^{588}$ Ying-shih Yü, “Changing Conceptions of National History in Twentieth-Century China,” 276.

${ }^{589}$ Zhang's letter to Liang is quoted in Tang Zhijun 湯志鈞, Zhang Taiyan nianpu changbian 章太炎年譜 長編 (Beijing: Zhonghua, 1979), 1: 139-140.

${ }^{590}$ Ying-shih Yü, “Changing Conceptions of National History in Twentieth-Century China,” 276.
} 
the history of the world; as he indicated, after the 1800s "China has become the China of the world." 591

In his programmatic article "New Historiography" ${ }^{292}$, Liang complained that the biggest flaw of traditional historiography was that it was explicitly rooted in the "dynastic" paradigm, which based its chronological order on the genealogies of the ruling houses and focused almost exclusively on narratives about how an Imperial court conquered, ruled, and finally lost the 'All-Under-Heaven.' With 'basic annals' and 'biographies' as its main categories, 'dynastic history' recorded only the activities of certain individuals but ignored China as a collective whole. ${ }^{593}$ Moreover, the history of a dynasty was always compiled or written after the demise of the previous dynasty; therefore, it inevitably gave rise to an 'antiquarian fallacy' whereby the traditional historians were always collectors of dead facts and shunned contemporary developments. To overcome the faults of China's old historiographical tradition, Liang emphasized the function of historical knowledge in the establishment of China's national solidarity, advocating a new national history based on universal ideas such as citizenship, popular sovereignty, and constitutional monarchy, rather than on criteria of a particular race or culture ${ }^{594}$ His historiographical claims deeply influenced the next generation of historians, such as Hu Shih, Liu Yizheng, and Qian $\mathrm{Mu}$.

Overall, as China turned towards a new century and faced a new role in the global context, the old tradition of 'comprehensiveness' was redefined by modern Chinese historians under the rubric of 'general history' with several defining factors: 1) extended time span and geographical scope that surpassed dynastic boundaries; 2 )

\footnotetext{
${ }^{591}$ Liang Qichao, “Zhongguoshi xulun 中國史敘論,” YBSHJ, Wenji 6, 11-12.

${ }^{592}$ According to Yü, there was a subtle shift in emphasis between the "Prolegomena to Chinese History" of 1901 and "New History" of 1902. In the former essay, Liang was seeking to redefine Chinese history from the perspective of world history, whereas in the latter he was looking for the "spirit" or "ideal" in Chinese history from the national point of view. Ying-shih Yü, "Changing Conceptions of National History in Twentieth-Century China," 279.

${ }^{593}$ Tang Xiaobing, Global Space and the Nationalist Discourse of Modernity: The Historical Thinking of Liang Qichao (Stanford: Stanford University Press, 1996).

${ }^{594}$ See Chang Hao, Liang Ch'i-ch'ao and Intellectual Transition in China.
} 
observation with historical insights and national standpoint; 3) systematic, organized framework and periodization based on Western theories; and 4) historiographical interpretations based on universal principles.

\section{Genealogy}

Compared to the official histories, which ordered their narratives according to the sequence of emperors, traditional Buddhist historians tended to apply a genealogy of lineage-a succession of masters-as the paradigm of historical narrative. ${ }^{595} \mathrm{As}$ enumerated by Lü Cheng, traditional historical writings with 'general history' form included Fei Zhangfang's Lidai sanbaoji 歷代三寶記, Zhipan's 志磐 Fozu tongji 佛祖統 紀, Zuxiu's 祖琇 Longxing biannian tonglun 隆興編年通論 596 , Benjue's 本覺 Shishi tongjian 釋氏通鑒, Nianchang's 念常Fozu lidai tongzai 佛祖歷代通載; Xizhong's 熙仲 Lidai shishi zijian 歴代釋氏資轝; Jue'an's 覺案 Shishijigu lue 釋氏籍古略, and so on. ${ }^{597}$ These 'general histories,' according to Lü, constituted a significant part of the traditional historical writings on Buddhism apart from the monk biographies.

As the word 'comprehensive' used in some of these works indicated, a consciousness of 'general history,' inherited from Shiji, had influenced chinese Buddhist historians from a very early age.$^{598}$ Later, a paradigm of genealogy could be observed in the works of Tiantai and Chan monks, who adopted a Sinicized historical viewpoint on Buddhist tradition. Beginning in the Tang dynasty, Chinese Buddhist sects placed their efforts into historical writing in order to establish their own

\footnotetext{
${ }^{595}$ John Kieschnick, Buddhist Historiography in China, forthcoming, 30. 'Genealogy' was also a form of historical thought in Renaissance Europe, see Anthony Grafton, What Was History? The Art of History in Early Modern Europe (Cambridge: Cambridge University Press, 2007), 153-163.

${ }^{596}$ In Longxing biannian tonglun, a strict chronological history of Buddhism modelled on the Zizhi tongjian, the compiler, Zuxiu, prudently begins his work with the entrance of Buddhist to China, perhaps because of the difficulties with determining accurate dates for events and figures in India. ${ }^{597}$ See Lü Cheng 吕澂, Huang Chanhua 黄擮華, Foxue yanjiu fa •Foxue gailun 佛學研究法·佛法概論 (Yangzhou: Guangling shushe, 2009), 49.

${ }^{598}$ One representative example is Sengyou 僧祐's Shijia pu 釋迦譜(T. no.2040, vol.50), in which he attempted to
} 
lineages by linking native masters to Indian patriarchs. Demonstrating various levels of sophistication and authenticity, their historical writings served the purpose of legitimating their own traditions ${ }^{599}$ Driven by sectarian agendas, most of the works after the Tang dynasty, such as the Lidai fabaoji 歷代法寶記 and the Baolin zhuan 寶林 傳, emphasized the transmission line of the Dharma from one patriarch to the next and limited their narrative to one certain school. ${ }^{600}$ Buddhist historians inherited the 'genealogy' genre as one prominent paradigm of Buddhist historiography and complicated it by adding elements from other historiographical traditions, for example, dynastic histories and Confucian clan-genealogies [pudie 譜牒 or jiapu 家 譜]. ${ }^{601}$

The Song witnessed an unprecedented flowering of Buddhist historiography. ${ }^{602}$ As this era experienced an overall development of Chinese traditional historiography, including the formation of the conception of historical entity and a growing emphasis on institutional history, new comprehensive history was produced, modeled on the official imperial histories and influenced by the historiography of Sima Guang and Ouyang Xiu 歐陽修—despite the fact that neither

\footnotetext{
${ }^{599}$ For the Tiantai lineage, see Linda Penkower, "In the Beginning... Guanding (561-632) and the Creation of Early Tiantai," in Journal of the International Association of Buddhist Studies, 23,2 (2000); for the lineage of Chan, see John R. McRae, The Northern School and the Formation of Early Ch'an Buddhism (Honolulu: University of Hawaii Press, 1986); Bernard Faure, The Will to Orthodoxy. A Critical Genealogy of Northern Chan Buddhism (Stanford: Stanford University Press, 1997).

${ }^{600}$ See John Kieschnick, Buddhist Historiography in China, forthcoming, 252. Other Buddhist historians, who had no strong sectarian identity, then referred little to the history of Indian Buddhism in their works.

${ }^{601}$ Helwig Schmidt-Glinzer, Die Identität der Buddhistischen Schulen und die Kompilation Buddhistischer Universal geschichten in China (Wiesbaden: Franz Steiner.1982), 5-6.

${ }^{602}$ An overview in English is Jan Yün-hua, "Buddhist Historiography in Sung China." Zeitschrift der Deutschen Morgenländischen Gesellschaft, 114, 2 (1964), 360-381. Chen Yuan offered in-depth discussions of a few works. See Chen Yuan 陳垣, Zhongguo fojiao shiji gailun 中國佛教史籍概論 (Peking: Zhonghua shuju, 1962). Also see Schmidt-Glinzer, Die Identität der buddhistischen Schulen und die Kompilation buddhistischer Universalgeschichten in China. Ein Beitrag zur Geistesgeschichte der Sung Zeit and Cao Ganghua 曹剛華, Songdai fojiao shiji yanjiu 宋代佛教史籍研究 (Shanghai: Huadong shifan daxue chubanshe, 2006).
} 
Sima nor Ouyang were friends of Buddhism. ${ }^{603}$ Due to the exemplary effect of the Zizhi tongjian as well as the changing political and historical conditions, Buddhist historical writings in Southern Song and the Yuan continually formed their narratives using the annalistic style [biannian 編年].$^{604}$ The most significant work of Buddhist historiography in premodern times-Zhipan's Fozu tongji 佛祖統紀一was a 'general history' in the form of biannian ${ }^{605}$ that cast all parts of the official histories into a Buddhist mold in its fifty-four fascicles. ${ }^{606}$ Although Zhipan began his chronology from the birth of the Buddha and gave a year-by-year account, the connection to India became discernably less and less important in the narratives of Tiantai and Chan, for the bone of contention was usually which Chinese lineage should be given preeminence and which doctrines in Chinese texts were to be taken as orthodox.

\section{Interpretation}

${ }^{603}$ Richard L. Davis, "Chaste and Filial Women in Chinese Historical Writings of the Eleventh Century." J. of the American Oriental Society 121, no.2 (June 2001): 205.

${ }^{604}$ Cao Ganghua listed the surviving works in this style during the Song in his work. The majority of the works were written by Chan monks or laymen affiliated with Chan school. See Cao Ganghua, Songdai fojiao shiji yanjiu 宋代佛教史籍研究.

${ }^{605}$ Fozu tongji "in more than one regard is the apex of the historiographical efforts of [Chinese] Buddhists." See Helwig Schmidt-Glinzer, Die Identität der Buddhistischen Schulen und die Kompilation Buddhistischer Universal Geschichten in China, 105. For an overall investigation of Zhipan and his Fozu tongji, see Jan Yün-hua, “The Fo-tsu-t'ung-chi, a Biographical and Bibliographical Study," in Oriens Extremus, 10, 1 (1963): 61-82.

${ }^{606}$ The basic annals [benji 本紀] were used to record the lives of Śakyamuni and the Tiantai patriarchs. The genealogies of noble houses [shijia 世家] of the Confucian model were used by Zhipan to provide information on groups of Tiantai monks who were ordained under the same master [zhuzu pangchu shijia 諸祖旁出世家]. Biographies [liezhuan 列傳] became hagio-biographies of eminent Tiantai monks [zhushi liezhuan 諸師列傳]. Tables [biao 表] illustrated the Tiantai lineage [lidai chuanjiao biao 歷代傳教 表]. Monographs and miscellaneous essays [zhi 志] were used to elaborate on topics such as Buddhist cosmography ( as the Shijie mingtizhi 世界名體志) or rebirth in the Pure Lands (such as the Jingtu lijiao zhi 淨土立教志). Especially valuable is a long annalistic section disguised as a monograph: the “Monograph on the Vicissitudes of the Teaching” [Fayun tongsai zhi 法運通塞志] in fifteen chapters. For the structure of the Fuzu tongji, see Jan, "The Fo-tsu-t'ung-chi, a Biographical and Bibliographical Study," 72-74. In this article, Jan also collected some historians' comments on this text and comments from Dong Qichang 董其昌 (1555-1636) and Yang Wenhui. 
Although Buddhist historiography in pre-modern China had demonstrated a strong sense of 'comprehensiveness' and a unique style of 'genealogy,' the traditional 'general histories' of Buddhism were still fragmentary, sect-centric, and biased. As Japanese scholar Taiken Kimura 木村泰賢 criticized, when traditional writings of Buddhism went into details, "the overall view [about Buddhist history] then became less-organized and lacking in order." ${ }^{607}$ To overcome this shortcoming, the modern historiography of Buddhism paid particular attention to constructing a continuum between events and an overall historical framework.

Historical interpretation, significantly, is an irreducible and inexpungable element in all historical narratives. With the reflections on the relationship between 'data' and 'theory' as well as the tendency of 'combining' these two elements together [shilun jiehe 史論結合], ${ }^{608}$ more historians felt that they should read their materials by constructing a moving pattern of images in which historical processes could be located and further interpretated. ${ }^{609}$ Given the fact that historical data is both too 'massive' and too 'sparse,' it is the historians' task to choose and organize what they need for their representation of a given slice of history while excluding anything from their account that is irrelevant to their underlying purposes. They also have to interpret their materials to fill in the gaps in information on inferential or speculative grounds. History is thus a congeries of facts, linked by adequate or inadequate explanations. ${ }^{610}$

\footnotetext{
${ }^{607}$ Taiken Kimura, “Fojiao yanjiu shi dafangzhan 佛教研究之大方針," in XFXC, vol.41, 94. His opinion had a profound influence on modern Buddhist studies in China. Taixu had a response to Kimura's idea. See Taixu, “Du Mucun boshi fojiao yanjiu zhi dafangzhen shuhou 讀木村博士佛教研究之大方針書 後,” TXQS, vol. 16, 102-103.

${ }^{608}$ For an interesting discussion of premodern Chinese historiography and its close relation to the topic of this dissertation see: Yves Chevrier, "La servante-maitresse: condition de la reference a l'histoire dans l'espace intellectual chinois," Extretne-Orient-extreme occident, Cahiers de recherches comparatives 9 (1987), 117-144

${ }^{609}$ For the development of the relationship between shi and lun, see Susanne Weigelin-Schwiedrzik, "On Shi and Lun: toward a Typology of Historiography in the PRC," in History and Theory, 35, 4 (1996): 74-95.

${ }^{610}$ Hayden White, “Interpretation in History,” New Literary History, 4, 2 (1973): 281-314.
} 
For 'general history' in the modern sense, a universal order behind the confusing changes and an ineluctably intention to interpret were admitted as premises. To modern Chinese historians, formulating new interpretations was perhaps the only way to 'protect' the past of China. Therefore, some historians believed that, for the sake of establishing a 'comprehensive' history that could depict the panorama of the past, scattered materials needed to be narrated in certain sequences in order to prove that the speculative philosophy of history would be valid in different time spectra. The explanatory and interpretative facets in historical narratives thus tended to be integrated in order to tell what had happened and to elucidate why it had happened as it did. This tendency palpably was demonstrated in the writings of Liang Qichao, Hu Shih ${ }^{611}$, Jiang Weiqiao, and Taixu, who traded in more or less a 'meta-narrative' of history instead of circumspect 'descriptions' ${ }^{612}$ Others, such as Tang Yongtong, Chen Yinke, and Chen Yuan, by contrast, did not devote themselves to writing general histories; they eschewed the impulse to solve "the riddle of history' and to identify the plan or goal of the historical process as a whole, but pursued more concrete aims, for example, investigating particular historical manifestations of the Chinese national spirit. However, even Chen Yinke, who had been called—although misleadingly-the "Chinese Ranke," ${ }^{\circ 13}$ maintained an underlying philosophical presupposition by which to justify their interpretative strategies were necessary for the representation of a given segment of the historical process.

\footnotetext{
${ }^{611} \mathrm{Hu}$ Shih is discussed here, although he did not write any general history of Buddhism, because he dedicated great efforts to writing the general history of Chinese philosophy, in which Buddhism played a crucial part.

${ }^{612}$ According to White, the term "meta-history" was used as a synonym for "speculative philosophy of history" by Northrop Frye in "New Directions from Old," in Fables of Identity (1963), 52-66. On the conception of "speculative philosophy of history" as implicit mythopoesis, see Karl Löwith, Meaning in History: The Theological Implications of the Philosophy of History (Chicago: The University of Chicago Press, 1949) and Hayden White, "Interpretation in History."

${ }^{613}$ For a thorough investigation of the misleading description of Chen Yinke and Fu Sinian, see Axel Schneider, Wahrheit und Geschichte: Zwei chinesische Historiker auf der Suche nach einer modernen Identität für China (Wiesbaden, 1997).
} 
Historians such as Liang Qichao, Hu Shih, and Taixu made efforts to establish a pragmatic, critical, and conceptual history based on their understanding of the mechanism running the world, which, they believed, provided shi-the historical facts-principle and meaning. They thus narrated historical events into histories according to a certain order. In this process, histories gain their explanatory effect not merely by their success in making stories out of chronicles but also by "the encodation of the facts contained in the chronicle as components of specific kinds of plot structures." ${ }^{114}$

Hu Shih, for example, followed his mentor John Dewey and advocated that the "intelligent understanding of past history is to some extent a lever for moving the present into a certain kind of future." As Eber described it, that history in Hu's view was "a kind of dynamic continuum." ${ }^{\prime 15}$ In a 1919 lecture, Hu stated:

......very few of the former scholars who studied the ancient books had held the outlook of historical evolution; they were not at all particular about origins and learning and the causal relations of thought ....... 前人研究古書, 很少有歷史進化的 眼光的, 故從來不講究一種學術的淵源, 一種思想的前因後果 ${ }^{16}$

According to $\mathrm{Hu}$, a new historiography needed to figure out how all learning and thought arose, and after arising, what influence and results it had; after thoroughly verifying and rendering the meanings of the ancients, historians could reveal the “true face” [zhen mianmu 真面目] and “true values” [zhen jiazhi 真價值] of every concept and thought. ${ }^{617}$

For Liang, historical records had to be interpreted through an 'observation' that could penetrate the reality of history as well as grasp the thread of historical development. This 'observation' was a cognitive act, which, in Liang's view, had to be

\footnotetext{
${ }^{614}$ Hayden White, Metahistory: The Historical Imagination in Nineteenth Century Europe (Baltimore: Johns Hopkins University Press, 1973), 7-11, esp. 8.

${ }^{615}$ Eber, "Hu Shih and Chinese History: The Problem of Cheng-li Kuo-ku." 172.

${ }^{616} \mathrm{Hu}$ shih “Xin sichao de yiyi 新思潮的意義.” Xin Qingnian 新青年 7.1 (1919). Translation see Eber, "Hu Shih and Chinese History: The Problem of Cheng-li Kuo-ku." 172. Also, Eber, "Hu Shih and Chinese History: The Problem of Cheng-li Kuo-ku." 175-176.

${ }^{617}$ Ibid.
} 
distinguished from the traditional narrative of 'praise and blame' based on Confucian moral standards. Therefore, he emphasized the 'basic principles' [yuanli 原理] in history and causality, advocating a combination of factual representations and conceptual embodiments. To Liang, there was a "necessary relationship" in history ${ }^{618}$ through which the innate meaning and coherence within it would come into view and historical facts would be plotted into an identifiable and predictable history that could explain the present and foresee the future.

Both Liang Qichao's and Hu Shih's interests in writing the history of Buddhism were mainly stirred up by their impulse to write an 'intellectual history' of China. $\mathrm{Hu}$ Shih, for example, began his research on the history of Chan Buddhism when he attempted to expend the pattern in his dissertation, which was about pre-Qin philosophy, to the medieval era and to write a general history of Chinese philosophy as a whole. ${ }^{619}$ In the context of this larger agenda, he encountered the problem of Buddhism. ${ }^{620}$ Liang Qichao, as well, proposed his project of writing a comprehensive history of Chinese Buddhism when he compiled his long article "The Major Trends of

\footnotetext{
${ }^{618}$ I borrowed the term "necessary relationship" from Axel Schneider. He has defined it as "assuming that the principles governing history are pre-given (be it as immanent or transcendent) and just have to be discovered." He also has referred to a "pluralistic relationship," a situation where the historian has to apply different possible interpretations to history in order to judge their plausibility, as well as to an "arbitrary relationship," which is a situation in which everybody ends up being his own historian because history is essentially meaningless and has to be invested with meaning from an alwayschanging present perspective. See “世界歷史與歷史相對主義的問題 - 1919 年以后梁啟超的史學” [World history and the problem of historical relativism: Liang Ch'i-ch'ao's historiography after 1919], in Zhenli yu lishi: Fusinian, ChenYinke de shixue sixiang yu minzu rentong 真理與歷史：傅斯年、陳寅恪的 史學思想與民族認同 (Beijing: Shehui kexue wenxian chubanshe, 2008), 238-259.

${ }^{619}$ McRae, "Religion as Revolution in Chinese Historiography: Hu Shih (1891-1962) on Shen-hui (684758)." 68.

${ }^{620} \mathrm{Hu}$ 's dissertation The Development of the Logical Method in Ancient China appeared in expanded form in Chinese in 1921 as the first volume of a projected multi-volume work called Outline of Chinese Philosophy (Volume One) [Zhongguo zhexue shigang 中國哲學史綱] (Shanghai: Commercial Press, 1921). This was the only volume to appear. His writings on Buddhism were planned to be the second volume of his shigang.
} 
Chinese Scholarship." Later in 1920, when Liang returned from Europe, he developed this project into a separate study of the 'general history' of Buddhism. ${ }^{621}$

We do not have to match these Chinese historians' work with Hayden White's classification of the modes of emplotment, since this concept was grounded in the tradition of Western literature. ${ }^{622}$ However, it must be admitted that there was always a plot structure in their narratives, even in the more 'synchronic' histories, such as Chen Yuan's studies of Ming-Qing Buddhism, which discussed less about 'developments' and 'changes.' No matter how these historians differed from each other over the frameworks they applied and over the, the history of Buddhism was narrated again and again with different time frames, interpretative patterns, and philosophical or religious archetypes. These narratives demonstrated the historians' efforts to bridge segments in history with continuity and their assessments of the impact, influence, or significance of empirically established facts. ${ }^{623}$

\section{Evolution and Buddhism}

The first question historians encountered when they tried to write a general history of a certain tradition was how to re-organize the scattered materials into a systematic, logical framework. From the Confucian theory of the "three ages 三世" propagated by Kang Youwei, to Liang Qichao's view of historiographical revolution inspired by nineteenth century nationalism and social Darwinism, to the movements of "organizing the national past" and "doubting antiquity" led by Hu Shih and Gu Jiegang, and onward to the application of Marxist theories, Chinese historians were

\footnotetext{
${ }^{621}$ When Liang began to plan his writing on the general history of Buddhism in 1920, his idea of historiography experienced a big change. For a study on this topic see Axel Schneider, "Shijie lishi yu lishi xiangdui zhuyi de wenti - 1919 nian yihou Liang Qichao de shixue 世界歷史與歷史相對主義的問 題--1919 年以后梁啟超的史學”, 238-259. The transformation of Liang's historiography after 1919 and the influence of Buddhism in this transformation will be further elaborated in the latter part of this chapter.

${ }^{622}$ White, Metahistory: The Historical Imagination in Nineteenth-Century Europe. 7-11.

${ }^{623}$ Isaiah Berlin, "History and Theory: The Concept of Scientific History," History and Theory 1, no. 1 (1960): 1-31.
} 
constantly looking for answers from external intellectual sources. In this process, many professional historians and Buddhist scholars made efforts to narrate the history of Buddhism in accordance with modern discourses linked with the progressive, scientific, and secular modernity based on Western experience.

\section{Linear Time}

The deep conflict between the Buddhist concept of time and China's lasting tradition of historiography existed for quite a long time. However, in modern era, it was engulfed by the huge challenge caused by the concept of linear time coming from the West. ${ }^{624}$

In Chinese culture, at least in the Confucian and Daoism traditions, the heterogeneous and discontinuous nature of time prevented the notion of linear time from evolving into a priori understanding of cosmos and history, although traditional Chinese histories indeed contained certain linear elements. ${ }^{625}$ Time in the Chinese conception was generally empirical and moved cyclically. Neither the introduction of Buddhism nor the rise of Chan could successfully establish an abstract, transcendent concept of time in Chinese people's minds. Notions of emptiness and impermanence had never shaken the dominance of 'empirical' time in the spiritual world of the chinese.

Buddhism, admittedly, did bring changes to the existing cosmology of the Chinese people; for example, based on the doctrines of Mahāyāna Buddhism, such as the Heart Sūtra, Chinese Chan master Dahui Zonggao 大慧宗杲(1089-1163) had realized that "past, present, future are all delusions;" because these three periods

\footnotetext{
${ }^{624}$ Emile Durkheim and Marcel Mauss, Primitive Classification. (Chicago: University of Chicago Press, 1963 [1930]), 40-47.

${ }^{625}$ An example is the Three Age theory of New Text Confucianism. Joseph Needham (1900-1995) even believed that ancient Chinese models of history were essentially linear-see Luke S. K. Kwong, "The Rise of the Linear Perspective on History and Time in Late Qing China c. 1860-1911," Past and Present 173 (2001): 165-66.
} 
"are ultimately empty and still." ${ }^{626}$ The "pure experience' of samādhi also led Chinese Buddhist practitioners to claim a transcendent time. As early as the Jin dynasty, Master Huiyuan stated explicitly in a letter to the emperor that the first principle he pursued was "not to be obedient to changes." ${ }^{27}$ This claim was judged radical in Huiyuan's time, even in Buddhist circles, and was believed to cause immediate karmic retribution. One interesting and often quoted story in Chan literature about the karma caused by a wrong time view was the meeting of master Baizhang Huaihai 百 丈懷海 and a fox: appearing as an old monk, the fox told Huaihai that he was formerly a Chan master. However, for once saying that the enlightened master is not subject to the law of change, he was condemned to be reincarnated in this animal form during five hundred lifetimes. Nevertheless, he finally gained redemption from his suffering fate as a fox when Huaihai confirmed to him that the enlightened man would live in but never be opposed to changes. The lesson of this story is ambiguous-it seems to promise a path to escape from time and change but at the same time, it asserts that everyone should yield to the power of changes.

The Buddhist view of history originated from its two overlapping, entangled, but fundamentally antithetical views of time. One is the cyclical time of the movement of samsāra; the other one is the linear time of the corpus of the Buddha. Together with the circular notion of cosmic time-the kalpa, which was derived from the cosmology of Hinduism-Buddhism maintained a kind of linear time in its doctrines, especially in the Vinaya teachings - the chronology of Buddha's life and the "Dotted record" of the Vinaya transmission. ${ }^{628}$ Due to this linear time, as Hubert Durt has pointed out, "one can detect in almost all Buddhist countries a relation

\footnotetext{
${ }^{626}$ Clearly, Thomas and J. C. Clearly, trans. The Blue Cliff Records. vol.3, (Boulder: Shambala), 24-25.

${ }^{627}$ Hongming Ji 弘明集, T. 52, 2102, 29-32.

${ }^{628}$ The 'Dotted records' [Shengdian ji] was a copy of the Vinaya transmitted to China; it was allegedly written down at the first Council and subsequently dotted at every annual assembly [pravāranā]. It is quoted twice in the Lidai sanbaoji. See T.49, 2034: 23a, 95b. The number of dots allowed scholars to reconstitute the date of the Nirvāna of the Buddha as 485 B.C. On this question, see Hubert Durt, "La date du Buddha en Corée et au Japon," Heinz Bechert ed., Die Datierung des historischen Buddha, Göttingen: Vandenhoeck \& Ruprecht, 1991). Also, W. Pachow, “A Study of the Dotted Record," Journal of the American Oriental Society, 85, 3 (1965): 342-349.
} 
between monastic discipline and historiography." ${ }^{629}$ Such a tradition in the Vinaya school grew out of the necessity of tracing the emergence of monastic regulation back to particular events that happened during the lifetime of the Buddha. For example, the cult of worshiping relics encouraged people to discover the history of these relics and inspired the compilation of chronicles such as the Thüpavamsa. ${ }^{630}$ Thus Buddhist historical narratives developed hand in hand with hagiography, which always adopted a linear form of the time spectrum. This linear time, however, is different from linear time in modern sense; the emphasis on the cult of the tooth relic of the Buddha or of the Arhat Pindola in China must be understood as an attempt to link Chinese Buddhism to the sacred time in which the Buddha lived and finally gained enlightenment, instead of a presentation of any universal principles. ${ }^{631}$

The temporality in Buddhism, on the one hand, had also been interpreted as regression, declining from the perfection of the time in which the Buddha lived to the age of the declining Dharma, the most corrupt age waiting for doom. Although initially derived from the cyclical theory of kalpa, the notion of the 'declining Dharma' was used in China to establish a periodization that had been prevalent from the sixth century onwards to the end of the Imperial time. On the other hand, this linear time could be also progressive, theoretically. Some scholars, like Bernard Faure, believe that the concept of progress was innate in Chinese Buddhism. It justified the founding of the new schools via a 'doctrinal classification' system [panjiao 判教], which was based on a teleological model that gave primacy to one school over all others. According to Faure, this kind of progress also affected the formulation of geographic notions such as the "central kingdom, ${ }^{1632}$ serving as the rationale for the

\footnotetext{
${ }^{629}$ Hubert Durt, "La date du Buddha en Corée et au Japon," in Die Datierung des Historischen Buddha (Göttingen, Vandenhoeck \& Ruprecht, 1991), 465.

${ }^{630}$ B. G. Gokehale, "The Theravāda-Buddhism View of History." Journal of the American Oriental Society, 85, 3 (1965): 356.

${ }^{631}$ Bernard, Chan Insight and Oversight.178.

${ }^{632}$ In the early narrative, India was undoubtedly the 'central land.' See, for example, Gunabhadra's statement in the Lengqie shiziji 楞伽師資記: “This land [China] is located at the Eastern outskirts and [its inhabitants] do not have a method to cultivate the Way... in my middle Kingdom there existed an orthodox Dharma, but it is secret and is not transmitted [at random].” T. 85, 2837: 1284a.
} 
transformation through which China promoted itself from a peripheral, barbarian country to the center of the Buddhist world.

The idea of a circular cosmic time marked by samsāra, the traditional Chinese concept of cyclical changes, as well as the linear time in Vinaya and later in some Chinese Buddhist doctrines, determined the multifaceted, contradictory strata of time in the traditional Buddhist historiography. With this hybrid concept of time in mind, ordinary practitioners as well as clergy worshiped the Buddhist masters as ancestors, were fascinated with relics and funerary, and were extremely sensitive about the ages and the death dates of eminent monks. The pessimistic feeling of change and transience also constantly incited Buddhist followers to dig into the mythical past or wait for the future Buddha, Maitreya, to appear.

Only in the modern age was this view of time fundamentally challenged. In the West, the linear conception of time had been since Kant accepted as a prior category of perception and an absolute condition of the world of phenomena. This conception, which of course was a product of history itself, paved the way for a reorientation of historical knowledge from the past to the future and profoundly changed the cosmological and epistemological view of people, who were physically and mentally in the distance. The Chinese, although they were physically and mentally distinct from Kant, began to develop a new abstract sense of time that was associated not only with new techniques, such as modern clocks and calendars, ${ }^{633}$ but also with Western philosophy. ${ }^{634}$

The defeats China suffered in wars and the weakness of its economy, at times, led to the pain of failure and a strong sense of 'lagging behind' among the late Qing intellectuals, bringing a feeling of crisis and uncertainty about China's future. Western history then became a mirror through which countries like China could see

\footnotetext{
${ }^{633}$ Bastid-Brugière, “Jikan kaishaku to Nihon eikyô -- Chûgoku kindai ni okeru kako, gendai, mirai no gainen” 時間解䣋と日本影響一中国近代における過去、現代、未来の概念, in Hazama Naoki 狭間 直樹 ed., Seiyō kindai bunmei to Chūka sekai 西洋近代文明と中華世界, Kyoto, Kyoto daigaku gakujutsu shuppankai , 2001, 41-54

${ }^{634}$ Peter Zarrow, China in War and Revolution, 1895-1949 (New York: Routledge, 2005), Chapter 1 and 3.
} 
the road ahead. ${ }^{635}$ In this sense, China accepted modern linear time and reoriented itself to the future, which became imagined or shaped based on the Western model. This Western concept of linear time thus was silently substituted for traditional Chinese temporality; a gap between 'ancient' and 'modern' then emerged and increased. ${ }^{636}$

Modern Chinese intellectuals made efforts to establish a new worldview, grappling with the conflicts, tensions, and confusion they faced. Tan Sitong, for example, attempted to synthesize Buddhism, Confucianism, and modern science to explain historical developments. ${ }^{637}$ Kang Youwei's theory of the three ages ${ }^{638}$ and Yan Fu's creative interpretations of Herbert Spencer and Thomas Huxley were attempts to combine Confucianism or Taoism with evolutionary temporality in order to construct a moral vision of progress. In modern China, progressivism and social Darwinism opened a window for intellectuals to observe and understand the outside world and their own traditions. It convinced them to believe hopefully in the rise of China as a civilized, modern nation. As Benjamin Schwartz argued in Yan Fu's case, to the intellectuals "groping towards the notion of China as a society-nation,"

\footnotetext{
${ }^{635}$ This view was deeply influenced by the form of 'civilizational history' [wenming shi 文明史] in Japan, especially the works of Fukuzawa Yukichi 福澤諭吉 and Taguchi Ukichi 田口卯吉. See E. G.

Pulleyblank and W.G. Beasley, 'introduction' in Historians of Japan and China (London: Oxford University Press, 1971), 15.

${ }^{636}$ According to Wang Fan-sen, the concept of linear time, which is usually compared to a cyclic or regressive historical concept, assumes that time is linear, purposeful, directional, and progressive, and that it never repeats or reverses. See Wang Fansen, “Jindai Zhongguo de xianxing lishiguan, yi shehui jinhualun wei zhongxin de taolun 近代中國的線性歷史觀: 以社會進化論為中心的討論, Xin Shixue 新史學, 19, 2 (2008): 1-46.

${ }^{637}$ Tan Sitong, An Exposition of Benevolence: the Jen-hseuh of Tan Ssu-t'ung, Chan Sinwai trans., (Hong Kong: The Chinese University of Hong Kong Press, 1984), 132-33; Tan Sitong, Renxue 仁學, (Beijing: Huaxia chubanshe, 2002 [1896]), 80.

${ }^{638}$ Kang divided history into three ages: the age of disorder [juluanshi 據亂世], the age of ascending peace [shengpingshi 界平世], and the age of great peace [Taipingshi 太平世]. See Wu Ze 吴澤, “Kang Youwei gongyang sanshi shuo de lishi jinhua guandian yanjiu: Kang Youwei shixue yanjiu zhiyi 康有為 公羊三世說的歷史進化觀點研究: 康有為史學研究之一, in Zhonghua wenshi luncong 中華文史論丵, vol.1, (Shanghai: Zhonghua shuju,1962), 229-74.
} 
progressivism and Spenser's vision of the social organism provided the "most vivid possible image of the nation." ${ }^{139}$

Tangling with the sense of nationalism, concepts of progressivism and linear time were well popularized throughout China ${ }^{640}$ When the new century came, 'progressivism' and 'evolutionism' had become common slogans in historical writing; even historians in the 'conservative' camp sometimes acknowledged that they were inspired by these theories. ${ }^{641}$ As analyzed by Wang Fansen, this new paradigm transformed history into a map with blanks framed by timelines. Historians then merely needed to do the filling-in exercises-fitting the Chinese data into the scale of development. ${ }^{642}$ The past, which had been seen as "a fixed entity, like a tangled ball of thread," " was unraveled into a single linear development. Therefore, the "universal pattern' of progressivism, which had been proved by the experience of the West, was also possible and suitable for the Chinese case. This reception of the progressive view of history, as Praesenjit Duara suggested, was a consequence of the desire to depict China as a cohesive society and to emplot the Chinese experience as historical progress that evolved towards a modern nation-state. ${ }^{644}$

\footnotetext{
${ }^{639}$ Benjamin Schwartz, In Search of Wealth and Power (Cambridge, MA: Harvard University Press, 1983), 56.

${ }^{640}$ For the reception of linear time, see Wang Fansen, “Jindai Zhongguo de xianxing lishiguan, yi shehui jinhualun wei zhongxin de taolun 近代中國的線性歷史觀: 以社會進化論為中心的討論.” Also see Luke S. K. Kwong, "The Rise of the Linear Perspective on History and Time in Late Qing China c. 18601911," Past \& Present, 173 (2001), 157-190.

${ }^{641}$ Wang, Fansen, "The Impact of the Linear Model of History on Modern Chinese Historiography," Brian Moloughney and Peter Zarrow ed., Transforming History: The Making of a Modern Academic Discipline in Twentieth Century China (Hong Kong: The Chinese University of Hong Kong Press, 2012), 139.

${ }^{642}$ Ibid., 142.

${ }^{643}$ Ibid.

${ }^{644}$ Presenjit Duara, Rescuing History from the Nation: Questioning Narratives of Modern China (Chicago: University of Chicago Press, 1995), 4, 25, 28. According to Duara, nationalists used the evolutionary narrative to legitimatize the nation-form as an advance beyond the previous political organization. However, Duara's argument on the nature of modern Chinese historiography is based primarily on more radical essays. Actually, there was a distance between such proclamations for change and the type of historical narrative produced. See Q. Edward Wang, Inventing China through History: The May Fourth Approach to Historiography.
} 


\section{Reflections on Evolutional Theory}

The model of progressivism was welcomed by the Chinese in the modern period since it had to a certain degree been proved to be valid, at least in the realms of technology and science. ${ }^{65}$ However, difficulties remained when this model was applied to China's particular situation. When Chinese intellectuals encountered the progressive West, they always felt a bitter dilemma between the promised brighter future and the seemly endless misery China was experiencing at that very moment. All the metanarratives of history, even the felicitous notion of the 'end of history,' were ironically related to a tension between an ideal human order and the disorder of the past (although that ideal order could be conceived as having been actualized). They realized that, more or less from an emotional perspective, the age they lived in could never be a good time that had evolved from the past, but on the contrary, was the worst time. This was, to some of them, what the Buddhist doctrines had predicted and revealed: the dark age of the declining Dharma. ${ }^{646}$

Around the Meiji Restoration, intellectuals in Japan had already attempted to link Buddhism with evolutionary theories. In the debate between Katō Hiroyuki (1836-1916) and Inoue Enryō (1858-1919) over the relationship between Buddhism

\footnotetext{
${ }^{645}$ In this sense, the term 'progress' was understood as equivalent to 'modernity' and a tool of competition with other civilizations. See Wang Fansen, "The Impact of the Linear Model of History on Modern Chinese Historiography." For other discussions on this topic, see Zhang Pengyuan 張朋園, “Shehui daerwen zhuyi yu xiandaihua: Yan Fu and Liang Qichao de Jinhua guan 社會達爾文主義一嚴 復、梁啟超的進化觀, ” in Tao Xisheng xiansheng bazhi rongqing lunwenji 陶希聖先生八秩榮慶論文集 (Taipei: Shihuo chubanshe 1979), 187-230; Yoshihiro Ishikawa 石川禎浩 “Ryō Keichō to bunmei no shiza 梁啓超と文明の視座 [Liang Qichao and the view of civilization],” in Kyōdō kenkyū Ryō Keichō: Seiyō kindai shisōJuyō to Meiji Nihon 共同研究梁啓超一西洋近代思想受容と明治日本, 106-131. ${ }^{646}$ There were, of course, other factors that led to the Buddhist critiques of modernity and linear time. For example, in Japan, the newly imported theory of evolution evoked debates among intellectuals, for example, the debate between Katō Hiroyuki (1836-1916) and Inoue Enryō (1858-1919) over the relationship between progressive conceptions of history and Buddhism. It is precisely because Meiji Japan was successful in modernization that some intellectuals began to reflect on the dark underbelly of capitalist modernity.
} 
and progressive concepts of history ${ }^{647}$, Buddhist philosopher Inoue Enryō advocated an idea of 'bi-directional' evolution, that is, evolution could also be retrograde and lead to degeneration. As Funeyama Shinichi has explained, in Inoue Enryō's view, "evolution is not one-sided, but also encompasses its opposite, namely regression."

This view influenced Zhang Taiyan, and he developed it into his own theory of evolution一the 'double-edged evolutionism [jufen jinhualun 俱分進化論]—and his critique of progressivism. ${ }^{649}$ In his early article "Basic Guidelines of Chinese History" [Zhongguo tongshi lueli 中國通史略例] in the Qiushu, published in 1900, Zhang adopted the idea of linear time as a universal pattern (although with some reservations) and believed that all of humanity followed the laws of progress. ${ }^{650}$ However, when he revised his Qiushu in 1913, he omitted this article, indicating that he had abandoned making progress a historical principle. ${ }^{651}$ Realizing the inherent pitfall of modernity and its unsuitability for the Chinese context, Zhang began to censure linear, capitalist progressivism harshly and formed a new concept of history based on a Buddhist worldview. ${ }^{652}$ By using Buddhist concepts and categories, such as ālaya and manas, he

\footnotetext{
${ }^{647}$ Viren Murthy, “Transfiguring Modern Temporality: Zhang Taiyan's Yogacara Critique of Evolutionary History," Modern China, 38,5 (2012): 495.

${ }^{648}$ Shinichi Funeyama, Funeyama Shinichi chosakushū [Selected works of Funeyama Shinichi], vol. 6 (Tokyo: Kobushi-shobō,1996), 358.

${ }^{649}$ Because Zhang explicitly mentioned the thinking of famous Japanese intellectuals, such as Anesaki Masaharu's ideas about religion and German idealism, it is certain that he was familiar with Japanese assessments of the concept of evolution. Kobayashi Takeshi has provided a great amount of evidence to show that Zhang was deeply immersed in Meiji philosophical texts, including Inoue Enryō's Tetsugaku yōrei [Outline of Philosophy]. See Kobayashi Takeshi, Shō Heirin to Meiji shichō mō hitotsu no kindai 章炳麟と明治思潮: もう一つの近代 [Zhang Taiyan and Meiji intellectual trends: another modernity] (Tokyo: Kenbun shuppan. 2006).

${ }^{650}$ Zhang Taiyan, “Zhongguo tongshi lueli 中國通史略例,” Qiushu 訄書 (Beijing: Sanlian shudian, 1998 [1900]), 201.

${ }^{651}$ Chang Hao has pointed out that the early 1900s were a turbulent period in Zhang's life. He experienced physical and mental abuse in prison and his close friend and fellow revolutionary Zou Rong died in jail. Such "boundary situations" probably encouraged him to use Buddhism to go beyond conventional limits and to question concepts taken for granted by his Chinese and Japanese contemporaries. See Chang Hao, Chinese Intellectuals in Crisis: Search for Order and Meaning (Berkeley: University of California Press, 1987), 120.

${ }^{652}$ For the overall thought of Zhang Taiyan and his "Buddhist worldview," see Chang Hao, ibid, 105-145 and Wang Hui, Xianzai Zhongguo sixiang de xingqi 現代中國思想的與起 (Beijing: Sanlian shudian, 2002);
} 
counterposed a relativistic or pluralistic model to the unilinear one of progress, and meanwhile, grounded his model in the play of karmic forces. ${ }^{653}$

In his essay "On Double-Edged Evolution," published in 1906, Zhang interpreted history as a movement of ălaya consciousness according to the Yogācārin doctrine of karmic seeds. ${ }^{654}$ In Zhang's view, the problem with Western evolutionary theories was not in the descriptions they made, but rather in their evaluative dimension. He argued that "one cannot negate that fact of evolution, but one should not accept the effects of evolution on us." ${ }^{155}$ Under the influence of the pessimistic view of German philosopher Schopenhauer, Zhang asserted that evolution could not guarantee a better future in any sense; on the contrary, it was neutral, interdependent, and karmic, moving in two directions at the same time: evil grows with good, pleasure goes with pain. History, as the presentation of karmic seeds, similarly, had such a dual-oriented structure as well. ${ }^{656}$ Therefore, against the ideas of people like Kang Youwei, Zhang rejected the premise that, at the 'end of history,' good will eventually prevails if evolution runs its course properly; instead, he contended that "it is better to leave this world earlier and seek enlightenment beyond sight, hearing, words and thought, saving all living things, and negating them" [miedu zhi 滅度之]. ${ }^{657}$

Zhang's notion, although radical, aroused sympathy among other intellectuals who were also interested in Buddhism. Wang Enyang, for example, was an important figure who used Buddhism to criticize evolutionary theory. As a lay believer, he rejected the prevailing view of evolutionism that saw Buddhism as a barbaric myth,

Kobayashi Takeshi has discussed Zhang's Buddhist thought in relation to Meiji intellectual trends; see Kobayashi Takeshi 小林武, Shō Heirin to Meiji shichō mō hitotsu no kindai 章炳麟と明治思潮: もう一つの 近代(Tokyo: Kenbun Shuppan, 2006).

${ }^{653}$ Murthy, The Political Philosophy of Zhang Taiyan.136. For a contextualized discussion on Zhang's critique of linear time and the progressive view of history, see the chapter 4 of this book.

${ }^{654}$ Zhang Taiyan, “Jufen Jinhua lun 俱分進化論," in Jiang Fen 姜玢 ed., Gegudingxin de zheli: Zhang Taiyan wenxuan 革故鼎新的哲理: 章太炎文選 (Shanghai: Shanghai yuandong chubanshe, 1996), 150.

${ }^{655}$ Ibid., 151.

${ }^{656}$ Ibid., 150.

${ }^{657}$ Ibid. 
refuting the opinion of 'Mahayana is not Buddhism' [dasheng feifo 大乘非佛] based on evolutionary theory ${ }^{658} \mathrm{He}$ criticized that there are three major false assumptions in evolutionary theory: first, it assumes that the evolutionary track will always move from simple to complex, from barbarian to civilized; second, it relies heavily on causality; third, it predicts that the encounter of two forces will create a third one. All these assumptions are incompatible with Buddhism and thus fail to prove the universality of evolutionary theory. ${ }^{659}$

Liang Shuming, "this century's foremost Confucian traditionalist," surreptitiously used a multi-directed notion of 'change' to substitute for the assumptions of linear time and progressivism. To answer the question of "whether Eastern cultures should be eradicated from their roots, or can they come back to life," which he asked in his Eastern and Western Cultures and Their Philosophies, Liang rejected the portrayal of an antithetical modern/traditional division; he emphasized a synchronic cultural pluralism instead of a diachronic opposition between modern and premodern. ${ }^{661}$ To a certain extent, Liang utilized the theory of progressivism to prove Buddhism to be "the true religion of pure transcendence"; for example, he referred to the idea of progress to criticize the authority of the Dasheng Qixin lun. ${ }^{662}$ At

\footnotetext{
${ }^{658}$ Since 1900, there has been a trend in Japanese scholarship which advocated that "Mahayana is not Buddhism," asserting that Buddhism developed gradually from primitive Buddhism, sectarian Buddhism, Exoteric Mahayana, and Esoteric Mahayana. In 1923, Wang wrote the article "On the Saying of 'Mahayana is Not Buddhism' [Dasheng feifo shuo bian 大乘非佛說辩] to refute the phenomenon that "all the Mahayana classics were said to be forgeries of later generations, and that the teachings of Buddhism were developed by the evolution of thought and not founded by Buddha alone" 咸謂大乘契 經皆后世偽作, 佛法教理實由思想進化次第發展, 非佛一人所創立. Wang Enyang, “Dasheng feifo shuo bian 大乘非佛說辨," [Haichaoyin, 4,5 (1923)], in MFQ, vol.156, 203-16.

${ }^{659}$ Wang Enyang, Zhongguo fojiao yu weishixue 中國佛教與唯識學 (Beijing: Zongjiao wenhua chubanshe, 2003), 127-28.

${ }^{660}$ Guy Alitto, The Last Confucian: Liang Shu-ming and the Chinese Dilemma of Modernity (Berkeley: University of California Press, 1986) 3, 9. Notably, Liang himself openly rejected the notion that he could be classified as a conservative. See Liang Shuming 梁漱溟, Liang Shuming quanji 梁漱溟全集, vol.8, Committee of the Academy of Chinese Culture ed., (Jinan: Shandong Renmin, 2005), 1175. ${ }^{661}$ Thierry Meynard, The Religious Philosophy of Liang Shuming: The Hidden Buddhist (Leiden and Boston: Brill, 2011), 34

${ }^{662}$ Liang Shuming, Yindu zhexue gailun 印度哲學概論, in Liang Shuming quanji 梁漱溟全集, vol. 1, 28. See also Thierry Meynard, The Religious Philosophy of Liang Shuming: The Hidden Buddhist, 105-110.
} 
the same time, he established his 'process philosophy ${ }^{163}$ by adopting Yogācāra epistemology. In Liang's view, the issues humans faced were changing. Material problems could be resolved -- Westerners had successfully demonstrated how to dominate nature and modify the natural environment in order to satisfy the basic needs of humanity; however, dissonance, uncertainty, polarity, and other problems pertaining to the interactions between human beings would be aroused. Therefore, Western modernity would ultimately head towards a revival of 'oriental cultures,' which had the potential to solve these issues in the spiritual sphere. He then placed the West in a peripheral position in his framework of progress, arguing that the West represented only a partial and limited image of the universal entity of modern culture. By this means, Liang reinserted his own understanding of 'tradition' within his teleological narrative of modernism, and thus reauthorized the supremacy of Chinese culture, although at the cost of making Chinese traditions de-complexified, homogenized, and de-historicized. ${ }^{664}$

Unlike Liang Qichao and Zhang Taiyan, who chose Buddhism in their historiographical narratives due to strategic considerations but were not committed Buddhists, Liang Shuming's understanding of history was largely presupposed on his philosophical ideas and religious commitment. ${ }^{665}$ His view of progressivism actually influenced his ambivalent position vis-à-vis Buddhism. He did share the idea of Taixu, Xiong Shili, and others, who found in Buddhism a metaphysical blueprint through which Buddhism as a perfect religion could lead to a supra-mundane reality. However, he emphasized the transcendental character of Buddhism and tried to keep Buddhism "intact and held in reserve for eschatological times." ${ }^{" 666}$ He believed that it

\footnotetext{
${ }^{663} \mathrm{Wu}$ Zhanliang 吳展良, “Liang Shuming de shengsheng sixiang jiqi dui xifang lixing zhuyi de pipan （1915-1923）梁漱溟的生生思想及其對西方理性主義的批判,” in Dangdai ruxue lunji: chuantong yu chuangxin 當代儒學論集: 傳統與創新 (Taipei: ), 9-14.

${ }^{664}$ On the tendency of modern Chinese intellectuals to portray the Chinese tradition as a homogeneous whole that either should be or was in fact independent of foreign influence, see John Makeham, "Disciplining Tradition in Modern China: Two Case Studies," in History and Theory 51 (2012): 89-103. ${ }^{665}$ In his youth and later years, he had a long experience of practicing Buddhism. On several occasions, he declared himself a Buddhist.

${ }^{666}$ Thierry Meynard, The Religious Philosophy of Liang Shuming: The Hidden Buddhist, 129.
} 
was immoral and irresponsible to practice Buddhism in an age of turmoil, for it would lead to social escapism and weakened efforts toward national salvation. ${ }^{667}$ On this count, he had little sympathy for Taixu and Yinshun's attempts at inventing a Buddhist 'social gospel.'

The prominent force of progressivism in the first decades of the twentieth century and the increasing opposition to it led to ceaseless debates within and between the circles of historians and Buddhists. The attitudes of the modern Chinese intellectuals towards progressivism were always divergent and ambiguous, varying from individual to individual. ${ }^{668}$ Not only did Zhang Taiyan reject the assumptions of linear time and progressive history, other intellectuals, like Wang Guowei, Chen Yinke, and Liu Yizheng, also questioned the validity of modernity by emphasizing the multi-layered changes operating in each age and the particularity of Chinese cultural tradition. ${ }^{669}$ Facing the challenge of modernity and the social upheaval China had undergone, modern intellectuals were forced to moderate the tension between the chaos in the present and the promise of the future, the universal pathway of progress and the particularity of each tradition, mundane issues and the transcendental ideal. Liang Qichao and Taixu, despite their different stands, are two representative examples who can show how the modern Chinese were attracted by the theory of progressivism and how they strategically attempted to utilize this theory or reconcile the serious disagreements it provoked.

\section{Narrating the Evolution of Buddhism}

\footnotetext{
${ }^{667}$ Liang, Eastern and Western Cultures and Their Philosophies, in Liang Shuming quanji 梁漱溟全集, vol. 1, 533-534.

${ }^{668}$ Brain Moloughney and Peter Zarrow, Making History Modern: The Transformation of Chinese Historiography, 1895-1937, in Transforming History: The Making of a Modern Academic Discipline in Twentieth Century China, 27-32.

${ }^{669}$ One of the famous statements is Wang Guowei's 'every age had its own literature.' See Yuan Yingguang 袁英光 and Liu Yinsheng 劉寅生, Wang Guowei nianpu changbian 王國維年譜長編 (18771927) (Tianjing: Tianjing remin chubanshe, 1996), 91.
} 
Had Chinese Buddhism evolved or regressed vis-a-vis its Indian origin? This was a very crucial question that Liang Qichao asked but did not answer. ${ }^{670}$ It was, of course, difficult for historians to answer such a question, for the standard of progress varied. More fundamentally, this question was associated with the discursive meaning of 'progress' or 'regress' itself and hinged on how these notions were defined and conceptualized. Many modern Chinese intellectuals, no matter to which degree they embraced the modern definition of time, were attempting to legitimatize changes and reunite the split time dimension - whether it was linear, regressive, or cyclicalinto a historical continuum, when they were writing histories. This phenomenon is also evident in the modern historiography of Buddhism. Liang Qichao and Taixu are two representative examples.

\section{Liang Qichao: Nationalist Progressivism}

The influence of linear history and Progressivism on Liang Qichao was profound. When he participated in the Wuxu Reform in 1898, Liang's definition of history was still characterized by a moral cosmology, although a distinctive touch of progressivism can be observed ${ }^{671}$ Following the views of his mentor, Kang Youwei, the history of China, to young Liang, was a part of the three-phase movement that was proceeding towards an end, when the world would be united in the Great Harmony maintained by moral perfection. ${ }^{672}$ After the failure of the Reform, however, Liang abandoned these pretensions but more firmly supported a worldview deeply rooted in a nationalistic and evolutionary concept of history. He advocated a history

\footnotetext{
${ }^{670}$ Liang, “Fojiao jiaoli zai Zhongguo zhi fazhan 佛教教理在中國之發展,” in SBP, 149. This article was one chapter of Liang's planned general history of Chinese Buddhism. According to Liang's plan, he would discuss the development of every sect of Chinese Buddhism after this overall investigation. ${ }^{671}$ Chang, Hao, Liang Chi'-chao and Intellectual Transition in China, 1890-1907. 1971. Also Joseph Levenson, Confucian China and its Modern Fate, 1968.

${ }^{672}$ According to Levenson, in this phase (1989-1912), a paradigm shift could be observed in Liang's discourse: the "precarious Confucian-Western" structure Liang had achieved in the 1890s readily gave way to a history-oriented belief in progress and nationalism. See Joseph Levenson, Liang Ch'i-ch'ao and the Mind of Modern China, 84-92.
} 
that could provide an explanation for the course of history so that anticipation of the future and guidance for political and social movements would be possible.

In Liang's booklet On the Trends of the Chinese Scholarship published in 1902-his early attempt to systematically summarize and narrate the historical trends of Chinese scholarship — he placed 'the age of Buddhism' after 'the age of Daoism' (approximately from the Late Han to the Jin dynasties), marking it as one part of the zenith of Chinese civilization. ${ }^{673}$ Here, Liang Qichao adopted an 'eight-ages' scheme of periodization, ${ }^{674}$ which was developed from the thesis of Kang Youwei's three epochs and resonantly matched the Western model of historical progress. ${ }^{675}$ In this introductory work, Liang's study of Buddhism did not go beyond the framework set by several Japanese works, including Gyōnen's 凝然 (1240-1321) Hasshū kōyō 八宗網 要, Kōchō Ogurusu's Bukkyōjūnishū kōyō 佛教十二宗綱要 (1886), and the five volumes of Bukkyō kakushū kōyō 佛教各宗網要 (1896) compiled by Shimaji Mokurai 島地默雷 (1838-1911). ${ }^{676}$ Referring to these works, Liang itemized ten sects and summarized their history very briefly and in order. At this time, Liang's idea of the new historiography was still in its embryonic stage, but he had consciously improved the traditional historiographical model of 'rise and fall,' introducing the idea of progressivism in his writing. As indicated by the subheadings in this chapter on Buddhism, his study focused on investigating the 'beginning' [faduan 發端] and 'gradual flourish' [jianci fada 漸次發達] of Buddhism in China. ${ }^{677}$ To Liang, the story of Chinese Buddhism could be, to a certain degree, considered a typical example of successful evolution: a foreign 'other' adapted to a new environment, rooted in new

\footnotetext{
${ }^{673}$ According to the proposal Liang listed in the 'General Introduction,' there was an 'age of BuddhistConfucianism' [儒佛混合時代] after 'the age of Buddhism.' However, he did not finish this part ultimately.

${ }^{674}$ Liang, “Zhongguo xueshu sixiang bianqi zhi dashi 中國學術思想變遷之大勢,” YBSHJ, Wenji: 7, 1-103.

${ }^{675}$ For the acceptance and critique of progressivism in modern China, see the articles in Thomas Fröhlich and Axel Schneider eds. Chinese Visions of Progress, 1895 to 1949, (Leiden, Brill, 2020).

${ }^{676}$ Liang noted that although he had strong interests in Buddhism, his knowledge in this domain was still limited. He then listed the works he had referred to. Liang, "Zhongguo xueshu sixiang bianqi zhi dashi 中國學術思想變遷之大勢,” YBSHJ, Wenji: 7, 71 .

${ }^{677}$ Ibid. 62-63.
} 
soil, took in nutrients from indigenous elements and grew into prosperity. Meanwhile, this foreign thought also breathed new air into the native culture and led it to "the full bloom" [quansheng 全盛]. ${ }^{678}$

Also, Liang tried to build up a causal link between the prevalence of Buddhism and the advanced native culture of China, portraying the history of Buddhism with a seminal progressive narrative and a nationalist concern. In the chapter 'The Age of Buddhism,' Liang suggested that Chinese Buddhism was a "new civilization of our nation"; it was not a simple inheritance of the Indian tradition, but was an innovative outgrowth of the Chinese people. He interpreted the acceptance of Buddhism as an active choice, a natural result of the evolution of Chinese civilization. As he suggested, the prevalence of Mahāyāna Buddhism could be attributed to the fact that "religion also complies with the universal principle of evolution"; 679 that is, people would by instinct choose more mature, advanced religion. Following the track of the 'evolutionism of religion,' he argued that people's spiritual condition would evolve from "terrorism to salvationism, from egoism to altruism." Therefore, the embracement of Mahāyāna Buddhism, which Liang believed to be the most spiritual part of Buddhism, demonstrated that the Chinese had already arrived at a higher stage of evolution compared to people in India and other regions, such as Tibet and Mongol, for they chose to believe in a more altruist, rationalized version of Buddhism. ${ }^{680}$

A distinct methodological consciousness, especially a confidence in the method of science, permeated Liang's writings on the history of Buddhism. For example, he delicately attempted to discover a 'universal pattern' of the distribution of Buddhism in China, applying the theory of historical geography to explain the early transmission of Buddhism with the paradigm of 'Northern and Southern divergence. ${ }^{681} \mathrm{He}$ propagated as well the idea that we should understand the

\footnotetext{
${ }^{678}$ Ibid., 63.

${ }^{679}$ Ibid., 3.

${ }^{680}$ Ibid.

${ }^{681}$ Here Liang might be influenced by Yu Yue’s “Jiujiu Xiaoxia lu” 九九銷夏錄 and Huang Yizhou 黄以 周's “Ziyou Zixia wenxue shuo” 子遊子夏文學說 as well as studies of historical geography written or
} 
development of Buddhism as an evolutionary progression in a biological sense, since the development of Buddhism in China adhered to "the universal pattern of physiology" [shenglixue zhi gongli 生理學之公例] in which crossbreeding between populations often has positive effects on fitness-related traits (he cited grafting technique in botany and the principle of human and animal reproduction as evidence) ${ }^{682}$

This view of progressivism led him to sing the praises of the achievements of Chinese Buddhism, which, he believed, would help China regain its dignity. The successful Sinicization of Buddhism historically proved that, as Liang claimed, China would again create a brilliant, unique, and extraordinary civilization by creatively synthesizing different thoughts into a harmonious entity, just as the ancient Chinese Buddhists did. The purpose of his writing of Buddhist history, then, was to eulogize the "great cause of those eminent Buddhist figures in the Sui and Tang dynasties" and to further "encourage our new youth" to dedicate themselves to the same calling. ${ }^{683}$ His concern with the youth was not surprising, giving the symbolic existence of Liang's multiple identities-a dedicated historian, a professional journalist, and an active educator. To him, Buddhism was not just a passive or silent object of historiography but a powerful tool of intellectual reformation: It was an ideal exemplar of the progress of religion, and also convincible evidence that optimistically ensured a successful revival of culture.

In 1918, after a prolonged interruption of his academic career, Liang eventually returned to his large project of writing a general Chinese history, ${ }^{684}$ in

\footnotetext{
translated by some modern Japanese historians, such as Ukichi Taguchi, Shigetaka Shiga, and so on. For this issue, see Chen Jingxu 陳經序, “Nanbei wenhua guan 南北文化觀, ” in Lingnna xuebao 嶺南學 報, 3, 4 (1934). one of the most important projects of his academic life. In 1901, he published his Zhongguo shi xulun, which was, as planned, the introduction to his general history. Another article, Xin shixue, was considered the theoretical framework for this project. See Ding Wenjiang 丁文江 ed., Liang Qichao
} 
which he planned to write a chapter on a comprehensive investigation of Chinese 'religions.' However, only a few months later, this plan was disrupted again by a severe illness. During this period, Liang immersed himself in Buddhist literature, such as the Sutra of Perfect Enlightenment [Yuanjuejing 圓覺經] and the Śüranigama Sütra [Shou lengyan jing 首楞嚴經], as well as the essays written by Ouyi Zhizu, Hanshan Deqing 䔮山德清 (1546-1623) and other eminent monks of the Ming era to "console his 'guilt' of idling his time away." in Shanghai for the South Pacific to begin a year-long journey across Europe, which was still embroiled in the catastrophe inflicted by World War I. The Buddhist image of the 'declining Dharma,' which is miserable, unpredictable, and ceaselessly moving, accorded with what Liang observed in Europe. The devastated postwar landscape and the rampant social crises, together with the pessimism prevailing among European intellectuals, led to some serious transformations of Liang's understanding of modernity. ${ }^{686}$

In Europe, the crisis of modernity had emerged in the late nineteenth century. Accompanying this crisis was the long-term failure to reestablish a universal teleology of history. Universal reason, the backbone of the Enlightenment, was explicitly denied as the dominant factor in history and became itself historicized. ${ }^{687}$ By the time of Liang's travel in Europe, he sensitively realized there had been a change: the setting of modernity was experiencing a steady decline. Controlled by dis-causality and discontinuity, crises were increasing both ontologically and epistemologically. When he returned to China in 1920, Liang had concluded that the project of modernization had to be reimagined; otherwise, it would never be

nianpu changbian 梁啟超年譜長編 (Shanghai: Remin chubanshe, 2009), 157. By 1904, Liang had completed 200,000 words and later published them under the title Guoshi gao 國史稿.

${ }^{685}$ Ding Wenjiang ed., Liang Qichao Nianpu changbian 梁啟超年譜長編.

${ }^{686}$ Tang, Global Space and the Nationalist Discourse of Modernity: The Historical Thinking of Liang Qichao. 4-5.

${ }^{687}$ See Jörn Rüsen: Konfigurationen des Historismus. Studien zur deutschen Wissenschaftskultur (Frankfurt a. M: Suhrkamp, 1993), 18-113; as well as Friedrich Jaeger, Jörn Rüsen, Geschichte des Historismus: Eine Einführung (München: Verlag C.H. Beck, 1992). 
completed as a truly global experience ${ }^{688}$ His resistance to modern ideologies began with his action against the iconoclastic May Fourth movement in 1919 and continued into debates on Eastern/Western cultures ${ }^{689}$ and on science and metaphysics. ${ }^{690}$ In the next few years, he published a series of influential articles, increasingly doubting the evolutionary view of history that he had previously propagated. ${ }^{691}$ At the same time, he returned to Buddhist history and proposed writing a new general history of Buddhism.

According to Liang's uncompleted plan, the general history of Buddhism would consist of two stages: first, Buddhism before Sinicization and second, postSinicized Buddhism. He further divided the first part into two chapters: Buddhism in India, which included his several articles on textual studies of original Buddhist literature, and Buddhism in the Western region [xiyu 西域]. The second part focused on the development of Buddhism after it had entered into China-namely, the "rise and fall" [xingshuai 興衰] of Chinese Buddhism ${ }^{692}$, including a series thematic articles focusing on topics such as the distribution of Buddhism, the translation of Buddhist scriptures, the formation of sects, and so on.

\footnotetext{
${ }^{688}$ Liang did not give up the project of China's modernization and rejected the value of science. See Liang, “Kexue jingshen yu Dongxi wenhua 科學精神與東西文化” (8.20.1922), in YBSHJ: Wenji 39: 1-9, especially 8-9. "Rensheng guan yu kexue" (5.23.1923), in YBSHJ: Wenji 40, 20 -27. See Tang, Global Space and the Nationalist Discourse of Modernity: The Historical Thinking of Liang Qichao. 5.

${ }^{689}$ Alitto, Guy, The Last Confucian, Liang Shu-ming and the Chinese Dilemma of Modernity, 1979.

${ }^{690}$ Kwok, D.W.T., Scientism in Chinese Thought, 1900-1950 (New Haven: Yale University Press, 1965) and Furth, Charlotte, Ting Wen-chiang: Science and China's New Culture (Cambridge, MA: Harvard University Press, 1970).

${ }^{691}$ See his “Ou you xinying lu 歐遊心影錄” (10-12.1919), in YBSHJ: Zhuanji 23:1-162, “Kexue jingshen yu zhongxi wenhua 科學精神與中西文化”; “Guanyu xuanxue kexue lunzhan zhi 'zhanshi guoji gongfa' 關於科學玄學論戰之戰時”國際公法”” (1923), in YPSHJ: Wenji 40: 27-28, “Rensheng guan yu kexue 人 生觀與科學” (1923), 21-27; see also Joseph Levenson, Liang Ch'i-ch'ao and the Mind of Modern China, 84169.

${ }^{692}$ According to Liang's plan, this article would be the second chapter of the second part of his general history of Buddhism. The first chapter of this part, “Fojiao zhi chushuru” 佛教之初輸入, had already been published in the journal Gaizao 改造 in August 1921. Later, Liang reassigned this article as an introductory chapter to the second part of his general history of Buddhism.
} 
A nationalist historiographical view continued in Liang's works of Buddhism, although he gradually gave up some of his former presuppositions, such as the universal progress of religion. ${ }^{693} \mathrm{He}$ focused his studies on "the distinctive characteristics of Chinese Buddhism," or what he called the "real face" of Buddhism: not the Indian origin of Buddhism but the real development of Buddhism throughout Chinese history. For example, in 1922, Liang Qichao wrote an article expounding that Dasheng Qixinlun was produced by Chinese Buddhists. However, instead of blaming Chinese Buddhism for its infidelity or lack of authenticity, he boasted, from a nationalistic perspective, that Chinese people should take pride in having created such a profound text by themselves. ${ }^{694}$

However, there were many contradictions in Liang's writing on the history of Buddhism. On the one hand, he stressed the immanence of meaning in particular history and tried to define Buddhism as a part of the unique identity of China; on the other hand, he searched for universal coherence to depict Buddhism as a world religion and integrate China into world history. ${ }^{695} \mathrm{In}$ "The Early transmission of Buddhism," the first article he wrote about the history of Buddhism during this phase, he suggested the mission of history was to clarify the developmental stages of Buddhism as one segment of the 'universal pattern' of intellectual evolvement. ${ }^{696}$ However, he soon realized that it would be problematic to judge something as complex as Buddhism by such a subjective and dualist standard as 'progressiveness': If Chinese Buddhism had evolved from an Indian origin, how could Chinese Buddhism really be Chinese? If it was a result of evolution, how could it originate from a

\footnotetext{
${ }^{693}$ Liang's political position as well as his view of religion and history experienced a turn at the end of 1918. However, many scholars, such as Guo Peng, Xiao Wanyuan, and so on, have ignored this conceptual turn when discussing Liang's Buddhist study. See Guo Peng 郭朋, Zhongguo jindai foxue sixiangshi 中國近代佛學思想史稿, chapter 12; Xiao Wanyuan 蕭萬源, Zhongguo jindai sixiangjia de zongjiaoguan yu guishenguan 中國近代思想家的宗教觀與鬼神觀 (Hefei: Anhui renmin chubanshe, 1991), chapter 4.

${ }^{694}$ In 1924, Liang Qichao published Dasheng qixinlun kaozheng 大乘起信論考證 (Beijing: Shangwu yinshuguan, 1924).

${ }^{695}$ Axel Schneider, "Shijie lishi yu lishi xiangdui zhuyi de wenti - 1919 nian yihou Liang Qichao de shixue 世界歷史與歷史相對主義的問題-1919 年以后梁啟超的史學,”238-59.

${ }^{696}$ Liang Qichao, “Fojiao zhi chushuru 佛教之初輸入," in SBP, 29.
} 
declining Indian Buddhism? And how could it become lifeless and corrupt after the Song dynasty? If Chinese Buddhism was basically created by the Chinese, how could it fit into the universal pattern of the evolution of Buddhism? This dilemma unavoidably led Liang to the dangerous and paradoxical conclusion that Chinese Buddhism was not Buddhism at all.

Interestingly, Liang had never tried to cut the link between Chinese Buddhism and Indian Buddhism but rather placed great emphasis on the coherence between them. Among the over thirty articles he wrote on Buddhism from 1920 to 1925, around one-third were about the "primary Buddhism in India" or Indian Buddhist texts, such as Abhidharma Mahāvibhāṣā Śāstra and āgama. This tendency made Liang the first modern historian to break regional boundaries and write a general history of Buddhism from the age of the Buddha onwards to the full establishment of Chinese Buddhism. It represented his proposal to write a 'global cultural history,' which, some scholars believe, was based on his conceptual construction of the "global imaginary of difference." ${ }^{" 697}$ In Liang's view, Buddhism in India, following the 'universal pattern of organic growth,' determined the "characteristics of species" of Buddhism, based on which Chinese Buddhism developed its own features. ${ }^{698} \mathrm{He}$ described this relationship as 'evolving in parallel' [pianjin 駢進], which differed from his earlier use of 'evolution' [jinhua 進化].

Knowing the transcultural process of 'pianjin', Liang claimed, was "the basic preparation for writing the histories of every Buddhist sect." ${ }^{"}$ Heg Here, Liang implied a comparative way of thinking, which further led him to emphasize the particularity of different traditions. Using Buddhism as one example, he tried to contextualize the coherence in cultural development with the real objects of history-the concrete experience caused by the 'pianjin' between different cultures. From this comparative perspective, he avoided the model of "survival of the fittest" in his early narrative and abandoned his former framework of the 'the universal pattern of physiology,'

\footnotetext{
${ }^{697}$ See Tang, Global Space and the Nationalist Discourse of Modernity: The Historical Thinking of Liang Qichao. 5. But I do not agree Tang's idea that Liang gave up his "history writing in the nationalist tradition."

${ }^{698}$ Liang Qichao, SBP, 40

${ }^{699}$ Ibid, 41.
} 
which involved a deterministic teleology and an oversimplified logic based on science. However, he still attempted to resurrect some sort of certainty and maintained that there is a tendency of moving towards this certainty in history.

After he wrote a dozen articles on Buddhist history, Liang published in the autumn of 1921 one of the most important theoretical works on the ontology and methodology of historiography: Methods for the study of Chinese history [Zhongguo lishi yajiu fa 中國歷史研究法] ${ }^{700}$ As indicated in this text, Liang's theory had profoundly changed. One year later, Liang further systematized his developed ideas on history as supplementary remarks on methods in the article "What is Culture" " [Shenme shi wenhua 甚麼是文化] and in his talk under the same title at Jingling University. Inspired by Buddhism, especially the Yogācārian doctrines, which he was studying under the guidance of Ouyang Jingwu, he redefined "culture" by introducing the Buddhist term of karma [deed, ye, 業], and further drew a distinction between “individual deeds" [bieye 別業] and “general deeds” [gongye 共業]. Liang argued, the latter, which was involved in the construction of culture, was not a preset structure, but heavily depended on human agency. Hence, culture was not determined by causality but by human creation and imitation, which was free, limited, and interdependent. ${ }^{702}$ By distinguishing individuality from eternal values, Liang stressed the occasional, subjective, and emotional factors in history. ${ }^{703}$ This transition had already appeared in his writings of the history of Buddhism. In one article, he discussed the function of one human free will, 'the will for knowledge [xuewenyu 學 問照], in the acceptance of Buddhism among the learned Chinese. ${ }^{704}$ In another article, he stressed this "will for knowledge" and "the wish for mental comfort" as essential motivations behind Buddhism-related historical events and activities, such

\footnotetext{
${ }^{700}$ This text is based on a series of lectures Liang Qichao gave at Nankai University during which he obviously started to reconsider his view of history; thus, he ended the sixth and last lecture by contradicting the first one.

${ }^{701}$ Liang, “Shenme shi wenhua 什麼是文化," YBSHJ, Wenji 39: 97-104.

${ }^{702}$ Ibid.

${ }^{703}$ Axel Schneider, "Shijie lishi yu lishi xiangdui zhuyi de wenti - 1919 nian yihou Liang Qichao de shixue 世界歴史與歷史相對主義的問題--1919 年以后梁啟超的史學,” 251.

${ }^{704}$ Liang Qichao, SBP, 4.
} 
as the pilgrimages of Chinese monks to India and the early undertakings of translation of Buddhism doctrines.$^{705}$ These immanent factors related to human free will, to Liang, may not have been the fundamental cause of historical developments but were a dimension that should not be overlooked when examining historical changes.

Oscillating between his respect for particular identity and his wish to envision a normative and universal core of history, Liang attempted to find ways to reconcile the paradox of nationalism and modernity by borrowing from Buddhism, a resource he believed to be "the supreme cultural outcome of human beings." ${ }^{\text {" } 706}$ In the essay "Several Important Questions of Studying Cultural History" he published later, Liang stressed again the element of culture behind historical issues and once more defined the subject matter of history as individual and particular in both temporal and spatial dimensions ${ }^{707}$ Here, Liang borrowed the Buddhist notion of "interdependenc" [huyuan 互緣] and used it to replace the mechanical, unidirectional concept of causality. ${ }^{708}$ According to him, one should avoid readily associating historical phenomena with philosophical laws. He was also opposed considering the mission of history to be describing one facet of our physical world and further rejected an objective historiography. In his Buddhist history, Liang had realized 'the intellectual undercurrent' and 'the background of time' behind the transmission, acceptance, and Sinicization of Buddhism in China, which have been to some extent occasional, emotional, and unique. ${ }^{709}$

Liang's sustained effort to write the history of Buddhism had profoundly influenced his whole scholarship. Current studies on Liang's historiography, however,

\footnotetext{
${ }^{705}$ Ibid.

${ }^{706}$ Ding Wenjiang, “Wei chuanban wenhua xueyuan shi qiuzhu yu guozhong tongzhi 為創辦文化學院 事求助於國 中同志” in Liang Qichao xiansheng Nianpu changbian, 梁啟超先生年譜長編, 1223.

${ }^{707}$ Liang, “Yanjiu wenhua shi de jige zhongyao wenti 研究文化史的幾個重要問題” (1922), in YBSHJ: Wenji 40, 1-7.

${ }^{708}$ There were still realms that Liang insisted were controlled by the universal law of evolution, for example, natural science. See Liang, “Zhongguo lishi yanjiu fa (bubian) 中國歷史研究法(補編)," YBSHJ, Zhuanji, 73: 111-113.

${ }^{709}$ Liang Qichao, SBP, 5
} 
have focused too heavily on external impacts, Western ideologies, political forces, and so on while ignoring his critical reflections on modernity and his adaption of this concept by picking over concepts and theories from native thought. It is important that, no matter how hard he promoted new theories, the Sino-centric discourse in his writings remained emphatic and decisive. Buddhism, which fundamentally contradicted his earlier belief in Darwinist progressivism, did not bring him any feeling of repugnance but, in contrast, helped to form his cosmology and his own outlook on life. ${ }^{710}$ Buddhism helped him to banish his too-optimistic faith in certainty and causality and inspired him to reflect on national particularity, historical coherence, and cultural interdependence. Therefore, Liang was not 'unwittingly' revealing the meaning of modern Chinese history, as Levenson has described, but consciously attempting to overcome the pitfall of progressivism and the shortcomings of modern historiography, amending them with Buddhist and some other traditional discourses (Confucianism, for example). ${ }^{711}$

\section{Taixu: Buddhist Evolutionism}

As a Buddhist reformer, Taixu made efforts to visualize Buddhism as a 'modern, global and useful religion.' He called for several innovative but sometimes 'radical' religious changes, including institutional reorganization, a new style of monastic education, compassionate social action, and global ecumenical missionaries. Instead of pursuing rebirth in the Western Paradise of Amitābha, Taixu was concerned more about the fulfilment of the Pure Land in this world. This conception of Buddhist modernism was provocative at that time. ${ }^{712}$ Behind this groundbreaking manifesto of

\footnotetext{
${ }^{710} \mathrm{Ibid}, 1217$. About what he learnt from Buddhism, he noted especially two points, which both related to his view of time and space: 1 . The cosmos is not perfect; 2 . Humans cannot exist fully independently. ${ }^{711}$ Joseph Levenson, Confucian China and its Modern Fate, A Trilogy (Berkeley, Los Angeles: University of California Press, 1970), 1.

${ }^{712}$ For example, the respected Pure Land Master Yinguang portrayed Taixu as gifted but dangerously strident and disruptive voice in the Buddhist community. See Pittman, Toward a Modern Chinese Buddhism: Taixu's Reforms. 2
} 
"Buddhism for the human world" was Taixu's novel but controversial understanding of Buddhist history and his critical interpretation of evolutionary theory.

Similar to many young people in that era of transition, Taixu considered modern theories, which had been introduced from the West to China by intellectuals such as Kang Youwei, Yan Fu, Zhang Taiyan, and Liang Qichao, to be instruments for his plan of building a relevance between Buddhism and modern society. His envisioned plan, according to Don. A. Pittman, was to propagate Buddhism all over the world through well-educated and modern-style clergy. To Taixu, the rehabilitation of samgha as well the global transmission of Buddhism as a world religion would be fulfilled not through reliance on the spiritual merit and power of other great bodhisattvas and buddhas, but through the qualified dedication and sacrificial hard work of thousands of average Buddhist believers. ${ }^{713}$ Therefore, Taixu emphasized the systematic preaching of Buddhist teachings to massive audiences with lucid, updated, or 'fashionable' expressions. History and science were two main tactics he used to interpret Buddhist doctrines to make them seem more comprehensible, convincing, and attractive.

Among Taixu's voluminous works, a short essay "A Brief History of Buddhism" [Fojiao shilue 佛教史略] is not conspicuous but important. Published in 1909, this work demonstrated Taixu's view of Buddhism in world history. Under the influence of newly written books on world history, for example, H.G. Wells' A Short History of the World, ${ }^{714}$ Taixu made his first attempt to describe the creation, development, and distribution of Buddhism from the Buddha's time to a globalizing age in a simple, grand outline, targeting common readers who had limited knowledge of Buddhism. Describing India as the origin of Buddhist history, Taixu in this writing roughly

\footnotetext{
${ }^{713}$ Pittman, Toward a Modern Chinese Buddhism: Taixu's Reforms, 222.

${ }^{714}$ In a review of Wells' book, full of references to evolution, geology, progress, and science, Taixu criticized Wells for his treatment of both Chinese and Buddhist history. See Taixu "Lun Shijieshi gang 論世界史網," in TXQS, vol.16, 256-264. Wells had consulted with Fu Si-nian for his chapters on China, so ironically Taixu's primary contact with Fu Sinian's historiography was through the Chinese translation of Well's work. For an analysis on this issue, see John Kieschnick, Buddhist Historiography in China, forthcoming. 310. For Wells and Fu, see Wang Fansen, Fu Ssu-nien: A Life in History and Politics (Cambridge: Cambridge University Press, 2010), 57-58.
} 
depicted a larger Buddhist world that included Tibet, Ceylon, and the pan-East Asian area. Besides, he used a new pattern of periodization to replace the traditional doctrinal classification system and lineage-based narrative, arranging Buddhist history into a framework combining religious priority with a secularized geographic principle. ${ }^{715} \mathrm{He}$ first divided the history of Buddhism into two stages: the age of creation [chuangpi shidai 創闢時代] and the age of dissemination [liuchuan shidai 流 傳時代]. Then he applied a historio-geographical framework to further divide postBuddha Buddhism into three branches: the Indian Age, the Asian Age, and the Global Age. He further demarcated two phases of development in the Asian Age: "from embryonic to flourishing" [cong kaichuang dao quansheng 從創開到全盛]" and “from transforming to declining” [cong biantong dao shuailuo 從變通到衰落]. He indicated in this essay that if there was no complete history of Buddhism that could record events that manifested Buddhism's rise and fall and convey its universal and supreme principles, the “reasons" [yuanyin 原因] or “spirits" [jingshen 精神] within Buddhist teaching would not be uncovered. ${ }^{716}$

In this early text, Taixu tried to locate Chinese Buddhism in the broader, transregional historical context. To him, Buddhism was, from the Buddha's time, initially a religion for all sentient beings. He emphasized that the history of Buddhism - with all its developments, divergencies, and changes - was the representation [yinghuag 應化] of an ultimate root: the Buddha's teaching. ${ }^{717}$ This "principle of the development of the Dharma," which determined Buddhism historically, in Taixu's words, was the Buddha's “heart seal” [xinyin 心印]. ${ }^{718}$ Therefore, when discussing the changes in Buddhism over a longer period of time, Taixu always referred to the Buddha's time as a criterion. He organized historical phenomena and made judgments, according to his dichotomic frame of time: a

\footnotetext{
${ }^{715}$ Taixu might have been influenced by Liang Qichao. Liang had applied a similar framework in his Dashi. However, their views differed in some ways. For example, Liang dismissed the legend of the early transmission of Buddhism in Han China in his article “Fojiao zhi shuru 佛教之初輸入.”

${ }^{716}$ Taixu, “Fojiao shi lüe 佛教史略,” TXQS, vol.1, 895.

${ }^{717}$ TXQS, vol.2, 388.

${ }^{718}$ Ibid.
} 
primary, original, Indian age and a diverse, derivative, global age. In the chapter "History of Teaching" [xueshi 學史] in his General Introduction to Buddhism [Fofa zonglun 佛法總論], this framework was continuedly used but with some slight changes: Buddhist history was summarized into two major categories: "Indian Buddhism with three stages" and "global Buddhism with three pedigrees." ${ }^{119}$

Taixu's account of Chinese Buddhism relied heavily on traditional narratives that had been circulated in China for centuries. ${ }^{720}$ For example, Taixu's discussions of Chinese Buddhist history conventionally bridged Chinese lineages with Indian masters by referring to doctrinal evidence; he also uncritically accepted the traditional story of Buddhism's early transmission in the Later Han dynasty, which had been widely contested by many historians and Buddhism scholars as lacking textual evidence, ${ }^{721}$ and he showed less interest in newly discovered materials, such as the Dunhuang scriptures. Partly influence by the legendary deeds of ancient Buddhist figures (Aśvaghoṣa, Nāgārjuna, Vasubandhu, Asanga, Emperor Yang of Sui, Emperor Taizu of Ming, etc.) Taixu emphasized a historical heroism, which he believed responded to the call for a Buddhist 'revival' in the modern age. With his statement that "history is the genealogical records of heroes" modern samgha and Buddhist believers to take up the burden of responsibility of writing and publicizing "a national history of Chinese Buddhist heroes" for the sake of encouraging changes and revolution. ${ }^{723}$

As early as when Taixu wrote of the shilue, he had realized with full selfconsciousness that he was not a 'good' historian; but rather, he would be someone who would witness, participate in, and also create history. Partly because of this hope

\footnotetext{
${ }^{719}$ TXQS.vol.1

${ }^{720}$ For example, he claimed that the first scripture the Buddha preached was the Avatamsakasūtra.

${ }^{721}$ In Taixu's time, there were several debates on the beginning of Chinese Buddhism; most of them were first started by Liang Qichao. Other debates focused on the issue of the authenticity of some important Buddhist scriptures, such as the Dasheng qixinlun 大乘起信論 and Mouzi lihuo lun 牟子理惑 論. For a detailed study on these debates, see chapter. 5 .

722 “歷史第為英雄之牒譜.” Taixu, “Fojiao shi lüe 佛教史略,” in TXQS, vol.1, 895.

${ }^{723}$ Taixu, “Fojiao zhi Zhongguo minzu yingxiong shi 佛教之中國民族英雄史," in Haichaoyin, 24, no.6: 2; in MFQ, v.201, 226.
} 
to contemplate the future of Buddhism in a more independent and theoretical way, in October 1914, Taixu entered a voluntary isolated study and meditation known as "sealed confinement" [biguan 閉關] for three years. ${ }^{724}$ Surrounding by silence and tranquility on Putuo Island, Taixu devoted himself to an extensive reading program ranging from the Buddhist canon and Chinese classics to modern Western literature. New ideas and theories, especially in the works of Yan Fu and Zhang Taiyan, inspired him to scrutinize the Tripitaka from some new angles. ${ }^{725}$ After this seclusion, Taixu's reflection on the past and future of Buddhism had deepened. Besides his general preaching of Buddhist wisdom in comprehensible, simple language, he began to establish a Buddhist worldview-a synthesized, hybrid discourse of cosmology on time, space, and humankind. By doing so, Taixu explored, from a historical perspective, the possibility that Buddhism could explain past and present changes, solve the current dilemma, and promise this world the fulfillment of the Pure Landnamely, the possibility that Buddhism could become "the sound of the sea tide" for a new era.

From 1915, the notion of 'evolution' became one of the key words in Taixu's writing. However, Taixu always used 'evolution' in a strategical manner. In 1915, he published a text entitled “On the School of Evolutionism” [Lun tianyan zong 論天演 宗], providing a critical commentary on the theory of evolution from the perspective of Buddhism. In this article, he described evolutionism as the most influential school of thought 宗 during the nineteenth century, which was developed from Kant, Spenser, to Darwin and other philosophers and sociologists. He discussed that the theory of evolution was an expression (in the sense of language) of the universal pattern of changes under the rubric of modern science, which, according to him, shared a common foundation of the Dharma. Similar to the Buddhist doctrines, Taixu argued, this theory also had four dimensions: phenomenon [guandai daoli 觀待道理],

\footnotetext{
${ }^{724}$ Biguan, as a ritual of self-isolation, is a highly respected religious practice of self-discipline for Chinese monks, during which they are released from the usual expectations associated with communal living and permitted to read and meditate on their own. On the practice of biguan, see Welch, The Practice of Chinese Buddhism, 1900-1950 (Cambridge, MA: Harvard University Press, 1967), 321-322. ${ }^{725}$ Pittman, Toward a Modern Chinese Buddhism: Taixu's Reforms. 83.
} 
definition [zhengcheng daoli 證成道理], function [zuoyong daoli 作用道理], and essence[faer daoli 法爾道理], which generally corresponded to the domains of phenomenology, epistemology, teleology, and ontology in the framework of Western philosophy. ${ }^{726}$

However, as mentioned above, Taixu's utilization of 'evolution' was always an 'expedient means'. He had never been entirely convinced by this modern discourse or related theories such as social Darwinism and progressivism. Taixu acknowledged that evolutionism had a positive impact on civilizations because it not only contributed to the birth and development of science but also encouraged people to pursue a better future through expanding the realm of knowledge and following the principle of causality. ${ }^{727}$ However, although Taixu admitted that the theory of evolution "is extensive, profound and has the insights into changes and details," pointed out that the scope of this theory was still temporally and spatially limited; it was only an imperfect description of the ' $f a$ ' 法, the truth of the inherent law of the universe. ${ }^{729}$

Further, Taixu pointed out that the theory of evolution encountered several dilemmas. First, according to the theory, things can change or move only when a power triggers the movement in the very first place. Therefore, 'evolution' has its beginning and end; it is controlled, determined, and can be accelerated or stopped. Taixu named the driving force suggested by the theory of evolution "the power of meta-material [yuanzhi li 原質力].” This power, in Taixu's view, is however unknowable and untouchable. Questions about the intrinsic characteristics of this meta-material power, for example, whether it is homogeneous or heterogeneous, cannot be answered. Therefore, the theory of evolution is not perfect; this power of meta-material, as Taixu's argued, is essentially equivalent to 'God', in the Western

\footnotetext{
${ }^{726}$ TXQS, 287.

${ }^{727}$ Ibid, 299.

${ }^{728} \mathrm{Ibid}, 284$. The original text is: “察化知微, 思精體大.”

${ }^{729}$ According to Taixu, the 'law' did not originate from the theory and would not be enhanced by it. Ibid, 283-284.
} 
religious sense. Therefore, the whole setting of evolutionism is not as 'scientific' as it claims.

Second, Taixu compared the theory of evolution to the Buddhist teaching of 'yuanqi' [pratitya-samutpāda; dependent origination; 緣起]. Taixu suggested that the assertions of the theory of evolution, such as the law of conservation of energy, the connections and differentiations between things, the principle of movement, etc., had already been elaborated by the Buddhist idea of twelve-fold links [nidāna; shier yinyuan 十二因緣] and the Buddhist logico-epistemology. For example, the term 'material' in the theory of evolution was equivalent to the Buddhist concept of rūpa [form; se 色]; the term 'force' was similar to the Buddhist skandha [the aggregates of clinging; yun 蘊]. ${ }^{730}$ Almost every concept of evolutionism had been already elaborated by the Buddhist doctrine of "the craving [Taṇhā; ai 愛], clinging [Upādāna; $q u$ 取] and becoming [Bhava; you 有] of yuanqi [yuanxing yuanqi zhi ai qu you san zhi 緣性緣起之愛取有三隻].” Very sensitively, Taixu asked a crucial question in this essay: after observing the degeneration, corruption, and chaos of our world, why did the Tianyan school still wish to justify the process of evolution? To Taixu, the theory of Tianyan, which targeted this phenomenal world, was "the illusory principle of the universe [yuzhou jiafa 宇宙假法].” It would inevitably fail to lead people to real 'liberation.' Moreover, its concepts overstressed the 'function' or 'effect [yeyong 業 用]' of human actions but ignored the transcendental essence of the 'heart'. The mechanical causality it advocated, Taixu argued, was also problematic, for it always blamed other external factors as reasons and exonerated oneself from responsibility. Therefore, the theory of evolution had attached itself to the captive material world; it obeyed illusory changes 幻化 and dismissed the Tathātā [suchness, zhenru 真如].

Third, the overall development of human society, Taixu stated, was not a linear movement towards a brighter future, but rather "neither progressive nor degenerate, neither karmic nor non-karmic."731 As demonstrated in his article "Are

\footnotetext{
${ }^{730}$ In seeking to connect science and the Dharma, Taixu occasionally stretched his point, as in a discussion of evolution in which he appeared to conflate biological evolution with transmigration. [Principles 34].

${ }^{731}$ Taixu, “Shijian wanyou wei Jinhua yi wei tuihua 世間萬有為進化抑為退化,” TXQS, 336.
} 
All Worldly Things Evolving or Regressing?" [Shijian wanyou wei jinhua yiwei tuihua 世間萬有為進化抑為退化], Taixu divided the universe into three realms, following the framework Monk Fazang 法藏 (643 712) had precisely parsed in his "Huayan wujiao zhang 華嚴五教章”: the mundane [laukika; shijian 世間], the supramundane of the three vehicles [Triyāna, sansheng 三乘], and the transcendent supramundane belonging to the one vehicle [ekayāna, dasheng 大乘]. ${ }^{732}$ The mundane Dharma [shijian fa 世間法] applied to the world [bhäjanaloka, qishijian 器世間] of ordinary sentient beings and the karmic changes in a cyclic movement ${ }^{733}$; the supramundane Dharma, which refers to enlightened practitioners such as bodhisattvas, demonstrated the path to the tranquil, changeless, and empty realm of Buddhahood. According to Taixu, the supramundane Dharma of the three vehicles is not progressive, but rather regressive, moving backwards from formation to dissolution and finally towards soteriological freedom, namely the moksha. The supramundane Dharma of the shared one vehicle [dasheng gongfa 大乘共法], however, is progressive again (when judging from the perspective of the "practice-position [yinwei 因位]" in Taixu's words), because the bodhisattvas must make progress to achieve the fruition of becoming Buddha. After entering into the stage of being Buddha, there will be no progress anymore but only “perfection and eternity [yuanchang 圓常]." ${ }^{334}$ Taixu's attitude towards Evolutionism, therefore, had two points: firstly, things in the mundane world are in karmic movement; secondly, real 'progress' can only be observed and understood as one phase of the bodhisattva path, which is determined by "the

\footnotetext{
${ }^{732}$ According to Fazhang, of the ten stages [daśabhūmi] of the path leading to buddhahood, stages one through three belong to the mundane [laukika]; the fourth to the seventh stages are supramundane from the standpoint of the three vehicles [Triyāna 三乘] of śrāvaka [shengwen 聲聞], pratyekabuddha [yuanjue 緣覺], and bodhisattva [pusa 菩薩]; and the eighth to the tenth stages transcend even the supramundane and belong to the one vehicle [dasheng 大乘].

${ }^{733}$ In Sanskrit, Qishi jian means literally "container world," referring to the wider environment, or the physical or inanimate world, whose function is to serve merely as a "container" for the lives of ordinary sentient beings [sattva]. Its ancillary production and cessation as well as its overall physical qualities are considered to be by-products of the actions [Karman] of sentient beings. Qishi jian moves ceaselessly in the circle of 'formation' [vivartakalpa], 'duration' [vivartasthāyikalpa], 'dissolution' [samvvartakalpa], and 'nothingness' [saṃvartasthāyikalpa].

${ }^{734}$ Taixu, “Shijian wanyou wei Jinhua yi wei tuihua 世間萬有為進化抑為退化,” TXQS, 336.
} 
practice-position of the transcendent supramundane Dharma that belongs to the one vehicle 出世的一分大乘不共因位菩薩法." ${ }^{735}$

Based on this cosmological understanding, Taixu 'invented' his 'Buddha-lized' theory of evolution under the rubric of "evolutionism for the gradual teaching of the great vehicle" [Dasheng jianjiao jinhua lun 大乘漸教進化論]. In his eponymous lecture delivered in 1930, Taixu maintained his early division of the mundane and supramundane realms, but largely generalized the concepts of 'progress' and 'evolution' as universal verdicts in Buddhist teaching. In detail, he argued that the evolutionism of the great vehicle had eight dimensions. It 1) was unlimited in time and space; 2) moved from bad interests [equ 惡趣] to meritous interests [shanqu 善 趣]; 3) moved from wrong views [xiejian 邪見] to right views [zhengjian 正見]; 4) moved from mundaneness [sushi 俗世] to true eternity[zhenchang 真常]; 5) moved from the lower vehicle [xiacheng 下乘] to the upper vehicle [shangcheng 上乘]; 7) moved from understanding and practice 解行 to personal realization 親證; 7) moved from bodhisattva to Buddha; 8 ) moved from being Buddha to saving all sentient beings[du youqing 度有情]. As shown in this article, he accepted the notion of evolution but re-wove it into a Buddhist version of evolutionism. As shown here, Taixu, as a Buddhist modernist, embraced new concepts and values to reform Buddhism into the most 'evolutionary' religion, "a tolerant, receptive, universal faith which is essential to the realization of world unity," ${ }^{736}$ and for propagandizing this modern image of Buddhism to the rest of the world.

Partly out of pragmatic choice, Taixu considered 'evolution' as the key to the 'survival' and 'revival' of Buddhism. The solution for the crisis Buddhism faced in such a secular, modern world would be linking the best part of the past with new

\footnotetext{
735 “出世的一分大乘不共因位菩薩法 Ibid, 337. The unshared Dharma [Āvenika(buddha)dharma, bugongfa, 不共法, literally means the special qualities that are unique to the Buddha. They usually appear in a list of eighteen. For this unshared Dharma, see the entry of 'Âvenika(buddha)dharma' in the Princeton Dictionary of Buddhism, 85. Also Yinshun, Chenfo zhidao 成佛之道, Chapter 5. Taixu's classification of the shared Dharma and the unshared Dharma has also been accepted by later Buddhists, such as Shengyan. See Shengyan, “Zhengxin de fojiao 正信的佛教." 736 "Urge Cultural tie with the Orient: Delegates Representing Eastern and Western Religions Unite in Movement to Promote World Peace," New York Times, March 6, 1929.
} 
concepts and interpretations appropriate to the future, ${ }^{737}$ that is, preserving an organic connection with the old Chinese Buddhism and at the same time freeing it from the entanglements of superstitions and obscure practices that had loaded it down and brought it under the scorn of so many educated people. ${ }^{738}$ To reach this goal, Taixu set a hierarchy between Buddhism and other religions and other forms of knowledge. ${ }^{739}$ He wrote that

The scientific method in its study of the natural world organizes and classifies knowledge through careful analysis... but the things which have been analyzed are actually a complete whole, or a living organism. Science cannot analyze [the whole]." ${ }^{\text {40 }}$

Clearly, to Taixu, science, although not conflicting with Buddhism, was overconfident in its methods and myopically attempted to "improve [its] instruments rather than [its] inner vision." ${ }^{741}$ Thus it consequently ignored the Dharma and could never achieve the direct insight necessary for seeing the entire universe as it really is, i.e. the suchness. ${ }^{72}$ Only Buddhism, which was based not upon an untenable belief in a creator god but upon the "eternal, unlimited, and absolute conception of the spiritual and material phenomena of the universe, ${ }^{143}$ had the potential to remedy the lack of

\footnotetext{
${ }^{737}$ Pittman, Toward a Modern Chinese Buddhism: Taixu's Reforms, 237.

${ }^{738}$ Karl L. Reichelt, “Trends in China's non-Christian Religions," Chinese Recorder 65 (March 1934): 763.

${ }^{739}$ Taixu classified what he saw as the primary forms of knowledge in a hierarchy ranging from merely animal awareness to the perfect awareness of an enlightened Buddha. Included in this scheme were "theoretical forms of knowledge" that Taixu tried to bring into harmony with the Dharma. These "theoretical forms of knowledge" came in four varieties: scientific, philosophical, religious, and moral. See Taixu, "Learning: Its Purpose and Method," T'ai-hsü: His Life and Teachings, ed. Chou Hsiang-kuang (Allahabad: Indo-Chinese Literature Publications 1957], 63. For the summary and a very clear diagram of Taixu's classification, see Justin Rizinger, Taixu: To Renew Buddhism and Save the Modern World, thesis, Lawrence University (1999): 23-24.

${ }^{740}$ Paul E. Callahan, “T'ai-hsü and the New Buddhist Movement." Harvard University: Paper on China 6 (1952): 163.

${ }^{741}$ Taixu, “Fojiao yu kexue 佛教與科學,” TXQS, 47.

${ }^{742}$ Ibid., 41.

${ }^{743}$ Taixu, “The History of Buddhism and Its Recent Tendencies," T'ai-hsü: His Life and Teachings, ed. Chou Hsiang-kuang (Allahabad: Indo-Chinese Literature Publications, 1957), 22.
} 
science. In this sense, Buddhism, alone among religions, "does not contradict scientific truth but rather confirms it." ${ }^{144}$

Taixu's attitude towards Western philosophy, however, was somewhat less consistent. At times he gave it credit for its pursuit of truth, while at other times he treated it as little more than a two-thousand-year mistake. For instance, in a lecture given in France he described the entire history of Western philosophy as a sort of 'progressive' descent towards error. ${ }^{745}$ According to him, Western philosophy, over centuries, had gradually digressed from its ancient Greek origin and its proper aim of investigating the noumenon and fallen into endless controversies, impeding real progress. This descent, he argued, originated from the methods that people used to penetrate the noumenon. Noumenon could not be known by analysis and observation, but through meditation and awakening. ${ }^{746}$

Similar criticism has been observed in Taixu's comments on modern historiography. Being unsatisfied with Wells' Short History of the World and criticizing that Wells misunderstood Buddhism as a "progressive religion" and was "unable to fully understand the Buddha," ${ }^{447}$ Taixu formulated his own general view of history, which he called "the dependently-originated conception of history [yuancheng shiguan 緣成史觀].” This view of history, as shown in a lecture he delivered in 1930, concentrated on the causal links between historical developments while he seemed ignore other factors, such as the diachronic changes in particular phenomena and the disruptions in history. Taixu suggested that history needs to focus on the universal, inescapable, and interdependent conditions [yuan 緣] among all sentient beings. ${ }^{748} \mathrm{He}$ used the term yuancheng to take the place of historical continuity, relationship, and reason. For example, the life of the Buddha was narrated as a historical, provable

\footnotetext{
${ }^{744}$ Ibid, 30. For Taixu's ideas on science, for example, Einstein's theory of relativity, see Wing-tsit Chan, Religious Trends in Modern China (NY: Columbia University Press, 1953), 88-9.

${ }^{745}$ TXQS.

${ }^{746}$ Taixu, "Philosophy and Buddhism," in Chou Hsiang-kuang ed., T'ai-hsü: His Life and Teachings, (Allahabad: Indo-Chinese Literature Publications, 1957), 48-57.

${ }^{747}$ TXQS, 164

${ }^{748}$ Ibid, 167, 169.
} 
exemplar that demonstrated the interdependence between historical moments and the potentiality of the realization of Buddhahood, which could be actualized again in a 'future' time span. This idea, which linked the interdependence of historical actors with a promised 'achievement' [cheng 成], indicated a soteriological end in history that could be manifested by the fulfilment of every individual. ${ }^{749}$ In this sense, the historical thumbnail of Buddhism's past that Taixu depicted here was, to a large extent, a referential image of his Buddhist revolution in the present.

In creating a discourse that could harmonize Buddhism with modernity and justify Buddhism in the flow of time, Taixu indeed mediated his belief in Buddhism with the mainstream of modern ideologies - science, progressivism, and revolutionby claiming that modern theories all approached the truth of Buddhism and that both these theories and Buddhism envisioned the future similarly. Therefore, Taixu believed that history, although it had had a long-term decline after the golden age of the Buddha, would be redirected in a progressive direction by the revival of Buddhism. This open-future view of history was an innate facet of the path of the bodhisattva and the faith of Maitreya, and had no contradictions with the modern discourses such as atheism and utopianism. ${ }^{750}$ He even wrote, articulating a Mahāyāna Buddhist argument with Marxist overtones,

Progress in the realm of government is from the authority of tribal chieftains to a monarchy, and from a monarchy to a republic, and from a republic to [the ideal of] no-government at all. In religion, progress is from [the belief in] many gods to one

\footnotetext{
${ }^{749}$ In the original Indian tradition, though Maitreya arrives in a future golden age, he does not bring it about. However, by the seventh century, some Chinese Buddhists had developed a different view that considered Maitreya to be a power of salvation. This became a powerful idea for the rest of Chinese history, associated with rebellions and uprisings. See Jan Nattier, "The Meanings of the Maitreya Myth: A Typological Analysis," in Alan Sponberg and Helen Hardacre ed., Maitreya, the Future Buddha (Cambridge: Cambridge University Press, 1988), 36.

${ }^{750}$ For Taixu's position on anarchism and utopianism, see Ritzinger, "Anarchy in the Pure Land: Tradition, Modernity, and the Reinvention of the Cult of Maitreya in Republican China," 28-98.
} 
god, from one god to sages and worthies, and from sages and worthies to no religion at all. ${ }^{751}$

In Taixu's view, Mahāyāna Buddhism, which contains elements of atheism and anarchism, demonstrated the superior stage of the evolutionary process of all human civilizations. The religion-less future would come when the Buddhist Dharma had infiltrated the lives of all sentient beings. 'Buddhism' itself, as a formally structured religious tradition, would be forgotten, ${ }^{752}$ but the essence of Buddhism, Taixu asserted, would expand to every corner of the earth. Finally the universal, eternal truth of Buddhism [pubian hengchang de zhen 普遍恆常的真] would sweep out all the illusion of the past and erase the boundaries between new and old. ${ }^{753}$

\section{Revival or Decline?}

Let us return to the question that Liang Qichao asked in the 1920s: Is Buddhism progressive or regressive ${ }^{754}$ This question, which should be one of the core issues of the history of Chinese Buddhism, had, however, seldom been directly addressed by historians or Buddhist scholars. Fundamentally, this predicament was just one 'historical mirror' of the more general situation China was experiencing at that moment: the inescapable clash of traditions and external forces (here, modernity). Its crux, however, was neither how these modern figures thought about modernity nor whether they had correctly understood the theory of modernization, but instead was more teleological: namely, what they really needed from the modern theories, which questions they asked, and what kind of answers they were looking for.

Liang Qichao's and Taixu's cases show that there was more divergence than accordance in their studies on the history of Buddhism, although both of them attempted to establish a paradigmatic narrative of the general history of Buddhism

\footnotetext{
${ }^{751}$ Taixu, “Wushen lun 無神論,” TXQS, 13, 41.27: 286

752 Ibid, 295.

${ }^{753}$ Taixu, “Xin jiu wenti de genben jiejue 新舊問題的根本解決,” TXQS, vol.22, 33-40.

${ }^{754}$ Liang, fojiao jiaoli zai Zhongguo zhi fazhan 佛教教理在中國之發展, SBP, 137.
} 
with some modern elements. For example, Liang and Taixu both intended to trace Chinese Buddhism back to its Indian origin. However, Liang's purpose was to shed light on the particularity of Chinese Buddhism through historical comparison, while Taixu's emphasis on Indian Buddhism was derived from his belief that the purest, ultimate form of the Dharma only existed in the age of the Buddha. These different opinions led to different patterns of periodization. Generally, Liang classified the history of Buddhism into two periods, i.e. pre-Sinicized Buddhism and post-Sinicized Buddhism (he also further applied a temporal framework of formation, development, and flourishing based on the thesis of 'three ages,' as mentioned before); Taixu, on the other hand, basically divided the history of Buddhism into two stages: the age of the Buddha and the age after the Buddha's death. ${ }^{755}$ Clearly, Liang's pattern used China/Chinese as the criteria of periodization while Taixu's pattern centred on 'the Buddha.'

A more profound divergence between them lay in their views of history and their concepts of historical changes. To Liang Qichao, especially before 1928, progressivism was the universal principle of history and the 'causality' behind the complicated historical phenomena. Buddhist history, in his view, confirmed the theory of progressivism and could be explained and organized using the linear model of progress. Taixu, in contrast, moved in another direction. He showed less interest in providing historical interpretations of Buddhism in specific historical contexts; rather, he utilized Buddhist teachings to judge and explain progressivism and other prevailing modern thoughts. To him, the reason and purpose for history were truistic and unable to be obtained beyond the Dharma.

However, somewhat ironically, Taixu's conclusion suggested not the abandonment of the new Western thoughts that he criticized with such dedication, but the reformation of Buddhism itself-a Buddhist revolution, through which Buddhism could become more ethical, socially engaged, "humanist," and modern. Liang Qichao, on contrary, showed clearly in his later works that Buddhism, as an essential element of Chinese tradition, should maintain its own character and be

${ }^{755}$ Taixu, “Fojiao shilue 佛教史略,” TXQS, vol.1, 895. 
protected from succumbing to secular powers and modern values. He saw Buddhism itself as self-consistent, complete, and requiring no revision.

It seems, at least from most of the contradictory opinions of Liang Qichao and Taixu, that there was a considerable gap between historians and religious figures, which was probably attributed to their identities, their beliefs as well as the class to which they belonged. This gap, which was always covered by the friendly and harmonious atmosphere in academia at that time, could be observed here and there in their debates and communications. One example might be the limited but cautious contact between Taixu and Hu Shih. In one letter Hu wrote to Taixu before Taixu's trip to Europe, Hu carefully advised Taixu "to give up the self-insistence [wozhi 我執] on 'the Oriental spirituality' and to be a student, rather than a missionary or religious leader." 756 On the other side, Taixu, in his article "On Hu Shih's Outline of the History of Chinese Philosophy" criticized straightforwardly that Hu Shih's "concept of history" relied on Western progressivism and was fundamentally wrong. He argued that Hu prejudicially concentrated on the so-called "trend of time" [shidai chaoliu 時 代潮流] and devoted himself narrowly to the 'reason' and 'effect' of every single historical event, ignoring that 'reason' and 'effect' are not always correspondingly related and are not relevant to the 'truth.' As in the case of Buddhism, he bluntly commented that Hu was "judging something that he even did not understand."757 In another article, Taixu criticized more directly that Hu hurt Chinese scholarship badly by applying Western theories indiscriminately; therefore, Taixu wrote, "he [Hu] would better not continue with writing the general history of Chinese philosophy." ${ }^{158}$

This situation was actually quite common in modern China. It was undoubtedly not the first time Hu Shih encountered this kind of censure-he had already known the responses from other Buddhist leaders, such as D.T Suzuki. However, did this scenario really only amount to a dialogue between the deaf? The real issue, or the foundation of the dialogue between historians like Hu Shih and

\footnotetext{
${ }^{756} \mathrm{Hu}$ Shih 胡适, “Zhi Taixu 致太虛.” Geng Yunzhi 耿雲志, Ouyang Zhesheng 歐陽哲生 ed., Hu Shih Shuxinji 胡適書信集 (Beijing: Peking University Press, 1996), 401.

${ }^{757}$ TXQS, vol. 28, 276-77

${ }^{758}$ Taixu, “Ping Zhongguo xueshu shi gailun 評中國學術史概論,” TXQS, vol 28, 247.
} 
Buddhist reformers like Taixu, lay not in their concepts of history or Buddhism but in their understanding of modernity and the whole enterprise of China's modernization.

In much significant scholarship on Chinese religion, the dominant discourse was the "the pull of modernity. ${ }^{759}$ According to this interpretation, the advent of modernity was a 'challenge' to which religion must 'respond.' Earlier studies of this model often presumed a "soft version of classical secularization theory," in which modernity by its nature condemned religion to a shrinking sphere of social and cultural life. More recent works tended to see secularism as an ideological project rather than a law of social development. Either way, religion in China was considered forced into the modernization of some forms as the price of survival in the new age. Although some scholars also stressed that this was a 'creative' response, religion was nonetheless portrayed as fundamentally degenerate, reactive, and defensive. The core narrative-Buddhism adapts to meet the challenge of the modern era-and conclusion-demythologization, rationalization, and social engagement—remained the same. ${ }^{760}$

Regardless of its Euro-centric and Protestant implications ${ }^{761}$, this narrative model of 'challenge and response' did prepare the ground for discussion between intellectuals with 'more secular' and 'more religious' positions, as in the case of Liang Qichao and Taixu: they were both thinking about the future when they wrote their

\footnotetext{
${ }^{759}$ Ritzinger, "Anarchy in the Pure Land: Tradition, modernity, and the reinvention of the cult of Maitreya in Republican China," 7-11.

${ }^{760}$ It was widely employed by the studies of Japanese Buddhism in the wake of the Meiji persecution. See for example, Orion Klautau, "Against the Ghosts of Recent Past: Meiji Scholarship and the Discourse on Edo-Period Buddhist Decadence," in Japanese Journal of Religious Studies 35, no. 2 (2008): 263-303.

${ }^{761}$ Protestantism, according to Weber, played an important role in the emergence of modernity; see Max Weber, The Protestant Ethic and the Spirit of Capitalism (New York: Routledge Classics 2001); and Max Weber, Economy and Society (Berkeley: University of California Press 1978), 10-12, 15. This view had been taken by several scholars as the archetype of the 'modern religion' and attempted to understand modern forms of Buddhism's accommodation to modernity in term of a 'Protestantization'. This is most explicit in Obeyesekere's formulation of "Protestant Buddhism'. See Gananath Obeyesekere, "Religious Symbolism and Political Change in Ceylon," Modern Ceylon Studies 1, 1 (1976): 43-63. Also, Richard Gombrich and Gananath Obeyesekere, Buddhism Transformed: Religious Change in Sri Lanka (Princeton, NJ: Princeton University Press 1988), 13-15 and chapter 6.
} 
histories. This tendency also led to a prevailing, if not monopolistic, discourse: the Buddhist revival. It proposed that although Buddhism was forced to adapt to the modern era to avoid extinction, modernization was also good for Buddhism, since it would bring about its 'revival' and further promise a better Buddhism that would be more suitable for the future.

This was, nevertheless, highly problematic and represented a situation that Gadamer has called the "hermeneutical circle". This 'revival' discourse imposed its own 'progressive' expectations upon the historical investigations of Chinese Buddhism, interpreting the transformation (or revolution) of Buddhism as a teleological agenda. It was, fundamentally, not a description of what had happened, but an expression of the prejudice within this revival interpretation itself. Indeed, when scholars made judgments about the Buddhist revival, they already had their own understandings of modernity as well as a sort of 'criterion' [Maßstab], which, in Gadamer's sense, was the twofold one of correspondence and coherence. ${ }^{762}$ In this sense, if we discuss people's descriptions and reflections on the history of Buddhism at that time within the framework of the Buddhist 'revival', it is easy to conclude that the understanding of the history of Buddhism by Liang Qichao, Taixu, and others was always in the service of the reform and modernization of Buddhism. And Buddhism could gain its historical status by proving its 'progressiveness' in the historical experience of the past.

Indeed, Taixu emphasized 'newness' in his Buddhist revolution, especially at the institutional level; however, we can gather from his historical writings a more conservative facet of him, which was highly skeptical about the faction of modernity and was attached to the perfect, superior Dharma essence. Liang Qichao, also, never used the word "revival," and indicated several times that Buddhism itself need not be reformed. The historiography of Buddhism in modern China reveals precisely the ambiguous position among believers and researchers who reflected on the fate of

\footnotetext{
${ }^{762}$ Hans-Georg Gadamer, Truth and Method (London: Bloomsbury, 2004), 279.
} 
Buddhism and China, showing us an attitude toward this religious heritage beyond the picture of 'revival'.

Maybe it is time to return to Welch, who, for the first time, explicitly posted the term 'revival' in his influential monograph The Buddhist Revival of Modern China. Based on his observation of Taixu's failure of the Buddhist revolution, Welch portrayed Taixu as an intelligent but too idealist, or even ridiculous, figure in his book. This impression was more or less premature, for Taixu's revolution continued and to a certain degree succeeded through the efforts of his disciples and other modern clerics after his death. However, Welch's concern is crucial: the fruition of 'Buddhist revival' could be bitter. As he warned, if the modernizing, secularizing reforms had been fully fulfilled, "most of the identifiably Buddhist, specifically religious institutions and practices would have faded away." ${ }^{" 63} \mathrm{~A}$ 'revival' might have been, for Buddhism, suicide rather than survival, and it would not lead Buddhism to a better future but push it off the cliff. Insightful as Liang Qichao and Taixu were, they must have had a similar feeling. That is the reason why there were always paradoxes and hesitation in their writings of Buddhist history.

\footnotetext{
${ }^{763}$ Welch, The Buddhist Revival in China, 51, 269.
} 


\section{CHAPTER 5}

\section{Questioning Buddhist Canon}

Texts of Dazangjing 大藏經 ${ }^{764}$, the canon of Buddhist scriptures written in literary form ${ }^{765}$ have served as the foundation for the thought and practice of Chinese Buddhism from the medieval period onwards to the present. During the transmission of Buddhism in China, the canonical literature was traditionally conceived as the Chinese translation of original Buddhist texts in Sanskrit, or at least as conveying the true sayings and teachings of the Buddha. ${ }^{766}$ To the Chinese, among whom nobody had seen the Buddha or listened to his voice in person, Dazangjing consisted of the entity of the Dharma, both historically and doctrinally. However, this textual foundation was not stable. Once introduced to China by foreign monks, Buddhist texts experienced ceaseless translation, editing, modification, and misreading. The authorship, dates of creation, and the circulating information of some scriptures remain unclear. Adding the fact that Śākyamuni's teachings were initially in oral form and the lack of historical records on the Dharma lineage in India, the

\footnotetext{
${ }^{764}$ For the definition of Dazangjing, Fang Guangchang 方廣錩, “Defining the Chinese Buddhist Canon: Its Origin, Periodization, and Future," Journal of Chinese Buddhist Studies 28 (2015): 1-34.

${ }^{765}$ The word 'canon' is derived from the Greek word 'kanon', 'can', 'ruler', figurative: 'rule', 'norm', 'model'. For the etymology and historical development of the term, see Gerald T. Sheppard, "Canon," Mircea Eliade ed., The Encyclopedia of Religion, vol. 3 (New York: Macmillan, 1987), 62-69. Jonathan Z. Smith has defined canon broadly as "the arbitrary fixing of a limited number of 'texts' as immutable and authoritative." "Sacred Persistence: Toward a Redescription of Canon," id., Imagining Religion: From Babylon to Jonestown (Chicago/London: University of Chicago Press, 1982), 36-52. Also, Paul Harrison, “Canon." In Encyclopedia of Buddhism. Robert E. Buswell ed., 115 (New York: Macmillan Reference USA, 2004), 111-115.

${ }^{766}$ The Pali canon was more or less fixed. We can be fully sure about its actual contents only from Buddhaghosa's commentary in the 5th century onwards. Cf. K.R. Norman, "Buddhism and Canonicity," id., A Philological Approach to Buddhism: The Bukkyo Dendo Kyokai Lectures 1994 (London: SOAS, 1997); cf. also Gregory Schopen, "Two Problems in the History of Indian Buddhism: The Layman/Monk Distinction and the Doctrines of the Transference of Merit." Studien zur Indologie und Iranistik, 10 (1985): 9-47.
} 
authenticity of Buddhist scriptures and their Chinese translations had been questioned by Chinese Buddhists from the Tang dynasty onwards. ${ }^{767}$ The increasingly skeptical attitude to Chinese Buddhist texts propelled monk Xuanzang 玄奖 (600-664) to make his historical pilgrimage to India. However, in the centuries after Xuanzang, the passion for searching for original truth from scattered Buddhist texts gradually died out. ${ }^{768}$

At the beginning of the twentieth century, the historical basis of Dazangjing was called into question again, especially for the texts that were highly related to the origin or nature of Chinese Buddhism, such as the Sütra of Forty-Two Chapters [Sishier zhangjing 四十二章經], Treatise on Awakening Mahāyāna Faith [Dasheng qixinlun 大乘起 信論] and the Sütra of Perfect Enlightenment[Yuanjuejing 圓覺經], the Platform Sūtra [Tanjing 壇經] and so on. This academic trend of re-examining Buddhist texts, which soon attracted attention from many leading intellectuals in the first half of the twentieth century in China, consequently resulted in two phenomena: the first one was that the Buddhist canon became involved in a process of "de-canonization" and became a neutral, objective source waiting to be examined and utilized. Its historical value as truth started to replace its religious function. The second one was an 'anxiety about orthodoxy' - the prevailing suspicion concerning Buddhist texts shook up the basis of the structure of Chinese Buddhism. Hence, Chinese Buddhism, as a mixture of native ideologies and foreign thoughts, had to reclaim its particularity as a Chinese cultural tradition; meanwhile, after thousands of years of indigenization, it needed to re-identify its 'real' origin and clarify its kinship with Indian Buddhism. ${ }^{799}$

\footnotetext{
${ }^{767}$ For the process of the creation, categorization, and circulation of the Chinese Buddhist literature, see Jiang Wu and Lucille Chia, “Spreading Buddha's Word in East Asia," (New York: Columbia University Press, 2015), 432.

${ }^{768}$ The reason why Chinese Buddhists after the Tang dynasty showed less interest in searching for original Dharma, according to some scholars, was the establishment the sanctity of Chinese Buddhism, especially the emergence of the Chan school.

${ }^{769}$ Most of these studies on Buddhist texts were collected and arranged by Zhang Mantao 張曼漙 into three volumes in his Xiandai fojiao xueshu congcan 現代佛教學術叢刊, see XFXC, vol. 2-4.
} 


\section{The Authenticity of Chinese Buddhist Texts}

Since Buddhism entered into the Middle Kingdom, the perplexity of 'authentic Buddhism' haunted Chinese Buddhists for centuries. The scarcity of authoritative Indian Buddhist masters coupled with the lack of accurate translations of Indian texts rendered a proper understanding of Buddhist canonical texts virtually impossible. Although the apologists of Buddhism, like the scholar-monks in the Wei and Jin eras, attempted to build reliable parallels between Indian Buddhism and its native variations (the hermeneutic strategy of 'geyi' 格義 [matching concepts/meanings] is one example $)^{770}$, they failed to prevent Buddhism from being conflated with Chinese thought.

When the essential ambiguity of Buddhist texts in the Sanskrit and Pali traditions is taken into account, as well as the general attitude of Buddhism towards 'words,' which is linked profoundly with Buddhist cosmology, the issue of authenticity becomes even more complicated. ${ }^{771}$ In Early Buddhist scriptures, the universe is depicted as governed by impersonal laws, namely the Dharma-an idea whose the roots lie in the notion of $r t a$ [cosmic order] of the early Vedas. The Buddha, although believed to be a historical figure who lived in the history of India, is actually not a 'human,' but an embodiment of impersonal forces that ceaselessly move in accordance with the flow of the mahäkalpa [cosmic cycles]. In this line of thought, the historical Buddha, Śakyamuni, is rendered into a symbolic term, not a transient body

\footnotetext{
${ }^{770}$ The issue of 'matching concept' [geyi], along with the related historiographical contexts in the modern scholarship are elucidated in the chapter 6 of this dissertation. In this chapter I will only focus on the historical critique of the Buddhist literature at the textual level.

${ }^{771}$ For the authenticity of Buddhist canons in general, see Lewis Lancaster, "Buddhist Literature: Its Canons, Scribes, and Editors," in The Critical Study of Sacred Texts, ed. Wendy Doniger O'Flaherty (Berlekey: Berkeley Religious Studies Series, 1979). 215-29. See also Laurie Patton ed., Authority, Anxiety, and Canon: Essays in Vedic Interpretation (Albany: State University of New York Press, 1994).
} 
with flesh and blood but rather a figure represented by his eternal teachings, the dharmakāya [body of the dharma, fashen 法身]. ${ }^{72}$

Because of the impersonality of the Buddha, ${ }^{773}$ there is a common statement in Buddhism that the Buddha himself never uttered a single word. One may understand this notion merely as a metaphor for the ineffability of the absolute, as demonstrated in Mūlamadhyamakakārikā 中論; however, it indeed intensifies the transcendental, quiescent image of the Buddha. The logical outcome of this silent Buddha is the superficiality and limitation of information in any textual form. Since the Buddha conveys his teaching without language, the complete and perfect Dharma cannot be written down. In this sense, the literal truth of Buddhist scriptures should not even be a problem, because it is nevertheless far away from the Dharmic truth. Especially in the Mahāyāna tradition, sūtras with the opening words "thus have I heard [rushi wowen 如是我聞]" present themselves not as real historical 'records', but as the 'sayings of the Buddha' that disciples had heard. ${ }^{774}$

In China, the authenticity of Buddhist doctrine was largely equated with the quality of the translation, because the reception of Buddhism by the local audience relied on the translated literature. This process demonstrated a switch in the religious 'paradigm': the truth of a Buddhist text lay no longer in its immediate link with the Buddha's real sayings, but in the literal accuracy of the translation from Sanskrit to Chinese. ${ }^{775}$ Early Buddhist translators like Zhi Qian 支謙 (fl. 224) and

\footnotetext{
${ }^{772}$ For the relationship between the body of the Buddha and Buddhist writing, see Robert H. Sharf, Coming to Terms with Chinese Buddhism: A Reading of the Treasure Store Treaties (Honolulu: University of Hawai'i Press, 2009), 100-10.

${ }^{773}$ For example, the first fascicle of the Samādhirāja-sūtra [月燈三昧經] declares that there are one thousand billion buddhas, all with the same name, with sons and disciples of the same name, all born in Kapilavastu.

${ }^{774}$ Gethin, The Foundations of Buddhism, 56.

${ }^{775}$ Some scholars of earlier generations believed that the only appropriate way of examining Buddhism was to turn to its most ancient texts while neglecting later, allegedly degenerate, developments. However, current scholarship rightly opposes this implicit canonization, agreeing that there should be no restriction whatsoever as to which texts or religious expressions are selected for research. See the articles in Curators of the Buddha: The Study of Buddhism under Colonialism, edited by Donald S. Lopez, Jr. (Chicago: University of Chicago Press, 1995).
} 
Kumārajīva had realized the difficulties of conveying meanings through translation; ${ }^{776}$ the learned monk Dao'an, although knowing no Sanskrit, concluded that there were five kinds of distortion [wushiben 五失本] in the translation process of Buddhist scriptures, emphasizing the momentousness of the translation quality. ${ }^{777}$

The request for the accuracy of scriptural translation reached its peak in the Tang dynasty and encouraged two eminent monks, Xuanzang and Yijing 義凈(635713), to travel to Southern and Central Asia. With sufficient knowledge of Sanskrit, both of them, compared to their contemporaries, were more capable of identifying the original version of Sanskrit texts and avoid fallacies in translation. As shown by the record of Fozu tongji 佛祖統紀 written by Zhipan 志磐, a highly institutionalized or even bureaucratic system of scriptural translation was established by Xuanzang, with an 'assembly line' of nine segments. ${ }^{778}$ Through such a meticulous process, the problem of the translation was largely avoided.

After the Tang era, Chinese Buddhism came to adopt an exclusively Mahayanist outlook in a way that it never did in India and embarked on its independent development. The issue of 'authenticity' was more or less ignored, and a

\footnotetext{
${ }^{776}$ Zhi Qian and Kumārajīva emphasized literalness 直 (concentrating on the wording) and the transmission of the substances 質 with refined style 文 and elegance 雅. For example, Kumārajīva had commented that "when converting the Sanskrit into Chinese, the literary embellishments lost. even when it has the basic thought, it is far from the substance of the text." [改梵為秦, 失其藻蔚, 雖得大 意, 殊隔文體]. See Hui Jiao 慧皎, Gaoseng zhuan 高僧傳, CBETA, T, 2059. 50, 332b.

${ }^{777}$ The wu shiben are: 1 . The barbarian speech may be turned completely upside down in order to follow Chinese syntax; 2. The barbarian classics prize substance, whereas the Chinese people prize elegance so that the transmitted text may please the heart of the masses where, without literary polish, it would not fit; the third to the fifth types of shiben involve the practices of blindly deleting repeated sentences and aphorisms from the original Buddhist texts, or summarizing them in one's own words. See Lü Cheng, Zhongguo foxue sixiang gailun 中國佛學思想概論 (Taipei: Tianhua chuban gongsi, 1982), 65. ${ }^{778}$ The nine segments include: 1. yizhu 義主 (the master of translation who reads the Sanskrit texts); 2. zhengyi 證義 (the philological assistant who reviews the texts); 3. zhengwen 證文 (the text appraiser who checks for errors); 4. Shu zi fanxueseng 書字梵學僧 (transliterator who written down the Sanskrit pronunciation with Chinese characters); 5. bishou 筆受 (the translator- scribe who renders the Sanskrit sounds into Chinese words); 6. zhuiwen 緅文 (the text editor who reverses the words into meaningful sentences); 7. canyi 參譯 (the proofreader who compares both texts and corrects faults); 8. kanding 刊 定(the subeditor who deletes the unnecessarily long expressions and balances the phrasing); 9. runwen 潤文 (the stylist who adds the finishing touches). See:fozu tongji, vol. 43. CBETA, T49n $2035430398 a 23$.
} 
new legitimacy merely based on the translated Chinese Buddhist canon gradually formed. ${ }^{779}$ Through a largescale hermeneutic movement conducted by native Chinese Buddhist schools, an indigenized system of Buddhist discourses and terminology was eventually established. Buddhists, normally without Sanskrit training, suspended the further pursuit of the 'original' truth of Buddhist doctrines or the 'genuine Buddhism.' Instead, they placed their attention on the exegetic and hermeneutic issues in texts. Some sects of Chinese Buddhism, such as the Chan school, even fundamentally dispelled the meaning of Buddhist doctrinal texts. ${ }^{780}$

This position invokes a potentially misleading tendency of setting literary sources of Buddhism aside. Moreover, the appearance of a plethora of native 'apocryphal' scriptures exacerbated the deviation of Buddhism from its Indian origin. ${ }^{781}$ Essentially, this situation was not only caused by the limitations of translation techniques or the lack of knowledge about Buddhist doctrines, but was related to the logic that was deeply rooted in the epistemology of the Chinese people and their views of 'truth' in both historical and philosophical senses. In Chinese

\footnotetext{
${ }^{779}$ According to Tairyō Makita 牧田諦亮, the attitude toward sutra was "rather focusing on the thought and technology of excellent translation of the Chinese Buddhist texts than attaching importance to Sanskrit classics, Chinese translation of the Buddhist classics is Chinese Buddhism. For Chinese, Chinese translation is everything about Buddhism. This is the correct view." Tairyō Makita, Yijing yanjiu - Zhongguo fojiao Zhong zhi zhenjing yu weijing 疑經研究--中國佛教中之真經與疑經,” trans. Yang Baiyi, 楊白衣. Huagang foxue xuebao 華岡佛學學報 4 (1980): 286

${ }^{780}$ As indicated by the famous phrase "not establishing words or letters; transmitting outside teachings” [不立文字, 教外別傳], in Puji 普濟, Wudeng Huiyuan 五燈會元第 1 卷.CBETA, T. x80n1565 $10028 b 23$.

${ }^{781}$ The most important studies on the Buddhist apocrypha including the works of Japanese Buddhologists Yabuki Keiki 矢吹慶輝, Hayashiya Tomojirō 林屋友次郎, Mochizuki Shinkō 望月信亨 and Tokiwa Daijō 常磐大定 in the early in middle part of the twentieth century, while more recently the topic has been treated in the works of such scholars as Mizuno Kōgen 水野弘元 and Makita Tairyō 牧田諦亮. The most comprehensive of all works that treat apocrypha are Mochizuki's monumental Bukkyō kyōten seiritsushi ron [佛教經典成立史論] and the more recent Gikyō kenkyū (僞經 研究) by Makita Tairyō. Recently 'apocryphal studies' has become a prominent topic for Western scholars of East Asian Buddhism. In the English language, an extremely valuable volume, Chinese Buddhist Apocrypha, was published in 1990, edited by Robert Buswell. Important Chinese works on this topic include Wang Wenyan 王文顏, Fojing yiweijing yanjiu yu kaoju 佛教疑偽經研究與考錄 (Taipei: Wenjing chubanshe, 1997).
} 
traditions, the practice of formulating one's own theory under the name of ancient sages was quite common. ${ }^{782}$ Intentionally or unintentionally, peddling ideas with the label of 'Classics' or in the parlance of other traditions was believed to have the effect of facilitating understanding, increasing persuasiveness, and resisting attacks. ${ }^{783}$

Due to the inherent difficulties of translation as well as the propensity to create new doctrines, Dazang jing became a multifold production, an unsolid, miscellaneous collection with questionable content. A major portion of the earlier apocryphal texts might have been compiled for the sake of overcoming the initial difficulties of making this Indian thought acceptable in its new home. In the later stages of Buddhism's assimilation in China, new texts were composed for the purpose of clarifying certain doctrinal points that were thought to have been far from adequately treated or to reconcile philosophical and soteriological dilemmas that were not problematic in India. In a process of 'canonization,' some of these texts even became the pedestal for the presentation of the originality of East Asian Buddhism. As Robert Buswell noted, since most of the Chinese Buddhist apocrypha were indigenous compositions instead of translations of Indian texts, they actually addressed "their domestic authors' own religious interests and social concerns." ${ }^{\text {784 }}$

\footnotetext{
${ }^{782}$ In China, there was a tradition of producing 'apocrypha' outside Buddhism. For example, in the Han dynasty, when Confucianists recovered the texts that the Qin had destroyed, they set about the embellishment of the texts by parallel compilation with their own. See Hans Van Ess, "The Apocryphal Texts of the Han Dynasty and the Old Text/New Text Controversy." T'oung Pao, 85, no. 1-3 (1999), 29-64; also, Jack Dull, "A Historical Introduction to the Apocryphal (ch'an-wei) Texts of the Han Dynasty," Ph.D. dissertation (University of Washington, 1966).

${ }^{783}$ In any case, East Asian writers of new Buddhist texts who wanted their particular piece to become canonical followed a strategy of attempting to write in a style and format as close to the Indian texts as possible. If style, format, and content, as well as other considerations, such as luck and timing, were sufficient, a text stood a good chance of making it into the Chinese canon.

${ }^{784}$ Robert E. Buswell, Jr., "Introduction: Prolegomenon to the Study of Buddhist Apocryphal Scriptures," in Chinese Buddhist Apocrypha, ed. Robert E. Buswell, Jr. (Honolulu: University of Hawai'i Press, 1990), 1. See also Koichi Shinohara, "Rethinking the Category of Chinese Buddhist Apocrypha." Studies in Chinese Religions 1, no. 1 (2015): 70-81.
} 
The motivations behind these activities of forgery varied. ${ }^{785}$ Therefore, there were different types of apocrypha: for example, some apocrypha historicized the Buddha or Buddhist deities as a corporeal person who lived in history or had connections with Chinese figures; ${ }^{786}$ some were made to gain acceptance with the rulership or to endorse a particular political power; ${ }^{787}$ there were also a large number of apocrypha aimed at mediating the conflict between Buddhism and local thoughts and catering to the taste of the Chinese audience or fulfilling the requirement of folk religious practice. ${ }^{788}$ Some very influential Chinese scriptures, in all three branches of sūtra, vinaya, and abhidharma, formulated sectarian thoughts and ideologies by creating new 'canonical texts' under the name of the Buddha or ancient eminent

\footnotetext{
${ }^{785}$ The reasons for producing apocryphal can be divided into different categories: for example, Shinkō Mochizuki lists five forms of apocryphal scriptures: 1. texts related to Taoism and folklore religions; 2 . texts related to the Mahayana vow and Bodhisattva path; 3. texts related to tathagatagarbha doctrine and Tantric Buddhism; 4. Dasheng qixinlun [Treatise on the Awakening of Mahāyāna Faith]; 5. Chinese scriptures under the names of Aśvaghoșa and Nāgārjuna. See Shinkō Mochizuki 望月信亭, “Fojiao chengli shilun 佛教經典成立史論,” trans. Shi Yinhai 釋印海, Zhongguo fojiao 中國佛教, 41, 7 (1997): 42-46. In his “Yijing yanjiu 疑經研究," Tairyō Makita listed six kinds of apocryphal scriptures: 1. political works that echo the intention of government power; 2. texts that criticize the political power; 3. texts that compromise with or compare to other Chinese traditional thoughts; 4 . texts that propagandize certain sectarian doctrines or beliefs; 5 . works under the names of particular individuals; 6. works related to superstitious activities, such as praying and curing. See Tairyō Makita, "Yijing yanjiu - Zhongguo fojiao Zhong zhi zhenjing yu weijing 疑經研究--中國佛教中之真經與疑經," 284306.

${ }^{786}$ For the relationship between Taoism and the Huahu jing, see Holmes Welch, Taoism: The Parting of the Way (Boston: Beacon Press. 1957), 152; some scholars believe that it is a forgery because there are no historical references to it until the early 4 th century CE. It has been suggested that the Taoist Wang Fu [zh] 王浮 may have originally compiled the Huahujing circa 300 CE. See Louis Komjathy, Daoist Texts in Translation, 34.

${ }^{787}$ See also N. Harry Rothschild, Emperor Wu Zhao and Her Pantheon of Devils, Divinities, and Dynastic Mothers (New York: Columbia University Press, 2015). Rothschild has addressed how supporters forged connections between Emperor Wu Zetian and female deities of various origins including Confucian, Daoist, and Buddhist.

${ }^{788}$ Examples include the Foshuo fumu enzhong nanbao jing 佛說父母恩重難報經 (see Kenneth Ch'en, "Filial Piety in Chinese Buddhism." Harvard Journal of Asiatic Studies 28 (1968), 81-97); the GaoWang Guanshi Yinjing 高王觀世音經, see Yü Chun-fang 于君方, “Weijing yu Guanyin Xinyang 偽經與觀音信 仰,” Chung-Hwa Buddhist Journal 中華佛學學報, 8, (1995): 97-135; also her Guanyin, The Chinese Transformation of Avalokiteśvara (New York: Columbia University Press, 2001), and so on.
} 
monks, for example, Yüanjuejing, Brahmajāla-sūtra 梵網經, Śūramgama-sūtra 楞嚴經, Dasheng qixin lun, Treasure Store Treatise 寶藏論, and so on.

In the traditional Chinese context, the boundary between the 'apocryphal' and 'authentic' texts was sometimes vague. ${ }^{789}$ Even within the framework of 'apocrypha,' texts could further be categorized into two types, 'suspicious scriptures 疑經 and 'fake scriptures 偽經'. The latter referred to texts that were not only literally fake, but also could not fulfill the criteria for exemption from being doubted by the standard of doctrine itself. However, yijing was a more controversial phrase that often indicated some profound problem attributable to a lack of information about the translation or authorship of a text. Guardians of the Buddhist canon were aware, early on, of the profusion of non-authentic texts. They compiled bibliographical categories 經錄 to track the creation and distribution of Buddhist texts. ${ }^{790}$ From Dao'an, the author of the first Chinese Buddhist bibliography Zongli zhongjing mulu 綜 理眾經目錄 to Zhisheng 智昇, who compiled the monumental work of the Buddhist bibliography, Kaiyuan shijiao lu 開元釋教錄, these Buddhists made efforts to list doubtful and spurious sūtras and to "identify the authentic and fake, clarifying the true and false." ${ }^{791}$

\footnotetext{
${ }^{789}$ Other Chinese apocryphal scriptures may also including chaojing 抄經 or jingchao [經抄] (namely, coping some sentences from a sūtra and merging them into a new one.), as well as the scriptures prohibited by political reasons, such as the classics of Sanjie jiao 三階教 [the Three levels movement]. For the studies on sanjie jiao, see Yabuki Keiki 矢吹慶輝, Sangaikyō no kenkyū 三階教の研究 [Studies on the Teaching of the Three Stages] (Tokyo, Iwanami shoten, 1927); also Jamie Hubbard, Absolute Delusionm, Perfect Buddhahood: The Rise and Fall of a Chinese Heresy (Honolulu: University of Hawai'i Press, 2001).

${ }^{790}$ For the study of Buddhist bibliography, see articles in Wu, Jiang, and Lucille Chia ed., Spreading Buddha's Word in East Asia (New York: Columbia University Press, 2015). Also see Tanya Storch, The History of Chinese Buddhist Bibliography: Censorship and Transformation of the Tripitaka (Cambridge: Cambridge University Press, 2014); and Kyoko Tokuno, "The Evaluation of Indigenous Scriptures in Chinese Buddhist Bibliographical Catalogues," in Chinese Buddhist Apocrypha, ed. Robert E Buswell (Honolulu: University of Hawaii Press, 1990), 31-47.

791 “別真偽明是非.” Zhisheng also divided the apocryphal texts into those of doubtful authenticity and those considered definitely spurious. See Tanya Storch, The History of Chinese Buddhist Bibliography: Censorship and Transformation of the Tripitaka, Chapter 5.
} 
Based on this bibliographical labor, the Chinese Buddhist canon was formed and gradually established its 'orthodoxy' during the Song dynasty. ${ }^{792}$ However, the difficulty of authenticity, although largely overlooked afterwards, has never really been solved. In the Chinese context, this issue has not only been connected with the literal quality and narrative truth of texts, but has also been concerned with the survival and fortune of Chinese Buddhism. Ironically, textual fidelity sometimes was no guarantee of long-lasting canonicity. A certain number of the 'doubtful' works would later be accepted as authentic and canonical, either because their content was judged to be consistent with Buddhist teachings, or because there were appropriate circumstances at the time that allowed them to be incorporated. Those Buddhist texts that failed in adapting to the native religious, intellectual, or socio-political climate might disappear, even if they were totally authentic. ${ }^{793}$ Therefore, the phenomenon of apocryphal scriptures in the Chinese context is not simply related to 'fidelity' or the "dark side of Chinese monasticism" — the degenerate state of Chinese Buddhism, as claimed by Erik Zürcher ${ }^{794}$ - but is a historical issue related to the formation and legitimization of Chinese Buddhism.

\section{Textual Orientation}

The formation of the canonicity of Dazang jing was a long journey full of debates, suspicions, and twists. ${ }^{795}$ The composition of Kaiyuan shijiao lu itemized the general

\footnotetext{
${ }^{792}$ Fang Guangchang divided the establishment of the Dazangjing into several stages, according to its form of production. See Fang, Guangchang, "Chinese Buddhist Canon: Approaches to Its Compilation," Studies in Chinese Religions 2, no. 2 (2016): 1-18.

${ }^{793}$ For an excellent examination of the complexity of the factors involved in the attainment of canonicity by a text, see Barbara Herrstein Smith's essay "Contingencies of Value" in von Hallberg's volume entitled Canons (5-39). Smith in particular clarified the dynamics of the interplay among the extremely various types of "value judgments" involved in canon formation.

${ }^{794}$ Erik Zürcher, "Prince Moonlight: Messianism and Eschatology in Early Medieval Chinese Buddhism." T'oung Pao 68, no. 1-3 (1982): 1-75.

${ }^{795}$ According to Aleida and Jan Assmann, there were three tasks within the process of the formation of the canons: censoring; maintaining the text; and maintaining its meaning (Zensur, Textpflege, and Sinnpflege). Aleida and Jan Assmann, "Kanon und Zensur," in Kanon und Zensur: Beiträge zur Archäologie
} 
corpus of the Chinese Buddhist canonical literature. Later, from the Late Ming to Qing dynasties, there was a Buddhist textual revival generated by the flourishing publishing industry. The distribution of Buddhist texts (especially the private publishing of the Jiaxing Canon 嘉興藏) and the expansion of readership spurred intensive reading and interpretation of Buddhist scriptures. This textual revival of Buddhism also led to the formation of a Buddhist-literati community and a syncretic Buddhist culture. ${ }^{796} \mathrm{~A}$ more profound change emerged after the mid-nineteenth century, when China gradually lost its monopoly on the Buddhist canon across East Asia because of the 'posterior' involvement of the West and Japan in Buddhist scholarship. The rapid developments in relevant disciplines outside China indicated a switch of methodological paradigm and a transfer of the power of authority from China to other places, even those unrecognizable to most Chinese Buddhists and scholars at that time. ${ }^{797}$ The 'authenticity crisis' and the consequent struggle to recapture China's prior status in Buddhist scholarship incited the effort to seek and assemble Buddhist texts. In an effort conducted by Yang Wenhui and other Buddhists leaders, large-scale Buddhist texts were re-collated and re-published. The emergence of new resources also stimulated scholars outside the Buddhist circle to study Buddhist texts with new ideas and from new perspectives.

\section{Evidential Learning and Doubting Antiquity}

der literarischen Kommunikation II, ed. Aleida and Jan Assmann (München: Fink, 1987), 7-27. See also the articles in the same volume by Alois Hahn, "Kanonisierungsstile," 28-37; and Carsten Colpe,

"Sakralisierung von Texten und Filiationen von Kanons," 80-92.

${ }^{796}$ Monks in the Late Ming dynasty, for example, the 'Four eminent Monks,' joined the literati circles and were highly trained in literary composition and art, such as calligraphy, music, and painting. For the literary outputs of the Buddhist clergy and the relationship between clergy and literati, see Liao Zhaoheng 廖肇亭's articles, such as “Wanming sengren sanju shi lunxi: yi hanyue fazang wei zhongxin 晚明詩人山居詩論析：以漢月法藏為中心," in Zhongbian, shichan, mengxi: mingmo qingchu fojiao wenhua lunshu de chenxian yu kaizhan 中邊・詩禪 - 夢戲--明末清初佛教文化論述的呈現與開展 (Taipei, Yunchen Wenhua, 2008), 273-300.

${ }^{797}$ For the 'crisis' narrative, see Wu Jiang, Living for the Rising Sun: Chinese Zen Master Yinyuan \& the Authenticity Crisis in Early Modern East China (Oxford: Oxford University Press, 2015). 
The extensive re-examination of Buddhist texts that emerged at the beginning of the twentieth century was an inevitable outcome of the philological turn of the Qing scholarship, especially the influential Evidential Learning [kaozheng 考證]. As Benjamin Elman remarked, this philological grid represented a fundamental shift in the common codes of elite knowledge about the past, namely, "a shift from SongMing rationalism, typified by the moral philosophy of Zhu Xi, to a more skeptical and secular classical empiricism." ${ }^{\text {" }} 98$ Representative figures of this trend, from Gu Yanwu 顧炎武 and Huang Zongxi 黄宗羲 to Hui Dong 惠楝, Dai Zhen 戴震, and so on, advocated for an empirically based scholarship grounded on concrete facts, verifiable institutions, historical truth, and literal evidence, instead of abstract ideas and principles [li 理].

Fundamentally, the goal of kaozheng was to retrieve lost fragments of ancient books and identify their versions, authorships, and other publishing data, as well as judge the authenticity of their content. From the Han to Qing dynasties ${ }^{799}$, kaozheng had developed into a systematic field with concrete methods, including bibliography [jiaochou xue 校倠學] $]^{800}$, philology [xiaoxue 小學] ${ }^{801}$ and textual criticism [laozheng xue 考證學 ${ }^{802}$, with a set of approaches, such as cataloguing, collating, editing,

\footnotetext{
${ }^{798}$ Benjamin Elman, "Early Modern or Late Imperial Philology? The Crisis of Classical Learning in Eighteenth Century China," Frontiers of History in China 6, no. 1 (2011): 6.

${ }^{799}$ The tradition of Kaozhenguxe can be traced back to Han scholar Liu Xiang 劉向 (79-8 BC) and his son Liu Xin 劉歆 (46 BC-AD23). They for the first time combined the term ' $m u$ ' 目 (literally 'subtitle') with the term 'lu' 錄 (literally 'record', 'report') and composed the bibliographical work qilue 七略, which marked the beginning of the Chinese bibliographic (mulu) tradition. See Yu Jiaxi 余嘉錫, Muluxue fawei 目錄學發微 (Beijing: Zhonghua shuju, 2007), 23-26.

${ }^{800}$ Sub-branches include mulu xue 目錄學 [studies on bibliographical catalogues], banben xue 版本學 [studies on the version of books], and jiaokan xue 校勘學 [collation]

${ }^{801}$ Xiaoxue include xunguxue 訓詁學 [text-based semantics], wenzixue 文字學 [etymology], and yinyunxue 音韻學 [phonology].

${ }^{802}$ These branches in classical Chinese are often mixed and therefore hardly to define, both historically and literally. In general, muluxue, banbenxue, and jiaokanxueindicate the studies on books can be brought into the domain of jiaochouxue 校隹誰學, in a generalized sense. The branch of textual criticism is closer to a method of exegesis and is basically equal with jiaochou. See Rudolf Blum, Bibliographia: An Inquiry into Its Definition and Designations, trans. Mathilde V. Rovelstad (Chicago: American Library Association, 1980); Luigi Balsamo, Bibliography: History of a Tradition, trans. William A. Pettas (Berkeley: B.M. Rosenthal, 1990).
} 
summarizing, literature listing, and so on. As mentioned by Elman, kaozheng studies, although maybe not 'scientific' or 'objective' per se, represented an embryonic form of 'science,' replacing the moral discourses of lixue 理學, and shifted the goal of scholarship from the pursuit of perfect personality to the systematic study of empirical knowledge that could be deployed in secular life. ${ }^{803}$ To this degree, this philological turn of scholarship was an innovation of 'technique', within which more and more emphases were placed on methodology and materials.

Along with methodological innovation, towards the end of the eighteenth century, the prestige of the Classics had diminished vis-à-vis historical studies. Scholars like Zhang Xuecheng 章學誠 began to "place the timeless Classics within the framework of the endless flux of history." ${ }^{804}$ Admittedly, scholars like Zhang were still 'traditional' literati who remained committed to the ideals of Confucianism and sought to restore the classical visions of state and society according to their Confucianist faith. In this sense, Evidential Learning was never really 'revolutionary. ${ }^{805}$ Under the veil of Daoxue, the Late Qing literati returned to the past to root Chinese scholarship again by resuscitating the path of 'Han Learning.' The Late Han dynasty (as opposed to the Former Han, in which the New Text school was in vogue) was seen to represent the solemn force of the Old Text school, an ideal of Classical Learning, but also the latest period that the interpretations of the Confucian Classics had not been influenced by Taoist and Buddhist notions ${ }^{806}$ Remarkably, this

\footnotetext{
${ }^{803}$ The evidential studies were related to natural studies such as mathematics and physics, as Elman has mentioned.

${ }^{804}$ Benjamin Elman, "Early Modern or Late Imperial Philology? The Crisis of Classical Learning in Eighteenth Century China," 9.

${ }^{805}$ Although Elman has called Evidential Learning a scientific "revolution of discourse," he has noted the difference between traditional kaozheng and the new scholarship that emerged in the twentieth century. Michael Quirin has made this point even clearer by claiming that kaozheng is "rather a further elaboration of the critical aspects of the special hermeneutics of the classics which became more and more elaborate from the Tang and Song dynasties onward." See Michael Quirin, "Scholarship, Value, Method, and Hermeneutics in Kaozheng: Some Reflections on Cui Shu (1740-1816) and the Confucian Classics," History and Theory 35, no. 4 (1996): 34-53.

${ }^{806}$ According to Chen Yinke, the 'orthodoxy' of Confucianism had been influenced by Buddhism in Tang dynasty. The foundation of Song learning, namely Neo-Confucianism, which was formed by Han
} 
attitude led the late Qing literati to carefully examine the Buddhist element in Classical Learning and the impact of this foreign thought on native cultural heritage. Although maintaining a critical attitude towards 'Buddhisized' Classical Learning, they never fully banished Buddhism, from either their scholarship or their personal lives. ${ }^{807}$ For example, Qing classist Qian Daxin 錢大昕 deployed Buddhist scriptures and Buddhist phonetic books to discuss the alphabet and phonetic system of Chinese. ${ }^{808}$ Other scholars, such as Gong Zizhen, Weiyuan, and Yu Yue, wrote commentaries for Buddhist scriptures and drew on Buddhist ideas to elaborate on the Gongyang Learning. ${ }^{809}$

The marginalization of the Classics as well as the alienation of 'knowledge,' 'application,' 'belief,' and 'practice' led to a conceptual lag in the transformation of Chinese scholarship in late imperial China ${ }^{810}$ and influenced the new generations of scholars. ${ }^{811}$ During the early Republican era, the lasting influence of the kaozheng paradigm had persuaded historians, from Liang Qichao and Wang Guowei to younger scholars such as $\mathrm{Gu}$ Jiegang, to respect historical truth as the foundation of knowledge in the field of humanities. Some scholars, such as Liang Qichao, even used

Yu, was inspired by the xinxing [心性] theory of Buddhism. See Chen Yinke, “Lun Han Yu 論韓愈,” in JMCB, 321-22.

${ }^{807}$ Private belief in and practice of Buddhism were very common among Late Qing literati. See chapter 3 "Buddhism of the Late Qing Literati."

${ }^{808}$ Qian Daxin used Xuanying 玄應's Yiqiejing yinyi 一切經音義 and Yuqie shi di lun 瑜珈師地論 to demonstrate that the Chinese phonetic system of thirty-six letters originated from Mahāparinirvāna Sütra, instead of Huayan Sütra. See Qian Daxin, Shijiazhai yanxin lu 十駕齋養新錄. As Chen Yuan noted, in the Late Qing dynasty, studies on 'yiqie yin [ 一切音] were very popular [顯學]. Chen Yuan, Zhongguo fojiao shiji gailun 中國佛教史籍概論.

${ }^{809}$ See Ma Tianxiang 麻天祥, Wanqing foxue yu jindai shehui sichao 晚清佛學與近代社會思潮 (Taipei: Wenjin, 1992), vol.1, 22-37; vol.2, 33-95.

${ }^{810}$ Wang Fansen, "Introduction," in Sixiang shi shenghuo de yizhong fangshi: Zhongguo jindai sixiang shi de zai sikao 思想是生活的一種方式一中國近代思想史的再思考 (Taipei: Linking, 2017).

${ }^{811}$ One of the intriguing questions of modern Chinese history is how the marginalization of Confucian doctrinal concerns relates to the development of the modern Chinese intelligentsia that grew out of the traditional intellectual elite. See Luo Zhitian, "The Marginalization of Classical Studies and the Rising Prominence of Historical Studies during the Late Qing and Early Republican: A Reappraisal," in Transforming History: The Making of a Modern Academic Discipline in Twentieth Century China, 49-55; and Michael Quirin, “Die chinesische Intelligenz und die Macht,” Oriens Extremus, no.1-2 (1995), 239-258. 
kaozheng to refer to the whole of Qing scholarship and others, like Xiong Shili, tried to reveal its transcendental facet. In this sense, as Luo Zhitian and Chang So-an analyzed, ${ }^{812}$ the term (kaozheng or kaoju) was actually overused as an independent discipline, ignoring that it was originally, as Fu Sinian argued, "only method, not a goal." ${ }^{" 13}$

Around the 1890s, under multiple influences, including confrontation with Western imperialism and a rising Japan, the destructive impact of the Taiping Rebellion, and the revisionist developments within traditional scholarship, ${ }^{814}$ the kaozheng movement underwent its eventual denouement. Nevertheless, skepticism about traditional historical materials remained strong, especially under the influence of the New Culture and May Fourth movements.

In the 1920s, the Doubting Antiquity School was officially formed with the propagation of historians such as Hu Shih and Gu Jiegang and his fellows. ${ }^{815}$ Newly

\footnotetext{
${ }^{812}$ For relevant questions as to whether Evidential Learning can be considered as an independent discipline or not and the Qing scholars' own discussions on this topic, see Luo Zhitian 羅志田, “Fangfa cheng le xueming: Qingdai kaojuxue heyi chengxue 方法成了學名: 清代考據何以成學.” Wenyi yanjiu 文㙯研究, 2010. And Chang Sho-an 張壽安 “Qingru de 'zhishi fenhua' yu 'zhuanmen zhixue' mengya: cong jichang bianlun tanqi 清儒的 “知識分化”與 “專門之學”萌芽: 從幾場論辯談起, ’ in Lingnan Journal of Chinese Studies 嶺南學報, 3 (2015): 59-94.

${ }^{813}$ Fu Sinian, “Taida ‘shehui kexue luncong’ fakan ci 臺大<社會科學論丵>發刊詞” [1950]. In Fu Sinian quanji 傅斯年全集 (Changsha, Hunan jiaoyu chubanshe, 2003) vol. 3, 367.

${ }^{814}$ See Elman, "From Philosophy to Philology," 232-253. On the difficulties of the modern empirical disciplines in nineteenth-century China see for example Knight Biggerstaff, The Earliest Modern Government Schools in China (Port Washington, N.Y. and London, 1972).

${ }^{815}$ The Doubting Antiquity school was represented by Gushibian 古史辨 (Debates on Ancient History), a scholarly movement led by Gu Jiegang, centred on the magazine of the same name. Seven issues of the magazine, 1926-1941, contained about 350 essays. Most of their criticism concerned the authenticity of pre-Qin texts and dealt with questions put forward by past dynastic writers, as well as other subjects. Hu Shi initiated the critical movement, with his pupil Gu Jiegang and his friend Qian Xuantong continuing this school of thought. Their writings also had influence on many Western Sinologists, including Bernhard Karlgren and Samuel Griffith. For the studies on the Doubting Antiquity school, see Schneider, Ku Chieh-kang and China's New History: Nationalism and the Quest for Alternative Traditions.; Wang Fansen, Gushi bian yundong de xingqi 古史辨運動的興起 (Taipei: Yunchen, 1987); Pung Mingfei 彭明輝, Yigu sixiang yu xiandai Zhongguo shixue de fazhan 疑古思想與現代中國史學 的發展 (Taipei: Shang wu yinshu guan, 1991).
} 
discovered excavated materials, such as the oracle bone inscriptions, Han dynasty wooden slips from Guodian 郭店, Dunhuang manuscripts, and so on, revealed that the existing literature was full of dubious texts. From Zhang Xuecheng and Cui Shu to the New Text critics initiated by Kang Youwei, ${ }^{816}$ a revisionism of critiquing the inherited beliefs and the nature of antiquity emerged, laying the foundation for the new forms of disciplinary practice of history in a scientific, objective way. ${ }^{817}$

To the Doubting Antiquity school, the Chinese textual tradition was always guilty of historicizing legends and myths through a kind of euhemerization. Therefore, in order to recover the "true face" [benlai mianmu 本來面目] (a term Gu Jiegang borrowed from Buddhism) of China's past, historians needed to examine historical texts with “scientific methods 科學方法” and sift the authentic materials from the falsified ones. The general attitude and approach of the Doubting Antiquity school received approbation throughout modern academia. In one article published in 1924, Hu Shih endorsed the method of the Doubting Antiquity school for it followed the standard of "evidence." ${ }^{1818} \mathrm{Hu}$ Shi affirmed this approach and argued that critiquing and questioning the credibility of antiquity would not cause the loss of faith or the "corruption of people's minds [renxin bianhuai 人心變壞]”; rather, this

\footnotetext{
${ }^{816}$ According to the studies of some scholars, the intention of 'doubting antiquity' had long existed in the tradition of Classics learning. Scholars such as Zhang Xuecheng 章學誠 and Cui Shu 崔述 tried to return back to the origin of the Sage's Dao [shengren zhidao 聖人之道] and Six Classics, instead of relying on the Han scholars's commentaries. Cui's ideas in his Kaoxinlu deeply influenced Gu; however, despite the ideological background of Zhang, Cui was fundamentally different from Gu Jiegang and Qian Xuantong. See Pung Mingfei, Yigu sixiang yu xiandai Zhongguo shixue de fazhan 疑古思想與現代中 國史學的發展, 17-32.

${ }^{817}$ As mentioned below, both Hu and Gu had advocated using a 'scientific method' to arrange the 'national essence.' See Gu Jiegang, “Wo men duidai guogu caiqu de taidu 我們對國故採取的態度”; and Hu, Zhixue de fangfa yu cailiao 治學的方法與材料." Some scholars have thought that there is a direct relationship between the historiographies of $\mathrm{Hu}$ and $\mathrm{Gu}$ and Western scientific thought, especially the pragmaticism of Dewey. See Laurence A. Schneider, Ku Chieh-kang and China's New History, 62-63. However, other scholars have argued that Hu and Gu's understanding of science was very limited. For example, Lin Yusheng 林毓生 has pointed out that Hu's 'science' was actually ‘scientism.' See his The Crisis of Chinese Consciousness, Radical Antitraditionalism in the May Fourth Era (Madison: University of Wisconsin Press. 1979), 85,89, 91-92. Also, Daniel Kwork, Scienticism in Chinese Thought.

${ }^{818} \mathrm{Hu}$ Shih, “Gushi taolun de duhougan 古史討論的讀後感,” in Gushibian, 1, 190.
} 
scientific, objective historiography would contribute to the establishment of a "new system of history [xinde lishi xitong 新的歷史系統]." ${ }^{1919}$

By filtering out the forgery from the authentic, historians of the Doubting Antiquity school sought to place Chinese history on the basis of factual, provable 'truth' through de-canonization and de-mythologization. To them, reading the ancient books with suspicion should be the first, if not the most important, step in restoring the past along empirical lines. This attitude, which combined kaozheng with a 'pragmatist genetic' method imported by Hu Shih, became an influential research paradigm and was widely practiced by historians. ${ }^{820}$ As a consequence, the common philosophical foundation of Chinese scholarship —Confucianism - was replaced by a shared, universal methodological tendency. ${ }^{821}$ The lively research activities of this school not only indicated that the value of the factual-evidential truth had surpassed the value of morals in historiography, but also embodied a further separation between historical materials and historical concepts. Historiography, then, became fundamentally a kind of 'science' with a consensus about its function: different historical writings might conflict with each other in certain stances on faiths or concepts; however, they had the same innate value as defending knowledge and truth. Because historiography had further escaped from the burden of philosophical commitments $^{822}$, the Doubting Antiquity school argued that the mission of historiography was to overcome a distorted tendency of historicizing un-real

\footnotetext{
${ }^{819}$ Ibid.

${ }^{820}$ Surrounding $\mathrm{Gu}$ and the publications led by Gu, such as Gushi bian and Yugong 禹貢月刊, an academic community was formed. Besides, this method focused on historical materials was also endorsed by Fu Sinian and his colleagues in the History and Philology Department of the Academia Sinica 中研院史語所.

${ }^{821}$ See Pung Mingfei, Yigu sixiang yu xiandai Zhongguo shixue de fazhan 疑古思想與現代中國史學的發展.

${ }^{822}$ Actually, historians like Gu Jiegang still could not cast off the influence of the Six Classics and relied too much on texts such as the Analects and Shijing. See Pung Mingfei, Yigu sixiang yu xiandai Zhongguo shixue de fazhan 疑古思想與現代中國史學的發展, 90. The paradox within Gu's study has also been analysed by Laurence Schneider; see Schneider, Ku Chieh-kang and China's New History: Nationalism and the Quest for Alternative Traditions., 2. Ursula Richter also saw Gu as a "a traditional and yet modern scholar who was true to tradition also in that he 'obeyed yet resisted'." See Zweifel am Altertum.: Gu Jiegang und die Diskussion über Chinas Alte Geschichte als Konsequenz der 'Neuen Kulturbewegung' ca. 1915-1923 (Frankfurt a. M: Steiner Franz Verlag, 1992), 288.
} 
information into history and to reveal the mythical nature of the traditional narratives that had long been understood as historical and real. ${ }^{823}$

The concept of myth and its related discourses emerged in the historiography of the Doubting Antiquity school and its neighboring fields, such as folklore studies. ${ }^{824}$ This research trend echoed historians' interests in popular literature, including Buddhist vernacular narratives such as the recorded sayings of Chan Buddhism, avadāna [piyu 譬喻], bianwen [transformation texts, 變文] and so on. Dividing myth from history was a rule that helped historians to draw boundaries around their writings ${ }^{825}$ since the deployment of the term of 'myth' actually indicated a new sense of historicity, according to which some inherited knowledge was discarded, and some was recategorized. ${ }^{826}$ Through a similar process, the canonized corpus of Dazangjing was carefully divided into different sub-categories, such as Buddhist folk literature, Buddhist histories, Buddhist doctrines, Buddhist ritual texts, and so on. This classification, according to Brain Moloughney, followed the invisible track of the 'secularization' of religious knowledge. ${ }^{827}$

\footnotetext{
${ }^{823}$ See G. Boltz William, “Kung Kung and the Flood: Reverse Euhemerism in the 'Yao Tian', ' in T'oung Pao, 67 (1981): 141-53.

${ }^{824}$ Most of the studies were published in the nine issues of the Folksongs weekly. For the relationship between the folklore study of Gu and the May Fourth movement, see Haiyan Lee, "Mengjiang nü and the May Forth Folklore Movement," Wilt L. Idema, trans. \& ed., Meng Jiangnu Brings Down the Great Wall: Ten Versions of a Chinese Legend (Seattle: University of Washington Press, 2008), 24-41.

${ }^{825}$ However, as pointed out by Brain Moloughney, there was a linguistic confusion between the terms 'myth' and 'legend' that remained undiscussed in Gu's work. See Brain. Moloughney, "Myth and the making of history: Gu Jiegang and the Gushi bian debates," in Transforming history: The making of a modern academic discipline in twentieth-century China, 243. The term 'shenhua' 神話 was a modern neologism, coined in Japan by Takagi Toshio 高木敏雄(1876-1922) and soon deployed to advance the development of the modern discipline of folklore studies, especially through the work of Yanagita Kunio 柳田國男(1875-1862). See Mori Kōichi, “Yanagita Kunio: an interpretative study,” Japanese Journal of Religious Studies 7, no.2-3 (1980): 83-115.

${ }^{826}$ For the relationship between historical study and myth, see William H. McNeill, "Mythistory, or Truth, Myth, History, and Historians," in The American Historical Review, 91, no. 1 (1986), 1-10. Also, Andrew von Hendy, The Modern Construction of Myth (Bloomington: Indiana University Press, 2002). ${ }^{827}$ Brain Moloughney, "Myth and the making of history: Gu Jiegang and the Gushi bian debates," in Transforming history: The making of a modern academic discipline in twentieth-century China,
} 
Radically, the Doubting Antiquity school considered the traditions about early China as the outgrowth of deliberate fabrication. Hence, 'ancient history' was no longer a "credible history [xinshi 信史] ${ }^{828}$ Based on this knowledge, historians should not follow the common procedures of 'questioning-investigating-proving', but using the principle of 'argument from silence [mozheng 默證]' ${ }^{829}$ that is, systematically rejecting all the writings of ancient history from the very beginning. ${ }^{830}$ This attitude towards ancient Chinese Buddhist texts could be observed in Hu Shih's critical interpretation of Chan Buddhism as well as Lü Cheng's skepticism towards Chinese Buddhist literature. ${ }^{831}$

In particular, Gu's famous stratification thesis, or the theory of the "layered creation of ancient Chinese history [cenglei zaocheng de Zhongguo gushi 層累的造成 的中國古史]" ${ }^{332}$ formed a lucid picture of the formation of Chinese history. Although problematic to a certain extent ${ }^{833}$, the stratification thesis was adopted by many historians. For example, Tang Yongtong analyzed that the historical accounts of the White Lotus sects were shaped by the layered imaginations and associations of later

${ }^{828}$ The late Qing scholars tended to believe that more ancient a historical text was, more creditable it might be. 'The adoration of ancientness' was a mainstream concept in Qing scholarship. For example, the scholarship of Hui Dong as "anything if ancient then real." For this tradition and the challenge of the New Textual School, see Wang, Fansen, Gushi bian yundong de xingqi 古史辨運動的與起, chapter 2. ${ }^{829}$ This method of mozheng 默證 was criticized by Zhang Yinlin 張蔭麟. Zhang cited the saying of Seignobos to point out that Gu ignored the nature and historical context of texts and the limits of the form of mozheng itself. Actually, the absence of a certain concept or term does not mean it did not exist. See Zhang Yinlin, “Ping jinren duiyu gushi zhi taolun (Gushi jueyilu zhiyi) 評近人對於古史之討 論(古史決疑錄之一).” Xueheng, 40 (1925).

${ }^{830}$ Pung Mingfei, Yigu sixiang yu xiandai Zhongguo shixue de fazhan 疑古思想與現代中國史學的發展, 6265.

${ }^{831}$ For further analysis, see the latter part of this chapter.

${ }^{832} \mathrm{Gu}$, Yu Qianxuantong xiansheng lun gushi shu 與錢玄同先生論古史書," in Gushi bian 古史辩 (Shanghai: Shanghai guji chubanshe, 1982), vol.1, 59-66. For a contextual study of the Gushibian movement and Gu's stratification thesis, see Wang Fansen, Gushi bian yundong de xingqi 古史辨運動的 興起.

${ }^{833}$ Gu's approach to the textual evidence about early China, which Wang Fansen argued was that "of a conspiracy theorist" was critized by Wang Guowei, Liu Yizheng, Qianmu, Zhang Yinling 張蔭麟, and so on. See Brain. Moloughney, "Myth and the making of history: Gu Jiegang and the Gushi bian debates," in Transforming history: The making of a modern academic discipline in twentieth-century China, 245-256. 
believers ${ }^{834}$ Historically, Buddhist texts were perfect examples of the process of 'stratification,' for they combined authentic facts with fictional narratives in a layered way: miracle tales, oral accounts, prophecies, omens, and legends were utilized without division in order to strengthen the power of belief, establishing the religious authority, or serving sectarian purposes. Hu Shih's study of Chan Buddhism, also followed the same pattern to reveal how Chan history was full of accumulated fabrications by depicting it as "clambering the dragon and phoenix [fanlong fufeng 攀 龍附鳳].” The story of Bodhidharma's meeting with Emperor Wu of the Liang dynasty, which Hu analyzed as an example, went through this process of stratification, like "rolling a snowball that became bigger and bigger." ${ }^{835} \mathrm{To} \mathrm{Hu}$, the revised and enlarged versions of Chan scriptures, such as the creation of the Platform Sütra, were the result of Chan monks' intentional activities of 'tampering with ancient books [wanggai gushu 妄改古書]."

The Doubting Antiquity movement, although not directly related to the development of Buddhist scholarship, drove the transformation of Buddhist textual tradition and further influenced the newly emerged historiography of Buddhism by emphasizing textual evidence as well as the less-religious features of Buddhism. In this modern period, this radical historiographical standpoint provoked the Buddhist 'insiders' and 'outsiders' to think more seriously about what the 'credible' history of Buddhism should be; what was the relationship between true belief and the 'truth' that could be filtered by science and located in the framework of 'knowledge'?

\section{New Materials and New Questions ${ }^{837}$}

As kaozheng and textual criticism began to perform as a shared methodology among scholars from the Late Qing dynasty, new materials became the crux of

\footnotetext{
${ }^{834}$ Tang, Hanwei, 575-77.

${ }^{835} \mathrm{Hu}$, “Puti damo kao 菩提達摩考," in HSWC, part 3, vol.4.

${ }^{836} \mathrm{Hu}$, “Tanjing kao zhier 壇經考之二," in HSWC, part 4, vol. 2.

${ }^{837}$ Chen Yinke 陳寅恪, Chen Yuan Dunhuang jieyu lu xu 陳垣敦煌劫餘錄序, in JMEB, 266.
} 
historiography. ${ }^{838}$ Newly discovered materials opened the door for scholars to enter into unexplored territory, stimulating them to organize these data into the existing literary corpus. The obsession with textual materials reached its peak in the Qing dynasty and eventually caused the 'antiquarianization [gudonghua 古董化]' of scholarship. ${ }^{839}$ Then the younger, Western-educated scholars such as Hu Shih, Fu Sinian, Gu Jiegang, and so on ${ }^{840}$ further advocated "an equal perspective [pingdeng de yanguang 平等的眼光]" towards materials. ${ }^{841}$ Against this background, Buddhist texts became extremely important 'new material.'

Remarkably, a large portion of the new sources discovered or regathered during the Republican era were Buddhist texts, including the Dunhuang manuscripts, the Jiaxing Canon, and the re-published Buddhist Tripițaka in Chinese (with a supplement from the Japanese Taisho), Tibetan, and Mongolian, as well as some Buddhist-related archives from the Grand Secretariat archives. The wealth of these materials attracted many scholars to devote themselves to the study of Buddhist texts. For example, Hu Shih's groundbreaking study on Chan Buddhism was incited by his discovery of the Dunhuang collection. Chen Yuan's study on Ming and Qing Buddhism, especially his two monographs A Study on Buddhism in Yunnan and Guizhou Provinces in Mid-Ming and Debates Between Monks in the Early Qing Dynasty, was based on

\footnotetext{
${ }^{838}$ For a modern reflection on the traditional concept of historical materials [shiliao 史料], see Wang Fansen 王汎森, “Shenme keyi chengwei lishi zhengju? Jindai Zhongguo xinjiu shiliao guandian de chongtu 什麼可以成為歷史證據? 近代中國新舊史料觀點的衝突,” in Zhongguo jindai sixiang yu xueshu dexipu 中國近代思想與學術的系譜, 343-376.

${ }^{839}$ Zhang Xueshu 張學書, Xin faxian de Fu Sinian Shuzha jilu 新發現的傅斯年書札輯錄, unpublished, cf., Wang Fansen, Zhongguo jindai sixiang yu xueshu de xipu 中國近代思想與學術的系譜, 346.

${ }^{840} \mathrm{Hu}$ Shih elaborated his critique in the essays “Guogu jikan fakan ci” 國故季刊發刊詞 and “Zhixue de fangfa yu cailiao” 治學的方法與材料. In HSWJ, vol.4, 105-06.

${ }^{841}$ The equality of historical materials was stressed by many modern historians, such as Hu Shih, Gu Jiegang, Li Ji, and so on. See ibid; also Gu Chao, Gu Jiegang nianpu 顧頡剛年譜, 119; Li Ji, “Zhongguo zuixin faxian zhi xin shiliao 中國最新發現之新史料, ” in Guoli zhongshan daxue yuyan lishi xue yanjiu suo zhoukan 國立中山大學語言歴史研究所週刊, 5, 57/58 (1928): 3.
} 
the Yulu of Chan Monks in the Jiaxing Canon he discovered in the royal collections in the Imperial Palace. ${ }^{842}$

The development of the study of bronze and stone inscriptions [jinshixue 金 石學] and historical geography also provided more relevant data and a new perspective to this field. Scholars like Tang Yongtong, Chen Yuan, and Hu Shih placed great emphasis on epigraphical texts-inscriptions on tablet, tombstones, Buddhist statues, etc., as well as chorographical texts, such as temple gazetteers, local chronicles, and so on. Besides the collection of rare, unused primary sources, the scope of materials was largely expanded due to a more open attitude towards texts with different origins and fragmentary materials scattered in local archives, folk literature, images, and so on. For example, Tang Yongtong's History demonstrated the highly synthetized utilization of different sources of materials from official histories to historical narratives written by Buddhist historians, such as the Gaoseng zhuan and Chusanzang jiji. He paid special attention to the modifications, overlaps, distinctions, and alterations between texts, both at literal and content levels. When investigating the life and lineage of Monk Fayao 法瑤, he not only cited the biographies of Fa Yao and other monks, such as Huijing 慧靜 and Daoping 道平 in Gaosengzhuan, but also referred to other Chinese Buddhist texts, such as Ke jingang pi xu 科金剛錍序 ${ }^{843}$, Fahua

\footnotetext{
${ }^{842}$ The Jiaxing zang, which Chen Yuan saw in the archive of the Grand Secretariat of Qing, was persevered in the collection of the Ming and Qing royal palace. It has 10,888 volumes with 2,141 kinds of scriptures, for a total of 2,453 volumes in 344 cases. This version of Dazangjing was printed between 1579, the seventh year of the Wanli era of the Ming dynasty and 1707, the forty-seventh year of the Kangxi era of the Qing dynasty. During the Shunzhi, Kang xi, and Yongzheng eras, it was revised, enlarged, and copied, and stored in the Grand Secretariat in the Qiankong era. For a historical investigation of the Jiaxing zang, see Shi Fachuang 釋法幢, “Mingqing zhiji jiaxingzang diaoyin de shimo yinyuan 明清之際嘉興藏雕印的始末因緣.” Zhongguo foxue 中國佛學 1 (2014): 23-40. For the scholarly significance of the Jiaxing Canon, seeLi Xueqing 李學勤, “Jianxiangzang yu mingqing zhiji lishi yanjiu <嘉興藏>與明清之際歷史研究,” Gugong bowuyuan yuankan 故宮博物院院刊 105 (2003): 5; also Dai, Lianbin, “The Economics of the Jiaxing Edition of the Buddhist Tripitaka." T'oung Pao 94 (2008): 306-359.

${ }^{843}$ CBETA: T n1932, p. 781a06.
} 
wenju 法華文句, and Sanlun yizhang 三論義章, and records from official histories, such as the biography of Zhang Rong 張融. ${ }^{844}$

This "equal sight" also directed historians to texts in different languages. Due to their Sino-Western hybrid educational background, many modern scholars became very sensitive to changes of meaning in translation. They also acquired the ability to read and compare multi-language texts. In one letter to his sister, Chen Yinke stressed this method of comparative linguistics:

The Tibetan Buddhist canon has many materials written by Nāgārjuna, Aśvaghoṣa, which have not been translated into Chinese. Even for the translated ones, [the Tibetan Buddhist canon] can be used for comparative collation...... If [we] can use the Western method of linguistic science to do the comparative study between Chinese and Tibetan texts, [we] can reach a higher level than the Qianjia School 西藏文藏 經, 多龍樹馬鳴著作而中國未譯者。即已譯者, 亦可對勘異同……如以西洋語言 科學之法, 為中藏文比較之學, 則成效當較乾嘉諸老更上一層. ${ }^{845}$

To Chen, using the approach of Western linguistic science that he had learned from Orientalists such as Lüders and Lanman was one potential path to making an outstanding contribution to the fields of philology and history. ${ }^{846}$ However, his research also differed from mainstream of Western Indology ${ }^{847}$ He did not concern himself with Vedic studies, which were the most popular branch in Germany in his time, and he seldom dealt with the linguistic problems, such as vocabulary, grammar, etc., of Sanskrit and Pali. His study focused on the translation process of texts from

\footnotetext{
${ }^{844}$ According to the records in Songshu and Gaoseng Zhuan, Tang found that after the Xinan Temple was established by the Xiaowu Emperor, Fayao started to teach the meaning of 'gradual enlightment' there for 19 years, till his death.

${ }^{845}$ Chen Yinke, “Yu mei shu 與妹書," JMEB, 355-56. In a letter to Fu Sinian, Chen emphasized again this method. Chen Yinkeji · Suxin, 23-24.

${ }^{846}$ For the language knowledge of Chen Yinke, see Chen Huaiyu, Zai xifang faxian Chen Yinke: Zhongguo jindai renwenxue de dongfangxue yu xixue Beijing 在西方發現陳寅恪: 中國近代人文學的東方學與西學 背景, 100-122.

${ }^{847}$ For the history of Western Indology, see William Peiris, The Western Contribution to Buddhism (Delhi: Motilal Banarsidass, 1973), 81-161. For Indology in Germany, see Velentina Stache-Rosen, German Indologists: Biographies of Scholars in Indian Studies Writing in German: With a Summary on Indology in German Speaking Countries (New Delhi: Max Müller Bhavan, 1990).
} 
Sanskrit into Chinese, namely, the changes in meaning, signifiers, and contexts between the different language systems. This research model was what he sometimes called Oriental studies but more often called comparative textual criticism.

Other scholars, such as Lü Cheng, also valued this method ${ }^{848}$ When compiling Zang yao, a bibliographical work of the Dazangjing, Lü summarized the method he used as:

I oppose the practice of collating only based on Chinese Buddhist scriptures in the past, but using Sanskrit, Palī, Tibetan and other texts to conduct a comparative study with Chinese translated Buddhist scriptures. 我一反過去僅就漢譯佛典作校勘的做 法, 而是利用梵、巴（巴利文）、藏等幾種文字與漢譯佛典進行對勘。 ${ }^{849}$

Lü conducted this comparative research in a very meticulous way. He firstly translated each Buddhist scripture from Sanskrit, Tibetan, and Pali into Chinese, and then literally compared and collated these different translations with their original texts in Indian languages and their early Chinese translated versions. By doing so, he identified the latter sectarian commentaries, records, and teachings mixed into the

\footnotetext{
${ }^{848}$ One piece of evidence is that Chen, Hu, and Lü had learned from or cooperated with Alexander von Staël-Holstein 剛和泰 (1877-1937). According to Chen Yinke's daughter, Chen Liuqiu 陳流求, Chen visited Staël-Holstein every Saturday. See Jiang Tianshu 蔣天樞, Chen Yinke xiansheng biannian shiji 陳寅 恪先生編年事輯 (Shanghai: Shanghai guji chubanshe, 1997), 77. According to Hu's diary, Hu had cooperated with Staël-Holstein for two years as the interpreter of Staël-Holstein's course on the history of Ancient Indian religion at Peking University. Hu also learned Sanskrit from Staël-Holstein. See Hu Shih riji 胡適日記 [1937. 3. 16] (Beijing: Zhonghua shuju, 1985).

${ }^{849}$ see Gao Zhennong, “huai nianenshi Lü Cheng xiansheng 懷念恩師吕澂先生” in Wutaishan yanjiu 五 台山研究, 1 (1998): 33.
} 
text, exploring their origins and historical strata. ${ }^{850}$ This approach was described by Lü Cheng as "smelting Sanskrit, Pali, Chinese and Tibetan in one furnace." 851

In contrast to the traditional attitude towards Buddhist texts, new materials and questions in Buddhist scholarship reinforced the importance of textual resources, indicating a tendency which Philip Almond has called "textualism." ${ }^{152}$ As unprecedent emphasis had been placed upon evidence written on paper, stone, and other artifacts, 'truth' then largely relied on the authenticity of text itself; the history of Buddhism, consequently, sometimes became a history of Buddhist literature. Behind this tendency was a profound shift in the ownership of primary materials. New materials-scriptures from the Dunhuang caves, the imperial treasury, and museums and libraries (some in Europe and Japan)—-were firstly obtained by nonBuddhist scholars from universities and research institutes instead of by monks and nuns. As more and more archaic languages became known to non-Buddhist scholars, and more and more venerable texts were amassed and cataloged in 'secular' institutes, the historiographical method acquired a burgeoning authority over the monastic institution of knowledge. When the historians read Buddhist texts, the imaginary enemy in their minds was also no longer learned monks and religious authorities, but rather Western Sinologists ${ }^{853}$, such as Alexander Staël von Holstein

\footnotetext{
${ }^{850}$ For example, in the collation notes of the Mahā-prajñāāāramitā Sūtra [Da borejing 大般若經], Lü clarified that: "the collation of this volume went through three rounds. The first one is the 'translation-collation' [yijiao 譯校] that using the Mahā-Prajñāpāramitā Sūtra translated by Kumārajīva

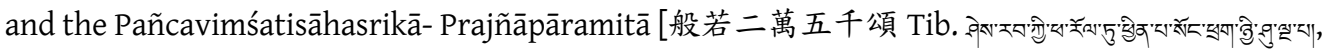

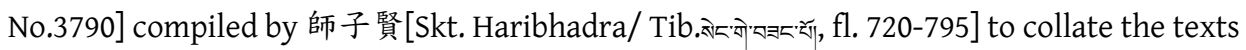
comparatively. The second one is the 'apology-collation' [leijiao 類校] that using the MahāPrajñāpāramitā Sūtra translated by Xuanzang and the Mahāprajñāpāramitāśāstra translated by Kumārajiva; The third one is edition-collation [kejiao 刻校] that using the different block-printing versions to collated with each other.” Lü Cheng, “Da borejing dierfen jiaokan shuoming 大般若經第二 分校勘說明,” in Zangyao 藏要, Ouyang Jingwu 歐陽竟無 ed., (Shanghai: Shanghai shudian, 1991), 3-4. 851 “冶梵、巴、漢、藏於一爐.” Gao Zhennong, “Huai nianenshi Lü Cheng xiansheng 懷念恩師吕澂先 生,” 34 .

${ }^{852}$ Philip C. Almond, The British Discovery of Buddhism (Cambridge: Cambridge University Press, 1988), 3, $24,27$.

${ }^{853} \mathrm{Hu}$ Shih, for example, was amazed to read Staël von Holstein's work on Chinese ancient phonetics using Buddhist Dhāran̄īs. See Hu Shih Riji quanbian 胡適日記全編, Cao Boyan 曹伯言 ed. (Hefei: Anhui
} 
and K. Klas Benhard 高本漢, and 'the seniors of the Qian-jia school [qianjia zhulao 乾 嘉諸老]'.854

Despite their varied perspectives, different methods, and often contradictory conclusions, modern scholars focused their studies on several common issues, some of which were not totally out of the vision of the pre-modern Buddhist scholars but were addressed with new perspectives. First was the bibliographical information of Buddhist scriptures and treatises. Traditionally, the authenticity and fidelity of Buddhist texts, though noted by many scholarly monks, such as Xuanzang, was not considered a critical issue. The doubts surrounding scriptures centered on whether the texts accurately conveyed the Buddha's intentions in the translation process, although the bibliographical facts of certain texts, such as the identity of the author, the date of its compilation, and information about its versions had also been recorded and examined. In modern China, however, clarifying the origin of texts and their bibliographical background became the primary task of historians and the prerequisite for all their follow-up studies. This tendency, of course, emerged under the influence of both Qing Learning and the development of Western bibliographical scholarship. ${ }^{855}$ Text was seen a self-supporting system and, as Hu Shih noted, "can only be addressed by 'paperwork [zhishang de gongzuo 紙上的工作]', such as collation and exegesis; going beyond this scope would make stupid mistakes." This

jiaoyu chubanshe, 2001), vol.3, 605. He was also surprised that Sinologists like Benhard had surpassed the Qing scholars. Hu Shih wencun, vol.3, 120-121. See also Wang Fanseng, "Shenme keyi chengwei lishi zhengju 什麼可以成為歷史證據, " in Zhongguo jindai sixiang yu xueshu de xipu 中國近代思想與學術的 系譜, 348. Chen Yinke also influenced by K. Klas Benhard. See Yu Dawei, "Huainian Chen Yinke xiansheng 懷念陳寅恪先生,” Lishi yuyan yanjiusuojikan 歷史語言研究所集刊, 41, 1 (1969).

${ }^{854}$ Chen Yinke, “Yu mei shu 與妹書," JMEB, 355-56.

${ }^{855}$ In the early decades of the twentieth century, large numbers of bibliographies on Sinology and Oriental studies were published in Europe, such as the Orientalische Bibliographie published in Germany and the Bibliotheca Sinica published in France. See Chen Huaiyu, Zai xifang faxian Chen Yinke: Zhongguo jindai renwenxue de dongfangxue yu xixue Beijing 在西方發現陳寅恪: 中國近代人文學的東方學與西學 背景, 165-97. Japanese scholars, such as Naitō Torajirō, 島内翰 highly stressed bibliographical studies. See Qian Wanyue, “Cisheng chengjiu mingshan ye, buyan chongyang shi wanghuan: Neiteng Hunan Zhongguo fangshu jiqi xueshushi yiyi shulun 此生成就名山業, 不厭重洋十往還一内藤湖南中國訪書 及其學術史意義述論, ”Journal of East Asian cultural interaction studies 東アジア文化交涉研究, 3 (2008): 135-59. 
kind of work, namely collecting, identifying, and arranging lost, fragmentary materials, was named by Chen Yuan 'the study of historical origins [shiyuan xue 史源 學]', the very basic “insight and method of reading all history books." ${ }^{1856}$ As indicated in his book An Overview of the Historical Texts of Chinese Buddhism [Zhongguo fojiao shiji gailun 中國佛教史籍概論], the accuracy of the title [mingmu 名目], abbreviated title [lüemu略目], volume number, and version information of every book, as well as the background of the author, ${ }^{857}$ although they might not be directly related to the content of the book, were the prerequisite for its historical legitimacy and further philosophical validity. Every historiographical statement needed to have its root solidly in primary textual records. This was considered not only a practical technique of historians but also their essential expertise and responsibility.

The second issue was the historical context of Buddhist texts. Traditionally, Buddhist texts, no matter whether doctrinal or ritual, were read as purveyors of the Dharma. However, in modern times, as 'secular' historians entered this area, Buddhist texts were no longer the expression of concepts but a response to historical circumstances. Therefore, historians were asking question about why these texts were produced and how they were read under certain historical condition. Through a 'contextual reading' of Buddhist texts as historical materials, these historians tried to reveal the conceptual inadequacy of purely scriptural studies and their relevant exegetical problems, and further avoided anachronistic misunderstandings and ignorance of the changing phenomena behind texts. In particular from the 1930s to 1940s, many historians began to write the history of Buddhism as a kind of political or social history. For example, Chen Yinke had commented on Chen Yuan's works on Ming-Qing Buddhism as "participating in the trend" of modern scholarship, for they explored new ways of writing religious history as "political history." ${ }^{858}$ Liang Qichao's critique of Chinese Buddhist treatises, Chen Yinke's reading of translated Buddhist

\footnotetext{
${ }^{856}$ Chen Yuan, Shiyuan xue xuexi ji qingdai kaozheng fa 史源學學習及清代考證法 (Beijing: Shangwu yinshuguan, 2014), 1. For Chen's methodology of 'historical origins', see Shi Lijun, Chen Yuan de shiyuan xue lilun yu shijian 陳垣的史源學理論與實踐 (Beijing: Renmin chubanshe, 2016).

${ }^{857}$ CYQJ, vol. 17, 496.

${ }^{858}$ Chen Yinke, 敦煌劫餘錄序. JMCB.
} 
literature, Tang Yongtong's study of Wei-Jin monks, Hu Shih's discovery of the recorded sayings of Shenhui, and Chen Yuan's reading of the Ming-Qing Buddhist texts all led towards the 'contextualization' of Buddhism. Remarkably, none these studies went as far as historical determinism or emphasized too much the socioeconomical elements in history; they still adhered to texts and focused on the dynamic interplay between different cultural forces. It was true that this methodology was consciously resisted, in particular by Buddhists, who insisted on the autonomy of scriptural studies. However, even the most Dharmic interpretations of Buddhist canons written by the Buddhists during this period of time included both some concession to knowing something of social and political conditions, and some gesture toward paying 'due regard' to the historical context that had produced the texts themselves, as we can see in the works of Ouyang Jingwu and Lü Cheng.

\section{Apocryphal Canon? Debates on the Chinese Texts of Mahāyāna}

\section{Buddhism}

Most of the 'dubious' Buddhist texts were early Chinese compositions of Mahāyāna Buddhism written in the guise of original Indian works. Some of them were 'sūtras,' namely scriptures setting the doctrinal foundation of Buddhist thought, such as The Sūtra of Forty-Two Sections 四十二章經 and Yuanjuejing 圓覺經. Others used the term 'treatise' [lun 論] (in Sanskrit śastra), the exegetic or doctrinal works that normally contained teachings on the same level as sūtras and conveyed the Buddha's meaning, ${ }^{859}$ for example, "Treatise on Awakening Mahāyāna Faith." All these Buddhist

\footnotetext{
${ }^{859}$ As Francesca Tarocco has pointed out, the title of many East Asian sūtras begins with the words $\mathrm{fa}$ shuo [佛說] or 'the Buddha says.' The widespread use of this formula highlights the importance placed on direct oral transmission to authenticate Buddhist writings. "Lost in Translation? The 'Treatise on the Mahāyāna Awakening of Faith (Dasheng qixin lun)' and Its Modern Readings." Bulletin of the School of Oriental and African Studies, University of London 71, no.2 Scripture and Modernity: A Tribute to Professor John Wansbrough (2008): 323-343. On issues of translation and Buddhist language see, for example, see Jan Nattier, “Church language and vernacular language in Central Asian Buddhism." Numen 37 no.2 (1990): 195-219; For some interesting comments on the use and reception of sacred texts
} 
texts were highly influential in the history of Chinese or even East Asian Buddhism. ${ }^{860}$ However, the popularity of these texts could not be attributed simply to their doctrinal content (some of them were quite rough and slipshod), but rather to what could be described as 'spiritual capital' —an accumulated power of belief. ${ }^{861}$ Although the authorship, version, and bibliographical nature of these texts remained questionable, they were historically read and worshipped as the original works of Indian Buddhist masters, until the modern age.

\section{Debates on The Sūtra of Forty-Two Sections 四十二章經}

The history of the Sütra of Forty-Two Sections [Sishi'er zhang jing 四十二章經, below: the Sütra] is linked to the earliest stage of the legendary mission of Buddhism from India to China in the Eastern Han dynasty. According to the traditional narrative, this Sütra was firstly introduced into China by two Indian monks, whose names have been rendered variously as Kasyapa Matanga 迦葉摩騰 and Gobharana or Dhamaratna 筑

法蘭. As pointed out by Usr App, this text and its tale of the introduction of Buddhism from India to China played an extraordinary role both in East Asia and later in the Western discovery of Buddhism. ${ }^{862}$ The popularity of the Sütra cannot merely be attributed to the early date of its translation but also to its doctrinal content and its compilation style, which facilitated its transmission. It is not a complete, systematic

within Buddhist traditions see Miriam Levering, Rethinking Scripture: Essays from a Comparative Perspective (Albany: State University of New York Press, 1989), 13-14; 58-101.

${ }^{860}$ With regard to the use here of the term 'East Asian Buddhism,' it should be noted that the Buddhist source texts used in China, Korea, Japan, and even Vietnam are identical and that together they form the tradition that gave rise to what is commonly referred to now in Chinese as dazangjing or the canon of Buddhist scriptures written in literary Chinese.

${ }^{861}$ In her article on the modern reading of the Treatise on the Mahāyāna Awakening of Faith, Francesca Tarocco has used this term by referring Bradford Verter, "Spiritual capital: theorizing religion with Bourdieu against Bourdieu," Sociological Theory 21 no. 2 (2003): 150-74.

${ }^{862}$ The Sütra was not only the first complete Indian scripture to be translated into Chinese, but also the first Buddhist scripture to have been translated into a Western language. See Urs App, The Birth of Orientalism (Philadelphia: Pennsylvania University Press, 2010). 
work, but rather a short collection of "aphorisms and pithy moralistic parables." Meanwhile, because of this unique form, its purported Indian origin is questionable: it may have been compiled in Central Asia or even China. All versions of this Sütra only demonstrate signs that every revision of this text has been based on its earlier versions, and that it was in circulation during the earliest period of Buddhism in China. ${ }^{864}$

The suppositions on this Sütra cannot undermine its importance in the history of East Asian Buddhism. ${ }^{865}$ It attracted attention from Western and Japanese Buddhist scholarship as early as in the eighteenth century ${ }^{866}$, and also triggered heated debates in China during the 1920s and 1930s. The most important studies on this text included $^{867}$ : 1) Liang Qichao's "The Sūtra of Forty-Two Chapters as Falsehood" [“Sishier zhangjing bianwei” 四十二章經辩偽]; 2) Hu Shih's “The Investigation of the Sütra of Forty-two Chapters" ["Sishier zhangjing kao" 四十二章經考] and the commentary from Chen Yuan; 3) Tang Yongtong's “Evidential Studies on the Sūtra of Forty-two Chapters”[“Sishier zhangjing kaozheng”四十二章經考證]; 4) Lü Cheng's

\footnotetext{
${ }^{863}$ Robert H. Sharf, "The Scripture in Forty-two Sections," in Religions of China in Practice, ed. Donald S. Lopez, Jr. (Princeton University Press, Princeton, 1996), 360-71.

${ }^{864}$ Ibid.

${ }^{865}$ For instance, App has examined how one particular Ch'an-influenced edition of the Sutra (the 守遂 註本) had a profound influence on the understanding of Buddhism at the time in Europe, a time in which Buddhist Sanskrit texts were unknown. This influenced philosophers such as Diderot and Schopenhauer.

${ }^{866}$ From the 1750 s to 1800 s, scholars like De Guignes and Klaproth had paid attention to this text. The work of De Guignes displayed an anthropological-historical interest in the subject-after all, the sutra was included as an appendix to the history of the Huns. However, it was couched in religio-centric terms: Buddhism was seen as being derived from early Christian heresies. Fifty years on, Klaproth, on the other hand, flatly contradicted de Guignes on the question of origins: he claimed instead that Christianity was derived from Buddhism. It may well be the case that he sought to cover up his plagiarism by introducing a rival, conflicting interpretation, but it is tempting to see in this a product of the times: post-Revolutionary religious studies were often characterized by a rationalist, politicized-if not outright anti-clerical—tone. Examples see Charles-François Dupuis, The Origins of All Religious Worship (New Orleans: C.C. W Müller, 1872).

${ }^{867}$ The most influential works on this topic in Chinese have been collected by Zhang Mantao ed., Xinadai fojiao xueshu congkan 現代佛教學術叢刊. Articles not mentioned here also include: Related to the research on this sūtra, the textual studies of the mouzi liluo lun are also very important. Articles on Mouzi include:
} 
"The Transcription Time of the Sütra of Forty-two Chapters ["Sishier zhangjing chaochu de niandai”四十二章經抄出的年代]. These articles mainly focused on three issues: first, its date of creation (when the Sütra appeared for the first time in China; was it written or compiled as early as in the Eastern Han, as it claimed, or created later?); second, the nature of this text (Is the Sütra a translated work based on an original Indian scripture in Pali or Sanskrit, or is it a native composition of Chinese Buddhists?); and third, the changes in the versions of this sūtra (namely, during the distribution of this text, was there only one version or two different versions?). Furthermore, discussions surrounding the Sütra also touched upon other relevant issues in Buddhist history, for example, the early acceptance of Buddhism in Northern and Southern China, the path of the transmission of Buddhism, the formation of early Buddhist terminology, and so on. ${ }^{868}$

Partly under the influence of Japanese scholarship, Liang Qichao firstly called the authenticity of this sūtra into question. The title of his article makes Liang's conclusion obvious: the sūtra was an 'apocryphal' Chinese composition that was produced in a comparatively late age.$^{869}$ It was not translated from any Indian text, but rather was a collection that merged different and even contradictory content into a single text by adopting the form of Xiaojing 孝經 and Laozi 老子. Liang argued this for two reasons: first, according to the content of the Sütra and its writing style, he believed that the author should be someone who was very familiar with the prevalent metaphysics of Lao-Zhuang Learning and lived in a time when Mahāyāna Buddhism had already been distributed throughout China. Second, the Sütra had not been recorded in the Dao An 道安's Bibliography [anlu 安錄], but appeared only in later bibliographies, such as Seng You 僧祐's Chusanzangjiji 出三藏記集. Therefore, Liang believed that this Sütra was created in the Eastern Jin dynasty, instead of the Wu

\footnotetext{
${ }^{868}$ For detailed study, see Tsintsin Peng, “Jindai fojiao shixue de beijing he jiaodian: yi weirao "sishier zhangjing' de lunzheng weili 近代佛教史學研究的背景和焦點: 以圍繞《四十二章經》的論爭為例.” Huaren zongjiao yanjiu 華人宗教研究, 5 (Taipei: Xinwen feng, 2015).

${ }^{869}$ According to Liang, "not easier than Eastern Wu while not later than Eastern Jin Dynasty," in SBP, 32.
} 
Kingdom 吳. ${ }^{870}$ Although Liang did not develop his argument into much detail, ${ }^{871}$ his conclusion raised wide attention concerning the Sütra and the issue of the authenticity of early Chinese Buddhist texts.

Soon, Liang's assertion was opposed by Zhou Shujia 周叔迦, Tang Yongtong, and $\mathrm{Hu}$ Shih. One of the pieces of evidence presented by Tang and Hu was two idiomatic expressions - the "leather bag with blood" [genang chengxue 革囊盛血] and “sleeping one night under a tree" [shuxia yisu 樹下一宿], ${ }^{873}$ which could be found in the biography of Xiang Kai 襄楷 in the Houhan shu 後漢書. They used this record-which was in use by Xiang Kai 襄楷 in 166 CE (the ninth year of Yanxi period of the Huan Emporor in the Eastern Han) - to demonstrate that the Sütra had been introduced into China in the Late Han. Tang also tried to find an explanation for Liang's query that the Sūtra was not recorded in Daoan's categories. He claimed (although without concrete evidence) that there would be two versions of the Sütra; the older, less polished one had been replaced by this existing version, which was more literate. However, there were also difficulties with these arguments. Neither Tang nor Hu could clarify the doubt about why there were so many Taoist teachings in this Sütra if it was a translation based on Indian texts. They were also unable to provide conclusive proofs to solve the question about its over-ornate style, which seemed incompatible with other translated Buddhist texts before the Eastern Jin era.

The historian Chen Yuan came to a similar conclusion to Liang's, expounding that the Sütra was translated in a comparative later period (or at least after the Late

\footnotetext{
${ }^{870}$ Ibid. $30-32$

${ }^{871}$ Liang's conclusion was based on several hypotheses and 'unsolid' arguments. For example, he argued that the sutra was created in a later period because of its ornate and polished style. He also quickly moved to other issues, such as the mode of xuefen nanbei 學分南北 of Chinese Scholarship. In the later part of this section, I will further discuss Liang's study.

${ }^{872}$ The original text in the Sūtra is: “天神遺以好女, 浮屠曰: ‘此但革囊盛血.”遂不䀠之.” In Hou Hanshu 後漢書, vol.3, Xiang Kai zhuan 襄楷. However, this phrase could also literally be found in some earlier texts, such as Shiji 史記 (Yin Benji 殷本紀). For a detailed study on the word nang 霊 in Qin and Han texts, see Hu Bo 胡波, Xianqin lianghan 'tuo', 'nang' yanbiankao - jiyu chuanshi yu chutu wenxian de zonghe kaocha 先秦兩漢“橐”、“囊”演變考一基於傳世與出土文獻的綜合考察.” Liyun yuyan xuekan 厲耘語言學刊 2 (Beijing: Zhonghua shuju, 2018).

${ }^{873}$ The original text in the sutra is: “日中一食, 樹下一宿, 慎勿再矣。使人愚蔽者, 愛與欲也.”
} 
Han dynasty). Chen Yuan's discussion, in his commentary on Hu's study of the Taoist work Zhengao 真誥, ${ }^{874}$ adopted a different perspective, focusing on the usage of the term ' $f o$ ' 佛 in the Sūtra. He cited several non-Buddhist writings as evidence to show that the term 'fo,' which was used to translate the Sanskrit word "Buddha," only appeared after the time of the Three Kingdom (before, 'Buddha' had been translated as 'futu' 浮屠). This terminological change from fo to futu, according to Chen, showed that the Sūtra must be written after the Late Han. ${ }^{875}$

Relying on a literal comparison between the Sütra and the Sanskrit scripture of the Dharmmapada 法句經 ${ }^{876}$, Lü Cheng reached a final verdict that was close to the conclusion of Liang Qichao and Chen Yuan while opposing Tang Yongtong's opinion in almost every aspect. Unlike Tang, who believed that there existed at least two versions of the Sūtra, Lü believed that there was only one version of the Sütra before the Liang 梁 dynasty, which had been produced no earlier than the period of Emperor Hui of the Jin 晉惠帝 (fl.306) and was recorded by Sengyou 僧祐 in his Chusanzang jiji. Moreover, Tang suggested that the Sütra was directly translated from the Pali canon; Lü, instead, thought that the Sütra was a collected work of transcribed and copied sentences from the Chinese translation of the Dharmmapada. ${ }^{877}$ According

\footnotetext{
${ }^{874} \mathrm{Hu}$ 's discussion on the sūtra came from his studies of the Taoist literature. He found that in Tao Hongjing 陶宏景's Zhengao 真誥, more than twenty volumes of the contents were copied from the Sütra. This discovery, which Hu considered his original idea, had actually already been discussed by Zhu Xi 朱喜, Huang Bosi 黄伯思, and Sikutiyao 四庫提要.

${ }^{875}$ The letters between Hu and Chen were collected in both Hu and Chen's complete collection of works. See Hu Shih, Hu Shih wenji p 184; Chen Zhichao, Chen Yuan wanglai shuxin ji, pp. 179-183. Their discussion on the Sutra and its broad scholarly context has been discussed by Ge Zhaohuang, “ 'Liaowei youyi de bisai' - Cong Chen Yuan yu Hu Shih de zhenglun shuo dao zaoqi Zhongguo fojiao shi yanjiu de xiandai dianfan 聊為友誼的比賽”一一從陳垣與胡適的爭論說到早期中國佛教史研究的 現代典範,” in Lishi yanjiu 歷史研究 1 (2013): 132-46; Also, Chen Yiai 陳以愛, “30 niandai Hu Shih yu Chen Yuan de jici xueshu jiaoshe 30 年代胡適與陳垣的幾次學術交涉, ” in Jiewang Erbian 結網二編, ed., Zhou Liangkai (Taipei: Dongda tushu gongsi, 2003), 341-408.

${ }^{876}$ Some current scholars, for example, Robert Sharf, did the similar work to Lü, comparing the Sütra with the Dharmmapada. See Robert H. Sharf, "The Scripture in Forty-two Sections," in Religions of China In Practice, ed. Donald S. Lopez, Jr., (Princeton University Press, Princeton, 1996).

${ }^{877}$ In the appendix to his article, Lü provided a detailed table of comparison at the sentence level between the Sütra and the Dharmmapada.
} 
to Lü, the Dhammapada, as a canonical text of the Dharmaguptaka School 法藏部, was translated from Sanskrit into Chinese by Tanguo 曇果 at the end of the East Han dynasty (no earlier than the late years of Emperor Ling 漢靈帝), based on a revised version created by Dharmatāta [Fajiu 法救], a Indian monk who had lived in the era of Emperor Kanishka of the Kushan dynasty. When the Dhammapada arrived China, it had been formed into a style of 'metaphor' [piyu 譬喻], with new content, entries, and commentaries. This piyu style, as well as its loose structure and the traces of the teaching of the Dharmaguptaka school in the Sütra, confirmed its link with the Dhammapada. Adding the records in Buddhist bibliographies, such as the Chusanzang jiji and the Jinglun doulu 經論都錄 compiled by Zhi Mindu 支烣度 (fl. 290-326), Lü concluded that the Sütra was composed by Chinese Buddhists at the transition time between the Western and Eastern Jin dynasties ${ }^{878}$ Against the most persuasive evidence provided by Tang Yongtong and Hu Shih, namely the idioms cited by Xiang Kai, Lü put forward a quite convincing explanation that these two stories might not directly be cited from the Sütra, for both of the phrases had already existed in the Ekottaragama [Zengyi ahan 增一阿含], which had been translated into Chinese as early as in the period of An Shigao 安世高 (c. 140-180 CE). ${ }^{879}$

Although these discussions did not reach a consistent conclusion, these debates were significant for the writing of Chinese Buddhist history since they covered a wide range of issues that were relevant to the early encounter between China and Buddhism, such as the translation and interpretation of the terms $f_{0}$ and futu and the route of the transmission of Buddhism from India to China, ${ }^{880}$ as well as

\footnotetext{
${ }^{878}$ Here Lü also provided proof that, in the prologue of the Sütra, there is the sentence "the former Emperor Xiaoming of Han [Xi Han Xiaoming di 昔漢孝明帝]”; the words “xi” and “Han” implied that the Sūtra was created after the (Eastern) Han dynasty 東漢.

${ }^{879}$ The early Chinese translated version of the Ekottaragama Sūtra was called Ekottaragama Sūtra of One Hundred and Sixty Chapters [Zeng yi ahan bai liushi zhang 增一阿含百六十章], according to Lü's arguments.

${ }^{880}$ There are different opinions about the route of the transmission of Buddhism. In his article "MeouTseu ou les'doutes Leves," Paul Pelliot has pointed out that, besides the route of central Asia, there could be other routes, including a land route between Yunan and Burma as well as a sea route via the South Sea and Guangdong; see Paul Pelliot 伯希和, “Meou-Tseu ou les' doutes Leves," T'oung Pao, SerieII, vol. XIX (1920). This article was translated into Chinese by Feng Chengjun 馮承鈞 and
} 
the more general principle of evaluating ancient Buddhist texts. Most of these issues touched upon fundamental questions about Chinese Buddhism, including its origin and early development. At the same time, these debates suspended or evaded the potential ambiguities and conflicts at the doctrinal level. As historical material, the Sütra was noteworthy to these historians because of its historicity, instead of for its religiosity as the foundation of religious wisdom and faith. It was its historiographical value, instead of its preaching power or doctrinal construction, that attracted these scholars. As Hu Shih pointed out, "discussions (on the Sütra), although minor, is very crucial in matters of methodological questions." ${ }^{881}$

As shown in these debates on the Sütra, Buddhist and non-Buddhist texts, regardless of their origin or background, have been equally unfolded in front of readers and historians. ${ }^{882}$ However, in practice, there are always tensions and controversies between historians. For instance, in their research on the Sütra, both $\mathrm{Hu}$ Shih and Chen Yuan seemed to have dissent concerning the way the other handled the materials. Hu criticized that Chen "had too much conviction in the writings of non-Buddhist historians" and "unfairly ignored all the existent Buddhist

published in Mouzi congcan xinbian 牟子丵殘新編 (Beijing: Zhongguo shudian, 2001): 91-114. Liang Qichao also agreed with the sea-route hypothesis. In his “Fo jiaozhi chu shuru: Appendix 2" 佛教之初 輸入: 附錄二, he claimed that “the import of Buddhism did not follow the overland route, but the marine route. It was firstly located in Jiangnan, instead of Luoyang [佛教之來, 非由陸而由海, 其最 初之根據地, 不在京洛而在江淮].” See SBP. Hu Shih's opinion was the same. He repeatedly elaborated this opinion when discussing relevant Buddhist issues with Chen Yuan, Zhou Yiliang 周良, and Yang Liansheng 楊聯陸. He also asked Yang to forward his opinion to Paul Demiéville to see if Demiéville could find any evidence in Vietnam. See Hu Shih, Zhi Zhou Yiliang 致週一良 (1948. 08. 07); There were different versions of this letter, see Geng Yunzhi ed., Hu Shih shuxinji 胡適書信集, vol. 2 (Beijing: Peking University Press, 1996), 1150; Also, Lunxue tanshi ershi nian-Hu Shih Yang Liansheng wanglai shuzha 論學談詩二十年一胡適楊聯陸往來書札 (Taipei: Lingking, 1998), 92, 134.

${ }^{881}$ The original text is: “此次所論, 問題雖小, 而牽涉的方法問題頗關重要.” See Ge, Zhaoguang. “'Liao wei youyi de bisai' - cong Chen Yuan yu Hu Shih de zhenglun shuodao zaoqi Zhongguo fojiaoshi yanjiu de xiandai dianfan “聊為友誼的比賽”一從陳垣與胡適的爭論說到早期中國佛教史研究的現代 典範," 135.

${ }^{882}$ Admittedly, the use of the 'inner' or 'outer' materials in traditional writings had basically not been sealed off. There was always mutual utilization between them. See John Kieschnick, The Eminent Monk: Buddhist Ideals in Medieval Chinese Hagiography (Honolulu: University of Hawaii Press, 1997), 10-11. 
historical sūtras and treatises, like Mouzi." ${ }^{183}$ Chen, in contrast, rejected Hu's conclusion and commented that "evidential study of history must be meticulous; any flaws would make research become a joke." ${ }^{884}$ Chen explained, "I think it is better to believe in evidence than in confessions, so I always look for evidence outside the history written by the believers. ...... To study doctrine, one should naturally look into the scriptures, and to study the history, one should look for evidence outside scriptures." ${ }^{185}$ As historian Ge Zhaoguang concluded, their conflicting opinions showed the complexity of the historiography of Buddhism; it was not only a conflict of conclusions, but also a theoretical divergency, as represented by the issues they discussed: the attitude towards primary materials, the understanding of particular terms or concepts, and the principle of approaching and judging evidence. ${ }^{886}$

\section{Debates on the Treatise on Awakening Mahāyāna Faith 大乘起信論}

A more profound 'crisis of faith' for Chinese Buddhism emerged when the Treatise on Awakening Mahāyāna Faith [Dasheng Qixin lun 大乘起信論; below: Treatise], which was believed to be the philosophical foundation of Chinese Mahāyāna Buddhism, was also called into question. ${ }^{887}$

\footnotetext{
883 “過信此等教外史家, 而抹殺教中一切現存後漢譯經及 《牟子》等, 似乎未為平允.” See Hu Shih, Sishier zhangjing kao 四十二章經考, in HSWJ, vol.5, 143-57.

884 The original text is: “考證史事, 不能不縝密。稍一疏忽, 即易成笑柄,” in Chenyuan laiwang shuxinji 陳垣來往書信集 (1933.4. 1; 3; 5; 8), 179-188.

${ }^{885}$ The original text is: 船以為信供不如信證, 故每在教史以外求證……研求教義, 自當寻之内 典, 研求教史, 不能不證之外典也,”ibid.

${ }^{886}$ Ge Zhaohuang, “'Liaowei youyi de bisai” - Cong Chen Yuan yu Hu Shih de zhenglun shuo dao zaoqi Zhongguo fojiao shi yanjiu de xiandai dianfan 仰為友誼的比賽”一一從陳垣與胡適的爭論說到早期中 國佛教史研究的現代典範," 136.

${ }^{887}$ For example, some of the major contributions to the question of the authorship of the Treatise on the Mahāyāna Awakening of Faith are the studies by Paul Demieville, "Sur l'authenticite du Ta tch'eng k'i sin louen," Bulletin de la Maison franco-japonaise, 2, no. 2. (1929): 1-78; Walter Liebenthal, "New light on the Mahāyāna-śraddhotpada śastra.” T'oung Pao 46 (1958): 155-216; and William H. Grosnick, “The Categories of T'u Hsiang, and Yung: Evidence that Paramartha Composed the Awakening of Faith." Journal of the International Association of Buddhist Studies 12 no.1 (1989): 66-92. Grosnick has suggested
} 
In the Taishō edition of the East Asian Buddhist canon, there are two versions of the Treatise (T.1666 and T. 1667). As stated in its preface ${ }^{888}$ this Treatise is attributed to the Indian patriarch Aśvaghosa, a figure to whom medieval Chinese Buddhists granted high significance in the transmission of the Buddha Dharma. Although the authenticity of this Treatise received suspicion from some Buddhists in medieval times, eventually, the highly authoritative catalogue Kaiyuan shijiao lu composed by Zhisheng declared it as a legitimate translation of an original Indian text, guaranteeing its canonicity.

The Treatise's key concern is the discussion of ultimate reality, referred to as 'suchness' or 'thusness' [zhenru 真如] and another essential concept, 'the buddha body' [foshen 佛身]. It also elaborates upon earlier Indian Buddhist notions of tathdgatagarba ['embryo', foxing 佛性] ${ }^{889}$ These concepts, as the hub of Buddhist spirits, at least in most Chinese believers' view, had initiated new discourses on the intrinsic possibility for enlightenment, which had enormous consequences for the development of East Asian Buddhist soteriology ${ }^{890}$ After its canonization, the widespread fortune of the Treatise was witnessed, above all, by the wealth of commentarial literature composed by eminent scholar-monks in the pre-modern period. ${ }^{891}$ As one of a finite number of canonized texts that had been reprinted, commented upon, and worshiped by believers throughout history, the popularity and significance of this text is beyond doubtful. However, its canonical status is not only

that Paramartha may be the real author of the text. For a critique of Grosnick's methodological assumptions, see Sharf, Coming to Terms with Chinese Buddhism: A Reading of the Treasure Store Treatise, 104 ${ }^{888}$ The preface to T. 1666 , however, is almost certainly spurious. It is inaccurate with reference to Paramartha and contains several other anachronisms. See Paul Demieville, "Sur l'authenticite du Ta tch'eng k'i sin louen,” Bulletin de la Maison franco-japonaise, 2 no.2 (1929 [reprinted]): 11-19. ${ }^{889}$ About the issue of foxing, see for example the study on doctrinal transformation in twentiethcentury Chinese Buddhism in Scott Hurley, "The Doctrinal Transformation of Twentieth-Century Chinese Buddhism: Master Yinshun's Interpretation of the Tathāgatagarbha Doctrine," Contemporary Buddhism 5, no. 1 (2004): 29-46.

${ }^{890}$ Francesca Tarocco, "Lost in translation? The Treatise on the Mahāyāna Awakening of Faith [Dasheng qixin lun] and its modern readings."

${ }^{891}$ According to a Japanese survey from the 1920s, there are about 173 surviving commentaries on the Treatise. See Hakeda Yoshito, The Awakening of Faith (New York and London: Columbia University Press, 1967 [Reprinted in 2006 with a preface by Ryuichi Abe]), 5. 
due to its hermeneutical value for the exegetical project of Buddhist thinkers, but also to its association with the legendary Buddhist patriarch Aśvaghosa, which could bring mystical power similar to his own to its practitioners.

The intensive attention on the Treatise in modern China ${ }^{892}$ was catalyzed by Yang Wenhui. ${ }^{893}$ Just like his life-long friend, the Japanese scholarly-monk Nanjō Bunyū, Yang kept an active bibliographical interest in searching for 'lost texts. ${ }^{894}$ Both Yang and Benyū tried in vain to discover the lost original Sanskrit version of the Treatise, in order to confirm the text as a legitimate source for the doctrinal authority of Buddhism. Probably because of their influence, the Treatise, both in content and 'spirit,' soon became the 'favorite' of both Buddhists and laymen in Japan and China during the first decades of the twentieth century. ${ }^{895}$

Along with the increasing attention to the Treatise, suspicion about its authenticity had also been incited. As early as 1906, Japanese scholar Suisai Funahashi 舟橋水哉 had put forward his doubt about the authorship of the treatise. Following him, famous Buddhologist Mochizuki Shinkō 望月信亨 reposted a similar opinion that the Treatise was an indigenous Chinese composition instead of a translation from

\footnotetext{
${ }^{892}$ Because the debates over the Treatise, compared to those about the Sütra of the Forty-Two Chapters, were more complex and important, current scholars have had more discussion on this topic. See Huang Xianian 黄夏年, “Dasheng qixinlun yanjiu bainian zhilu 大乘起信論研究百年之路, ” in Pumen xuebao 普門學報, 6 (2001): 1-21; Also, Binbin Yao, “Xiandai foxue sixiang xipu zhi fenye - yi 'Dasheng Qixinlun' zhenwei zhizheng wei qiji 現代佛學思想系譜之分野一以 《大乘起信論》真偽之爭為契 機," Chung-Hwa Buddhist Studies 中華佛學研究, no. 12 (2011), 85-114.

${ }^{893}$ According to some sources, Yang's conversion to Buddhism was indeed sparked by reading the Qixinlun. One source for this statement is the biography written by Yang Wenhui's granddaughter Yang Buwei Chao. Yang Buwei Chao, Autobiography of a Chinese Woman, Buwei Yang Chao. (Westport: Greenwood Press, 1970 [1948]): 82.

${ }^{894}$ On the exchanges between Yang Wenhui and Nanjo Bun'yu see Goldfuss, Vers un bouddhisme du XXe siecle. Yang Wenhui (1837-1911), reformateur laique et imprimeur, 68-78. Yang's letters to the Japanese Buddhologists are published in volume 10 of his Collected Writings, see Yang Wenhui, Yang Renshan jushi yizhu 楊仁山居士遺著 (Nanjing: Jinling kejingchu, 1998). For a study of the intellectual context surrounding Nanjo Bun'yu and other Asian scholars at Oxford see N. J. Girardot, “Max Muller's 'Sacred Books' and the nineteenth-century production of the comparative science of religions," History of Religions 41, no. 3 (2002): 213-50.

${ }^{895}$ See Goldfuss, Vers un bouddhisme du XXe siecle. Yang Wenhui (1837-1911), reformateur laique et imprimeur, 203 and Lewis Hodous, Buddhism and Buddhists in China (New York: Macmillan Company, 1924), 67.
} 
Indian scripture. Other Japanese scholars, such as Ryōtai Hadani 羽溪了諦, Senjō Murakami 村上專精, Daijō Tokiwa 常盤大定, Bunzaburō Matsumoto 松本文三郎, Hayashiya Tomojirō 林屋友次郎, and so on, also joined the debates that lasted from the 1900 s to the 1920 s. $^{896}$

Under the Japanese influence, Zhang Taiyan published an essay in 1908 that claimed that the Treatise was an authentic canonical text written by Aśvaghosa, based on a bibliographical investigation of Fei Changfang's lidai sanbao ji. ${ }^{897}$ Later, a widespread discussion was instigated in 1922 by Ouyang Jingwu. ${ }^{898}$ Opposing his mentor Yang Wenhui, Ouyang for the first time publicly questioned the authority of the Treatise. ${ }^{899}$ After him, Liang Qichao published an article titled "Textual Criticism on the Treatise on Awakening Mahāyāna Buddhism" [Dasheng qixinlun kaozheng 大乘 起信論考證], claiming that the text was composed in China by Chinese Buddhist[s]. ${ }^{900}$

\footnotetext{
${ }^{896}$ The debates over the Qixinlun began in 1902 and reached their peak in 1919, when Mochizuki published several essays on the treatise (collected essays published in 1922, titled 大乘起信論研究, Tokyo: 金尾文淵堂). For an investigation of the overall picture of the Japanese studies on the Qixinlun, see Kosei Ishii 石井公成, “近代アシア゙諸国における『大乘起信論』の研究動向”) (2005) and his talk“近代日本における『大乘起信論』の受容,”(2012).

${ }^{897}$ Zhang Taiyan, “Dasheng qixinlun bian 大乘起信論辩, Mingbao 民報 vol. 19 (1908). Reprinted in XFXC, vol. 35.

${ }^{898}$ Most important articles (in total 15) on Qixinlun in modern China have been collected in Zhang Mantao ed., Dasheng Qixinlun yu Lengyan jing kaobian, XFXC, vol. 35.

${ }^{899}$ In his lectures “Weishi jueze tan 唯識抉擇談” (1922), Ouyang had criticized the teaching of a "mind of suchness” in the Treatise as confusing 'suchness' (tathatā, 真如) and 'correct knowledge' [samyagjñāna, zhengzhi 正智]. See Ouyaung Jingwu, “jueze wufa tan zhengzhi 抉擇五法談正智.” See also Cheng Gongrang 程恭讓, Jueze yu zhenwei zhijian - Ouyang Jingwu foxue sixiang tanwei 抉擇於真偽之 間一歐陽竟無佛學思想探微 (Shanghai: Huadong shifan daxue chubanshe, 2000): 112-135. For Ouyang's attitude towards Chinese Buddhism in the later phase of his life, see Eyal Aviv, "Ouyang Jingwu: From Yogācāra Scholasticism to Soteriology," in Transforming Consciousness: Yogacara Thought in Modern China, 303-306.

${ }^{900}$ Liang Qichao's study was based on the wealth of scholarship on this text that had already appeared in Japan since the late nineteenth century, especially the study of Mochizuki. He also was influenced by Ouyang Jingwu, although he was not officially a disciple of Ouyang like Lü. In one letter Liang wrote to his daughter, he wrote that: "Every week, on Mondays, Wednesdays and Fridays from 7:30 to 9:30 am I go to the Institute of Inner Learning to listen to Mr. Ouyang Jingwu's lecture on Buddhism." See: Xu Qingxiang 徐清翔, Ouyang Jingwu pingzhuan 歐陽竟無評傳 (Changsha: Baihua wenyi chubanshe, 2010), 78. Liang also wrote that: "It is only after having heard the teachings by Master Ouyang Jingwu on the
} 
Aiming at a larger community of intellectual elite, ${ }^{901}$ again, Liang's article soon gathered attention within academia and Buddhist circles. ${ }^{902}$

Following Ouyang and Liang, some historians and Buddhist scholars began to question the doctrinal authority as well as the theoretical value of the Treatise. In 1923, Wang Enyang 王恩洋 (1897-1964), a scholar of the Neixueyuan, published his article "Selection and Measurement of the Treatise on Awakening Mahāyāna Buddhism" [Dasheng qixin lun liaojian 大乘起信論料簡], in which he claimed that the Treatise had not only been falsified by Chinese Buddhists but was also a propagated heresy. ${ }^{903}$ His radical conclusion received strong repercussions within Buddhist monastic circles, especially from Taixu and his disciples in the Wuchang Buddhist Institute. Before the emergence of Wang's article, Taixu had already written an essay titled "Comments on [Liang Qichao's] Textual Criticism on the Treatise of the Awakening of the Mahāyāna Buddhism” under the pseudonym of 'Feixin' 非心 to refute Liang Qichao's argument. Soon, debates surrounding this Treatise were heating up; scholars like Chen Weidong 陳維東, Tang Dayuan 唐大圓(1885-1941), and Chang Xing 常惺 (1896-1938) followed Taixu to criticized Wang for making damaging statements on the Dharma and judging the Mahāyāna wisdom through blinded evidential study and the narrowed prejudices of the Yagācarā school. Their works were later collected and published with a preface written by Taixu by the Wuchang Sutra Press 武昌印經處, under the title of Dasheng Qixinlun Yanjiu 大乘起信論研究.

Discussions surrounding the Treatise continued for years in the early twentieth century and caused a so-called 'sectarian conflict' [fanan 法難] between the Wuchang Buddhist Institute and the China Institute of Inner Learning, and

thought of the Yogacara school that I knew there exists a Genuine Buddhism." See Liang Qichao Quanji 梁啟超全集, vol. 8, Band 20 (Beijing: Beijing chubanshe, 1999), 6041.

${ }^{901}$ Liang's article was published by the Commercial Press in Shanghai, which, according to Francesca Tarocco, was well known for its new-style textbooks and periodical publications aimed at newly educated young people. See Francesca Tarocco, "Lost in Translation? The 'Treatise on the Mahāyāna Awakening of Faith (Dasheng qixin lun)' and Its Modern Readings," 333.

${ }^{902}$ See Wang Enyang, XFXC, vol.35, 83-121.

${ }^{903}$ In this article, Wang claimed that “斯論之作, 固出於梁陳小兒” almost negated the legitimacy of the Treatise. Ibid.. 
further led to a confrontation between Neo-Confucianism and Buddhism. ${ }^{904}$ Debates and controversies went far beyond the scope of textual criticism and bibliographical investigation to develop into an enduring retort to the fundamental philosophical questions and the legitimacy of the whole system of the Chinese Buddhist tradition. In some cases, the debate was so intensified that it turned into a kind of "action on impulse without consideration" [yiqi zhizheng 意氣之爭], as Ge Zhaoguang commented. ${ }^{905}$

The context and background of this 'sectarian conflict' are complicated, entangled in the philosophical dilemma of the text itself, its version divergence, and of course the contradictory academic pursuits of every scholar who participated in this debate. One of the hidden reasons why scholars of the camp of the Wuchang Buddhist Institute had to raise this scholarly discussion into fanan might be their lack of 'textual evidence.' Failing to solve the puzzle of this text with concrete facts, they argued that Wang Enyang's textual criticism "was just the old habit of Evidential Learning among the classicists," and claimed that "everyone who had basis knowledge of Buddha's teaching will dismiss such views with a laugh." ${ }^{906}$ This empty refutation actually avoided the real issues that scholars like Wang Enyang were concerned about.

\footnotetext{
${ }^{904}$ For a summary of the general situation of the debates over the Qixinlun in modern China, see Xiao Jiefu 蕭筆父 “Guanyu Dasheng Qixinlun de lishi dingwei 關於大乘起信論的歷史定位,” Xiao Jiefu Wenxuan 蕭筆父文選, (Wuhan, Wuhan University Press), 177. Huang Xianian, Dasheng qixinlun yanjiu bainian zhilu 大乘起信論研究百年之路," 1-21. Gao Zhennong 高振農, “Dasheng qixinlun jianlun zhi si 大乘起信論簡論之四,” in Jinxiandai Zhongguo fojiao lun: Gao Zhennong wenji 近現代中國佛教論: 高振 農文集 (Beijing: Zhongguo shehui kexue chubanshe, 2002), 120-136. Yao Binbin, “Xiandai foxue sixiang xipu zhi fenye - yi ‘Dasheng Qixinlun’ zhenwei zhizheng wei qiji 現代佛學思想系譜之分野一以《大 乘起信論》真偽之爭為契機, ” 85-114. In my dissertation, I will focus my research on the textual study of this text.

${ }^{905}$ Ge Zhaoguang, “Shinian Haichaoyin - 20 niandai Zhongguo fojiao xin yundong de neizai lilu yu waizai zouxiang 十年海潮音-20 年代中國佛教新運動的內在里路與外在走向,” in Ge Zhaoguang zixuanji 葛兆光自選集 (Guilin: Guangxi shifan daxue chubanshe, 1997), 168.

${ }^{906}$ Orig. text: “考證只就歷史說馬鳴無其人與《起信》偽作, 不過經生考據習氣, 如往日張五民等 疑《法華》已亡之說, 稍解佛理者, 一笑置之而已.” See Tang Dayuan 唐大圆, “Qixinlun jiehuo 起 信論解惑, XFXC, vol. 35, 133-150
} 
In the $1950 \mathrm{~s}^{907}$, Lü Cheng, the leading scholar of the China Institute of Inner Learning, devoted several essays to claiming again that the Treatise and some other texts, such as the Lañkāvatāra-sūtra [Lengqiejing 楞伽經] were all pseudepigraphic creations pretending to be original texts. ${ }^{908}$ Continually utilizing the approach of inter-textual criticism that he had used in the case of the Sütra of the Forty-Two Chapters, he listed seven pieces of evidence to prove that the Treatise was a spurious text based on erroneously translated vocabulary stolen from the Wei version of the Lañkāvatāra. It was not an authentic translation, but rather something refashioned in a muddled manner, with terms and concepts from certain error-riddled predecessors. ${ }^{909}$ Lü's argument, although not widely accepted by the Chinese Buddhist community, was clear and credible, and has also been further confirmed by more recent studies aided by computer technology. ${ }^{910}$

Most current scholars who have tried to picture the panorama of modern Chinese Buddhology have categorized the tangled debates on the Treatise into two or three camps with different positions. ${ }^{911}$ However, few studies have noted the voices

\footnotetext{
${ }^{907}$ Although these essays were published in the 1950s, Lü's main opinion on the Qixinlun was formed as early as in the 1920s, as shown in his letters to Xiong Shili.

${ }^{908}$ Before comparing the Qixinlun with Lañkāvatāra, Lü discussed the versions of Lañkāvatāra. He pointed out that long before the Qixinlun circulated in China, there were already two versions of the Lañkāvatāra. The first one was the translation by Gunabhadra 求那跋陀羅 in the Liu-Song (420-479) dynasty (楞伽阿跋多羅寶經 T.16.670); the second one was the translation by Bodhiruci 菩提流支 in the Wei dynasty (入楞伽經, T. 16.671). When examining these two texts in comparision with the texts in Sanskrit and Tibetan, we find that the early version, namely the Gunabhadra's translation, matched more closely, while the Wei translation is filled with errors and deviations. See Lü, LFLX, vol.1, 293. ${ }^{909}$ Ibid.

${ }^{910}$ See Takemura Makio 竹村牧男, “Kishiron to Jūjikyōron 起信論と十地経論 [The Awakening of Faith and the Daśabhūmi-sūtra-bhāṣya]," in Tōhōgaku, no. 72 (1986): 1-15. And Frédéric Girard, Traité sur l'acte de foi dans le Grand Véhicule (Tokyo: Keio University Press, 2004), xxxi-xxxii. See also Dan Lusthaus, "Lü Cheng, Epistemology, and Genuine Buddhism," in Transforming Consciousness: Yogacara Thought in Modern China, 340-342.

${ }^{911}$ For example, Du Jiwen and Huang Xianian categorized the scholars who participated in the debates into two groups: the Buddhist monastic community 僧界 and the lay Buddhist community 居士界. See Du Jiwen 杜繼文, “Dasheng qixinlun shuping 大乘起信論述評,” in Zhongguo fojiao yu Zhongguo wenhua 中國佛教與中國文化 (Beijing: Zongjiao wenhua chubanshe, 2003) 299-336; Yao Binbin divided them into three camps of researchers: 1. lay Buddhists linked to the China Inner Studies Institute; 2. Taixu, Yinshun, and other Buddhists who believed in the doctrinal value of the Treatise; 3 . Xiong Shili, Mou
} 
from real 'outsiders.' For example, Chen Yinke published an article in 1948 titled "True Materials in Zhikai' Preface of the translated Treatise of the Awakening of the Mahāyāna Buddhism in the Liang dynasty" [Liangyi dasheng qixin lun wei Zhikai xu zhong zhi zhen shiliao 梁譯大乘起信論偽智峘序中之真史料]. In this short essay, he commented on the previous studies of the Treatise in the 1920s but stressed that, despite the disputation on the Treatise's content and doctrine, there were 'facts' in this 'forged text': that is, the real historical phenomenon of the textual insufficiency of Chinese Buddhism and the propensity to subjective conjecture covered by the divergence of faith positions.

\section{Rewriting the History of Chan Buddhism}

As the most influential native Buddhist tradition, the heritage of the Chan/Zen school was deeply interwoven with the fabric of Chinese culture. It was considered by modern scholarship to be the pinnacle of Eastern transcendental spiritualism and was marketed from the late nineteenth century as an antidote to Western rationalism and materialism by some Chan apologists influenced by Orientalism and other modern ideological agendas. ${ }^{912}$ However, the historical legitimacy of Chan Buddhism began to receive criticism at the turn of the twentieth century with important discoveries of numerous documents in the Dunhuang Caves. The origin of Chan tradition and the transmission pedigree of the Chan lineage were also called into question.

\section{The Discovery of Shenhui}

\footnotetext{
Zongshan, and other Neo-Confucian scholars. See Yao, "Xiandai foxue sixiang xipu zhi fenye - yi ‘Dasheng Qixinlun' zhenwei zhizheng wei qiji 現代佛學思想系譜之分野-- 以《大乘起信論》真偽之 爭為契機," 85-114.

${ }^{912}$ One of the most successful examples is the popularization of D.T. Suzuki and his audience in the West. See Robert H Sharf, "Whose Zen? Zen Nationalism Revisited," in Rude Awakenings: Zen, the Kyoto School, and the Question of Nationalism, edited by James W. Heisig and John Maraldo (Honolulu: University of Hawai'i Press, 1995), 44-46.
} 
In the traditional historical narrative of Chan Buddhism, Monk Shenhui had long been marginalized. ${ }^{913}$ Even in the early years of the twentieth century, this figure was still ignored in the comprehensive histories of the Chan tradition written by Chisa Kohō and Nukariya Kaiten and was not even mentioned by D.T. Suzuki in his famous Essays in Zen Buddhism. ${ }^{914}$ Although the study on Chan/Zen Buddhism had undergone several epochal shifts over the course of the nineteenth century, ${ }^{915}$ the traditional narrative of Chan history was deeply challenged by Hu Shih's study on Shenhui.

In the preface to his Collection of the Lost Works of Monk Shenhui [Shenhui heshang $y i j i$ 神會和尚遺集], Hu described that:

In 1924, when I was trying to write the draft of a history of Chinese Chan, I developed extreme doubts when I came to Huineng; when I reached Shenhui, then I had to stop writing. ${ }^{916}$

Realizing that the materials after the Song dynasty were untrustworthy, Hu decided to seek historical data related to Shenhui among the manuscripts from Dunhuang. Two years later, in 1926, he took the opportunity of visiting Europe to examine the

\footnotetext{
${ }^{913}$ In the traditional annals of the Chinese Chan school, the name of Shen Hui appears only as a minor figure in the Platform Sütra; he is left unmentioned in any famous "public cases" and in texts such as Dunwu yaomen 頓悟要門 or Linji lu 臨濟錄.

${ }^{914}$ Nukariya's work is titled Zengaku shisōshi 禪學思想史, vol. 1 (Tokyo: Genkōsha, 1923). Suzuki's Essays was first published in London by Rider in 1949, but it includes a 1923 preface written by the author. ${ }^{915}$ The representative scholars at the time of Hu include Paul Pelliot (1878-1945), Paul Demiville (18941979), Jacques Gernet, Iriya Yoshitaka 入矢義高 (1910-1999), and Yanagida Seizan 柳田聖山 (19212006). Their works include: Paul Pelliot, “Notes sur quelques artistes des Six Dynasties et des T'ang," T’oung Pao, 22 (1923): 215-91; Paul Demiéville, “Le miroir spirituel,” Sinologica 1.2 (1947): 112-37; Paul Demiéville, Le concile de Lhasa: Une controverse sur le quiétisme entres les bouddhistes de l'Inde et de la Chine au VIIIe siècle de l'ère chrétienne (Paris: Presses Universitaires de France, 1952); Jacques Gernet, Entretiens du Maître de Dhyāna Chen-houei du Ho-tsö (Paris: Publications de l'École française d'Extrême-Orient, 1949); Yanagida Seizan, Shoki zenshū shisho no kenkyū 初期禅宗史書の研究 (Kyoto: Hōzōkan, 1967). For a more complete bibliography on Western scholarship see Bernard Faure, "Chan and Zen Studies: The State of the Field(s)," in Chan Buddhism in Ritual Context, ed. Bernard Faure (London: Routledge Curzon, 2003), 1-35.

${ }^{916} \mathrm{Hu}$ Shih, Shenhui heshang yiji 神會和尚遺集 (1968 [1930]), 1-3.
} 
Dunhuang collections in London and Paris. ${ }^{917} \mathrm{Hu}$ soon discovered three versions of Shenhui's recorded sayings in Paris and Hui's Xianzongji 顯宗記 in London. These materials affirmed Hu's working hypothesis. ${ }^{918}$ Based on those newly discovered historical materials, Hu published subsequent works on Shenhui's biography and the history of early Chan Buddhism. These works stimulated the emergence of international debates in Buddhist studies. ${ }^{919}$

The discovery of new Chan texts from the Dunhuang collections, which was considered by Hu Shih as one of the most significant achievements of his own scholarship, encouraged him to "rewrite the whole history of Chan Buddhism" [jiang yizhengbu chanzong de lishi chongxin xieguo 將一整部禪宗的歷史重新寫過]. Based on the recorded sayings of Shenhui, Hu claimed that the Platform Sūtra was composed by Shen Hui and his followers. In order to rehabilitate his teacher Huimeng's 慧能 (638-713) status and build up the legitimacy of the Southern School, Shenhui had altered the transmission pedigree of the Chan tradition by diminishing the influence of the Northern school and the teaching of gradual enlightenment [jianwu 漸悟]. Shenhui's campaign and its eventual victory represented a fundamental transformation in the Chan history. ${ }^{920}$ In his radical interpretation of the "battle"

\footnotetext{
${ }^{917}$ Some Chinese Chan texts from Dunhuang had been displayed in public in Japan by Yabuki Keiki 矢 吹慶輝. After he left Europe, Hu met Yabuki in Japan and heard that Yabuki had discovered the ancient version of the Tanjing in the Dunhuang collection. Ibid.

${ }^{918}$ Although Hu did not mention the reason why he had such suspicion about the history of Chan Buddhism in the first place, according to Jiang Canteng, he might have been influenced by Meng Wentong 蒙文通, the author of Zhongguo chanxue shi 中國禪學史 which was published in and by Nukariya Kaiten 忽滑骨快天's Zengaku shisōshi 禪學思想史 (Tokyo: Genkosha, 1925). See Jiang Canteng 江燦騰, “Hu Shih chanxuean zai Zhongguo xuejie de fazhan yu zhengbian 胡適禪學研究在中國學界 的發展與爭辯,” in Xiandai Zhongguo fojiaoshi xinlun 現代中國佛教史新論, (Kaohsiung: Jingxin wenjiao jijinhui, 1994). This opinion also was proved by Yanagida Seizan. See Jiang Canteng, "Hu Shih yu Huhuagu kuai tian: zaitan Hu Shih zaoqi chanxue yanjiu wenti 胡適與忽滑谷快天：再探胡適早期禪 學研究問題," Hanxue yanjiu tongxun 漢學研究通訊, 30, no.4 (2011): 14-15.

${ }^{919}$ Yanagida Seizan 柳田聖山, “Goroku no rekishi - Zen bunken no seiritsu-teki Kenkyū 語錄の歷史 一禪文獻の成立的研究, Tōhō gakubō 東方學報 57 (1985): 365 .

${ }^{920}$ Most of the conclusions of Hu have been contested by recent scholarship. See Faure, Bernard. The Rhetoric of Immediacy (Princeton University Press, 1994). John R. McRae. "Shen-Hui and the Teaching of Sudden Enlightenment in Early Ch'an Buddhism," in Sudden and Gradual: Approaches to Enlightenment in Chinese Thought, ed. Peter N. Gregory (Honolulu: University of Hawaii Press, 1987), 227-275.
} 
between the Southern and Northern Schools, Hu boldly re-depicted the minor figure Shenhui as a "militant, even rabidly aggressive, innovator and exponent of a new and widely influential teaching." ${ }^{\text {"21 }}$ This new image of Shenhui profoundly influenced the entire enterprise of Chan/Zen studies in both China and Japan after 1935, as Yanagida Seizan pointed out. ${ }^{922} \mathrm{Hu}$ Shih's discovery of the historical materials of Chan Buddhism also encouraged scholars to further reflect on other historical literature of Chan Buddhism, including biographies, Records of Lamp, and other comprehensive sectarian historical writing. ${ }^{923}$

\section{Hu Shih's Chan Buddhist Historiography}

Hu Shih's initial interest in Chan Buddhism originated from his project of writing a comprehensive history of Chinese philosophy done according to strictly modern methodological standards. He undertook this project beginning in 1917 after he finished his dissertation The Development of the Logical Method in Ancient China at Colombia University, ${ }^{924}$ and he developed it during his teaching career at Peking University. Hu's analysis of classical Chinese philosophy was groundbreaking for his

\footnotetext{
${ }^{921}$ John R McRae, "Religion as Revolution in Chinese Historiography: Hu Shih (1891-1962) on Shen-Hui (684-758)," Cahiers d'Extrême-Asie 12, no. 1 (2001): 63.

${ }^{922}$ Yanagida Seizan 柳田聖山, “Hu Shih boshi yu Zhongguo chuqi chanzong shi zhi yanjiu 胡適博士與 中國初期禪宗史之研究,” in Hu Shih Chanxue an 胡適禪學案 (Taipei: Zhongzheng shuju, 1975); 17-18. According to Seizan, Ui Hakuju's Zenshū shi kenkyū 禪宗史研究(1939), D.T. Suzuki's Zen shisōshi kenkyū daini: daruma kara enōni 禅思想史研究第二:達摩から慧能に至る (1952) and Shindai Sekiguchi 關口 真大's Daruma daishi no kenkyū 達摩大師の研究 (1958) all “covered by the shadow of Hu Shih's 'Lengqie zong kao 楞伽宗考”.

${ }^{923}$ For more recent developments in the field of Chan/Zen studies, see: John R. McRae, "Buddhism,” in John R. McRae and Daniel L. Overmyer, "Living Religious Traditions: Taoism, Confucianism, Buddhism, Islam and Popular Religon," in JAS 54.2 (1995): 354-71; and Bernard Faure, "Chan and Zen Studies: The State of the Field(s)," in Chan Buddhism in Ritual Context, ed. Bernard Faure (London: Routledge Curzon, 2005), 1-35. See also essays by this cohort of scholars in Cahiers d'Extreme-Asie 7 (1993-1994), a special issue dedicated to the work of Yanagida Seizan.

${ }^{924}$ Jin Yuelin 金岳霖, The Development of the Logical Method in Ancient China (Shanghai: Oriental Book Co., 1922; rpt. New York: Paragon Book Reprint Corp., 1963). This appeared in expanded form in Chinese in 1921 as the first volume of a projected multi-volume work called Zhongguo Zhexueshi dagang 中國哲學 史大綱 (Shanghai: The Commercial Press, 1921).
} 
rigorous approach of penetrating into the subject matter without any transcendental concerns. From a methodological perspective, his undertaking was largely unprecedented within Chinese intellectual tradition. ${ }^{925}$

\section{a. The Discovery of Chan Materials}

One of Hu's main contributions to Chan studies, and also the less controversial one, was his discovery and organization of the lost textual materials of the Chan school. At that time, more Buddhist texts, for example, the Dunhuang documents, were preserved and controlled outside the Buddhist community. Scholars like Hu Shih then were able to address those materials from a broader perspective and refrained from the dominant narrative of the Chan school as a succession of individual patriarchs and their teachings. As an outsider to any religious community, Hu placed much more emphasis on the 'hard facts' in the historical narrative and focused his studies on the textual and historical authenticity within materials. He was extremely skeptical of traditional legends and nourished an extraordinary sensitivity toward minor or unorthodox texts.

In 1930, the materials Hu Shih discovered in Europe and the Dunhuang version of the Platform Sūtra that he had obtained from Japan were arranged and published by Hu Shih under the title The Posthumous Collection of Ven. Shenhui [Shenhui heshang yij 神會和尚遺集]. In the first period of Hu's work on Chan Buddhism during the 1920s to 1930s, Hu's study did not receive many direct responses within Chinese academia. ${ }^{926}$ However, the materials he discovered, for example, the Lengqie Shizi ji, were cited and used by scholars such as Tang Yongtong and Chen Yinke. ${ }^{927}$ Outside China, the Lengqie shiziji he found was published between 1931 and 1933 by the

\footnotetext{
${ }^{925}$ For a summary of Hu Shih's contribution to Chan studies, see Lou Yulie 樓宇烈, “Hu Shih Chanzong shi yanjiu pingyi 胡適禪宗史研究評議,” in Beijing daxue xuebao 北京大學學報, 3 (1987). In this paper, Lou provided many observations based on Hu's diaries and his marginal comments on Buddhist texts. ${ }^{926} \mathrm{Hu}$ complained of this to D.T. Suzuki when Suzuki visited him in 1933. Suzuki recorded Hu's complaint in his paper published in Bungeishunjū, volume 26, no.7 in 1948. See Yanagida Seizan 柳田聖 山, “Hu Shih boshi yu Zhongguo chuqi chanzong shi zhi yanjiu 胡適博士與中國初期禪宗史之研究,” 11-12.

${ }^{927}$ Chen referred to the Lengqie shiziji in his essay 禪宗六祖傳法偈之分析, but Chen did not mentioned Hu's name; see JMEB, 187-191
} 
Korean scholar Kim Ku- kyŏng 金九經. During this period, Hu also collected several textual materials of Chan Buddhism in Japan to supplement his study, including the Caoxi dashi biezhuan 曹溪大師別傳, and the Platform Sütra found in the Kōshō Ji Temple in Kyoto. ${ }^{928}$ Hu's discoveries of the Chan Buddhist materials were informative and controversial. In one article Hu published in the newspaper "The Times," he commented on D.T. Suzuki's study that "did not refer to the Dunhuang manuscript." His critique inspired Suzuki to further investigate materials in the Dunhuang collection. ${ }^{929}$ During the latter phase of his life, although experiencing several disruptions, Hu continued collecting, arranging, and collating the textual materials of Chan Buddhism. It is fair to conclude that Hu's discovery and publication was a major stimulus to the emergence of the field of Chan/Zen study. ${ }^{930}$ His editions of Shenhui's texts later appeared in the $85^{\text {th }}$ volume of the Taisho shinshū daizōkyō 大正新脩大藏經, complete with Hu Shih's emendations in red and green ink.

\section{b. The Narrative of The Transformation of the Early Chan Tradition}

Hu Shih's reevaluation of Shenhui also shook the prevailing worship of the traditional pedigree of Chan Buddhism and established a new narrative about the relationship between the Northern and Southern School and their teachings.

Hu Shih's understanding of Shenhui's role in the formation of Chan Buddhism and the development of the Chan school before the Song dynasty was based on a scrutiny of Shenhui's own writings, the Platform Sutra, and the Lengqie shizi ji. In 1935,

\footnotetext{
${ }^{928}$ Based on these two texts, Hu wrote his articles “Tanjing kao zhiyi 壇經考之一” and “Tan jing kao zhier 壇經考之二," in HSWJ, vol.5, 237-258.

${ }^{929}$ Lou Yulie, “Hu Shih Chanzong shi yanjiu pingyi 胡適禪宗史研究評議.” For the communication with Hu Shih and D.T. Suzuki, see Yanagida Seizan, ed., Ko Teki zengaku an 胡適禪學案 (Kyoto: Chūbun shuppansha 1975); Chinese edition: Hu Shih Chan xue an 胡適禪學案 (Taipei: Zhongzheng shuju, 1975). Also see Zhuang Meifang 莊美芳, “Hu Shih yu Linmu dazhuo lun Chan xuean - Cong Taiwan xuejie de huiying tanqi 胡適與鈴木論禪學案—從台灣學界的回應談起” (unpublished, 1998); Qiu Minjie 邱敏捷, “Hu Shih yu Linmu dazhuo 胡適與鈴木大拙," in Liangan dangdai chanxue lunwen ji (shang) 兩岸當代禪學論文集(上), ed., Zheng Zhiming 鄭志明 (Jiayi: Nanhua University, Religion centre 南華大學宗教中心, 2000), 155-78.

${ }^{930}$ John R McRae, "Religion as Revolution in Chinese Historiography: Hu Shih (1891-1962) on Shen-Hui (684-758)," Cahiers d'Extrême-Asie 12, no. 1 (2001): 61-62.
} 
he published “A Study on Lengqie School” [Lengqie zong kao 楞伽宗考],” the core essay of his Chan study. ${ }^{931}$ In this essay, Hu listed evidence in the Record Saying of Shenhui, arguing that the teaching of Lengqiejing was replaced by the teaching of the Diamond Sütra; he concluded that:

From the Bodhidharma to Shenxiu, they all belong to the orthodox Lengqie school...... [However] Shenhui boldly replaced the Lankeavvatāra-sūtra [Lengqiejing] with the Diamond Sütra. The legal orthodoxy system of the Lengqie school was overthrown, and its 'heart' also fell. Therefore, the revolution of Huineng and Shenhui is not that the Southern school reform the Northern school [of Chan], but the Bore school reformed the Lengqie school 從達摩以至神秀, 都是正統的楞伽宗.......神會很大膽 的全把《金剛經》來代替了《楞伽經》。楞伽宗的法統是推翻了, 楞伽宗的「心 要」也掉了。所以慧能神會的革命, 不是南宗革了北宗的命, 其實是一個般若宗 革了楞伽宗的命. .32

In this passage, Hu used a word to sum up the development of Chan in the sixth century: "revolution" [geming 革命]. Hu's basic view on the history of Chan remained unaltered throughout his entire career, from the 1920s to the 1960s. His groundbreaking view on the orthodoxy of Chan Buddhism, although problematic or even unacceptable to some scholars, influenced the writing of the history of Chan afterward. His narrative of the Chan revolution was partly accepted by Tang Yongtong but with a milder tone: "restoration" [zhongxin 中興]. Impressed by Hu's fresh view on Chan history, Tang Yongtong wrote a letter to Hu asking his general opinion on the history of Chan in 1928 after reading Hu's "A Study on Bodhidharma" [Puti damo kao 菩提達摩考]. ${ }^{933}$ In his response to Tang, Hu mentioned the newly discovered materials he had used and shared with Tang his whole proposal of writing the Chan history. In Tang's History published in 1938, Tang agreed with Hu's idea that

\footnotetext{
${ }^{931}$ According to Seizan, Hu Shih's “Lengqie zong kao 楞伽宗考” was the most important work of Hu’s early studies of Chan history. He was very confident about his claims in this paper. This study brought modern Chan study into a new stage. Yanagida Seizan 柳田聖山, “Hu Shih boshi yu Zhongguo chuqi chanzong shi zhi yanjiu 胡適博士與中國初期禪宗史之研究,” 18.

${ }^{932}$ In HSWJ, vol.5, 191; see also Yin Shun's analysis in Zhongguo Chanzong shi 中國禪宗史 (Taipei: Zhengwen Chubanshe 1971).

${ }^{933}$ In a remark Hu wrote in 1935, he cited Tang Yongtong's analysis in Hanwei as the evidence of his discussion. Ibid. Hu said: "He [Tang] discussed this issue, which I raised, at great length."
} 
the old tradition of Lengqie from the first patriarch Bodhidharma to the fourth patriarch Hongren 弘忍 had been seviously modified with an emphasis on Huineng's teaching of Prajña. ${ }^{934}$ Lü Cheng, as well, also followed the line of Hu Shih and thought that the teaching of the Diamond Sütra had replaced the prior Lengqie tradition. ${ }^{935}$

\section{c. Methods and Purpose}

Based on a historical reading of the primary texts of Shenhui, Hu provided a modern interpretation of the formation of Chan orthodoxy. He approached materials and his research questions with syncretic analytical methods, combining traditional Evidential Learning with modern scientific procedures. Among modern Chinese scholars, Hu had a comparatively stronger consciousness of the importance of methodology. With a tendency toward 'reductionism,' he considered all scholarship and philosophical traditions, including Chan Buddhism, to be expressions of methods. ${ }^{936}$ As Hu said,

All the '-ism', all the scholarship, are all the tools for us to study questions [切主義, 一切學理, 都只是我們研究問題的工具]. ${ }^{937}$.

As well, Chan Buddhism, as a method, was the tool that Buddhists like Shenhui used to reform the tradition of Buddhism. Chan's assertion, narrative and theorical framework were all questionable in his problem-oriented historiography. As $\mathrm{Hu}$ himself described, Thomas H. Huxley's agnosticism and John Dewey's pragmaticism

\footnotetext{
${ }^{934}$ According to Tang, Bodhidharma taught the four-volume version Lengqie [Lankāvatāra-sūtra] to his followers while Huneng stressed Jinggang bore 金剛般若 [vájra-cchedikā-prajñā-pāramitāa-sūtra]. After Hongren, the Chan school placed more and more emphasis on Jingang bore; one reason for this change, Tang noted, was the influence of the trend in the South [南方風氣]. Tang considered this transformation to be "restoration" [zhongxing 中興]. See Tang Yongtong, Suitang fojiao shigao 隋唐佛教 史稿, chapter “Chan School.” In this chapter, Tang did not use the materials Hu discovered in Europe. In a later work, Tang labelled this work as "an old text” [舊文].

${ }^{935}$ Lü Cheng 呂澂, Zhongguo foxue yuanliu luejiang 中國佛學源流略講 (Taipei: Liren shuju, 1985), 223.

${ }^{936} \mathrm{Yu}$ Ying-shih, "Zhongguo jindai sixiangshi shang de Hu Shih - "Hu Shizhi xiansheng nianpu changbian xu” 中國近代思想史上的胡適-- 《胡適之先生年譜長編初稿》序, ” in Chongxun Hu Shih licheng 重寻胡適歷程 (Taipei: Linking, 2004), 215-216.

${ }^{937} \mathrm{Hu}$ Shih, “Sanlun wenti yu zhuyi 三論問題與主義,” in HSWJ, vol.2, 249-52.
} 
had taught him to regard every existing theory and idea with suspicion. Before being influenced by these Western philosophers, Hu had already developed a skeptical attitude toward ancient books, especially old historical narratives under the influence of the Song philosophers of lixue 理學, such as Zhuxi and Zhang Zai 張載. Meanwhile, this was also the lessons he had learned from Evidential Learning: a deeprooted concept of 'truth' and an appreciation of the importance of "carefully seeking verification" [xiaoxin de qiuzheng 小心的求證] to uncover the truth. ${ }^{939}$

Hu's rigorous textual studies and his critical suspicion were the core elements of his "historical view" [lishi de yanguang 歷史的眼光] of the world, knowledge, and values. ${ }^{940}$ However, this scientific method was still hardly able to overcome the inherent limits of his "suspension of judgement" and excessive deconstructive force, as Yü Ying-shih discussed. ${ }^{941}$ His studies on Chan Buddhism, as well, had this pitfall: although he claimed to adopt scientific, objective approaches toward the subject with critical doubts, there were still some things he did not or could not doubt. His study of Chan Buddhism, which attributed the historical transformation of the Southern and Northern School entirely to Shenhui, for example, relied too much on the records in the Platform Sütra and the narrative of the orthodox Southern School. However, as some critiques demonstrated, the two teachings of the sudden and the gradual, which represented a fundamental difference in Hu Shih's opinion, would be better considered as dialectically inseparable motifs within the context of Buddhist spiritual training and doctrinal discourses. ${ }^{942}$ To Hu, the battle between the sudden and the

\footnotetext{
${ }^{938}$ For the intellectual background of Hu's thingking, see Yu Ying-shih, “Zhongguo jindai sixiangshi shang de Hu Shih - “Hu Shizhi xiansheng nianpu changbian xu” 中國近代思想史上的胡適 -- 《胡適之 先生年譜長編初稿》序, ”210-227.

${ }^{939} \mathrm{Hu}$ Shih, “Zhixue de fangfa yu cailiao 治學的方法與材料,” in HSWJ, vol.4, 105.

${ }^{940} \mathrm{Hu}$ listed three keys of the "method of researching, observation and governing [求學論事觀物經國 之術]”: inductive theory, historical view and evolutionary concept [歸納的理論, 歷史的眼光和進化 的觀念].” See Hu Shih, Hu Shih liuxue riji 胡適留學日記 (Shanghai: sanlian shudian, 2014), vol.3, part 1,167 .

${ }^{941}$ Yu Ying-shih, "Zhongguo jindai sixiangshi shang de Hu Shih - "Hu Shizhi xiansheng nianpu changbian xu” 中國近代思想史上的胡適 -- <胡適之先生年譜長編初稿>序, ” 228-240.

${ }_{942}$ Bernard Faure. The Rhetoric of Immediacy: A Cultural Critique of Chan/Zen Buddhism (Princeton: Princeton University Press, 1991), 32-52.
} 
gradual teachings and the inexorable victory of the sudden campaign were uncontestable historical "facts." However, more and more evidence had shown that although the dichotomy of sudden/gradual was important in the early Chan tradition, it did not circumscribe the most basic transformation in Chan. ${ }^{943} \mathrm{Hu}$ 's redepiction of the formation of the Chan orthodoxy, although he questioned the legitimacy of Huineng's teaching, still kept the prerequisite that there was an "orthodoxy" of Chan Buddhism as an uncontested truism. It was, as Bernard Faure discussed, "a will of orthodoxy." "944

Furthermore, Hu's instrumental rationalism, which questioned and even expelled the vast majority of traditional Chinese philosophical expressions and ideological standpoints, led him to a complete rejection of the religious background of the Chan texts. As a consequence, Hu basically considered the history of Chinese Buddhism, which is composed of scriptures as well as traditional Buddhist historical writings such as the Lamp records, biographies of monks, etc., to be a narrative of legends filled with supernatural power, mysterious experiences, and apparitions. Similar to the Doubting Antiquity School, Hu also believed that, although many of the fabricated details in those narratives might seem slight and insignificant, the flaws mounted as more and spurious things accumulated until their sheer number eventually made the case compelling and decisive. Therefore, the main mission of historiography was to unravel the multiplicity and complexity within texts, and to expose how distortions and fallacies were accumulated in ancient history layer by layer. This historiographical standpoint actually denied the religious nature of the Chan Buddhist texts, which subjected Hu to the critique of having an "inability to understand the nature of Buddhist spiritual training." ${ }^{945}$ In some scholars' view, Hu,

\footnotetext{
${ }^{943}$ See John R McRae, "Religion as Revolution in Chinese Historiography: Hu Shih (1891-1962) on ShenHui (684-758)," 82-83. Also, his “The Ox-School of Chinese Buddhism: From early Chan to the Golden Age," in Studies in Chan and Hua-yen, Studies in East Asian Buddhism, ed. R. M. Gimello and P. N. Gregory (Honolulu, University of Hawaii Press, 1983), 169-253.

${ }^{944}$ Bernard Faure, The Will to Orthodoxy: A Critical Genealogy of Northern Chan Buddhism, trans. Phyllis Brooks (Stanford: Stanford University Press, 1997), 4-5.

${ }^{945}$ John R McRae, "Religion as Revolution in Chinese Historiography: Hu Shih (1891-1962) on Shen-Hui (684-758)," 83.
} 
as a historian, seems not to have recognized that Chan/Zen had its own life independent of history. ${ }^{946}$

Hu's dedication to history caused him to ignore the historical context those medieval monastics actually lived in. He kept cynical about the educational level of the Chinese Buddhist clergy and accused them of lacking historical consciousness and knowledge of Sanskrit. ${ }^{947} \mathrm{Hu}$ complimented the Lengqie shiziji for some critical viewpoints that could only be found by a modern scholar while failing to realize that the text was written in a traditional, sectarian context of historiography. ${ }^{948}$ Because of his distaste for historical inaccuracy, most of the Chan texts were unable to pass Hu's lie detector or matched his restrict criteria of authenticity-in Hu's own words, the entire of body of Chan literature of Recorded Sayings was "ninety-nine percent false." ${ }^{" 49}$ Hu's prejudice against religion, therefore, brought an imaginative facet into his arguments and eventually led to some distorted historical judgements.

Besides his repulsion from religion in general, there was also an injection of personal belief in Hu Shih's objective research means. His contemporary scholars, like Chen Yinke and Jin Yuelin 金岳霖, had commented on Hu's work in their reviews of Feng Youlan's 馮友蘭 Zhongguo zhexueshi 中國哲學史 [The history of Chinese philosophy], published in 1931. Chen suggested that, although Hu's subject was ostensibly ancient Chinese philosophy, he was actually discussing his own ideas; Jin, as well, remarked that $\mathrm{Hu}$ had unconsciously adopted optimistic American attitudes toward progress and results, thereby revealing his own discomfort with the ancient

\footnotetext{
${ }^{946}$ Daisetz Teitaro Suzuki, “Zen: A Reply to Hu Shih,” Philosophy East and West 3, no. 1 (1953), 26

${ }^{947} \mathrm{Hu}$ Shih, Shenhui heshang yiji 神會和尚遺集, 27

${ }^{948}$ See John R. McRae, The Northern School and the Formation of Early Ch'an Buddhism (Honolulu: University of Hawaii Press, Honolulu, 1986), 91. McRae thought that the error of Hu Shih committed here was the "historians' fallacy," referring to David Fischer's description that "the error of assuming that a man who has a given historical experience knows it, when he has it, to be all that a historian would know it to be, with the advantage of historical perspective." See David Hackett Fischer, Historians' Fallacies: Towards a Logic of Historical Thought (New York: Harper Torchbooks, 1970), 209.

${ }^{949} \mathrm{Hu}$ Shih, “Chanzong shi diyi xin kanfa 禪宗史第一新看法.” Taipei: Zhongyang ribao 中央日報 (1953.1.12).
} 
world. ${ }^{950}$ Therefore, Hu's methodological construction only served the purpose of expressing his philosophical commitments. ${ }^{951}$

\section{New Paradigm of the Historiography of Buddhism}

Hu's rewriting of Chan history, although it had its limits, was a pivotal event that quite literally made possible the enterprise of Chan studies. ${ }^{952}$ Despite the controversial nature of his works, ${ }^{953}$ it should be admitted that Hu's work explored and established the 'paradigm' [典範] for the modern historiographical revolution, which also further propelled the transformation of Chinese scholarship. According to Yü Ying-shih, the reason why Hu's studies were revolutionary is that, as a follower of the tradition of Evidential Learning, he was able to combine the old mode of scholarship with a new framework of conceptual categories and methodological system. His work not only covered the "entire constellation of beliefs, values and techniques" in a broad sense but also offered "shared examples" in studies on specific issues. ${ }^{954}$ Although new research tendencies could be observed in many contemporary scholars, such as Liang Qichao, Chen Yinke, Chen Yuan, and Tang Yongtong, Hu might be the one who most clearly and plainly formulated a methodology in words and openly propagandized his scientific settings (he also went further, even to extremes

\footnotetext{
${ }^{950}$ Feng Youlan 馮友蘭, Sansongtang zixu 三松堂自序 (Beijing: sanlian shudian, 1984), 226-228.

${ }^{951}$ For a further discussion of Hu's historiographical agenda and his viewpoints on the role Buddhism played in Chinese history, see the Chapter 7 of this dissertation.

${ }^{952}$ For an overall description of Chan/Zen Studies, see Faure, Bernard: Chan and Zen studies: the state of the field (s). In this article, Hu Shih was also considered as the one who brought the attention of the Sinological world to Chan Buddhism. See Bernard Faure ed., Chan Buddhism in Ritual Context, 1.

${ }^{953}$ Not only limited to Hu's study on Chan Buddhism, his historical studies on Chinese literature and pre-Qin philosophies also opened a new ethos in modern Chinese academia.

${ }^{954}$ See Yu Ying-shih, “Zhongguo jindai sixiangshi shang de Hu Shih - "Hu Shizhi xiansheng nianpu changbian xu”中國近代思想史上的胡適 --<胡適之先生年譜長編初稿>序, ” 188. Also, “Zhongguo zhexue shi dagang yu shixue geming 中國哲學史大網與史學革命, ” ibid., 241. Here Yü refers to Thomas S. Kuhn's term "paradigm." See Thomas Kuhn, "Second thoughts on Paradigm," in The Essential Tension: Selected Studies in Scientific Tradition and Change (Chicago: Chicago University Press, 1977), 293319.
} 
towards system and order). The "paradigm" set by $\mathrm{Hu}^{955}$, which was presented in but not limited to his study of the history of Chan Buddhism, contained three dimensions:

Firstly, as a non-Buddhist historian, Hu wrote a history of one Buddhist sect without any sectarian dedication and re-assigned the task of recovering the past of Buddhism to history, instead of religious utterance. He broke the shackles of the traditional Buddhist narrative and introduced a secularized, chronological system of historiography based on modern discourses into the field of Buddhist studies. A structured scheme of "arranging the national essence" and a clear understanding of value, method, and belief, which were presented in his Outline of the History of Chinese Philosophy, could always be observed behind his concrete investigations. ${ }^{956}$ In a sophisticated way, he replaced the religious ends in Buddhist texts with an inquiry into historical facts and reconstruction of the historical thread of the transmission of Chan and the Sinicization of Buddhism.

Secondly, he expanded the scope of Chan studies by introducing new materials into this field. Through his collection, organization, and examination, more primary materials were brought to the table. He completely abandoned the monogenic preconception of the traditional narrative and applied an "equal view" [pingdeng de yanguang 平等的眼光] ${ }^{957}$ toward all materials. To Hu Shih, the history of Chan Buddhism needed to be rewritten outside the old genealogy fabricated by believers. To do so, a full utilization of non-Buddhist materials, including inscriptions, collected works, local records, and so on, was crucial. He examined and arranged the bibliographical catalogue of the Buddhist and Taoism inscriptions according to the records in Quan Tangwen 全唐文; in his later career, he carefully identified and collated some inscription materials with recourses to epigraphy. ${ }^{958}$ His utilization of

\footnotetext{
${ }^{955}$ Ge Zhaoguang, Ren zai Hu Shih de yanchang xianshang: youguan Zhongguo xuejie zhonggu chanshi yanjiou zhi fansi 仍在胡適的延長線上: 有關中國學界中古禪史研究之反思, ” in Lingnan xuebao fukan 嶺南學報復刊, vol.7 (Shanghai: Shanghai guji chubanshe, 2017), 16.

${ }^{956}$ Yu Ying-shih, “Zhongguo zhexue shi dagang yu shixue geming 中國哲學史大綱與史學革命,” 251253.

${ }^{957}$ Cai Yuanpei, “Zhongguo zhexue shi dagang xu 中國哲學史大綱序.”

${ }^{958} \mathrm{Hu}$ Shih, “Quantangwen li de Chanzong jia shiliao 全唐文裡的禪宗假史料,” HSWJ, vol.9, 441-444. Also, “Jinshilu li de Chanzong chuanfa shiliao 金石錄裡的禪宗傳法史料, i ibid., 539-541. See Ge
} 
Dunhuang manuscripts and ancient Japanese scriptures as well as Buddhist and nonBuddhist texts demonstrated a broadening of the horizons of Buddhist scholarship, which encouraged scholars to examine the origins and early development of Chinese Buddhism in a manner never before possible.

Thirdly, Hu established a historiographical paradigm of religious study pivoting on kaozheng. The legitimacy of Hu's own scholarship, as mentioned by Cai Yuanpei in his preface to Hu's Outline, was derived from the tradition of Han Learning. Hu considered that the logical character of the Qing scholars (beginning with $\mathrm{Gu}$ Yanwu 顧炎武 and culminating with Qian Daxin 鈛大昕, according to $\mathrm{Hu}$ ) composed the basis of the modern method and the spirit of science. The foci of the Qing scholarship-historical perspective; the discovery of [historiographical] tools; inductive research; and prioritizing evidence-had also been maintained as principles in his studies. ${ }^{959}$ This kaozheng inclination, which differed from the metaphysical tendency of Japanese Zen/Chan studies as well as the linguistic/archaeological path of Western scholarship, was the most distinctive characteristic of the Chinese scholarship of Buddhist history ${ }^{960}$

What needs to be noticed here is that these dimensions mentioned above were not Hu Shih's invention. Similar tendencies could be observed in many contemporary scholars, such as Liang Qichao, Chen Yinke, Chen Yuan, and Tang Yongtong. Although Hu might be the one who most clearly and plainly formulated a methodology in words and openly propagandized his scientific settings (he also went further, even to extremes towards system and order), his pursuit of establishing a modern paradigm

Zhaoguang, Ren zai Hu Shih de yanchang xianshang: youguan Zhongguo xuejie zhonggu chanshi yanjiou zhi fansi 仍在胡適的延長線上: 有關中國學界中古禪史研究之反思, ”18-19.

${ }^{959}$ The original words Hu used are: “歷史的眼光;工具的發明;歸納的研究;證據的注重.” In “Dai Dongyuan de zhexue 戴東原的哲學.”

${ }^{960}$ Ge Zhaoguang, Ren zai Hu Shih de yanchang xianshang: youguan Zhongguo xuejie zhonggu chanshi yanjiou zhi fansi 仍在胡適的延長線上: 有關中國學界中古禪史研究之反思, "19-26. Ge has investigated the main tendencies within the field of Chan/Zen studies in Japan and the West. He has suggested that the Japanese scholars emphasized more the "modern interpretation of traditional Chan thought; the Western scholars, on the other hand, stressed on the ritual and religious practices of Chan Buddhism." 
of scholarship and the use of the techniques of historiography was shared by his peers.

\section{Beyond Text}

In 1944, Tang Yongtong's monograph Hanwei won the "Prizes for the Writing, Invention and Art" awarded by the Ministry of Education of Republican China [Minguo jiaoyu bu zhuzuo faming jiangli 民國教育部著作發明美術獎勵]. ${ }^{961}$ Almost sixty years later, a recently discovered document has revealed that Lü Cheng and Liu Yizheng, as the reviewers of Tang's work, had completely opposite opinions. ${ }^{962}$

In his review ${ }^{963}$, Liu, the leading scholar of the Xueheng school 學衡派, highly praised Tang's History as "peeling the banana and reeling off raw silk from cocoons, making cutting and satisfactory reasoning” [bojiao choujian, qieli yanxin 剥蕉抽䒽, 切理厭心]; he commented that Tang's work "not only clarified the complex socialpolitical phenomenon logically but also analyzed the doctrines of different sects concisely and thoroughly." In particular, on some crucial issues, Tang's exposition was “extremely subtle" [youji jingwei 尤極精微] and “with extraordinary insights" [youjian teshi 尤見特識]. Thus, Liu concluded that, according to the selection standards, the History of Tang should undisputedly be awarded the first Prize.

Lü Cheng, on the contrary, classified Tang's History into the "third level." He listed several fallacies in the History in detail, such as Tang's investigation of the Sütra of the Forty-Two Chapters, and complained that Tang misunderstood many essential

\footnotetext{
${ }^{961}$ Tang applied (probably through the others' recommendation) for these prizes in 1943. Therefore, he won the prizes of the "sanshisan niandu" 三十二年度.For a detailed investigation on these prizes and the process of Tang's application, see Lai Yueshan 賴岳山, “Kaolun: Mingguo jiaoyubu 'zhuzuo faming ji meishu jiangli (1941-1949) yu Lu Cheng Liu Yizheng 'Tang Yongtong Han wei liangjin nanbeichao fojiao shi shencha shu’ 考論: 民國教育部 “著作發明與藝術獎勵” (1941-1949)”與吕澂柳詒徵“湯用䑣<漢魏兩 晉南北朝佛教史>審查書”, ” in Hanyu foxue Pinglun 漢語佛學評論 3 (2013): 11-121.

${ }^{962}$ For a copy of these two documents, see Hanyu foxue Pinglun 漢語佛學評論, Vol. 3, 2013. 963 “全屬同一面貌, 復何有於歷史之說钦.” Both the original versions of Lü’s and Liu's reviews were discovered in the archive of the preparatory office of the museum of Tsinghua University, Taiwan. See Yao Zhihua 姚治華, ibid. 8.
} 
Buddhist concepts, such as Buddha nature [Buddha-dhātu; 佛性], Prajñā, nirvāṇa, and dhyāna. As well, Tang's description of the relationship between Buddhism and the xuanxue, according to Lü, "failed to distinguish China and India, ancient and current" [wuhua wufan, wugu wujin 無華無梵, 無古無今]. He lamented that Tang's History "mixed all the things up, [so] how could it be called as history"? In the end, Lü concluded that:

The materials used in this book are wide-ranging, but not precise enough. His descriptions and explanations are vague and inappropriate; only the narrative structure is relatively clearly organized, so this book can be used for reference. 是著 取材博而不精，論斷泛而葟當，僅敘次有序，可資參考而已. ${ }^{964}$

Considering the good personal relationship between Tang and Lü, it is a little bit surprising to see such severe criticism. This document unveiled the huge gap between individuals within the same circle, which had always been concealed by the friendly atmosphere during that time ${ }^{965}$ It is noteworthy that the discussions over the historical materials and phenomenon of Chinese Buddhism have often exceeded the literal domain and tangled with different academic and religious standpoints. To Tang, as well as the historians Chen Yinke and Chen Yuan, Buddhism was more a 'relic' that has been preserved in books and artifacts than a living life form. This 'isolated' standpoint, however, was rejected by Lü Cheng and other Buddhist scholars. Behind his critical comment, Lü posted a question to all the professional historians without Buddhist faith: could someone really obtain the true knowledge of Buddhism without any relevant religious experience? This question not only exposed the tension between truth and faith but also led to more divergences on the 'teleological' level of history.

\footnotetext{
${ }^{964}$ Ibid. 7-8. According to the editor, Yao Zhihua, Lü’s student Zhang Chunbo 張春波 probably has seen a copy of this document (or its copy); however, Zhang thought that it was "not suitable for publishing." ${ }^{965} \mathrm{Ge}$, “'Liaowei youyi de bisai' - Cong Chen Yuan yu Hu Shih de zhenglun shuo dao zaoqi Zhongguo fojiao shi yanjiu de xiandai dianfan 聊為友誼的比賽”一一從陳垣與胡適的爭論說到早期中國佛教史 研究的現代典範.”
} 


\section{“The Scholarship of Truth” 真實之學 and “The Scholarship of Life” 為人 之學}

Reading religious texts from a historical perspective was not only aimed at reconstructing and expounding knowledge about the past of a certain religion, but rather was a project tangled with belief, doctrine, values, and science. To a certain extent, the textual studies of Buddhism against a modern academic background degraded the canonical Buddhist literature into a collection of written information waiting to be explained, verified, and deciphered. Texts, then, became sources from which those who were seeking historical knowledge obtained evidence. Fundamentally, the modern reading of Buddhist texts was a hermeneutical practice with different angles, from the historiographical interpretations based on knowledge and materials, to a teleological ascending path of thinking. ${ }^{966}$ Although scholars narrowed their studies to very grounded facts in Buddhist texts, the innate tension between 'faith' and 'truth' was intensified, combining their personal choice and tastes with the irreconcilable conflict between science and religion. ${ }^{967}$

Although the ghost of the apocrypha always haunted the Chinese Buddhist canon, it was only in the modern period that those textual controversies exceeded the bibliographical and doctrinal level and went beyond the monastic circle. This process led to a further de-canonization of Buddhist literature and a deeper separation between knowledge and religious value. Realizing this separation, in one talk on the main missions of the China Institute of Inner Learning, Lü Cheng stressed the re-unification of "the learning of truth" and "the learning of life." He elaborated:

The establishment of the institute was to study the development of Buddhist culture from an academic perspective. At that time, such a goal was proposed to be achieved at least through both the learning of truth and the learning of life.......Because Buddhism spread in China comes from translation, the texts and understandings all

\footnotetext{
${ }^{966}$ See Ricoeur, Paul, The Conflict of Interpretations, trans. Evanston (The North-western University Press. 1974).

${ }^{967}$ This conflict, as mentioned in Chapter 2, was rooted in the nature of modernity. For the relationship between science and Chinese traditional culture, see David W. Y. Kowk, Scientism in Chinese Thought (New Heaven, CT: Yale University Press, 1965).
} 
contain various barriers and have always distorted. Only via a thorough organization of the research materials and the acquisition of the truth can the real face of Buddhism then be observed. Secondly, the practice of Mahāyāna Buddhism actively benefits the world; but when it came to China, it went through a transcendental path. To rectify it, we must re-execute the Mahāyāna spirit of serving sentient beings. Our work is designed to move toward this goal. 本院的創設, 是要由學術方面去研究何 發揚佛教文化的。當時提出了這樣的目標至少做到真實之學和為人之學......因為 我國傳播的佛學乃經翻譯而來, 文字上, 理解上, 種種隔閬, 一向是多少走失了 原樣, 必需先把研究資料徹底整理得其真實, 才會見到佛學的本來面目。其次大 乘佛學的實踐本系積極地利益世間, 但傳來我國卻走上了超然自了的途徑, 要矯 正它, 必得重行發揮大乘為人的精神, 我們的工作, 就是朝著這樣的目標前進 的. 968

This tendency, which combined the instrumental and spiritual functions of scholarship together, was echoed by Taixu and later Yinshun 印順. Taixu's belief in the authenticity of Chinese Buddhist texts, from his standpoint as an apologist of Buddhism, derived from his tacit consent to the missionary utilization of these canons for the sake of safeguarding Buddhist faith. To him, all the textual deviations were just strategies of interpretation, behind which the Dharma remained unaltered. With a similar position that the 'truth' of Buddhism had never been challenged by apocrypha, scholastic monk Yinshun, although he admitted the questionable status of some Chinese Buddhist texts and supported the Evidential methodology, believed that the alterations of the original Indian texts would be better understood as innovative developments of Buddhism or an effort of its indigenization, which had never harmed the Dharma. ${ }^{969}$

Compared to these scholars, Hu Shih and Lü Cheng were less positive. As more iconoclasts than guardians of tradition, Hu and Lü's skepticism led them to very

\footnotetext{
${ }^{968}$ Lü Cheng 吕澂, “Neixueyuan yanjiu gongzuo de zongjie he jihua 內學院研究工作的總結和計畫,” in Jinxiandai zhuming xuezhe foxue wenji 近現代著名學者佛學文集, ed., Huang Xianian 黄夏年, Beijing: Zhongguo shehui kexue chubanshe, 1995), 301.

${ }^{969}$ See Yinshun, Dasheng qixinlun jiangji 大乘起信論講記 (Taipei: Zhengwen chubanshe, 1991), Xuanlun 懸論; Original texts based on the notes of Yinshun's serial lectures in Hong Kong in 1950. The representive work of Yinshun's Buddhist history is his “Zhongguo zanzongshi” 中國禪宗史 published in 1971.
} 
radical conclusions. Both of them criticized that Chinese Buddhism was full of fallacies, intentional distortion, mythical narratives, and even lies. Lü considered Chinese Buddhist texts as 'heresy', therefore, he was aiming to veer Chinese Buddhism back to its origin and to recover the "credible history of Buddhism" [xinshi 信史]. ${ }^{970} \mathrm{To} \mathrm{Hu}$, who claimed a standpoint of positivism, Chinese Buddhist texts were basically narratives of legends and myths that had deceived Chinese people for centuries. In his view, by exposing the tricks of "those counterfeiting monks" [zuojia de heshang daoshi 作假的和尚道士], the real 'national essence' would be freed from the negative effects of 'Indianization' [yinduhua 印度化].

Chen Yinke, Chen Yuan, and Tang Yongtong chose carefully a balanced position between faith-oriented judgment and purely scientific analysis. They did not simply categorize certain Buddhist texts as unauthentic or forgeries but rather accepted them as undoubtedly existing primary sources for historiography. To them, the behavior of falsification and its historical, political, and intellectual background were what they, as historians, should pay attention to. Therefore, the authenticity of texts was not the end of their textual criticism. What they preferred was historiography with an explanatory power, which could identify, criticize, and interpret the particular historical phenomena behind the changes in the texts. However, could these non-religious, historicized discourses guarantee a 'truer truth'? To these 'secular' historians, this question, which put forward by Lü Cheng and his Japanese counterparts, such as D.T. Suzuki, was hard (or not necessary) to answer.

\section{Text without History}

The encounter of the Buddhist textual tradition with the modern construction of world religion largely complicated the issue of authenticity surrounding Buddhist texts. When some of the Buddhist texts had been read and presented to the modern audience, they had been transformed into a discursive composition; they might be apocryphal or even heretical, but they could be popularized as a representative

\footnotetext{
${ }^{970}$ Lü Cheng, Fojiao yanjiufa 佛教研究法. XFXC, vol. 41, 243.
} 
articulation of Buddhism itself. For example, the Treatise was translated and published in 1900 by D. T. Suzuki and again by Briton Timothy Richard soon after (1845-1919).$^{971}$ Soon, this text became part of what has been described as the "occidentalist strategies" of Japanese Buddhists, whereby they discovered the role Western studies of Buddhism could play in legitimizing their tradition in the eyes of their local critics. In particular, to those Japanese Buddhist clerics and laypeople interested in what James Ketelaar has called "the construction of Eastern Buddhism," the Treatise, although it might be a counterfeited production, was one of the texts that could be used to manufacture a Buddhism beyond sectarian boundaries -- a united, trans-historical, essential Buddhism.

Even in D. T. Suzuki's translation of the Treatise, the "Chineseness" of the text had been smoothed down. Suzuki worked hard both to re-define the Western views of Mahāyāna Buddhism and to help convince people at home that Buddhism was useful to the modern Japanese nation. By emphasizing the 'Japanese spirit' in Zen, he and some other Japanese scholars overcame suspicion about the authenticity of the Buddhist canon and gained "approval of Buddhism as the most appropriate religion for the modern, scientific world" by utilizing sophisticated philosophical idioms and appropriating many of the philological and historicist tools of Western Buddhology.

Recently, more and more scholars have criticized that, behind the modern construction of the 'objective,' 'absolute' textual tradition of Buddhism, there was always a socio-political inquiry that was deeply rooted in this-worldly and particular historical contexts. ${ }^{972}$ As described by Ishii Kosei 石井公成, Japanese academia in the late nineteenth century used the teachings of the Huayan school to rationalize the ideology of Japanese nationalism; while in China, intellectuals like Kang Youwei, Tan

\footnotetext{
${ }^{971}$ Timothy Richard carried out the second but completed translation of the Qixinlun, which published in 1907. As a Baptist missionary, one of Richard's key proselytizing strategies was to open a dialogue with Chinese political and cultural elites and to seek to influence them. He also put forward the theory that the so-called Buddhism of the "Great Vehicle" [Mahāyāna] was not Buddhism at all, but rather a form of Christianity. See Mitchell, Dumoulin, and Peachey, "A History of Zen Buddhism."

${ }^{972}$ Representative works include Victoria Brian, Zen at War (Lanham, MD: Rowman \& Littlefield Publishers. 1997). 1997; Robert H Sharf, “The Zen of Japanese Nationalism,” History of Religions 33, no. 1 (1993): 1-43; Faure, Chan Insight and Oversight.
} 
Sitong, and Zhang Taiyan deployed the same teachings to support their revolutionary or even anarchist ideas. ${ }^{973}$ In the unique context of modern China, Buddhist texts, to some Chinese intellectuals, were not the real subject of Evidential Studies or the science of religion, but philosophical resources for their critiques and reflections on other ideologies. For example, in Xiong Shili's "agonizing questing for authentic existence, ${ }^{, 974}$ he borrowed from Buddhist ideas to establish a dynamic ontology in which reality [ti 體] gained its normativity through ceaseless movement of creation and transformation. ${ }^{975}$ In one letters to Lü Cheng, Xiong argued that the question of whether Buddhist scriptures such as Lengyanjing 楞嚴經, Yuanjue Jing 圓覺經 and the Qixin lun were Chinese apocrypha or not was less relevant to doctrinal reflection, because the main ideas in those texts did "not inevitably obey the Dharma." However, although he criticized Buddhism harshly, Xiong, as well as other NeoConfucian philosophers, drew substantial (albeit largely unacknowledged) philosophical inspiration from the concepts of emptiness, transformation, and nature origination ${ }^{977}$ in Buddhist heritage. Buddhist texts, even questionable ones, served as valuable intellectual resources for their constructive philosophies.

\footnotetext{
${ }^{973}$ Kosei Ishii 石井公成, “Kindainihon ni okeru daijōkishinron no juyō”近代日本における大乗起信論 の受容," Ryūkokudaigaku Ajia bukkyō bunka kenkyū senta 2012 Nendo dai 10 kai zentai kenkyūkai 龍 谷大学アジア仏教文化研究セン夕 2012 年度第 10 回全体研究会, Kindainihon bukkyō kenkyū dai 2-kai 近代日本仏教研究第 2 回.

${ }^{974}$ Tu Weiming, Neo-Confucian Thought in Action: Wang Yang-Ming's Youth (Berkeley: University of California Press, 1976), 254.

${ }^{975}$ Xiong's religio-philosophical conversion from Buddhism to Confucianism happened after 1923. From 1920 to 1922, he studied Buddhism, especially the Consciousness-Only school with Ouyang Jingwu in Nanjing, and his doctrinal position was rather faithful to the Yogacara tradition. See Lin Chen-kuo, "Hsiung Shih-Li's Hermeneutics of Self: Making a Confucian Identity in Buddhist Words." NCCU Philosophical Journal 8 (2002): 69-90.

${ }^{976}$ Xiong Shili, Xiong Shili quanji 熊十力全集, vol.8, 436.

${ }^{977}$ Xiong's theory of Buddhism's nature origination [xingqi 性起] was influenced by Huayan tradition. It indicated that all phenomenal appearances are nothing but manifestations of nature (reality).

According to Peter N. Gregory, this goes beyond conditioned arising in locating an ultimate ontological basis for the phenomenal world. See Peter Gregory, Inquiry into the Origin of Humanity: An Annotated Translation of Tsung-mi's Yüan jen lun with a Modern Commentary (Honolulu: University of Hawaii Press, 1950), 18. Also, see Makeham, John. "Xiong Shili’s Critique of Yogācāra Thought in the Context of His Constructive Philosophy," in Transforming Consciousness: Yogacara Thought in Modern China, 242-282.
} 


\section{CHAPTER 6}

\section{Geyi 格義: Reflections on Tradition, Culture, and History}

The formation of Chinese Buddhism, which has been depicted as a scene of 'Sinicization,' has captured the attention of generations of scholars in both Asia and the West. One of the essential pieces of the puzzle of Buddhist Sinicization is translating, rendering, interpreting, and deciphering the concepts of Indian Buddhism into the Chinese language, a process that usually has been labeled with the term geyi [matching concepts or matching meanings] in Buddhist historiography. ${ }^{978}$

Commonly, the practice of geyi has been historically considered by the current Buddhist scholarship as an inevitable stage of reception; though it 'failed,' it played a decisive role in the early transmission and indigenization of Buddhism in China. Indeed, how could foreign thought be understood without any existing conceptual background or any 'Vorurteile' [prejudgment 前見]? As the scholar Whalen Lai said: "Perhaps all human understanding is ko-i [geyi], that is, an endless appropriation of new ideas relying on the flexibility of the old." ${ }^{1979}$ He then argued that, rather than criticizing geyi for its incorrectness and indiscrimination, it would be more proper "to see why and how ko-i [geyi] failed." ${ }^{980}$ Since Buddhism is an imported religion after all, the term 'geyi' sounds quite proper and natural, for it highlights the transcultural implantation of concepts and ideas. Therefore, geyi and its derivative term 'ko-i' [geyi] Buddhism' thus have been widely employed and became the main target of the so-

\footnotetext{
${ }^{978}$ Most Western scholarship on early Chinese Buddhism has touched on geyi [ko-i]. See Eric Zürcher, The Buddhist Conquest of China (Leiden, Brill, 1959); see also the bibliography in Arthur Wright, Buddhism in Chinese History (Stanford, Stanford University Press, 1959): 131-32, also 38-39.

${ }^{979}$ Lai Whalen. "Limits and Failure of 'Ko-I' (Concept-Matching) Buddhism," in History of Religions 18, no. 3 (1979): 239.

${ }^{980}$ Ibid., 239.
} 
called 'critical Buddhism' prevailing in Japan throughout the twentieth century. ${ }^{981}$ However, describing the character of Chinese Buddhism as 'matching concepts' is highly problematic and oversimplified, as it presumes the 'impurity' of Chinese Buddhism and an unsuccessful indigenization. Some scholars have pointed out that geyi, though enshrined as a cardinal principle of the early encounter between Indian Buddhism and China, was historically a brief, unimportant episode. Its historical significance emerged actually as a matter of modern scholarship. ${ }^{982}$

\section{‘Geyi' Revisited}

As Victor H. Mair analyzed, geyi was one product of the modern scholarship on Chinese Buddhism. Although this notion transpired in history, geyi, as one facet of Chinese Buddhism, was invented rather than discovered. Although current discussions on geyi have addressed the complicated historical context of this term, they have left some crucial questions unanswered: why did the discourse of geyi gain attention during the early twentieth century and why it was selected and used to describe one essential facet of Chinese Buddhism? How was this discourse formed and emphasized by modern Buddhology through historiography? How did historians in modern China, such as Chen Yinke and Tang Yongtong, understand this phenomenon from the perspective of the entire process of Chinese history, and what kind of historiographical concept and cultural viewpoint can be observed from their interpretation of geyi?

\section{Geyi in Historical Context}

\footnotetext{
${ }^{981}$ For the important works of Critical Buddhism see esp. Matsumoto, Shirō, Enji to kū: Nyuraizō shisō hihan (Tokyo: Daizō Shuppan, 1989), 1993; and Noriaki Hikamaya, Hongaku shisō hihan 本覺思想批判 (Tokyo: Daizō Shuppan, 1989) and Hihan bukkyō (Tokyo: Daizō Shuppan, 1990); see also the English accounts in Jamie Hubbard and Paul. L. Swanson, eds., Pruning the Bodhi Tree: The Storm Over Critical Buddhism (Honolulu: University of Hawaii Press, 1997); and James Mark Shields, Critical Buddhism: Engaging with Modern Japanese Buddhist Thought (Burlington: Ashgate, 2011).

${ }^{982}$ See Victor H. Mair, “What Is Geyi, After All?” in China Report 48, no. 1 (July 23, 2012): 29-59.
} 
In common usage, geyi is usually rendered in English as "matching concepts/meanings" or "measuring concepts/meanings" and is explained as a 'translation technique' serving to pair Sanskrit Buddhist terms with Sinitic Daoist terms "when the Chinese neo-Taoist intellectuals were drawn to the emptiness philosophy of Prajñā-Pāramitā-sūtras." ${ }^{183}$

In the massive Chinese historical texts, geyi, in its textual form, was limited used, in either Buddhist literature or in other religious and secular contexts. According to Victor H. Mair's investigation, no single example of geyi can be found in Taoist canons or in the whole collection of the twenty-four official histories. Similarly, no occurrence of geyi can be observed in Zizhi tongjian 資治通鑑 or Xu Zizhi tongjian 續資治通鑑. Neither is there an independent instance of geyi in the entirety of the enormous Gujin tushu jicheng 古今圖書集成 nor in the mega collection of Siku quanshu 四庫全書. ${ }^{984}$ Only in Buddhist texts does the term geyi appear several times: it is mentioned four times in Gaoseng zhuan, and two times in Chu sanzang ji ji. It is also scattered in several other Buddhist scriptures and categories, such as Fayuan zhulin 法 苑珠林, Xu gaoseng zhuan 續高僧傳, Kaiyuan shijiao lu 開元釋教錄, and so on. Most of these texts are biographies of Buddhist figures or bibliographical records of scriptures. ${ }^{985}$

The primary and most important document for the history of geyi is the biographical account of Zhu Faya 筑法雅 (who lived between the late Western Jin [265-316] and the early Eastern Jin [317-420]) in the Gaoseng zhuan:

[Zhu] Faya was a man of Hejian. He was of a staid, tolerant disposition. As a youth, he excelled at non-Buddhist studies, and when he grew up, he became proficient in Buddhist doctrine...... Consequently, [Zhu Fa] ya, with Kang Falang and others,

\footnotetext{
${ }^{983}$ See Lai, Whalen. "Limits and Failure of 'Ko-I' (Concept-Matching) Buddhism," 239. And Mair, Victor H. "What Is Geyi, After All?" 30.

${ }^{984}$ Mair, Victor H. "What Is Geyi, After All?" 32. He also has mentioned in the same article that there is no occurrence of geyi in Shishuo xinyu, which would be significantly abnormal if geyi were a dominant or famous concept among the intellectuals in the Wei, Jin, and Southern-Northern dynasties.

${ }^{985}$ The only exception was Zhongguan lunshu 中觀論疏 written by master Jizang 吉藏(549-623), which was an exposition on the doctrine of Madhyamakaśāstra.
} 
correlated the enumerations of items [shishu] in the sūtras with non-Buddhist writings as instances to engender understanding ${ }^{986}$; this was called 'matching concepts' [geyi]. 法雅, 河間人。凝正有器度。少善外學, 長通佛義......雅乃與康法 朗等, 以經中事數擬配外書, 為生解之例, 謂之格義. ${ }^{987}$

This passage has been invariably cited several times in Chinese Buddhist texts; however, until Chen Yinke's article on the theory of Zhi Mindu 支慗度, it did not draw much attention among scholars or Buddhists. ${ }^{988}$ After Chen, however, this passage was much discussed while still poorly understood. One of the problems was the implication and meaning of the expression 'shishu' 事數, which literally means 'enumeration of items.' Many scholars believed that the term shishu could be to a large extent equated with 'fashu' 法數 [numerical Dharma] or 'mingshu' 名數 [numerical terms], which in Sanskrit is linked to "dharma-paryāya" [formulaic terms of the dharma] and signifies "Buddhist terms that begin with a number." 989 Therefore, shishu may be appropriately translated as 'numerical categories' and denotes the categorized groups of terms in Buddhist doctrines, such as four truths [sidi 四諦], five sense-organs [wugen 五根], six paths [liudao 六道], twelve links of dependent origination [shier yinyuan 十二因緣], etc. ${ }^{990}$

\footnotetext{
${ }^{986}$ The meaning and proper translation of the phrase "shengjie" 生解 was controversial. There has been no satisfactory translation until now. A possible alternative could be "lively understanding," which considers "sheng" 生 to be an adjective.

${ }^{987}$ CBETA. T50, no.2059, 4, p.347a20. Translated cited from Mair, Victor H. “What Is Geyi, After All?” (2012): 32.

${ }^{988}$ Chen Yinke 陳寅恪, “Zhi Mindu xueshuo kao 支毀度學說考,” in JMCB, 167-180.

${ }^{989}$ For example, this definition of shishu was adopted by Buddhologist Erik Zücher in his famous book The Buddhist Conquest of China: The Spread and Adaptation of Buddhism in Early Medieval China, 184.

${ }^{990}$ One convincible example supporting this explanation can be found in Shishuo xinyu 世說新語 [A new account of tales of the world] with the commentary of Liu Xiaobiao 劉孝標 (462-521): Shishu means, for example, the Five Personality components/aggregates (pañcaskandha), the Twelve Entrances (dvādaśāyatanāni), the Four Truths (catvāri ārya-satyāni), the Twelve Links of Dependent Origination (dvādaśanga pratityasamutpāda), the Five Sense-organs (pañcendriyāni), the Five Powers (pañca balāni), and the Seven Factors of Enlightenment (sapta bodhyangāni) [事數謂若五陰, 十二入, 四諦, 十二因緣, 五根, 五力, 七覺之屬].
} 
However, in actual practice, the utilization of shishu was variable and flexible and did not have to mean "numerical categories. ${ }^{.991}$ Basically, the term shishu had an indigenous root. The single character shu, which was used to translate "Sāmkhya" (an Indian philosophical tradition whose name was normally defined as 'enumeration', 'investigation,' or 'categorization' of the phenomenal world), can be found in dozens of early Chinese philosophical and historical texts, such as Yijing 易經. The combination of 'shi' and 'shu,' which appears only two times in the translated Buddhist scriptures in Chinese, did not signify "numerical categories." ${ }^{" 992}$ As Chen Yinke noted, 'shishu' as a term was continually used by Buddhists and scholars in later times, but the signification of this term was wide-ranging. ${ }^{993}$ Even in the Southern and Northern dynasties, the implications of 'shishu' had been generalized and were not limited to'fashu' 法數 [numerical categories]. ${ }^{994}$ It usually denoted 'discourse and

\footnotetext{
${ }^{991}$ Shishu, as a term, had been actually used for centuries before Buddhism was imported from India into China. It was related to an augury based on Zhouyi and meant a kind of mathematic technique that was applied to predict the destiny and future of certain people and events. Examples of such a usage can be find in the commentary of Zhouyi, xici 繫辭: “極數知來之謂占, 通變之謂事, 陰陽不 測之謂神”; also “極其數, 遂定天下之象.” Here shu [numbers] were considered the cipher of the changes and images of heaven. By 'exhausting numbers' one could capture the changing phenomenon of the universe. This idea of "jishu" 極數 [exhausting numbers] also had a pronounced influence on Chinese Buddhists; for example, Sengzhao 僧肇 used the phrase “qiongling jishu” 窮霝極數” [exhaustly penetrating the spirits and numbers] in his Bore ushi lun 般若無知論. Taishō 45: 155a ff.

${ }^{992}$ The first example is in Sifenglü 四分律 [Dharmagupta-vinaya], volume 52. The original text is: “爾時 世尊在王舍城。時優波離與諸比丘共論法律, ......新學年少比丘不解事數相涉, 聽用算子記數.” See CBETA, T22, no.1428, p.956b3. The second example is in Dafangguangfo huayan jing 大方廣佛華嚴 經 [The Great Vaipulya Buddha Flower Ornament Scripture; Sank. Buddhāvatamsakaka-mahāvaipulyasūtra], translated by 佛䭾跋陀羅譯 in 420, volume 36. The original text is: “佛子! 譬如字章, 悉入一 切字數、一切事數、一切語言數、一切算數、一切世間、出世間而無所住.” See CBETA, T9, no.278, 33, p.627c15. In both examples, the meaning of 'shishu' was not only "numerical categories."

${ }^{993}$ For example, in weimojiejing xuanshu <維摩詰經>玄疏 [ Commentary on Vimalakīrti-Nirdeśa-Sūtra], Zhiyi 智顗, wrote that: “此經理致深遠言旨淵玄。若但依文帖釋恐止事數而已。一教宗極終自難 量。猶須略忖幽微, 顯不思議旨趣.” See CBETA, T38, no. 1777, p521a5; In his “Miaofalianhua jing xuanyi 妙法蓮華經玄義, ” CBETA, T.33, no. 1716, he used shishu as: “既知 “化成”一事是佛權施, 則遍 達恆沙佛法, 遠通久劫方便。故《華嚴》中明, 為阿鞞跋致多明事數, 即其義也.”

${ }^{994}$ There are two examples in Chu sanzang ji ji compiled by Sengyou 僧祐. The first one is in <Dapinjing> $x u$ 大品經序 [the Preface of the Pañcavimiśatisāhasrikā Prajñāpāramitā] written by Sengrui 僧频 that: “胡本唯序品阿鞞跋致品魔品有名。餘者直第其事数而已。法師以名非佛制。唯存序品略其二 目。其事数之名與舊不同者。皆是法師以義正之者也。如陰入持等名。與義乘故隨義改之。”
} 
concepts of dharma' in a broad sense and approximately equated with the Buddhist term 'mingxiang' 名相 [names and appearances]. ${ }^{995}$

Geyi, as an approach to dealing with the issues of shishu, thus cannot simply be understood as a technique of translation or a method of categorizing Buddhist terms. Also, it means not merely matching the Buddhist concepts with China's indigenous thoughts (especially Daoism). Considering the variable and obscure meanings of shishu and geyi, historians like Chen Yinke observed and interpreted geyi as a historical phenomenon that had existed in the early stage of the transmission of Buddhism in China, rather than as a systematized method of translation. They also noticed that geyi was continuously criticized as early as when it had just emerged because it abruptly and problematically fashioned a synthesis bridging two intellectual systems. One of the most famous examples was Dao'an's rejection of geyi by the middle of the fourth century in his conversation with Monk Sengxian 僧先 (?) as “The old 'matching concepts' [geyi] of the past was often at odds with Buddhist principles." ${ }^{996}$ Another example was Sengrui's 僧叡 (352-436) repudiation of geyi in his “Pimoluojietijing yishu xu” 毘摩羅詰堤經義疏序 that “the matching of concepts [employed in them] was pedantic and at odds with the original [sense of the Indian texts being discussed]; the Six Schools [of Prajñāpāramitā] were biased and did not touch [the truth]." ${ }^{197}$ Apparently, approximately one hundred years after its rise, geyi had long ceased to be applied as a functioning device. The opposition against it had been cemented by Buddhist exponents; the limitation and defect of geyi had also

\footnotetext{
See CBETA: T55, no.2145, 8, p.52c28. The second example is in DaXiaopin duibi yaochao xu 大小品對比要 抄序 written by Zhi Daolin 支道林: “是故出小品者。參引王統。簡領群目。鉒域事數。摽判由宗。

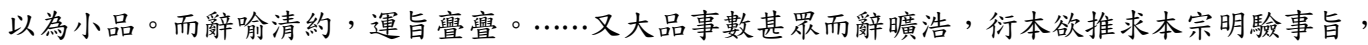
而用思甚多勞審功又葟, 且稽驗廢事不覆速急.” See CBETA: T55, no.2145, 8, p.55a14. In both examples, the term 'shishu' refers to theoretical principles and terms of Buddhism in general. ${ }^{995}$ Even modern Buddhist scholars have maintain this usage of 'shishu' in their arguments on Buddhist doctrines, for example, Lü Cheng has mentioned that "the teaching of prajñā only talks about 'emptiness' [xingkong 性空, sunyata] vaguely and generally; if we want understand this term, we must figure out the 'shishu' (namely, names and appearances [mingxiang, 名相]).” In Zhongguo fojiao yuanliu lüejiang 中國佛教源流略講, 45.

${ }^{996}$ CBETA: T50, no.2059,50, 5, p.355a25.

${ }_{997}$ CBETA: T55, n2145, p.58c13.
} 
become fully exposed. Buddhist historian Sengyou 僧祐 (445-518) concluded in his biography of Kumārajīva that:

Since the Great Law covered the east, beginning in [the time] of Emperor Ming (5875) of the [Later] Han and passing through the Wei (220-265) and the Jin (265-420), the (translated) sūtras [scriptures] and Śāstras [treatises] that were produced gradually became numerous. Yet the [translations] produced by Zhi [Qian] and Zhu [Fahu] ${ }^{998}$ mostly [were plagued by] stagnant wording ${ }^{999}$ and concepts matching. 自大 法東被, 始於漢明, 歷涉魏晉, 經論漸多, 而支、筑所出, 多滯文格義. ${ }^{1000}$

In this passage, 'ge' 格 is used in parallel with 'zhi' 滞 and was probably intended to mean 'obstruct, stagnant, stiff, confine', and so on. Sengyou here chastised the early translators like Zhi Qian and Zhu Fahu because their interpretations of Buddhist doctrines were laborious, superficial, and based too much on the literal meaning of the texts. Even the term geyi may be an extension of the basic meaning of 'compartment(alize)'; it is palpable that Sengyou's understanding of geyi did not equate with its primary meaning - which was a method of exegesis, rather than a technique of translation. ${ }^{1001}$ Some scholars, such as Erik Zürcher, believe that, to the

\footnotetext{
${ }^{998}$ One of the explanations of the word 'zhizhu' is to treat it as an abbreviation referring to Rouzhi 月支 and Tianzhu 天竺; here 'zhizhu' would more likely designate Zhi Qian (fl. 220-252) and Zhu Fahu (i.e. Dharmarakșa), according to Sengzhao 僧肇 in his preface to the Vimalakīti-sūtra (CBETA: T55, no. 2145 p.58b9). See Robert Shih, trans. and annot. Biographies des moines éminents (Kao seng tchouan) de Houei-kiao. Bibliothèque du Muséon, vol. 54 (Louvain: Institut Orientaliste, 1968). In a detailed study of the translation techniques of this period, Boucher has pointed out that by zhiwen geyi, Sengzhao criticized overly Sinicized or indigenised translations that came at the expense of faithfulness to the Indic originals. Zhiwen geyi is a pejorative stigmatisation of the translation style of Zhi Qian and Zhu Fahu. See Daniel J. Boucher, Buddhist Translation Procedures in Third Century China: A Study of Dharmaraksa and His Translation Idiom (University of Pennsylvania, Diss., 1996), 8

${ }^{999}$ For a note on the origin and significance of this expression, see Shih (1968: 74, n. 57), who pointed out that it may ultimately derive from Dao'an's preface to the Extracts from the Mahāprajñapāramitāsūtra, in which Dao'an stated: “Whenever I come to a stagnant sentence [滞句] or a passage where the beginning and the ending are obscured, I set the scroll aside and think deeply, regretting that I never met such men as Dharmarakșa and Mokșala' (CSJ 8; T.55 [2145] 52b.p.11-13).

${ }^{1000}$ From Chuzanzang ji ji, CBETA: T55, n2145, p.101b13. Copied with a couple of minor variants in Gaoseng zhuan, CBETA: T50, n2059, 2, p.332a28.

${ }^{1001}$ It can be, furthermore, restricted to the explication of numbered lists, as some of the scholars have insisted. See Mair, Victor H. "What Is Geyi, After All?" 29-59.
} 
generation of Buddhists like Sengyou, the meaning of geyi had already become very vague. $^{1002}$

Influenced by Sengyou, Buddhist exponents in the Sui and Tang dynasties continued to use the phrase "stagnant wording and matching concepts" [zhiwen geyi 滞文格義] verbatim when discussed the early translation of Buddhist doctrines. ${ }^{1003}$ Jizang 吉藏 (549-623), for example, repeated the identical set of paired clauses: "matching concepts were pedantic and went against the fundament; the Six [Prajñā] Schools were biased and off the mark." ${ }^{1004}$ Commenting on this sentence, he criticized geyi as distorting the original meaning of the Buddha's teaching. He mentioned that geyi had its practical function before the advent of Kumārajīva but did not refer to how it actually worked. None of these Buddhists provided any concrete definition of geyi or recorded any further development or extension of this method in the following centuries after Dao'an's time.

After all these reproaches, geyi seems to have been ostracized by the Buddhist circle. It disappeared from the history of Chinese Buddhism, at least literally, and was seldom discussed or mentioned again. More precisely, as some scholars have pointed out, geyi did not disappear overnight, but when the Buddhist concepts like prajña and śūnyatā were more appropriately rendered and digested by the Chinese, the demise of geyi was inevitable..$^{1005}$

In sum, geyi was neither a vital technique of translation nor an essential philosophical principle; rather, it was a hermeneutic strategy to cope with the concepts and ideas in the Buddhist canon. It was a method of exegesis with a very pragmatic intent, controversial, ephemeral, and abortive to a certain extent, which

\footnotetext{
${ }^{1002}$ See Erik Zürcher, The Buddhist Conquest of China, 184; also see Leon Hurvitz, tr., Zenryū Tsukamoto, A History of Early Chinese Buddhism Vol. 1 (Tokyo: Kodansha International Ltd., 1985), 294.

${ }^{1003}$ For example, Sengyou's censure of the translations of Zhi Qian and Dharmaraks as zhiwen geyi was repeated verbatim by Daolang 道朗 (T55, no.2145, p.101b13-1542), Huixiang 慧祥 (T51, no.2067, 15b910), Daoshi 道世 (T53, no.2122, p.474b16-17), Zhisheng 智昇(T55 [2154] 514c13-15), Yuanzhao 圓照 (Eastern Jin) (T55, no.2157, p.811c3-4)

1004 格義迁而乘本, 六家偏而未即. T42, no.1824, p.4c11, 29a7-8; T42, no.1825, p.174a12-13, $183 a 2$.

${ }^{1005}$ See Lai Whalen. “Limits and Failure of 'Ko-I' (Concept-Matching) Buddhism,” 238.
} 
was applied by a limited group of Buddhist advocates to make Buddhist teaching accessible and acceptable for more people. It is not necessary to limit geyi to categorizing 'shishu' with a numerical framework, as Zürcher did; however, it was, without doubt, a short-lived stage of the Sinicization of Buddhism and quietly changed its meaning during the development of Chinese Buddhism. The main reason geyi was known as a critical feature of Chinese Buddhism was the re-examination of modern Buddhist scholarship and historiography. There was no significant mention of geyi until the twentieth century, when it was miraculously revisited by modern historians such as Chen Yinke and Tang Yongtong and was re-interpreted as a key factor in the early development of Chinese Buddhism.

\section{The Modern Interpretations of Geyi}

As discussed before, geyi was a temporary solution for early Chinese Buddhists to overcome the daunting obstacles they faced. Because of the scarcity of accurate knowledge in both language and philosophy, as well as "a plethora of 'apocryphal' scriptures," ${ }^{1006}$ the propensity to confuse or conflate Buddhism with native Chinese thought was ignited. Geyi was one conspicuous example. It lasted for around two centuries, and then, as a hermeneutic strategy, it was criticized and rejected, and disappeared from the historical context. Then, how did such a transient, pragmatic (or maybe insignificant, as some scholars have claimed) ${ }^{1007}$ strategy became one of the cardinal features of Chinese Buddhism? To answer this question, we need to trace the discovery of geyi in modern scholarship that occurred in the 1920s and illustrate the discursive transformation of geyi from an exegetical technique of limited, circumscribed application into a key label of Chinese Buddhism as well as a vital element of its historiography.

\footnotetext{
${ }^{1006}$ The 'apocryphal scriptures' here mean the indigenous Chinese texts written so as to resemble translations of Indic originals, which had emerged on large scale since the Eastern Jin dynasty.

${ }^{1007}$ See Victor H. Mair, "What Is Geyi, After All?" 59.
} 
The issue of geyi is believed to have been raised by Chen Yinke for the first time. ${ }^{1008} \mathrm{He}$ resurrected the obscure notion of geyi and brought it back into the vision of scholarship. Moreover, he established the prototype of the discourse of geyi that was followed by almost all the scholars after him. ${ }^{1009}$ As mentioned before, Chen's pioneering study of geyi was a part of his inquiry into a marginal Buddhist figure in the Eastern Jin dynasty, Zhi Mindu (who also served as the starting point for his boarder investigation of medieval Chinese Buddhist literature) and his teaching of xinwu 心無 [the nonexistence of the mind]. With regard to the interpretation of the term of geyi, he quoted Zhu Faya's biography in the Gaoseng Zhuan as well as Liu Xiaobiao's commentary on shishu and explained:

During the Jin era, the scholars who engaged in Pure Conversation [qingtan 清談] mostly favored strained comparisons [bifu 比附] between Buddhist texts and nonBuddhist writings. What is more, among the monks, there was a concrete method called geyi. Although the term geyi is seldom seen in written records, it was prevalent for a period, and its influence on contemporary thought was profound; therefore, the issue of geyi should be elaborated 蓋晉世清談之士, 多喜以内典與外書互相比附。 僧徒之間復有一種具體之方法, 名曰 “格義”。“格義”之名, 雖叒見載記, 然 曾盛行一時, 影響於當日之思想者甚深, 固不可以不論也. ${ }^{1010}$

Chen accepted Liu's interpretation of shishu and provided some examples. However, he suggested that it was not necessary to limit shishu and geyi only to the numerical Buddhist concepts. Instead, Chen interpreted geyi in a general sense, referring to Huiyuan 慧遠 (334-416) and Sun Chuo 孫綽 (ca. 311-368) as two representative examples of the practice of geyi: Huiyuan recounted the meaning of shixiang 實相 [reality] by using the sources in Zhuangzi 莊子; Sun Chuo connected the legend of 'seven worthies of the bamboo groves' [ zhulin qixian 竹林七賢] with seven monks from India. In Chen's opinion, geyi was not only a natural outgrowth of the early encounter between Buddhism and Chinese culture but also a common conduct

\footnotetext{
${ }^{1008}$ At least Chen was the most influential scholar who discussed this issue.

${ }^{1009}$ See Victor H. Mair, "What Is Geyi, After All?” 47; Takatoshi, Itō. ‘The Formation of Chinese Buddhism and "matching the meaning" [geyi], trans. Rolf W. Giebel, Memoirs of the Research Department of the Toyo Bunko (The Oriental Library), no. 54 (1996): 69.

${ }^{1010}$ Chen Yinke 陳寅恪, Zhi Mindu xueshuo kao 支㥿度學說考, in JMCB, 141-67.
} 
related to the prevalent trend of qingtan among the literati. The propensity to discuss metaphysical issues during that time led to the practice of matching concepts. The reason why xinwu, a misconception derived from the literal misunderstanding of the Aștasāhasrikā Prajñāāāramitā 道行般若經 ${ }^{1011}$ could be developed by Zhi Mindu into a popular thought, according to Chen, could also be attributed to this "scholarly trend" [xueshu fengqi 學術風氣]. Chen noted that, just as its vanguards一xingkong 性空 and benwu 本無, invented by Dao'an 道安 and Fatai 法汰 ${ }^{1012}$ 一the teaching of xinwu was also consistent with the purport of Laozi 老子 and Xici 繫辭 (the commentary of Yijing) and did not conform with the original meaning of emptiness in Prajñāpānamitā scriptures.

In one lecture, Chen further critically investigated the historical appearance of geyi by using 'zhulin qixian' as an example. ${ }^{1013}$ According to Chen's investigation, zhulin was the Chinese translation of the celebrate Venuvana or Karandāvenuvana; $;^{1014}$ qixian 七賢, as a shishu, originated from the mysterious zuozhe qiren 作者七人 [the seven men who acted] of the Analects. Driven by the scholarly mechanism of geyi, these two unconnected terms combined into the notion of zhulin qixian, referring to a group of bohemian, nonconformist intellectuals, poets, musicians, and tipplers in

\footnotetext{
${ }^{1011}$ In his article Zhimindu xueshu kao, Chen expounded that the teaching of xinwu was based on three Buddhist sūtra: Fangguang bore jing 放光般若經, Daoxing borejing 道行般若經, and Chitian fantian suowen jing 持心梵天所問經, in which the expression xinwu could be observed frequently in the form of the phrase 'youxinwuxin' 有心無心. Chen compared the Chinese translation of these three sūtras with the original manuscripts in Sanskrit, and showed that xinwu 心 無 was an equivalent of cittam acittam in Sanskrit; cittam meant xin, and acittam meant wuxin. Therefore, xinwu was not a proper word and actually should be wuxin. Chen also mentioned that in most of the early translated Buddhist sūtras, xinwu was translated as feiyi 非意 or feixin 非心'.

${ }^{1012}$ See Chen Yinke 陳寅恪, Zhi Mindu xueshuo kao 支㤵度學說考, in JMCB, 160.

${ }^{1013}$ His lecture was titled “Qingtan wuguo” 清談誤國 and was delivered at Sun Yet-sen University in 1947. See Wan Shengnan 萬繩楠 (ed.), Chen Yinke Wei Jin Nanbeichao shi jiangyan lu 陳寅恪魏晉南北朝 史講演錄 (Hefei: Huangshan Shushe, 2007), 45-64.

${ }^{1014}$ Venuvana or Karandāvenuvana [Zhulin] is a monastery park near the city of Rājagrtha that was donated to Śkyamuni by King Bimbisāra (or, according to another account, by the elder Karanda). However, in Wei and Jin, the real meaning of 'zhulin' was already unreachable.
} 
Luoyang 洛陽. ${ }^{1015}$ Later, Confucianist Sun Chuo further compared the legendary Tianzhu Qi Seng 天竺七僧 [the seven monks of India] to this Chinese zhulin qixian. ${ }^{1016}$ Through this example, Chen demonstrated how geyi cumulatively affected the transformation and implantation of concepts between cultural parallels.

For Chen, the utilization of geyi was not restricted to the earliest phase of Buddhist Sinicization during the Wei-Jin period, or specifically before Kumārajīva . He extended the scope of geyi onwards to the Northern Song dynasty. Historically, as Chen noted, geyi, although it had been rejected by the Buddhist community, performed as a subterranean flow in medieval Chinese cultural history. ${ }^{1017}$ It was the hidden logic behind the formation of many new theories-borrowing concepts and ideas with different origins to form something fresh and compatible. For example, according to Chen, Zhu Xi 朱喜's Neo-Confucianism, was influenced essentially by Buddhist thought and therefore a tangible form of geyi. The amalgamation of the three religions [sanjiao 三教]—Buddhism, Confucianism, and Daoism—was a variation of geyi as well. Other forms of syncretism followed the spirit of geyi

\footnotetext{
${ }^{1015}$ The ‘Zhulin qixian’ includes: Ji Kang 嵇康, Ruan Ji 阮籍, Shan Tao 山漙, Xiang Xiu 向秀, Liu Ling 劉 伶, Wang Rong 王戎, Ruan Xian 阮咸.

${ }^{1016}$ Chen quoted Sun Chuo's Dao Xian zhuan 道賢傳 [Biographies of the Sages] to explain how people at the time paired the Zhulin qixian with seven Indian eminent monks. For example, 法護 was paired with Shan Tao (高僧傳一・暴摩羅叉傳), Bai Fazu 白法祖 was paired with Ji Kang (高僧傳一・帛遠傳), Fa Cheng 法乘 was paired with Wang Rong (高僧傳四・法乘傳), Zhu Daoqian 竺道潛 was paired with Liu Ling (高僧傳四・竺道潛傳), Zhi Dun was paired with Xiangxiu (高僧傳四・支遁傳), Yu Falan 於法蘭 was paired with Ruan Ji (高僧傳四・於法蘭傳), Yu Daosui 於道遂 was paired with Ruan Xian (高僧傳 四・於道遂傳). See Wan Shengnan 萬繩楠 (ed.), Chen Yinke Wei Jin Nanbeichao shi jiangyan lu 陳寅恪魏晉 南北朝史講演錄, 45-64.

${ }^{1017}$ Chen did notice that, after the Jin Dynasty, the term geyi was seldom discussed by Buddhists and intellectuals, with the result that the tree significance of geyi was also unreachable. In his example of 'Zhulin qixian,', he pointed out that in the Northern dynasty, people such as Li Daoyuan 麗道元, the author of the Shuijing Zhu 水經註, had already missed the meaning and origin of 'zhulin' 竹林 and tried to find sights of bamboo groves near Ji Kang's living places. See ibid.
} 
dispersed in Chinese intellectual history, such as the thought of Zongmi 宗密 (780$841)^{1018}$

Following Chen, many scholars joined the discussion. One of the most important articles was written by Tang Yongtong. In this article, Tang defined geyi as:

'Ko' [Ge], in this context, has the meaning of 'to match' or 'to measure'; 'yi' means 'name', 'term' or 'concept'; 'Ko-yi' [Geyi] is (the method or scheme of) 'matching ideas' (or terms), or 'the equation of ideas. ${ }^{1019}$

Tang's explanation, due to its wide reception in the English-speaking world, determined the standard translation of geyi as 'matching concepts. ${ }^{1020}$ In the chapter “The study of prajñā at the time of Shi Daoan" [Shi Daoan shidai zhi bore xue 釋道安 時代之般若學] in his History, he wrote:

What is geyi? 'Ge' 格 means 'measure', to estimate, evaluate [liang 量]. It is a method of facilitating people's understanding of Buddhist writings by combining and matching them with Chinese thought. ${ }^{1021}$

Tang's explanation here was in very general terms. He illustrated that geyi was a convenient way for understanding Buddhism and that this method had only been practiced before Dao'an's and Kumārajīva's times. He attached the examples of Dao'an [his conversation with Sengxian] and Sengrui 僧幪 to emphasize the fact that Dao'an had already realized the pitfall of geyi and considered geyi to be circuitous and to run counter the principles of Buddhism. The aim of geyi, Tang further argued, was to

\footnotetext{
${ }^{1018}$ Some of the scholars then questioned whether Chen had the proper understanding of geyi, because he extensively applied geyi to a larger spectrum. However, this opinion ignored the background of Chen's own historiographical position.

${ }^{1019}$ Tang Yongtong, Lun geyi-zui zao yi zhong ronghe Yindu Fojiao he Zhongguo sixiang de fangfa 論 $\ulcorner$ 格義」一最早一種融合印度佛教與中國思想的方法. The English Translation by M.C. Rogers was published in 1950. Translated from English to Chinese by Shi Jun 石峻, in Lixue, Foxue, Xuanxue 理學・佛 學·玄學 (Beijing: Beijing daxue, 1991), 282-94. This has also been collected in TYQJ, vol. 5, 231-42. The original Chinese draft on which Rogers based his English translation has not been found.

${ }^{1020}$ Some scholars, such as Mair, have contested the accuracy of the rendered English term 'matching concepts.' However, due to the absence of Tang's original text in Chinese, it is not easy to see if Tang's understanding of geyi was vague or not.

${ }^{1021}$ Tang Yongtong, Han Wei liang Jin Nanbeichao Fojiao shi 漢魏兩晉南北朝佛教史(Beijing: Zhonghua shuju 中華書局, 1983) 168, Or geliang, 格量 as on page 170.
} 
blend Chinese thought with foreign ideas about Buddhism. It was an effective and pragmatic means; therefore, even Dao'an, who opposed the problematic geyi, also fused Taoist Lao-Zhuang thought into his writings on Buddhism.

As the harbingers of discussion on the issue of geyi, both Chen Yinke and Tang Yongtong presented the intention of considering geyi to be one of the most representative and fundamental methods of the integration of different traditions. Moreover, these two historians shared the hypothesis that the Chinese Buddhism, or even the entire landscape of Chinese culture, was the outcome of geyi; based on the logic of geyi, China went through several external cultural impacts and eventually formed its own cultural peculiarities. ${ }^{1022}$

The discourse of geyi was elaborated by Japanese specialists into the term 'kakugi Bukkyō' 格義仏教 ['geyi Buddhism'] and was promulgated as an equivalent to or synonym for Chinese Buddhism, with countless disquisitions being written on its nature and impact. ${ }^{1023}$ The Japanese researcher Ui Hakuju 宇井伯壽 discussed geyi by quoting Zhu Faya's biography from the Gaoseng Zhuan and explained it as one "practice of comparing and matching the principles expounded in the sūtras with non-Buddhist works," which he identified exactly with Taoist texts. Another Japanese scholar, Tokiwa Daijō 常盤大定, also asserted that "geyi means to employ LaoZhuang [thought] to interpret Buddhism." The opinions of both Japanese scholars indicated the influence from Chen Yinke and Tang Yongtong, but remarkably narrowed the scope of geyi and limited the non-Buddhist teaching that participated in the process of geyi to Daoism. ${ }^{1024}$

The expression 'geyi Buddhism' [kakugi Bukkyō] was used for the first time by Japanese scholar Tsukamoto Zenryū 塚本善隆. The chapter “The unfolding of geyi

\footnotetext{
${ }^{1022}$ Other Chinese scholars who discussed geyi included Hu Shi 胡適, Feng Youlan 馮友蘭 and Ren Jiyu 任繼愈.

${ }^{1023}$ For example, Kobayashi Masayoshi 小林正美(1997). Also see Hayashima Kyōshō and Takasaki Jikidō, eds, Bukkyō-Indo shisqjiten 仏教インド思想辞典 (Tokyo: Shunjūsha, 1987), 54b-55b.

${ }^{1024}$ For a detailed examination of the Japanese scholarship on 'geyi Buddhism' or 'kakugi Bukkyō,' see Takatoshi, Itō. 'The Formation of Chinese Buddhism and 'Matching the Meaning' [geyi]', trans. Rolf W. Giebel, Memoirs of the Research Department of the Toyo Bunko (The Oriental Library), 54 (1996): 71-73.
} 
Buddhism towards a society of pure conversation during the Eastern Jin" [Kakugi Bukkyō no Tō Shin seidan shakai he no tenkai 格義仏教の東晉清談社会への展開] in his Shina Bukkyō shi kenkyū 支那仏教史研究 [A study on the history of Chinese Buddhism] also indicated influence from Chen Yinke. ${ }^{1025}$ After the previous section of 'Daoist Buddhism' [Dōkyōteki Bukkyō] (which offered an even more dubious proposition) ${ }^{1026}$ he followed Ui and Tokiwa to emphasize the significance of Daoism in the Eastern Jin period and advocated geyi as a vital factor in the early development of Chinese Buddhism that connected the 'Dark/Abstruse/ Metaphysical Learning' [xuanxue 玄學] of the Wei-Jin period with prajña à studies. Tsukamoto's notions of 'Dōkyōteki Bukkyō' and 'kakugi Bukkyō' were adopted and used, for they described one staple of the thought of the Wei-Jin literati and a form of faith that was promoted in parallel among the ordinary people.

From the second half of the twentieth century, the discourse of geyi was widely established in Western academia. It became a constant theme presented in nearly all introductory and general expositions of Chinese Buddhist history.

The Western reception of the discourse of geyi can be dated back to the enormously influential A History of Chinese Philosophy [Zhongguo zhexue shi 中國哲學史] written by Feng Youlan 馮友蘭. Under the influence of Feng, as well as Chen Yinke and Tang Yongtong, scholars such Arthur Link, Arthur Wright, Wing-tsit Chan, Kenneth Chen, Robert Shih, etc., gradually settled on the rendering of 'matching concepts' or 'matching meanings' as the most crucial and representative feature of Chinese Buddhism and defined geyi as a method of translation that connected the prajñ $\bar{a}$-sūtra with Sinitic Lao-Zhuang thought. ${ }^{1027}$ Even the primary meaning and scope

\footnotetext{
${ }^{1025}$ Tsukamoto, Zenryū 塚本善隆, Shina Bukkyō shi kenkyū 支那仏教史研究 (Tokyo: Kōbundō shobō, 1924), 25-34.

${ }^{1026}$ It is problematic because Daoist religion was hardly well enough established before the Eastern Jin (the period to which Tsukamoto is here referring) to have subsumed or significantly coloured Buddhism.

${ }^{1027}$ Arthur Link, from 1957, began a long series of articles in which he focused on the problem of geyi. Influenced by Tang Yongtong, he defined geyi initially as "matching meanings," a method in which Chinese terms and concepts (chiefly Taoist) were paired with analogous Indian terms and ideas. Arthur Wright, in his Buddhism in Chinese History, rendered geyi as 'matching concepts' and stated that "[ $\mathrm{t}]$ his
} 
of geyi was vague; it was enshrined as a cardinal principle and an unavoidable process in the transmission of Buddhism from India to China. In modern scholarship, geyi has been conceptualized not as a technical term but as an abstract sketch of the general identity of Chinese Buddhism, without any sectarian biases. To this extent, geyi is a discourse that has been uprooted from its historical context. Its intended meaning was simplified, generalized, extensively interpreted, and mixed up with interpretations and even imagination. Fundamentally, geyi and its extended variations in modern scholarly writing are conceptual and 'less-historical.'

\section{The Discourse of Geyi: Chen Yinke's Reflections}

Although geyi was 're-invented' by modern scholarship and became a discursive narrative of Chinese Buddhism, current studies of this issue began to focus on the essence of this term itself by examining its historical existence and further revealing how geyi has been constantly distorted and misunderstood. Chen and Tang, then, have been criticized as missing the real historical function of geyi or misevaluating its long-term significance. Such comments rightly suggest the nature of geyi and its historical limitations, but meanwhile leave out questions such as why scholars in modern China 'occasionally' noticed geyi and purposely promoted it into a core feature of Chinese Buddhism, or why geyi was chosen and established as a discourse in the writing of Buddhist history. To answer these questions, it becomes necessary to trace the fundamental historiographical concepts of Chen and Tang and reveal their contemplations on the history, tradition, religion, and culture of China.

\footnotetext{
device was prevalent in the second and third centuries." Wing-tsit Chan in his A Source Book in Chinese Philosophy defined geyi as "the practice of matching concepts of Buddhism with Daoism, in which one Buddhist concept is matched one in Chinese thought." Based heavily on Tang Yongtong, Kenneth Chen described geyi as "the method of matching the meaning. This method was used especially by the translators of the Prajñā sūtras for the purpose of making Buddhist thought more easily understood by the Chinese." Most of the representative ideas of geyi in modern Western scholarship were influenced by Chen and Tang, at least to ca ertain extent. For the detailed investigation on geyi in the modern Western scholarship, see Mair, Victor H. “What Is Geyi, After All?” 49-52.
} 
The innate similarities and the complementary character between Chinese and Indian civilization, as the initial point of interpenetration, drove the early Buddhist apologists, such as Dao'an and Huiyuan, to find parallels between Buddhism and Chinese native thought. To Chen and Tang, this activity of bridging indigenous and foreign thought, which happen naturally, demonstrated a vital facet of both Chinese culture and Buddhist tradition. Historically, geyi, as one significant method of interpretation, was not required by the 'authentic' Dharma, but rather, presented how Chinese civilization responded to external impacts in a particular way. Therefore, instead of delimiting geyi or evaluating the pros and cons of practicing geyi ${ }^{1028} \mathrm{Chen}$ and Tang's studies immediately focused on the intellectual background and socio-political perquisite for geyi, namely, the motivation and means of the chinese to adapt to and domesticate foreign thought, intellectually and practically.

\section{Buddhism and Chen Yinke's Historiography}

For the scholars who try to rebuild the past of Chinese Buddhism, 'Sinicization' was an inescapable issue. Chen Yinke was perhaps the first scholar who coped with this issue in Chinese academia. Realizing the historicity of geyi as well as its reference in a specific time, Chen partly admitted that geyi was firstly an instrumental way to make an alien faith palpable to local people. Indeed, how could Buddhism be understood without some recourse to the familiar? Although, as Zürcher suggested years ago, ${ }^{1029}$ this term must have referred to something more specific, such as the pairing of Buddhist numerical categories found in the older dhyana and Abhidharma literature with superficially similar Chinese numerical lists, ${ }^{1030}$ in Chen's view, geyi was not something ephemeral. He considered it to be one step in the broader historical process of the Sinicization of foreign thoughts, and understood it as a cultural pattern

\footnotetext{
${ }^{1028}$ As cited before, Chen and Tang both only provided a brief description of geyi. Some scholars, like Mair, have then questioned whether Chen and Tang had sufficient knowledge of this term.

${ }^{1029}$ Erik Zürich, The Buddhist Conquest of China: The Spread and Adaptation of Buddhism in Early Medieval China, 184.

${ }^{1030}$ Zürich's discussion was somewhat ignored by some later scholars, for example, Walen Lai.
} 
that presented the basic scenario of the encounter between 'the others' and 'the self ${ }^{1031}$ As such, Chen upgraded this hermeneutic strategy into a historical stereotype of the formation of Chinese cultural identity.

Chen Yinke's two most cited texts on geyi, mentioned before, echoed the central theme of his "national cultural history" [minzu wenhua zhishi 民族文化之 史] ${ }^{1032}$ As early as 1919, Chen mentioned in a conversation with Wu Mi 吴宓 that the transmission of Buddhism was particularly worth investigating, ${ }^{1033}$ since, compared with Confucianism, which had a deep influence on social regulation and moral principles, Buddhism had more profoundly changed the intellectual sphere of the Chinese. ${ }^{1034}$ As a silent power, this religious belief had sometimes propelled but sometimes obstructed changes in other domains, such as politics, economy, literature, and art. Therefore, Chen stressed that understanding the issue of "belief" [xinyang 信仰] was the "prerequisite" [xianjue tiaojian 先決條件] for establishing the past of China. ${ }^{1035}$ To him, political elements, especially the behavior and activities of the emperors and courts, were only one facet of the whole picture. He contended that the inheritance and discontinuity of religious tradition within or between clans, literati, gentry communities, and so on, were another thread of Chinese intellectual history. In particular, the dis-synchronic tempos of religious and political changes, following crisscrossing conflicts both inside and outside China, profoundly influenced or even determined many historical scenarios. Accentuating the term 'religious belief,' Chen declared that only with the knowledge of mutual-utilization between religion and other socio-political powers and the realization of the conflicts between individual beliefs and the larger atmosphere of faith in a particular era-which is the

\footnotetext{
${ }^{1031}$ Here I oppose Mair's claim that Chen did not understand that geyi is a historical product.

${ }^{1032}$ Chen, Yinke, “Chen Yuan 'Yuan xiyuren huahua kao’ xu 陳垣元西域人華化考序, J JMEB, 270.

1033 “佛教流布, 實為世界文明史上, 大可研究者.” See Wu Mi, Wu Mi Riji 吴宓日記, ${ }^{1034}$ Chen, “Feng Youlan Zhongguo zhexue shi (xia ce) shencha baogao 馮友蘭中國哲學史下冊審查報告,” JMCB, 283.

${ }^{1035}$ Chen, Tao Yuanming sixiang yu xingtan zhi guanxi 陶淵明思想與清談之關係. JMCB, 224, 227-228. As Chen implied here, Liang Qichao's study might be unqualified, because Liang's studies on Tao Yuanming ignored the background of Tao's pedigree and belief and made judgements based on his own experience.
} 


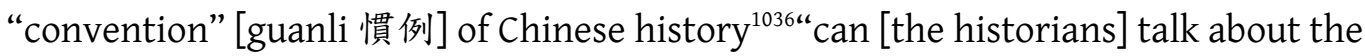
cultural history of medieval China." ${ }^{1037}$

\section{'Theoretical Geyi' and the Innovation of Old Meaning}

Chen Yinke's interpretation of geyi firstly appeared in his works during the 1930s as one part of his construction of Chinese national cultural history. To Chen, Buddhism was always linked with a first-person possessive, such as 'our nation' [wuguo 吾國]. Buddhism, definitely, is not Chinese; however, in Chen's observation, the significance of Buddhism in Chinese history transformed this quintessential (in Chen's sense) external tradition in a departure from its Indian roots that caused it to gain a certain 'Chinese-ness.'

After 1932, Chen's studies on Buddhism experienced a transition from comparative textual analyses on Buddhist scriptures to thematic investigations of the cultural and ethnic manifestations of Buddhism in medieval Chinese history. ${ }^{1038}$ In 1935, he published an article entitled "Empress Wu Zhao and Buddhism" [Wuzhao yu fojiao 武旺與佛教], in which he fabulously expounded on how religion (here Buddhism) as a discursive mechanism functioned in historical processes and engaged in socio-political changes from the Sui to the Tang dynasty. He started his argument by investigating the belief tradition of Empress Wu's maternal clan and the historical origins of this belief within the royal court of the Sui, linking it with the broader

\footnotetext{
${ }^{1036}$ For example, in his article “Tianshidao yu binghai diyu zhi guanxi” 天師道與濱海地域之關係, he pointed out that "in Chinese history, political reforms always presented certain kinds of 'religiosity' or 'mysticism'. Even today, this 'historical convention' continues," in JMCB, 45.

1037 “始可與言吾國中古文化史也.” Ibid, 38. Chen also discussed the issue of religion in his “Wozhao yu fojiao 武晊與佛教” (JMEB, 153-74) and “Tao Yuanming zhi sixiang yu weijin qingtan zhi guanxi 陶淵明 之思想與魏晉清談之關係” (JMCB, 201-39). Both of these articles demonstrated how the family religious tradition was 'deep and strong' [深且固]. One example Chen provided here was Shen Yue. Although Shen believed in Buddhism and wrote dozens of articles to defend and advocate for Buddhism, he still followed the Daoist ritual of “shangzhang shouguo” 上章首過 when he was dying. ${ }^{1038}$ As investigated in Chapter 3, at this stage of Chen's career (from 1927-1937), religion remained the core theme of his studies. However, after he moved to Yunman and taught at Xinan lianda 西南聯大, he switched his interests from religious history to the history of politics and literature in medieval China, partly due to limited access to research sources.
} 
context of the rise and fall of Buddhism from the Northern Zhou era to the early Tang. As Chen demonstrated, the attitude of Empress Wu towards Buddhism was not only related to her practical quest for consolidating political power but also rooted in her faith background and religious experience of her childhood. From Wu's promotion of the Mahāmeghasūtra [Dayun jing 大雲經], ${ }^{1039}$ Chen suggested the multilayers of the mutual exploitation between religion and politics: a dynastic change in secular power could not immediately shake the faith foundation of society; rather, religion was always utilized in political turmoil as an apparatus for enhancing certain political powers or sustaining social status. Therefore, he concluded, "the historical materials always reveal that religion and politics depend on each other." ${ }^{1040}$

This article not only clarified the role religion played in political changes but also covered some other essential issues closely related to the transformation of Chinese Buddhism. The first one was the fundamental contradiction between the Buddhist and Confucianist concepts of ethics. Citing a passage from Fozu tongji 佛祖統 紀 written by Zhipan 志磐, Chen brought to light how a monk of the Tiantai school depicted the Emperor Yang of the Sui dynasty, a brutal despot, as a savior, labeling him "the king Ajātasattu." 1041 Secondly, Chen, in his conclusion, touched upon the critical issue of 'dissimilarity between China and the Western regions' [huayi zhibie 華夷之別] by referring to Xie Lingyun's 謝霝運 (385-433) Bianzong lun 辩宗論. Furthermore, he also discussed the encounter between different religious and cultural traditions. The Buddhist scripture Dayunjing, he analyzed, was not an

\footnotetext{
${ }^{1039}$ According to Chen's argument, Wu Zhao was influenced by Buddhism through her mother at a very young age. Based on the records in the Dunhuang scripture of Dayun Jingshu 大雲經疏 [Commentary on the Mahāmeghasūtra] in the British Museum in London, Chen argued that Wu even ordained as a nun before she entered the palace. However, her promotion of Buddhism also had a political intention. Because her ascendence to the throne could not be supported by the Confucian classics, she had to turn to Buddhism to get legitimacy. In the Mahāyāna classics, there was the narrative of 'being recorded to be Chakravartin as woman' [nüsheng shouji wei zhuanlunshengwang chengfo 女身受記為 轉輪聖王成佛]. Wu then made use of this story to justify her position as Empress. See part “bing 丙.” See Chen, “Wozhao yu fojiao 武曌與佛教”, in JMEB, 153-74.

1040 “自來史實所昭示, 宗教與政治終不能無所關涉.” See Chen Yuan mingji dianqian fojiao kao xu 陳 垣明季滇黔佛教考序, in JMEB, 272.

${ }^{1041}$ Ibid. $159-160$
} 
apocryphal scripture created in the Middle Kingdom but originated from a district near Khotan Kingdom 于睤. However, the term “female king” [nüshen weiwang 女身 為王] in this scripture, which Empress Wu made use of, was initially created by Han immigrants living in the Western Region, instead of the Indians or Khotanese themselves. Therefore, the formulation of Dayunjing could not be solely assigned to the Empress but instead resulted from unavoidable cultural contacts. The historical process is complex, containing coincidence, backward flow, and political intentions, as well as conceptual exchanges. Therefore, the case of Dayujing was not only concerned with the 'legitimacy' of 'power' but rather demonstrated a special model of 'dialogue' between cultures: one tradition borrows and imports its own concepts through the others.

The issues discussed in this essay reflected the central concerns of Chen Yinke's historiography, which included: firstly, the relationship between religions (especially Buddhism) and other socio-political powers in the Chinese historical context; secondly, the contradiction and compromise between external and domestic traditions; thirdly, the formation of the particularity of the Chinese nation and culture, especially the role Buddhism had played in this process. Therefore, the key point of Chen's studies was not the static state of so-called "historical truth" but rather "relationships" (alteration, discontinuity, and convergence), which gradually impelled the Chinese to establish their own historical path and conceptual system.

From the 1930s to the 1940s, Chen published several articles about geyi and some relevant issues, such as qingtan. The most important ones are "A study of Zhi Mindu's teaching” [Zhi Mindu xueshuo kao 支敗度學說考] (1932), “An investigation of Xiang Xiu and Guo Xiangs' interpretation of 'Xiaoyao You'” [Xiaoyaoyou Xiang Guo yi ji Zhi Dun yi tanyuan 逍遙遊向郭義及支遁義探源] (1937), and “The Relationship Between Tao Yuanming's idea and pure conversation" [Tao Yuanming zhi sixiang yu qingtan zhi guanxi 陶淵明之思想與清談之關係]. ${ }^{1042}$ Without providing any direct

\footnotetext{
${ }^{1042}$ In current scholarship, most of studies on geyi have paid attention to the first article because it was the initial investigation of this term. However, the other two articles should not be ignored since they provide indispensable information on Chen's meaning. Axel,
} 
clarification of the term geyi, all these articles addressed one question: what is the relationship between qingtan and geyi? - namely, is geyi a result of pure conversation, or vice versa? Indeed, as some scholars have pointed out, connecting Buddhism with qingtan, a trend of xuanxue 玄學, revealed Chen's deviation from the original meaning of geyi. However, this judgment is somewhat of a detour and misreading of the real intention behind Chen's discussion. ${ }^{1043}$ To Chen, the relationship between geyi and qingtan was not only about a special historical phenomenon, but touched upon issues that he concerns: how Chinese cultural tradition dealt with influences from the outside and how cross-cultural exchanges had taken place throughout China's history. His reflections echoed his historical interpretation of the cultural universality and integrity in China's past as well as in its present and future.

Never formulating a definition for geyi, however, Chen realized that geyi was a method or strategy applied in a limited situation and properly noticed the relationship between geyi and shishu. Although chen quickly moved to a generalized historical context, this did not mean that Chen had only a vague understanding of this term. In the article on Zhi Mindu's teaching, he provided a very innovative yet convincing elucidation for the term 'shengjie' 生解, ${ }^{1044}$ an expression that had an equivalent meaning to geyi, and clearly pointed out the limitation of geyi in a methodological sense.

In his article on Guoxiang and Xiang Xiu's comments on "Xiaoyaoyou," Chen investigated the commentary of Monk Zhidun on the Taoist classics Zhuangzi as a representative instance that showed how Buddhism had impacted native Chinese thought and what kind of social and ideological transformation had supported the popularity of Buddhism among the Chinese literati. According to Chen, Guo and

\footnotetext{
${ }^{1043}$ For example, Victor H. Mair wrote that: Chen's discussion of geyi is filled with this sort [like Chen's investigation of Zhulin Qixian 竹林七賢] of unbridled attribution of practically any syncretic tendencies to this eclusive snark" and made "bold assertion." See Victor H. Mair, "What is Geyi, After All?," China Report 48, no. 1-2 (2012).

${ }^{1044}$ In Chen's opinion, 'shengjie' 生解 was related to the term 'zizhu' 子注. There is a intertextuality between 'sheng' 生' and 'zi' 子, 'jie' 解, and 'zhu' 注. Chen criticized the method of 'shengjie' and advocated for the method of 'zizhu.' See Chen “Zhi Mindu xueshuo kao 支䁈度學說考,” in JMCB, 181-85. This issue will be further discussed in the next part of this chapter.
} 
Xiang's commentaries on "Xiaoyuao you" from Zhuangzi, one of the most important and profound texts of the Daoist philosophy, were based on 'the theory of talent and personality' [caixing lun 才性論], which originated from the system of 'pure judgment' [qingyi 清議], a method for selecting talented people by judging their personalities. However, after the Eastern Jin dynasty, with the disintegration of the influential-family system [menfa zhidu 門閥制度], qingyi gradually transformed into a trend of qingtan-'pure conversations' on abstract and philosophical topics. Against this background, Zhi Dun 支遁, an eminent monk living in the Jiangdong 江東 area, used the doctrine of the Aștasāhasrikā-prajñāpāramitā-sūtra [Daoxing jing 道行經] to comment on "Xiaoyao you," matching the concepts of prajña to the Taoist idea of 'nature' [ziran 自然] and 'non-doing' [wuwei 無為]. This kind of geyi, in particular using Buddhist doctrines to interpret Taoist classics, Chen argued, emerged as early as in the period of Dao'an and Huiyuan and continually developed into a main trend of qingtan. ${ }^{1045}$ In this sense, it was the shift from the dying political system of qingyi to a scholastic, theoretically vibrant trend of qingtan that encouraged the prevalence of discussing metaphysical questions by matching, pairing, and comparing concepts within and across different systems of thought. Even as Dao'an harshly criticized the method of geyi as “deviating from reason" [yuli duowei 於理多違], he was comfortable with his own practice of mixing the theories of Daoxing jing and "Xiaoyao you" together. Clearly, under an atmosphere of qingtan, Dao'an himself was also actually "bearing geyi in mind." ${ }^{1046}$ Therefore, the term geyi, which fundamentally meant a specific technique for comparing numerical categories, had been understood

\footnotetext{
${ }^{1045}$ Actually, as Chen noticed, using Buddhist terms and concepts to comment on "Xiaoyao you" was an admired, popular intellectual activity in the Wei and Jin dynasties that could demonstrate the commentator's intelligence and talent. Here Chen gave a very interesting explanation of Senxian's saying of “qie rong fenxi xiaoyao" 且容分析逍遙. In his article “Zhimindu xueshuo kao," Chen did not explain the meaning of xiaoyao; some of the scholars have translated this sentence as "analysing carefreely" and have treated the xiaoyao here as an adverb word (see Mair, "What is Geyi, After All?." 41). However, Chen changed his opinion in this article and thought xiaoyao in this context specifically referred to Zhuangzi's “Xiaoyao you” 逍遙遊. See Chen, “Xiaoyaoyou Xiang Guo yi ji Zhi Dun yi tanyuan 逍遙遊向郭義及支遁義探源, ” in JMCB, 96. 1046 “道安心中有此格義.” Ibid.
} 
and deployed by early Buddhist apologists like Dao'an and Huiyuan ${ }^{1047}$ as a more general hermeneutic strategy for matching Buddhist concepts with indigenous terms or using them to interpret local teachings. This kind of conceptual shift, although it seems misleading when referring to the criteria of modern scholarship (both Buddhology and historiography), breathed new air into the scholarship and intellectual life at that very moment in history.

Chen continued his discussion on geyi in the article "The Relationship between Tao Yuanming's Idea and the Pure Conversation" with a question from another angle: why are there no Buddhist elements in Tao Yuanming's poems, given Tao's close personal association with Buddhist figures such as Huiyuan? The previous articles discussed how the trend of qingtan had supported people's understanding of Buddhism. Here, using Tao Yuanming as an example, Chen hoped to explain the overall cultural climate in the Wei-Jin dynasties and to discuss the extent to which Buddhism, in turn, had been resisted, covered, or rejected in the spiritual life of the Chinese literati. To Chen, Tao's case was representative and special, for it involved two crucial issues: the relationship between philosophical qingtan and religious belief, and the Daoist tradition of Tao's clan. ${ }^{1048}$ Chen argued, the collapse of the system of 'the nine-ranking system [jiupin zhongzhengzhi 九品中正制] and caixing lun, although accelerated by political forces, was fundamentally an outgrowth of the built-in tension between two contradictory concepts or standpoints: 'nature' [ziran 自然] and the 'doctrine of names' [mingjiao 名教]. ${ }^{1049}$ In the Wei era, this implacable collision could cause tragedy on some extreme occasions, such as the dramatic death

\footnotetext{
${ }^{1047}$ For the Huiyuan case, Chen cited Huiyuan's biography in the Gaoseng Zhuan (“遠乃引莊子義為連 類。於是惑者曉然, 是後安公特聽慧遠不廢俗書”), which also demonstrated that, in the time of Huiyuan, it was very common to make an analogy between Zhuangzi and prajña doctrines. See ibid., 96. ${ }^{1048}$ In his lecture “Qingtan wuguo” 清談誤國 delivered at Sun Yat-sen University in 1947, Chen repeated the same issue as the one expressed in this article. See Wan Shengnan 萬繩楠 ed., Chen Yinke Wei Jin Nanbeichao shi jiangyan lu 陳寅恪魏晉南北朝史講演錄, 45-64.

${ }^{1049}$ There are different explanations of the term 'mingjiao.' Basically, mingjiao means the "teachings of social stations, the crux of Confucian social ethics," which can also be called 'lijiao' 禮教. See Kai-wing Chow, The Rise of Confucian Ritualism in Late Imperial China: Ethics, Classics, and Lineage Discourse (Stanford University Press, 1996), 10.
} 
of Ji Kang 嵇康 (223-263), the icon of Daoist naturalism. However, as Chen argued, by abstracting this collision into a philosophical conversation and keeping far away from politics, intellectuals after Ji Kang were able to reach a balance by creating a parallel state between these two standpoints: namely, "following the principle of Confucianism on the outside, while maintaining the beliefs of Buddhism or Daoism in the heart” [waifu rufeng, neizong fan(dao)xing 外服儒風，內宗梵(道)行].”1050 Qingtan thus became a highly intellectualized activity, cutting its links with political attitude or goals, and becoming a pure 'decoration' or 'ornament' without any practical function. It was empty, impractical, and tedious and, hence, faced inevitable decline. However, this unrealistic or even pretentious trend broke into new territory after the Eastern Jin dynasty, as Chen noted, since Buddhism provided enormous numbers of new ideas and perspectives to this more and more lifeless qingtan system.

To Chen, theoretical innovation through absorbing new concepts and ideas was an indispensable condition for the existence and growth of a certain system of thought. Tianshidao 天師道 (also known as Wudoumi 五斗米 [five pecks of rice]), for example, could survive only by absorbing external learnings, such as Buddhism, or through personal innovations from excellent believers, such as Tao Yuanming. The encounter between Buddhism and domestic Daoism in the time of Tao, according to Chen, could be divided into three types: first, believers maintained their previous belief in Daoism but realized that their own faith needed to be reformed; second, the former belief was abandoned and replaced by the new faith of Buddhism; third, the belief in Daoism partially lost its status but survived by becoming mixed up with Buddhist doctrines. Tao's Daoism belongs to the first type. Under the inspiration and pressure from Buddhism, non-Buddhist Tao Yuanming became aware of the limitations and crisis his own beliefs faced. Tianshidao had to be changed through

\footnotetext{
${ }^{1050}$ Namely, following the principle of Confucianism in appearance, while maintaining their beliefs in Buddhism or Daoism in their hearts. Throughout the intellectual history of pre-modern China, this strategy had been employed with variations very often. This trend, in some sense, was an ideal for Chinese intellectuals. According to Chen's explanation, since Confucianism was not a real religion, there should not any antagonistic contradiction between Confucianism and Buddhism. See Chen, "Tao Yuanming zhi sixiang yu qingtan zhi guanxi 陶淵明之思想與清談之關係,” in JMCB, 219.
} 
doctrinal innovation. Tao's contribution, Chen concluded, was reinterpreting ziran as a natural process of 'conforming to the changes and destinies' [weiyun shunhua 委運 順化], a seemingly passive but ingenious way to reconcile individuals with the times, especially a time that was full of violent political and social unrest. By doing so, he contributed to the subsequent development of Daoist naturalism. ${ }^{1051}$

The newness Buddhism brought into the Chinese cultural landscape, Chen summarized, "opened a magnificent scenario in Chinese intellectual history." ${ }^{1052}$ To the Wei and Jin literati, Buddhism not only matched their 'metaphysical' taste but also became a respected new theory that could "guide the chaotic world and all the unhappy minds away from confusion and suffering." ${ }^{1053}$ Due to this 'Buddhist turn' among the literati, the core of qingtan and its philosophical format was eventually maintained; moreover, geyi, a 'Buddhisized qingtan,' breathed fresh air into the stagnation of old scholarship and ideology, replacing the empty quarrels on philosophical notions, terms, and concepts with vital theoretical innovations. This phenomenon was called and emphasized by Chen as an "innovation of the old meanings" [jiuyi gexin 舊義革新]. ${ }^{1054}$

For Chen, "innovation of the old meanings" was a glimmer of hope that could save a tradition or spiritual heritage from elimination; it might be the most effective, if not the only, way of intellectual 'renaissance.' Through the study of Buddhism, Daoism, and other traditions, he enumerated examples of this kind of renaissance or, in his words, the "groundbreaking elucidation of unique ideas" [guming xianfa 孤明 先發]: the utilization of Chan Buddhism by the Daoists in the Song dynasty; the formation and development of lixue by employing Buddhism to discuss the theory of xinxing 心性 [luminous mind]; the Tiantai Master Zongmi's commentary on the Ullambana Sūtra [Yulanpen Sūtra 孟蘭盆經] and so on. All those phenomena and

\footnotetext{
${ }^{1051}$ According to Chen, this was because Tao was able to innovate the idea of Tianshi dao. See "Tao Yuanming zhi sixiang yu qingtan zhi guanxi 陶淵明之思想與清談之關係,” in JMCB, 219.

1052 “開震旦思想史從來未有之勝境.” Ibid.

1053 “實於紛亂之世界, 煩悶之心情具指迷救苦之功用.” Ibid.

${ }^{1054}$ Chen, “Tao Yuanming zhi sixiang yu qingtan zhi guanxi 陶淵明之思想與清談之關係,” in JMCB, 229.
} 
practices of "innovating the old meanings," according to Chen, represented geyi in its variations. ${ }^{1055}$

In his analysis of Zhi Mindu's theory of xinwu 心無 [the nonexistence of the mind], Chen revealed Zhi's misunderstanding of this term by referring to its original meaning in Sanskrit. As a typical scenario of geyi, Zhi's new meaning of xinwu had been colored by Chinese thought. However, instead of criticizing the deviation of Zhi's understanding, Chen stressed the popularity of the xinwu theory among the Chinese, which, as Chen believed, mainly resulted from its 'Sinicized' feature. The emergence and prevalence of xinwu should not be attributed to the limitation of translation technique or the lack of 'authentic' Buddhist knowledge, but were triggered by social conduct, scholastic atmosphere, and the taste of the literati and educated gentry at that time. Geyi, although inevitably containing misunderstandings, was the result of cultural choice, which sometimes might be passive or unconscious but at least was vigorous enough. ${ }^{1056}$ Therefore, geyi was a conceptual displacement rather than merely incompetence or fallacy. As Chen further clarified:

[I] once have said that the idea that there is one kind of theory when judging by historical linguistics, is totally fallacy; however, when judging from the perspective of philosophy, it has no reason not to be progressive. For example, Yijing [The book of change] originally was a book of prophecy and divining. The commentaries of Wang Fusi and Cheng Yichuan as philosophical works, although were different from the

\footnotetext{
${ }^{1055}$ See Chen, “Zhi Mindu xueshuo kao 支毀度學說考,” in JMCB, 173. Using native concepts to match the imported ones was also a kind of geyi, which Chen called reversed geyi, namely, "fanxiang geyi." Scholars have had some discussions on this term. See, Liu Xiaogan, 劉笑敢, Quanshi yu dingxiang Zhongguo zhexue yanjiu fangfa zhi tanjiu 詮釋與定向 一中國哲學研究方法之探究 (Beijing: Shangwu yinshuguan 商務印書館, 2009), 441; Zhang Rulun 張汝倫, “Handan xuebu, shiqi gubu - yetan Zhongguo zhexue yanjiu zhong de 'fanxiang geyi' wenti 期鄲學步, 失其故步一也談中國哲學研究中的 “反向格義”問題,” in Nanjing daxue xuebao 南京大學學報,” 4 (2007): 60-76.

${ }^{1056}$ As Chen cited in “Zhi Mindu xueshuo kao” 支畋度學說考, Hui Yuan’s “引莊子義為連類” and Dao'an's “不廢俗書” are all illustrations of geyi. The examples of geyi mentioned by Chen also including Yan zhitui's analogy between “wujin” 五禁” in the “neidian” 內典 and “wuchang”五常 in the “waidian" 外典 ; Tiantai master Zhiyi 智顗's teaching in his mohe zhiguan 摩訶止觀 and renwang huguo bore jing shu 仁王護國般若經疏; and so on. “Zhi Mindu xueshuo kao 支畋度學說考,” in JMCB, 173
} 
'original' meaning of Yijing, are even better than those 'authentic' interpretations. [嘗 謂世間往往有一類學說, 以歷史語言學論固為謬妄, 而以哲學思想論未始非進步 者, 如《易》本卜筮象數之書, 王輔嗣、程伊川之〈注〉、〈傳〉雖與《易》之 本意不符, 然為一種哲學思想之書, 或竟勝於正確之訓詁]. ${ }^{1057}$

This passage was said by Chan in response to the studies of the Orientalists in Western academic circles. Here, he contended in this passage that the 'inconsistency' of meaning at a literal level does not amount to a misunderstanding at the theoretical level; on the contrary, it might be even a dynamic and positive factor. For example, Han Yu 韓愈 (768-824), despite his rejection of Buddhism, was influenced by Chan thought. His harmonization of the mind/nature theory and the Confucianist political ideal was not a negative aberration from the original teaching of Confucius, but an innovative geyi that deployed "the Indian learning as the foundation and the Chinese learning as practical application" [Tianzhu weiti, huaxia weiyong 天筑為體, 華夏為 用]. ${ }^{1058}$ In another example of Cui Hao 崔浩 (381-450), Chen clarified that although Daoism was a local production, it had developed into a profound intellectual system by absorbing diverse thoughts, especially Buddhism. Therefore, geyi was historically a valid path that encouraged bold innovation by modifying and mixing new theories into the old, native ideological system. It might be 'wrong' or contain fallacies; however, it could be beneficial and necessary when judged from a historical perspective. As Chen argued, as an alien system, Buddhism included elements inappropriate to China's ideals and values, such as its rejection of dyadic ties between the ruler and the ministers [junchen 君臣] and its abandonment of filial piety. If Buddhism stubbornly persisted with its “real face” [benlai mianmu 本來面目], just as

\footnotetext{
${ }^{1057}$ Chen, “Dasheng yizhang shuhou 大乘義章書後," in JMEB, 185.

${ }^{1058}$ See Chen, “Lun Han Yu 論韓愈," in JMCB, 322. Chen thought that Han Yu's combination of Buddhism and Confucianism established the base for the Neo-Confucianism in the Song dynasty [退之 於此奠定後來宋代新儒學的基礎]. In this article, Chen also analyzed that Han Yu's assertion on “直指 人倫，掃除章句之繁瑣” was deeply influenced by the idea of “直指人心，不立文字” of Chan Buddhism; his tendency towards “restoring the ancient style of literature” [文體復古] and “以文為詩” also was inspired by “Chang hang” 長行, a Buddhist literary style. Accoding to Chen, his rejection of Buddhism originated from his political concerns caused by 安史之亂 (as shown in his claims of resisting the foreign invader, namely, “yixia shifang [夷夏之防]”), instead of his philosophical standpoint.
} 
Xuanzang's Yogācāra did, it might "shock the people in a short time, but finally go to depression and disappearance." ${ }^{1059}$ Therefore, the historical continuity of Buddhism lay upon "the process by which Buddhism was modified and absorbed by the Chinese." 1060 This process, which Chen named “guantong 貫通” [thoroughly and continuously linking things up], marks one particular characteristic of Chinese culture. Chen suggested, the intellectual development in the West was normally driven by questioning, critique, and negation, while the development of Chinese thought originated from integration, synthesis, and reconciliation. ${ }^{1061}$

By means of depicting the historical process of guantong, Chen indicated that there was no ontological hierarchy between different thoughts, including Confucianism, Daoism and Buddhism; instead, when these traditions transformed from universalistic ideals into historical structures, their own ideals and values all facilitated the changes in China's past and the formation of China's cultural particularity. This dynamic mechanism provided China its historical cohesion and created its culture system - which should be distinguished from the political entity of the nation state. Noticeably, the cultural system in Chinese history was also relativized in Chen's writing and therefore became historicized. His own academic practices also adopted a relativistic standpoint and followed the path of guantong. As he once stated in a report on Feng Youlan's monograph The History of Chinese Philosophy [Zhongguo zhexueshi 中國哲學史], his historiographical studies, rhetorically, were meant to make fresh the "old wine" by pouring it into a "new bottle." 1062 Instead of simply throwing the 'old' things—-the traditions-away, he was pursuing a "neither-old-nor-new" [bugu bujin zhixue 不古不今之學] scholarship, which was aimed at maintaining the traditions in the container of modern

\footnotetext{
1059 “雖震動一時之人心, 而卒歸與消沈歇絕.” Chen Yinke, “Feng Youlan Zhongguo zhexue shi (xia ce) shencha baogao 馮友蘭中國哲學史下冊審查報告, ”JMEB, 283.

1060 “經國人吸收改造之過程.” Ibid.

${ }^{1061}$ Chen Yinke, “Chen Yuan 'Yuan Xiyu Ren Huahua Kao' Xu 陳垣《元西域人華化考》序,” in JMEB, 238-39.

${ }^{1062}$ Che Yinke, “Fengyoulan Zhongguo zhexue shi (xia ce) shencha baogao 馮友蘭中國哲學史下冊審查報 告," JMEB, 283.
} 
scholarship and re-evaluating or reinterpreting them with new perspectives and methodologies in order to make them acceptable again. ${ }^{1063}$

This reinterpretation of the past was entirely congruent with Chen's awareness of contemporary issues. His claims for the veracity of history and empathy towards tradition opened his horizon to the future. Through reading and writing histories, Chen believed, the historical experience of 'innovating the old meanings' and 'guantong' would be recalled and activated. This was the heritage the Chinese learned from the Buddhist geyi, and it could help to prevent cultural disintegration, counter the ills introduced by the Western hegemony, and overcome the decay and alienation of the 'past'. Chen's studies of culture, religion, and nation were all heading in this direction.

\section{'Methodological Geyi' and National Identity}

When Chen Yinke discovered geyi from Chinese Buddhist texts and reintroduced it as a vital factor in Chinese scholarship and culture, he was experiencing the dramatic contradiction of views within modern Chinese academia, especially in the domain of historiography. The divergence between radical iconoclasts and the protectors of tradition was intense, and both camps failed to eclipse the other. In this fractious

\footnotetext{
${ }^{1063}$ About [不古不今], there are some different opinions. Some scholars, such as Wang Rongzu 汪榮祖, have argued that the 'bugu bujin' refers to the medieval period in Chinese history; therefore, scholarship neither old or new means the study of the history of the Wei and Jin to the Tang and Song dynasties [中古史]. This opinion, however, might be problematic, because before this phrase of 'bugubujin,' Chen used a word meaning 'in the whole life' [pingsheng 平生], which indicated that this scholarship was Chen's lifelong pursuit. However, his studies of medieval Chinese history began after 1933. Lu Yaodong 逐耀東 and Sang Bin 桑兵 have thought that the phrase 'bugu bujin' refers to the contentions between the Old Text school and the New Text School and [gu 古] may specifically mean Tang Youwei's 康有為 'tuogu ‘托古 and Gu Jiegang 顧頡剛's 'yigu' 疑古, while the 'new' means the movement of 'arranging the national essence' [zhengli guogu yundong 整理國故運動] advocated by Hu Shi 胡適; Chen Qianfan 程千帆 has noticed that this phrase originated from the Taixuan Jing 太玄經 and was related to another phase, 'tongniu jiaoma' 童牛角馬,' which literal means a cross-bred animal. From this point, it is reasonable to deduct that, to Chen, 'bugu bujin' referred to a mixed, hybrid, and thorough intention of scholarship. This opinion has also been supported by historians Huang Qinglian 黄清漣 and Luo Zhitian 羅志田.
} 
terrain, Chen Yinke carefully stood on the middle ground. He conceived his own method through deliberations on the national and cultural identity of China, profoundly interweaving his historiographical concept, value standard, and concerns for the past and future of Chinese individuals and society. Being pulled out from the past and placed in front of the future, geyi, in Chen's view, became one fulcrum of the overall project of the China-West encounter: it might be a potential way to secure the status of the Chinese tradition and its external appearances, forms, and normative patterns, and meanwhile it also needed play its role in the transformation of Chinese national identity.

This dual expectation in Chen's historiography was present in his seemingly paradoxical narrative of geyi. Although the complexity and even paradoxical nature of Chen's account of geyi has been noticed and discussed later schorlars, the inner tension within his narrative has been largely ignored. Chen's attitude towards geyi hence has been oversimplified as dualist and self-contradictory. ${ }^{1064}$ To Chen, geyi as a discourse had multiple implications: from a theoretical aspect, geyi embodied the characteristic of Chinese culture, revealing the deep logic behind the changes in Chinese culture on an intellectual level—namely, through absorbing different intellectual resources to reach the goal of 'the innovation of old meaning'; meanwhile, it was also an encumbrance for scholarship and academic exploration from a methodological perspective that contained limitations and pitfalls. Chen's discussions on geyi, which are scattered in his works here and there, clearly but indirectly indicated that he drew a distinct boundary between theoretical geyi as a historical characteristic and methodological geyi as a strategy for introducing new theories. He criticized that the latter, which came into fashion in modern China, should be avoided due to its danger of uncritically merging heterogeneous things together while ignoring the essential incompatibility between them.

\footnotetext{
${ }^{1064}$ For example, historian Sang Bing has claimed that Chen's attitude towards geyi is rejection and opposition; while Victor Mair's idea has been that Chen's assessment of geyi was positive or even exaggerated.
} 
It is necessary to clarify the background of the methodological geyi and its very meaning in Chen's thought. Clearly, his critique of geyi as a method was a response to the spreading of Western Learnings [xixue 西學]. Compared to his peers, Chen's observations of the West were more direct and thorough, on account of his long experience of living and studying in Europe and North America. ${ }^{1065}$ Throughout his entire career, his understanding of the Western world not only stimulated his academic interests but also established a frame of reference for his transcultural comparison and evaluation. ${ }^{1066}$ As early as when he was in Europe, some of his daring theses on the advantages and shortcomings of Chinese civilization based on an East/West comparison had surprised his contemporaries and been considered "exceptional opinions that man never heard about." ${ }^{1067}$ Because of his knowledge of Western philosophy, literature, and art, as well as theories such as the psychoanalysis of Sigmund Freud and Marxism ${ }^{1068}$, Chen was considered the most representative and excellent figure of 'Western Learning,' instead of an expert on 'Chinese studies,' and was respected for his achievements in Oriental studies. ${ }^{1069}$

\footnotetext{
${ }^{1065}$ See Bian Senghu 市僧慧, Chen Yinke xiansheng nianpu changbian 陳寅恪先生年譜長編.

${ }^{1066}$ About Chen's “free and thorough discussion on the Chinese and foreign cultures”[縱談中外文化], see Wu Mi, “12.14.1919," in Wu Mi riji 吴宓日記, vol.2, 90. In his diary, Wu also recalled that Chen had talked about the relationship between Indian philosophy and China as well as Greece. Wu believed that the Chen's extensive knowledge stemmed from his wide reading of Western books. Cf. also Wu Mi riji, $28,55$.

1067 “聞所未聞的奇論.” See Xiying 西䝁, “Xianhua 閒話.” Xiandai Pinglun 現代評論 3, no. 65 (1926).

${ }^{1068}$ Chen commented that the theories of Freud and Marx's discussion went no further than the old Confucian. Bian Senghu 市僧慧, Chen Yinke xiansheng nianpu changbian 陳寅恪先生年譜長編.

${ }^{1069}$ When he returned to China, ${ }^{1069}$ his academic success encouraged other scholars, such as Fu Simian, to believe that Chinese scholarship would surpass its Western competitors, and eventually "the orthodoxy of the scientific Oriental Studies will be established in China” 要科學的東方學之正統在中 國. See Fu Sinian, “Lishi yunyan yuanjiu suo gongzuo zhi zhiqu 歷史語言研究所工作之旨趣,” in Lishi yuyan yanjiusuo jikan 歷史語言研究所集刊 1, no.1, (1928). Fu was not good at Oriental studies; however, Chen's capability made him believe that China's achievement in Oriental Studies would surpass that of the West. After he helped to establish the Department of History and Philology in Academia Sinica, he then immediately hired Chen as a researcher. However, it is worth noting that Chen's and Fu's research positions were very different. See Sang Bing 桑兵, “Minguo xueren de songdai yanjiu jiqi jiujie 民國學人的宋代研究及其糾結,” in Xueshu jianghu: wanqing minguo de xueren yu xuefeng 學術江湖: 晚清民國的學人與學風” (Guilin: Guangxi shifan daxue chubanshe, 2017): 279320.
} 
However, unlike many scholars who stayed abroad, such as Liang Qichao, Hu Shih, and Fu Sinian, Chen intentionally distanced himself from the trend of interpreting Chinese heritage through Western studies. Within his numerous writings, he hardly ever discussed or even mentioned any Western theories or concepts directly, or, at least, he never officially demonstrated any preference for certain Western thoughts. On the contrary, Western learning was disassembled, examined, and re-packed by Chen in a subtle and critical way. Interestingly enough, despite his iconic image as a scholar 'with a thorough understanding of China and the West' [xueguan zhongxi 學貫中西], he always presented himself as a 'conservative' figure, whose "ideas of scholarship and politics were in opposition to the current trend" [lunxue lunzhi, jiongyi shiliu 論學論治, 迥異時流]. ${ }^{1070}$

Chen's historiographical methodology contained two aspects: first, textual comparison and second, historical interpretation. In one letter to Liu Shuya on the questions for the Chinese examinations and his preface to Chen Yuan's religious history, he affirmed the method of comparative study based on textual criticism, which originated in the historiographical tradition of the Song dynasty; in his reports on Feng Youlan's history of Chinese philosophy, he emphasized more strongly the hermeneutic approach and its function of complementing textual criticism with historical interpretation of the motives of the historical protagonists. Both sides, with respective scholarly implications, were succinctly reflected in his rejection of the methodological geyi.

Three points were crucial to Chen's rejection of geyi: first, the method of geyi to a large extent involves blind comparison between objects that do have something in common but are fundamentally different. In a very important letter, Chen discussed the pitfall of the geyi method:

Today's grammar system based on Indo-European language, namely, the geyi grammar in the Ma Shi Wentong, cannot be applied to Chinese; ...... Only a small part of one language's grammar rules is consistent with the general principles of language in

\footnotetext{
${ }^{1070}$ Chen Yinke, “Du Wu Qichang zhuan Liang Qichao zhuan shuhou 讀吴其昌撰梁啟超傳書後,” in HLTJ, 168.
} 
a universal sense. In most cases, the grammar of one language comes from summarizing the particular usages of this language into several more general rules and then developing them into a unique, systematic thesis, so can this thesis be named as the law of one language. It is impossible to generalize the grammar law of a particular language into a universal system that would be applied to all the cases without contradictions. 今日印歐語系化之文法, 即馬氏文通「格義」式之文法, 既不能施之於不同語系之中國語文……所謂某種語言之文法者, 其中一小部 分, 符於世界語言之公律, 其大部分皆由研究此種語言之特殊現相, 歸納為若千 通則, 成立一有獨立個性之統系學說, 定為此種語言之規律。並非根據某以特種 語言之規律, 即能推之以概括萬族, 放諸四海而準者也. ${ }^{1071}$

As suggested in this passage, the 'geyi' Chen discussed here was not a historical phenomenon but a research method. He demanded here that the particular aspects of a language (implicitly also of a culture) that deviates from the "universal laws" should be investigated inductively; then, some "general rules" [tongze 通則] within particularity could be established. Only by this means could a comparative method be applied. In another letter, he further explained the foundation of this comparative method:

Such a comparative research method must have at its disposal the notion of historical change and systematic concepts of similarity and difference. Otherwise, one could compare past and present, China and abroad, people and heaven, dragons and spirits. 蓋此種比較研究方法, 必須具有歷史演變及系統異同之觀念, 否則古今中外, 人 天龍鬼, 無一不可取以相與比較. ${ }^{1072}$

Here, by stressing both changes — a diachronic aspect [ 貫] —and system-a synchronic [tong 通] aspect-he related the method of historiographical comparison to his theoretical view of guantong. The diachronic investigation aimed to find out the historical origins of phenomena, whereas the synchronous investigation required a systematic comparison of the respective differences between phenomena. Otherwise, Chen criticized, oversimplified conceptual comparison or 'matching' that ignored the prerequisite of analogies and glosses over the fundamental difference between two

\footnotetext{
${ }^{1071}$ Chen, "Yu Liu Shuya jiaoshou lun guowen shiti shu," in JMEB, 251 ${ }^{1072}$ Ibid.
} 
things would create a "hybrid monster" [hundun guaiwu 混沌怪物]. ${ }^{1073}$ Observing this danger of "incoherence" [butong 不通] ${ }^{1074}$ caused by the strategy of geyi that had been hastily practiced as an approach to 'Westernization' by the so-called 'reformers' of Chinese scholarship, Chen warned of the zany and catastrophic result of geyi: "implausible pairing, grotesque distortion ominously." 1075

After his critique on blind comparison, he moved to the second dimension of his methodology, interpretation (or "understanding" [liaojie 了解], to use his own word). The example of Tao Yuanming, as mentioned before, indicated his disapproval of a 'geyi with hindsight': namely, applying the experience and knowledge of current people to their ancestors. This 'ahistorical' geyi, Chen argued, was a common mistake prevailing among the 'new' scholars (he was talking about Liang Qichao, in particular $)^{1076}$, who were infatuated with fashionable ideas and new techniques and believed that the new perspectives and methodological tools would help them to better reach the 'real' truth of history than their predecessors who were confined either to Han Learning or Song Learning. However, pitfalls might emerge, as Chen observed, when they exerted their own suppositions on the behavior of ancient people. In the example of Han Yu and Kou Qianzhi, Chen argued, if we understood Han Yu and Kou Qianzhi according to our own thinking, it would be impossible to explain why these figures, who had expressed hostility and antipathy towards Buddhism, also at the same time utilized the intellectual resources of Buddhism to change their own beliefs-Confucianism or Daoism. Based on these examples, Chen emphasized that textual criticism, which went hand in hand with the demand to deal

\footnotetext{
${ }^{1073}$ Chen Yinke, “Yu Liu Shuya lun guowen shiti shu 與劉叔雅論國文試題書,” in JMEB, 251. ${ }^{1074}$ Ibid. Yuanming chose a life of seclusion. In Liang's opinion, the incorporation of Tao with the court of the Eastern Jin and his retreat could be attributed to Tao's psychological status caused by his feelings of exhaustion and disgust when faced with the corruption, deception, and fraud in officialdom. However, Chen argued, Liang's opinion was just a superficial hypothesis based on Liang's own experience; the deeper reason behind Tao's political choice was his religious belief, which was related to his ethnic background and the tradition of his clan.
} 
with extensive historical material with reference to "general historical knowledge," should be combined with historical hermeneutics. This point of view, as summarized in his comments on Feng Youlan's book, called upon historians to put themselves in their subject matter and to understand their research objects empathetically.

To Chen, it was impossible to gain an 'absolute' truth from history because 'absolute' means 'ahistorical.' Therefore, he carefully identified a 'relative' historical truth in his writings-, its tasks and limits, and the intellectual presuppositions and political implications of such truth that could only be understood historically. The essential characteristic of this truth, therefore, was both complete and limited: the historical materials could be proved sufficient and credible, at least to a certain degree; however, the reading of these materials could not and should not be conducted in an objective and impartial way. From such reflection, Chen emphasized that an "sympathy with understanding" rested in the comprehensive historical knowledge of the multiple facets of certain traditions as well as the 'family resemblance' between cultures. He portrayed this empathy as "the artist's perspective and attitude when viewing old paintings and carvings." ${ }^{1077}$ He expounded:

This so-called real understanding requires spiritual journeys and deep meditation ....... so that we can evaluate the gain and loss of their teachings without any prejudices. Otherwise, all the ancient teachings, which were produced in a fundamentally different circumstance, seem to be ridiculous and hilarious. 所謂真瞭解者, 必神遊 冥想.......始能批評其學說之是非得失, 而無隔閶膚廓之論。否則數千年前之陳言 舊說, 與今日之情勢迥殊, 何一不可以可笑可怪目之乎? ${ }^{1078}$

Chen indicated that historical interpretations need to approach ancient people's intentions and motives with respect, instead of making judgements according to the historians' own criteria. Being aware of the problem of the hermeneutical circle, Chen posited a more prudent, meticulous approach towards particular historical

1077 “藝術家欣賞古代繪畫雕刻之眼光及精神.” Che Yinke, “Fengyoulan Zhongguo zhexue shi (xia ce) shencha baogao 馮友蘭中國哲學史下冊審查報告,”JMEB, 282-85. Here Chen was criticizing the debate on Mozi. Zhang Taiyan, Hu Shih, and other 'doubting antiquity' scholars had participated in this debate.

${ }^{1078}$ Ibid., 285. 
circumstances in order to prevent misunderstandings, or in his words, "a bad habit of making strained interpretations and drawing farfetched analogies." 1079

Possibly with Hu Shih in mind, Chen questioned the 'geyi' of formulating historical interpretation and organizing historical sources according to a preset philosophy. To Chen, a prerequisite for historical study was that the historian must be able to examine the fragments of historical materials first and then reframe them with a kind of constructed totality. There might be imaginative or subjective elements involved in this process, which Chen did not deny, but he believed that the destination of this kind of 'spiritual journey' was not offering evidence for a certain presupposed theory but understanding the life and recent experiences of the ancients. Therefore, this totality differed from a 'systematic organization' [xitong zhengli 系統整理] of traditions, for the latter, which always contained a preconceived system, was 'far away from the truth of the ancient doctrines' and was just "repeating the historian's own theory."

Following the two methodological steps of comparison and interpretation, Chen also mentioned the third dimension of his methodology: critique-critical commentaries on the 'correctness and merits' [shifei deshi 是非得失] of historical phenomena, which referred to political implications and moral statements that historians might convey tacitly or explicitly. ${ }^{1081}$ This dimension of critique is indispensable for understanding and assessing the theoretical and ideological views of Chen's historiography. For him, describing and representing the "national spirit" and its manifestations were not the end; it was also the task of historians or the consequence of their practice to protect the status of tradition and further provide guidance for the present and the future.

Chen implicitly discussed the proper position of historians and their task in his study of the Neo-Confucianist Han Yu and the Daoist priest Kou Qianzhi. Using

\footnotetext{
1079 “穿錅附會之惡習.” Che Yinke, “Fengyoulan Zhongguo zhexue shi (shang ce) shencha baogao 馮友 蘭中國哲學史上冊審查報告, in JMEB, 279-81.

1080 “去古人學說之真相愈遠.” Ibid.

${ }^{1081}$ Ibid.
} 
these two, and especially their attitudes towards Buddhism, as examples, he clarified 'the defense zone between Yi (barbarian) and Xia (China)" [yixia defang 夷夏大防], namely the salient hierarchy between native traditions and external influences. ${ }^{1082}$ This hierarchy had also been proved by the experience of Xuanzang' Yogācāra Buddhism: the ignorance of the prior position of 'national spirit' would not only lead to the failure of acclimatization ${ }^{1083}$ but also injure the self-identity of individuals. Especially in an era subjected to repeated foreign invasions, it was immoral and even brutal to tout new theories mindlessly or impose any imported theories on native traditions blindly. To Chen, the real 'great achievement' [dacheng 大成] of historiographical methods relied on an attitude that combined modesty and conservatism. ${ }^{1084}$ Therefore, absorbing foreign teachings, while also keeping in mind the standing of one's own nation was the bottom line. ${ }^{1085}$ This delicate and middleground stand, which Chen summarized as "the real spirit of Daoism and the old path of the Neo-Confucianism," was the historical experience Chen read from the communications between China and other traditions throughout the past two millennia. ${ }^{1086}$

To Chinese intellectuals, finding a balance between the appealing, advanced 'others' and a crisis-ridden 'self' was not just a historical issue but also a realistic predicament. Even Chen himself sometimes faced a similar dilemma in cases when his

\footnotetext{
${ }^{1082}$ As a foreign religion, Buddhism became Han's main target.

${ }^{1083}$ Chen noted that if we import an external thought without "defining the position of our own nation' [本民族之地位]," the result would be as failed as Xuanzang' Yogācāra teaching. In Che Yinke, “Fengyoulan Zhongguo zhexue shi (xia ce) shencha baogao 馮友蘭中國哲學史下冊審查報告,”JMEB, 28485.

${ }^{1084}$ Chen used Daoism as an example and pointed out that Daoism had absorbed external thoughts, such as Buddhism and Manichaeism, as much as possible, but still did not forget the original status of the nation. After these theories had merged into Daoism, Daoism then insisted on the division between Yi [barbarian] and Xia [middle kingdom] to exclude foreign teachings. This ideological attitude has continued since the Six Dynasties. Although it seems paradoxical, its components are able to complement each other. Neo-Confucianism was an example that inherited this heritage and succeeded. See Chen, “Lun Han Yu 論韓愈, ” JMCB, 319-32.

${ }^{1085}$ Original text: “一方面吸收輸入外來之學說, 一方面不忘本民族之地位.” Che Yinke, “Fengyoulan Zhongguo zhexue shi (xia ce) shencha baogao 馮友蘭中國哲學史下冊審查報告,”JMEB, 282-85.

1086 “道教之真精神, 新儒家之舊途徑.” Ibid.
} 
research path led towards certain truths that might shake the foundation of Chinese national spirit and glory. ${ }^{1087}$ Sometimes, the revolution of knowledge, if not handled with caution, would end in the 'vacuum of comparison' or the dissipation of meaning. Being aware of the dramatic impact of new approaches and ideas, Chen remained vigilant against an 'instrumental objectivity' in historical studies. Although Chen partially accepted the genetic method as propagated by Hu Shih, which had been used by $\mathrm{Hu}$ as an iconoclastic power against the authority of tradition, the antitraditional undertone that $\mathrm{Hu}$ associated with this approach at the time of the May Fourth movement was completely absent from Chen's writing. Criticizing a formulaic, unsympathetic geyi, Chen opposed an 'empty' historiography without value concerns and moral responsibility. Also, at this point, he separated himself from Ranke's Historicism, which claimed a disinterested construction of hard factual truth by recording every event 'wie es engentlich gewesen. ${ }^{1088}$ Never abandoning his pursuit of the meaning in history, Chen kept away from the 'neutral' zones of scientism and avoided going into a 'historical nihilism' that stripped away any 'ultimate' meaning or universal matters from historiography. Overall, he never blurred the internal standard of ethics and the venerable features of nationality in his historical writings.

This is the political mission for historians as well as for a historiography with meaning. As shown in his preface to Wang Guowei's collection and some other texts, Chen's view of history and his political attitude combined with his judgment of historical legality. He doubted the existence of causal relations; rather, he assumed "mutual relations" between historical events and concluded that change in "human affairs" [renshi 人事] is therefore not accidental but follows principles that can be recognized in advance [qianzhi zhili 前知之理]. In this sense, he defined the tasks of

\footnotetext{
${ }^{1087}$ Examples included Chen's studies on the royal family of the Tang dynasty and his investigation on the family background of the poet Li Bai. See Chen, “Litang shizu zhi tuice 李唐氏族之推測," JMEB, 320-32.

${ }^{1088}$ Although he has been called “the Chinese Ranke” [中國的蘭克], Chen never mentioned Ranke's name in his works. Some scholars believe that Chen was deeply influenced by Ranke. See Wang Rongzu 汪榮祖, Shijia Chen Yinke zhuan 史家陳寅恪傳 (Taipei: Linking, 1988), 53-57. For further discuss on this issue, see Axel Schneider, "Reconciling History With The Nation? Historicity, National Particularity, And The Question of Universals" (2003).
} 
historians as continuing the achievements of their predecessors to criticize, explain, and influence their society, and to shed light upon some basic principles that could offer guidance for the future. ${ }^{1089} \mathrm{He}$ suggested that these principles are neither exclusively immanent to history nor universal, but can only be observed from the particular historical experience of the realization of the "national spirit."

Drawing parallels was ubiquitous; seeking for the more sophisticated, if not more correct, methods was also necessary for scholarship. As an open-minded scholar, Chen did not reject methodological innovation. His critique, however, was aimed at some popular trends in the domain of historiography: the movement of organizing national heritage [zhengli guogu 整理國故] and the Doubting Antiquity school. ${ }^{1090}$ In Chen's opinion, neither of these two camps could escape from the hazard of methodological geyi: improper comparison, spurious interpretation, and suspended critique. To avoid these shortcomings, Chen tried to conceptualize a view of history capable of accommodating change without, however, necessarily leading to a breach of continuity and identity. ${ }^{1091} \mathrm{He}$ achieved this by means of a methodology that took historicity and culture seriously - a hermeneutic method that combined textual criticism with cultural-national concerns.

Based on the above reflections, Chen proposed one possible alternative to overcome the methodological difficulty of geyi: a comparative method based on “composite texts and interlinear notes" [heben zizhu 合本子注]. This specific method, which Chen formulated during his historical investigation into the history of Buddhism, combined trans-language and trans-textual comparison with historical hermeneutics. Chen understood heben zizhu as an exegetic approach created by early Buddhist apologists for the sake of understanding Buddhist scriptures. It shared common ground with geyi in terms of comparing, pairing, and categorizing terms and

\footnotetext{
${ }^{1089}$ Chen, “Wang Jingan yishu xu 王靜安遺書序.”

${ }^{1090}$ For a detailed analysis of Chen Yinke's approach in comparison with other historiographical trends of the 1920s and 1930s, see Axel Schneider, Wahrheit und Geschichte: Zwei chinesische Historiker anf der Suche nach einer modernen Identität für China (1997), 126-146.

${ }^{1091}$ Axel Schneider, "Reconciling History With The Nation? Historicity, National Particularity, And The Question Of Universals."
} 
concepts, at least at first glance; however, it was essentially different from geyi, for heben focused on the textual transformation between different translations rather than conceptual matching. ${ }^{1092}$ In his article "Zhi Mindu Xueshuo kao," Chen cited examples in the Chu sanzang jiji to define 'heben' and sketched its development during the Wei and Jin Dynasties:

In the Middle Land of China, a large number of Buddhist canons were translated and always preserved with different versions of translation. Hence the "combined version" was compiled to assist comparison. Both 'heben' and geyi are methods monks and their disciples applied in the Six Dynasties to study Buddhist doctrines. From the perspective of form, they all emphasized comparing and pairing sentences and texts. Although these two methods look similar, however, they were fundamentally different and need to be separated....The comparison of geyi is based on the comparison between Buddhist texts and non-Buddhist texts, while the comparison of 'heben' is a comparison between the different translations of one text. The methods seem to be similar, but the results are the opposite. One is a far-fetched analogy between Chinese and foreign learnings, just like the example of 'xinwu.' The later implantations of Buddhism, Confucianism, and Daoism were all developed from this method. The other one corresponds to the current comparative methodology of linguistics. For example, the Lengqiejing huiyi written by Yuanke in the Ming dynasty, which is one of the excellent works of Chinese Buddhism, inherited the spirit of 'heben.' 中土佛典譯出既多, 往往同本而異譯, 於是有編纂「合本」, 以資對比者 焉。「合本」與「格義」二者皆六朝初年僧徒研究經典之方法。自其形式言之, 其所重俱在文句之比較擬配, 頗有近似處, 實則性質迥異, 不可不辨也。……夫 $\ulcorner$ 格義」之比較, 乃以内典與外書相配擬。「合本」之比較, 乃以同本異譯之經 典相參校。其所用之方法似同, 而其結果迥異。故一則稱為傅會中西之學說, 如 心無義即其一例, 後世所有融通儒釋之理論, 皆其支流演變之餘也。一則與今日

\footnotetext{
${ }^{1092}$ According to Chen's investigation, Monk Zhi Mindu, who use geyi to create the teaching of xinwu 心 無, was very familiar with the technique of 'heben' as well. In Chu Sanzang jiji, there are several prefaces tp the combined version of Buddhist scriptures written by Zhi Mindu. In those prefaces, Mindu described this approach as “合令相附, “使事類相從.” However, later in the Northern dynasty (the period of Luoyang jialan ji 洛陽伽藍記) this method disappeared, or to say it better, was replaced by the generalized geyi; the real meaning of 'heben' was also incomprehensible. See Chen Yinke, "Du Luoyang jialan ji shuhou 讀洛陽伽藍記書後," JMEB, 176-180.
} 
語言學者之比較研究法暗合, 如明代員珂之楞伽經會譯者, 可稱獨得「合本」之 遺意, 大藏此方撰述中罕覞之作也. ${ }^{1093}$

This approach, in Chen's view, was the ancient version of historical-comparative linguistics, and it echoed what Chen had learned from his teachers of Oriental Studies in Europe. ${ }^{1094}$ Specifically, this methodology required historians to identify the origins of texts through a comparative investigation of all the textual changes in a broad historical context. He emphasized that language nuances, rhetorical strategies, and tones of expressions in historical materials needed to be carefully examined. To Chen, the comparison of heben had its literal ground and well maintained the diverse textual manifestations of concepts and ideas. By presenting all the interpretations of the same text equally in front of readers, the changes behind the text would be adequately displayed and further "the universality of abstract ideals" [chouxiang lixiang zhi tongxing 抽象理想之通性], which would be admitted and stressed through particular textual phenomena. ${ }^{1095}$ Therefore, the difference between heben and geyi was that heben respected the particularity of every cultural element while geyi erased differences and inevitably led to an uncritical mixture of old and new, self and other. Through the method of heben, namely demonstrating historical changes, divergences, and discontinuities comparatively and equally, the real thread of historical development would become evident. By this means, the historian could reconstruct universality from particular historical experience and further reach the unity of subject and object.

\footnotetext{
${ }^{1093}$ Chen Yinke, “Zhi Mindu xueshuo kao 支敗度學說考,” in JMCB, 185.

${ }^{1094}$ See Chen Huaiyu, Chen, Zai xifang faxian Chen Yinke: Zhongguo jindai renwenxue de dongfangxue yu xixue Beijing 在西方發現陳寅恪: 中國近代人文學的東方學與西學背景., chapter 3 and chapter 7. Although he adopted the methodology of the European Oriental Studies, the main focus of his research was on a very important historical process一the sinicization of Buddhism 佛教中國化. He was not interested in Vadas [吠陀], one of most important topics of German Indology; for the other popular topics in Buddhology, such as the stone inscription of Aśoka, he also showed little interest. Although he was good at Sanskrit and other ancient languages in the Central Asian area, he paid little attention to linguistic issues of grammar, words, and so on. ${ }^{1095}$ Chen, Wang Jingan yishu xu 王靜安遺書序.
} 
This particularism indicated that every culture was unique. Moreover, this uniqueness was universal and waiting to be revealed through historical comparison, interpretation, and critique. In this sense, the universality of abstract ideals was not only inherent in the Chinese national spirit, but also present in the equivalence of different cultures. Referring to it, Chen recovered the lost universal ground not by proclaiming a humanistic Chinese civilization superior to the West (as e.g., Zhang Junmai), or by referring to universal science (as e.g. Fu Sinian), but by assuming the formal universality of humans, who do vary from culture to culture and change in the course of history, but have to be protected in order to safeguard the identity of their respective culture. As Chen showed in China's case, abstract ideals, although they had been concretized in particular social institutions, economic conditions, and cultural contexts, had not perished but were anchored in the Chinese cultural identity and orientation. In Chen's later works, this unity of particularity and universality responded to impulses from current questions and problems, on the one hand, as the immanent form of the 'national spirit' that connected past and present, and, on the other hand, as the result of interpretation and criticism.

Partly attributable to the socio-political turmoil surrounding him, ${ }^{1096}$ Chen's reflection on cultural particularity and the responsibility of the historian to protect this particularity became an intensive 'implication' [jituo 寄託] in his writings. ${ }^{1097}$ Switching between different issues, he always returned to one theme: the mutual contact between Han China and foreign forces in history, which was closely linked to the issue of geyi. To Chen, geyi was a phenomenon that had emerged from the import of Buddhism to aid the formation of Chinese cultural entity; it also contained pitfalls on the level of methodology that should be carefully avoid. The heritage of geyi would help the Chinese to understand the fundamental elements of Chinese culture more

\footnotetext{
${ }^{1096}$ As some scholars have pointed out, the lack of research sources was one main reason for the switch in Chen's studies. After the 7.7 issue, it was impossible for Chen to access to the Beijing libraries anymore; he also lost his personal collection of books. His wartime correspondence recorded his hardship on the road as he moved to China's southwest. See Yeh Wen-hsin, "Historian and Courtesan: Chen Yinke and the Writing of Liu Rushi Biezhuan," East Asian History, no. 27 (2004).

${ }^{1097}$ Yü Ying-shih 余英時, “Chen Yinke shixue sanbian 陳寅恪史學三變,” in Chen Yinke wannian shiwen shizheng 陳寅恪晚年詩文釋證 (Taipei: Dongda chuban gongsi, 1998).
} 
profoundly; they were synthetic, pluralistic, and multi-ethnic, as demonstrated repeatedly in Chen's discussion of the religious heritage and family tradition of the Chinese literati, geographic and racial elements of different social groups, and so on. Also, geyi was also a perpetual problem China had had and would face. Chen's reflection on both theoretical and methodological geyi, in general, was what he learned from China's past and what he wished to convey through his historical writings.

\section{The Lesson of Geyi}

When the new generation of historians, like Chen Yinke and Tang Yongtong, started to write the history of Buddhism, the storm of new ideology, especially the 'spirit of the May Fourth movement' [wusi jingshen 五四精神], had swept through the entire Chinese intelligentsia. In modern China, Western Learning was appealing, just like Buddhism had been during the Wei and Jin dynasties. It not only directly brought in new theories and information but also had proved its effectiveness through the successful modernization of Japan and other countries. To survive and further compete with nations like Japan, Chinese people needed to learn more than simple technical knowledge; they needed to transform, root and branch, their entire society, government, military, and even ideology. This transformation was impeded by longstanding Chinese chauvinism against foreigners, who were always denigrated as 'barbarian' [yi 夷]. However, Late Qing intellectuals, such as Yan Fu and Zhang Zhidong, although they still used this term, had realized that the new $y i$-the 'West'- was utterly unlike anything China had encountered before. Facing this situation, Buddhism became almost the only experience that those modern Chinese could glean from their history. It signified particular forms of cultural production that associated exemplary historical precedents with new intellectual dispositions, maintaining self-cultivation and also securing broader socio-cosmic order. Neither conquering the 'foreigners' nor submitting to their influence, the success of Chinese Buddhism had resulted from a self-transformation, which had often been described under the rubric of 'Sinicization'-a process of making Chinese-ness, which was 
based on the re-interpretation of different cultural elements (language, belief, rituals, and so on) rather than on brutally replacing the existing faith background and ethnic identification of individuals.

To some historians, the discourse of 'Sinicization' exhibited a normative effect: namely, the process of Sinicization proved China's capability of establishing standards, setting frameworks, utilizing foreign resources actively, and finally establishing the triumph of its native culture over them. ${ }^{1098}$ Behind this standpoint was, fundamentally, the popular logic of 'Chinese Learning as substance, Western Learning for application' [zhongti xiyong 中體西用], which was closely tied to a view that knowledge, including historical knowledge, is neutral, functional, and can be used both to destroy traditions or to protect them. As some of the modern Chinese intellectuals believed, knowledge and social practices are not law-like, or valuesuspended, nor do they manifest themselves in certain 'superior' civilizations. Rather, they are determined and formed by what people think, say, and believe in specific historical contexts.

Confronting the West, historiography bore a new responsibility—to establish a 'new national history' in which China could be properly located in the new global world. To fulfill this responsibility, modern Chinese historians varied-as shown by the example of Liang Qichao and Zhang Taiyan - between universalistic and particularistic conceptions. Chen Yinke and Tang Yongtong leaned to the side of particularity but kept a relative cultural continuity at the core of their writings. In such a particularistic view, historical knowledge was constructed through cultural relationships. ${ }^{1099}$ Perhaps inspired by the role Buddhism had played in Chinese history, both Liang and Zhang had noted the way in which historiography is indebted

\footnotetext{
${ }^{1098}$ One example is Liang Qichao's nationalist narrative of Buddhism. For the issue of national identity, see also Frank Dikötter's analysis of Chinese racial theories in The Discourse of Race in Modern China (London: C. Hurst \& Co., 2015).

${ }^{1099}$ This view can also be found in the West from the twentieth century. One of the advocates of the particularistic view of knowledge is Charles Taylor. See Charles Taylor, "The Politics of Recognition," in Multiculturalism and "The Politics of Recognition" (Princeton, NJ: Princeton University Press, 1992); also, Source of the Self: The Making of the Moswen Identity (Cambridge, MA: Harvard University Press, 1989).
} 
to particular pasts and concrete intellectual contexts. Only by affirming the particularity of each utterance and situation in history could they avoid assimilating history into the historian's own terms and thereby distorting its meaning.

The writings of Chen and Tang presented their construction of a narrative that revolved around the historical process of cross-cultural engagement. That is, when they wrote history, they also "had a geyi in mind," just like Dao'an. This idea of geyi was not simply comparison or a trans-conceptual loan, but rather a Gadamerian 'fusion of horizon.' Such a fusion - the "empathy with understanding" in Chen's words and "silent response with empathy" in Tang's words-as explained by Roxanne Euben and others, "attempts to cross divides of meaning by acknowledging and appropriating their own prejudices within a language that evolves to accommodate and ultimately transform disparate understandings into mutually intelligible meanings." ${ }^{1100}$ Realizing the very ground of geyi, an intellectual similarity between the 'abstract ideals' of human beings, they were able to avoid the trap of relativism and to get rid of the 'hermeneutical circle.' This 'culturalist alternative' or 'conservativism" ${ }^{\prime 1101}$, as some scholars have called it, in a way combined universalism and particularism together for it assumed the general applicability of particular cultural norms. Such a historical attitude is actually the lesson to be obtained from geyi; it lies behind the historical observation that the 'other' can become Chinese.

The universality Chen and Tang found was the Chinese tradition as cultural entity. It was by no means universal law-like principles of historical change but instead was the "personality and thinking of the ancient sages" [gu xianxian zhi renge sixiang 古先賢之人格思想] (Tang) or “the national spirit” (Chen). Neither endorsing any Western model nor subjectively twisting the history of China to support any other worldview, they understood this universality as a 'formal' attachment that varies from culture to culture, and changes in the course of

\footnotetext{
${ }^{1100}$ Euben, Enemy in the Mirror, 37.

${ }^{1101}$ The most paradigmatic study on conservativism is Karl Mannheim, "Conservative Thought." For studies of modern Chinese conservatism, see Charlotte Furth, ed., The Limits of Change: Essays on Conservative Alternatives in Republican China (Cambridge, MA, and London: Harvard University Press, 1976).
} 
history. ${ }^{1102}$ This view, which differs from the philosophical standpoint of 'classicist conservativism' - namely, advocating for an absolute and universal moral ordercan be categorized as 'historicist conservativism,' which means that the universality is dependent, historicized, and only exists in histories. ${ }^{1103}$

Compared to Chen's obscure and abstruse language style, Tang often made straightforward responses against universalists and particularists. As a scholar belonging to the Xueheng school, he intended to express his academic position in a more clear-cut way. He had once frankly declared that he "was unwilling to say that all the good things come from foreign countries." ${ }^{1104}$ In another essay, he criticized that neither the reformers who treated the West as spiritual mentor nor the 'fogeys' [shoujiu zhe 守舊者] who utilized foreign thoughts to prove or protect their own views could grasp 'the truth' that was rooted in cultural traditions. ${ }^{1105}$ This anticulture/anti-tradition tendency, he wrote, embodied "the decaying phenomenon of the collapse of the Chinese spirit” [固有之精神湮滅之衰相]. ${ }^{1106}$

The past of China, for Tang, played a dual role: it was respected antiquity and also a dynamic, flowing voice that people should still listen to. Therefore, Tang advocated a historiography with explanatory power. Issues such as the differences between sects, the reformation of Buddhist communities, and the relationship between different thoughts and discourses, were waiting to be read and interpreted reasonably and contextually. This ability of explanation, according to Tang, was guaranteed neither by any positivistic 'trueness' nor by methodological 'newness', but rather by a kind of philosophical comprehension. He argued:

\footnotetext{
${ }^{1102}$ Chen, “Wang Guantang xiansheng wanci bingxu 王觀堂先生輓詞並序.”

${ }^{1103}$ I borrowed the categories of 'classicist conservatism' and 'historicist conservatism' from Axel Schneider. According to Schneider, Strauss, Voegelin, and Babbitt belong to the former group. See Axel Schneider, “The One and the Many," unpublished Paper for AAS, 2005.

1104 “頗有一個私見, 就是不願意說什麼好東西都是外國來的.” See Hu Shi riji quanji 胡適日記全集, 7.373 .

${ }^{1105}$ Tang Yongtong, “Wenhua sixiang zhi chongtu yu tiaohe 文化思想之衝突與調和,” in TYQJ, vol.5, 273.

1106 “固有之精神湮滅之衰相.” ibid.
} 
Religious sentiment exists deeply in people's minds but is often displayed as suspicious historical records or symbols or legends. Therefore, searching the traces in the past but without a tacit response with empathy it is hard to attain the truth. Philosophy is very subtle; the essence of the world can only be obtained by Enlightenment. The ancient wisdom is innocent and unaffected, but also full of prudent discernment. Its expression is condensed into a few words, but the meaning is far-reaching. Therefore, the evidential study of text that lacks comprehension from the heart can obtain dross. 宗教情緒, 深存人心。往往以莫須有之史實為象徵, 發揮神妙之作用。故如僅憑陳跡之搜討, 而無同情之默應, 必不能得其真。哲學 精微, 悟入實相。古哲慧發天真、慎思明辨。往往言約旨遠, 取譬雖近, 而見道 深弘。故如徒於文字考證上追求, 而乏心性之體會, 則所獲者其糟粕而已. ${ }^{1107}$

In this important passage, Tang emphasized a philosophical concern of historiography - a 'truth' that is derived from but goes beyond historical evidence. The mission of history is “attaining the truth" [deqizhen 得其真]: not only to discover facts, but rather, “to explore ‘truth" [zhenli zhi tantao 真理之探討]. ${ }^{1108}$

To both Chen and Tang, the term 'empathy' implied that historiography should find a balance between evidential research and hermeneutics, and should be concerned with religion, culture, and worldview. Tang's attitude, as described by his friend the philosopher He Lin 賀麟 (1902-1992), was close to that advocated by Qian $\mathrm{Mu}$ - "warmth and respect for the history of the nation's past." ${ }^{1109}$ As Qian commented on Tang's studies:

[Tang] puts himself in their position, tries to understand them sympathetically and never treats them unjustly. He neither criticizes the ancients, nor distorts them to support his own sayings. 設身處地, 同情瞭解古哲, 決不枉屈古人。既不抨擊異 己之古人, 亦不曲解古人以伸已說. ${ }^{1110}$

\footnotetext{
${ }^{1107}$ Tang Yongtong, “Han Liangjin nanbeichao fojiaoshi ba 漢兩晉南北朝南北朝佛教史跋,” in TYQJ, vol.1, 655 .

${ }^{1108}$ Tang Yongtong, “Ping jinren zhi wenhua yanjiu 評近人之文化研究,” TYQJ, vol.5, 274. 1109 “對其本國已往歷史之溫情與敬意,” in Qian Mu, “fan du benshu qing qianju xialie zhu xinnian 凡讀本 書請先具下列諸信念, "Guoshi dagang 國史大綱 (Beijing: Shangwu yinshuguan, 2010), 1. ${ }^{1110}$ He Lin 賀麟, Dangdai Zhongguo zhexue 當代中國哲學 (Shanghai: Shanghai shudian, 1945), 25.
} 
This attitude, obviously, echoed Chen's expression of "the artist's perspective." ${ }^{1111}$ It was summarized by Tang with a sentence cited from Shiji: "living in this world, following the old way, reading history as a mirror of one's self. The past and the present are not the same." ${ }^{1112}$

In this sense, Tang defined himself also "neither-old-nor-new." ${ }^{1113}$ Or, he had noticed and acknowledged that there was always a tension between the new and the old, in the form of geyi. His own historiography of Buddhism also presented itself as a dialogue bridging the old and the new, facts and concepts, phenomena and structure, particularism and universalism. On the one hand, he critically inherited the tradition of Han Learning, emphasizing textual organization, collation, and perusal, for he noticed that the scarcity and limitation of ancient sources would hinder interpretation. Only through "widely collecting and searching both Chinese and foreign materials" 1114 would the textual evidence be justified and properly utilized. On the other hand, Tang had the feeling (although maybe not consciously) that positivism, although claimed to be unprejudiced and impartial, had intentionally restricted philosophy to be the guardian of the 'proper' methods of scientific enterprises. Therefore, textual criticism needed to be practiced followed by a systematic, constructive understanding at a macroscopic level. ${ }^{1115}$ Different from Chen, who discussed Buddhism from "the periphery" and focused on Buddhism's impact on other political and cultural elements, Tang started his observation from

\footnotetext{
${ }^{1111}$ See the former section in this chapter: "Methodological geyi and National Identity." 1112 “居今之世, 志古之道, 所以自鏡, 未必盡同.” Tang Yongtong, “Wenhua sixiang zhi chongtu yu tiaohe 文化思想之衝突與調和,” in TYQJ, vol.5, 281. The original text in Sima Qian, “Gaozu gongchen hou zhe nianbiao xu 高祖功臣候者年表序, ” in Shiji.

${ }^{1113}$ For further discussion on Tang's writing of the history of Chinese Buddhism, see: Chapter 6. Here only issues related to "geyi," for example, Tang's attitude toward the Western theories and the concrete application of the new methodologies, are discussed.

1114 “中外文化之材料, 廣搜精求.” Tang, “Ping jinren zhi wenhua yanjiu 評近人之文化研究, TYQJ, vol. 5, 276.

${ }^{1115}$ This was different from Chen's path of "seeing the whole world from a grain of sand” 以小見大. Yan Gengwang had summarized that Chen's historiography "gathers many seemingly irrelevant trivial materials and trivial cases, collects them, organizes them, makes them systematic, and tells a big problem, big conclusion.” Yan Gengwang 嚴耕望, Zhi shi jingyan tan 治史經驗談 (Taipei: Shangwu yinshuguan, 1997): 94.
} 
the 'inside': the transformation of Buddhism itself, or systems, threads, and layers behind particular phenomena of Buddhist development. In his own words, he was seeking to "explore and organize the thread of ancient thought and the changes of sects." 1116

This systematic framework in Tang's historiography, obscure and well covered, was not based on any existing, imported, or universal system, but still was an outcome of "glaring at the Western books" [kui xiji 窺西籍]. ${ }^{1117}$ Given the training in philosophy and history he had received during his student period, ${ }^{1118}$ it is not surprising to see Western-originated paradigms behind Tang's elaboration. According to He Lin, the translator of the book Grundriss der Geschichte der Griechischen Philosophie [Outlines of the history of Greek philosophy 古希臘哲學史綱] written by Eduard Zeller, Tang's Buddhist history referred to Zeller's structure, although he never professed this openly. At times, Tang also mentioned Wilhelm Windelband as a paradigm for writing a "problem-centric history." ${ }^{1119}$ Similar to Zeller and Windelband, 'system' [tixi 體系] was very significant in Tang's work. To Tang, history needed to "manage the overall situation" [tongji quanju 統計全局] and to be conducted in a systematic way by linking the particular with the general and the holistic with the local, as he modestly concluded his Hanwei that:

It [the book Fojiao shi] provides some credible materials for the history of Chinese Buddhism; it constructs the general thread of the changing of Chinese Buddhism; and it reveals some important phenomena in the history of Chinese Buddhism. 它供給了

\footnotetext{
1116 “疏寻往古思想之脈絡、宗派之變遷.” Tang Yongtong, “Han Liangjin nanbeichao fojiaoshi ba 漢兩 晉南北朝南北朝佛教史跋, ” in TYQJ, vol.1, 655

${ }^{1117}$ Qi Mu 錢穆, Bsshi yi shuangqin shiyou zanyi hekan 八十憶雙親師友雜憶合刊, in Qian Bingsi xiansheng quanji 鈛賓四先生全集, vol. 51 (Taipei: Lianjing, 1998): 204.

${ }^{1118}$ For Tang's academic background, see Zhao Jianyong 趙建永, “Tang Yongtong liuxue hanmulin daxue shiqi zhexue wengao tanwei 湯用粀留學漢姆林大學時期哲學文稿探微.” Shijie zhexue 世界哲 學 3 (2008): 105-112; Also, Zhao, “Tang Yongtong hafo daxue shiqi zhexue wengao bianxi 湯用粀哈佛 大學時期哲學文稿辨析,”Zhexue dongtai 哲學動態, 4 (2006): 33-39.

${ }^{1119}$ He Lin 賀麟, Dangdai Zhongguo zhexue 當代中國哲學 (1945), 24-25.
} 
中國佛教史的一些比較可信的材料, 它提出了中國佛教史發展變遷的一般線索, 它也還揭露了中國佛教史上某些重要現象. ${ }^{120}$

Admittedly, the specter of relativism that haunted Windelband pestered Tang Yongtong as well. His studies on Buddhism, following a similar track, sometimes also slip into 'historicization,' just as historicism reduced philosophy to the history of philosophy. To avoid this situation, when Tang rebuilt the past of Chinese Buddhism, he tried to re-find a structure of axiology or typology in order to have the possibility of arriving at binding truth. For example, the dichotomy between 'body' [ $\mathrm{ti}$ 體] and 'function' [yong 用] was one yardstick in his writings; a three-stage framework was also implied in his narrative of Buddhist history and the general progress of cultural assimilation. ${ }^{1121}$ Throughout his voluminous works, category, periodization, and causality are always relevant.

When comparing Tang and Chen, it might be proper to conclude that the object of Chen Yinke's study was the political or intellectual history of China, while Tang's object was Buddhism itself as one branch of philosophy. Chen's study rested on the 'essence' of the historical thinking and faith background of the Chinese, touching upon abstract cosmological concepts and ethical principles behind the traditional historical narratives. Chen discussed Buddhism as a key factor (along with other factors such economy, politics, and race) that profoundly influenced Chinese history. On the other hand, Tang focused his study on the changes within and between Buddhist sects and the communication of Buddhism and other thoughts, such as the Dark Learning, Daoism, and Confucianism. He considered Buddhism to be a complex structure consisting of various sects or schools, divergent monastic organizations, and intricate lineages and networks.

\footnotetext{
${ }^{1120}$ Tang Yijie 湯一介, Women sandairen 我們三代人 (Hongkong: Sanlian shudian, 2016), 173.

${ }^{1121}$ Tang divided Buddhist history into three stages: the period of Fo-Dao, the period of Fo-Xuan, and the period of independence. For the first stage, see Tang, "Han Wei foxue de liangda xitong 漢魏佛學 的兩大系統," in TYQJ, vol.5, 177; for the second stage, see Hanwei, in TYQJ, vol.1, 89-99; for the third stage, see “Sui Tang foxue zhi tedian 隋唐佛學之特點," in TYQJ, vol.2, 325-331. Also, see Zhao Jianyong, Tang Yongtong yu xiandai zhonggu xueshu 湯用形與現代中國學術 (Beijing: Remmin chubanshe, 2015), 171-174.
} 
Aside from their differences, both Chen and Tang learned from the lesson of geyi. Their conservative approaches, although seemingly rejected to modern standards and defending the value of tradition, was actually also a product of the Enlightenment and modernity. Meanwhile, in modern China, even the May Fourth radicalism, which targeted the symbols and practices of China's traditional order, also expressed particularistic beliefs in the significance of a given past. Inevitably, China's historical continuity and cultural particularity within its past always contained heterogeneous elements that were not in line with the 'ideal China.' As Michel de Certeau has described:

The ambiguity proper to the exchange between cultures, or related to their succession, does not nullify the reality of the connections, but rather specifies their nature. Ambiguity of communication is related to an 'anxiety' that intertwines the continuity of history and the discontinuity of its system: difference. ${ }^{1122}$

In this sense, when the modern Chinese intellectuals tried to create a narrative for China as a nation and as a cultural entity, they were also exposed to an impression that China was not, in fact, homogeneous or unique. On the one hand, the history they wrote suggested that China was developed under ceaseless influences from the outside; on the other hand, China needs to become more and more like the West. Not only was China acquiring all the accoutrements of modernity, but it was also discovering and experiencing its ills. This ambiguity and the feel of difference, which was discomforting but somewhat inspiring, was always attached to the meaning of geyi.

\footnotetext{
${ }^{1122}$ Michel de. Certeau, Heterologies: Discourse on the Other. Translated by Michael Massumi (Minneapolis: University of Minnesota Press, 1986), 180-81.
} 


\section{CHAPTER 7}

\section{Sinicization: A Modern Narrative of Chinese Buddhism}

The story of Chinese Buddhism begins with an 'encounter': Buddhism drifted into China in the Eastern Han dynasty (A.D. 25-220) via trade routes linking China to Central and South Asia. Historically, most of the early Buddhist missions might have been spontaneous activities conducted by monks, businessmen, and immigrants who had no official background. However, in the traditional narratives, the Chinese encounter with Buddhism was initiated through the dream of one emperor: Emperor Ming of the Later Han dynasty dreamt of a huge golden God coming from the West. The emperor then signed an edict to dispatch a group of envoys to ancient India and bring back a foreign teaching, which is Buddhism. ${ }^{1123}$ The thorny route between India and the Middle Kingdom, as well as the scarcity of authoritative Indian Buddhist knowledge coupled with the lack of accurate translations of Indian texts, rendered a proper understanding of Buddhism almost impossible. Therefore, transformation and assimilation seemed unavoidable. This process took place in two dimensions at once: textual and practical. Therefore, Buddhism in China's past actually has two histories: one was the 'encounter' between Buddhism and Chinese civilization at political, social, and cultural levels, which was filled with conciliations and conflicts; the other one was the reception history of Buddhist canons, referring to the well-organized and

\footnotetext{
${ }^{1123}$ Detailed records of the legend can be found in Mouzi Lihuolun as: "In olden days Emperor Ming saw in a dream a god whose body had the brilliance of the sun and who flew before his palace; and he rejoiced exceedingly at this. The next day he asked his officials: 'What god is this?' The scholar Fu Yi said: 'Your subject has heard it said that in India there is somebody who has attained the Dao and who is called Buddha; he flies in the air, his body had the brilliance of the sun; this must be that god'. The emperor then sent an envoy to Tian Zhu (India). Translated into French by Henri Maspero. English edition: Henri Maspero, Taoism and Chinese Religion, tr. by Frank A. Kierman Jr., (Amherst: University of Massachusetts Press, 1981), 402. In modern China, it was called into question by Liang Qichao.
} 
long-term translation project of turning Buddhist writings from Indian languages into Chinese.

As described in the modern narrative about the history of Buddhism, in the late Han dynasty, an age when Confucianism fell into disrepute, the initial utilization of Buddhism by the Chinese was grounded in their pragmatic needs and superficial impression of the similarity between Buddhism and other local traditions. Through a hermeneutic strategy known as “matching concepts" [geyi 格義] ${ }^{1124}$, Chinese people gradually conflated Buddhism, especially the Mahāyāna tradition, with native Chinese thoughts. The core concepts of Buddhism, such as celibacy, mendicancy, and other forms of social renunciation, although they were ultimately antithetical in many respects to the local Confucian and Daoist conventions, were accepted and acclaimed as dynamic elements for Chinese civilization. This process has been described in the modern scholarship of Buddhism as the 'Sinicization/Sinification' of Buddhism ${ }^{1125}$ or the 'Indianization of China'. ${ }^{1126}$

Admittedly, although widely used, neither the discourses of 'Sinicization' nor 'Indianization' can been considered to capture the irrefutable character of Chinese and East Asian Buddhism in the scholarly circles of both Buddhology and Sinology. Current scholarship has realized that the situation of the Indo-Chinese encounter was much more complex; the examples of the Sinicization of Buddhism are also

\footnotetext{
${ }^{1124}$ For a detailed the investigation of geyi and the modern interpretation of this term, see chapter 6. ${ }^{1125}$ In most cases, the two word 'Sinicization' and 'Sinification' are used without distinction. However, some scholars intend 'Sinicization' to refer to religious and ethical assimilation, while they use 'Sinification' to refer to the political and military expansion of China. See Michel Strickmann, "The Tao Among the Yao: Taoism and the Sinification of South China," in Rekishi ni okeru minshū to bunka-Sakai Tadao Sensei koki shukuga kinen ronshū 歷史における民眾と文化一酒井忠夫先生古稀祝賀紀念論集 [Peoples and Cultures in Asiatic History: Collected Essays in Honour of Professor Sakai Tadao on his Seventieth Birthday] (Tokyo: Kokusho Kankokai, 1982), 23-30. Also, John R. McRae, "State Formation, Indigenization, and Buddhism in East Asian History: The Theoretical Foundation," in Indo tetsugaku bukkyōgaku kenkyū インド哲学仏教学研究, no.13 (2006): 45-73.

${ }^{1126}$ The most influential expression of this discourse was Hu Shih's lecture "The Indianization of China: A Case Study of Cultural Borrowing" in Independence, Convergence and Borrowing in Institutions, Thought and Art, Harvard Tercentenary Publications (Cambridge, MA: Harvard University Press, 1937), 219-247.
} 
questionable. ${ }^{1127}$ It is, fundamentally, not a real existant historical fact, but rather a modern-made narrative - a story that was first formulated and recounted by modern historians. ${ }^{1128}$

\section{The Anxiety of Origins}

In modern China, issues like the origin of Chinese Buddhism became so important because they were directly linked with the historical formation and continuity of Chinese culture. To modern Chinese historians, the social change they faced and their confrontation with the West urged them to reflect on and describe the historical processes in the past that had seen intellectual and socio-political conflicts but eventually formed something that could be called tradition-something with 'coherence,' 'unity,' or 'uniqueness.' As the 'Sinicization' of Buddhism might embody such a process and the strategies the ancient Chinese used to address similar conflicts, modern Chinese intellectuals, therefore, became sensitive to this issue and the origins of Buddhism.

\footnotetext{
${ }^{1127}$ Several articles and books have discussed the inadequacy and misleading of the 'Sinicization' discourse. For example, Gregory Schopen has contested that filial piety [xiaodao 孝道] was the outgrowth of the Sinicization of Buddhism, but has claimed it rather to be an innate idea of Indian Buddhism itself as shown by several pieces of archaeological evidence. See Gregory Schopen, "Filial Piety and the Monk in the Practice of Indian Buddhism: A Question of 'Sinicization' Viewed from the Other Side," T'oung Pao 70, no. 1/3 (1984): 110-26. Other scholars, such as Tansen Sen, Stanley Abe, Yü Chunfang, John Kieschnick, Robert Sharf, and so on, have criticized the discourse of Sinicization from the aspects of Chinese religious, cultural, artistic, and material life. For a summarized investigation on current reflections on 'Sinicization', see John Kieschnick, “Guanyu Fojiao hanhua de xingsi 關於佛教漢 化的省思,” in Zhongguoshi xinlun: zongjiaoshi fence 中國史新論: 宗教史分冊, ed., Lin Fu-shih 林富士 (Taipei, Lingking, 2011), 259-273. Also Teng, Wei-jen 鄧偉仁, “Jige pipan 'gojiao Zhongguohua' lilun de zai shenshi 幾個批判 “佛教中國化”理論的再審視, ” in Qiufa yu Hongfa 求法與弘法, ed., Shi Guojing 釋 果鏡, Liao Zhaoheng 廖肇亭 ed., (Teipei: Fagu Wenhua, 2015), 79-104.

${ }^{1128}$ In this chapter, I will not repeat the attempts of the scholars mentioned above to discuss the content, meaning, and applicability of the "Sinicization of Buddhism"; instead, I will investigate why and how this narrative about Chinese Buddhism was formed and developed in the modern Chinese context. Besides, the term 'Sinicization' has recently experienced a remarkable change. The political leader of China, Xi Jingping, uses this term to describe the current basic religious policy of China.
} 
An origin is normally considered to be a historically determined, unchangeable point. In the case of Chinese Buddhism, the identification of origin is complicated, for Buddhism is not a native tradition to China. Thus, historians in modern China needed to create an understanding of how to define the authenticity and continuity of Chinese Buddhism with its Indian origin; meanwhile, they had to distinguish Chinese Buddhism from Indian Buddhism by reasserting its 'Chineseness.' In this sense, they needed to confirm something of their 'own' in the other. Foucault has noted this kind of 'anxiety of origin':

It is no longer origin that gives rise to historicity; it is historicity that, in its very fabric, makes the necessity of an origin which must be both internal and foreign to it: like the virtual tip of a cone in which all differences, all dispersions, all discontinuities would be knitted together so as to form no more than a single point of identity, the impalpable figure of the Same, yet possessing the power, nevertheless, to burst open upon itself and become Other." ${ }^{" 129}$

With a strong willingness to build 'self,' origin thus became 'foreign'; it marked a moment when tradition was born from something alien. Because of this dilemma, searching for the origin of Chinese Buddhism was full of tensions. Furthermore, the pious wish for preserving tradition in a time of transition, to be sure, was not merely an academic issue, but also a political attitude of idealizing certain aspects of China's past in order to arrest the disintegration of society. This tendency indicated that, historically, tradition is a product of 'traditionization.' Tradition, in reaction to new threats, is unstable, generative, and constantly changing, and thus points to a greater cohesion, which is in itself a goal and value. ${ }^{1130}$ All the manifestations of tradition, then, are historically oriented toward the interior and require retrospection. Against this background, in modern China, not only the so-called conservatives but also the modern politicians, reformist religious figures, and Western-style industrialists all more or less participated in this turn to the past and to origins.

\footnotetext{
${ }^{1129}$ Michel, Foucault, The Order of Things: An Archaeology of the Human Science, trans. Alan Sheridan (New York: Vintage Books, 1973), 329-39.

${ }^{1130}$ For an informative analysis on tradition, see Abdallah Laroui, The Crisis of the Arab Intellectual: Traditionism or Historicism, tran. Diarmid Cammell (Berkeley: University of California Press, 1976), 33-43.
} 


\section{The Puzzle of Route}

Various legends had described the presence of ancient Buddhism on Chinese soil. According to the scholarly consensus, Buddhism came to China in the first century through missionaries from India. The term 'Buddhism' was for the first time mentioned in an edict in $65 \mathrm{AD}$, which was quoted by the compiler of the Book of the Later Han. ${ }^{1131}$ Buddhist scriptures were believed to be imported on the backs of white horses; the transmission of Buddhism started with two Indian monks, Dharmaratna and Kaśyapa Mātanga, who arrived in China along with the envoy of Emperor Ming and began their preaching in Luoyang. Historical events related to the early encounter between China and Buddhism were recorded in Buddhist sūtras, biographies of monks, and several official histories, including the Houhan shu and the Weishu ${ }^{1132}$ Those widespread legends as well as convincing records about the historical relationship between China and the Western Land [xiyu 西域] ${ }^{1133}$ largely fixed the image of Chinese Buddhism in its early stage. Those traditional accounts, although ceaselessly narrated, polished and refined, had never been publicly challenged. ${ }^{1134}$ Only during the modern era did the vague details and contradictory narratives catch

\footnotetext{
${ }^{1131}$ The earliest record of Buddhism can be found in Houhan shu 後漢書.

${ }^{1132}$ Most of the later versions of this story in the Buddhist literature had an obvious propaganda function: they served to enhance the prestige of the Buddhist Church either by telling tales of its triumphant entrance at the imperial court and the immediate conversion of the Chinese emperor, or by demonstrating the early existence of Buddhism on Chinese soil. See Zürcher, The Buddhist Conquest of China, 19.

${ }^{1133}$ Military, commercial, and diplomatic activities between Middle Kingdom and the Western Land can be found as early as in Shiji, Han Shu and Hou Hanshu. For example, in "Xiyu zhuan" in Houhanshu, it is recorded that, in 74 A.D., the Emperor Ming sent troops to fight against the Huns and occupied several countries in the Western Regions. This activity built up a direct connection between China and the Western Land.

${ }^{1134}$ Some of the late Qing scholars, such as Shen Zengzhi, had already noticed cultural communication between China and India through the sea route. See Ge Zhaoguang, "From the Western Regions to the Eastern Sea: Formations, Methods and Problems in a New Historical World," in Here in 'China' I Dwell: Reconstructing Historical Discourses of China for Our Time (Leiden: Brill, 2017), 172-86.
} 
the attention of scholars who tried to study Chinese Buddhism from a historical perspective. ${ }^{1135}$

The biggest difficulty modern historians faced was the scarcity of reliable materials, not only because of their limited quantity, but also because of the sectarian implications behind those early texts. For example, many early historical sources (from before the Sui era) that have survived until today were written by Confucian historians who showed less interest in Buddhism. They only recorded Buddhist events when they were directly related to political affairs or the activities of governors or the royal family. ${ }^{1136}$ Their descriptions of Buddhist figures also presented a strong legendary tone, which indicated their suspicious or even rejection of Buddhism.

The first missing piece of the puzzle is the route via which Buddhism entered China. Liang Qichao was one of the most influential figures who supported the maritime route hypothesis. In his article "The Early Transmission of Buddhism in China," he claimed that before Dharmaratna and Kaśyapa Mātanga, Buddhism firstly arrived at the Yangzi-Huai 江淮 river region via the sea route. ${ }^{1137}$ He cited the biography of King Ying of Chu (present-day Jiangsu) in Hou hanshu and the record of Ying's joint worship with the Yellow Emperor, Laozi, and the Buddha to show that in a very early time Buddhism had been prevailing in Southern China. Liang believed that the detailed record that King Ying "observed fasting and performed sacrifices to

\footnotetext{
${ }^{1135}$ For the beginning of the incubation of Buddhism in Chinese soil, there are several opinions. However, most of them are legends. For an enumeration of the legends, see Tang, Yongtong, History; also, Zürcher, The Buddhist Conquest of China, 20-22.

${ }^{1136}$ Some historians, like Shen Yue 沈約, were committed Buddhists; however, they carefully kept a distance from their personal faith to fulfill their responsibilities as professional historians [shijia 史家]. For example, in his Book of Song, Shen Yue only wrote biographies for two Buddhists, Huilin 慧琳 and Daosheng 道生. For analysis on this issue, See Zürcher, The Buddhist Conquest of China., 19. According to Zürcher, the materials in the secular historical literature should not be overestimated, for "they certainly do not indicate the beginning of Buddhism in China, nor are they in any way representative of the spread of Buddhism at the time they were written down. They are important as symptoms of conditions which, by a fortuitous combination of external circumstances, happen to have been recorded."

${ }^{1137}$ Liang, SBP, 32.
} 
the Buddha"1138 demonstrated not only the formation of the Buddhist communities in the Jiangnan area but also the popularity of Buddhist ritual practices within the upper class living in the South. ${ }^{1139}$ He further suggested in a long footnote that, based on the record in Houhan shu, there had already been an advanced commercial connection between China and the South Asian subcontinent as early as in the later Han period, which began from Guangzhang and had its final destination in Huangzhi 黄支, a kingdom in present-day India. ${ }^{140}$

Similar opinions have been put forward by the Sinologist Pelliot, who believes that, in the first century B.C., a Chinese mission, by order of the court, traversed the India Ocean "on ships of the barbarians." ${ }^{1141}$ Through the same path, Buddhism was introduced into China. According to Liang and Pelliot's analyses, the sea route to and from the West had been built up at that time, and the Chinese from that time onwards participated in the economic, diplomatic, and missionary activity of India via this maritime route. ${ }^{1142}$

This bold hypothesis, in Liang's interpretation, might provide a persuasive explanation for the phenomenon that most activities related to Buddhism, such as the translation and composition of the Chinese Buddhist canon, happened in Southern China instead of in regions along the line of the overland Silk Road. By referring to the biographies of An Shigao 安世高 (?-168) in Chusanzang jiji and Gaosengzhuan, Liang pointed out that the locations of An's early peregrination, from Guangzhou, Kuaiji 會稽, and Yuzhang 豫章 to Jingzhou 荆州 and Danyang 丹陽,

\footnotetext{
1138 “為浮屠齋戒祭祀,” in Houhanshu, $72.4 \mathrm{~b}$

${ }^{1139}$ Such detailed records about Buddhist rituals, according to Liang's investigation, could not be observed in any historical texts written about Northern China

${ }^{1140}$ Before Liang, French sinologist Ferrand G. identified that the Kingdom of Huangzhi (Huang Chih) was Kanchipuram (i.e. Conjevaram, forty-six miles south-west of Madras, the then capital of the Pallava dynasty). See Gabriel Ferrand, "Le K'ouen Louen et les anciennes navigations," extrait du Journal Asiatique (1919): 196, 203. Japanese scholar Fujita Toyohachi also held the same opinion. See Fujita Toyohachi 藤田丰八, Zhongguo nanhai gudai jiaotong congkao 中國南海古代交通叢考, trans. He Jianmin 何健民 (Shanghai : Shangwu yinshuguan, 1936).

${ }^{1141}$ Paul Pelliot, “Autour d'une traduction sanscrite du tao tö king," T'oung Pao 13, no.2 (1912): 460.

${ }_{1142}$ J. J. L. Duyvendak, China's Discovery of Africa: Lectures Given at the University of London on January 22 and 23, 1947 (London: Arthur Probsthain, 1949), 12.
} 
sketched the earliest centers of the transmission of Buddhism: the region near Cangwu 荅梧 and Jiaozhou 交州 ${ }^{144}$, which are both in the South. In another paragraph, Liang cited from Sanguo zhi to describe a splendid rite called "bathing the Buddha," which was organized by the local warlord Ze Rong 笮融 in Guangling 廣陵, Xiapei 下䂙, and Pengcheng 彭城 (all in present-day Jiangsu). This record, to Liang, was more evidence that proved his thesis. ${ }^{1144}$

Radical enough, this hypothesis soon attracted wide attention in academia. Hu Shih, for example, responded to this issue when he discussed the authenticity of the Sütra of the Forty-Two Sections with Chen Yuan in 1933. In a 1948 letter Hu wrote to Zhou Yiliang 周一良, he claimed that "there should be a large group of Indian and Southern-Sea Buddhists who reached Jiaozhou via a sea route and permanently resided there for commercial (or maybe missionary) purposes." ${ }^{1145}$ Repeating the evidence Liang had shown, Hu held the idea that Buddhism had arrived in China via the maritime route much earlier than Emperor Ming's dream and the composition of the Mouzi Lihuo hun, one of the earliest Chinese Buddhist texts. Although failing to gather any direct evidence, his confidence in this view never changed. After $\mathrm{Hu}$ moved to Taiwan, he still wrote to Yang Liansheng 楊聯陸 and suggested Yang forward his letter to the French Sinologist Demiéville to see if Demiéville could find some materials in European libraries to support this hypothesis. ${ }^{1146}$

The sea route hypothesis, however, always provoked disputes due to the paucity of evidence. Most scholars still maintained the theory of the overland

\footnotetext{
${ }^{1143}$ In the preface, it was written as Jiaozhi 交趾.

${ }^{1144}$ This hypothesis accords with the opinion of Paul Pelliot. In the introduction to his translation of Mouzi, Pelliot suggested that multiple routes of the early transmission of Buddhism might have existed in the first century, including an overland link between Yunan and Burma and a sea route from Jiaozhou to India. See Paul Pelliot, “Meou-tseu ou les doutes levés," T'oung Pao, 19, no.5 (1919): 256. ${ }^{1145} \mathrm{Hu}$ Shih 胡適, “Zhi Zhou Yiliang (1948.8.7).” This letter has different versions. This one is cited from Geng Yunzhi 耿雲志 ed., Hu Shih shuxinji (zhong)胡適書信集(中) (revised version based on Hu Shih yigao ji micang shuxin 胡適遺稿及秘藏書信, vol.19), 1150.

${ }^{1146} \mathrm{Hu}$ Shih, Lunxue tanshi ershinian - Hu Shih Yang Liansheng wanglai shuzha 論學談詩二十年一胡 適楊聯陡往來書札” (Taipei: Linking, 1998), 92, 103.
} 
route. ${ }^{1147}$ One of the most representative voices came from Tang Yongtong. Following the traditional narrative, Tang believed that Buddhism first entered into the Western regions, including Greater Yuezhi 大月氏, Sogdiana 康居 and Parthia 安息, and then crossed the western boundary of the Han Empire before it finally arrived the "Middle Kingdom.' He stated, 'it seems beyond doubt that it [Buddhism] traveled primarily by the land road." ${ }^{1148}$ Although Tang could not prove the authenticity of the story of Emperor Ming's dream, he examined in detail the geographic dissemination of Buddhism in the Han dynasty and clarified the chronological sequence of the arrival of Buddhism in a broader historical context. In the fourth chapter of his Hanwei, "The Spread of Buddhism in the Han Dynasty," he referred to several records in Chinese historical texts relevant to the overland route of Buddhist transmission, including those that had been cited by Liang. However, the most important evidence Tang posted was the story of the instruction of (a) Buddhist sūtra(s) by Yi Cun 伊存 [known as the story of 'yicun shoujing' 伊存授經]. ${ }^{1149}$ This story directly led Tang to a different verdict. He considered the residents in the Western Region as the 'intermediaries' of Buddhism and believed that Luoyang was the first and major Buddhism center in China. Further, he credited the flourishing of Buddhism in the Qi-Chu and YangziHuai River area to the prevalence of esoteric arts [fangshu 方術] (especially the Huanglao practice 黄老之術 ${ }^{1150}$ in these regions. Such local atmosphere might

\footnotetext{
${ }^{1147}$ Some scholars outside China who have supported the overland hypothesis include Kurakichi Shiratori, Hakuju Ui, Arthur Wright, Kenneth Ch'en, Erik Zürcher, and so on. However, there are still some debates on the concrete date and route of the dissemination of Buddhism from India to China.

${ }^{1148}$ Tang, Hanwei, in TYQJ, vol.1, 63.

${ }^{1149}$ Other matertials deployed by Tang included the payment of homage to both the Buddha and Laozi by the Emperor Huan 桓帝 (147-167 A.D.), the translation of Buddhist sūtra by An Shigao and Lokakșema 支婁迦驖 (147-? A.D.) in Luoyang, the practicing of Buddhism by Zhai Rong, and the composition of Mouzi. See Tang. According to Rong Xinjiang 榮新江, the "scope of the historical texts cited by Tang Yongtong remains undisputed to this day." See Rong Xinjiang, "Land Route or Sea Route? Commentary on the Study of the Paths of Transmission and Areas in which Buddhism Was Disseminated during the Han Period," Sino-platonic Papers, vol. 144 (2004): 3.

${ }^{1150}$ Maspero has pointed out that it is better to take the term Huanglao 黄老, when it occurs in Han texts, as referring to Huanglao (jun) 黄老君, the main deity of the early Daoist pantheon who was especially venerated by the Yellow Turbans, and not as denoting two persons, the Yellow Emperor and
} 
accelerate the distribution of Buddhism but did not guarantee that Buddhism had first landed there.

The reason why Tang's conclusion was different from those of Liang, Pelliot, and Hu lay in the so-called 'calibration in historiography' or, in Hu Shih's words, "the marker stone on the route" [jili de shizhu 記里的石柱]—the solid, credible, 'prior' records that could be used to examine other historical materials while they themselves could not be questioned. To Tang, the story of Yicun was one calibration. Although, he argued, this story had slightly different details in different books [Pei Songzhi's commentary on the Sanguo zhi, Liu Jun's commentary on Shishuo xinyu, etc.], such as the location and also the participants in the event, the main narrative remained the same: a Chinese scholar [boshi 博士] studied Buddhist sūtras with a monk from the Greater Yuezhi. ${ }^{1151}$ This story, which marked the earliest contact between China and Buddhism, unquestionably proved the existence of the overland route of Buddhist transmission across Central Asia.

Other scholars, such as Jiang Weiqiao and Huang Chanhua, also considered Yicun's story to be a credible "historical record" [shilu 實錄]. In his History of Chinese Buddhism, Jiang reiterated the authenticity of Yicun's story and basically accepted the traditional narrative. ${ }^{1152}$ Huang, following Hakuju Ui ideas, contested the traditional accounts of Emperor Ming but read the story of Yicun as the real beginning of Chinese Buddhism. ${ }^{1153}$

Lü Cheng, on the contrary, might have had some reservations on this matter. In one of his lectures, he referred to the study of Japanese scholar Kurakichi Shiratori 白鳥庫吉 (1865-1942) and argued that there had been no established Buddhist belief during the first two generations of the Kusha Dynasty in Bactria. Therefore, it was

\footnotetext{
Laozi, which seems to be a later scholarly interpretation of the term. See Henri. Maspero, "Les origines de la communauté bouddhiste de Luoyang," Journal Asiatique (1934), 90.

${ }^{1151}$ Tang, Hanwei, in TYQJ, vol.1, 36-38.

${ }^{1152}$ Jiang Weiqiao, Zhongguo fojiao shi 中國佛教史(1929).

${ }^{1153}$ According to Lü, Jiang Weiqiao's Zhongguo fojiaoshi was translated from the History of Chinese Buddhism written by Sakaino Satoru; Huang's history was based on Hakuju Ui's Outline of the History of Chinese Buddhism, 1936.
} 
highly doubtful that the Greater Yuezhi tribes, which were even earlier than the Kushanas, could have held Buddhism as a popular belief; the story of Yicun, therefore, was also dubious. ${ }^{1154} \mathrm{Lü}$ also rejected the whole story of Emperor Ming as a myth. It was, Lü claimed, a propaganda story full of anachronisms that was fabricated based on an edict of Emperor Ming: Because, in the official history, there was a record that the Emperor sent back the silks that the King Ying of Chu had submitted for redemption in order to "encourage the rituals of upāsakas 伊蒲塞 and Śramaṇas 桑 門," people then mistakenly connected the Emperor Ming with Buddhism. ${ }^{1155}$

Despite their contradictory conclusions, narratives of 'Sinicization', or the origin of Chinese Buddhism, reached some consensus: the authenticity of the story of Yicun was largely acknowledged; also, it was agreed that Buddhism had slowly infiltrated from the North-West, via the two branches of the continental Silk Road to the North China plain, where in the Later Han times the capital Luoyang, was situated. ${ }^{1156}$ Also, the existence of Buddhism in the Late Han was attested. ${ }^{1157}$ The conclusion written in the textbooks nowadays is simple; however the hypothesis that Buddhism came from the Southern coast of China has never fully disappeared. ${ }^{1158}$

\footnotetext{
${ }^{1154}$ Lü Cheng, Zhongguo gojiao yuanliu luejiang 中國佛教源流略講, lecture one, ${ }^{1155}$ HHS 12.5a; Hou-Han ji 10.4b; see also Tang Yongtong, op. cit., pp. 53-55; For the studies on the ritual, see Fukui Kōjun 福井康順, Dōkyō no kisoteki kenkyū 道教の基礎的研究 (Tokyo: Risosha, 1952), 99-106; Henri Maspero, Essay sur le Taoïsme, ch. III, “Le Taoïsme et les débuts du Bouddhisme en Chine," in Mélanges posthumes vol. II (1950): 185.

${ }^{1156}$ This view had been presented in many introductory and general expositions of the history of Buddhism, both in classroom or in written works, and the date of the Yicun's introduction, B.C.2, had also been officially designated as "the Arrival Year of Buddhism." In 1998, under the lead of Zhao Puchu趙樸初, 中國佛教協會 held a ceremony to celebrate the 2000th anniversary of the import of Buddhism.

${ }^{1157}$ See Zürcher, The Buddhist Conquest of China.23.

${ }^{1158}$ After the 1980s, newly discovered archaeological Buddhist iconographic materials expanded the early phase of Buddhism's dissemination area to include present-day Sichuan and the coastal areas near Jiangsu. the view of Buddhism coming to China via the sea route has resurfaced and seems more closer to the final conclusion. See Rong Xinjiang, "Land Route or Sea Route? Commentary on the Study of the Paths of Transmission and Areas in which Buddhism Was Disseminated during the Han Period," 3.
} 


\section{The Textual and Cultural Journey of Buddhism}

After Buddhism arrived in China, the attempt to translate and interpret Buddhist doctrines and regulations into indigenous expressions lasted for over two centuries. It was another important facet of the early encounter between China and Indian Buddhism; it was also the real 'agent' of Buddhist Sinicization, at least in the view of the modern historiography of Buddhism.

Until the distinguished Kuchean Buddhist scholar, Kumārajiva's 鳩摩羅什 (350-ca. 409) ${ }^{1159}$ sophisticated, if not "authentic," translations of several essential Buddhist scriptures and commentaries arrived China, Chinese believers did not stop their pursuit for the real Buddha's Dharma through their direct or indirect contacts with Indian Buddhist masters and their reading of Pali or Sanskrit texts. To that early generation of Chinese Buddhists, India, instead of China, was the center of the world; it was a sacred land where the Buddha had gained his perfection. ${ }^{1160}$ This imagination with aspiration and anxiety became a "broader complex," which, as described by Tansen Sen, was a prevailing voice within the early dialogue between China and India. ${ }^{1161}$

Later, the South Asian missionaries and translators who followed Kumārajīva, such as Bodhiruci 菩提流支 (?) and Paramārtha 真諦(499-569), facilitated the development of Chinese counterparts to the Indian exegetical systems, establishing the Chinese people's own structures of Buddhist hermeneutics: Sanlun 三論 (based on Indian Mādhyamika treatises), Dilun 地論 (based on the Daśabhūmikasūtraśāstra), and Shelun 攝論 (based on the Mahāyānasamgraha). Generally, during the

\footnotetext{
${ }^{1159}$ For these dates, see Tsukamoto 塚本善隆: “The Dates of Kumārajīva and Seng-chao Reexamined,” in Zinbun Kagaku Kenkyūjo Silver Jubilee Volume, trans. Leon Hurvitz (Kyoto: Kyōto daigaku jinbun kagaku kenkyūjo), 568-584

${ }^{1160}$ In the seventh century, Monk Daoxuan, for instance, recorded in great detail his vision of a monastery in India. See Tan Zhihui, "Daoxuan's Vision of Jetavana: Imaging a Utopian Monastery in Early Tang," Ph.D dissertation, University of Arizona, 2002.

${ }^{1161}$ Tansen Sen, Buddhism, Diplomacy, and Trade: The Realignment of Sino-Indian Relations, 600-1400 (Honolulu: University of Hawai'i Press, 2003). According to Sen, this concept was derived from Antonino Forte, "Hui-chih (fl. 676-703 a.d.), A Brahmin Born in China," Estratto da Annali dell'Istituto Universitario Orientate 45 (1985): 106-134.
} 
Southern and Northern Dynasties (ca. 317-589), the more ascetic, devotional, and thaumaturgic forms of Buddhism found their home in the "barbarian" kingdoms of the north, while the more metaphysical and philosophical facets of Buddhism proved attractive to segments of the displaced Han elite in the south. ${ }^{1162}$

This indigenizing process reached its peak in the Sui and Tang dynasties, the so-called 'golden age' of Chinese Buddhism. Advances in trade and travel along the Silk Road and sea route via the Southeast Asian sea ${ }^{1163}$ encouraged Chinese monks such as Faxian, Xuanzang, and Yijing 義淨 (635-713) to make pilgrimages to India and import the latest texts and teachings to China. Their writings and translations allowed the Chinese audience to perceive India from a more familiar angle. ${ }^{1164}$ However, these practices, which were aimed at establishing 'authentic' Indian thought, 'failed': because of Xuanzang's translation expertise and the importation of the Buddha's relics, the "border complex" of Chinese Buddhists was largely replaced by local worship of the new sacred sites and canons in China, the 'Middle Kingdom' [zhongtu 中土]. ${ }^{1165}$ At the same time, the favorable cultural and political climate, together with the patronage of a succession of Sui and Tang rulers, spurred the development of genuinely indigenous Chinese schools, including Tiantai, Huayan, Pure Land, and, most important of all, Chan. ${ }^{1166}$ Chinese Buddhism then had come of

\footnotetext{
${ }^{1162}$ Robert Sharf. Coming to Terms with Chinese Buddhism, 5

${ }^{1163}$ For Indian- Chinese trade, see Liu, Xinru, Ancient India and Ancient China: Trade and Religious Exchange AD 1-600 (Oxford: Oxford University Press, 1988).

${ }^{1164}$ The travel accounts of these Chinese pilgrims can be considered to provide only indirect access to India, as they are tied up with preconceptions of both the authors and what the authors assumed their Chinese readers wanted to know. See John Kieschnick and Meir Shahar, India in the Chinese Imagination (Philadelphia: University of Pennsylvania Press, 2013), 4; See also Timothy H. Barrett, "Did IChing Go to India? Problems in Using I-ching as a Source for South Asian Buddhism," in Buddhist Studies Review 15, no.2 (1998): 142-156.

${ }^{1165}$ See Sen, Tansen, Buddhism, Diplomacy, and Trade: The Realignment of Sino-Indian Relations, 600-1400 (Honolulu: University of Hawai'i Press, 2003); Also, John Kieschnick and Meir Shahar, India in the Chinese Imagination, Myth, Religion, and Thought, (Philadelphia: University of Pennsylvania Press, 2013). ${ }^{1166}$ The Buddhist traditions that were to emerge from the Tang relatively unscathed (Pure Land and Chan) survived precisely because they were less dependent on scriptural learning, monastic ritual, and clerical regulation, and thus were less susceptible to the vagaries of state and aristocratic patronage. Pure Land and Chan were oriented toward individual faith and salvation gained through meditative
} 
age: it was ready and willing to distance itself from the authority of Indian Buddhism and to strike out in new directions.

The emergence of those indigenous Buddhist schools and the formation of the body of Dazangjing marked the accomplishment of Buddhist Sinicization. Although, along with this process, there was a long and inexorable decline of Buddhism, especially at the philosophical and spiritual level ${ }^{1167}$, the encounter between China and India through the vehicle of Buddhism 'invented' the normativity and particularity of Chinese Buddhism.

This narrative about Buddhism's journey from India to China, as formalized by Arthur Wright over forty years ago, can be divided into four phases: "preparation" (Eastern Han and early Six Dynasties), "domestication" (Northern and Southern Dynasties), "independent growth" (Sui and Tang dynasties), and "appropriation" (Five Dynasties to 1900). ${ }^{1168}$ This paradigm was widely adopted throughout the modern academic circle because of its resilience. ${ }^{1169}$ Similar paradigms had already appeared in the writing of the history of Buddhism during the early twentieth century in China. Questions such as 'Should the different Chinese interpretations of a Buddhist doctrine be understood as misunderstandings or creative appropriation?' or 'Does India have the exclusive rights to the orthodoxy of Buddhism?' were also under

practice, rendering them accessible and appealing to the masses respectively. As such, these traditions, infused at times with popular forms of Tantra, came to dominate the Chinese Buddhist landscape down to the present day.

${ }^{1167}$ The notion that Buddhism went into a protracted decline following the watershed of the Tang is similarly based on longstanding but unwarranted historiographical biases; Buddhist institutions and intellectual traditions continued to flourish through the Sung dynasty (960-1279) and enjoyed periods of renewed vigor and growth in later periods as well. For the critique of the 'decline' narrative of postTang Buddhism, see Griffith Foulk, "Myth, Ritual, and Monastic Practice in Sung Ch'an Buddhism," in Religion and Society in T'ang and Sung China, edited by Patricia Buckley Ebrey and Peter N. Gregory (Honolulu: University of Hawai'i Press, 1993), 147-208.; and the collection of essays in Peter N. Gregory and Daniel A. Getz ed., Buddhism in the Sung (Honolulu: University of Hawai'i Press, 1999).

${ }^{1168}$ Arthur Wright, Buddhism in Chinese History (Stanford: Stanford University Press, 1959).

${ }^{1169}$ Currently, only two scholars, John McRae and Robert Sharf, have advocated completely abandoning the notion of "Sinicization." Sharf has criticized that: "The Chinese encounter or dialogue with Buddhism took place almost exclusively among the Chinese themselves, on Chinese soil, in the Chinese language." See Sharf, Coming to Terms With Chinese Buddhism: A Reading of the Treasure Store Treatise, 2. 
discussion, although a consensus was still out of reach. In the modern Chinese context, the controversy within the studies of the history of Chinese Buddhism owed mainly to the dichotomy between 'Chinese culture' and 'Indian Buddhism,' which still was framed in terms of the interrelationship between discrete and autonomous historical entities. Scholars modeled the process of Sinicization in different ways, depending on their (sometimes hierarchical) understanding of the relationship between Indian tradition and Sinitic culture.

\section{The Contradiction of Explanations}

In practice, the deficiency of information might be helpful if we were trying to list all the proofs we actually have. However, to distinguish what we know from what we have conjectured or reconstructed or hypothesized is another thing. ${ }^{1170}$ As discussed before, the modern scholars should have known, at least to some extent, that the limited historical and Buddhist writings preserved in the ancient Chinese books were unreliable, since these texts were either written by secularized literati or translated by believers with patchy knowledge of foreign language and historiography. Therefore, all their writings on the history of Buddhism were 'critical.'

The mist surrounding the history of Chinese Buddhism and early Chinese Buddhist literature was mentioned in Liang Qichao's article "Brief Remarks on the Development of Chinese Buddhist Dharma." First, why could Buddhism prevail in China? Second, why was Mahāyāna Buddhism, instead of Hinayana Buddhism, able to be cultivated in Chinese soil? ${ }^{1171}$ Both of these questions had never been touched in the traditional historical narratives of Buddhism.

\footnotetext{
${ }^{1170}$ Gregory Schopen, “Two Problems in the History of Indian Buddhism: The Layman/Monk Distinction and the Doctrines of the Transference of Merit," in Bones, Stones, and Buddhist Monks: Collected Papers on the Archaeology, Epigraphy and Texts of Monastic Buddhism in India (Honolulu: $\mathrm{U}$ of Hawai'I Press, 1997), 23-55.

${ }^{1171}$ Liang, “Zhongguo fofa xingshuai yange shuolue” 中國佛法興衰沿革說略,”SBP, 4
} 
Chinese civilization has been preoccupied with record-keeping and historymaking since its very beginning. ${ }^{1172}$ This sustained dedication to the enterprise of writing down the main events of each dynasty and reign for posterity has transfixed China for more than two millennia. The Chinese have demonstrated an admiration for chronicles, annals, bibliographies, documents, and other written accounts of the enactment of rulers and government institutions on a day-to-day basis. This strong dominance of secular historiography, along with a legendary lineage of the transmission of the Buddha Dharma, determined the complexity and multivocality of the story of Chinese Buddhism. The mission of writing Chinese Buddhist history was not just patching up the fragments and missing parts with new materials, but also finding answers to questions similar to those Liang posed, ${ }^{1173}$ namely, providing explanation, judgment, and principles; the writing of Chinese Buddhist history was expected not only to tell stories but also to reveal the causality, order, and ideals behind them.

Liang's study, for example, focused on grasping the 'continuity' behind historical events while rejecting occasional factors. For example, he criticized the legend of Hanming qiufa as "a saying without any evidence; it began from the false accusation framed by bad Daoists and was narrated with the implausible fabrication of the silly monks." ${ }^{1174} \mathrm{He}$ also rejected the opinion that the flourishing of Buddhism in China could be attributed to the conflict between the faiths of Taoism and Confucianism within the Han court. ${ }^{1175}$ On the contrary, Liang summarized two reasons for the success of Buddhism in Later Han China, especially among the literati. One was the “intellectual undercurrent”[sixiang zhi fuliu 思想之伏流], namely the vacuum of faith left by the empty textualization of Classic Learnings and the esoteric

\footnotetext{
${ }^{1172}$ For a summary treatment of all the main facets of the historical tradition of Chinese civilization, see Endymion Wilkinson, Chinese History: A Manual, Harvard-Yenching Institute Monographs Series, 52 (Cambridge, Mass.: Harvard University Asia Center, 2000).

${ }^{1173}$ Liang wrote: “The answer to this question is rooted only in history” [此答案非求根柢與歷史焉不 可也]. SBP, 48.

${ }^{1174}$ Liang, “Fojiao zhi chushuru 佛教之初輸入," SBP, 29.

${ }^{1175}$ Liang claimed that this saying was derived from the record in Houhanshu: “聞宫中立黄老、浮屠 之祠." However, Liang did not mention who had said this saying. Ibid., 23.
} 
arts of 'religious' Taoism. The other reason was the "background of time" [shidai zhi Beijing 時代之背景]—a feeling of 'impermanence [wuchang 無常] among people, which was stimulated by the socio-political turbulence from the end of the Han dynasty to the Sui dynasty. ${ }^{1176}$

Hu Shih stressed more the Chinese cosmology and philosophical conceptions in pre-Qin and early Han eras. He repeatedly mentioned that Buddhism in ancient China had been imagined as a great religion, for it provided Chinese people a hierarchical, layered system of Heaven and Hell. This conception, which was in accordance with the natural element of shamanism in Chinese culture, Hu suggested, resulted in the Buddhist 'conquest' of China, or the 'Indianization' of China. ${ }^{1177}$ This historical process, he described rhetorically, was "a small witch meets a big witch" [xiaowu jian dawu 小巫見大巫]. ${ }^{1178}$

Rather than simply dismissing any single traditional account, Tang Yongtong used his own judgment of the textual and logical reliability of these accounts to enumerate all the prevailing legends and stories about the spread of early Buddhism. (In the first chapter of the History, he presented ten different accounts). After listing numerous events related to the indigenization of Buddhism-early translation activities, religious events, rituals, and ceremonies-he also took into account the current social, political, and economic conditions. Although he did not use the term "Sinicization," Tang was one of the first to depict this historical process over a longer span of time. In the Hanwei, he divided the early reception of Buddhism into two stages. The first stage was the last Later Han era, during which Buddhism was considered a kind of esoteric art such as Huanglao (Daoism) and was practiced by the common people; the second stage was from the Wei to the Northern and Southern

\footnotetext{
${ }^{1176}$ Liang, “Zhongguo fofa xingshuai yange shuolue 中國佛法興衰沿革說略,”SBP, 5.

${ }^{1177}$ The term 'conquest' was not used for the first time by Erik Zürich, although it was he who made it famous. Hu used this metaphor in his 1945 lecture at Harvard, which was published in the same year in the Bulletin of the Divinity School, Harvard University under the title "The Conception of Immortality in Chinese Thought." For a Chinese translation, see Wenji, vol.12, p 354. For a similar expression of Hu, see lecture “Chanzong shi de yige xin kanfa 禪宗史的一個新看法” (1953), in HSWJ, 389. ${ }^{1178}$ Ibid.
} 
dynasties, during which Buddhism became significant and prevalent among the elites with the help of xuanxue. ${ }^{1179}$ Examining the mutual relationship between Buddhism and local thoughts and emphasizing the esoteric and exotic facet of Buddhism, ${ }^{1180}$ Tang linked the acceptance of Buddhism with three-fold influences consisting of the Daoist esoteric arts, the migration from Central Asia, and the Dark Learning that prevailed among the Late Han literati, rulers, and royal families. ${ }^{1181}$

Although Tang was already aware of the unique form of faith of ordinary believers and the 'popular accretion"1182 of Buddhist culture, he paid more attention to the religious life of the elite stratum. According to Tang, when the centralized organization of the Han empire started to collapse and Confucianism, as "veritable orgies of scholasticism"1183, lost much of its former prestige, disappointed literati started to look for other means to replace or modify their beliefs. Against this background, a new trend in Chinese philosophy, xuanxue, emerged. Xuanxue appears primarily to be the philosophy (and, in many cases, the intellectual pastime) of a refined and aristocratic leisure class whose interest had turned from the practical business of everyday life to gnostic and ontological problems such as the "original non-being" [benwu 本無], the presence or absence of emotions in the Sage, the

\footnotetext{
${ }^{1179}$ Tang, TYQJ, vol.1, 39-46; 89.

${ }^{1180}$ Tang referred the Mouzi and the Sutra of Forty-Two Sections to demonstrate that Buddhism in the Han dynasty was called "the Dao of Buddha" or "the Dao of Śakyamuni." See Tang, TYQJ, vol.1, 65. ${ }^{1181}$ Ibid, 142-44.

${ }^{1182}$ The popular accretion included shamanism, ancestor worship, cults directed toward the veneration of

aboriginal gods and local holy men, thaumaturgy, auguring and divination, appeasement of baleful spirits and wayward ghosts, ritual possession and exorcism, and any number of other indigenous practices. See Sharf, Coming to Terms With Chinese Buddhism: A Reading of the Treasure Store Treatise. 13-14. For the tantrism of Buddhism see Heinz Bechert ed., Buddhism in Ceylon and Studies on Religious Syncretism in Buddhist Countries (Göttingen, Vandenhoeck \& Ruprecht, 1978); Richard Gombrich, Theravåda Buddhism: A Social History from Ancient Benares to Modern Colombo (London: Routledge and Kegan Paul, 1988); Ian Reader and George Tanabe, Practically Religious: Worldly Benefits and the Common Religion of Japan (Honolulu: University of Hawai'i Press, 1998); Rolf A. Stein, Tibetan Civilization (Stanford: Stanford University Press, 1972), 191- 247; as well as the extensive ethnographic studies by Melford Spiro, Gananath Obeyesekere, Sherry Ortner, Stanley Tambiah, and so on. ${ }^{1183}$ Zürcher, The Buddhist Conquest of China, 45.
} 
extent to which words can express ideas, and other subjects of a highly speculative nature. ${ }^{1184}$ Tang had in his Hanwei convincingly demonstrated how this native cultural setting acted as a factor of the utmost importance in the development of early Chinese Buddhism, especially in the gentry circles in the Huabei plain and Jianghuai regions, the major locales of Buddhist distribution. ${ }^{1185}$ Comparatively, in his panorama of Chinese Buddhism, religious forms that were more closely linked with monastic clerics, such as Vinaya, ritual, and meditation, were less discussed.

This approach to intellectual history has been criticized by several scholars, such as Erik Zürcher, Daniel Overmyer, Michel Strickmann, and Stephen Teiser. As Zürcher has noted, "as soon as we go below that top-level, quite another picture emerges, in which Buddhism loses much of its sharp contour, as it is absorbed into the surrounding mass of Chinese indigenous religion." ${ }^{1186}$ Since Zürcher, scholars of the social history of Asian religion have increasingly focused on the faith situation of non-elites, opening up new horizons for the study of religion. At the same time, however, if we consider that Zürcher's research was profoundly influenced by Tang Yongtong, it can be argued that it was Tang's approach that triggered Zürcher's reflections. ${ }^{1187}$

In general, the interpretations of scholars showed differences in both premises and conclusions. Liang rejected the authenticity of the traditional narratives and formed an explanation for the Chinese embrace of Buddhism with the evidence he sifted through; Hu's conclusion, which was more straightforward,

\footnotetext{
${ }^{1184}$ Tang, Hanwei, in TYQJ, vol.1 91-114.

${ }^{1185}$ Ibid., 115-140

${ }^{1186}$ Erik Zürcher, "Perspectives in the Study of Chinese Buddhism," in Journal of the Royal Asiatic Society (1982): 173; see also the discussions in Michel Strickmann, "The Tao among the Yao: Taoism and the Sinification of South China," In Rekishi ni okeru minshū to bunka - Sakai Tadao Sensei koki shukuga kinen ronshū 歴史における民眾と文化一酒井忠夫先生古稀祝賀記念論集 (Tokyo: Kokusho Kankokai, 1982), 23-30; and Daniel L. Overmyer "Buddhism in the Trenches: Attitudes toward Popular Religion in Chinese Scriptures Found at Tun-Huang," in Harvard Journal of Asiatic Studies 50.1 (1990): 197-222. ${ }^{1187}$ Zürcher himself then used the term "gentry Buddhism" to label the Buddhist faith among the cultured upper class in medieval Chinese society. Zürcher, The Buddhist Conquest of China, 4-6; Cf. E. G. Pulleyblank, “'Gentry Society': some remarks on recent work by W. Eberhard," in Bulletin of the School of Oriental and African Studies (BSOAS), xv, (1953): 588.
} 
critically read mysticism and esoterism as the main factors related to the prevalence of Buddhism in China. Tang wrote the past of Chinese Buddhism from a broad perspective of intellectual history but ignored the popular facet of Buddhism as a 'lower culture.' Nevertheless, as was analyzed before, what is important is not whether these interpretations were right or wrong, but the position from which these scholars made their judgments. All these historians were not passively following Tang's sources, but actively interpreting them. They inquired why the Chinese people were willing to embrace Buddhism and also how Buddhism was 'Sinicized'.

\section{The Formation of Chinese Buddhism}

The scholarly consensus indicated that the Sinicization of Buddhism was accomplished in the middle of the Tang dynasty, when the indigenous Buddhist schools, Tiantai, Huayan and Chan, had been completely established by Chinese Buddhist masters. However, before the modern era, Buddhism in China was normally called 'shijiao' 釋教 or 'shijia' 釋家 in traditional texts; it was never called 'Chinese Buddhism' [Zhongguo fojiao/hanzhuan fojiao 中國佛教/漢傳佛教]. The appearance of the term 'Chinese Buddhism' was a modern product that was not only related to the invention of Buddhism as a "world religion" ${ }^{1188}$ but also the formation of China as a nation.

\section{Chinese Buddhism in the West}

The emergence of the independent field of Buddhist study with a focus on China was closely linked with how the Orientalists and Sinologists understood or imagined Chinese religions. During the last three centuries, the Western attitude towards

\footnotetext{
${ }^{1188}$ In the last twenty years, a diverse array of scholars from Talal Asad and Jacques Derrida to Daniel Dubuisson, Timothy Fitzgerald, Jonathan Z. Smith, and Tomoko Masuzawa have all repeatedly demonstrated that religion is not a universal entity but a culturally specific category that took shape among Christian-influenced intellectuals and missionaries.
} 
Buddhism and China has gone through several ups and downs. The earliest narratives about 'China,' which came from travelers like Marco Polo, John of Montecorvino, and so on, never mentioned Buddhism. ${ }^{1189}$ Only beginning with Matteo Ricci, the man whom Demiéville has called the "founding father of Western Sinology," ${ }^{1190}$ did Buddhism enter into the vision of Westerners. To a certain extent, the Western attitudes toward Chinese Buddhism as well as other local religions were determined mainly by the descriptions given by the Christian missionaries. However, the outstanding achievement of those Christians had a high cost: because of their prejudices against Buddhism and Daoism, the entire branch of Chinese religion was always excluded from the field of Sinology ${ }^{1191}$ Inherited from Ricci and other Christian missionaries, Buddhism and other Chinese religious traditions continued to be ignored in Western academic writings during this early stage.

During the seventeenth and eighteenth centuries, however, many Western philosophers began to imagine China as a "paradisiacal universe," a model of rational government, and a moral land in which native religious tradition was just a "heap of superstitions." ${ }^{1192}$ In this view, Buddhism caught the attention of Western scholars and was portrayed as an expression of quietism and nihilism. Such interpretations paved the way for the Western characterization of Buddhism. ${ }^{1193}$ In the nineteenth century, Buddhism definitely constituted an object of scholarly discourse and was "rectified as a textual object." This can be attributed to the "Oriental Renaissance,"1194

\footnotetext{
1189 Paul Demiéville and Martin Faigel, “The First Philosophic Contacts Between Europe and China," in Diogenes 15, no. 58 (1967), 75-103.

${ }^{1190}$ Paul Demiéville, “Aperçu historique des études sinologiques en France," in Acta Asiatica: Bulletin of the Institute of Eastern Culture 11 (1966): 56-110.

${ }^{1191}$ On Ricci's attitude towards Chinese religion, see also Paul A. Rule, "Jesuit and Confucian? Chinese Religion in the Journals of Matteo Ricci," in Journal of Religious History 5 (1968). 105-24; Frederick P. Braudauer, "The Encounter between Christianity and Chinese Buddhism from the Fourteenth Century through the Seventeenth Century," in Ching Feng 11, no. 3 (1968). 30-38; Iso Kern, "Matteo Riccis Verhältnis zum Buddhismus," in Monumenta Serica 36 (1984): 65-126.

${ }^{1192}$ For the Western understanding of Chinese Buddhism, especially Chan, see Bernard, Chan Insight and Oversight. 19-45.

${ }^{1193}$ Bernard, Chan Insight and Oversight. 34

${ }^{1194}$ Almond, The British Discovery of Buddhism, 139.
} 
which, in Raymond Schwab's words, demonstrated a textualization that permitted a 'historicized' Buddha and the convenient opposition between a pure, canonical, early Buddhism in India and the decadent Buddhist religion in later Asia. ${ }^{1195}$ Accordingly, many Western scholars considered Chinese Buddhism an offspring of Indian mysticism that had modified, twisted, or wildly supposed the doctrines of Indian Buddhism.

Around the middle of the nineteenth century, or particularly under the influence of Hegel, a variant of the evolutionist schema was applied. Buddhism was interpreted by Hegel as "a definite and necessary step of religious representation," which would eventually be aufgehoben by Western thought. ${ }^{1197}$ Moreover, owing to the development of the "scientific study of Buddhism" established by Eugène Burnouf, Max Müller, and so on, the romantic search for the old Oriental wisdom gave way to the cultural versions of this Hegelian evolutionism in which Buddhism (as well as Hinduism, Confucianism, Daoism, etc.) was reduced to one early stage of mankind. ${ }^{1198}$ As colonialism expanded over Asia, the image of China evolved from that of a model of enlightened government (as in Voltaire's opinion ${ }^{1199}$ ), to that of a corrupted, apathetic, and radically inferior country. Under this circumstance, the 'great tradition' of Confucianism continued to consume most of the efforts of the

\footnotetext{
${ }^{1195}$ See Raymond Schwab, The Oriental Renaissance: Europe's Rediscovery of India and the East, 1680-1880, trans. Gene Patterson-Black (New York: Columbia University Press, 1984).

${ }^{1196}$ Heinrich Dumoulin, "Buddhism and Nineteenth-Century German Philosophy," Journal of the History of Ideas 42, no. 3 (1981): 462.

${ }^{1197}$ Hegel remained very dependent on Jesuit accounts, from which he inherited the conception of the Buddhist principle [li], "the matter of all things" [Grundstoff]. From this outset, he was convinced that "world history moves from East to West, Europe being the end of world history." However, Hegel's understanding of $l i$ was not correct. It was based on Longobado's misinterpretation (1701) of Confucian $l i$ as being of a material nature.

${ }^{1198}$ For a summary of this issue, see Goethe, in a discussion with Eckermann about Hindu philosophy, in Gespräche mit Goethe (Berlin: Bong, 1949), 224.

${ }^{1199}$ For instance, Voltaire, Correspondence, 112, Letter of 28 November 1762.
} 
Sinologists ${ }^{1200}$, while 'sub-great traditions,' here Daoism and Buddhism, ${ }^{1201}$ were largely overlooked or, as an afterthought, fitted into the preexisting scheme established for the 'great' tradition. ${ }^{1202}$ Moreover, because of the combination of a development of scholarly Orientalism, Christian intolerance, and colonialist selfimportance, the formulation of Buddhist degeneration reached its peak among Western scholars. ${ }^{1203}$ Most of the Western Buddologists at that time failed or refused to distinguish Chinese Buddhism from its Indian origin. For example, the Chan school, one of the most representative Chinese Buddhist traditions, was interpreted as a meditation form of quietism and a forerunner of annihilation. Carefully hiding their polemical tactics behind scholarly erudition, these nineteenth-century Orientalists believed themselves more sophisticated than their Christian predecessors in rediscovering the Indian origins of Mahāyāna Buddhism. However, even the most excellent scholars among them, such as Eugène Burnouf, dismissed the miracle told in the Lotūs Sūtra or simply labeled it as "incredible nonsense," and were unable to completely free themselves from prejudice and condescension. ${ }^{1204}$ Based on this epistemological position, the 'annihilation' thesis spread and became the established

\footnotetext{
${ }^{1200}$ For instance, Marcel Granet downplayed the role of Taoism and Buddhism in his picture of Chinese religion (1927); Max Weber, although not a Sinologist, reflected the same premises in his work on China (The Religion of China: Confucianism and Taoism, 1951); Joseph Levenson's influential work Modern China and its Modern Fate (1968) also demonstrated a special emphasis on Confucianism.

${ }^{1201}$ In addition to the sets of great "Western" and "Eastern" religions, in the early twentieth century, there was another category of religions that were perhaps not so great, or what were sometimes termed "little traditions," which tended to go by certain generic, lower-case names (shamanism, animism, etc.) often with particular local markers attached. See Masuzawa, The Invention of World Religions: Or, How European Universalism was Preserved in the Language of Pluralism, 15. Here I use the 'subgreat tradition' to mean the non-Confucian traditions that were not orthodox or dominant in the Chinese historical context but influential in the intellectual domain.

${ }^{1202}$ Norman J. Girardot, “Chinese Religion and Western Scholarship," in China and Christianity: Historical and Future Encounters, ed. Yu-ming Shaw James D. Whitehead, Norman J, Girardot (Notre Dame: University of Nortre Dame Press, 1979). 64 ${ }^{1203}$ Jules Barthélémy Sanit-Hilaire, for example, in his work entitled "The Buddha and His Religion," considered Buddhism to be an ideological foil, a convenient way to extol the virtues of positivism and Western democracy. His reassertion of the intellectual superiority of the West had a great influence on Friedrich Max Müller and many other scholars of the second half of the nineteenth century.

${ }^{1204}$ Eugène Burnouf, Le Lotus de la bonne loi (Paris: 1973, Adrien Maisonneuve, 1973 [1852]) vol.1, 417.
} 
view among Europeans. It was developed with nuance by Max Müller, who claimed that Chinese Buddhism was a deviation from the original teachings of the historical Buddha.

Noticeably, it was only the mystical facet of Chinese Buddhism, especially the Chan 'mysticism,' that caught the eyes of European researchers, and they tried to define the Chan as Indian instead of Chinese. ${ }^{1205}$ For instance, the Chan school was depicted by some scholars as one of the two sides (the other is Christianity) of the essential religious phenomenon of "perennial mysticism." By doing so, Chan Buddhism was considered fundamentally "non-Chinese"; it was seen as "profoundly Indian, even more so than Buddhism itself." ${ }^{1206}$ Even, in some academic discourses, the origins of Chan were linked with various Indian teachings outside Buddhism, for example, Vedantism, Jainism, and so on. Therefore, Chan was defined at times by several Western scholars as neither Chinese nor Buddhism, ${ }^{1207}$ but Indian. The 'mysticity' of Chan's meditation techniques, transmission means, and its rhetoric form of expression - the 'encounter dialogue' - were emphasized and even became a cliché in the characterization of the Chan tradition.

Linking certain Chinese Buddhist sects back to India was one of the attempts to trace Chinese Buddhism back to its Indian origin. ${ }^{1208}$ Many other accounts and discourses, which were dominant in the field of comparative religious studies, relied too heavily on textual comparison and hence downplayed China's novelty. Sinicized Buddhism, which later was transplanted to Japan as a kind of 'Chinese wisdom,' was

\footnotetext{
${ }^{1205}$ For example, scholars like James Livingstone Stewart, Karl Neumann, and so on.

${ }^{1206}$ Bernard, Chan Insight and Oversight. 41.

${ }^{1207}$ Léno, Wieger, for example, in his work entitled "A History of the Religious Beliefs and Philosophical Opinions in China" considered Chan a "Chinese paganism" that he associated with Vadantism. E. Lamariesse also interpreted the Linji school of Chan as an "esoteric school" against the ritualism of Chinese Buddhism and an interiorization of morality; he considered the Nirvāna not as a beatitude through science. (1893: 84, 68-69) Other scholars who had the similar opinion included Henri Doré, Henri Bernard and so on. Some other scholars, such as Edkin, believed Chan was a Jain outgrowth. ${ }^{1208}$ Taking the study of the Chan school as example, some scholars, such as James L. Stewart, have refused to consider Chan as a Mahāyāna tradition, but have tried to demonstrate its inheritance from Hīnayāna/Thervāda Buddhism.
} 
interpreted as a passive and distorted version of Indian metaphysics that was negatively contaminated with neo-Confucian morality. Not surprisingly, this Western interpretation of Buddhism was criticized in East Asia, especially in the Buddhist circle. After a long (but basically failed) 'dialogue' between the West and Buddhism in the pan-Asian circle, this situation was finally changed by the outstanding Japanese Buddhist scholar D.T. Suzuki. With his efforts and those of his followers of the Kyoto school, Japanese Buddhism, in particular the Zen tradition, acceded to full visibility. Suzuki not only provided a doctrinal basis for a unified and universal Buddhism through his translations and commentaries on a 'minimalized' or 'selected' Zen canon ${ }^{1209}$ but also interpreted the teachings of Zen ${ }^{1210}$ with modern discourses that matched the taste of the Western audience better than the former missionaryinfluenced descriptions or the 'great tradition' offered by Sinologists.

Japan's experience gained tremendous responses in Western society as well as in China. Along with a stronger urgency for learning or even copying the Western model, a desire for self-portrait and a sense of self-identity disseminated among Chinese elites. The success of Suzuki encouraged the Buddhists in China to transform their native Buddhist tradition into something more unique, dynamic, and universal (even by misrepresenting some doctrines while consciously keeping silent about others) and interpret it as a supporting power of a modern nation or a core of the spirit of Chinese culture. ${ }^{1211}$ However, Buddhism in China largely failed to free itself from its cultural ties with any specific religious or philosophical traditions, as Zen did. ${ }^{1212}$ The path of Japan and the models borrowed from the West also could not

\footnotetext{
${ }^{1209}$ The canon included works such as the Awakening of Faith in Mahāyāna, the Green Cliff Record [Hekiganroku; 碧嚴錄], the Platform Sutra [dangyō; 壇經], the Song on the Realization of the Way [Shōdōka, 証道歌], and Hakuin's Orategama. Later, it came to include the works of Shenhui and the Japanese Master Bankei. See Ketelaar, Of Heretics and Martyrs in Meiji Japan: Buddhism and Its Persecution, 187-191. ${ }^{1210}$ Suzuki's notion of Zen, as Faure noted, pointed to the Kamakura and Muromachi periods, the time Zen supposedly embodied the highest values of the rising warrior class. See Bernard, Chan Insight and Oversight. 57.

${ }^{1211}$ See ibid., 65-66, also, Sharf, "The Zen of Japanese Nationalism."

${ }^{1212}$ For Suzuki's "psychological antecedents," see D.T. Suzuki, Essays in Zen Buddhism (London: Rider and Company, 1949-1953), vol.2, 28-34.
} 
uncritically be applied to Chinese contexts. Modern Chinese scholars either needed to search through traditional sources to find something corresponding and reinterpret it by referring to new conceptual frameworks, or they could change the concepts themselves and use them under particular conditions. The titles of many scholarly works during the modern era, with the terms "Chinese religion," "Chinese Buddhism," "Chinese philosophy," and so on, suggested their endeavor of 'announcing possession' and setting a boundary.

\section{Defining Chinese Buddhism}

The Western narrative of Buddhism, which was based heavily on Christianmissionary or Orientalist presuppositions, failed to capture its panorama due to the absence of the Chinese image. To many modern Chinese historians, it was misleading in a way that made Buddhism the substantive noun and the notion 'Chinese' merely as adjectival qualifier. On the contrary, these historians believed that being 'Chinese,' which could be interpreted as a cultural bricolage that historically formed the characteristic of Chinese Buddhism, had its fundamental value. Historians in China, from Liang Qichao to Hu Shih, demonstrated less interest in the soteriological doctrine of certain sects and the original, fundamental teachings of the Buddha in the canon. Palī and Sanskrit literature was emphasized, but mostly from a comparative perspective. To a certain degree, when these Chinese historians applied the notion of 'Chinese Buddhism,' what they had in mind totally differed from their European and American counterparts. They were focused more on the word 'Chinese' instead of 'Buddhism.' Therefore, the strategical usage of the term "Chinese Buddhism," which has 'Chinese' as a genitive case to the nominative noun of Buddhism, actually inverted the relationship between China and Buddhism. In this sense, this was the new beginning of the 'Sinicization', in a conceptural, discursive way. 
The Problematic Concept of "China"

The word 'Chinese', which indicated the geographical separation and ethnic uniqueness of China was vague and somewhat premature. One initial problem was the absence of the terminology, especially the ambiguity of the term 'China' [Zhongguo 中國] itself, in Chinese historical texts. In the chapter "The Denomination of Chinese History" [Zhongguo shi de mingming 中國史的命名] in his introductory work Zhongguo shi xulun published in 1921, Liang described this dilemma:

Nothing is more shameful than the fact that our country has no name. It is commonly called Zhuxia [all the xia], or the Han people, or the Tang people, which are all names of dynasties. Foreigners call it Zhendan [Khitan] or Zhina [Japanese for China], which are names that were not named by us. If we use Xia, Han, or Tang to name our history, it will pervert the goal of respect for the guomin [citizens]. If we use Zhendan, Zhina, etc., it is to lose our name to follow the master's universal law [gongli]. Calling it Zhongguo or Zhonghua is pretentious in its exaggerated self-esteem and selfimportance...... We might as well use what has become customary. It may sound arrogant, but respect for one's country is the way of the contemporary world. If our citizens could realize the difference between name and reality, this would be also a way of encouraging spirit. 吾人所最慚愧者, 莫如我國無國名之一事。寻常通稱或 日諸夏, 或曰漢人, 或日唐人, 皆朝名也。外人所稱, 或曰震旦, 或日支那, 皆 非我所自命之名也。以夏漢唐等名吾史, 則戻尊重國民之宗旨。以震旦支那等名 吾史, 則失名從主人之公理。日中國, 日中華, 又未免自尊自大。……仍用吾人 口頭所習慣者, 稱之曰中國史, 雖稍䣖泰, 然民族之各自尊其國, 今世界之通義 耳。我同胞苟深察名實, 亦未始非喚起精神之一法門也. ${ }^{1213}$

As shown in this passage, the word Zhongguo, according to Liang's criterion, was not a 'perfect' name for the historical existence of the 'land of the Middle kingdom.' Liang realized the perennial question of 'zongguo' in disciplinary practice and raised this issue in the writing of the new 'comprehensive history' as one definition that needed to be clarified from the beginning.

The term 'China', from Liang onwards, gradually became fixed and was used by modern Chinese scholars uncritically. At times, the notion of China or Chinese was

${ }^{1213}$ Liang, “Zhongguo shi Xulun 中國史緒論," 1-12, esp. 3. 
indistinctly applied to the dynasties founded by non-Han ethnicities. However, historians in modern China realized that, mostly, it referred to extremely different territories in space and also covered various time spans. Chen Yinke and Chen Yuan, for example, had already realized that the complexity behind the name China was unavoidable. ${ }^{1214}$ Regardless of whether they were speaking about, for instance, the Tang, Ming, or Qing dynasties, the diversity within China was tremendous with regard to ethnicity, descent, clan, and religions. ${ }^{1215}$ The attempt to write Buddhism as one part of the national history of China represented this diversity. It demonstrated that the scholarly consensus that the Qing territorial bequest had laid the foundation for the modern Chinese state as a geographic and ethnic entity ${ }^{1216}$ was an oversimplified self-identification instead of an existant historical fact. ${ }^{1217}$

${ }^{1214}$ The Qing definition of China has been criticized by several New Qing scholars. They have pointed out that the concept of China as a multi-ethnic empire was defined by the Qing and continued throughout the modern period, while the name China referred only to the peoples of the Han group and the region of China proper. James A. Millward, Beyond the Pass: Economy, Ethnicity, and Empire in Qing Central Asia, 1759-1864 (Stanford: Stanford University Press, 1998), 9, 12-13, 201, 249; Pamela Kyle Crossley, A Translucent Mirror: History and Identity in Qing Empire Ideology (Berkeley: University of California Press, 1999), 341. For a summarized investigation, see also Zhang Gang, "Reinventing China: Imperial Qing Ideology and the Rise of Modern Chinese National Identity in the Early Twentieth Century," Modern China, Vol. 32, No. 1 (2006): 3-30

${ }^{1215}$ Sabine Dabringhaus has deepened this issue by investigating "the work between Sinology and Central Asian Studies"; she has named Owen Lattimore, Paul Pelliot, Herbert Franke, Joseph Fletcher, Morris Rossabi and Nicola Di Cosmo were the few scholars who were able to overcome these lines of division. See Sabine Dabringhaus, Geschichte Chinas von der Mongolenherrschaft bis zur Gründung der Volksrepublik (München: Oldenbourg Verlag 2006), 127.

${ }^{1216}$ Ho, Ping-ti, “The Significance of the Ch'ing Period in Chinese History.” The Journal of Asian Studies, 26 no.2 (1967): 189-195.

${ }^{1217}$ China's nationalism has recently been a hot topic among American scholars of Qing history, although they have not paid much attention to the change in the concept of China. There have been some studies that have explord the change in the concept of China; see, for example, Edward Rhoads's book Manchus and Han: Ethnic Relations and Political Power in Late Qing and Early Republican China, 1861-1928, which focuseds on the Qing court's construction of China as a multi-ethnic entity (Seattle: University of Washington, 2000). Many scholars have discussed the origin and evolution of China. See (Wang Ermin 王爾敏, “Zhongguo mingcheng suyuan jiqi jindai chanshi 中國名稱溯源及其現代関釋” in Zhongguojindai sixiang shilun 中國近代思想史論 (Taipei: Huashi chubanshe, 1977), 441-80; Ge Zhaoguang, Zhaizi Zhongguo: Chongjian youguan 'Zhongguo' de lishi lunshu 宅茲中國:重建關於 “中國”的 歷史論述 (Beijing: Zhonghua shuju, 2011), and Hewei Zhongguo: Jiangyu, minzu, wenhua yu lishi 何為 “中 
In history, religious diversity has always occurred against the background of trans-ethnic assimilation. Therefore, when it came to the issue of religion, the grand unification [dayitong 大一統] model needed to be challenged, as well as a simplified but long-lasting conflation of China and Han. Liang Qichao made clear that he only used China for convenience; however, as shown in the passage cited above, there was indeed a tendency towards nationalism in Liang's understanding of China. Although realizing the dilemma behind the term China, most historians could and would not abandon this term. Instead of confirming the political model of a multiethnic empire of Qing, historians tended to redirect China towards Han China, which was designed not to integrate all the ethnic communities into a homogenous state in reality, but was a highly theoretical setting. ${ }^{1218}$ They tried to dissolve the terminological confusion of China by redefining it through a process of theoretical assimilation, which Levenson called a "culturalist approach," ${ }^{1219}$ that re-integrated the non-Han culture and community into a cultural "China as nation-state. ${ }^{1220}$ In both cases of nationalism and culturalism, ${ }^{1221}$ historians in modern China eventually were able to suspend the ambiguity of the concept of China and keep using it instrumentally.

國”: 疆域,民族, 文化與歷史 (Hong Kong: Oxford University Press, 2014); Kawashima Shin 川島真, “Tenchō kara Chūgoku he: Shinmatus gaikō bunsho ni miru 'Chūgoku' no shiyorei,”天朝から中國一: 清末外交文書にみられ「中國」の使用例, Chugoku: Shakai to bunka no.10 (1997): 41-54; Luo Zhitian, Minzu zhuyi yu Zhongguo jindai sixiang 民族主義與中國近代思想 (Taipei: Dongda Tushu, 1998), 1-9; Hu Axiang 胡阿祥, “Weizai siming: ‘Zhongguo’ gujin chengwei yanjiu 偉哉斯名: ‘中國’古今稱謂研究 (Wuhan: Hubei jiaoyu chubanshe, 2000); Lydia Liu, The Clash of Empires: The Invention of China in Modern World Making (Cambridge, MA., Harvard University Press, 2004).

${ }^{1218}$ John Fairbank, ed., The Cambridge History of China: Volume 10: Late Ch'ing 1800-1911, vol. 10, The Cambridge History of China (Cambridge: Cambridge University Press, 1978), 3-5.

${ }^{1219}$ J.R. Levenson, Liang Ch'i-ch'ao and the Mind of Modern China (Cambridge, MA.: Harvard University Press, 1959), 103-112. Levenson introduced this term to describe the turn from an early notion of Chinese self-definition based on culture towards a new notion based on a nationalist approach for selfdefinition per se.

${ }^{1220}$ This approach was still prevalent in the late twentieth century. See Philip C.C. Huang, "Theory and the Study of Modern Chinese History:Four Traps and a Question," Modern China 24, no. 2 (1998): 192. ${ }^{1221}$ According to Levenson, the modern history of China then is one in which nationalism replaced culturalism as the dominant Chinese view of their own identity and place in the world. See Levenson, Liang Ch'i-ch'ao and the Mind of Modern China., 109-122. This thesis was criticized by James Townsend (1992), John Fitzgerald (1995), Benjamin I. Schwartz (1992), and Franke Dikötter (1995) who argued 


\section{Territorial Definition}

In his writing of the history of Buddhism, Liang primarily defined Chinese Buddhism based on the territorial concept of China (regardless of the instability of Chinese territory throughout history). In Liang's opinion, Buddhism automatically became Chinese after it stepped across the frontier. In his first article on Chinese Buddhism, “Zhongguo fofa xingshuai yange shuolue 中國佛法興衰沿革說略,” Liang used the notion of "the Buddhism of China" [Zhongguo de fojiao 中國的佛教] but put it in quotation marks, which indicated his hesitation to use this term. Chinese Buddhism, as he noted, is not equal to Indian Buddhism, but also ambiguous enough to be categorized as something Chinese. ${ }^{1222}$ In the later part of this essay, he mentioned twice the term “history of Chinese Buddhism” [Zhongguo fojiao/foxue shi 中國佛教/ 佛學史]. However, in most cases, he preferred to use "the Buddhism of our country" [wuguo fojiao 吾國佛教] with a more humble but more nationalist tone.

Nevertheless, no matter which word Liang chose to use, a sense of selfidentity was quite palpable. In his essay entitled "The Development of Buddhist Doctrines in China," he made a “solemn declaration”[zhenzhong shenming 珍重聲明] that Buddhism came from India; undoubtedly, the essential spirit of Buddhism was Indian. However, "after it entered China, it became China's Buddhism." ${ }^{1223}$ Buddhist schools, such as Tiantai, Huayan, and Chan, were purely Chinese; even the schools of Sanlun, Faxiang, Lü, and Mi were all full of Chinese characteristics. ${ }^{1224}$

rightly that culturalism was not replaced but was still maintained as an important view among modern Chinese intellectuals. See James Townsend, "Chinese Nationalism," The Australian Journal of Chinese Affairs, no. 27 (1992): 97-130. John Fitzgerald, "The Nationless State: The Search for a Nation in Modern Chinese Nationalism," The Australian Journal of Chinese Affairs, no. 33 (1995): 75-104; Benjamin I.

Schwartz, "Culture, Modernity, and Nationalism - Further Reflections," in China in Transformation, Tu Wei-ming, ed. (Cambridge, MA: Harvard University Press, 1993); Franke Dikötter, The Discourse of Race in Modern China (Stanford: Stanford University Press, 1995).

${ }^{1222}$ Liang, SBP, 4.

1223 “Fojiao jiaoli zai Zhongguo zhi fazhan 佛教教理在中國之發展," in Liang, SBP, 149

${ }^{1224}$ Ibid., 149. 
Compared with other Chinese scholars, Liang stressed the boundary between China and India, paying more attention to the doctrinal distinction between them. ${ }^{1225}$ He discussed less the process of Buddhism's Sinicization, as well as the detailed phenomenon of Chinese Buddhism after its localization, but was attracted by the early propagation of Buddhism in China, especially the early missionary and translation activities that occurred when Buddhism entered China. To Liang, Sinicization was of course a long process; however, the inner diversity and complexity of this process were overlooked in Liang's account. As he imagined China as an undivided geographical region rather than a multicultural nation-state, ${ }^{1226}$ he also presumed Chinese Buddhism to be a solid entity that would become more and more homogenous. This homogeneity was also able to guarantee that Chinese Buddhism could stand beside its Indian ancestor independently and "light up the intellectual history of China." ${ }^{1227}$ Although Liang touched on the issue of the 'transformation' of Indian Buddhism to Chinese Buddhism, he somewhat evaded the questions of how 'China' became 'Chinese' or how and when the 'Chinese-ness' of Chinese Buddhism was formed and imagined under the sign of 'China.'

Liang's territorial definition of Chinese Buddhism implied a conceived nationform with which he wished to replace the imperial regime of grand unification; however, at the same time, by using the term Chinese Buddhism in a territorial sense, he simplified the historical relevance between China and Buddhism. To thinkers like Liang, the new nation demanded a new history for its substantiation. In this process of "inventing China through history," as Edward Wang described it, the most important mission for a historian like Liang was to guide the traditions of ancient China towards the goal of fostering national consciousness. Therefore, in such a

\footnotetext{
${ }^{1225}$ There are eight articles in his shibapian dealing with the issue of Indian Buddhism and the original Buddhist canons. He also had several studies on the translation of Buddhist canons and Buddhism in the Xiyu and communication between India and China. Among all his studies, there is only one essay (a preface to a collection related to Xuanzang) that is related to the Buddhism after the Sui dynasty. ${ }^{1226}$ In his “Zhongguo shi xulun 中國史緒論” Liang divided Chinese people based on the Chinese territory and their geographical surroundings. In this long article, he paid much attention to the geographical facts of China.

${ }^{1227}$ Liang, “光飾我思想史,” in SBP, 36.
} 
narrative, the task of historically retelling the Sinicization of Buddhism was "to bear witness to struggles to achieve the national idea that was already implicit at the origins of historical time," as in Melissa Brown's phrase. ${ }^{1228}$ This strategy, which unified 'Chinese Buddhism' as an entity existing in a certain geographical realm with consistency, rested its claims to legitimacy not on 'hard' historical facts, but on the will of constructing a Chinese Buddhism, which normally using a political voice.

\section{Ontological Definition}

Different from Liang, Tang linked 'Chinese Buddhism' with Sinicization instead of with the geographical concept of 'China': Chinese Buddhism was determined by its special rituals, lineages, monastic systems, and of course, its unique doctrines. Tang Yongtong also used the term "Chinese Buddhism" in his Hanwei published in 1937. As he wrote in the epilogue, "the history of Chinese Buddhism is complicated to discuss." However, throughout the whole book, he seldom used the term "Chinese Buddhism." Only when he talked about the long-term and general influence of certain historical figures and events did he add the word "Chinese" before Buddhism. ${ }^{1229}$ One of the few examples of this was his discussion of An Shigao's translation activities. He noted that An had had a significant influence on 'Chinese Buddhism' [zhonghua fojiao 中華佛教] ${ }^{1230}$ In another place, Tang emphasized in his general methodological discussion a 'textual criticism' for understanding the historical changes in 'Chinese Buddhism. ${ }^{.1231}$ However, throughout his Hanwei, Tang preferred to use "the theory coming from the West" [zilai zhifa 西來之法] to refer to

\footnotetext{
${ }^{1228}$ Melissa J Brown, Is Taiwan Chinese?: The Impact of Culture, Power, and Migration on Changing Identities (Berkeley: University of California Press, 2004). 28-33.

${ }^{1229}$ In the whole book of his History, Tang only used the term 'Chinese Budhdism' [中國佛教] six times. ${ }^{1230}$ Tang, History, 48; He also mentioned Yan Futiao 嚴浮調, the disciple of An, as the "first Chinese Buddhist" [Zhongguo fojiao tu 中國佛教徒]; Hanwei, 50

${ }^{1231}$ Hanwei, 416.
} 
Buddhism and particularly separated it from "the teaching of China" [zhongxia zhixue 中夏之學] ${ }^{1232}$

Given Tang's frequent use of the notion of Chinese Buddhism in his later work Shigao, it is reasonable to speculate that Tang avoided applying 'Chinese Buddhism' when talked about pre-Tang Buddhism. Obviously, Tang had already conceived a clear definition of what Chinese Buddhism was and when Buddhism had been fully Sinicized. In the preface to his Shigao, he declared that "Chinese Buddhism, although based on translated scriptures, was developed doctrinally due to local writings." ${ }^{1233}$ The emergence of native Buddhist sects in the Sui and Tang periods, such as Tiantai and Chan, according to his criterion, marked the establishment of "purely Chinese Buddhism." When he further analyzed each of the sects, he clearly named them under the rubric of 'Chinese,' such as "the Chinese san-lun school" [zhonghua sanlun zong 中華三論宗] ${ }^{1234}$, “the Chinese Tiantai school” [Zhongguo tiantai zong 中國天台 宗 ${ }^{1235}$, and so on. The terminology of Chinese Buddhism, in Tang's view, defined itself only after each different school of Indian Buddhism had been inherited by its Chinese followers, after a Sinicized doctrinal system had been built up based on Chinese canons, and after native monastic lineages had been established at local sacred sites. This historical process was rendered by Tang as 'living on its own' [zili menhu 自立門 $户] .{ }^{1236}$ In general, in Tang's definition (although he never really put it forward), 'Chinese Buddhism' did not indicate simply the Buddhism in China, but rather, it meant the Buddhism which had accomplished its process of Sinicization.

\footnotetext{
${ }^{1232}$ The term zhongxia literally is an abbreviation of the two words zhongtu 中土 and huaxia 華夏. This word in Tang's usage may come from the Sutra of the Forty-Two Sections, where it was written: 於是發使 天筑, 寫致經像, 表之中夏. In Tang's History, the word zhongxia was always used as the counterpart of xiyu/xifang [西域/西方]. For examples see History, 34, 104, 207. The word zhongxia was also an important concept in the prevailing debate of yixia [夷夏之辩] between the Song and Qi dynasty. See Gu Huan 顧歡, on "yixialun" in Houhanshu. Tang in his History discussed this debate and cited the relevant argument about zhongxia written by Gu Huan. History, 350-352.

${ }^{1233}$ The Original text: “中國佛教, 雖根源譯典, 而義理發揮, 在於本土論述,” Tang, Shigao, 5

${ }^{1234}$ Tang, Ibid., 113.

${ }^{1235}$ Ibid., 134.

${ }^{1236}$ Ibid., 5.
} 
However, Tang's definition still remained vague in several aspects. For example, he ignored the ethnic dimension of China when he used the term Chinese Buddhism; Buddhist belief among the non-Han Chinese seemed largely excluded from his research domain. Moreover, there were still questions left unanswered in his whole narrative, such as the uniqueness of Sinicized Buddhism and its relationship with the original Indian Buddhism. Taking account of Tang's extreme emphasis on Chinese Buddhist texts, it might be better to understand his conception of Chinese Buddhism as a documentary or philological tradition that based its core doctrines on texts written in Chinese (with the Japanese and Korean Buddhist texts excluded as well). This classification was, however, very narrow and sometimes contained paradoxes. Tang had already realized that the Buddhist canons written in Chinese were not equivalent to the 'Chinese' Buddhist canons, since the translated Buddhist texts were not really Chinese. In one letter he wrote in 1963, he suggested Lü Cheng revise the title "The Category of Chinese Buddhist Canon" [Zhonghua dazangjing mulu 中華大藏經目錄] and use “The Chinese-Translated Canon” [hanyi 漢譯] instead. ${ }^{1237}$ Tang also emphasized in another place that the main textual corpus of Chinese Buddhism is primarily "the expositions of the [Chinese] ancients" [qianxian zhuanshu 前賢撰述] instead of the translated works. However, he also noted that translated texts, as another crucial part of the doctrinal foundation of Chinese Buddhism, represented the diverse reactions of the Chinese processors to foreign teachings. Further, these texts also gained their 'Chinese-ness' in the process of selection, translation, and distribution, although they still had their doctrinal roots in original Indian texts. ${ }^{1238}$

\section{Hu Shih's Revolution}

Compared with Liang and Tang, Hu Shih's study of Buddhism focused on Chan, the most Sinicized Buddhist tradition. Significantly, Hu had little interest in other Buddhist schools (Tiantai, Huayan, Faxiang, Pure Land, and so on). ${ }^{1239}$ Likewise,

\footnotetext{
${ }^{1237}$ Tang, TYQJ, vol.7, 660.

${ }^{1238}$ Tang, Hanwei, TYQJ, vol.1, 414.

${ }^{1239} \mathrm{He}$ only mentioned other schools when he needed to disparage them as being colonized by "India's complex philosophy," referring, for example, to Xuanzang's "falling into the great spider's web" of
} 
popular Buddhism and other religious traditions, such as Taoism, were conspicuously absent from Hu's horizon. To Hu, the study of Chinese Chan Buddhism, as indicated in several titles of his works, was equal with, or at least could represent, the study of Chinese Buddhism.

As a historian, Hu knew Chan in its historical manifestation, but not "Chan in itself." To him, Chan was a totally Chinese production, while Buddhism was always Indian. Although he never officially claimed this position, one can see that the history of Chan, in Hu's view, was an independent phenomenon rooted not in the Indian concept of dhyanna but in the context of Chinese culture, politics, and philosophy. In a letter to Yanagida, Hu wrote: "You are a first-rate Buddhist, a first-class Zen scholar, while I am a 'student' of the history of Chinese thought, someone who does not believe in any religion." ${ }^{1240}$ Clearly, Hu Shih's recurrent interest in Chan did not relate to any religious enthusiasm but could only be interpreted in terms of his efforts to rehabilitate Chinese classical philosophy and Chinese culture, namely his enterprise of the "Chinese Renaissance."1241

Hu defined the emergence of Chan as "a revolution" of Chinese Buddhism: it was an inner transformation that led to a "new Buddhism which never existed in India”; the 'Chan school' [chanzong 禪宗] or 'Chan sect' [chanmen 禪門], he wrote, was a "new religion." ${ }^{1242}$ This new religion, which Hu called the "new Buddhism of China' [Zhongguo xin fojiao 中國新佛教], was established in the mid-Tang, after an

\footnotetext{
Yogācāra idealism and being unable to escape it. Hu Shih (1970, 42-43), also John R McRae, "Religion as Revolution in Chinese Historiography: Hu Shih (1891-1962) on Shen-Hui (684-758)," Cahiers d'ExtrêmeAsie 12, no. 1 (2001): 59-102.

${ }^{1240}$ Letter dated 15 January 1961, in Zenggaku kenkyū 53 (1973): 162-170; Reprinted Hu Shih 1975,614655. See Yanagida's reply in Zenggaku kenkyū 53 (1973): 170-172.

${ }^{1241}$ See Hu Shih, The Chinese Renaissance (Chicago: University of Chicago Press, 1934). According to McRae, Hu's study had a close link with his theory of 'Chinese Renaissance,' which he posited as the theoretical outline of the movement of 'recognizing the national past.' See John R. McRae, "Religion as Revolution in Chinese Historiography: Hu Shih (1891-1962) on Shen-Hui (684-758)," Cahiers d'ExtrêmeAsie 12, no. 1 (2001): 59-102; For the issue of the Chinese Renaissance and its influence on Hu Shih's scholarship, see also Jerome B. Grieder, Hu Shih and the Chinese Renaissance: Liberalism in the Chinese Revolution, 1917-1937 (Cambridge MA.: Harvard University Press, 1970).

${ }^{1242}$ Hu Shih, HSWJ, vol.12, 338.
} 
inner revolution within the monastic community of the Chan school. Compared to the Indian tradition of Buddhism, this Chan Buddhism was pictured by Hu as simple, rational, and native. ${ }^{1243}$ Here Hu indicated a 'revolutionary' rupture between the Chan discourse and Indian Buddhism as well as the pre-Chan Buddhist tradition. He thus slightly replaced the concept of Chinese Buddhism with his setting of Chan. In his booklet A Brief History of Medieval Chinese Thought [中國中古思想小史], ${ }^{1244}$ he wrote in the eleventh chapter, entitled "Indian Buddhism becomes Chinese Chan," that

From the eighth century, Chan replaced Buddhism. Chan monasteries replaced the Vinaya monasteries. The word "Chan" was used as the synonym of "Buddhism" in poems and essays. Buddhism had completely become Chan. 八世紀以下，「禪學」 代替了佛教, 禪院代替了律居。詩文中的「禪」字即使「佛教」的代名詞。佛教 已完全變成禪學了. ${ }^{1245}$

As he described it, Hu tacitly replaced 'Buddhism' with 'Chan', which indicated his standpoint that the tradition of 'Chan', which is stood in lieu of Buddhism in the intellectual world of the Chinese, was actually not 'Buddhism.' To Hu, historically, there was no such thing as 'Chinese Buddhism' at all, but instead this concept consisted of two things that were fundamentally exclusive and independent: 'Indian Buddhism' and 'Chinese Chan.' From the perspective of intellectual history, $\mathrm{Hu}$ composed his general reevaluation of Chinese civilization by dividing Chan from Buddhism and excluding other Buddhist traditions from his framework of the 'national past.' In this sense, Hu invented his object: a Buddhism named Chan.

Since Hu used the term 'Chinese Buddhism' repeatedly and established an interpretative relevance between 'Chinese Buddhism' and Chan, he undoubtedly had his own standard for separating Chan from its predecessor. Unlike Liang, who defined Chinese Buddhism with his nationalist imagination of 'China,' or Tang, who focused on the formation of Chinese Buddhism and its historical manifestations, $\mathrm{Hu}$ conceptualized Chinese Buddhism with his philosophical criteria. As demonstrated in

\footnotetext{
${ }^{1243}$ Ibid., 395

${ }^{1244} \mathrm{Hu}$ Shih, Zhongguo zhonggu sixiangshi changbian 中國中古思想史長編, (Taipei: Yuanliu, 1986 [19311932]), 3-74.

${ }^{1245}$ Ibid., 63.
} 
his critique that Chinese religions were fundamentally shamanism, his positivism led him to blindness towards the religious character of Chan and Chinese Buddhism but remarkably emphasized the role Chan had played in the intellectual history of China. Notably, Hu's Western-originated rationalism paradoxically reinforced his nativist outlook on Chinese culture, prompting him to see Chan as the privileged expression of a Chinese nationalist humanism, which he called “Sinicism” [huaxia zhuyi 華夏主 義]. ${ }^{1246}$ In Hu's interpretation, 'Sinicism' was a kind of "primitive rationalism," a "Socratic tradition" that respected truth, fact, knowledge, and independent thinking. ${ }^{1247}$ Taking this one step further, Hu tried to philosophize 'Chan' by scraping all the irrational or ritual touches from it. It is evident, in this regard, that Hu already had presuppositions about 'Chinese Buddhism' and "how it should be." He then, just as Faure described, extolled “the 'Ockham's razor' of Chan-its sharp nominalist criticism of Indian Buddhist's scholasticism"-to interpreted Chinese Buddhism/Chan as "an instrument of intellectual emancipation from all 'superstitions, beliefs in Buddhas, Bodhisattvas, magic powers, charms, spells,' of traditional Buddhism and as a genuine manifestation of the pragmatism of 'Chinese mentality.". 1248 This is the reason why Hu treated Chan as a pivot for the 'Chinese Renaissance' that took place in the Tang and continued throughout the Song. During this 'Renaissance,' Hu noted, China was able to divest itself of intellectual and religious domination from India and revert to the simple, humanistic rationalism of the native Chinese tradition, with the help of Chan. ${ }^{1249}$

\footnotetext{
${ }^{1246}$ Hu Shih, “Zhongguo ren sixiang zhong de buxiu guannian 中國人思想中的不朽觀念.” HSWJ, vol.12, 340 . Buddhism in China," The Chinese and Political Science Review, 15 (1932): 481.

${ }^{1249}$ John R McRae, "Religion as Revolution in Chinese Historiography: Hu Shih (1891-1962) on Shen-Hui (684-758)," (2001): 64. According to McRae, the version of Hu's theory I am dealing with here is developed most clearly in his "Religion and Philosophy in Chinese History," in Sophia H. Chen Zen (Ch'en Heng-che), ed., A Symposium on Chinese Culture (Shanghai: China Institute of Pacific Relations, 1931): 31-58.
} 


\section{Sinicization and Indianization}

The discourse of "Sinicization," although under critique nowadays, did not bother the modern scholars too much when they wrote the history of Chinese Buddhism, since the historical phenomenon through which Buddhism became a part of Chinese culture seemed an unquestionable fact to them. However, several epistemological and hermeneutical issues still remained in their narratives of Sinicization. As is well known to us through historical sources, the writing of Chinese Buddhism was a product of two traditions that sometimes overlapped, sometimes contradicted, and sometimes ignored each other: Buddhist philosophy and Chinese historiography. The complex attitudes and tendencies towards these two currents were represented by the debates and divergence between scholars.

\section{Sinicization}

In the view of the nineteenth-century Orientalist studies, Indian Buddhism was considered to be the only source of the authentic knowledge of Buddhism. Indeed, from the viewpoint of Buddhist orthodoxy or essence, Chinese Buddhism was an outgrowth of the reconciliation of Indian Buddhism with local Chinese spirits and was undeniably a 'distortion' of Indian Buddhism. However, outside the Western schema of Orientalism, the issue of Sinicization, to modern Chinese historians and scholars, discernably demonstrated the particularity of Chinese Buddhism: a Buddhism in the particular Chinese context. ${ }^{1250}$ Therefore, the process of Sinicization, which indicated the vigor or even superiority of Chinese culture, became closely linked with

\footnotetext{
${ }^{1250}$ The term of Sinicization was also a very important concept in Chinese political and cultural history. It has been discussed recently by the New Qing historians. For example, Evelyn S. Rawski has argued that "Sinicization - the thesis that all of the non-Han peoples who have entered the Chinese realm have eventually been assimilated into Chinese culture--is a twentieth-century Han nationalist interpretation of China's past." See Evelyn S. Rawski, "Reenvisioning the Qing: The Significance of the Qing Period in Chinese History." The Journal of Asian Studies 55, no.4: 829-50; see also John McRae, "State Formation, Indigenization, and Buddhism in East Asian History: The Theoretical Foundation" (2006): 45-72.
} 
historiography (although it was a secular discipline) and its object: the national history of China.

The Choice of the Chinese

For the early acceptance of Buddhism during the Han era, Erik Zürcher has explained: "Despite occasional (and surprisingly rare) terminological borrowings from Confucian and Daoist lore, the most striking aspect of Han Buddhism is its novelty. The view of Buddhism was accepted because it, in certain ways, accorded with indigenous traditions must be rejected: Buddhism was attractive not because it sounded familiar, but because it was something basically new." ${ }^{1251}$ The feeling of "exoticism" Zürcher mentioned here echoes the opinion of Hu Shih.

In his article "On the Concept of Immortality in Chinese Thought," Hu noted that not because of its sophisticated philosophical setting but because of its newfangled gadgets of karma, Samsāra and the dichotomy of good and evil, which had never been imagined by the Chinese before, had attracted the ordinary Chinese people and made them imagine Buddhism as one great religion. ${ }^{1252} \mathrm{Hu}$ used the words "shock" and "frighten" to describe the first impression Buddhism left on Chinese people and he narrated their reaction as "confusing and dazzling." He wrote, "These novel conceptions were accepted by the Chinese men and women impatiently, because they are what the Sinic religions [huaxia zongjiao 華夏宗教] lack." ${ }^{1253} \mathrm{Hu}$ suggested that the ancient Chinese in the Han dynasty neither passively accepted Buddhist teachings nor were forced by any external force to change their original beliefs to Buddhism. Rather, the Chinese used Buddhism as an intellectual appeal, carefully picking up certain concepts, symbols, and ideals from Buddhist doctrines to enhance the native Huaxia system of thinking. ${ }^{1254}$ Being blind to back and forth within

\footnotetext{
${ }^{1251}$ Erik Zürcher, "A New Look at the Earliest Chinese Buddhist Texts," in From Benares to Beijing: Essays on Buddhism and Chinese Religion in Honour of Prof. Jan Yün-Hua, Shinohara Koichi and Gregory Schopen ed., (Oakville: Mosaic, 1991), 291.

${ }^{1252} \mathrm{Hu}, \mathrm{HSWJ}$, vol. 12, 354.

${ }^{1253}$ Ibid.

${ }^{1254}$ Current scholarship has reemphasized Hu's and Zürcher's viewpoint. For example, Yü Chunfang, in her monograph Kuan-yin, has argued that Chinese people became attracted by Kuan-yin not because
} 
the process of Buddhist Sinicization, Hu simplified the Chinese transformation of Chinese Buddhism to a linear narrative in which Buddhism gradually lost its exoticism and strangeness after entering into China and was finally replaced by a new Buddhism called Chan. After doing so, Hu claimed, "Heaven now adopted a Chinese name, and Hell was governed by Chinese emperors and judges." ${ }^{255}$

To Hu Shih, therefore, the 'dialogue' between Buddhism and China was a soliloquy on the Chinese side. Ancient Chinese people utilized and absorbed some ingredients of Buddhism as a supplement to their local thought, while abandoning others as useless. This opinion, which showed less sympathy to Buddhism itself, was criticized by D.T. Suzuki as "utterly unable to grasp what Chan is." ${ }^{1256}$ However, as Bernard Faure has pointed out, the divergence between Hu and Suzuki was actually smaller than Suzuki claimed, for they "were only considering different strata of some reality and taking part for the whole." 1257 Just like Suzuki, who considered Zen to be the expression of the spirit of Japan, Hu held a similar position that the Sinicized Buddhism, namely Chan, was a product of the Chinese mentality. ${ }^{1258}$

A similar emphasis on the role China played in Buddhist Sinicization can be observed in Liang's writings. With a more pronounced nationalist orientation, Liang believed that the choice of the Chinese was the most important factor in Buddhism's ability to take root in Chinese soil and experience prosperity. However, unlike $\mathrm{Hu}$ Shih, Liang considered the cultural accordance between Buddhism and Chinese native thought, instead of the feeling of exoticism, as the premise of Sinicization.

Kuan-yin bore any resemblance to any Chinese indigenous deity, but because "none of them was like him/her." See Chün-fang Yü, Kuan-yin: The Chinese Transformation of Avalokitesvara (New York: Columbia University Press, 2001), 5.

${ }^{1255} \mathrm{Hu}, \mathrm{HSWJ}$, vol. 12, 354

${ }^{1256}$ D.T. Suzuki, “Zen: A Reply to Hu Shih.” Philosophy East and West 3, 1 (1953): 29.

${ }^{1257}$ Bernard, Chan Insight and Oversight. 97.

${ }^{1258}$ See D.T. Suzuki, “Zen: A Reply to Hu Shih.” (1953): 40-41. Also, Theodore Griffith Foulk, “The "Ch'an School" and its Place in the Buddhist Monastic Institutions," Ph.D. Diss., University of Michigan (1987), 28. 
In his first article on Buddhism, entitled "The Early Import of Buddhism" [Fojiao zhi chu shuru 佛教之初輸入] and published in 1920, ${ }^{1259}$ Liang used the NorthSouth dualism as the pattern to explain and narrate the transmission of Buddhism in its early stage. According to this scheme, the cultural structure of China in the preBuddhist era was divisible into two basic types: the North (religious, practical, militaristic, and pure) and the South (philosophical, abstract, cultured, and mystical). This typology resembles Herbert Spencer's description of the development of world history and was influenced by Henry Thomas Buckle. ${ }^{1260}$ Under such a historicalgeographical framework, Liang argued that geographical conditions mold fundamental cultural characteristics that determined the missionary route of Buddhists in China. Rather than the activities of the early Buddhist missionaries and the promotion of political powers, Liang argued that the liberal, scholarly atmosphere in the South, which agreed implicitly with the Buddhist view, was the real reason for the popularity of Buddhism. ${ }^{1261}$ This dualist view, in Liang's narrative, was not only the reason why Buddhism became popular among the Chinese beginning in the Late Han period but also was the evidence for his sea route hypothesis. ${ }^{1262}$

Further, Liang discussed that the proclivity for "religious color" [zongjiao secai] in Northern China led to the prevalence of Buddhist monasticism (including temple construction, rituals, the expansion of the population of clerics, and so on) but meanwhile a slow and weak development of its doctrinal dimension. Liang was not satisfied with the Northern tradition of Chinese Buddhism because it could not represent the national character of China. He argued that, after the uprising of the Five Barbarians, the northern region of China then was occupied by non-Han

\footnotetext{
${ }^{1259}$ In 1922, it was collected with eleven other articles into one volume of the three-volume collected work of Liang Qichao titled Liang Rengong jinzhu 梁任公近著 and was published by Zhonghua shuju 中 華書局 in 1922. These collected works are the first batch of Liang's studies on Buddhism.

${ }^{1260}$ Tang Xiaobing, Global Space and the Nationalist Discourse of Modernity: The Historical Thinking of Liang Qichao, 40.

${ }^{1261}$ Liang thought that the popularity of Buddhism in the northern part of China relied on the imperial power. It is more like superstition that relied on the power of despotism. See SBP, 9.

${ }^{1262}$ Liang, SBP, 33-36, also, 9.
} 
ethnicities that had not been assimilated by "our nation." In this situation, the "most distinguished" Chinese intellectuals had all moved to the South; therefore, "the NonHan development could not be considered as our national characteristics" and remained just a subsidiary factor of the Sinicization of Buddhism. ${ }^{1263}$

Liang's nationalism and Hu's nativism, however, might have led them to an overestimation of China's subjectivity. For example, neither Hu nor Liang, in their writings of Buddhist history, really addressed the issue of who made the choice for Buddhism. They also did not answer the question of why Buddhism in Chinese history had distanced itself not only from Indian Buddhism but also from the mainstream of Chinese thought. Because of the limited sources at their disposal (namely the literature written by or for the literati), both $\mathrm{Hu}$ and Liang actually narrowed their horizon to the Buddhist intelligentsia-cultured clergy and literati. It was true, perhaps, that Buddhism was an 'exotic alternative' that was chosen by the Chinese; however, it was not merely chosen by the "gentry" or educated elite, but also chosen by the majority of ordinary, marginalized, illiterate Chinese men and women. Noticing this flaw in Liang's writing, Tang Yongtong pointed out that most of the materials existing now picture only one segment of the immensely complex phenomenon. He criticized Liang's deduction that Buddhism had first spread among the Southern literati as an argument that "makes no sense," since Liang relied too heavily on the biographical records of An Shigao in the Gaoseng zhuan but failed to realize the fact that the author of Gaoseng zhuan, Huijiao, was himself a scholarly monk who lived in Southern China. ${ }^{1264}$ Tang argued, with subtle, abstruse philosophical expressions and refined, highly artificial, over-stylized language, the circulation of these texts must have been restricted to a distinct, highly important,

\footnotetext{
${ }^{1263}$ Here Liang argued that after the Uprising of the Five Barbarians, the northern part of China became long occupied by different tribes and non-Han ethnic groups; their lifestyle, conventions, and spiritual characteristics were not rooted in Chinese national identity 未能根於我國民性也]. See ibid.

${ }^{1264}$ Tang, TYQJ, vol.1, 63. Tang pointed out five flaws in Liang's argument, including that in the official histories of the Han and Jin dynasties, there are records of Buddhist preaching activity in Luoyang called “聽者雲集”; also, since Buddhism was primarily a kind of mystic art that first emerged in the regions of Yan 燕 and Zhao 趙 (present-day Hebei province), Buddhism should also first have become popular in the northern region of China.
} 
but relatively small part of the Buddhist population - the cultured elite and those monks who had obtained a literary education that enabled them to become members of this elite circle. Moreover, even the Buddhism of the elite contained heterogeneous elements. For example, the majority of the cultured clergy may have come from the lower strata of society and closely served the local community of believers during their whole lives through rituals, rites, and other forms of religious practices, while isolating themselves from other activities of the elite. Therefore, the Chinese choice of Buddhism needs to be contextualized, since it was not the game of the 'privileged.' In fact, one of the most significant concepts of Buddhism promoted in Chinese society was the 'monastic ideal'-the great equality of all [zhongsheng pingdeng 眾生平等]. As one part of Buddhism's Indian heritage, this concept to a certain extent challenged the innate social hierarchy of medieval China and provided opportunities for people from the most diverse origins to engage in intellectual activities. ${ }^{1265}$ This "novum in Chinese cultural history" 1266 indicated that Buddhism was far from submissively waiting for the decision of the Chinese elite, as Liang and Hu described; on the contrary, Buddhism changed the old class boundaries and created new social strata and organization.

\section{Buddhism and Local Spirit}

Buddhism's contacts with local Chinese traditions, such as religious Daoism, happened immediately after it entered China. Folk religions, although they were somewhat repressed and failing, also profoundly influenced Buddhism and played a significant role in its Sinicization. Tang Yongtong was one representative historian who deeply discussed the relationship between Chinese folk culture and Buddhism in a systematic way. Tang had observed from considerable evidence in Chinese historical writings, both official and unofficial, that the early image of Buddhism in Han China was always intensely entangled with the local religious atmosphere. ${ }^{1267}$ In

\footnotetext{
${ }^{1265}$ Zürcher, The Buddhist Conquest of China., 4-9. ${ }^{1266}$ Ibid.

${ }^{1267}$ On this issue, Robert Sharf has pointed outthe study of Wu Hong, which claimed that the Buddha was worshipped as a foreign god of imposing visage possessing supernatural powers. While the foreign origins of this buddha-god may have been appreciated, the Buddha was nonetheless thought of and
} 
his Hanwei, Tang examined in detail the connection between Buddhism and local cults, which are now often subsumed under the category of 'religious Daoism,' in his chapter titled "Buddhism and Daoism." According to Tang's analysis, there were two kinds of indigenous ideas that contributed to the early prevalence of Buddhism. The confrontation between Buddhism and local Daoism went through two stages:

First was the cosmology based on the Yijing. The Chinese conception of the universe, as presented in the ritual life of the court of the Han dynasty, was an interconnected harmonious whole that was expressed by the cyclic progression of wuxing 五行 and the yin-yang schema. ${ }^{1268}$ This naturalist world view then was developed into a full-fledged cosmology by Daoists and Confucianists, such as Dong Zhongshu 董仲舒 (BC. 192-BC. 104). ${ }^{1269}$ Daoist priests designed several patterns and orders, referred to as “correlative thinking," to use Needham's words, through which

worshipped as a member of the indigenous pantheon. See Sharf, Coming to Terms With Chinese Buddhism: A Reading of the Treasure Store Treatise. 22; Wu Hong, The Wu Liang Shrine: The Ideology of Early Chinese Pictorial Art (Stanford: Stanford University Press, 1986), 273.

${ }^{1268}$ The common use of the term "element" for xing 行 can be traced to misconceptions on the part of early European missionaries to China; see Manfred Porkert, The Theoretical Foundations of Chinese Medicine: Systems of Correspondence (Cambridge, Mass.: MIT Press, 1974), 45. It continues to be used by some even though xing carries none of the connotations of "essential material substance" associated with the term "element" in medieval European alchemy or modern science. Xing is etymologically and semantically closer to "phase" or "process." However, Schwartz has expressed reservations, noting that "if the term 'five elements' overemphasizes the role of the 'static substances,' the terms 'phases' and 'activities' overlook the role of static substances and categories within the entire syndrome of the wuxing 五行”; see Benjamin I. Schwartz, The World of Thought in Ancient China (Cambridge, MA.: Harvard University Press, 1985), 455. A.C. Graham has preferred to distinguish between early (pre-Han) usage, for which the translation "process" or "conduct" is preferred, and later (Han and post-Han) usage, for which "phase" is more appropriate; see Yin-Yang and the Nature of Correlative Thinking (Singapore: Institute of East Asian Philosophies, National University of Singapore, 1986), 74-77, 89-92.

${ }^{1269}$ Henderson has suggested that by "consigning numerological speculations and occult ideas to a particular classical school, all taint of such ideas could be removed from classical Confucianism and Taoism. One could thus attribute the embarrassing appearance of questionable cosmological conceptions in the postclassical Confucian and Taoist traditions to an extrinsic source"; see John B. Henderson, The Development and Decline of Chinese Cosmology. New York: Columbia University Press, 1984), 35. Relatively recent views of the early development of Chinese correlative thinking before the Han can be found also in Vitaly A. Rubin, "The Concepts of Wu-Hsing and Yin-Yang," in Journal of Chinese Philosophy 9, no.2 (1982): 131-157; Schwartz, The World of Thought in Ancient China, 356-378; and Graham, Yin-Yang and the Nature of Correlative Thinking, 70-92. 
the cosmos would be understood and controlled; ${ }^{1270}$ they also embodied this system with rituals and practices such as pseudo-prophecy, 'weft-texts' [wei 緯] and numerocalendric 'charts' [tu 圖], self-cultivation, eating drugs [fushi 服石], and so on. ${ }^{1271}$ As the logic behind these designations, a theory of sympathetic resonance [ganying 感 應 ${ }^{1272}$ (in the Confucian expression, a phenomenalism known as "interaction of heaven and man" [tianren ganying 天人感應]) was applied and was transformed into a hermeneutic approach to interpreting Buddhist concepts such as the resonant-body of the Buddha and resonant retribution [baoying 報應]. ${ }^{1273}$ In Tang's view, this striking character of 'synthesis' of the Han cosmology and religious Daoism was the prerequisite for the dissemination of Buddhism. ${ }^{1274}$

Secondly, from the Jin dynasty, xuanxue, which emphasized the eternal existence of $q i$ 氣 and the quiescence of nonaction, dominated the intellectual sphere of the Chinese. Originating from the teaching of Zhuangzi, xuanxue depicted the spirit of humanity as an immortal, universal being, spontaneously responding to the stimuli of nature. Due to the prevalence of xuanxue among the Chinese literati, Buddhist figures were matched with Daoist sages; for example, Laozi was portrayed as a Buddhist or even one of the reified Buddhas. This phenomenon represented a blend of the Chinese models of the sage-king and the Indian ideal of bodhi. According to Tang, these conceptual overlays formed the intellectual foundation for the Sinicization of Buddhism in the pre-Tang era. Realizing the entanglement of foreign

\footnotetext{
${ }^{1270}$ Joseph Needham, "Human Laws and Laws of Nature in China and the West." Journal of the History of Ideas 12 (2): 230.

${ }^{1271}$ For the historical examination of Chinese early mysticism in the Taoist tradition, see Livia Kohn, Early Chinese Mysticism: Philosophy and Soteriology in the Taoist Tradition (Princeton: Princeton University Press, 1992).

${ }^{1272}$ The principle of ganying is used to explain the mechanism of invocation in Taoism as well; see Isabella Robinet, Méditation taoïste (Paris: Dervy livres, 1979), 81-82.

${ }^{1273}$ For a detailed investigation of this issue, see Sharf, Coming to Terms With Chinese Buddhism: A Reading of the Treasure Store Treatise. 120-133.

${ }^{1274}$ Tang, History, 39-43. Tang argued that the theory of wuxing had synthesized with Daoism in the Han dynasty. Later, Buddhism also became one part of this large synthesis [為此大綜合之一部分].
} 
conceptions of Buddhism with native beliefs and cults, ${ }^{1275}$ Tang focused more on the interaction between different faiths and the epistemological tensions between them than on the inner doctrinal division within Buddhism and certain localized ritual practices. ${ }^{1276}$

The relationship between Buddhism and Daoist esoteric arts was a main topic of Chen Yinke's study of the history of Chinese Buddhism. According to Chen's observation, proceeding its long journey to China, Buddhism was at first a foreign religion under the guise of mythology, introducing new deities, demons, and exotic rituals into a highly secularized civilization that worshipped the historical-evidential ancestors and blood ties within clans. In contrast to Tang, who emphasized the mystic tradition of religious Daoism, Chen Yinke focused more on the tantric element within Buddhism. In Chen's view, despite some native potential rivals, ${ }^{1277}$ the Indic mythology of Buddhism was also an essential aspect of its initial appeal for the Chinese. ${ }^{1278}$ An instance was the story of Huatuo 華佗, a widely circulated legend about a doctor. Using the approach of comparative linguistics, Chen analyzed the possible Buddhist origin of the name Huatuo and some other names of Indian doctors scattered in the books of Chinese traditional medicine, ${ }^{1279}$ demonstrating how Chinese

\footnotetext{
${ }^{1275}$ Faure used the term 'locative' to discuss the tension between a specific place and an abstract space. According to Faure, he borrowed the term from Jonathan Z. Smith. Smith defined the locative vision as emphasizing place and the utopian vision as stressing the value of being in no place. See Bernard, Chan Insight and Oversight. 156; Jnathan Z. Smith, Map is Not Territory: Studies in the History of Religions (Leiden: Brill, 1978), 101.

${ }^{1276}$ The contact between Buddhism and local cults also cause antagonism, especially in the case of Chan Buddhism, which was refined, de-ritualized, and intellectualized.

${ }^{1277}$ Bernard Faure, "Indic Influences on Chinese Methodology: King Yama and His Acolytes as God of Destiny," in Kieschnick and Shahar, India in the Chinese Imagination. 46. He also pointed out this interpretation has been contested by Victor Mair See his "What Is Geyi, After All?," China Report 48, no. 1-2 (2012): 29-59.

${ }^{1278}$ See Rolf A. Stein, "the Guardian of the Gate: An Example of Buddhist Mythology, from India to Japan," in Asian Mythologies, ed. Yves Bonnefoy ans Wendy Doniger (Chicago: University of Chicago Press, 1991), 119-21; and Michel Strickmann, Mantras et mandarins: Le bouddhisme tantrique en Chine (Paris: Gallimard, 1996).

${ }^{1279}$ In his article “Sanguozhi Cao Chong Hua Tuo zhuan yu fojiao gushi 三國志曹沖華佗傳與佛教故 事," Chen analyzed that the eminent doctor Hua Tuo was also a Chinese fabrication that named a
} 
people re-portrayed mythic Indian doctors, such as Qiyu 耆域, as real historical Buddhist monks who had traveled to China with Buddhist missionaries and lived in Chinese cities. ${ }^{1280}$ To Chen, this process of 'historicization' or 'de-mythization' indicated the role myths and legends played in the early contact between Buddhism and Chinese local traditions. In other articles, Chen also elaborated that the Sinicization of Buddhism in its early stage was more or less driven by the enthusiasm of some Daoist reformers for rehabilitating Daoism into a more powerful belief that would fit better the Chinese taste for esotericism and mysticism. ${ }^{1281}$

Compared to Tang, Chen Yinke was more sensitive to confrontations than harmony in the encounter between Buddhism and China. He did not depict the Sinicization of Buddhism as a mild and smooth "acculturation" of different traditions; ${ }^{1282}$ on the contrary, Chen suggested that Buddhism, although initially changing itself to gratify the needs of its Chinese audience, was also sometimes forced to give up some of its characteristics and was transformed under the compulsion of certain political and ideological forces on particular occasions. He noticed that the way Chinese people tampered with the Indian Buddhist texts to make them compatible with native ideologies and ethical principles, such as filial piety and chastity, was a very crucial issue in Buddhist Sinicization. ${ }^{1283}$ In his article "Epilogue to the Causes

Chinese historical figure with an Indian name originating from Buddhist myth. See Chen, HLTJ, 176181.

${ }^{1280}$ Chen further listed the other records in the Gaoseng zhuan and other literature in the Wei and Jin dynasties to demonstrate that the early generation of Buddhist monks, such as Yu Fakai 于法開 and Yu Daosui 于道遂, always had identities as doctors. Chen even suspected that the name of the legendary doctor Qing He was also fabricated under the influence of Indian medical theory. "Cuihao yu Kou Qianzhi 崔浩與寇謙之," in JMCB, 128-130.

1281 Ibid.

${ }^{1282}$ The term "acculturation" [涵化]' here is borrowed from Wittfogel. See Karl A. Wittfogel and Feng Jiasheng, History of Chinese Society: Liao (907-1125) (Philadelphia: American Philosophical Society, 1949). See also John Kieschnick, “Guanyu Fojiao hanhua de xingsi 關於佛教漢化的省思,” in Zhongguoshi xinlun: zongjiaoshi fence 中國史新論: 宗教史分冊, ed., Lin Fu-shih 林富士(Taipei, Linking, 2011), 272.

${ }^{1283}$ Kenneth Ch'en, for example, has argued that the emergence of Buddhist texts that propagated filial piety demonstrated how Buddhism was Sinicized and obeyed the rule of Confucian morality. See Kenneth K. Ch'en, Buddhism in China, A Historical Survey (Princeton: Princeton University Press, 1964), 
[nidana] of Ordination of the Bhikșunī Utpala-varṇā" [Lianhua seni chujia yinyuan ba 蓮華色尼出家因緣跋], Chen scrutinized the story of Bhikṣunī Utpala-varnāa in the Dunhuang manuscript of Foshuo zhujing zayu yinyou ji 佛說諸經雜線喻因由記 ${ }^{1284}$, pointing out that the claimed seven retributions Utpala-varnā experienced before she was ordained as a Buddhist nun were altered and became six when this story was introduced into China. ${ }^{1285}$ Through further investigation, Chen confirmed that the sin and punishment of Utpala-varnā's incest were completely deleted from the Chinese translated version in the Dazang jing. Comparing the Pali scriptures and the Chinese translated texts in the collected Dunhuang manuscripts, he contended that the plot point of Utpala-varnā committing incest was deliberately removed by the Chinese translators because such a story was unacceptable according to the Confucian principle of women's chastity. ${ }^{1286}$

More generally, Chen interpreted the Sinicization of Buddhism as a mechanism compelled by political forces and social obstacles. The contradictions and compromises between Buddhism and China sometimes were very severe, as he observed; sayings such as "Śramaṇa should not bow to kings" [shamen bujing wanzhe 沙門不敬王者] and “Śramana should not worship the mundane affairs”[shamen bubai sushi 沙門不拜俗事] demonstrated the Buddhists' rejection of Confucian morality and the relationship between the ruler and minister [juchen 君 $匚$ ⿷匚]. Another

179. Also, Ch'en "Filial Piety in Chinese Buddhism," Harvard Journal of Asiatic Studies 28 (1968): 81-97; The Chinese Transformation of Buddhism (Princeton: Princeton University Press, 1973), 14.

1284 “Fo shuo zhujing zayuan yu yin you ji 佛說諸經雜緣喻因由記” (Beijing, National Library 國家圖 書館藏), Number: BD03129.

${ }^{1285}$ Chen noted that, in the text, the author repeatedly mentioned that Utpala-varnā had experienced seven retributions as “投盟作七種之誓, “作如是七種咒誓惡報.” However only six of them are recorded. Also, the number 'seven' was a fixed formula in Buddhist scripture; therefore, it was impossible that the author of the text unintentionally wrote "seven" instead of "six." See Chen Yinke, “Lianhuase ni chujia yinyuan ba 蓮花色尼出家因緣跋," HLTJ, 169-75.

${ }^{1286}$ Chen's opinion, however, was criticized by later scholars. According to Zhao Xin's 趙欣 master's thesis “Lianhuase biqiuni jiqi xiangguan renwu de yanjiu” 蓮花色比丘尼及其相關人物的研究, the story was mentioned but without details 22 times in Dazangjing, and the story was recorded but without the plot detail of committing incest 45 times. However, the whole story appeared only three times in the Vinaya. See Zhao, 22-23. Although this issue exceeds the scope of this dissertation, I think the examples in the Vinaya cannot fully negate Chen's hypothesis. 
example Chen mentioned was that Chinese Buddhism, in particular the Chan school, had revised Buddhist monastic regulation, domesticating the Indian Vinaya teaching into a Sinicized system of rules of purity [Qinggui 清規] that better suited the political principles of Confucianism. ${ }^{1287}$

The impact of India is a common cliché in the modern historiography of Buddhism. Indeed, Buddhism and its religious and cultural attachments played a crucial role in China's history; however, the different interpretations mentioned above indicate that 'Sinicization' was not an 'either-or' issue. Meanwhile, the different prepositions behind these modern interpretations sometimes blur the problems that the ancient Chinese really faced, but instead present the actual situation those modern historians themselves encountered: how could China regenerate itself by critically adapting foreign intellectual resources but maintain the survival, or even triumph, of the native traditions at the same time? The history of Buddhism was always circling around this issue and revealed its difficulty and ambivalence.

\section{Mistranslation}

The nationalist tendency in modern Chinese historiography sometimes led to an overestimation of the one-sided function of China in the process of Buddhist Sinicization: namely, Buddhism was selected, accepted, and ceaselessly re-interpreted by the Chinese. This consensus among modern Chinese scholars more or less exaggerated the role China played in the Buddho-Sino encounter. Only a few scholars have inquired into this narrative and have noticed the weakness within the Chinese attempt to domesticate foreign religion.

Chen Yinke and Lü Cheng realized that the foundation of Chinese Buddhism was a set of mistranslations and was therefore shaky. Writing the history of Buddhism with translated materials was also problematic. As analyzed before,

\footnotetext{
${ }^{1287}$ Other examples mentioned by Chen included the Buddhist vegetarianism in China. Chen found evidence in the Gaoseng zhuan that vegetarianism was not a rule for Buddhists before the sixth century (the period of Emperor Wu) in the Liang dynasty. See Chen Yinke, Dushu Zhaji sanji 讀書札記三集 (Beijing: Sanlian shudian, 2009), 38.
} 
although early Chinese Buddhists had realized the shortcomings of geyi in conveying accurate meanings and consciously repudiated it, the practice of geyi did not, and indeed could not, be stopped in the Chinese religious culture. It was believed that the problem of mistranslation would be ameliorated as the Chinese were given access to better translations. However, the Chinese had their own criteria for selecting and judging the texts of translated Buddhist scriptures. For example, the advance of Kumārajīva's translations over those of his predecessors was not due to their fidelity to the originals (perhaps only the modern scholars like Chen Yinke could explicitly point out the fallacies in the old translation as an arbiter of Buddhist knowledge), but rather due to the elegance and accessibility of his prose. ${ }^{1288}$ From the historiographical perspective, judging the accuracy of Chinese translations may beg the question. The shortage of high-quality translation was not a severe obstacle for the distribution of the Buddha's teaching but just the beginning of the domestication of Buddhism. ${ }^{1289}$

Under the rubric of 'the Buddha's teaching,' the rift in translation was very deep. Lü Cheng noted the pitfalls of mistranslation and considered it a forced, inexorable form of 'Sinicization'. It resulted unavoidably in a distortion of the authentic meaning of the Dharma. Lü cited the mis-translation of the terminology 'tathat $\vec{a}$ ' as an example in the introduction to his book The Origins and Changes of Chinese Buddhism [Zhongguo fojiao yuanliu luejiang 中國佛教源流略講]. ${ }^{1290}$ The term 'tathatä' was initially translated as benwu 本無 in early Chinese Buddhist texts. However, due to the literal confusion of benwu with some Daoist notions, this term,

\footnotetext{
${ }^{1288}$ Sharf, Coming to Terms with Chinese Buddhism: A Reading of the Treasure Store Treatise, 12.

${ }^{1289}$ The term domestication, as mentioned above, has been used by Arthur Wright in his Buddhism in Chinese History. Kenneth Ch'en also refers this term in the title of one chapter in his Buddhism in China: A Historical Survey. Some scholars, such as Yü Chun-fang, intend to replace the term 'Sinicization' with this term. As Yü clarified, her definition of 'domestication' comes from Todd Lewis and means “the dialectic process by which a religious tradition is adapted to a region's or ethnical group's socioeconomic and cultural life." See Yü Chun-fang, Guan-yin, the Chinese transformation of Avalokitesrava (New York: Columbia University Press, 2001). Todd T. Lewis, "Newar-Tibetan Trade and the Domestication of 'Siṃhalasārthabāhu Avadāna'," in History of Religions 33, no. 2 (1993): 135-60. ${ }^{1290}$ In the preface, Lü adopted the translation of "ruxing” [如性].
} 
which was closer to its Indian meaning, was gradually replaced by zhenru 真如, a word with a totally different meaning. ${ }^{1291}$ The enormous doctrinal divergence between Chinese and Indian Buddhism made Lü understand Chinese Buddhism as a new religion. He said, "We could not consider Chinese Buddhism as a transplanting [yizhi 移植] of Indian Buddhism; rather, it is a grafting [jiajie 嫁接] of Buddhism. There is a difference between them. That is to say, Chinese Buddhism has its roots in China, instead of in India." ${ }^{1292}$ According to Lü's observation, the backflow of Chineseness even influenced India Buddhism itself. He took Xuanzang as an instance and argued that, although Xuanzang dedicated himself to distributing the orthodoxy of Indian Buddhism, his translation and works were still full of the "taste of China" [Zhongguo fengwei 中國風味]. ${ }^{1293}$ When Xuanzang wrote Huizong lun 會宗論 at the Nalanda, he unconsciously introduced this "taste of China" into India. ${ }^{1294}$ This Chinese-ness, Lü believed, was a passive or even negative assimilation of different traditions. ${ }^{1295}$ Because of the inescapable 'nostalgia' in Xuanzang's writing, Lü argued, although he had direct contact with the Indian origin of Buddhism, Xuanzang failed to make the distance between China and India any closer.

For Lü, the sinicization of Buddhism was not chosen and compelled by the Chinese for their own purposes. ${ }^{1296}$ Rather, it was a product of the accumulation of

\footnotetext{
${ }^{1291}$ Lü, Yuanliu, 4

1292 Ibid.

${ }^{1293}$ Lü, Yuanliu, 4

${ }^{1294}$ Xuanzang travelled around India between 630 and 643 CE and visited Nalanda first in 637 and then again in 642 , spending a total of around two years at the monastery. There he received the Indian name of Mokshadeva and studied under the guidance of Shilabhadra, the venerable head of the institution at the time. See Sally H. Wriggins, Xuanzang: a Buddhist pilgrim on the Silk Road (Boulder, Colo.: Westview Press, 1996).

${ }^{1295}$ In Huizonglun, Xuanzang combined the Middle Way school [Sanskrit: Madhyamaka, 中觀] and Yogācāra school, which was unusual in the Indian Buddhist tradition. Lü, Yuanliu, 4. In his article “大乘 起信論放證” he repeated this opinion about the “hengtong” 横通 character of the Chinese people; see Lü, LFLX, 248.

${ }^{1296}$ In only a few cases, Lü mentioned the social-political background of the transformation of Chinese Buddhism. For example, when he discussed the core concept of “xinxing” 心性, Lü pointed out that Chinese Buddhism largely removed the notion of “zhuanyi” 轉依 from the Indian doctrine, for this
} 
mistranslations, which largely had resulted from the dearth of true knowledge of Buddhism. Thus, Lü Cheng advocated for a decisive rejection of the narrative of Sinicization, although he did not compeletely abandoned the logic of 'assimilation' between Buddhism and local culture. In Lü, the Sinicized Buddhism was not "genuine" Buddhism, but rather a heresy—the fake imitation, in his words-that betrayed the original meaning of the Buddha's teaching. Here, he jumped out of the discursive shackles of 'Sinicization' but declared the fundamental separation between Chinese Buddhism and Indian Buddhism.

\section{Indianization}

In 1936, Hu Shih wrote an article entitled "The Indianization of China: A Case Study of Cultural Borrowing." ${ }^{\prime 297}$ This critical essay on the intellectual transformation in Chinese history aroused a strong response. His remark in this article - "India conquered and dominated China culturally for twenty centuries without ever having to send a single soldier across her border"-became one of the most popular and extensively quoted statements among the later Sino-Indian discourses. After $\mathrm{Hu}$, the 'Buddhist conquest of China,' to a large extent, became a paradigm of the historical narrative of Chinese Buddhism in the field of both Buddhology and Sinology.

Leaving aside his controversial summation of this issue, Hu's notion of 'Indianization' was usually understood as an equivalent expression to 'Sinicization.' For scholars who concern about the Buddhism in its Indian form or the superiority of Indian thought, Hu's idea of Indianization provided an 'authoritative' acknowledgement of the cultural hegemony of India over ancient Chinese civilization. Because of its relatively radical tone, this idea was unique in Chinese academia at the time. However, soon it was tacitly recognized by Hu's Western

notion implied a will of social revolution that was not welcomed by the Chinese rulers. See Lü, LFLX, vol. 3: 1416.

${ }^{1297}$ This article was written for the Harvard Tercentenary Conference of Arts and Sciences, which was published in 1937 in Independence, Convergence, and Borrowing in Institutions, Thought, and Art (Cambridge, MA.: Harvard University Press, 1937), 219-247. 
counterparts because it encapsulated their ultimate concern. How did Buddhism change China?

\section{Chinese Renaissance}

The extraordinary claims to India's significance made in Hu Shih's article "The Indianization of China" were aimed at the audience in the Western world. Lin Yüsheng has suggested that this article was written in a mood of cultural nationalism when $\mathrm{Hu}$ Shih was inclined to explain the intrinsic cruelty of the Chinese people in terms of the influence of Indian Buddhism. ${ }^{1298} \mathrm{He}$ interpreted the Buddhinization [fojiaohua 佛教化] of China as the very key to his understanding of the medieval transformation of Chinese culture and his project of the independent re-evaluation of Chinese civilization. ${ }^{1299}$

Hu Shih's interests in Chinese history were remarkably broad, far transcending his work on early Chan Buddhism. For example, he became involved in academic discussions concerning the relative dating of Laozi and Confucius, the meaning of the rise of Neo-Confucianism in the Song dynasty, and the comparison between the rise of empirical scholarship during the Qing era and the European reformation. As a historian, no mere antiquarian, $\mathrm{Hu}$, in keeping with the pragmatist teachings of his mentor John Dewey, undertook the study of history by means of 'organizing the national essence' for the explicit purpose of serving the present. ${ }^{1300} \mathrm{In}$ its narrowest sense, organizing the national essence implied the use of rigorous methodologies and an inquisitive yet critical approach to primary sources. On a broader level, this slogan provided a justification for a two-pronged endeavor. On the one hand, the scholar - and indeed the educated person in general - was to use this process to come to terms with his or her own tradition and to understand the Chinese past and its transformations. On the other hand, this endeavor was always to take

\footnotetext{
${ }^{1298}$ See Lin's chapter on "the pseudoreformism of Hu Shih" in his The Crisis of Chinese Consciousness: Radical Antitraditionalism in the May Fourth Era (Madison, WI: University of Wisconsin Press, 1979), 99. ${ }^{1299}$ John R McRae, "Religion as Revolution in Chinese Historiography: Hu Shih (1891-1962) on Shen-Hui (684-758)," (2001): 64

${ }^{1300}$ Eber, "Hu Shih and Chinese History: The Problem of Cheng-li Kuo-ku." 169-207.
} 
place for the benefit of the present and, more specifically, on behalf of the successful modernization of China.

In Hu's works, religious issues always obeyed his secular concerns about the past, present, and future of China. In his early writings, Hu Shih was largely critical toward Confucianism for its 'superstitious' implications; however, propelled chiefly by the growing realization that he could not reject its religious dimension while rehabilitating its humanistic and rationalistic aspects, his attitude gradually changed. ${ }^{1301}$ In one article on religion, he announced that "probably I am a Confucianist" and discussed that although Confucianism was not a real religion and might be "dead," it could represent an ideal form of faith. ${ }^{1302}$ Confucianism, although it contradicted the principle of science, ${ }^{1303}$ had prepared China for modernization, in both institutional and intellectual dimensions. ${ }^{1304}$ Eber has concluded that Hu Shih was also moving toward a more positive appreciation of Daoism as a tradition that was conducive to modernization, although this position was only fully expressed in the 1950 s. ${ }^{1305}$

\footnotetext{
${ }^{1301}$ Compare his statements on Confucianism in his The Develoment of the Logical Method in Ancient China (Shanghai: Oriental Book, 1922; rpt., New York, Paragon Book, 1963), 7-9, 17, 56, and 69, and the article “Shuo ru 說儒," in Hu Shih Wencun 胡適文存 4, no. 1, 1-103, esp. 68 and 75. Also see Eber, “Hu Shih and Chinese History: The Problem of Cheng-li Kuo-ku," 187.

${ }^{1302} \mathrm{Hu}$ Shih, “The Task of Modern Religion,” Journal of Religion 14, no. 1 (1934): 104.

${ }^{1303}$ See his comments in Albert E. Haydon, ed., Modern Trends in World Religions (Chicago: University of Chicago Press, 1934), 46.

${ }^{1304}$ He mentioned the examination system, the abolishment of primogeniture, the censorial system, the concept of the goodness of human nature, and the rationale for rebellion against tyrannical government provided by the theory of the mandate of heaven. See Hu Shih, "Historical Foundations for a Democratic China," Edmund J. James Lectures on Government, Second Series (Urbana: University of Illinois Press, 1941), 54-63.

${ }^{1305}$ See Eber, "Hu Shih and Chinese History: The Problem of Cheng-li Kuo-ku." 199-202. It is significant that $\mathrm{Hu}$ Shih did not significantly alter his estimation of Buddhism and Shen-hui's role during the 1950s, when he modified several other aspects of his interpretation of Chinese history. For Hu's description of the successes and failures of Chinese classical scholarship during the last three hundred years, as well as a more detailed statement of the methodology of 'organizing the national essence,' see his “A Systematic Study of China's Cultural Heritage," Chinese Studies in History 14, no. 3 (1981): 80-87.
} 
During the early 1930s, just after his major work on Shenhui was completed and at virtually the same time that he was reevaluating the Confucian and Daoist traditions, Hu Shih articulated a general theory of the periods of Chinese history. The hallmark of this theory was the identification of several particularly creative epochs that he referred to as periods of 'renaissance. ${ }^{1306} \mathrm{Hu}$ Shih considered the emergence of Chan and the development of neo-Confucianism to be intimately related processes that profoundly influenced the emergence of the age of renaissance. Before the period of the 'Chinese Renaissance,' according to Hu Shih, was the period of the classical age, which ended about 200 B.C.E. (in another place he classified the first period as 'the Sinitic Age' [huaxia shidai 華夏時代], which lasted until the initial ascendency of Buddhism in the fourth century C.E), and the medieval or Buddhist age as long as eight hundred years, from approximately 200 B.C.E. to 1000 CE. According to $\mathrm{Hu}$, the classical age was characterized by humanism, rationalism, and intellectualism, and a spirit of freedom and democracy; purely religious sensibilities, however, were not as well developed as other aspects of ancient Chinese society:

[The Chinese people] had no time to indulge in speculating about the ways of the gods, or in effusive praises of the wonderful benevolence of heaven which they never enjoyed. They had a very simple religion consisting chiefly in a worship of their own ancestors, a belief in the spirits and the powers of the natural forces, a worship of a supreme God or heaven (which was probably evolved out of the worship of natural objects), and a belief in divination. To these they added a belief in the idea of retribution of good and evil. There was neither Hell nor Paradise; no life after death, only a firm belief in the importance of the perpetuation of the family line, primarily for economic reasons. This was the original religion of the chinese. The extreme simplicity of this racial religion was the most remarkable in the history of mankind. There was little mythology, and little elaborate ritualism. It never had a generic name, and I have elsewhere proposed to call it 'Siniticism. ${ }^{1307}$

\footnotetext{
${ }^{1306}$ This list occurs in the lecture "The Chinese Renaissance" from Hu Shih, The Chinese Renaissance (Chicago: University of Chicago Press, 1934), 44-45.

${ }^{1307} \mathrm{Hu}$ Shih, The Chinese Renaissance (1934), 80-81; the allusion at the end of this passage is to Hu's "Religion and Philosophy in Chinese History," in A Symposium on Chinese Culture, Sophia H. Chen Zen ed. (Shanghai: China Institute of Pacific Relations, 1931).
} 
As shown in this passage, the history of the pre-Buddhist age, namely the Sinitic or classical age, was marked by 'simplicity' and non-religiousness. As we shall see below, native Chinese thought was inherently and quintessentially simple, in direct contrast with the fundamental complexity of Indian Buddhism. The importation of Buddhism and its near-total domination of Chinese intellectual and religious life dramatically changed this landscape. ${ }^{1308}$ To the Chinese, Hu analyzed, Buddhism possessed "impressive images and grandiose rituals and unintelligible metaphysics and superstitious charms and spells"; an extreme religious zeal then was incited among the Chinese when they were under the sway of Buddhism for, particularly, its "inhuman fanaticism" of self-mortification. ${ }^{1309}$ In Hu's opinion, all the religions and philosophies of ancient China were free from the fantastic imaginativeness, hairsplitting analysis, and gigantic architectonic structure that can be found in almost all religious and philosophical texts of India. Gradually, "China was overwhelmed, dazzled, and dumbfounded by the vast output of the religious zeal and genius of the Indian nation. China acknowledged its defeat and was completely conquered." ${ }^{1310}$ This process was what Hu called "Indianization."

Hu's descriptions of the original Indian Buddhism, often in a manner that scarcely disguised his own contempt, were generally couched in terms of its complexity, which he saw as a shortcoming. For example, he dismissed Yogācāra idealism as quibbling that was both entirely inimical to the Chinese mentality and ultimately inexpressible in Chinese language. He also portraited the eminent pilgrim, translator, and Yogacara master Xuanzang as a monk with "close-minded fabrications," who traveled to India at a time when "complex philosophy" was in its very heyday, along with idealism, logic, and many kinds of "meaningless dhāranīs":

The great Xuanzang threw himself into the great spider's web and could not escape, so becoming a great believer and proselytizer of the Vijñānavādin School. At this

\footnotetext{
${ }^{1308} \mathrm{Hu}$ Shih, "Chinese Thought" in China, Harley Farnsworth MacNair, ed., (Berkeley and Los Angeles: University of California Press, 1951), 227.

${ }^{1309} \mathrm{Hu}$ Shih, “Development of Zen Buddhism in China,” in Seizan, Ko Teki zengaku an 胡適禪學案 (1975), 714.

${ }^{1310}$ Ibid., 715.
} 
time of the seventh century, China was transformed into a great colony of India's complex philosophy. ${ }^{1311}$

He used 'colony,' the modern concept of imperialism, to describe the Indianization of China. Further, he pointed out that although the flood of strange Buddhist ideas and practices overwhelmed the Chinese people for several centuries, this sense of fascination was always accompanied by a feeling of revulsion:

But the native rationalistic mentality of the Chinese intelligentsia gradually reasserted itself and revolted against this humiliating domination of the whole nation by a foreign religion which was opposed to all the best traditions of the native civilization throughout the country. Its celibacy was fundamentally opposed to the Chinese society which emphasized the importance of continuation of the ancestral lineage. Its mendicant system was distasteful to the Chinese social and political thinker who was naturally alarmed by the presence of millions of monks and nuns living as parasites on society. Its austere forms of asceticism and self-sacrifice and suicide were fundamentally against the idea of filial piety which regarded the human body as a sacred inheritance from one's parents. And its wonderfully abstruse mythology and metaphysics, never ending in the most ingenious inventions of new gods and new titles of the gods, and never failing in the most captious differentiations and sub-differentiations, were most foreign to the simple and straightforward ways of thinking of the native tradition. And, most important of all, the whole scheme of salvation preached in Buddhism seemed to the Chinese thinker as most selfish and anti-social. Each man endeavors to become an arahat [sic], a bodhisattva, or a buddha. But the Chinese began to ask, for what end? What value is there in a salvation which must require the forsaking of the family and the desertion of all one's duties to the family and the state? ${ }^{1312}$

\footnotetext{
${ }^{1311} \mathrm{Hu}$ Shih, Shenhui heshang yiji 神會和尚遺集. The original volume of the Yiji was published in 1930; here see the second edition, Shenhui heshang yiji fu Hu xianshang zuihou de yanjiu 神會和尚遺集附胡先 生最後的研究 (Taipei: Hu Shih jinianguan 胡適紀念館, 1968), 42-43; Hu Shih also dismissed the Tiantai school as a form of complex philosophizing. At one point, he also noted with obvious contempt that Zhiyi 智顗 was the sort of scholar who took 100,000 characters to explicate the two-character term for meditation, 'zhiguan' 止觀 [concentration and insight].

${ }^{1312} \mathrm{Hu}$ Shih, The Chinese Renaissance (1934), 85. In his distaste for superstition, Hu refers to Tantrism as one of the "worst features of Mahāyāna Buddhism"; see Hu Shih, "Religion and Philosophy in Chinese
} 
Undoubtedly, there was a long tradition of Confucian anti-Buddhist polemic thriving in Hu Shih's writings. He believed that the innate revulsion towards Buddhism was expressed publicly during the Age of the Chinese Renaissance. Then, China divested itself of the intellectual domination of India and reverted to the simple, humanistic rationalism of the native Chinese tradition. Buddhism, therefore, 'disappeared' when its contributions were appropriated by Chinese society as a whole. In this sense, in the third phase of Chinese history, as Hu described, China assimilated the more subtle elements of the Indian culture-the philosophy of the world and of life, the moral and social standards, the intellectual habits-things ...which had required much intermediate work of sifting, discarding, distilling, and reinterpreting, before some of them were sufficiently domesticated to be unconsciously appropriated into the Chinese culture. ${ }^{1313}$

The Chinese Renaissance thus involved four types of effort aimed at overcoming the "humiliating domination" by a foreign religion "which was opposed to all the best traditions of the native civilization." ${ }^{1314} \mathrm{Hu}$ argued, as scholar John McRae summarized, these efforts included (a) imitation, as practiced by the Daoists in an attempt to supplant Buddhism; (b) persecution, the motive for which was nationalistic in nature; (c) internal revolt, the process of radical simplification that occurred within Chinese Buddhism, and specifically within the Chan school; and (d) philosophical secularization, as undertaken by the Neo-Confucians of the eleventh and twelfth centuries. ${ }^{1315}$ By these means Buddhism was able to be fully 'integrated'

\footnotetext{
History," 51. On another occasion he said with obvious relief that in spite of the careers of Amoghavajra and Vajrabodhi, two of the major translators of esoteric texts, China did not "fall" into becoming an esoteric or lamiast state; see Hu Shih, “Chan xue gushi kao 禪學古史考," in Yanagida Seizan, Ko Teki zengaku an 胡適禪學案 (Kyoto: Chūbun shuppansha, 1975), 222.

${ }^{1313} \mathrm{Hu}$ Shih, “Indianization of China,” in Seizan, Ko Teki zengaku an 胡適禪學案, 239.

${ }^{1314} \mathrm{Hu}$ Shih, The Chinese Renaissance (1934), 85.

${ }^{1315}$ Yamaguchi cites various passages to indicate Hu believed that the task of the Sung and Ming Dynasty Neo-Confucians was only completed by the scholars of the Qing. See Yamaguchi Sakae 山口栄, “Ko Teki no Chūgoku Zenshūshi ni tsuite 胡適の中國禅宗史に就いて,” in Junsei Tanki Daigaku kenkyū kiyo 順正短期大學研究紀要, 3 (1973): 63- 76; esp. 71.
} 
into Chinese society and allowed to disappear. ${ }^{1316}$ In this sense, Hu made his bold and seemingly paradoxical conclusion of the 'Buddhist conquest' of China while he implied the tacit triumph of the Chinese essence.

\section{Transcultural Thesis}

Another paradigm modern historians used to describe the influence of Buddhism on Chinese culture was 'the unity of the three creeds' [sanjiao heyi 三教合一]. ${ }^{1317}$ Following a traditional narrative, this paradigm focused on the syncretism of Chinese Buddhism, which was considered by most scholars to be a significant evolution of Buddhism. ${ }^{1318}$ Chinese Buddhism was approached as emerging from an encounter that had engendered a certain degree of mutual borrowing and syncretic rapprochement. It was evidence for the flexibility, generosity, and critical thinking of Chinese

\footnotetext{
${ }^{1316} \mathrm{John}$ McRae pointed out that Hu thought Buddhism flooded China simply because it was complex and filled naive religious desires. Also, note his comment in "Indianization of China," (231) that after 1100 or so Buddhism simply failed to have influence in China - omitting mention of the decline of Buddhism in India and the loss of easy passage across Central Asia. John R McRae, "Religion as Revolution in Chinese Historiography: Hu Shih (1891-1962) on Shen-Hui (684-758),” (2001): 78 ${ }^{1317}$ See, for example, William E. Soothill, The Three Religions of China: Lectures Delivered at Oxford (London: Oxford University Press, H. Milford, 1923), 13; C. K. Yang, Religion in Chinese Society (Berkeley: University of California Press, 1961), 123-126; Nakamura Hajime 中村元, Ways of Thinking of Eastern Peoples: India, China, Tibet, Japan (Honolulu: East-West Center Press, 1964), 290-294; Henri Maspero, Les religions chinoises (Paris: Presses Universitaires de France, 1967):111-138; Taoism and Chinese Religion, trans. Frank A. Kierman Jr. (Amherst: University of Massachusetts Press 1981), 77-87; Judith A. Berling, The Syncretic Religion of Lin Chao-en (New York: Columbia University Press, 1980), 1-31; Shih Heng-qing, The Syncretism of Ch'an and Pure Land Buddhism (New York: Peter Lang, 1992), 7-18; Rodney L. Taylor, The Religious Dimensions of Confucianism (Albany: SUNY Press, 1990), 71-75; and Timothy Brook, "Rethinking Syncretism: The Unity of the Three Teachings and Their Joint Worship in Late-Imperial China." Journal of Chinese Religions 21 (1993): 13-44. ${ }^{1318}$ The term "syncretism" first appears in Plutarch referring to "the behavior of the Cretans who, despite the discord habitual among them, closed ranks when an external enemy attacked them." See Carsten Colpe, "Syncretism," in The Encyclopedia of Religion, trans. Matthew J. O'Connell, ed., Mircea Eliade (New York: Free Press. 1986), 218-27. The term was used frequently in the latter half of the nineteenth century in the context of the study of religion and historical theology, meaning something like a mishmash of religions (religionsmischerei). On the meaning, intellectual history, and ideological investments of the category "syncretism," see also, Robert D. Baird, Category Formation and the History of Religions (The Hague: Mouton, 1971), 142-152; Sven S. Hartman ed., Syncretism (Stockholm: Almqvist and Wiksell, 1969); and Charles Stewart and Rosalind Shaw eds., Syncretism/Anti-Syncretism: The Politics of Religious Synthesis (New York: Routledge, 1994).
} 
civilization; however, it also proved the dynamic and pluralistic facet of Buddhism. A syncretic Buddhism would seem particularly apposite to a multiethnic nation/state of China. ${ }^{1319}$

Chen Yinke, in his studies, provided several examples of the syncretism of Chinese Buddhism. Chen considered Buddhism to be an external stimulus and theoretical resource that had resulted in intellectual innovations in China. Buddhism also changed the behavior and thinking patterns of the Chinese. To Chen, China had an advanced construction of ethics but lacked "substantial concepts of philosophy"; Buddhism, as a sophisticated "metaphysics," could compensate for the deficiency of the Chinese spirit. Chen once argued that

[The Confucianists in the Song dynasty] borrowed the most exquisite doctrines of Buddhism to interpret the Confucian Classics; purporting to revitalize the ancient learning, they were actually absorbing 'hegemonies'; under the pretext of respecting Confucius and rejecting Buddhism, however, the teaching of Buddhism had deeply infiltrated into their minds. This is the former Confucianists' effort to save the world, which deserves to be respected. Therefore, Buddhism had rendered significant contributions to China. 採佛理之精萃以之註解四書五經, 名為䦐明古學, 實則吸 收異教。聲言尊孔辟佛, 實則佛之義理, 已浸漬濡染。此先需愛國濟世之苦心, 至可尊敬而曲諒之者也。故佛教實有功於中國甚大..$^{1320}$

Here, Chen claimed that Buddhism had played a very positive role in Chinese history; it "breathed fresh air into Chinese scholarship" [zengzhang yuanqi 增長元氣] so that the culture of the Tang and Song dynasties flourished extremely well. ${ }^{1321}$ Buddhism offered China something more spiritual, metaphysical, and transcendental,

\footnotetext{
${ }^{1319}$ However, current scholarship has contested this hypothesis of cultural dialogue, pointing out that the metaphor is misleading and overestimates the influence of India on Chinese culture. Sharf, for example, has argued that, because in most cases there was no direct contact between China and India, therefore, the so-called the Indian influence was actually Chinese productions. See Sharf, Coming to Terms With Chinese Buddhism: A Reading of the Treasure Store Treatise. 18

${ }^{1320} \mathrm{Wu}$ Mi, Wu Mi riji 吳宓日記, 9-13. After this passage, Wu Mi added a comment that this historical phenomenon was similar to the Christianization of Europe. ${ }^{1321}$ Ibid.
} 
effectively counteracting the very secular and pragmatic qualities of Chinese thought. ${ }^{1322}$

The encounter between Buddhism and Daoism in Chen's writing presented one pattern of sanjiao heyi: Buddhism disguised itself as one kind of Daoist esoteric art to enhance its religious attraction and borrowed concepts from Lao-Zhuang philosophy to facilitate the Chinese understanding of Buddhist teachings. ${ }^{1323}$ Daoism, on the other hand, absorbed the Buddhist knowledge of medicine, math, astronomy, and so on to innovate its doctrines, rituals, and rites. In his article "Cui Hao and Kou Qianzhi," Chen took the Daoist priest Yin Shao 殷紹 as an example to demonstrate how Buddhism brought new concepts and techniques into Daoist esoteric arts. According to Chen's analysis based on the biography of Yin Shao in the Weishu, the teachers of Yin, Chengong Xing 成公興, Tanying 昙影, and Famu 法穆, were all Buddhist monks. ${ }^{1324}$ In the same article, Chen further investigated how Daoist priests selected, rendered, and reinterpreted the Buddhist astronomical concepts to improve the old practice system of religious Daoism by taking Kou Qianzhi as an example. ${ }^{1325}$

Buddhist influence on Chinese literature was also one example of how Buddhism changed China. Chen elaborated in several articles that the form and style of Buddhist literature, which combined the long sentence of prose with rhyme and verse, developed into the chapter style [zhanghuiti 章回體] of the traditional Chinese novel and tanci 彈詞. ${ }^{1326}$ He used the story of The Vimalakirti Nirdeśa Sütra and its

\footnotetext{
${ }^{1322}$ For an opinion about India's spirituality, see the recollection of Chen Xiying in Bian Senghu 市僧慧, Chen Yinke xiansheng nianpu changbian 陳寅恪先生年譜長編, 77.

${ }^{1323}$ For examples and analysis, see the former part of this dissertation.

${ }^{1324}$ Chen, “Cui Hao and Kou Qianzhi 崔浩與寇謙之,” in JMCB, 127.

${ }^{1325}$ Some recent studies supported Chen's opinion. For example, Strickmann has argued that Tantrism had a much deeper influence on Chinese religion than earlier studies have acknowledged. He has gone so far as to claim that much of Taoism, as well as popular Chinese rituals such as the "Land and Water Assemblies," cannot be understood without Tantric Buddhism. See Michel Strickmann, Mantras et mandarins: Le bouddhisme tantrique en Chine, 16-58, 369-411.

${ }^{1326}$ Tanci is a narrative form of song in China that alternates between verse and prose. The literal name "plucking rhymes" refers to the singing of verse portions to a pipa. A tanci is usually seven words long and on some occations, ten words. Luo Zhenyu categorized the styles originating from Buddhist literature as "the category of foqu" [佛曲之目]. See, Chen, " Dunhuang ben Weimojie jing wenshu shili
} 
Chinese recension and adaption ${ }^{1327}$ as an example to investigate how the revised Indian myths and stories had influenced Chinese vernacular literature, such as Xiyou $j i$ 西遊記. ${ }^{1328}$ Based on these studies, Chen concluded that some genres of Chinese literature, such as the novel, were basically outgrowths of a 'Buddhicization' of literature..$^{1329}$

Besides, Buddhism introduced a new pattern of textual exegesis into Chinese scholarship. Based on his scrutiny of bianwen 變文, Chen demonstrated the unique method Chinese Buddhists utilized to comment and interpret scriptures-an enumeration of parables or 'metaphors' [avadāna, piyu 譬喻] to illustrate lessons or principles of the Buddha. In the Chinese Buddhist tradition, the examples used in such metaphorical constructions are mostly myths and fabrications, which differed from the traditional exegesis of Classical Learning that relied on historical narratives and official documents. ${ }^{1330}$ In the article "Preface to Yang Shuda's commentary on the Analects" [Yang Shuda lunyu shuzheng xu 楊樹達論語疏證序], Chen analyzed that from the Northern and Southern dynasties, this exegetical strategy profoundly influenced the commentary works in the "second classification" [yibu 乙部]. Historical works, such as Pei Songzhi's commentary on the Sanguo zhi 三國志, Liu Xiaobiao's commentary on Shishuo xinyu 世說新語, and Li Daoyuan's commentary on Shuijing 水經, all followed the stylistic rules of Buddhist treatises.

Significantly, Chen avoided addressing the complex mechanism of China's 'Indianization' from a single angle. He also noticed the Chinese resistance against the impact of Buddhism. For instance, Chen observed that Buddhist exegesis received only rare advocacy among Confucian commentators, since the orthodox method of Confucian exegesis was always based on "historiographical evidential study" [shixue

wenji pin yanyi ba 敦煌本維摩詰經文殊師利問疾品演義跋, ”JMEB, 203. Luo Zhenyu 羅振玉, Dunhuang linshi 敦煌零拾, vol.4 (1924). Zheng Zhenduo 鄭振鐸 had for the first time used the term ‘bianwen’ 變文. See Zheng, “Dunhuang de suwenxue 敦煌的俗文學, ” in Xiaoshuo yuebao 小說月報, 20, no.3 (1929).

${ }^{1327}$ Chen, JMEB, 203-210.

${ }^{1328} \mathrm{Ibid}, 217-223$.

${ }^{1329}$ Ibid, 209.

${ }^{1330}$ Ibid., 203. 
kaoju 史學考據]. ${ }^{1331}$ The dissimilarities between Buddhist and Confucian exegetic approaches seemed slight in format, but discernible in essence. Historically, Buddhist exegesis technique had never shaken the foundation of Han Learning and later, Song Learning. Therefore, as Chen observed, the boundary between Indian Buddhism and Chinese thought were blurred but always existed. For example, Chinese Buddhists preserved the orthodox genre of Indian scriptural commentary that was known as avadāna; however, works compiled by native Buddhist schools, the Tiantai school, for example, were totally “Sinicized” [zhina hua 支那化]. ${ }^{1332}$

This opinion was elaborated in detail by Chen in his study on Han Yu's NeoConfucianism. He began his discussion from the tradition of zhangju 章句, an exegesis paradigm of the Han Learning that involved a detailed analysis of the paraphrases for every line of a text, adding explanations by referring to other Classics. ${ }^{1333}$ This type of exegesis was imitated by Buddhist commentators during the Northern and Southern dynasties. However, this exegetic approach attracted critics soon after it was widely promoted, for its redundancy and garrulousness. Among all the critics, the most significant refutation of zhangju was the Chan Buddhism's 'revolution of discourse' with the motto "No dependence on the written letter, a special transmission outside the scriptures" [buli wenzi, jiaowai biechuan 不立文字, 教外別傳]. ${ }^{1334}$ Partly influenced by the Chan school's stand, the model of zhangju began to be criticized by the eminent Confucian intellectual Han Yu when it developed into a very rigid

\footnotetext{
${ }^{1331}$ Ibid. 263.

${ }^{1332}$ Chen Yinke. “Xiyouji Xuanzang dizi gushi zhi yanbian 西遊記玄牀弟子故事之演變,” in JMEB, 218.

${ }^{1333}$ David R. Knechtges defines zhangju as “a type of explication that involved long, sometimes irrelevant, digressions, about the moral and political implications of certain words or lines in a text." David R. Knechtges, "The Liu Hsin/Yang Hsiung Correspondence on the Fang Yen." Monumenta Serica 33 (1977-78): 314. For studies on the zhangju commentary tradition in the West Han, See, Nomura Shigeo, "Zen Kan shōku no gaku shidan," Aichi kyōiku, daigaku genkyū hōkoku, 27 (1978): 1-12. Also, Lin Qingzhang 林慶彰, “Liang Han zhangju zhi xue zhongtan 兩漢章句之學重探, ” in Zhongguo jingxueshi lunwen xuanji 中國經學史論文選集 (Taibei: Wenshizhe, 1992): 290.

${ }^{1334}$ This motto appeared in the eight century and was not found in earlier texts such as the Damo lun 達 摩論 [Treatise of Bodhidharma], although similar points had been made in the anthology of the early Chan. See Yanagida, "Den hōbōki to sono sakusha" [The Chu fabo ji and its Author]. Saizen, Zengaku kenkyū 53: 36; Bernard Faure, Le Traité de Bodhidharma: Première anthologie du bouddhisme Chan (Paris: Le Mail), 1986.
} 
subject of the imperial examination system. Inspired by the Chan school's understanding of language, Han advocated a 'Classical Prose Movement' to rectify the current scholarship back to the orthodoxy of the Chunqiu and Analects. ${ }^{1335}$ From Han Yu onwards to Zhu Xi, Chan Buddhism's reflection on language and the Buddhist teaching of xinxing 心性 inspired and to certain degree modeled the philosophical setting of Neo-Confucianism, playing a vital role in the Confucian philosophical repertoire. ${ }^{1336}$

Compared to Hu Shih, Chen approached the problem of how Buddhism influenced China from a contextualized perspective, illuminating it from a broader vision of culture, society, and ideology. At the same time, Chen's own attitude towards the historical scenario of 'Indianization' was milder and more 'sympathetic.' A similar attitude could be observed in Tang Yongtong. Tang dealt with the same issue in his two monographs, Hanwei and Shigao, in a comprehensive way. A more generalized and theoretical elucidation on the transcultural communication between Buddhism and native Chinese culture can be found in his two commentary articles on current cultural affairs: "Comments on the recent cultural studies" [Ping jinren wenhua yanjiu 評近人文化研究 ${ }^{1337}$ and “The conflicts and compromises of cultures and thoughts" [Wenhua sixiang zhi chongtu yu tiaohe 文化思想之衝突與調和]. ${ }^{1338}$ To Tang, contact between different traditions always led to a "cultural transplantation" [wenhua yizhi 文化移植] which he defined as "a culture moving to another nation/ethic community and growing into flourishment." ${ }^{1339}$ However, the issue of "transplantation" was complicated, for it involved two questions: firstly, whether this foreign thought could influence native culture; and secondly, whether the native culture would be fundamentally transformed by the foreign stimulus and lose its identity. ${ }^{1340}$ According to Tang, it was not easy to evaluate the extent to which

\footnotetext{
${ }^{1335}$ Chen Yinke, “Lun Han Yu 論韓愈," in JMCB, 321.

${ }^{1336} \mathrm{Ibid}$. For the Buddhist influence on Zhu Xi's philosophy, see John Makeham, The Buddhist Roots of Zhu Xi's Philosophical Thought (Oxford: Oxford University Press, 2018).

${ }^{1337}$ Tang Yongtong, TYQJ, 273-276. Original Published on Xueheng 學衡, 12 (1922).

${ }^{1338}$ TYQJ, 277-281. Original published: Xueshu jikan 學術季刊, 1, no. 2 (1943).

${ }^{1339}$ Ibid., 277.

${ }^{1340}$ Ibid., 278.
} 
the native cultural landscape was changed by the new force. As he observed, there were always two voices about the transcultural experience of ancient China: some people believed that although the external forces like Buddhism were tremendous, China was nevertheless able to maintain its 'great harmony', namely, the unified orthodoxy of Dao. In this sense, China had never lost its cultural identity [wenhua tezhi 文化特質]. Other people, on the contrary, believed that Chinese thought had been entirely and irreversibly changed by Buddhism; none of the cultural forms (philosophy, literature, art, material life, etc.) in the post-Buddhism era could entirely abandon Buddhist elements.

Chen Yinke stood in between. He highlighted both the Buddhist impact on native traditions and meanwhile the unchanged orthodoxy of Confucianism-the Daotong - which, as Chen believed, was and should be kept alive and inherited. Tang, comparatively, placed less emphasis on the 'daotong' and stressed the balance in the "conflicting and compromising" mechanism of cultural transplantation. Showing a tendency toward cultural relativism, he merged the two discourses of 'Sinicization' and 'Indianization' together into a generalized panorama of the Sino-Indian dialogue and summarized it as a dynamic image consisting of three phases based on a "critical/functional view of cultural anthropology":!1341 first, assimilation based on superficial similarities [yinwei kanjian biaomian de xiangtong er tiaohe 因為看見表 面的相同而調和]; second, conflict based on dissimilarities [yinwei kanbujian de butong er chongtu 因為看見不同而衝突]; third, a new assimilation based on similarities on the level of truth [yin zai fajian zhenshi de xianghe er tiaohe 因再發見 真實的相合而調和]. ${ }^{1342}$

\footnotetext{
${ }^{1341}$ Tang criticized the other two popular theories: Grafton Elliot Smith's theory that different groups learned from one another somehow indirectly (in other words, cultural traits spread from one place to another, or are "diffused"), and other ethnologists' (like Lewis Henry Morgan's) theory of "independent invention" in which different groups had the capability of creating similar beliefs and practices. Both of these theories were criticized by twentieth century anthropologists. Tang, TYQJ, 278279. See George Marcus and Michael M.J. Fischer: Anthropology as Cultural Critique: The Experimental Moment in the Human Sciences (Chicago: University of Chicago Press. 1986), 1.

${ }^{1342}$ Tang, “Wenhua sixiang zhi chongtu yu tiaohe 文化思想之衝突與調和,” TYQJ, vol. 5, 281.
} 
Here, Tang's attitude slightly leaned towards the camp of Sinicization, with a more robust 'confidence' in native traditions. He kept a distance from Hu Shih's bitter resentment of China's Indianization and, compared to Chen Yinke, he tended to conclude that the cultural elements of China, through constant communication, were eventually capable of maintaining most of their own identities. He placed more emphasis on the process through which heterogeneous concepts, thoughts, and cultures influenced each other mutually and how the particularity of each cultural tradition was preserved. By this means, he tried to provide a historical explanation for the contradictions between the traditions. Accordingly, Tang showed less interest in comparing different cultures (only in his early statements about the Chan school that he posted at Harvard as cited below can we see such comparison) or generalizing about a universal human nature; rather, he was focused on understanding particular cultures in those cultures' own terms.

There were only few cases in which he made an overall comparison between Indian and Chinese Buddhism. For example, he said:

Buddhism has two systems, “dhyāna" [chan 禪] and "Prajñā" [bore 般若]. Dhyāna, based on India's theory of meditation, later attached to the Chinese concepts of the yin-yang and the Five Elements (陰陽五行) as well as the Daoist theory of “health maintaining" [yangsheng 養生]; Prajñā, which is based on the Indian Buddhist notion of "Dharma-body" [fasheng 法身], interpreted Laozi as the body of “Dao" [daoli 道體] by referring to the Learning of Laozi from the Han dynasty. ${ }^{1343}$

As indicated in this passage, the comparison between Indian and Chinese Buddhism might be possible, but only on a systematic level, and it must take Chinese local beliefs, such as Daoism, into consideration. To Tang, two traditions could be hardly directly compared but only could be analyzed together through historical traces and manifestations. Noteworthily, Tang emphasized the relationship between Buddhism and Daoist thoughts more than Confucianism-especially the Daoist cult and xuanxue.

\footnotetext{
${ }^{1343}$ Tang, “Hanwei foxue de liangda xitong 漢魏佛學的兩大系統.” TYQJ, vol. 5, 177. Original published in Zhexue pinglun 哲學評論, 7, no.1 (1936).
} 
He also insisted that there was a fundamental controversy between Buddhism and Confucianism. In one article, he criticized:

Today, associations named 'benevolent societies' have emerged here and there, advocating the principle of 'the unity of the three creeds.' They do not understand that Confucianism and Buddhism are the products of two different cultures; their conceptions, their methods, and their aims are totally contradictory to each other. How can these two thoughts be mixed unconvincingly? This kind of theory that adheres to superstitions is wild rumors of this age of disorder. 今日大江南北有所謂 「同善社」者出, 傳聞倡「三教合一」之說。不明儒、釋為二種文化之產物。其 用心, 其方法, 其目的, 均各懸殊, 安可勉強混同? 此類妄說, 附以迷信, 誠亂 世之妖象也. ${ }^{1344}$

In Tang's opinion, assimilation means the presence of a différend in Jean-François Lyotard's sense: two discourses that do not share the same premises and therefore never meet on the same ground. ${ }^{1345}$ The history of Chinese Buddhism is not a narrative of 'who wins-who loses' but rather indicates a developing mechanism for how different cultural factors can coexist in a Chinese intellectual system.

\section{Between Hua and Fan 華焚之別}

The notion of Sinicization forms the basis of the modern narrative of Chinese Buddhism. Although it has seldom been referred to directly, this notion is always behind the writings of Buddhist history. However, the narrative of Sinicization or Indianization itself must be historized and contextualized. It is one historical variety of a larger epistemological issue, that of the encounters among native cultures and foreign thoughts, traditions, and modern discourses.

The 'dialogue' or 'encounter' between China and India in pre-modern times was for the most part indirect. Records of embassies between these two countries demonstrate that a select few did interact with their counterparts, but such

\footnotetext{
${ }^{1344}$ Tang, “Ping jinren zhi wenhua yanjiu 評近人之文化研究,” TYQJ, vol.5, 275.

${ }^{1345}$ See Jean-François Lyotard, The Differ end: Phrases in Dispute, trans. Georges van Abbeele (Minneapolis: University of Minnesota Press, 1988).
} 
exchanges were the exception rather than the rule. ${ }^{1346}$ Even in the case of Buddhism, India's most famous and successful export to China, direct contacts conducted by missionaries and pilgrims were also limited over the course of Chinese history. The legendary status of these eminent monks, such Kumārajīva and Bodhiruci on the Indian side and Faxian (337-ca. 422), Xuanzang, and Yijing (635-713) on the Chinese side, indicate that they are famous in part because they were exceptional and rare. Historically, especially after the Tang dynasty, most of the accomplished Chinese monks spent their whole lives in China, and only few of them expressed an intention to make the trip to the Buddha's land, not only because the journey to India went through the Taklamakan desert and the Himalayas, and the sea was considered too treacherous and risky, but also because of the establishment of Chinese sacred sites in the Middle Land. ${ }^{1347}$

Most modern Chinese scholars, like their predecessors, had little direct connection with Indian Buddhism. They had never journeyed to India, accessed any religious relics, or built close personal relationships with Buddhist clergy. Although some of them did develop fluency in Indic languages, acquire primary Sanskrit or Palī texts, and have their own understanding of Indian religious tradition, their knowledge about India and non-Chinese Buddhism was merely based on textual sources. To them, the land of Buddha only existed in books or on paper. Many elements of Indian Buddhism-rituals, rites, religious practices, clerical life, and monastic institutions, which had drifted into China over the past thousands of yearswere peripheral questions. What they were really concerned about was also fundamentally different from the issues raised by the ancient monks. Thus, despite their emphasis on the 'authenticity' of Buddhist texts and sometimes on the fidelity of Chinese Buddhist teachings, they actually looked for answers to questions that were quite different from those of the believers in the Wei and Jin dynasties or of their Western counterparts.

\footnotetext{
${ }^{1346}$ Kieschnick and Shahar ed., India in the Chinese Imagination. 2 ${ }^{1347}$ Ibid.
} 
Although they kept using the dichotomy of 'Indian' and 'Chinese,' most of the modern Chinese historians avoided judging Chinese Buddhism's 'fidelity' to its Indian origin. Instead, they created a narrative of Sinicization to depict a blurred, dynamic process that obscured the boundary between India and China. These scholars inverted the old schemas to serve their own purpose - to present the orthodoxy of Chinese Buddhism as a legitimate source and component of Chinese culture and scholarship. Their studies were not aimed to recover the 'primitive' Buddhism, but to elaborate its proper $t i$ 體 and yong 用 in the Chinese historical context. Only some of the Buddhist scholars, for example, Lü Cheng, rejected the ti-yong thesis and demonstrated an advocacy for a "return to the sources."

The modern Chinese understanding of 'orthodoxy' reflected a tough reconciliation with Western values, trends, and thoughts. To the modern Chinese intellectuals, because of the gradual collapse of Confucianism, rebuilding the 'orthodoxy' of the Chinese nation was envisaged as providing answers to the thorny situation of China's modernization. The shifting frames and references among the modern intellectuals and historians as well as their involvement in certain contradictions can be interpreted as the 'unsettled' mind coping with both sides of every issue through a situational reflex. Characteristically, their 'will to orthodoxy' might be seen as a symptom of the "boundary anxiety" that led to determining the boundaries between tradition and modernization, and between China, India, and the West. $^{1348}$

In general, it was not the historical evidence, but rather the interpretations of the modern scholars, that formed the discourse of Sinicization. This seemingly abstract hermeneutic issue had concrete ramifications for the way scholars framed, conceptualized, and represented Chinese religious phenomena. However, none of the historians who utilized the narrative of Sinicization could escape the pitfalls of the discourse itself. As John McRae has summarized, these scholars actually assumed a silent, passive Buddhism that accepted the Chinese transformation without

${ }^{1348}$ Judith A Berling, The Syncretic Religion of Lin Chao-en, 10-11 
resistance. ${ }^{1349}$ These tendencies reinforced the 'difference' between Hua 華 and Fan 梵 and sometimes led to the 'fundamentalism' of both Buddhism and China. Moreover, they were unable to escape from the time they lived in: these scholars actually read the past in terms of the present and understood Chinese Buddhism as having its telos of becoming one part of the Chinese national culture. The meaning of history, therefore, was created by the historian in the course of his own reflections, which could in turn provide a richer comprehension of the present and the ability to make certain estimates about the future. In this sense, the narrative of Sinicization in modern China was not necessarily related to concrete historical phenomena that really happened but fundamentally to interpretations. As such, Buddhism 'had to' and 'was willing to' be Sinicized, either by changing Buddhism itself or by changing the native environment; otherwise, Buddhism would have been erased from Chinese history. From such historical experience and observation, the modern scholars established a mirror of Buddhism that reflected the current 'final image': the extremity faced by China.

\footnotetext{
${ }^{1349}$ John McRae, "State Formation, Indigenization, and Buddhism in East Asian History: The Theoretical Foundation," (2006): 66-67.
} 


\section{Conclusion: The Invention of Chinese Buddhism}

"The history of Chinese Buddhism is not easy to discuss." This is the first sentence written by Tang Yongtong in the epilogue to his book, Hanwei. Tang's statement is reasonable, especially when we consider the time in which he lived. The historiography of Buddhism, as a newly emerging domain, occurred in a polarized cultural landscape. Intellectuals, scholars, and religious elites were beset by contrary expectations regarding belief, power, and identity. On the one side stood 'traditional' China, which was waiting to be preserved and venerated; on the other side was arrayed a different set of orientations, towards modernity and the values attached to modernity. This polarity of expectations made the modern Chinese period a controversial time. During this special era, two strands of influential inquiry emerged: the making of 'religion' and the making of 'history' in the modern sense. Buddhism, as a multifaceted tradition with a cultural breadth caused by transgeographical diffusion, was attempting to re-establish its legitimacy within the discursive pyramid of science, religion, and superstition and to re-shape itself as a modern faith; meanwhile, history was experiencing dramatic transformation and redefining its boundaries, competence, and limitations, to explain changes in the past and in the present.

In the general context of the Buddhist revival and the transformation of scholarship, the first half of the twentieth century witnessed a 'historiographical turn' in the Chinese scholarship of Buddhism. Rendering Buddhism into China's past became an important topic in the domains of both Buddhology and historiography. As can be seen from the case studies in this dissertation, historians ordered the textual corpus of Buddhism, interpreted the changes and influence related to Buddhism, and narrated Buddhism into certain chronological and periodized frameworks. Being recorded, organized, and interpreted by both Buddhist scholars and professional historians, most of whom were 'outsiders,' the history of Buddhism 
relied less and less on faith, doctrines, and the teachings of masters, ${ }^{1350}$ but became a matter of historical reading and interpretation, affected by certain epistemological shifts, categories, notions, and discourses in modern historiography. Buddhism, in the academic context of modern China, was thus historicized, de-religionized, temporalized, localized and also 'Sinicized'.

At the same time, Buddhism was then pushed to its "rival of historiography," as Bernard Faure has observed from the modern Chan/Zen history, ${ }^{1351}$ and was forced to respond to history's inquiry. As the cases in this dissertation demonstrate, Buddhists had to response to the inquiries from the historians, about, for example, the authenticity of some 'basis' canons. This process looks like an 'arrogation of history,' which implies a fault line in people's understanding of Buddhism and a 'closure' of the Buddhist canon. However, as shown in historical writings on Buddhist themes, a new interpretative space also emerged. On the one hand, Buddhism was depicted and defined by history sometimes as a textual tradition, sometimes as an example of transcultural communication, sometimes as one segment of Chinese national history, and sometimes as a cultural element of 'Chinese-ness.' One the other hand, Buddhism also provided abundant new resources for historiography and challenged some of its presuppositions, such as the authority of the Dao, the Grand unity of Imperial China, and the setting of 'all-under-heaven.' Buddhism revealed the complex, multi-faceted, mixed, and inclusive nature of Chinese history, as well as the constant tension between old and new, internal and external, orthodox and heterodox in China's past.

This dual dimension indicates the core responsibility of the historiography of Buddhism in modern China - inventing 'Chinese Buddhism' in history. This responsibility is reflected in the modern researchers' discussions of the relationship between Indian Buddhism and Chinese Buddhism, their narratives of the Buddhist Sinicization, as well as their concern about the issue of geyi. To modern Chinese

\footnotetext{
${ }^{1350}$ Here I do not mean that there was no doctrinal progress. Studies of Yogācāra Buddhism marked one of the most noticeable achievements.

${ }^{1351}$ Faure, Chan Insight and Oversight, 92.
} 
historians and scholars, the history of Buddhism was not just a narrative about Buddhism, but also a narrative about what China is and what happened in China's past. Buddhism, to a certain degree, became one part of Chinese national history, under the rubric of 'Chinese tradition. ${ }^{1352}$ As many studies have proven, history is a potent agent of 'inventing nations'; ${ }^{1353}$ from this dissertation, we can conclude that, in twentieth-century China, historiography helped to 'invent' Chinese Buddhism: its 'past,' its 'truth,' and its manifestation in different times and conditions. This discursive construction behind the writings of the history of Buddhism, although sometimes alleviated, at other times reinforced, was persistent in the works of Liang Qichao, Hu Shih, Chen Yinke, Tang Yongtong, Chen Yuan, Taixu, and so on.

To be sure, there was a lasting anxiety about historicity among Buddhist clergy, and later among Buddhologists and Orientalists: they always attempted to identify the biographical data of the Buddha as a historical figure, the authenticity of scriptures, the lineage of sects, and so on. However, the 'historiographical turn' in the scholarship of Buddhism in modern China was very remarkable and unique. It is unique in that this discursive invention of 'Chinese Buddhism' is always related to the construction of China as a nation-state and the formation of Chinese cultural identity. As a result, it was always entangled with some political commitments, such as 'reform' and 'revival', as we see in the works of Liang Qichao, Taixu, and Hu Shih. At the same time, this 'Chinese Buddhism' is often discussed outside the realm of

\footnotetext{
${ }^{1352}$ For a long time, theorists like David Apter assumed that the modernization process was characterized by the gradual decline of particular traditions and the development towards a universal modernity based on the Western model. This assumption has been challenged since the 1970s by alternative concepts that take more account of the influence of traditional cultures, especially in the cases of India, China, and Japan. Here I interpret the construction of tradition as a conscious attempt to integrate elements of the past into a development program to form a modern nation or to create cultural identity and social solidarity. For relevant discussions on tradition, see David E. Apter, The Politics of Modernization (Chicago: University of Chicago Press, 1965) and Samuel N. Eisenstadt, Tradition, Wandel und Modernität (Frankfurt am Main: Suhrkamp Verlag, 1979).

${ }^{1353}$ For studies of the 'invention of nation', see Benedict Anderson, Imagined Communities (London: Verso, 1983); Eric Hobsbawn and Terence Rager ed., Invention of Tradition (Cambridge: Cambridge University Press, 1983); David Lowenthal, The Past is a Foreign Country (Cambridge: Cambridge University Press, 1985)
} 
'religion': Chen Yinke focused on the relationship between family beliefs and social environments; Tang Yongtong discussed the connection between Buddhism and local intellectual resources; Chen Yuan, as well, "wrote religious history as political history."

At the same time, in contrast to their Western and Japanese counterparts, who placed more emphasis on linguistic or philosophical approaches, Chinese modern scholars always insisted on a path of historiography that combined textual criticism and historical interpretation, which still toughly attached to the tradition of the Evidential Learnings and Confucian historiography. Unlike scholars in the West, these historians and scholars in modern China are faced with the task of stepping beyond the traditional writing of Buddhist history. They therefore made use of new historical theories, such as the modern framework of historical periodization, and analyzed a large number of historical sources that had rarely been read in the past. But they were also unable to break completely with 'tradition', including the tradition of historiography and also the tradition of the Classic Learning. Therefore, they were not like their Western counterparts, who quickly detached themselves from texts and "looked down" -- to adopt, for example, the anthropological or sociological paths to study Chinese Buddhism. Meanwhile, they could not really take the position of fully accepting Buddhism and placing it on an equal footing with modern ideas and theories. Thus, unlike the modern Japanese Buddhist scholars, these Chinese historians and scholars were unable to propose issues full of the sense of 'modernity', such as 'the spirituality of Buddhism and the merits and shortcomings of Chinese and Western philosophies. Carefully limiting itself to the hermeneutic readings of texts related to Buddhism, the historiography of Buddhism in modern China prudently historicized Buddhism in China's historical context and formed a 'secularized', understanding of Buddhism, replacing the traditional narratives of lineage or hagiography.

Overall, the inventing 'Chinese Buddhism' (both in a historical and a discursive sense), was the product of two distinct milieux: Buddhist institutions and 'secular' academia, within which there were always tensions between Buddhology 
and historiography. Meanwhile, this field was influenced by various intellectual trends, such as the Evidential Learning of the Late Qing period, Oriental studies from Europe, the modern historiography formulated gradually in early Republican China, and so on. Therefore, writings on the history of Buddhism differed considerably according to the researchers' academic backgrounds, political standpoints, institutional affiliations, and also sometimes their individual idiosyncrasies and dogmatic adherence. There were always tensions within this field, which were shown in the debates on the nature of Chinese religious and cultural heritage, progressivism and linear time, and the relationship between Han China and foreign influences.

The commonalities within the historiography of Buddhism were very fragile. However, there were still some concerns shared by all these modern Chinese historians and scholars. To grasp the shared ground, we need to return to the most fundamental question that those historians and scholars ask when they wrote about the history of Buddhism - namely, what is Chinese Buddhism? This question contains several concerns: first, how should we define the origin and authenticity of Chinese Buddhism? Second, how should we understand the general trend of Chinese Buddhism over a long timespan? Or, as Liang Qichao asked in his essay published in the 1920s: is Chinese Buddhism progressing or in decline? Third, how can we learn from the historical experience of Chinese Buddhism, namely, how can we understand the indigenization of foreign thought in a more general historical context? Different reflections and responses to these concerns shaped several general tendencies in this field.

\section{Authentic Buddhism}

The transcultural 'dialogue' or 'encounter' between China and India was, for the most part, indirect and limited. Historically, especially after the Tang Dynasty, most accomplished Chinese monks spent their whole lives in China, and only a few of them had expressed an intention to make the trip to the Buddha's land, not only because the journey to India was treacherous, but also because of the establishment of the 
Chinese people's own sacred sites in the Middle Land. After the Song dynasty, especially the establishment of native Buddhist sects, such as Chan and the Tiantai, the questions of the authenticity, which had puzzled Chinese Buddhists for a long time, gradually faded from view. In the late Qing, this issue, with the increasing interests in Buddhism among literati, was raised again. However, unlike their predecessors, historians and scholars in this period focused their attention on the textual authenticity of Buddhism, such as the authorship, version, and dating of compilation of a particular Buddhist text, rather than on whether this text has the accurately conveyed the Buddha' teaching.

As many scholars have pointed out, modern Buddhology has given overriding primacy to textual sources, including both 'scriptural' texts and 'noncanonical' or 'secular' ones that were divorced from religious life and actual Buddhist practices. ${ }^{1354}$ Through discovering, editing, and translating the literary treasures of Buddhism, researchers could produce knowledge of Buddhism without having any connection to any monastery. To most of the historians and even to some scholars with Buddhist faith, Buddhism did not amount to ritual practices, or monastic regulations, or philosophical system, but instead was presumed to be a set of 'historical materials. ${ }^{1355}$

This textual attitude ${ }^{1356}$, which once had facilitated the invention of Buddhism as an Oriental religion, as Tomoko Masuzawa argued, provided the West with authority and supremacy in Buddhology, with their housing of 'oriental' literature in the libraries, museums, and research institutes in Europe as well as their exclusive knowledge of linguistics and philology. However, in the context of modern China, the 'obsession' with historical texts, although it might have had some connection with

\footnotetext{
${ }^{1354}$ J. W. de Jong, "The Study of Buddhism: Problems and Perspectives," in Studies in Indo-Asian Culture, vol. IV, de. P. Ratnam (New Delhi: 1975), 14. Also Gregory Schopen, Bones, Stones, and Buddhist Monks: Collected Papers on the Archaeology, Epigraphy, and Texts of Monastic Buddhism in India (The University of Hawaii Press, 1997), 2-3.

${ }^{1355}$ Here I contend that Buddhism as a tradition is 'reinvented' in the writings of Buddhist history. By reinvention I mean a process by which lived, heterogeneous traditions would be reduced to a few aspects and thus homogenized. By doing so, a "continuity with a suitable historical past" would be established. See Hobsbawm and Ranger, The Invention of Tradition, 1.

${ }^{1356} \mathrm{I}$ borrow this term 'textual attitude' from Said's Orientalism, 115, 93.
} 
the 'Orientalism' invented by the Europeans, ${ }^{1357}$ designated a complex but systematic manufacture of identities for 'China', instead of for Buddhism. The Chinese historians wanted to understand not the doctrinal history of Buddhism or Buddhism itself but rather 'China' and its historical and cultural past that existed in the collective imagination of the Chinese.

Because of this stand, Chinese historians turned to a body of data that had been overlooked or deliberately ignored by their Western counterparts-the texts written and produced in China. Some texts in this category had been carefully preserved, canonized, and heavily edited or commented upon by the monasteries but seldom had drawn attention from outside Buddhist circles, for example, the biographies of monks, Buddhist bibliographies, and some Chinese Buddhist treatises. Some had been read by historians but not were not considered as Buddhist historical writings, such as the records in the Official histories that related to Buddhism. And some texts had been mostly unedited or even 'unread' before, such as some manuscripts discovered in the cave of Dunhuang or the Sayings Records of the Chan masters from the Grand Secretariat collection. Behind these activities dealing with textual data lay two assumptions shared by these historians. Firstly, texts, no matter what ideological or moral implications they presumed, were treated as containers of historical information, which were able to be utilized by historiography. Secondly, even though these texts were not 'authentic' Buddhist scriptures, they were the product of historization and were seen as having emerged under certain social, economic and political circumstances; or at least having been, when they were produced, 'normative' expressions, which were aimed variously at setting ideals that the authors wished their readers to follow, establishing doctrinal and sectarian orthodoxy, inventing certain kinds of tenets and conventions, or responding to other practical concerns. Therefore, these texts were mirrors of the more general cultural landscape in China's past.

\footnotetext{
${ }^{1357}$ The teachers of some of the historians, such as Chen Yinke, Tang Yongtong, and Lü Cheng, were actually Orientalists; they might have directly influenced the research attitude of these Chinese historians. For more details, see chapter 3.
} 
Referring to the written records of Buddhism in ancient China, modern historians constructed a Chinese Buddhism, or, a Buddhist China. Bearing in mind the assumption that the history of Buddhism is essentially a 'literary artifact' (just like the 'records' they read), they suggested that the understanding of China and Chinese Buddhism was reliant largely on reading historical texts, especially those texts translated, commentated upon, modified, and created by the Chinese. Similar to 'the history of religions school' [Ge. Religionsgeschichtliche Schule], ${ }^{1358}$ these Chinese historians also emphasized a method of 'high criticism,' which assumed "a world behind the text." As a research domain sui generis, the modern Chinese historiography of Buddhism believed all the texts to be interwoven with each other, forming together the world of Chinese Buddhism. In this sense, there was not a world within the Tripitaka (the equivalent to 'the world of the Bible' as it is used in theology). For these historians, the real concern in their historical writing was not to construct the world of the Tripitaka, or the authentic, if not to say correct, meaning of Buddhist doctrines, but to establish a historical realm in which Buddhism could be properly located. Therefore, they knew Buddhism in texts and 'contexts,' but not 'Buddhism in itself. $^{1359}$

This historiographical attitude also brought to Buddhism - a tradition with a 'myth of authenticity' - challenges from historical objectivism and the corresponding epistemological neutrality. In keeping with science-based rationalism, Buddhologists and Orientalists in the West demonstrated a suspension of judgment and replaced the supreme ideal in religion—no matter whether religious or moral—with strict

\footnotetext{
${ }^{1358}$ The Religionsgeschichtliche Schule, beginning in 1903, refers to a group of German Protestant theologians who consistently applied the history of religions method to the interpretation of the Bible. This school of thought originated at the University of Göttingen and was made up of Hermann Gunkel, Wilhelm Bousset, Johannes Weiss, Ernst Troeltsch, Wilhelm Wrede, Heinrich Hackmann, and Alfred Rahlfs. The main method they used was 'historical-criticism.' See Gerd Lüdemann (ed.), Die „Religionsgeschichtliche Schule“: Facetten eines theologischen Umbruchs (Frankfurt am Main: Peter Lang, 1996); Carsten Colpe, Die religionsgeschichtliche Schule: Darstellung und Kritik ihres Bildes vom gnostischen Erlösermythus (Göttingen: Vandenhoeck \& Ruprecht, 1961).

${ }^{1359}$ The notion 'Buddhism in itself' I use here comes from D.T. Suzuki's critique of Hu Shih. Suzuki criticized Hu as knowing nothing about 'Zen in itself.' See D.T. Suzuki, “Zen: A Reply to Hu Shih,” Philosophy East and West, 3,1 (1953): 25.
} 
presentations of facts. This position was partly absorbed by modern Chinese historians. ${ }^{1360}$ However, as shown in this dissertation, they more or less had realized that pure objectivity was not, and never would be, possible, although they did not acknowledge this publicly. Buddhism was not only an 'object' but a living tradition that was constantly worshiped and had infiltrated the words, actions, and thoughts of every single Chinese, including themselves. Therefore, as observers, these historians were also part of their observation.

The reflections on historical objectivity can be observed in the works of many historians, such as Chen Yinke, Tang Yongtong. ${ }^{1361}$ Their writings showed that the historiography of Buddhism - its terminology, methods, and concepts-was forming under the rubric of what Gadamer called a "history of effects." As mentioned before, all the historians who endeavored to write the history of Buddhism were trying to build links between the past and present, and between subjects and objects, either through causal explanations or 'empathic understanding.' Exploring and reestablishing the past is a 'hermeneutical act' that is dialogical, implying reciprocity between the reader and the text of tradition. In the practice of writing the history of Buddhism, Buddhist scholars, although they felt the constant temptation to reapproach the 'truth' based on textual or 'objective' evidence, could not easily get rid of their sectarian biases and their expectation of reforming Buddhism. Professional historians, although they knew better the critical power of 'objectivism' and were more comfortable with it, were hesitant to embrace its effects, when thought about the inertia of traditional chinese scholarship or reflected on history, nation, and culture. In both cases, historians and Buddhist scholars were trying to fuse the past with their 'horizon of expectation'. In this sense, the emphasis on the authenticity of Buddhism can not be reduced to a search for objectivity, but is often an expression of historiographical independence and the historian's sense of responsibility, as well as a response to modern knowledge systems and to scientific discourses.

\footnotetext{
${ }^{1360}$ For example, Fu Sinian and the School of Historical [Shiliao xuepai 史料學派].

${ }^{1361}$ I have cited these important paragraphs in the chapter 5 of 'Geyi.'
} 


\section{A Modern Narrative}

If professional historians in modern China were not concerned with Buddhism per se, nor were they interested in the study of Buddhism in terms of doctrine (or even, like $\mathrm{Hu}$ Shih, rejected Buddhism), then what were their expectations? The answer may vary from case to case; however, there are still some notable common points. First, the historiography of Buddhism was conceived by modern Chinese historians as a practice of 'intellectual' history; here, the religiosity of Buddhism was enfeebled and framed into a certain kind of 'philosophized' expression. The Buddhist 'essence,' which had once been envisioned as ahistorical, was historicized, for it was believed that it had been thoroughly modified by the native cultural inheritance of China. In this sense, 'essence' was then replaced by historical truth. By replacing religious truth with historical truth, the knowledge of Buddhism was no longer monopolized by the monastic community, nor was it related to religious practice, monastic life, and rituals, but rather it was established alongside other 'secular' or 'scientific' disciplines in the modern academic system. Second, underlying these different writings were always narrative structures that were related to certain theoretical discourses and ideological settings. To be sure, narrative structures also existed in pre-modern texts. However, instead of telling the stories of 'masters'-namely, recalling the past in hagiographical or biographical genres or describing the decline of Dharma and the fulfillment of the Bodhisattva's path-the modern historiography of Buddhism constructed one kind of normative narrative, applying a general or universal framework of periodization to Buddhism. This framework included elements such as the progressive developmental pattern of historical process, the linearity of time, the formation and re-formation of tradition, and so on. Third, through detailed investigation of the relationship between Buddhism and other native intellectual resources, such as Confucianism, Daoism, and so on, historians, as narrators, also tried to identify the traditions they belonged to and to construct their identities. Therefore, historians were not passively following their sources, but interpreting 
them and producing a "self-understanding." 1362 They assessed the impact of Buddhism on China and the historical process of Chinese understanding and assimilation of Buddhism from a comparative perspective to integrate Buddhism as part of Chinese history. By doing so, to a certain extent they cut the ties between Chinese Buddhism and Indian Buddhism and emphasized the subjectivity of Chinese Buddhism. Thus, their conception of Buddhism sometimes seemed too radical to be widely accepted by the Buddhist community. However, this approach echoed the demands of nationalist historiography at the time and became an important practice in the construction of national identity.

Focusing on issues that had long been ignored in previous studies-for example, the relationship between religion and politics, the faith background of royal clans, the religious life of literati, and so on-historians developed several methodological tools to identify and analyze previously neglected dimensions. With these tools, historians who were outsiders to Buddhism could organize, explain, and interpret Buddhist texts and produce knowledge of Buddhism. However, although most of the historians discussed in this dissertation had stepped outside the shackles of sectarian thinking, their writings could still contain a "teleological fallacy" (in Benaud Faure's word) if they read the past in terms of the present. Even in the writings of Buddhist scholars who advocated a 'return to genuine Buddhism,' a certain 'telos' existed. For example, as we have seen, behind Lü Cheng's view that Buddhism had had its zenith in its earliest or most primitive form lay in fact a very modern understanding of Buddhism.

However, the teleological overtone in these writings was not the enemy but rather a remarkable characteristic of this field of research, indicating a "fusion of horizons, not escaping horizons." 1363 The question asked by Liang Qichao-is Chinese Buddhism progressing or in decline, when compared to its Indian origin? - which seems like a question about Buddhism's past, arose along with the historian's

\footnotetext{
${ }^{1362}$ Paul Ricoeur, Hermeneutics and the Human Science, ed. and trans John B. Thompson (Cambridge: Cambridge Press, 1981), 142.

${ }^{1363}$ Charles Taylor, "Comparison, History, Truth," in Myth and Philosophy, ed. David Tracy and Frank Reynolds (Albany: State University of New York Press, 1991), 42.
} 
understanding of modernity, especially the discourse of progress and evolution. In modern China, "the pull of modernity" was dominant, both in academia and other public spheres. ${ }^{1364}$ As shown, for example, in Liang Qichao and Taixu's writings, the evolutionary mode of narrative was tacitly used, whether scholars' positions were 'more secular' or 'more religious.' This view of progress of the history of Buddhism also led to a prevailing, if not monopolistic, discourse: the Buddhist revival. It proposed that although Buddhism was forced to abandon some of its tenets and conventions to adapt to the new era, modernization was good, since it would bring about 'revival' for Buddhism and further promise a better future.

Modern theories, such as progressivism, also caused a predicament to Buddhism. Obviously, Buddhism, both on the doctrinal and historical levels, could hardly fit into the model of evolution or progress. Therefore, we can often see in the works of modern historians and scholars a tendency toward 'geyi' - namely, their practice of forcibly applying modern theories to their research object. The crux of this practice, however, is neither how these modern figures thought about tradition nor whether they correctly understood the theory of modernization, but what they really needed from the modern theories, which questions they asked, and what kind of answers they were looking for. For example, the pattern of 'developmental stage' in the writings of Liang Qichao and Taixu imposed certain universal principles derived from the historical experience of other traditions on Chinese Buddhism, or portrayed the transformation (or revolution) of Chinese Buddhism as a predetermined scenario. It was, fundamentally, not a description of what had happened, but an expression of their expectations for 'revival' itself. Actually, when scholars made the judgment of a Buddhist revival, they already had a sort of 'criterion' [Maßstab], which in Gadamer's sense was the twofold one of correspondence and coherence: namely, on the whole, their historical interpretation was considered to be consistent with the content of history and can be defended by historical evidence; also, it was guided by the "anticipation of perfection (or

\footnotetext{
${ }^{1364}$ Ritzinger, "Anarchy in the Pure Land: Tradition, modernity, and the reinvention of the cult of Maitreya in Republican China," 7-11.
} 
completeness)" according to which the historical text one was interpreting were assumed to form a perfect unity of meaning. ${ }^{1365}$

Due to the gap between the predetermined 'criterion' and the reality these historians and scholars faced - a gap that had often been described and discussed as the relationship between lun 論 and shi 史, there were always paradoxes in their writings about Chinese Buddhism. For example, Taixu, although he felt skeptical about modernity and always tried to return to the perfect, superior Dharma essence, emphasized the 'modern characteristics' of Buddhism and tried to reform and change Buddhism to adopt to the new environment. Liang Qichao, as the representative figure of 'newness' and 'revolution,' on the other hand, never labeled Buddhism with the word "reform" and stressed in several places that Buddhism itself need not to be reformed but should be carefully preserved as a valuable cultural heritage.

\section{Transcultural Geyi}

The notion of geyi forms the basis of the modern narrative of Chinese Buddhism. Although seldom referred to directly, reflections on this notion were always behind the writings of Buddhist history. Geyi, in the modern historiography of Buddhism, was interpreted and discussed in various ways, sometimes as a historical phenomenon, sometimes as a hermeneutical strategy, sometimes as a method for the indigenization of foreign thoughts.

Although using the dichotomy of 'Indian' and 'Chinese,' most modern Chinese historians avoided judging Chinese Buddhism's 'fidelity' to its Indian origin. Instead, they created the narrative of Sinicization to depict a blurred, dynamic process of transcultural contacts, obscuring the boundary between India and China. By doing so, they inverted the old schemas to serve their purpose-to present Buddhism as one example of communication between civilizations. Chinese Buddhism, whether it was faithful to its Indian Buddhist origins or not, could be read as the product of the interaction between different intellectual traditions and as an embodiment of the

${ }^{1365}$ Hans-Georg Gadamer, Truth and Method (London: Bloomsbury, 2004), 279. 
diversity of Chinese culture. In this sense, writing the history of Buddhism was not aimed to recover 'primitive' Buddhism, but to elaborate on the proper relationship between 'body' [ $t i$ 體] and 'function' [yong 用] in the Chinese historical context. ${ }^{1366}$

Reflections on the issue of geyi were deeply related to modern historians' thinking about the challenge from Western learning. Just as Buddhism had profoundly transformed the Wei and Jin society, new theories from the West and Japan brought not only technical knowledge but also the pressure to fundamentally transform Chinese society, government, military, and also ideology. Intellectuals, such as Yan Fu and Zhang Zhidong, had realized that a new world order was being established and that the Chinese needed to learn from the foreigners whom they used to call yi 夷—'the barbarians.' Facing this situation, Buddhism became almost the only relevant experience that those modern chinese could mine from their history. To those modern Chinese historians, such as Chen Yinke, Chen Yuan and so on, the Sinicization [huahua 華化] of Buddhism signified particular forms of cultural production, which associated historical precedents with new intellectual dispositions, maintaining the independence of native culture and also securing broader social order. They believed, neither conquering the 'foreigners' nor submitting to their influence, the success of Chinese Buddhism resulted from an inner transformation, a process of making self-ness, which was based on re-fabricating various cultural elements (language, belief, rituals, and so on) in the local context rather on brutally replacing the existing intellectual system and identification of individuals with new structures of faith, ethics and orders. ${ }^{1367}$

\footnotetext{
${ }^{1366}$ As investigated in the Chapter 5, many historians in modern period, such as Tang Yongtong, had the dichotomy of ti-yong in mind. Only some Buddhist scholars, for example, Lü Cheng, rejected the tiyong thesis and demonstrated the ultimacy of the Indian origin of Buddhism.

${ }^{1367}$ This position of viewing foreign thought as passively being Sinicization is evident in the studies of these modern Chinese historians. For example, Chen Yuan's famous book on the issue of huahua, A Study of the Sinicization of the Westerners in Yuan Dynasty [Yuan Xiyuren huahua kao 元西域人華化考] has been criticized by Western readers for overemphasizing the power of local traditions. See Frederick Mote, "Western and Central Asians in China Under the Mongols. Their Transformation into Chinese. By Ch'en Yuan. Translated and annotated by Ch'ien Hsing-Hai and L. Carrington Goodrich. Monumenta
} 
In the modern period, a time of transition, the gap between the old and the new, and between China and the West, sometimes seemed too wide to bridge. How to deal with new theories then became a primary issue in academia, including the domain of modern Chinese historiography. To some historians (for example, Liang Qichao), the history of Chinese Buddhism proved China's capability to establish standards, set frameworks, utilize foreign resources actively, and finally establish the triumph of the native culture over them. ${ }^{1368}$ Behind this standpoint was, fundamentally, the popular logic of 'Chinese Learning as substance, Western Learning for application' [zhongti xiyong 中體西用], which was closely tied to a view that knowledge, including historical knowledge, is neutral and functional, and can be used both to destroy traditions and to protect them. Other historians, however, such as Chen Yinke and Tang Yongtong, read from the history of Buddhism that people's behavior, practices, and beliefs are not law-like or value-free, nor do they contain any preset 'superiority,' but rather are determined and formed by specific historical contexts. Therefore, every tradition has its particularity, and the task of history, then, is to reveal such particularities and the possible commonalities between them.

Through their discussion of the role Buddhism played in Chinese history, these historians applied their understanding of geyi to the more general process of cross-cultural engagement, reflecting on the relationship between different cultures, different traditions, and different forces in society. ${ }^{1369}$ Behind their comparative

\footnotetext{
Serica Monograph XV. Los Angeles: Monumenta Serica at the University of California, 1966," in The Journal of Asian Studies, vol. XXVI, no.4 (1967), 690-692.

${ }^{1368}$ One example is Liang Qichao's nationalist narrative of Buddhism. For the issue of national identity, see J. R. Levenson, Modern China and its Confucian Past: The Problem of Intellectual Continuity (Berkeley: University of California Press, 1964); Prasenjit Duara, "De-constructing the Chinese nation," in The Australian Journal of Chinese Affairs 30 (1993): 1-26; Henrietta Harrison, China: Inventing the Nation (London: Arnold, 2001). Also, Frank Dikötter's analysis on Chinese racial theories in The Discourse of Race in Modern China (London: C. Hurst \& Co., 2015).

${ }^{1369}$ This view can also be found in the West from the twentieth century. One of the representative advocates of the particularistic view of knowledge is Charles Taylor. See Charles Taylor, "The Politics of Recognition," in Multiculturalism and "The Politics of Recognition" (Princeton, NJ: Princeton University Press, 1992); also, Source of the Self: The Making of the Modern Identity (Cambridge, MA: Harvard University Press, 1989).
} 
approach, there was also a 'geyi' in their minds. This idea of 'geyi' was not simply comparison or trans-conceptual loan, but rather an "empathy" towards traditions as explained by Roxanne Euben and others, it was "attempts to cross divides of meaning by acknowledging and appropriating their own prejudices within a language that evolves to accommodate and ultimately transform disparate understandings into mutually intelligible meanings." ${ }^{1370}$ Realizing the very ground of geyi, an intellectual similarity between the 'abstract ideals' of human beings, historians could combine universalism and particularism together for geyi assumed that the phenomenon that every culture has its particular cultural norms is universal. Just as the historical experience of Buddhism proved, the proper application of geyi could help Chinese people to "absorb foreign doctrines on the one hand, while not forgetting the status of their own nation on the other hand." ${ }^{1371}$

\section{From Buddhism to Chinese Buddhism}

Throughout the twentieth century, there were endless discussions on the name, origin, nature, and formation of Chinese Buddhism. Even today, there is still no consensus on how to define Chinese Buddhism; for example, some thinkers have advocated for the abolition of the name Chinese Buddhism [zhongguo fojiao 中國佛教] and suggested replacing it with Han Buddhism [hanchuan fojiao 漢傳佛教]. ${ }^{1372}$ Historians and scholars in modern China reflected on this issue from a historiographical perspective. If, as these historians basically accepted, Chinese Buddhism was an outcome of indigenization, was it still faithful to the Buddha's teaching, or was it fundamentally a native production? And what was the meaning of this Sinicization, historically? Focusing on the issue of how Buddhism became

\footnotetext{
${ }^{1370}$ Euben, Enemy in the Mirror, 37. 1371 “一方面吸收外來之學說, 一方面不忘本民族之地位.” Chen Yinke, “Feng Youlan Zhongguo zhexue shi xiece shencha baogao 馮友蘭中國哲學史下冊審查報告,” in JMEB, 282.

${ }^{1372}$ For example, Master Shengyan prefers to use the term 'Hanchuan fojiao' 漢傳佛教, which emphasizes the importance of either Han culture or Chinese characters 'hanzi' 漢字 in the dissemination of the tradition throughout East Asia while avoiding the possible political connotations of the term Chinese Buddhism [Zhongguo fojiao 中國佛教].
} 
Chinese Buddhism, different perspectives led to several different tendencies in this field in general.

1. The Theory of Evolution

In the back-and-forth discussions, there seems to have been 'the differénd', in Lyotard's sense, among Liang Qichao, Hu Shih, and Taixu. However, they stood very close in their enthusiasm for narrating Buddhism with a certain kind of continuity and causality. These historians, regardless of their frame of reference or their standards of evaluating the role Buddhism had played in China's past, agreed that the transformation of Buddhism brought by indigenous Chinese traditions has promoted Buddhism to a new stage of development. The understanding, interpretation, and imaginative creation of Buddhism by the ancient Chinese breathed fresh air into Buddhism, a tradition that had been experiencing dramatic decline and even been threatened with extinction in India. In their view, the Sinicization of Buddhism had allowed this old wisdom to continue in the 'Middle Kingdom' and the Chineseinfluenced East Asian region for thousands of years.

To Liang Qichao, Chinese Buddhism's emphasis on Mahāyāna teachings and the establishment of the Chinese indigenous Buddhist traditions based on Mahāyāna, such as Chan and Tiantai, reflected the 'progressive' nature of Buddhism - a movement from superstition to intellectual belief [zhixin 智信], from ritual to spirituality, and from religion to philosophy. ${ }^{1373}$ Taixu, on the other hand, saw Chinese Buddhism as an important step towards the globalization of Buddhism. In his view, the historical trajectory of Buddhism could be depicted as an 'evolutionary' path from the Buddha's personal enlightenment to the awakening of his believers and then to the liberation of all sentient beings worldwide; thereafter, the Pure Land on Earth would be actualized. The introduction of Buddhism from India to China, the reformation and development of Buddhism conducted by Chinese Buddhists, and the emergence of Buddhism as a world religion were the necessary stages of this kind of Buddhist evolution. Hu Shih, despite his skepticism and even antipathy toward

\footnotetext{
${ }^{1373}$ Liang, “Lun Zhongguo xueshu sixiang bianqian zhi dashi,” in Xia Xiaohong 夏曉虹 ed. Xinshixue 新史學 (Beijing: Shangwu yinshu guan, 2015), 210-215.
} 
Buddhism, read in the historical experience of Chan Buddhism the possibility of a 'cultural Renaissance' of China. As he suggested, the emergence of Chan was the evolved form of Buddhism (he stressed that Chan is not Buddhism at all), since the demons and gods of Indian beliefs were abandoned and replaced by a practical, secularized spirit. This was, in Hu's 'evolutionary vision [jinhua de yanguang 進化的 眼光], a discursive revolution that brought 'Indianized' China back to the rational tradition of the pre-Qin era. Buddhism, as a religious faith, would inevitably be replaced by science and reason. And this path of Chan, he believed, would lead China once again to embrace science, reason, and other modern values.

Referring to external 'universal systems' hanging over the evidential level of 'facts,' their theoretical investments constructed a 'meta' structure in their studies and further burdened their historical writings of Chinese Buddhism. In Liang's case, especially in his early writings, the structure behind the historical changes in Chinese Buddhism was a linear, mechanical framework established by the universal order of progressivism; to Hu Shih, his pragmatism and his vision of a Chinese Renaissance prompted him to see Chinese Buddhism, especially Chan Buddhism, as the privileged expression of a Chinese humanism. Taixu's reflection on Buddhist history followed a unique evolutionary order that was legitimized by the doctrine of 'the stages of cultivation' [xiuxing cidi 修行次第] and the promised fulfillment of the 'pure land.' The histories these scholars wrote, which can be categorized as 'new historiography,' are more or less narratives guided, if not controlled, by predetermined theories or frameworks.

Their perceptions of the universal framework in history motivated these three researchers to participate in global conversations on both scholarship and religion; paradoxically, however, it reinforced their nativist outlook on Chinese Buddhism. They interpreted Sinicized Buddhism as an instrument that emancipated Buddhism from its exotic, superstitious, and tantric early form and considered it as a progressive, revolutionary manifestation of the 'Chinese mentality. ${ }^{.1374}$ To Liang and

\footnotetext{
${ }^{1374} \mathrm{Hu}$ Shih, "The Development of Zen Buddhism in China," The Chinese Political Science Review 15, 4 (1932): 481.
} 
Taixu, Chinese Buddhism was a successful combination of Indian and Chinese cultures, strengthening each other and lighting up the intellectual history of China; to Hu Shih, it overcame the shortfalls within the original Buddhist doctrines and proved the superiority of the Chinese essence. Therefore, the emergence and gradual independence of Chinese Buddhism, according to these scholars, yielded an evolved, developed version of Buddhism. Although this view led them to different conclusions, all retained 'China' as the nucleus of their overall narratives and the yardstick of their historical judgments.

\section{The Theory of Cultural Transplantation}

Being aware of the problem of universalism as well as the dilemma of applying new theories to traditions, some historians turned their eyes to the historical phenomena that defined the particularity of China. Chen Yinke, Chen Yuan, and Tang Yongtong were three representative historians belonging to this group. To them, there was no convincing evidence of the smooth evolution of 'essential' traditions (Buddhism, Daoism, Confucianism, etc.) from a historical perspective; the changes and transformation of these traditions in China's past could not match any pre-existing, universal framework. At the same time, Liang Qichao's questions-is Buddhism progressive or regressive (Here obviously Liang meant the historical process through which Indian Buddhism was 'Sinicized' to become Chinese Buddhism)? Or is it an innovation of Indian Buddhism or a disloyalty to the original teaching? - were absent from the visions of historians like Chen Yinke and Tang Yongtong. For them, such questions were inherently untenable because of their 'geyi' premise. These historians did not place the historical experience of Chinese Buddhism into a progressive framework, viewing it as a stage in the development of religion; rather, they portrayed the Sinicized Buddhism as the result of cultural 'transplantation' - the arrival of one intellectual resource into another cultural landscape, where the two mutually understood each other, adapted to each other and influenced each other, bringing about change on both sides. In the end, as the example of Buddhism demonstrated, it was not one tradition that triumphed over the other, but all traditions together that constitute the 'national spirit' of China. 
In their writings, therefore, Buddhism did not have an 'essential' form; it could only be understood historically and in contexts. As other traditions, Buddhism was not a clearly defined, changeless entity: if it was shared by certain members of society while rejected by others, then Buddhism in China's history was one segment of a fluid network of relationships, belonging to an ongoing process. It was not equivalent to the teachings of the Buddha, nor was it a Chinese creation, but rather a particular manifestation of certain abstract ideas in a concrete social context and cultural atmosphere. The Sinicization of Buddhism, thus, was read by these historians as an example of the equality, inclusiveness, and relativity within and among cultures.

These historians believed, inasmuch as a universal principle or absolute truth is fundamentally incompatible with history, the mission of historians, then, was to adequately understand, re-express historical 'facts,' interpret them, and further discover, or uncover, an 'abstract ideal' from particular events, individuals, and changes. In contrast to the previous group of scholars who applied the evolutionary theory to the history of Buddhism, these historians were concerned not with longterm tendencies, but with the ruptures and inconsistencies in history. Meanwhile, they tried to define some kind of continuity behind these ruptures. Revolving around their understanding of the particularity and continuity of Chinese cultural tradition, these historians chose Buddhism, an external force that interrupted the continuity of Confucian tradition -- to demonstrate how the cultural sustainability of China was maintained through, for example, the powerful but also problematic ability of 'matching concepts.' Placing Chinese Buddhism in the 'national cultural history,' these historians acknowledged its departure both from Indian Buddhism and from other mainstream Chinese thought. However, they also regained the innate, timehonored sequence of history -- in China's case, the national spirit -- behind this cultural departure, and interpreted it as a facet of a particularity which universally existed in history. ${ }^{1375}$ To these scholars, divergences and alterations might indicate

\footnotetext{
${ }^{1375}$ Qian Mu 錢穆, “Yi Ciyu 憶賜予,” Yanyuan lunxue ji 燕園論學集 (Beijing: Beijing daxue chubanshe, 1984), 26.
} 
the transformation of milieu, the exchange between intellectual resources, or the revolution of scholarship. Therefore, phenomena like Zhi Dun's 'geyi', or the production of Chinese Buddhist scriptures, such as The Treatise of the Awakening of the Mahāyāna Faith, in Chen and Tang's writings, were neither a 'progress' of Buddhism or a deviation from the Buddha's original saying, but rather parts of the dynamic process of the formation and continuation of national culture.

Combining facts with interpretation, this pattern of historiography applied the methods of high criticism to historical materials, comparing parallel versions of texts in terms of style, content, and background in order to isolate accretions, different strata, and heterogeneous components. This position allowed them to distance themselves from sectarian bias or predetermined theoretical settings from an outsider's viewpoint. However, it would be an oversimplification to interpret this stand as merely a warning to be on one's guard against any subjective opinions or judgements. No witness simply hands down a complete, photograph-like description of an event; rather, he selects, alters, interprets, and rationalizes. Insofar as this is true, an element of judgement is necessarily present in the writings of these historians. But as F. H. Bradley once perceptively pointed out, judgements are not mere random inventions or isolated occurrence of thought. They presupposed other judgements, beliefs, and opinions as the background against which they occurred and in light of which they had meaning. ${ }^{1376}$ In this sense, this attitude of historiography, following the "principle of rarefaction, ${ }^{, 1377}$ was never neutral or objective but had certain ideological effects. Thus, as described in the former cases in this dissertation, although well hidden, the writings of these historians on the history of Buddhism are always expressions of their views and reflections on the status quo. This is the reason why we can always find political implications in their writings of the history of

\footnotetext{
${ }^{1376}$ See F.H. Bradley, “The Presupposition of Critical History,” in Collected Essays (Oxford: Oxford University Press, 1953), I, 1-53.

${ }^{1377}$ As Foucault argued, a tradition and the canon that represents it are a result of limitation, of a 'rarefication' of discourse. This represents an ascent of an ideology, of an 'essential difference'. Michel Foucault, The Order of Discourse, in R. Young ed., Untying the Text: a Post-structural Anthology (Boston: Routledge \& Kegan Paul, 1981), 67.
} 
Buddhism -- that is, what Chen called 'jituo' [寄託] or Chen Yuan called 'the meaning of historiography."

\section{The Theory of Deviation}

While historians were more prone to learn 'about' Buddhism, Buddhists, such Lü Cheng, were intent on learning 'from' Buddhism. Buddhist scholars were easily distinguished from historians who lived a 'secular life'. However, there were differences within them as well. In the modern era, a group of influential Lay Buddhist scholars emerged, and Lü Cheng was one of them. Although Lü Cheng's understanding of the history of Buddhism was influential in monastic circles, his ideas differed from the mainstream view of the Buddhist community. Meanwhile, there were conceptual coincidences between Lü and his counterparts in the departments of history, despite his distance from academia; for example, as I analyzed in the seventh chapter, both Lü and Hu Shih stated that Chinese Buddhism was not 'true' Buddhism. Because of this complex and delicate position, Buddhist historians such as Lü Cheng have often been overlooked by past research. However, his study is important, for its critiquing preconceptions and assumptions about Buddhist traditions, which had been left untouched in Buddhist reflections on its own history.

Although he had his own sectarian bias, Lü's history of Buddhism was compiled in a very positivist, rigorous way, putting a premium on direct access to a large amount of primary resources as well as proper critical skills. Similar to most scholars who studied the history of Buddhism at the time, the core of Lü's writing was texts-authentic scriptures, qua canon, sacred books, etc.-behind which the essential character of Buddhism was believed to be preserved. Lü's emphasis on textual evidence and his sensitivity to the nuances between languages is similar to the comparative linguistic path advocated by Chen Yinke. However, unlike Chen Yinke and other historians, who were concerned with the integration and interaction between cultures, Lü focused on the difference and hierarchy between the 'origin' and the derivatives, in particular, between Indian Buddhism and the later Sinitic Buddhism. This is the primary framework of Lü's historiography. 
Clear enough, Lü actually 'imagined' certain 'original' texts - in particular those he meticulously compiled into his Zangyao; but he also realized that the Buddhist canon in front of modern readers had been manipulated by different hermeneutical traditions. Therefore, his task was to remove the latter-day attachments, derivations, 'corruptions,' and mis-readings from the 'truth' of Buddhism and to restore its genuine form. Through a retrospective perspective of historiography, Lü, as a believer and a historian, assumed that he was standing outside the tradition of Buddhism, at a safe vantage point from where Buddhism can be seen to develop from a simple origin (usually the earliest version of certain sutra written in ancient Indian language), towards increasing complexity, followed by periodical attempts to return to the source. As he demonstrated in his discussions on the Dashang qixin lun 大乘起信論 and Sishier zhangjing 四十二章經, only by identifying the deviations and distortions ${ }^{1378}$ in texts (even if these distortions had formed a developmental 'process' according to certain temporal sequence), researchers and believers were able to perceive earlier or more prior distortions imposed by those hermeneutical traditions, and then returned to the origin step by step. This textual attitude differs from that of most researchers with a religious position and is closer to that of a professional historian, such as Chen Yuan's path of ‘historical sources' [shiyuan xue 史源學].

Emphasis on 'original' texts and a retrospective view of history mutually reinforced each other in Lü's writings. This combination allowed Lü to 'envision' an origin from which the entire tradition of Buddhism was derived. It also led him to believe that he could stand at the time of 'singularity' in Buddhism's past, from which Buddhism had degenerated towards its current form. This notion of the 'genuine Buddhism' looks at odds with the view that the history of Buddhism, especially the formation of Chinese Buddhism, was progressive, because it saw Chinese Buddhism as a product of the decay of Indian Buddhism or a deviation from the right path. Because of its tendency of 'looking backward', which seemed to be incompatible with the

\footnotetext{
${ }^{1378}$ For instance, one of the most important, or in Lü's view, the most damaging distortions is the mistranslation and misunderstanding of the conception 'tathatā' [benwu 本無/zhenru 真如] in Chinese Buddhism texts, such as the Qixin.
} 
modern era that was 'looking forward,' this voice had often been buried in the wave of 'the Buddhist revival'. However, this historiographical view is logically sound in terms of the Dharma itself and is able to describe and explain the changes of Buddhism in the post-Buddha era, for if the Buddha's sayings are supremely perfect, then all subsequent exegeses, interpretations and transformations can only move further away from the essence of the Dharma. As such, it circumvented the dilemma that Taixu would encounter, namely, why a historically perfect Buddhism needs to be reformed. Unsurprisingly, the inquiry of this 'genuine Buddhism' posed challenges for monasteries. As a critical understanding of Buddhism and its past, this idea challenged the traditional Buddhist knowledge controlled by the Sangha, forcing the Buddhist community to reflect on assertions that had been considered as 'truth' but were actually suspect.

It is noteworthy that behind this conception of history of Buddhism there is also a setting of historical 'process' or 'movement', which has its beginning and direction. Lü Cheng also looked back toward the past from the present - a present that directed to a kind of implicit telos, which is not the telos of the teleological, progressive history, but more or less, was constructed according to the 'genuine' form of Buddhism that Lü Cheng had built in mind. In this sense, the conceptual divergence between Lü Cheng and Taixu in their writing about the history of Buddhism is not as huge as it seems at first glance. The same teleological expression can be found at work in the two opposite narratives of progress (Taixu) and decline (Lï) narratives that privileged either the origin in the past or the end in the future; and telos in their narratives are both had its soteriological dimension. More generally, this model is found behind all affirmations of a continuity, of a 'thread of history', of a perennial Buddhism -- just as the title of Lü's monograph, 'yuanliu,' indicated and stressed.

Underlying the teleological but 'backward' assumption is also a strong response to the prevailing discourses of modernity, especially science, which was driving China forward. Lü Cheng's concern with the history of Buddhism derived from his emphasis on knowledge, namely, 'the true Learning' [zhenshi zhixue 真實之 
學]. To Lü, the epistemology of Buddhism, including the Buddhist understanding of the nature, source, and scope of knowledge [i.e., wisdom 智慧], could enable Buddhism to find its niche in an age dominated by science. This tendency was related to the booming interest in Chinese logic at the turn of the twentieth century, which reflected the pressure of modernity among Chinese intellectuals. Chinese intellectuals assumed that European modernity had been grounded in the rationality of logic and epistemology, while in contrast the same rationality is considered absent in non-Western civilizations. The interest in Yogacārā at the time in both academic and religious circles was a response to this view. With an emphasis on the epistemological function of Buddhism, Lü suggested that instead of the metaphysical stance as exemplified in Qixin lun, which would lead to an impure form of 'enlightenment', 'Genuine Buddhism' took the epistemological stance to pursue valid knowledge first. Following this patten, true knowledge, including the knowledge about the past, as well as valid cognition could be established and would serve as the basis for spiritual and social liberation. ${ }^{1379}$

\section{The History of Buddhism?}

Lacking unified ground and horizons, struggling between faith and truth, and vacillating between universality and particularity, the historiography of Buddhism in modern China seemed to be an arena of discourses and worldviews. The different patterns mentioned above are still oversimplified, given the contradictions and overlaps we can read from those writings. Moreover, these patterns all contained

\footnotetext{
${ }^{1379}$ Later, when he when he taught at the Seminar of Buddhist Studies in Nanjing in 1961, Lü Cheng explicated his thesis on the social function of Buddhism in more detail in three articles on Qixin lun and Chan. He emphasized the idea of the sociality of doctrine, claiming that the theory of "the quiescent nature of mind" is ideologically progressive because it requires the transformation of cognition as the foundation of ethical, religious, and societal change. Of course, Lü's emphasis on the sociality of religious theory might reflect the dominance of Marxist ideology in China. For this issue, see Lin Chenkuo, "Metaphysics, Suffering, and Liberation: The Debate between Two Buddhisms," in Pruning the Bodhi Tree: The Storm over Critical Buddhism, ed. Jamie Hubbard and Paul L. Swanson (Honolulu: University of Hawai'i Press, 1997), 298-313.
} 
their own shortfalls. The theory of evolution read Buddhism as having its finality in a full Sinicized form but overlooked the innate complexity within Buddhism itself, such as doctrinal divergence, sectarian conflicts, historical slackening, and dislocation. The second pattern which focused on a transplantation between cultures, replaced the real meaning of Buddhism, or its essence, with the historical 'tradition' that was particular, secular, and somewhat 'detached.' It actually applied a dichotomy of $t i$ and yong upon Buddhism and history, transforming Buddhism into an instrument for understanding 'Chinese culture.' Viewing Chinese Buddhism as a deviation from 'genuine Buddhism' with a 'theological' tendency of advocating a return to the purest origin, as Lü Cheng did, define Buddhism as an ahistorical entity; however, the 'essence' it targeted, although supported by textual evidence, was still normative and strongly colored by certain factional and sectarian biases.

Stopping here, I would suggest a return to some general questions: why did writing the history of Buddhism matter to so many scholars, clergy, and laypeople? Is it proper to write (or 'rewrite') the history of something that claims an ahistorical nature? And what should we do if the 'truth' (in a historical sense) conflicts with faith?

Buddhism is, essentially, a vague term that was 'created' by a group of European Buddhologists and Orientalists. ${ }^{1380}$ From the late nineteenth century, with a strong historical consciousness entering into different research fields, historians began to argue in favor of a study of religions which would translate, reduce, or redescribe religion into the language they deem proper to the academy. ${ }^{1381}$ The history of Buddhism -- organizing and narrating the past of religion based on textual filiations, as well, developed into a main paradigm of religious. Kalpa and kșana were transformed into 'modern' time units; samsāra began to refer to 'secular' historical

\footnotetext{
${ }^{1380}$ Gregory Schopen, Bones, Stones, and Buddhist Monks: Collected Papers on the Archaeology, Epigraphy, and Texts of Monastic Buddhism in India (The University of Hawaii Press, 1997), 22.

${ }^{1381}$ Tomoko Masuzawa, In Search of Dreamtime: The Quest for the Origin of Religion (University of Chicago Press, 1993), 178.
} 
structures; the old biographical approach inherited from the hagiographical tradition was replaced by modern historiographical frameworks.

However, the historiography of Buddhism in modern China was neither aiming at restoring the life of the Buddha nor aiming at depicting the changes of the Dharma; it was mainly a reflection and refraction against which China measures itself (with both positive and negative connotations). It served different positions: the concept of progressive, positivist methodologies, nationalism, humanism, cultural studies, and so on. In this process, the religiosity of Buddhism was 'rarefied', while many ideological meanings and modern values were attached to it. This transformation and the controversy around its process played a crucial role in the transition of the Chinese religious landscape. It was, under the rubric of 'history,' a modern narrative-a creation from a remote (both temporally and spatially) intellectual world-intending to replace the doctrinal foundation of faith with an epistemological legitimacy linked with historical evidence and interpretations. This narrative itself, fundamentally, was also a production of historicization; and it could not and did not have to be insulated from some discursive presuppositions. For instance, there were always structures of dichotomy, which had their modern meanings: China/India, ti/yong and origin [yuan 源]/evolvement [liu 流], and so on. These dichotomies do not suggest that the writings of the history of Buddhism in modern China can not restore the 'truth' about Buddhism's past, but rather indicated that these writings were not primarily about Buddhism, but about China. Behind these writings, there was always a presumption: when Buddhism stepped beyond its original cultural bounds and diversified into different local forms, 'absolute' Buddhism then could not exist anymore. Only in this way, however, did Buddhism become a world religion. Modern Chinese historiography of Buddhism reinforced this impression of heterogeneity and displacement; it also embodied the transformation of heterogeneity and displacement from obstacles to objects of historical study. This process yielded new understanding and knowledge about Buddhism and about its formation, changes, and the cultural roles it had played in the past and should play in particular traditions. 
As we can read from the cases in this dissertation, the historicization of Buddhism has allowed historians without a faith background to participate in the construction of the Buddhist past. At the same time, however, the historiography of Buddhism barely touches on issues about the nature of Buddhism and the modern fate of Buddhism, nor did it address the question of how Buddhism should respond to the transformation in these particular modern times. These questions are actually also important dimensions of the historical research of Buddhism. Obviously, there was a kind of "silence" between historians and the religious community. For Buddhist scholars, the key question in the history of Buddhism is how the words and actions of eminent monks influenced the development of Chinese Buddhism at the levels of doctrine, practice, and institutions. They did not just want to know "what happened"; but intended to use theories from different disciplines (e.g., psychology, sociology, historiography etc.) to support and guide the Buddhist revival and reform.

The difference of intention between historians and religious scholars often makes writing the history of religion a challenge. Because the former always read religious texts with a critical or indifferent attitude; the latter, on the other hand, have increasingly lost their monopoly on religious knowledge. Earlier, questions like what was studied as religion and how it was studied had not been posed by religious scholarship, a field in which, as Steven Wasserstrom puts it, "the subject and the object of study were confused, conflated, confounded." ${ }^{1382}$ From the early twentieth century, scholars began to propose sophisticated theoretical models for the study of religion that they argued succeeded in separating the 'study of from 'religion'. Prominent among these are paradigms that view the study of religion as an 'explanatory' discourse modeled on historiography and various branched of social sciences. Only with this move to explanation, for many, will the field be brought closer to the discursive practices of the secular academy.

${ }^{1382}$ Steven Wasserstrom, Religion after Religion (Princeton: Princeton University Press, 1999), 239. 
Historiography has played an important role in this transformation of religious scholarship. Russell McCutcheon has articulated well the tendency of historicization at the heart of the explanatory paradigm.

After all, the premise that makes the human sciences possible in the first place is that human behaviors always originate from within, and derived their culturally embedded meanings from being constrained by, historical ... entanglement.... we always begin from the premise that there can be no release from the historical. ${ }^{1383}$

This premise encapsulates the position of most modern Chinese historians. In China, from the beginning of the twentieth century to the present, this 'autonomy' or 'privilege' of historiography is very strong in the scholarship of religion. Although there was some controversy and discussions about the validity and legitimacy of historiography in both religious and historical circles, for example, Lü Cheng's criticism of Tang Yongtong's history of Buddhism and the debate between D.T. Suzuki and $\mathrm{Hu}$ Shi on the history of Zen Buddhism. ${ }^{1384}$ However, historiographical terminology and methodology soon established one of the dominant research paradigms in the scholarship of religion. In the later decades, due to various reasons, especially the political environment, Chinese Buddhist studies were never able to break out of this paradigm. This textual-historiographical path -- namely, the integration of historical interpretation and textual criticism -- has always been the ethos and character of Chinese Buddhist scholarship that differs from that of the West and Japan. ${ }^{1385}$ To this day, it can still be argued that the foundations of modern scholarship of Buddhism laid by historians such as Liang Qichao, Hu Shih, Chen Yuan, Chen Yinke and Tang Yongtong, are still being continued and inherited.

\footnotetext{
${ }^{1383}$ Russell McCutcheon, Critics Not Caretakers: Redescribing the Public Study of Religion (Albany: State University of New York Press, 2001), 6-7.

${ }^{1384}$ Both these two cases have been discussed on the 5 chapter.

${ }^{1385}$ Since the early twentieth century, the study of Buddhist history in the West has been increasingly influenced by archaeology, anthropology, and sociology, while Japanese Buddhist studies have been distinguished by philosophical interpretation and criticism. See Ge, Zhaoguang 葛兆光, “Reng zai Hu Shih de yanchangxian shang: youguan Zhongguo xuejie zhonggu chanshi yanjiou zhi fansi 仍在胡適的 延長線上: 有關中國學界中古禪史研究之反思," in Lingnan xuebao fukan 嶺南學報復刊 7 (Shanghai: Shanghai guji chubanshe, 2017), 30.
} 
Because this tendency of historicization has located religion securely in relation to the academic constellation, current scholarship, especially in China, rarely discusses the limitation of the historiographical method in religious studies anymore and have paid little attention to the 'hegemony' of historiography. However, at the end of this dissertation, I would like to remind that it is also proper for us to realize the problem of this hegemony. First, historiography provides much more than a method, but to a certain extent a definition for religion -- religion becomes a specific, contingent, socio-political discourse, and its transcendence and faithfulness are ignored. Second, the historicization of religion weakens human subjectivity into a historical context or function. In other words, the individual's thoughts, feelings and actions, as well as beliefs, were interpreted as the result of historical change rather than the cause. Third, historiography often succumbs to different theoretical structures and is influenced from time to time by modern discourses such as science. As a result, religions are not always the real object of study for historians, but only a 'case study' in their discussion of historical universality or particularity, no different from other cultural factors, such as literature and art. Forth, the tendency of textual primacy in the historiographical path replaces religion in life with religion in records, thus neglecting the role religion had played in the transformation of the social life and material culture of the local people. The historiography of Buddhism in Modern China again draws our attention to how history distanced itself from religion, limiting its scope to material and methodology, and how historian was "wrapped up in the search for the elusive document that will establish him as an 'authority' in a narrowly defined field." ${ }^{1386}$ In this, we can see the difficulty of writing a history of religion and the difficulty of using history as a paradigm for the study of religion.

Meanwhile, the cases discussed in this dissertation remind us again how the historiographical approach 'explains' and defines religion with a defined 'truth' which may far differs from the 'essence' of certain religion. As some theorists of the history of religions, such as Van Austin Harvey, have argued, the 'truth' of history is

\footnotetext{
${ }^{1386}$ Hayden White, Tropic of Discourse: Essays in Cultural Criticism (Baltimore: Johns Hopkins University Press, 1978), 28.
} 
often a "judgment," while the 'truth' of religion is a "warrant."1387 The historiographical approach is to 'explain' and define religion in terms of a definite fact-based 'truth,' which cannot be equated with the 'truth' of religion. To historians as 'outsiders', Buddhism was always a sphere that sealed to them - or an 'other', historical, religious and political. They tacitly considered themselves as observers instead of practitioners. ${ }^{1388}$ Some of them, Hu Shih, for example, had claimed that historians have their advantages, because they are free from the bias of faith and are therefore more neutral and objective. However, what a witness thinks he sees is in large part filtered through the prism of his own individual perception which, in turn, is heavily influenced by the world of which he is a part. Both historians and Buddhist scholars are historical creatures, and their judgements reflect the 'world' that they

\footnotetext{
${ }^{1387}$ Van Austin Harvey, The Historian and The Believer (New York; The Macmillan Company), 102-126. He discussed the difference and connection of religious knowledge and historical knowledge in the field of theology. Also see Russell McCutcheon, Critics Not Caretakers: Redescribing the Public Study of Religion (Albany: State University of New York Press, 2001), 6-7; and his “'It's a Lie. There's No Truth in It! It's a Sin!': On the Limits of the Humanistic Study of Religion and the Costs of Saving Other from Themselves," in Journal of the American Academy of Religion, 74, 3 (2006): 724-72. In the field of the Buddhist studies, there are also some discussions on this issue, see, for example, the essays collected in Buddhist Theology, ed. by Roger Jackson and John Makransky (New York: Routledge, 2000) and David McMahan, Empty Vision: Metaphor and Visionary Imagery in Mahayana Buddhism (London: Routledge Curzon, 2002).

${ }^{1388}$ For example, Hu Shih once commented on the difference between Japanese Zen scholars and himself: "They are Buddhists, but I am only a historian"; "Those who study the history of Buddhism and those who really study Buddhism are in different positions, so the methods are also different." See Cao Boyan 曹伯言, Hu Shih riji quanbian 胡適日記全編, vol. 6, 229-39. Chen Yinke also said that he could not speak about the “meaning” of Buddhism 至其微言大義之所在, 則未能言也, " in JMEB, 360. Chen Yuan had also said several times that he is the “outsider 門外漢” of Buddhism. See for example, “zai Zhongguo foxueyuan jiaoxue wenti yantaohui shang de fayan 在中國佛學院教學問題研討會上的 發言,” in CYQJ, vol.2, 817; “Yesu jidu renzi shiyi xu 耶穌基督人子釋義序,” in CYQJ, vol.2, 406; Mingji dianqian fojiao kao 明季滇黔佛教考, in CYQJ, vol.7, 27. At the same time, many modern Chinese intellectuals often felt the distance between themselves and the world of faith. They often questioned themselves about whether they had a sufficient grasp of religious doctrine. For example, Liang Shuming taught Indian philosophy at Peking University in his early years; but he soon left when Indologist Baron A. Stael Holstein came to Peking University. Liang Qichao, who was also fond of talking about Buddhism, seldom talked about Buddhist Canon after he listened to Ouyang Jingwu's lectures in Nanjing and realized that the texts he read might be mistranslations. Also, Zhang Taiyan instructed his disciples to delete all references to Buddhism from his writings in his later years.
} 
bring with them and to which they appeal in support of those judgements. In modern China, amidst anxieties about self-identity and modernity, the imperative of historiography was not writing objective, ideology-free history, as it might claim or look like. It was always discursive, political-oriented, and even imaginary.

With this historiographical attitude, it is difficult for both historians and religious scholars to answer the question of how religious beliefs can be described and explained beyond history and whether there are any deficits in the historical enterprise. Undoubtedly, the approach of history has expanded our knowledge about religion and demonstrated a more complicated picture about the changes of certain religious landscape throughout a long span of time; however, the view that claims religion to be the product of history which can only be understood in historical context itself was historically determined and thus is itself an ideology. We should also realize that religion is never only support for or enactment of historical suppositions and ideals but can be centered on timeless experiences and antihistorical processes that help us break away from the 'secular' configurations preset by modernity. The conflicts between religious knowledge and the modern system of scholarship which is based on science and rationalism can guide us to think about the boundaries of historiography and other modern academic discourses, and further allow us to reflect on the limits of secularism and the pitfalls of modernity. As theologian Tyler Roberts suggests, history tends to domesticate difficult and even traumatic doctrinal, epistemological, and ethical questions in religion instead of facing them and facing the disturbances they would bring to the ideal of the autonomy of academic discourse. ${ }^{1389}$ Therefore, when approaching a certain religion, an attitude that is more cognizant of the limits of historiography will help us to traverse established research paths and those claimed 'scientific', 'objective' academic 'illusions', while also enabling us to better deal with the tension between faith and truth, which is at work in different forms of thought and practice in the realm of religion.

\footnotetext{
${ }^{1389}$ Tyler Roberts, "Between the Lines: Exceeding Historicism in the Study of Religion," in Journal of the American Academy of Religion, 74, no. 3 (2006), 697-719.
} 


\section{Bibliography}

\section{Primary Sources}

\subsection{Collections}

CEBTA, T Chinese Buddhist Electronic Text Association, Taisho Shinshu Daizokyo 大正新脩 大藏經

CEBTA, X Chinese Buddhist Electronic Text Association, Xuzang jing 續藏經

MFQ Mingguo fojiao qikan wenxianjicheng 民國佛教期刊文獻集成 [Collection of Republican-Era Buddhist Periodical Literature]. Beijing: Zhongguo shudian, 2013.

MFQB Mingguo fojiao qikan wenxian jicheng 民國佛教期刊文獻集成續編 [Supplement to the Collection of Republican-Era Buddhist Periodical Literature]. Beijing: Zhongguo shudian, 2013.

Zhang Mantao 張曼濤. Xian dai fo jiao xue shu yan jiu cong kan 現代佛教學術叢刊 [Collection of Modern Buddhist Studies]. Taipei: Dasheng wenhua chuban gong si, 1978.

\subsection{Other Primary Sources}

Chen, Yinque 陳寅恪. Jinmingguan conggao chubian 金明館叢稿初編. Peking: Shenghuo, dushu, xinzhi, sanlian shudian, 2001.

- - J Jinmingguan conggao erbian 金明館叢稿二編. Peking: Shenghuo, dushu, xinzhi, sanlian shudian, 2001.

-—-. Han liu tang ji 寒柳堂集. Peking: Shenghuo, dushu, xinzhi, sanlian shudian, 2001.

-—-. Shuxin ji 書信集. Peking: Shenghuo, dushu, xinzhi sanlian shudian, 2001.

Chen, Yuan 陳垣. Chen Yuan quanji 陳垣全集. Hefei: Anhui University Press, 2010.

-一- Chen yuan laiwang shuxin ji 陳垣來往書信集. Beijing: Shenghuo, dushu, xinzhi, sanlianshudian , 2010.

$\mathrm{Hu}$, Shih 胡適. Hu Shih quan ji 胡適文集. Beijing: Peking University Press, 1998.

-—-. Hu Shih wencun 胡適文存. Taipei: Yuandong tushu gongsi, 1990.

- - - Lunxue tanshi ershi nian-Hu Shih Yang Liansheng wanglai shuzha 論學談詩二十年一胡適 楊聯债往來書札. Taipei: Lingking, 1998.

- - - Hu Shih wanglai shuxin xuan 胡適往來書信選. Hong Kong: Zhonghua shuju, 1983.

-- . The Chinese Renaissance: the Haskell Lectures, 1933. Chicago: University of Chicago [1934]. Rep. New York: Paragon Book Reprint Corp. 1963.

- - . "Chinese Thought." In China, edited By Harley Farnsworth MacNair. Berkeley and Los Angeles: University of California Press, 1951.

- - . "Historical Foundations for a Democratic China." In Edmund J. James Lectures on Government, Second Series, 54-63. Urbana: University of Illinois Press, 1941. 
---. "The Indianization of China: A Case Study of Cultural Borrowing." In Independence, Convergence and Borrowing in Institutions, Thought and Art, Harvard Tercentenary Publications, 219-247. Cambridge, MA: Harvard University Press, 1937.

-_-. "The Task of Modern Religion.” Journal of Religion 14, no. 1 (1934): 104-108.

--_. "The Development of Zen Buddhism in China." The Chinese Political Science Review 15, 4 (1932): 475-505.

- - . "Religion and Philosophy in Chinese History." In A Symposium on Chinese Culture, edited by Sophia H. Chen Zen, 31-58. Shanghai: China Institute of Pacific Relations, 1931. Huang, Chanhua 黄懺華. Zhongguo fojiao shi 中國佛教史. Shanghai: Shangwu yinshu guan, 1947.

-—-. Fojiao gezong dayi 佛教各宗大意. Shanghai: Shangwu yinshuguan, 1947.

Jiang, Weiqiao 蔣維喬. Zhongguo fojiaoshi 中國佛教史. Shanghai: Shanghai guji chubanshe, 2007.

- - . Zhuweng ziding nianpu 竹翁自訂年譜. Manuscript. Shanghai: Shanghai Library. Liang, Qichao 梁啓超. Yinbingshi heji 飲冰室合集. Beijing: Zhonghua shuju, 1989.

---. Foxue yanjiu shiba pian 佛學研究十八篇. Shanghai: Shanghai guji chubanshe, 2001 Lü, Cheng 吕澂. Zhongguo foxue yuanliu lüejiang 中國佛學源流略講. Beijing: Zhonghua shuju, 1979.

- - . L Lü Cheng Foxue lunzhu xuanji 吕澂佛學論著選集. Jinan: Qilu shushe, 1991.

- - . Zhongguo foxue sixiang gailun 中國佛學思想概論. Taipei: Tianhua chuban gongsi, 1982. Ouyang, Jingwu 歐陽竟無. Ouyang dashi yiji 歐陽大師遺集. Taipei: Xinwenfeng Press, 1976. Shi, Taixu 釋太虛. Taixu dashi quanshu 太虛大師全書. Beijing: Zongjiao wenhua chubanshe, 2005.

Tang, Yongtong 湯用形. Tang Yongtong quanji 湯用形全集. Shijiazhuang: Hebei renmin chubanshe, 2000.

---. Hanwei liangjin nanbeichao fojiaoshi 漢魏兩晉南北朝佛教史. Beijing: Peking University Press, 2011.

- - - Suitang fojiao shigao 隋唐佛教史稿. Beijing: Peking University Press, 2010.

\section{Secondary Sources}

Abbott, Andrew. Chaos of Disciplines. Chicago: University of Chicago. 2001.

Akira, Hirakawa. A Buddhist Chinese-Sanskrit Dictionary. Tokyo: The Reiyukai, 1997.

Aleida and Jan Assmann, ed. Kanon und Zensur: Beiträge zur Archäologie der literarischen Kommunikation. München: Fink, 1987.

Almond, Philip C. The British Discovery of Buddhism. Cambridge: Cambridge University Press, 1988.

Anderson, Benedict. Imagined Communities: Reflections on the Origin and Spread of Nationalism. London: Verso. 1991. 
App, Urs. The Cult of Emptiness: The Western Discovery of Buddhist Thought and the Invention of Oriental Philosophy. Rorschach and Kyoto: University Media, 2012.

- - . The Birth of Orientalism. Philadelphia: Pennsylvania University Press, 2010.

Appleby, Joyce O., Hunt, Lynn, and Jacob, Margaret J. Telling the Truth about History. New York: W. W. Norton \& Company, 1994.

Apter, David Ernest and Saich, Tony. Revolutionary Discourse in Mao's Republic. Cambridge, MA: Harvard University Press, 1994.

-- . The Politics of Modernization. Chicago: University of Chicago Press, 1965.

Asad, Talal. Genealogies of Religion: Discipline and Reasons of Power in Christianity and Islam. Baltimore: The Johns Hopkins University Press, 1993.

Ashiwa, Yoshiko and Wank, David L. Making Religion, Making the State: The Politics of Religion in Modern China. Stanford: Stanford University Press, 2009.

Aviv, Eyal. “Ouyang Jingwu: From Yogācāra Scholasticism to Soteriology.” In Transforming Consciousness: Yogācāra Thought in Modern China, edited by John Makeham, 285-316. Oxford: Oxford University Press, 2014.

-_- "Differentiating the Pearl From the Fish Eye: Ouyang Jingwu (1871-1943) and the Revival of Scholastic Buddhism." Ph.D Dissertation, Harvard University, 2008.

Baberowski, Jörg. Der Sinn der Geschichte. Geschichtstheorien von Hegel bis Foucault. Munich: C. H. Beck, 2005.

Baird, Robert D. Category Formation and the History of Religions. The Hague: Mouton, 1971.

Balázs, Étienne. “Chinesische Geschichtswerke als Wegweiser zur Praxis der Bürokratie: Die Monographien, Enzyklopädien und Urkundensammlunge." Saeculum 8 ( 1957): 210-23.

Balsamo, Luigi. Bibliography: History of a Tradition, trans. William A. Pettas. Berkeley: B.M. Rosenthal, 1990.

Bambach, Charles R. Heidegger, Dilthey, and the Crisis of Historicism. Ithaca, NY: Cornell University Press, 1995.

Barash, Jeffery A. Martin Heidegger and the Problem of Historical Meaning. Dordrecht: Martinus Nijhoff, 1988.

-_- "Martin Heidegger in the Perspective of the Twentieth Century: Reflections on the Heidegger Gesamtausgabe.” The Journal of Modern History 64, no. 1 (1992): 76.

Barrett, Timothy H. "Did I-Ching Go to India? Problems in Using I-ching as a Source for South Asian Buddhism." Buddhist Studies Review 15, no.2 (1998): 142-156.

Barrows, John Henry ed. The World's Parliament of Religions. Chicago: The Parliament Publishing Company, 1893.

Bauer, Wolfgang. Geschichte der chinesischen Philosophie. München: C. H. Beck, 2006.

Bastid-Bruguière, Marianne. "Jikan kaishaku to Nihon eikyō -- Chūgoku kindai ni okeru kako, gendai, mirai no gainen” 時間解䣋と日本影響一中国近代における過去、現代、未来の概念. In Hazama Naoki 狭間直樹 ed., Seiyō kindai bunmei to Chūka sekai 西洋近代文明と中華世界, 41-54. Kyoto, Kyoto daigaku gakujutsu shuppankai, 2001. 
- - - “Liang Qichao yu zongjiao wenti 梁啟超與宗教問題.” In Liang Qichao, Mingzhi Riben, Xifang 梁啟超·明治日本·西方, edited by Hazama Naoki. Beijing: Shehui kexue wenxian chubanshe, 2001.

Beijing shifan daxue Chen Yuan yanjiushi 北京師範大學陳垣研究室. Chen Yuan xiansheng de shixue yanjiu yu jiaoyu shiye-jinian Chen Yuan xiansheng danchen 130 zhounian xueshu lunwenji 陳垣先生的史學研究與教育事業——紀念陳垣先生誕辰 130 週年學術論文集. Beijing: Beijing Normal University Press, 2010.

Benjamin, Andrew ed. Walter Benjamin and History. New York: Continuum, 2005.

Benjamin, Walter. Selected Writings, volume Four: 1938-1940. Translated by E. Jephcott, edited by H. Eiland and M.W. Jennings. Cambridge, MA: The Belknap Press of Harvard University Press, 2003.

Berlin, Isaiah. "History and Theory: The Concept of Scientific History." History and Theory 1, no. 1 (1960): 1-31.

Berling, Judith A. The Syncretic Religion of Lin Chao-en. New York: Columbia University Press, 1980.

Beyer, Peter. "The Modern Emergence of Religions and Global Social System for Religion." International Sociology, 13 (1998): 151-72.

Bian, Senghui 市僧慧. Chen Yinke xiansheng nianpu changbian 陳寅恪先生年譜長編. Beijing: Zhonghua shuju, 2010.

Biggerstaff, Knight. The Earliest Modern Government Schools in China. Port Washington, New York and London: Conell University Press, 1961.

Birnbaum, Raoul. "Master Hongyi Looks Back: A Modern Man Becomes a Monk in TwentiethCentury China." In Buddhism in the Modern World: Adaptations of an Ancient Tradition, edited by S. Heine \& C. Prebish, 76-124. New York: Oxford University Press, 2003.

Blum, Rudolf. Bibliographia: An Inquiry into Its Definition and Designations, trans. Mathilde V. Rovelstad. Chicago: American Library Association, 1980.

Borchert, Thomas. "Buddhism, Politics, and Nationalism in the Twentieth and Twenty-First Centuries." Religion Compass 1 (2007): 529-46.

Boucher, Daniel J. "Buddhist Translation Procedures in Third Century China: A Study of Dharmarakșa and His Translation Idiom.” PhD. Dissertation. University of Pennsylvania, 1996.

Bourdieu, Pierre. Distinction: A Social Critique of the Judgement of Taste. Cambridge: Harvard University Press, 1984.

Braudauer, Frederick P. "The Encounter between Christianity and Chinese Buddhism from the Fourteenth Century through the Seventeenth Century." Ching Feng 11, no. 3 (1968). 30-38.

Breisach, Ernst. Historiography: Ancient, Medieval \& Modern, 2nd edition. Chicago: University of Chicago Press, 1994. 
Bresciani, Umberto. Reinventing Confucianism: The New Confucian Movement. Taipei: The Taipei Ricci Institute for Chinese Studies, 2001.

Brian, Victoria. Zen at War. Lanham, MD: Rowman \& Littlefield Publishers. 1997.

Brokaw, Cynthia J. and Chow, Kai-wing ed. Printing and Book Culture in Late Imperial China. Berkeley, University of California Press, 2005.

Brook, Timothy. Praying for Power: Buddhism and the Formation of Gentry Society in Late-Ming China. Cambrige, MA: Council on East Asian Studies, Harvard University and HarvardYenching Institute, 1993.

- - . "Rethinking Syncretism: The Unity of the Three Teachings and Their Joint Worship in Late-Imperial China." Journal of Chinese Religions 21 (1993): 13-44.

Brubaker, Rogers. Grounds for Difference. Cambridge, MA: Harvard University Press, 2015. Burckhardt, Jacob. “Die geschichtlichen Krisen.” In Weltgeschichtliche Betrachtungen, Über geschichtliches Studium, Historische Fragmente, 167-216. Leipzig: Dieterich, 1985.

Burke, Edmund, Reflections on the Revolution in France and on the Proceedings in Certain Societies in London Relative to that Event: In a Letter Intended to Have Been Sent to a Gentleman in Paris.

[Reprinted], edited by Frank M. Turner. New Haven, London: Yale University Press, 2003. Burnouf, Eugène. Le Lotus de la bonne loi. Paris: Adrien Maisonneuve, 1973 [1852].

Buswell, Robert E. Jr. ed. Encyclopedia of Buddhism. New York: Macmillan Reference USA, 2004. -_- ed. Chinese Buddhist Apocrypha. Honolulu: University of Hawai'i Press, 1990.

Cabezón, José Ignacio. “The Discipline and its Other: The Dialectic of Alterity in the Study of Religion." Journal of the American Academy of Religion 74, no. 1 (2006): 21-38.

-- B. Buddhism and Language: A Study of Indo-Tibetan Scholasticism. Albany, N.Y.: State University of New York Press, 1994.

Campany, Robert Ford. "On the Very Idea of Religions (In the Modern West and in Early Medieval China)." History of Religions 42, no. 4 (2003): 287-319.

Campo, Daniela. "Chan Master Xuyun: The Embodiment of an Ideal, The Transmission of a Model." In Making Saints in Modern China: Profiles in Religious Leadership, edited by D. Ownby, V. Goossaert and Z. Ji, 99-136. New York: Oxford University Press, 2016.

Cao, Boyan 曹伯言 ed. Hu Shih Riji quanbian 胡適日記全編. Hefei: Anhui jiaoyu chubanshe, 2001.

Cao, Ganghua 曹剛華. Songdai fojiao shiji yanjiu 宋代佛教史籍研究. Shanghai: Huadong shifan daxue chubanshe, 2006.

Cao, Shibang 曹仕邦. “A Study Of Ch'en Yuan's Chung-kuo fo-chiao shih-chi kai-lun 論陳垣 中國佛教史籍概論.” Chung-Hwa Buddhist Journal, no. 3 (1990): 261-300.

Carus, Paul. The Religion of Science. Chicago: Open Court Publishing Company, 1893.

Casanova, José. Public Religions in the Modern World. Chicago: University of Chicago Press, 1994. Ch'en, Kenneth K. The Chinese Transformation of Buddhism. Princeton: Princeton University Press, 1973.

-_-. "Filial Piety in Chinese Buddhism." Harvard Journal of Asiatic Studies 28 (1968): 81-97. 
---. Buddhism in China, A Historical Survey. Princeton: Princeton University Press, 1964.

-_- "Anti-Buddhist Propaganda During the Nan-ch'ao." Harvard Journal of Asiatic Studies 15.1-2 (1952): 166-192.

Chan, Wing-tsit. A Source Book in Chinese Philosophy. Princeton: Princeton University Press, 1963.

-—-. Religious Trends in Modern China. NY: Columbia University Press, 1953.

Chang, Hao. “Zhongguo jindai sixiangshi de zhuanxing shidai 中國近代思想史的轉型時代.” Ershiyi Shiji 二十一世紀 (1999): 29-39.

--- Chinese Intellectuals in Crisis. Berkeley: University of California Press, 1987.

Chang, Sho-an 張壽安 “Qingru de ‘zhishi fenhua' yu ‘zhuanmen zhixue’ mengya: cong jichang bianlun tanqi 清儒的“知識分化”與“專門之學”胉芽: 從幾場論辯談起.” Lingnan Journal of Chinese Studies 嶺南學報, 3 (2015), 59-94.

Chapman, Mark. Ernest Troeltsch and Liberal Theology: Religion and Cultural synthesis in Wilhelmine Germany. Oxford: Oxford University Press, 2001.

Chappell, David W. "Early Forebodings of the Death of Buddhism." Numen 27 (1980): 122-155.

Chatterjee, Partha. Nationalist Thought and the Colonial World: A Derivative Discourse? London: Zed Books, 1986.

Chau, Adam Yuet. Religion in Contemporary China: Revitalization and Innovation. London:

Routledge, 2011.

- - . "Modalities of Doing Religion and Ritual Polytropy: Evaluating the Religious Market Model from the Perspective of Chinese Religious History." Religion 41, no. 4 (2011): 54768.

- - . "The Politics of Legitimation and the Revival of Popular Religion in Shaanbei, NorthCentral China." Modern China, 31,2 (2005): 236-78.

-- Miraculous Response: Doing Popular Religion in Contemporary China. Stanford: Stanford University Press, 2005.

Chen, Bing 陳兵 and Deng, Zimei 鄧子美. Ershi shiji Zhongguo fojiao 二十世紀中國佛教. Beijing: Minzu chubanshe 民族出版社.

Chen, Binhe 陳涁和. Zhongguo fojiao xiaoshi 中國佛教小史. Shanghai: Shijie shuju, 1927.

Chen Hsi-yuan 陳熙遠. “ 'Zongjiao' - yige Zhongguo jindai wenhuashi shang de guanjian ci “宗教”一一個中國近代文化史上的關鍵詞.”Xin Shixue 新史學 13 (2004): 37-66.

-_-. “Confucianism Encounters Religion: The Formation of Religious Discourse and the Confucian Movement in Modern China.” PhD dissertation, Harvard University, 1999.

Chen, Huaiyu 陳懷宇. Zai xifang faxian Chen Yinke: Zhongguo jindai renwenxue de dongfangxue yu xixue Beijing 在西方發現陳寅恪: 中國近代人文學的東方學與西學背景. Beijing: Beijing Normal University Press, 2013.

Chen, Jianhua 陳建華. ‘Geming’ de xiandaixing: Zhongguo geming huayu kaolun ‘革命’的現代性: 中國革命話語考論. Shanghai: shanghai guji chubanshe, 2000. 
Chen, Jidong 陳繼東. Ogurusu Kochō no Shin matsu Chūgoku taiken: Kindai Nitchū Bukkyō kōryū no kaitan 小栗栖香頂の清末中国体験: 近代日中仏教交流の開端. Tokyo: Sankibō busshorin, 2016.

———. Shinmatsu bukkyō no kenkyū 清末仏教の研究--楊文会を中心として. Tokyo: Sankibō busshorin, 2003.

Chen, Jingxu 陳經序. “Nanbei wenhua guan 南北文化觀.” Lingnna xuebao 嶺南學報, 3, 4 (1934).

Chen, Lesu 陳樂素. “Chen Yuan tongzhi de shixue yanjiu 陳垣同志的史學研究.” Zhongguo shi yanjiu 中國史研究,4, (1980), 3-17.

Chen, Qingzhi 陳青之. Zhongguojiaoyu shi 中國教育史. Beijing: Zhongguo shehui kexue chubanshe, 2009.

Chen, Yiai 陳以愛. “30 niandai Hu Shih yu Chen Yuan de jici xueshu jiaoshe 30 年代胡適與陳 垣的幾次學術交涉.” In Jiewang Erbian 結網二編, edited by Zhou Liangkai. Taipei: Dongda gongsi, 2003.

Cheng, Gongrang 程恭讓. Jueze yu zhenwei zhijian - Ouyang Jingwu foxue sixiang tanwei 抉擇於真 偽之間一歐陽竟無佛學思想探微.” Shanghai: Huadong shifan daxue chubanshe, 2000.

Chevrier, Yves. "Post-scriptum : La servante-maîtresse : condition de la référence à l'histoire dans l'espace intellectuel chinois." Extrême-Orient, Extrême-Occident 9, no. La référence à l'histoire (1987).

Chiang, Monlin. “Chinese Education: Force for Democracy.” Far Eastern Survey 14.13 (1945): 181.

Chikusa, Masaaki Chikusa 竺沙雅章. “Chen yuan yu sangyuan wuzang 陳垣與桑原䉆藏.” Lishi yanjiu 歷史研究 1 (1991): 13-19.

Ching, Julia. Chinese Religion. Maryknoll, New York: Orbis Books, 1993.

Chou, Hsiang-kuang. T'ai-hsü: His Life and Teachings. Allahabad: Indo-Chinese Literature Publications, 1957.

Chow, Kai-wing. The Rise of Confucian Ritualism in Late Imperial China: Ethics, Classics, and Lineage Discourse. Stanford: Stanford University Press, 1996.

Chow, Tse-Tsung. The May-Forth Movement: Intellectual Revolution in Modern China. Cambridge, MA: Harvard University Press, 1971.

Chun-Chieh, Huang and Jörn Rüsen ed., Chinese Historical Thinking: An Intercultural Discussion. Göttingen: V \& R Unipress, 2015.

Clark, William. Academic Charisma and the Origins of the Research University. Chicago, University of Chicago Press, 2006.

Clart, Philip and Scott, Gregory Adam ed. Religious Publishing and Print Culture in Modern China, 1800-2012. Boston and Berlin: De Gruyter, 2015.

- - . "Chinese Popular Religion." In The Wiley-Blackwell Companion to Chinese Religions, edited by Randall Nadeau, 219-35. Oxford: Wiley-Blackwell, 2012. 
--_. "The Concept of 'Popular Religion' in the Study of Chinese Religions: Retrospect and Prospects." Paper presented at the The Forth Fu Jen University International Sinological Symposium: Research on Religions in China: Status quo and Perspectives, Taipei, 2007. Clearly, Thomas and J. C. Clearly, trans. The Blue Cliff Records. Boulder: Shambala, 2013. Cohen, Paul A.. Discovering History in China: American Historical Writing on the Recent Chinese Past. New York: Columbia University Press, 1984.

Colpe, Carsten. "Syncretism." In The Encyclopedia of Religion, translated by Matthew J. O'Connell, edited by Mircea Eliade, 218-27. New York: Free Press. 1986.

--- Die religionsgeschichtliche Schule: Darstellung und Kritik ihres Bildes vom gnostischen Erlösermythus. Göttingen: Vandenhoeck \& Ruprecht, 1961.

Company, Robert Ford. "On the Very Idea of Religions (In the Modern West and in Early Medieval China)." History of Religions 42, no. 4 (2003): 300-06.

Cosmo, Nicola Di. Ancient China and Its Enemies: The Rise of Nomadic Power in East Asian History. Cambridge University Press, 2002.

Crossley, Pamela Kyle. A Translucent Mirror: History and Identity in Qing Empire Ideology

(Berkeley: University of California Press, 1999.

Dabringhaus, Sabine. Geschichte Chinas von der Mongolenherrschaft bis zur Gründung der Volksrepublik. München: Oldenbourg Verlag, 2006.

Dai, Lianbin, “The Economics of the Jiaxing Edition of the Buddhist Tripitaka." T'oung Pao 94 (2008): 306-359.

Davids, T. W. Rhys. Sakya, Or Buddhist Origins. London: Kegan Paul, Trench, Trubner and Co., Ltd., 1931.

--- Buddhism: Being a Sketch of the Life and Teachings of Gautama, the Buddha. London: Society for Promoting Christian Knowledge, 1899.

Davis, Richard L. "Chaste and Filial Women in Chinese Historical Writings of the Eleventh Century." J. of the American Oriental Society 121, no.2 (June 2001): 204-218.

De Certeau, Michel. Heterologies: Discourse on the Other. Translated by Michael Massumi. Minneapolis: University of Minnesota Press, 1986.

de Jong, J.W. A Brief History of Buddhist Studies in Europe and American. Durga Kund: BharatBharati, 1976.

--C. "The Study of Buddhism: Problems and Perspectives." Studies in Indo-Asian Culture, vol. IV (1975): 7-30

Dean, Kenneth. "Ritual and Space: Civil Society or Popular Religion? In Brook and Frolic." Civil Society China (1997): 172-92.

Demiéville, Paul and Faigel, Martin. "The First Philosophic Contacts Between Europe and China." Diogenes 15, no. 58 (1967), 75-103.

---. "Aperçu historique des études sinologiques en France." Acta Asiatica: Bulletin of the Institute of Eastern Culture 11 (1966): 56-110. 
-_- "Sur l'authenticite du Ta tch'eng k'i sin louen." Bulletin de la Maison franco-japonaise 2, no. 2. (1929): 1-78.

Deng, Zimei 鄧子美. Chuantong fojiao yu Zhongguo jindai hua 傳統佛教與中國近代化. Shanghai: Shanghai Huazhong shifan daxue chubanshe, 1994.

Dessein, Bart. "Time, Temporality, and the Characteristic Marks of the Conditioned: Sarvāstivāda and Madhyamaka Buddhist Interpretations." Asian Philosophy 21.4 (2011): 341-60.

Dhammajoti, Kuala Lumpur. Sarvāstivāda Abhidharma. Hong Kong: The University of Hong Kong, 2009.

Dikötter, Franke. The Discourse of Race in Modern China. Stanford: Stanford University Press, 1995.

Ding, Gang 丁鋼. Zhongguo fojiao jiaoyu 中國佛教教育. Chengdu: Sichuan jiaoyu chubanshe, 2010.

Ding, Wenjiang 丁文江. Liang Qichao nianpu changbian 梁啟超年譜長編. Shanghai: Shanghai renmin chubanshe 上海人民出版社, 2009.

Dirlik, Arif. "Global Modernity: Modernity in an Age of Global Capitalism." European Journal of Social Theory 6, no. 3 (2003), 278-279.

-- and Zhang, Xudong. "Introduction: Postmodernism and China." In Postmodernism and China, edited by Arif Dirlik and Xudong Zhang, 1-19. Durham, London: Duke University Press, 2000.

Dobbelaere, Karel. Secularization: An Analysis at Three Levels. New York: Peter Lang, 2002.

-_- "Secularization: A Multi-Dimensional Concept." Current Sociology 29 (1981): 3-153.

Du, Jiwen 杜繼文. “Dasheng qixinlun shuping 大乘起信論述評.” In Zhongguo fojiao yu Zhongguo wenhua 中國佛教與中國文化, 299-336. Beijing: Zongjiao wenhua chubanshe, 2003.

Du, Weiyun 杜維運. Zhongguo shixueshi 中國史學史. Taipei: Sanmin shuju. 2004.

Duara, Presenjit. Rescuing History from the Nation: Questioning Narratives of Modern China. Chicago: University of Chicago Press, 1995.

-_- "De-constructing the Chinese Nation." The Australian Journal of Chinese Affairs 30 (1993): 31-55.

- - . "Knowledge and Power in the Discourse of Modernity: The Campaigns Against Popular Religion in Early Twentieth-Century China." The Journal of Asian Studies 50, no. 1 (1991): 67-83.

- - Culture, Power, and the State: Rural North China, 1900-1942. Stanford: Stanford University Press, 1991.

Dull, Jack. "A Historical Introduction to the Apocryphal (ch'an-wei) Texts of the Han Dynasty." Ph.D. Dissertation. University of Washington, 1966.

Dumont, Louis. La civilisation indigenen et nous: Esquisse de sociologie compare. Paris: Librairie Armand Colin, 1964. 
Dumoulin, Heinrich. "Buddhism and Nineteenth-Century German Philosophy." Journal of the History of Ideas 42, no. 3 (1981): 457-70.

Dupuis, Charles-François. The Origins of All Religious Worship. New Orleans: C.C. W Müller, 1872.

Durkheim, Emile and Mauss, Marcel. Primitive Classification. Chicago: University of Chicago Press, 1963 [1930].

Durt, Hubert. "La date du Buddha en Corée et au Japon." In The Dating of the Historical Buddha,

Die Datierung des historischen Buddha, edited by Heinz Bechert, 426-440. Göttingen:

Vandenhoeck \& Ruprecht, 1991.

Duyvendak, Jan Julius L. China's Discovery of Africa: Lectures Given at the University of London on

January 22 and 23, 1947. London: Arthur Probsthain, 1949.

Eber, Irene. "Hu Shih and Chinese History: The Problem of Cheng-li Kuo-ku." Monumenta

Serica 27, no. 1 (1968). 169-207.

Eberhard, Wolfram. "Temple-Building Activities In Medieval And Modern China: An

Experimental Study." Monumenta Serica 23 (1964): 264-318.

Eckermann, Johann Peter. Gespräche mit Goethe. Berlin: Bong, 1949.

Eisenstadt, Samuel N. Tradition, Wandel und Modernität. Frankfurt am Main: Suhrkamp Verlag, 1979.

Ellen, Somakawa and Smith, Elizabeth E. "Theorizing the Writing of History or 'I Can't Think

Why It Should Be So Dull, for a Great Deal of It Must Be Invention."' Journal of Social History 22.1 (1988): 149-161.

Ellwood, R. S. and Pilgrim, R. Japanese Religion: A Cultural Perspective. Cliffs, NJ: Prentice-Hall 1985.

Elman, Benjamin A. "Early Modern or Late Imperial Philology? The Crisis of Classical Learning in Eighteenth Century China." Frontiers of History in China 6, no. 1 (2011): 3-25.

--- A Cultural History of Civil Examinations in Late Imperial China. Berkeley: University of California Press, 2000.

-C- A Classicism, Politics, and Kingship: the Chang-chou School of New Text Confucianism in Late Imperial China. Berkeley: University of Califonia Press, 1990.

Elverskog, Johan. Our Great Qing: The Mongols, Buddhism, And the State in Late Imperial China. Hololulu: University of Hawai'i Press, 2006.

Eppsteiner, Fred ed. The Path of Compassion: Writings on Socially Engaged Buddhism. Berkeley: Paradax Press,1988.

Fairbank, John K. and Goldman, Meler Goldman. China: A New History, Second Enlarged Edition ed. Cambridge, MA: Harvard University Press, 2006.

-C-. "Introduction: the Old Order." In The Cambridge History of China, edited by John K. Fairbank, 1-40. Cambridge: Cambridge University Press, 1987.

-- . The Cambridge History of China: Volume 10: Late Ch'ing 1800-1911, vol. 10. Cambridge: Cambridge University Press, 1978. 
Fan, Chunwu 范純武. “Jindai Zhongguo fojiao yu fuji 近現代中國佛教與扶乩.” Yuanguang foxue xuebao 圓光佛學學報, 3 (1999): 261-291.

Fang, Guangchang 方廣錩. “Chinese Buddhist Canon: Approaches to Its Compilation.” Studies in Chinese Religions 2, no. 2 (2016): 1-18.

- - . "Defining the Chinese Buddhist Canon: Its Origin, Periodization, and Future." Journal of Chinese Buddhist Studies 28 (2015): 1-34

Faure, Bernard. "Chan and Zen Studies: The State of the Field(s)." In Chan Buddhism in Ritual Context, edited by Bernard Faure, 1-35. London: Routledge Curzon, 2003.

- - . The Will to Orthodoxy: A Critical Genealogy of Northern Chan Buddhism, trans. Phyllis Brooks. Stanford: Stanford University Press, 1997.

- - . The Rhetoric of Immediacy: A Cultural Critique of Chan/Zen Buddhism. Princeton, NJ: Princeton University Press, 1994.

--_. Chan Insight and Oversight. Princeton, NJ: Princeton University Press, 1993.

Feil, Ernst. Religio. Göttingen: Vandenhoeck \& Ruprecht, 1986-2007.

Feng, Youlan 馮友蘭. Sansongtang zixu 三松堂自序. Beijing: sanlian shudian, 1984.

Ferrand, Gabriel. “Le K’ouen Louen et les anciennes navigations.” Extrait du Journal Asiatique (1919): 196- 203.

Feuchtwang, Stephan and Wang, Mingming. Grassroots Charisma: Four Local Leaders in China. London: Routledge, 2001.

Fischer, David Hackett. Historians' Fallacies: Towards a Logic of Historical Thought. New York: Harper Torchbooks, 1970.

Fitzgerald, John. "The Nationless State: The Search for a Nation in Modern Chinese Nationalism." The Australian Journal of Chinese Affairs, no. 33 (1995): 75-104.

Fitzgerald, Timothy. "A Critique of "Religion" as a Cross-cultural Category." Method \& Theory in the Study of Religion 9, no. 2 (1997): 91-110.

Forte, Antonino. "Hui-chih (fl. 676-703 a.d.), A Brahmin Born in China." Estratto da Annali dell'Istituto Universitario Orientate 45 (1985): 106-134.

Foucault, Michel. The Order of Discourse, in Untying the text: a post-structural anthology, ed. R. Young. Boston: Routledge \& Kegan Paul, 1981.

-- - The Order of Things: An Archaeology of the Human Science, trans. Alan Sheridan. New York: Vintage Books, 1973.

Foulk, Theodore Griffith. "Myth, Ritual, and Monastic Practice in Sung Ch'an Buddhism." In Religion and Society in T'ang and Sung China, edited by Patricia Buckley Ebrey and Peter N. Gregory, 147-208. Honolulu: University of Hawai'i Press, 1993.

-_- "The 'Ch'an School' and its Place in the Buddhist Monastic Institutions.” Ph.D. dissertation, University of Michigan, 1987.

Fraser, Julius T. and Haber, Francis C. eds. Time, Science, and Society in China and the West. Amherst: University of Massachusetts Press, 1986. 
Fröhlich, Thomas and Schneider, Axel eds. Chinese Visions of Progress, 1895 to 1949. Leiden, Brill, 2020.

$\mathrm{Fu}$, Sinian 傅斯年. “Mao Zishui ‘Guogu yu kexue jingshen’ shiyu 毛子水“國故與科學精神”識 語.” In Fu Sinian quanji 傅斯年全集, vol.4. Taipei: Lianjing, 1980.

- - - “Lishi yuyan yanjiusuo gongzuo zhi zhiqu 歷史語言研究所工作之旨趣." Lishi yuyan yanjiusuo jikan 歷史語言研究所集刊 1 (1928).

Fujita, Kotatsu. 藤田宏達, “Genshi bukkyō-syoki bukkyō·konpon bukkyō 原始仏教・初期仏 教·根本仏教 [Early”Buddhism, “Primitive” Buddhism or “Original” Buddhism].” Hokkaido journal of Indological and Buddhist Studies 印度哲学仏教学, 2 (1987): 20-52.

Fukui Kōjun 福井康順. Dōkyō no kisoteki kenkyū 道教の基礎的研究. Tokyo: Risosha, 1952. Funeyama, Shinichi 船山信一. Funeyama Shinichi chosakushū 船山信一著作集. Tokyo:

Kobushi-shobō,1996.

Furth, Charlotte ed. The Limits of Change: Essays on Conservative Alternatives in Republican China. Cambridge, MA, and London: Harvard University Press, 1976.

-- . Ting Wen-chiang: Science and China's New Culture. Cambridge, MA: Harvard University Press, 1970.

Furuta, Shokin. "Shaku Soen: The Footsteps of a Modern Japanese Zen Master." Philosophical Studies of Japan 8 (1967):

Gadamer, Hans-Georg. Truth and Method. London: Bloomsbury, 2013.

Gao, Yongxiao 高永霄. “Taixu dashi de sixiang tixi 太虚大師的思想體系.” Xianggang fojiao [Buddhism in Hong Kong] 286 (1960), 24-30.

Gao, Zhennong 高振農. “Dasheng qixinlun jianlun zhi si 大乘起信論簡論之四.” In Jinxiandai Zhongguo fojiao lun: Gao Zhennong wenji 近現代中國佛教論: 高振農文集, 120-136. Beijing: Zhongguo shehui kexue chubanshe, 2002.

- - “ “Huai nianenshi Lü Cheng xiansheng 懷念恩師吕澂先生.” Wutaishan yanjiu 五台山研 究, 1 (1998): 32-4.

Ge, Zhaoguang 葛兆光. “Ren zai Hu Shih de yanchang xianshang: youguan Zhongguo xuejie zhonggu chanshi yanjiou zhi fansi 仍在胡適的延長線上: 有關中國學界中古禪史研究 之反思.” Lingnan xuebao fukan 嶺南學報復刊 7. Shanghai: Shanghai guji chubanshe, 2017.

- - . "From the Western Regions to the Eastern Sea: Formations, Methods and Problems in a New Historical World.” In Here in 'China' I Dwell: Reconstructing Historical Discourses of China for Our Time, 150-171. Leiden: Brill, 2017.

- - “. “Yuliu de xuewen: chongfan xueshushi kan Chen Yinke de yiyi”預流的學問：重返學 術史看陳寅恪的意義.” Wenshizhe 文史哲, 5 (2015).

-- - Hewei Zhongguo: Jiangyu, minzu, wenhua yu lishi 何為 “中國”: 疆域,民族, 文化與歷史. Hong Kong: Oxford University Press, 2014. 
- - . “'Liaowei youyi de bisai' - Cong Chen Yuan yu Hu Shih de zhenglun shuo dao zaoqi Zhongguo fojiao shi yanjiu de xiandai dianfan 聊為友誼的比賽'一從陳垣與胡適的爭論 說到早期中國佛教史研究的現代典範.” Lishi yanjiu 歷史研究 1 (2013): 132-46.

- - . Zhaizi Zhongguo: Chongjian youguan 'Zhongguo' de lishi lunshu 宅茲中國:重建關於 “中國” 的歷史論述. Beijing: Zhonghua shuju, 2011.

-_- . "Kongjiao, fojiao yihuo yejiao: Yi jiu ling ling nian qianhou Zhongguo de xinli weiji yu zongjiao xingqu 孔教,佛教抑或耶教-- 一九零零年前後中國的心理危機與宗教興趣.” In Zhongguo jindai sixiangshi de zhuanxing shidai 中國近代思想史的轉型時代, edited by Wang Fansen 王沉森, 201-240. Taipei: Lianjing, 2007.

-C-. "Xichao que zi dongying lai-riben dongbenyuan si yu Zhongguo jindai fojiao de yinyuan 西潮卻自東瀛來-日本東本願寺與中國近代佛教的因緣.” In Xichao you dongfeng: wanqing minchu sixiang zongjiao yu xueshu shilun 西潮又東風: 晚清民初思想宗 教與學術十論, 47-66. Shanghai: Shanghai guji chubanshe, 2006.

- - . “'Xinshixue' zhihou-1929 nian de Zhongguo lishi xuejie 《新史學》之後-1929 年的 中國歷史學界.” Lishi yanjiu 歷史研究 1 (2003), 82-97.

- - - “Guanyu jindai fojiao yanjiu de shuping 關於近代佛教研究述評.” Si yu Yan 思與言 37, 2 (1999).

-C- "Shinian Haichaoyin - 20 niandai Zhongguo fojiao xin yundong de neizai lilu yu waizai zouxiang 十年海潮音-20 年代中國佛教新運動的内在里路與外在走向.” In Ge Zhaoguang zixuanji 葛兆光自選集. Guilin: Guangxi shifan daxue chubanshe, 1997. Gellner, Ernest. Nations and Nationalism. Ithaca, NY: Cornell University Press, 1983. Geng, Yunzhi 耿云志. Hu Shih nianpu 胡適年譜. Chengdu, Sichuan renmin chubanshe, 1989. Gentz, Joachim. "Language Of Heaven, Exegetical Skepticism And The Re-Insertion of Religious Concepts, in the Gongyang Tradition." In Early Chinese Religion: Part One: Shang through Han (1250 BC-220 AD), 869-894. Leiden, The Netherlands: Brill, 2009.

Ginzburg, Carol. "Checking the Evidence: The Judge and the Historian." Critical Inquiry 18 (1): 79-92.

Girard, Frédéric. Traité sur l'acte de foi dans le Grand Véhicule. Tokyo: Keio University Press, 2004.

Girardot, N.J. “Max Muller's 'Sacred Books' and the Nineteenth-Century Production of the Comparative Science of Religions." History of Religions 41, no. 3 (2002): 213-50.

Girardot, Norman J. "Chinese Religion and Western Scholarship.” In China and Christianity: Historical and Future Encounters, edited by Yu-ming Shaw James D. Whitehead, Norman J, Girardot, 83-111. Notre Dame: University of Nortre Dame Press, 1979.

Gokehale, B. G. "The Theravāda-Buddhism View of History." Journal of the American Oriental Society, 85, 3 (1965): 356.

Goldfuss, Gabriele. Vers un bouddhisme du XXe siècle: Yang Wenhui (1837-1911), réformateur laïque et imprimeur. Paris: Collège de France, Institut des Hautes Études Chinoises, 2001. 
Gombrich, Richard. Theravåda Buddhism: A Social History from Ancient Benares to Modern Colombo. London: Routledge and Kegan Paul, 1988.

-_-, and Obeyesekere, Gananath. Buddhism Transformed: Religious Change in Sri Lanka.

Princeton, NJ: Princeton University Press, 1988.

Gong, Jun 龔隽 and Chen, Jidong 陳繼東. Zuowei “zhishi” de jindai Zhongguo foxue shilun: zai dongya shiyu nei de zhishi shi lunshu 作為“知識”的近代中國佛學史論: 在東亞視闌內的 知識史論述. Beijing: Shangwu yinshuguan, 2019.

-—-. “Jindai Zhongguo fojiao jingxue yanjiu: yi Neixueyuan yu Wuchang foxueyuan weili 近 代中國佛教經學研究: 以内學院與武昌佛學院為例.” Xuanzang foxue yanjiu 玄牀佛學研 究, 24 (2015): 85-116.

-_-. "Tiaoshi yu fangkang - yi jindai dongya fojiao chuantong yu zhengzhi guanxi zhong de liangge gean wei zhongxin 調適與反抗一以近代東亞佛教傳統與政治關係中的兩個案 例為中心." Paper presented at Renjian fojiao, xinhuo xiangchuan: Di si jie Yinshun daoshi sixiang zhi lilun yu shijian xueshu yantaohui 人間佛教・薪火相傳: 第四屆印順 導師思想之理論與實踐學術研討會, Taoyuan: Hongshi foxue yuan, 2003.

- - - “Jindai Zhongguo foxue yanjiu fangfa jiqi pipan 近代中國佛學研究方法及其批判.” Ershiyi shiji 二十一世紀, vol. 43 (1997): 118-27.

Goossaert, Vincent. "Yu Yue (1821-1906) Explores the Other World : Religious Culture of the Chinese Elites on the Eve of the Revolutions." In Religion in Taiwan and China, edited by Hsun Chang and Benjamin Penny, 59-107. Institute of Ethnology Academia Sinica, Peter Lang AG, 2017.

- - - and Palmer, David A. The Religious Question in Modern China. Chicago: University of Chicago Press, 2011.

- - . "Détruire Les Temples Pour Construire Les écoles: Reconstitution D'un Objet Historique." Extrême-Orient Extrême-Occident, no. 33 (2011): 35-51.

--_. "State and Religion in Modern China: Religious Policies and Scholarly Paradigms." Paper presented at Rethinking Modern Chinese History: An International Conference to Celebrate the $50^{\text {th }}$ Anniversary of the Institute of Modern History, Academia Sinica, Taipei, June 29-July 1, 2005.

-_- "The Concept of Religion in China and the West." Diogenes 52, no. 1 (2005): 14-17. Gossman, Lionel. "Towards a Rational Historiography." Transactions of the American Philosophical Society 79, no. 3 (1989): 1-68

-- . "History as Decipherment: Romantic Historiography and the Discovery of the Other." New Literary History 18, no. 1 (1986): 23-57.

Grafton, Anthony. What Was History? The Art of History in Early Modern Europe. Cambridge:

Cambridge University Press, 2007.

Graham, A.C. Yin-Yang and the Nature of Correlative Thinking. Singapore: Institute of East Asian Philosophies, National University of Singapore, 1986.

Granet, Marcel. La penseé chinoise. Paris, Albin Michel, 1968. 
Gregory, Peter N. and Getz, Daniel A. Jr. ed. Buddhism in the Sung, vol. 13. Honolulu: University of Hawai'i Press, 1999.

--- ed. Sudden and Gradual: Approaches to Enlightenment in Chinese Thought, vol. 5. Honolulu: University of Hawai'i Press, 1991.

- - . Inquiry into the Origin of Humanity: An Annotated Translation of Tsung-mi's Yüan jen lun with a Modern Commentary. Honolulu: University of Hawaii Press, 1950.

Grieder, Jerome B. Hu Shih and the Chinese Renaissance: Liberalism in the Chinese Revolution, 19171937. Cambridge MA.: Harvard University Press, 1970

Grosnick, William H. “The Categories of T'u Hsiang, and Yung: Evidence that Paramartha Composed the Awakening of Faith." Journal of the International Association of Buddhist Studies 12 no.1 (1989): 66-92.

$\mathrm{Gu}, \mathrm{Chao}$ 顧潮. Gu Jiegang nianpu 顧頡剛年譜. Beijing: Zhongguo shehui kexue chubanshe, 1993.

Guo, Peng 郭朋. Zhongguojindai foxue sixiang shigao 中國近代佛學思想史稿. Chengdu: Bashu shushe, 1989.

Habermas, Jürgen. The Philosophical Discourse of Modernity: Twelve Lectures, trans. Frederick Lawrence. Cambridge, MA: The MIT Press, 1987.

Haenisch, Erich. "Das Ethos der chinesischen Geschichtschreibung." Saeculum 1, no. 1 (1950). Hanafin, John J. "The 'Last Buddhist': The Philosophy of Liang Shuming." In New Confucianism: A Critical Examination, edited by John Makeham, 187-218. New York: Palgrave, 2003.

Hammerstrom, Erik J. The Science of Chinese Buddhism: Early Twentieth-Century Engagements. New York: Columbia University Press, 2015.

-_- "Yogācāra and Science in the 1920s: The Wuchang School's Approach to Modern Mind Science." In Transforming Consciousness: Yogacara Thought in Modern China, edited by John Makeham, 170-199. Oxford: Oxford University Press, 2014.

Harrison, Peter. 'Religion' and the Religions in the English Enlightenment. Cambridge: Cambridge University Press, 2010.

Hartman, Sven S. ed. Syncretism. Stockholm: Almqvist and Wiksell, 1969.

Hastings, Adrian. The Construction of Nationhood: Ethnicity, Religion and Nationalism. New York, NY: Cambridge University Press, 1997.

Haydon, Albert E. ed. Modern Trends in World Religions. Chicago: University of Chicago Press, 1934.

He, Jinlin 賀金林. “Qingmo seng jiaoyuhui yu siyuan xingxue de xingqi 清末僧教育會與寺 院興學的興起.” Anhui shixue 安徽史學, 6 (2005): 28-64.

He, Jianming 何建明. “Minchu fojiao gexin yindong shulun 民初佛教革新運動述論.” Jindai shi yanjiu 近代史研究 2 (1992): 74-92.

He, Lin 賀麟. Dangdai Zhongguo zhexue 當代中國哲學. Nanjing: Shengli chubanshe, 1947.

Heidegger, Martin. “The Age of the World View.” Boundary 4, no. 2 (1976). 
Heinz Bechert ed. Buddhism in Ceylon and Studies on Religious Syncretism in Buddhist Countries. Göttingen, Vandenhoeck \& Ruprecht, 1978.

Henderson, John B. The Development and Decline of Chinese Cosmology. New York: Columbia University Press, 1984.

Hervieu-Léger, Danièle. “Pour une sociologie des 'modernités religieuses multiples': une autre approche de la 'religion invisible' des sociétés européennes." Social Compass 50, 3 (2003), 287-95.

--C. Danièle. Le pèlerin et le converti. La religion en mouvement. Paris: Flammarion, 1999.

-_- Danièle. La religion pour mémoire. Paris: Cerf, 1993.

Ho, Ping-ti. "The Significance of the Ch'ing Period in Chinese History." The Journal of Asian Studies, 26 no.2 (1967): 189-195.

-- . The Ladder of Success in Imperial China: Aspects of Social Mobility, 1368-1911. New York, London: Columbia University Press, 1962.

Hobsbawm, Eric and Ranger, Terence. The Invention of Tradition. Cambridge, New York: Cambridge University Press, 1983.

Hodous, Lewis. Buddhism and Buddhists in China. New York: Macmillan Company, 1924.

Hon, Tze-ki. "Cultural Identity and Local Self-Government: A Study of Liu Yizheng's History of Chinese Culture." Modern China 30, no.4 (2004): 506-542.

- - . "National Essence, National Learning, and Culture: Historical Writings in Guocui xuebao, Xueheng, and Guoxue jikan.” Historiography East \& West 1.2 (2003): 242-286.

Hou, Yunhao 侯雲影. “20 shiji Zhongguo shixue de xuekehua jincheng 20 世紀中國史學的學 科化進程.” Shixue yuekan 史學月刊 5 (1999): 90-97.

Howard, Thomas A. Protestant Theology and the Making of the Modern German University. New York: Oxford University Press, 2006.

Hsiao, Kung-ch'uan. A Modern China and a New World: K'ang Yu-wei, Reformer and Utopian, 18581927. Seattle: University of Washington Press, 1975.

Hsü, Immanuel C. Y. Intellectual Trends in the Ch'ing Period. Cambridge: Harvard University Press, 1959.

$\mathrm{Hu}$, Axiang 胡阿祥. Weizai siming: ‘Zhongguo’ gujin chengwei yanjiu 偉哉斯名: ‘中國’ 古今稱謂 研究. Wuhan: Hubei jiaoyu chubanshe, 2000.

$\mathrm{Hu}, \mathrm{Bo}$ 胡波. “Xianqin lianghan 'tuo', 'nang' yanbiankao - jiyu chuanshi yu chutu wenxian de zonghe kaocha 先秦兩漢 ‘䝴”、“囊”演變考一基於傳世與出土文獻的綜合考察.”In Liyun yuyan xuekan 勵耘語言學刊 2. Beijing: Zhonghua shuju, 2018.

$\mathrm{Hu}$, Chang-tze. "On the Transformation of Historical Thinking in Modern China." In Chinese Historical Thinking: An Intercultural Discussion, edited by Chun-chieh Huang, Jörn Rüsen, 53-87. Göttingen: V\&R Unipress, 2015.

Huang, Chin-shing 黄進興. “Zuowei zongjiao de rujiao: yige bijiao zongjiao de chubu tantao 作為宗教的儒教: 一個比較宗教的初步探討.” Yazhou yanjiu 亞洲研究 23 (1997): 184223. 
-_-. 'Zhongguo jindai shixue de shuangchong weiji: shilun 'Xinshixue' de dansheng ji qisuo minlin de kunjing 中國近代史學的雙重危機: 試論“新史學”的誕生及其所面臨的困境,” Journal of Chinese Studies 中國文化研究所學報 6 (1997): 263-284.

-- - . Liang Qichao de zhongji guanhuai 梁啟超的终極關懷. Shixue pinglun 史學評論, 2 (1980), 85-99.

Huang, Chun-chieh. "'Time' and 'Supertime' in Chinese Historical Thinking." In Notions of Time in Chinese Historical thinking, edited by Chun-chieh Huang and John Henderson, 1942. Hong Kong: The Chinese University Press, 2006, 19-41. and Henderson, John B. eds. Notions of Time in Chinese Historical Thinking. Hong Kong: The Chinese University Press, 2006.

Huang, Max K. W. "What is Tianyan? The Meaning and Significance of Yan Fu's Theory of Natural Evolution." Bulletin of the Institute of Modern History, Academia Sinica 中央研究院 近代史研究所集刊, no. 85 (2014): 129-87.

- - - "Liang Qichao yu Zhongguo xiandai shixue zhi zhuixun 梁啟超與中國現代史學之追 寻." Bulletin of the Institute of Modern History, Academia Sinica 中央研究院近代史研究所集 刊 41 (2002): 181-213.

Huang, Minlan 黄敏蘭. “Liang Qichao 'Xin shixue' de zhenshi yiyi ji lishixue de wujie” 梁啟超 <新史學>的真實意義及歴史學的誤解.” Jindaishi yanjiu 近代史研究 80.2 (1994): 219235.

Huang, Philip C.C. "Theory and the Study of Modern Chinese History: Four Traps and a Question." Modern China 24, no. 2 (1998): 183-208.

Huang, Tran Thanh. "Buddhism and Politics in Southeast Asia." Ph.D Dissertation, Claremont Graduate School, University Centre, 1970.

Huang, Xianian 黄夏年. “Dasheng qixinlun yanjiu bainian zhilu 大乘起信論研究百年之路.” Pumen xuebao 普門學報, 6 (2001): 1-21

Huang, Xingtao 黄興濤. Chongsu zhonghua: Jindai Zhongguo 'zhonghua minzu' guannian yanjiu 重 塑中華: 近代中國“中華民族”觀念研究. Hong Kong: Sanlian shudian, 2017.

Hubbard, Jamie and Swanson, Paul L. eds. Pruning the Bodhi Tree: The Storm Over Critical Buddhism. Honolulu: University of Hawaii Press, 1997.

Hubbard, Jamie B. Absolute Delusion, Perfect Buddhahood: The Rise and Fall of a Chinese Heresy. Honolulu: University of Hawai'i Press, 2001.

-_- "Salvation in the Final Period of the Dharma." Ph.D. Dissertation, University of Wisconsin, 1986.

Huntington Jr., C. W. "History, Traditon, and Truth." History of Religions, 46, no.3 (2007): 187227.

Hureau, Sylvie. "L'apparition de thèmes anticléricaux dans la polémique anti-bouddhique médiévale.” Extrême-Orient Extrême-Occident 24 (2002).17-29. 
Hurley, Scott. "The Doctrinal Transformation of Twentieth-Century Chinese Buddhism: Master Yinshun's Interpretation of the Tathāgatagarbha Doctrine." Contemporary Buddhism 5, no. 1 (2004): 29-46.

Huters, Theodore. Bring the World Home: Appropriating the West in Late Qing and Early Republican China. Honolulu: University of Hawai'i University, 2005.

Ichiko, Chūzō 市古宙三. “Hokyō to hempō 保教と變法.” In Kindai Chūgoku no shakai to keizai 近代中國の政治と社會, edited by Niida Noboru 仁井田陸, 115-38. Tokyo: Toko Shoin, 1951.

Iggers, Georg G. Historiography in the Twentieth Century: From Scientific Objectivity to the Postmodern Challenge. Middletown, CT: Wesleyan University Press, 2012.

-_- "Historicism: The History and Meaning of the Term." Journal of the History of Ideas 56, no. 1 (1995): 129-52.

--- and James M. Powell, eds. Leopold von Ranke and the Shaping of the Historical Discipline. Syracuse, NY: Syracuse University Press, 1990.

Ip, Hung-Yok, Hon, Tze-Ki, and Lee, Chiu-Chun. "The Plurality of Chinese Modernity: A Review of Recent Scholarship on the May Fourth Movement." Modern China 29, no. 4 (2003): 490-509.

Ishihama, Yumiko 石濱裕美子. Shinchō to Chibetto Bukkyō: bosatsuō to natta Kenryūtei 清朝と千 ベット仏教:菩薩王となった乾隆帝. Tokyo: Waseda University Press, 2013.

Ishii, Kosei 石井公成。“近代アジア諸国における『大乗起信論』の研究動向.”Zengaku kenkyu 禅学研究, 通号特別 (2005): 63-79.

Ishikawa, Yoshihiro 石川禎浩. “Ryō Keichō to bunmei no shiza 梁啓超と文明の視座.” In Kyōdō kenkyū Ryō Keichō: Seiyō kindai shisō Juyō to Meiji Nihon 共同研究梁啓超一西洋近代 思想受容と明治日本, edited by Hazama Naoki 陝間直樹, 106-131.Tokyo: Misuzu shobô 1999.

Iso, Kern. "Object, Objective Phenomenon and Objectivating Act According to the 'Vijñaptimātratāsiddhi' of Xuanzang (600-664)." In Phenomenology and Indian Philosophy, edited by Debi Prasad Chattopadhyaya, Lester E. Embree and Jitendranath Mohanty, 26269. Albany: State University of New York, 1992.

Isomae, Jun'ichi. Religious Discourse in Modern Japan: Religion, State, and Shintō. Leiden: Brill, 2014.

Jackson, Roger R. and Makransky, John J. Buddhist Theology: Critical Reflections by Contemporary Buddhist Scholars. London: Cruzon, 2000.

Jaeger, Friedrich and Rüsen, Jörn. Geschichte des Historismus: Eine Einführung. München: Verlag C.H. Beck, 1992.

Jan, Yün-hua. "Buddhist Historiography in Sung China." Zeitschrift der Deutschen Morgenländischen Gesellschaft, 114, 2 (1964), 360-381. 
Jänicke, Martin. “Krisenbegriff und Krisenforschung." In Herrschaft und Krise. Beiträge zur politikwissenschaftlichen Krisenforschung, edited by Martin Jänicke, 10-25. Opladen: Westdeutscher Verlag, 1973.

Jensen, Lionel. M. Manufacturing Confucianism: Chinese Traditions \& Universal Civilization. Durham: Duke University Press, 1997.

Jessup, James Brooks. “The House Holder Elite: Buddhist Activism in Shanghai, 1920-1956.” Ph.D Dissertation, University of California, Berkeley, 2010.

Ji, Xianlin 季羡林. “Fojiao de daoliu 佛教的倒流.” In Fojiao shiwu ti 佛教十五題. Beijing: zhonghua shuju, 2007.

Ji, Zhe 汲吉, “Ruhe chaoyue jingdian shisuhua lilun? Ping zongjiao shehuixue de sanzhong houshisuhua lunshu 如何超越經典世俗化理論?評宗教社會學的三種後世俗化論述。” Shehui kexue yanjiu 社會學研究 23.4 (2008): 55-75.

-_- "Buddhist Institutional Innovations." In Modern Chinese Religion II: 1850-2015, edited by Goossaert, Vincent, Kiely J. and Lagerwey J., 729-766. Leiden, Brill, 2006.

Jiang, Canteng 江燦騰. “Hu Shih yu HuHuagu kuai tian: zaitan Hu Shih zaoqi chanxue yanjiu wenti 胡適與忽滑谷快天: 再探胡適早期禪學研究問題.” Hanxue yanjiu tongxun 漢學研 究通訊 30, no.4 (2011): 1-10.

- - - “Hu Shih chanxue yanjiu zai Zhongguo xuejie de fazhan yu zhengbian 胡適禪學研究 在中國學界的發展與爭讋.” In Xiandai Zhongguo fojiaoshi xinlun 現代中國佛教史新論. Kaohsiung: Jingxin wenjiao jijinhui, 1994.

-——. “Lü Cheng yu Xiong Shili lunxue hangao pingyi 呂澂與熊十力論學函稿評議.” Dongfang zongjiao yanjiu 東方宗教研究, 1 (1990): 219-261.

Jiang, Haishu 蔣海恕. Wanqing zhengzhi yu foxue 晚清政治與佛學. Shanghai: shanghai guji chubanshe, 2012.

Jiang, Tianshu 蔣天樞. Chen Yinke xiansheng biannian shiji 陳寅恪先生編年事輯. Shanghai: Shanghai guji chubanshe, 1997.

Jin Yuelin 金岳霖. The Development of the Logical Method in Ancient China. Shanghai: Oriental Book Co., 1922; rpt. New York: Paragon Book Reprint Corp., 1963.

Johns, Adrian. The Nature of the Book: Print and Knowledge in the Making. Chicago: The University of Chicago, 1998.

Jones, Ken. The Social Face of Buddhism: an Approach to Political and Social Activism. London: Wisdom Publications, 1989.

-_- The New Social Face of Buddhism. Somerville: Wisdom Publications, 2003.

Jorgensen, John. “The 'Imperial' Lineage of Ch'an Buddhism: The Role of Confucian Ritual and Ancestor Worship in Ch'an's Search for Legitimation in the Mid-T'ang Dynasty." Papers on Far Eastern History 35 (1987): 89-133.

Josephson, Jason Ānanda. The Invention of Religion in Japan. Chicago: University of Chicago Press, 2012. 
Jullien, François. The Propensity of Things: Toward a History of Efficacy in China, trans. Janet Lloyd. New York: Zone Books, 1999.

Kaiten, Nukariya. Religion of the Samurai: A study of Zen philosophy and Discipline I China and Japan. London: Luzac \& Co, 1913.

Kaji, Nobuyuki 加地伸行. Chinmoku no Shukyō: Jukyō沈黑の宗教-儒教[A Silent Religion: Confucianism]. Tokyo: Tsukuma Shobo, 1994.

- - Jukyō to wa nani ga 儒教とは何か[What is Confucianism]. Tokyo: Chuo kolun sha, 1990.

Kalupahana, David J. “The Buddhist Conception of Time and Temporality.” Philosophy East and West 24, no. 2 (1974): 181.

Kamada, Shige 鐮田茂雄. “Jindai Riben de Zhongguo fojiaoshi yanjiu 近代日本的中國佛教史 研究,” trans. Shengkai 聖凱. Fayin 法音 2,(2000): 25-29.

Kamali, Masoud "Multiple Modernities and Islamism in Iran." Social Compass 54,3 (2007).

Katz, Paul R. “'Superstition' and its Discontents - On the Impact of Temple Destruction Campaigns in China, 1898-1948." Disijie guoji hanxue huiyi lunwenji: Xinyang, shijian, yu wenhua tiaoshi 第四屆國際漢學會議論文集: 信仰, 實踐, 與文化調適. Taipei: Academia Sinica, June 2013.

---. Religion in China and Its Modern Fate. Waltham: Brandeis University Press, 2014.

- - . "Yige zhuming shanghai shangren yu cishanjia de zongjiao shenghuo --Wang Yiting 個著名上海商人與慈善家的宗教生活一王一亭” in Cong chengshi kan Zhongguo de xiandaixing 從城市看中國的現代性, ed. Wu, Renshu 巫仁恕, Lin, Meili 林美莉, and Paul Katz 康豹. Taipei: Institute of Modern History, Academia Sinica.

Kawashima, Shin 川島真. “Tenchō kara Chūgoku he: Shinmatus gaikō bunsho ni miru “Chūgoku' no shiyorei 天朝から中國一: 清末外交文書にみら机「中國」の使用例.” Chugoku: Shakai to bunka no.10 (1997): 41-54;

Keiki, Yabuki Keiki 矢吹慶輝. Sangaikyōnokenkyū 三階教の研究. Tokyo, Iwanami shoten, 1927.

Kelley, Donald R. Fortunes of History: Historical Inquiry from Herder to Huizinga. New Heaven, CT: Yale University Press, 2003.

Kenneth, K. Inada. "Time and Temporality, a Buddhist Approach." Philosophy East and West 24.2 (1974): 171-79.

Kern, Iso. "Matteo Riccis Verhältnis zum Buddhismus.” Monumenta Serica 36 (1984): 65-126.

Ketelaar, James Edward. Of Heretics and Martyrs in Meiji Japan: Buddhism and its Persecution. Princeton, N.J.: Princeton University Press, 1993.

Kiely, Jan. "The Charismatic Monk and the Chanting Masses: Master Yinguang and his Pure Land Revival Movement." In Making Saints in Modern China, edited by David Ownby, Vincent Goossaert, and Ji Zhe, 30-77. New York: Oxford University Press, 2017.

Kieschnick, John. Buddhist Historiography in China. Unpublished manuscript.

- - . "Buddhism." In The Oxford history of Historical Writing, edited by Andrew Feldherr and Grant Hardy, 535-552. Oxford: Oxford University Press, 2017. 
and Shahar, Meir eds. India in the Chinese Imagination: Myth, Religion, and Thought.

Philadelphia: University of Pennsylvania Press, 2013.

- - . “Guanyu Fojiao hanhua de xingsi 關於佛教漢化的省思.” In Zhongguoshi xinlun: zongjiaoshifence 中國史新論: 宗教史分冊, edited by Lin Fu-shih 林富士, 259-273. Taipei, Linking, 2011.

-- - The Eminent Monk: Buddhist Ideals in Medieval Chinese Hagiography. Honolulu: University of Hawaii Press, 1997.

Kikanishi, Hiro 北西弘. “Meiji shoki ni okeru Higashi Honganji no Chūgoku kaikyō 明治初期 における東本願寺の中國開教.” Bukkyō daigaku sōgō kenkyūjo kiyō 仏教大学総合研究所 紀要,1 (1994): 331-49.

King, Sallie B. Being Benevolence: The Social Ethics of Engaged Buddhism. Honolulu: University of Hawaii Press, 2005.

Kitagawa, Joseph M. "Primitive, Classical and Modern Religions: A Perspective on Understanding the History of Religions." In The History of Religions : Essays on the Problem of Understanding, edited by Joseph M. Kitagawa, 39-65. Chicago: University of Chicago Press, 1967.

Klaus Epstein. The Genesis of German Conservatism. Princeton, NJ: Princeton University Press, 1966.

Klautau, Orion ed. Sengo rekishi-gaku to Nihon bukkyō 戦後歴史学と日本仏教. Tokyo: Hozokan 法藏館, 2016.

-—- Kindainihon shisō to shite no bukkyō shigaku 近代日本思想としての仏教史学 [Buddhist History as Modern Japanese Thought]. Tokyo: Hozokan 法藏館, 2012.

-_- "Against the Ghosts of Recent Past: Meiji Scholarship and the Discourse on Edo-Period Buddhist Decadence." Japanese Journal of Religious Studies 35, no. 2 (2008): 263-303.

- - . "The Modern Formation of the Theory of Buddhist Decadence in the Edo Period: Memory, Forgetting, and Meiji Buddhism 近世仏教值落論の近代的形成: 記憶と忘却 の明治仏教をめぐる一考察.” Journal of Religious Studies 81, no. 3 (2007): 581-601.

Kohn, Livia. Early Chinese Mysticism: Philosophy and Soteriology in the Taoist Tradition. Princeton: Princeton University Press, 1992.

Kōichi, Mori. "Yanagita Kunio: an interpretative study." Japanese Journal of Religious Studies 7, no.2-3 (1980): 83-115.

Kondylis, Panajotis. Konservativismus: geschichtlicher Gehalt und Untergang. Stuttgart: KlettCotta, 1986.

König, Matthias. "Religion and the Nation-State in South Korea: A Case of Changing Interpretations of Modernity in a Global Context." Social Compass, 47, 4 (2000), 551-70.

Koselleck, Reinhart. Futures Past: On the Semantics of Historical Time. New York: Columbia University Press, 2004. 
--_. "Geschichte, Historie." Geschichtliche Grundbegriffe, Historisches Lexikon zur politischsozialen Sprache in Deutschland, ed. Werner Conze Otto Brunner, and Reinhart Koeselleck. Stuttgart: Klett-Cotta, 1975.

Kraft, Kennett. The Wheel of Engaged Buddhism: The Map of the Path. New York: Weatherhill, 1999.

Krämer, Hans Martin. “Introduction: 'Religion'and ‘Heresy’ in East Asia between Continuity and Discontinuity." Bochumer Jahrbuch zur Ostasienforschung 33 (2009), 5-16.

Kurita, Naomi 栗田直躬.Chûgoku Shisôni okeru Shizen to Ningen 中國思想におけみ自然と人 間. Tokyo: Iwanami Shoten, 1996.

Kwong, Luke S. K. "The Rise of the Linear Perspective on History and Time in Late Qing China c. 1860-1911." Past \& Present, 173 (2001): 157-190.

Kyōshō, Hayashima and Jikidō, Takasaki ed. Bukkyō-Indo shisqjiten 仏教インド思想辞典. Tokyo: Shunjūsha, 1987.

Lackner, Michael and Vittinghoff, Natascha. Mapping Meanings: The Field of New Learning in Late Qing China. Leiden: Brill, 2004.

-- , Amelung, Iwo and Kurtz, Joachim eds. New Terms for New Ideas: Western Knowledge and Lexical Change in Late Imperial China. Leiden: Brill, 2001.

Lai, Whalen. "Limits and Failure of 'Ko-I' (Concept-Matching) Buddhism." History of Religions 18, no. 3 (1979): 238-57.

Lan, Jifu 藍吉富. Fojiao shiliao xue 佛教史料學. Taipei: Dongda tushu gongsi, 1997.

Lancaster, Lewis. "Buddhist Literature: Its Canons, Scribes, and Editors." In The Critical Study of Sacred Texts, ed. Wendy Doniger O'Flaherty, 215-229. Berlekey: Berkeley Religious Studies Series, 1979.

Laroui, Abdallah. The Crisis of the Arab Intellectual: Traditionism or Historicism, translated by Diarmid Cammell. Berkeley: University of California Press, 1976.

Lee, Haiyan. "Mengjiang nü and the May Forth Folklore Movement." In Meng Jiangnu Brings Down the Great Wall: Ten Versions of a Chinese Legend, translated and edited by Wilt L. Idema. Seattle: University of Washington Press, 2008.

Lee, Thomas H. C. "History, Erudition and Good Government: Cheng Ch'iao and Encyclopaedic Historical Thinking." In The New and the Multiple: Sung Senses of the Past, 163-200. Hong Kong: The Chinese University Press, 2004.

Levenson, Joseph R. Confucian China and its Modern Fate: A Trilogy. Berkeley: University of California Press, 1968.

-_-. "'History' and 'Value': Tensions of Intellectual Choice in Modern China." In Studies in Chinese Thought, edited by Arthur Wright, 146-194. Chicago: Univesity of Chicago Press, 1953.

Levering, Miriam. Rethinking Scripture: Essays from a Comparative Perspective. Albany: State University of New York Press, 1989. 
Lewis, Todd T. "Newar-Tibetan Trade and the Domestication of 'Siṃhalasārthabāhu Avadāna'." History of Religions 33, no. 2 (1993): 135-60.

Li, Guangliang 李廣良. “Ouyang Jingwu de foxue fangfa lun 歐陽竟無的佛學方法論.” Journal of Yunnan Normal University 云南師范大學學報, 5 (1999): 53-57.

Li, Huaiyin. Reinventing Modern China: Imagination and Authenticity in Chinese Historical Writing. Hololulu: University of Hawai i Press, 2013).

Li, Ji 李濟. “Anyang zuixin fajue baogao ji liuci gongzuo zhi zong guji 安陽最新發掘報告及六 次工作之總估計.” In Li Ji wenji 李濟文集. Shanghai: Shanghai renmin chubanshe, 2006.

- - - “Zhongguo zuixin faxian zhi xin shiliao 中國最新發現之新史料.” Guoli zhongshan daxue yuyan lishi xue yanjiu suo zhoukan 國立中山大學語言歷史研究所週刊, 5, 57/58 (1928).

Li, Shen 李申. “Guanyu rujiao de jige wenti 關於儒教的幾個問題.” Shijie zongjiao yanjiu 世界 宗教研究, 2 (1995): 1-10.

Li, Silong 李四龍. Oumei fojiao xueshu shi: xifang de fojiao xingxiang yu xueshu yuanliu 歐美佛教 學術史: 西方的佛教形象與學術源流. Beijing: Beijing daxue chubanshe, 2009.

Li, Xueqing 李學勤. “Jianxiangzang yu mingqing zhiji lishi yanjiu 嘉興藏與明清之際歷史研 究.” Gugong bowuyuan yuankan 故宮博物院院刊 105 (2003): 5.

Liang, Shuming 梁漱溟. “Jing yi qingjiao Hu Shizhi xiansheng 敬以請教胡適之先生.” In Hu Shih lunxue jinzhu 胡適論學近著, 56. Shanghai: Commercial Press, 1935.

- - - Liang Shuming quanji 梁漱溟全集, edited by Committee of the Academy of Chinese Culture. Jinan: Shandong Renmin, 2005.

Liao, Zhaoheng 廖肇亭. “Wanming sengren sanju shi lunxi: yi hanyue fazang wei zhongxin 晚 明詩人山居詩論析: 以漢月法藏為中心.” In Zhongbian, shichan, mengxi: mingmo qingchu fojiao wenhua lunshu de chenxian yu kaizhan 中邊・詩禪 - 夢戲--明末清初佛教文化論述 的呈現與開展, 47-74. Taipei, Yunchen Wenhua, 2008.

Liebenthal, Walter. "New light on the Mahāyāna-śraddhotpada śastra.” T’oung Pao 46 (1958): 155-216

Lin, Chen-kuo 林鎮國. “Hsiung Shih-li's Hermeneutics of Self: Making a Confucian Identity in Buddhist Words." NCCU Philosophical Journal 8 (2002): 69-90.

- - . Of Self: Making a Confucian Identity in Buddhist Words." NCCU Philosophical Journal 8 (2002): 69-90.

Lin, Liyue 林麗月. “ “Xueheng” yu xinwenhua yundong 《學衡》與新文化運動.” In Zhongguo xiandaishi lunji 中國現代史論集, vol,6. Taipei: Lianjing, 1980.

Lin, Shimin 林時民. “Zheng Qiao de Tongzhi lüe ji qi shixue 鄭樵的通志略及其史學”. Xingda lishi xuebao 5 (1995): 61-95.

Lin, Yusheng 林毓生. The Crisis of Chinese Consciousness: Radical Antitraditionalism in the May Fourth Era. Madison: University of Wisconsin Press. 1979.

Liu, Xianxin 劉咸炘. Zhishi Xulun 治史緒論. Taipei: Huashi Chuban 1980. 
Liu, Chengyou 劉成有. Jinxiandai jushi foxue yanjiu 近現代居士佛學研究. Chengdu: Bashu shushe, 2002.

Liu, Longxin 劉龍心. Xueke yu zhidu: xueke tizhi yu xiandai Zhongguo shixue de jianli 學科與制度: 學科體制與現代中國史學的建立. Taipei: Yuanliu, 2002.

Liu, Lydia. The Clash of Empires: The Invention of China in Modern World Making. Cambridge, MA., Harvard University Press, 2004.

-C-. Translingual Practice: Literature, National Culture, and Translated Modernity--China, 19001937. Stanford: Stanford University Press, 1995.

Liu, Shu-hsien. "Time and Temporality: The Chinese Perspective." Philosophy East and West 24.2 (1974): 145-53.

Liu, Xian 劉賢. “Chen Yuan jidujiao xinyang kao 陳垣基督教信仰考.” Shixue yuekan 史學月 刊, 10 (2006): 83-91.

- - . “On Chen Yuan's Study of Religions." Ph.D Diss. The Chinese University of Hong Kong, 2005.

Liu, Xiaobo 劉曉波, “That Holy Word, 'Revolution'.” Popular Protest And Political Culture In Modern China, ed. Wasserstrom, Jeffrey N. New York: Routledge, 2018.

Liu, Xiaogan 劉笑敢.Quanshi yu dingxiang - Zhongguo zhexue yanjiu fangfa zhi tanjiu 詮釋與定向 一中國哲學研究方法之探究. Beijing: Shangwu yinshuguan, 2009.

Liu, Xinru. Ancient India and Ancient China: Trade and Religious Exchange AD 1-600. Oxford: Oxford University Press, 1988.

Liu, Yinsheng 劉寅生. Wang Guowei nianpu changbian 王國維年譜長編 (1877-1927). Tianjing: Tianjing remin chubanshe, 1996.

Lopez, Donald S. Jr. Curators of the Buddha: The Study of Buddhism under Colonialism. Chicago: University of Chicago Press, 1995.

Lou, Yulie 樓宇烈. “Hu Shih Chanzong shi yanjiu pingyi 胡適禪宗史研究評議.” Beijing daxue xuebao 北京大學學報, 3 (1987): 59-67.

Lowenthal, David. The Past is a Foreign Country. Cambridge: Cambridge University Press, 1985.

Löwith, Karl. Meaning in History: The Theological Implications of the Philosophy of History. Chicago: The University of Chicago Press, 1949.

Lüdemann, Gerd ed. Die „Religionsgeschichtliche Schule“: Facetten eines theologischen Umbruchs. Frankfurt am Main: Peter Lang, 1996.

Luo, Zheng 羅鋝. Jinling kejingchu yanjiu 金陵刻經處研究. Shanghai: Shanghai shehui kexueyuan, 2010.

Luo, Zhitian 羅志田. “Fangfa cheng le xueming: Qingdai kaoju heyi chengxue 方法成了學名: 清代考據何以成學.” Wenyi yanjiu 文藝研究 2 (2010) 24-31.

- - . “'New Learning' in Daoguang and Xianfeng Period and Studies on the History of Learning in Qing Dynasty: An Introduction to On China's History of Learning in Recent 300 Years." Journal of Sichuan University (Social Science Edition), 146 (2006), 8-14. 
-—- “Xixue chongji xia jindai Zhongguo xueshu de yanbian 西學衝擊下近代中國學術的演 變." Shehui kexue yanjiu 社會科學研究 1 (2003): 107-114.

- - - Minzu zhuyi yu Zhongguo jindai sixiang 民族主義與中國近代思想. Taipei: Dongda tushu, 1998.

Lusthaus, Dan. "Lü Cheng, Epistemology, and Genuine Buddhism." Transforming Consciousness: Yogacara Thought in Modern China, ed. John Makeham. Oxford: Oxford University Press, 2014

--- Buddhist Phenomenology: A Philosophical Investigation of Yogacara Buddhism and the Ch'eng Wei-shih Lun. New York: Routledge, 2003.

Lyotard, Jean-François. The Differ end: Phrases in Dispute, trans. Georges van Abbeele. Minneapolis: University of Minnesota Press, 1988.

Ma, Tianxiang 麻天祥. Tang Yongtong pingzhuan 湯用泮評傳. Nanchang: Baihuazhou wenyi chubanshe, 1993.

- - - Wanqing foxue yu jindai shehui sichao 晚清佛學與近代社會思潮. Taipei: wenjin chubanshe, 1992.

Mair, Victor H. “What Is Geyi, After All?” China Report 48, no. 1 (July 23, 2012): 29-59.

Makeham, John ed. Transforming Consciousness: Yogācāra Thought in Modern China. Oxford: Oxford University Press, 2014.

-_-. "Xiong Shili's Critique of Yogācāra Thought in the Context of His Constructive Philosophy." In Transforming Consciousness: Yogacara Thought in Modern China, edited by John Makeham, 242-282. Oxford: Oxford University Press, 2014.

- - "Disciplining Tradition in Modern China: Two Case Studies." History and Theory 51 (2012): 89-103.

-- - Lost Soul: Confucianism. Contemporary Chinese Academic Discourse. Cambridge, MA.: Harvard University Press, 2008.

--- New Confucianism: A Critical Examination. New York: Palgrave Macmillan, 2003.

Makio, Takemura 竹村牧男. “Kishiron to Jūjikyōron 起信論と十地経論.” Tōhōgaku, no. 72 (1986): 1-15.

Makita, Tairyō 牧田諦亮. “Yijing yanjiu - Zhongguo fojiao Zhong zhi zhenjing yu weijing 疑 經研究--中國佛教中之真經與疑經,” trans. Yang Baiyi, 楊白衣. Huagang foxue xuebao 華 岡佛學學報 4 (1980): 284-306.

Mann, Albert. "Cheng Ch'iao: An Essay in Re-Evaluation," in Transition and Permanence in Chinese History and Culture: A Festschrift in Honour of Dr. Hsiao Kung-ch'üan, ed. D. C. Bauxbaum and F. W. Mote, Hong Kong: Cathay Press, 1972, 23-57.

Mannheim, Karl. “Conservative Thought.” In From Karl Mannheim, edited by H. Wolff, Kurt, 132-222. New York: Oxford University Press, 1971.

Maspero, Henri. “Le Taoïsme et les débuts du Bouddhisme en Chine.” Mélanges posthumes vol. II (1950).

-—-. Les religions chinoises. Paris: Presses Universitaires de France, 1967. 
--- Taoism and Chinese Religion, translated by Frank A. Kierman Jr. Amherst: University of Massachusetts Press, 1981.

Masur, Gerhard. "Crisis in History." In Dictionary of the History of Ideas, 4 vols., edited by Philip P. Wiener. New York: Scribner, 1968.

Masuzawa, Tomoko. The Invention of World Religions: Or, How European Universalism was Preserved in the Language of Pluralism. Chicago: University of Chicago Press, 2005.

--- In Search of Dreamtime: The Quest for the Origin of Religion. Chicago: University of Chicago Press, 1993.

Mazur, Mary G. "Discontinuous Continuity: The Beginning of a New Synthesis of "General History' in $20^{\text {th }}$ Century China." In The Politics of Historical production in Late Qing and Republican China, edited by Tze-ki Hon and Robert J. Culp, 107-142. Leiden: Brill, 2007.

McCarney, Joe. Hegel on History. London: Routledge, 2000.

McCutcheon, Russell T. “'It is a Lie. There's No Truth in It! It's a Sin!” Journal of the American Academy of Religion, 74.3 (2006): 720-750.

-- . The Discipline of Religion: Structure, Meaning, Rhetoric. London: Routledge, 2003.

McIntyre, John. "The Uses of History in Theology." Studies in World Christianity 7.1 (2001): 1-20. McMahan, David. The Making of Buddhist Modernism. New York: Oxford University Press, 2008. McNeill, William H. "Mythistory, or Truth, Myth, History, and Historians." The American Historical Review 91, no. 1 (1986), 1-10.

McRae, John R. “State Formation, Indigenization, and Buddhism in East Asian History: The Theoretical Foundation.” Indo tetsugaku bukkyōgaku kenkyū インド哲学仏教学研究, no.13 (2006): 45-73.

-_-. "Religion as Revolution in Chinese Historiography: Hu Shih (1891-1962) on Shen-hui (684-758)." Cahiers d'Extrême-Asie 12, no. 1 (2001), 11-65.

- - . and Overmyer, Daniel L. "Living Religious Traditions: Taoism, Confucianism, Buddhism, Islam and Popular Religion." JAS 54.2 (1995): 354-71.

-- . The Northern School and the Formation of Early Ch'an Buddhism. Honolulu: University of Hawaii Press, 1986.

- - . "The Ox-School of Chinese Buddhism: From early Chan to the Golden Age." Studies in Chan and Hua-yen, Studies in East Asian Buddhism, ed. R. M. Gimello and P. N. Gregory. Honolulu, University of Hawai'i Press, 1983, 169-253.

Mercer, Lewis Pyle. Review of the World's Religious Congresses of the World's Congress Auxiliary of the World's Columbian Exposition: Chicago, 1893. Chicago \& New York: Randy, Mcnally \& Company, 1893.

Merleau-Ponty, Maurice. Signs, translated by Richard McCleary. Evanston: Northwestern University, 1964.

Meyer, Christian. "The Emergence of "Religious Studies (zongjiaoxue) in Late Imperial and Republican China, 1890-1949.” Numen, 62 (2015), 40-75. 
Meynard, Thierry. The Religious Philosophy of Liang Shuming: The Hidden Buddhist. Leiden and Boston: Brill, 2011.

Michalson, Gordon E., Jr. "Faith and History." In Modern Historical Thought, edited by Alister E. McGrath. Oxford: Blackwell, 1993.

Millward, James A. Beyond the Pass: Economy, Ethnicity, and Empire in Qing Central Asia, 1759-1864 (Stanford: Stanford University Press, 1998.

Mircea Eliade ed. The Encyclopedia of Religion. New York: Macmillan, 1987.

Mittag, Achim. "Chinas Modernisierung und die Transformation des chinesischen Geschichtsdenkens unter westlichem Kultureinfluß-Drei Thesen." In Geschichtesdiskurs: vol.4: Krisenbeweßstein, Katastrophenerfahrungen und Innovationen 1880-1945, ed. Wolfgang Kuttler, Jörn Rüsen, and Ernst Schulin. Frankfurt am Main: Fischer Taschenbuch Verlag, 1997.

Miyamoto, Shoson. "Time and Eternity in Buddhism." Journal of the American Academy of Religion XXVII, no. 2 (1959): 118-26.

Mochizuki, Shinkō 望月信亭. “Fojiao chengli shilun 佛教經典成立史論,” trans. Shi Yinhai 釋 印海. Zhongguo fojiao 中國佛教, 41, 7 (1997): 42-46.

Moloughney, Brain. "Myth and the making of history: Gu Jiegang and the Gushi bian debates." In Transforming history: The making of a modern academic discipline in twentiethcentury China, edited by Brian Moloughney and Peter Zarrow. Hong Kong: The Chinese University of Hong Kong Press, 2012. and Zarrow, Peter ed. Transforming History: The Making of a Modern Academic Discipline in Twentieth-Century China. Hong Kong: The Chinese University of Hong Kong Press, 2012. Muller, Jerry Z. “Introduction: What is Conservative Social and Political Thought?" In Conservatism: An Anthology of Social and Political Thought from David Hume to the Present. Princeton, NJ: Princeton University Press, 1997.

Murakami, Senjō 村上專精. Riben fojiao shigang 日本佛教史網, in Shijie foxue mingzhu yicong 世界佛學名著譯叢, vol.53, ed. Lan Jifu 藍吉富. Taipei: Huayu chubanshe 1988.

Murakami, Shigeyoshi 村上重良. Zongjiao yu riben xiandaihua 宗教與日本現代化. Beijing: Jinri Zhongguo chubanshe, 1990.

Murthy, Viren, The Political Philosophy of Zhang Taiyan. Leiden: Brill, 2011.

- - . "Transfiguring Modern Temporality: Zhang Taiyan's Yogacara Critique of Evolutionary History." Modern China, 38,5 (2012): 483-522.

Naka, Michiyo 那珂通世. Shina tsūshi 支那通史. Tokyo: Iwanami Shoten, 1938-1941. Nakajima, Takahiro 中島隆博. “New Confucianism and Buddhism: Liang Shuming, Xiong Shili, and Mou Zongsan 新儒家と仏教一梁漱溟, 熊十力, 牟宗三.” Shiso no.9. Tokyo: Iwanami Shoten, 2007, 80-104.

Nakamura, Hajime 中村元. “Shūkyō to iu yakugo[宗教]という訳語.” Nihon gakushi'in kiyō日 本学士院紀要 46, no. 2 (1991): 64-68, 146. 
-- Ways of Thinking of Eastern Peoples: India, China, Tibet, Japan. Honolulu: East-West Center Press, 1964.

Nattier, Jan. Once upon a Future Time: Studies in a Buddhist Prophecy of Decline. Fremont: Jain Publishing Company, 1991.

-_- "Church language and vernacular language in Central Asian Buddhism." Numen 37 no.2 (1990): 195-219.

- - . "The Meanings of the Maitreya Myth: A Typological Analysis." In Maitreya, the Future Buddha, edited by Alan Sponberg and Helen Hardacre. Cambridge: Cambridge University Press, 1988.

Nedostup, Rebecca. Superstitious Regimes: Religion and the Politics of Chinese Modernity. Cambridge: Harvard University Asia Center, 2009.

--_. "Religion, Superstition and Governing Society in Nationalist China." PhD dissertation, Columbia University, 2001.

Needham, Joseph. "Le temps et l'homme oriental." In La chinoise et l'Occident: le grand titrage. Paris: Éditions du Seuil, 1977.

-- . "Human Laws and Laws of Nature in China and the West." Journal of the History of Ideas 12, no.1 (1951): 3-30.

$\mathrm{Ni}$, Guanning 倪管寜。“日本近現代佛教歷史學的發展與反思.” Shiyuan luntan 史原論壇 (2020.8.26) , http://shi-yuan.blog.ntu.edu.tw/xuexunaug20/.

Nienhauser, William H. ed. The Indiana Companion to Traditional Chinese Literature. Bloomington: Indiana University Press, 1986.

Nietzsche, Friedrich. "On Truth and Falsity in their Ultra moral Sense.” In The Complete Works of Frederick Nietzsche, edited by Oscar Levy. New York: Gordon, [1873]1974.

Niu, Runzhen 牛潤珍. Chen Yuan xueshu sixiang pingzhuan 陳垣學術思想評傳. Beijing: Beijing tushuguan chubanshe, 1999.

Nongbri, Brent. Before Religion: A History of a Modern Concept. New Heaven: Yale University Press, 2013.

Norman, K.R. "Buddhism and Canonicity." In A Philological Approach to Buddhism: The Bukkyo Dendo Kyokai Lectures 1994. London: SOAS, 1997.

Obeyesekere, Gananath. "Religious Symbolism and Political Change in Ceylon.” Modern Ceylon Studies 1, 1 (1976): 43-63.

Oldenburg, Hermann. Buddha, sein Leben, seine Lehre, seine Gemeinde. Berlin: Verlag von Wilhelm Hertz, 1881.

Ouyang Jingwu 歐陽竟無.“Huang Jian shilue 黄建事略.” Niexue I (1924): 179-180.

Overmyer, Daniel L. "Buddhism in the Trenches: Attitudes toward Popular Religion in Chinese Scriptures Found at Tun-Huang." Harvard Journal of Asiatic Studies 50.1 (1990): 197-222. Pacey, Scott. "Taixu, Yogācāra, and the Buddhist Approach to Modernity." In Transforming Consciousness: Yogacara Thought in Modern China, edited by John Makeham. Oxford: Oxford University Press, 2014, 
Pachow, W. "A Study of the Dotted Record." Journal of the American Oriental Society, 85, 3 (1965): 342-349.

Pan, Guiming 潘桂明. Zhongguo jushi fojiao shi 中國居士佛教史. Beijing: Zhongguo shehui kexue chubanshe, 2000.

Patton, Laurie ed. Authority, Anxiety, and Canon: Essays in Vedic Interpretation. Albany: State University of New York Press, 1994.

Paul E. Callahan. "T'ai-hsü and the New Buddhist Movement." Harvard University: Paper on China 6 (1952): 149-88.

Paul R. Katz. "Religion and the State in Post-War Taiwan." China Quarterly 174.2 (2003): 395412.

Pelliot, Paul. “Meou-tseu ou les doutes levés.” T'oung Pao, 19, no.5 (1919): 255-433.

-_- "Autour d'une traduction sanscrite du tao tö king." T'oung Pao 13, no.2 (1912): 350-431.

Peng, Tsintsin. “Jindai fojiao shixue de beijing he jiaodian: yi weirao 'sishier zhangjing' de lunzheng weili 近代佛教史學研究的背景和焦點: 以圍繞《四十二章經》的論爭為例.” Huaren zongjiao yanjiu 華人宗教研究, 5. (2015).

Penkower, Linda. "In the Beginning... Guanding (561-632) and the Creation of Early Tiantai." Journal of the International Association of Buddhist Studies, 23, 2 (2000): 245-296.

Pittman, Don A. Toward a Modern Chinese Buddhism: Taixu's Reforms. Honolulu: University of Hawai'i Press, 2001.

Pöggeler, Otto. Eine Ende der Geschichte? Von Hegel zu Fukuyama. Opladen: Westdeutscher Verlag, 1995.

Poon, Shuk-Wah. Negotiating Religion in Modern China: State and Common People in Guangzhou, 1900-1937. Hong Kong: The Chinese University of Hong Kong, 2011.

-C-. "Refashioning Festivals in Republican Guangzhou." Modern China 30,2 (2004): 199-227.

Porkert, Manfred. The Theoretical Foundations of Chinese Medicine: Systems of Correspondence. Cambridge, Mass.: MIT Press, 1974.

Prebish, Charles and Keown, Damien ed. Action Dharma: New Studies in Engaged Buddhism. London: Routledge Curzon, 2003.

Pulleyblank, Edwin G. "The Historiographical Tradition," in The Legacy of China, ed. Raymond Dawson. London: Oxford University Press, 1964.

-_- "Chinese Historical Criticism: Liu Chih-chi and Ssu- ma Kuang," in Historians of China and Japan ed. W. G. Beasley and E. G. Pulleyblank. London: Oxford University Press, 1961.

-_- "“Gentry Society': some remarks on recent work by W. Eberhard." Bulletin of the School of Oriental and African Studies (BSOAS), xv, 1953.

Pung, Mingfei 彭明輝. Yigu sixiang yu xiandai Zhongguo shixue de fazhan 疑古思想與現代中國 史學的發展. Taipei: Shang wu yinshu guan, 1991.

Pye, Michael. "Comparative Hermeneutics in Religion." In The Cardinal Meaning: Essays in Comparative Hermeneutics, Buddhism and Christianity, edited by Michael Pye and Robert Morgan. The Hague: Mouton, 1973. 
Qi Mu 錢穆. Bashi yi shuangqin shiyou zanyi hekan 八十憶雙親師友雜憶合刊, in Qian Bingsi xiansheng quanji 錢賓四先生全集, vol. 51. Taipei: Lianjing, 1998.

Qian, Wanyue 錢婉約. “Cisheng chengjiu mingshan ye, buyan chongyang shi wanghuan: Neiteng Hunan Zhongguo fangshu jiqi xueshushi yiyi shulun 此生成就名山業, 不厭重 洋十往還--内藤湖南中國訪書及其學術史意義述論。”Journal of East Asian cultural interaction studies 東アジア文化交涉研究, 3 (2008): 135-59.

Qiu, Minjie 邱敏捷. “Hu Shih yu Linmu dazhuo 胡適與鈴木大拙.” Liangan dangdai chanxue lunwen ji (shang) 兩岸當代禪學論文集(上), ed., Zheng Zhiming 鄭志明. Jiayi: Nanhua University, Religion centre 南華大學宗教中心, 2000, 155-78.

Queen, Christopher S. “Engaged Buddhism.” In Westward Dharma: Buddhism Beyond Asia, edited by Charles S. Prebish, Martin Baumann. Berkeley: University of California Press, 2002. --- and King, Sallie B. Engaged Buddhism: Buddhist Liberation Movements in Asia. Albany: SUNY Press, 1996.

Quirin, Michael. “Die chinesische Intelligenz und die Macht.” Oriens Extremus, no.1-2 (1995), 239-258.

--_. "Scholarship, Value, Method, and Hermeneutics in Kaozheng: Some Reflections on Cui Shu (1740-1816) and the Confucian Classics." History and Theory 35, no. 4 (1996): 34-53.

Ramanan, K Venkata. Nagarjuna's philosophy: as presented in the Maha-Prajnaparamita-Sastra, vol. 6. Motilal Banarsidass Publ., 1987.

Randall, John Herman, Jr. The Making of the Modern Mind: A Survey of the Intellectual Background of the Present Age. New York: Columbia University Press, 1926.

Rawski, Evelyn S. "Reenvisioning the Qing: The Significance of the Qing Period in Chinese History." The Journal of Asian Studies 55, no.4: 829-50.

Reader, Ian and Tanabe, George. Practically Religious: Worldly Benefits and the Common Religion of Japan. Honolulu: University of Hawai'i Press, 1998.

Reichelt, Karl L. “Trends in China's non-Christian Religions.” Chinese Recorder 65 (1934): 758768.

Reimon, Yūki. “Shina Bukkyō ni okeru mappō shisō no kōki” 支那佛教に於ける末法思想の 興起. Tōhō gakuhō 東方學報 6, no. 1 (1936).

Rhoads, Edward. Manchus and Han: Ethnic Relations and Political Power in Late Qing and Early Republican China, 1861-1928. Seattle: University of Washington, 2000

Ricoeur, Paul. Hermeneutics and the Human Science, edited and translated by John B. Thompson. Cambridge: Cambridge Press, 1981.

-- - The Conflict of Interpretations, trans. Evanston. The North-western University Press. 1974.

Riedel, Manfred. "Einleitung (Introduction)." In Der Aufbau der geschichtlichen Welt in den Geisteswissenschaften, edited by Wilhelm Dilthey. Frankfurt/Main: Suhrkamp, 1997. Ritzinger, Justin R. “Dependent Co-evolution: Kropotkin's Theory of Mutual Aid and Its Appropriation by Chinese Buddhists." Chung-Hwa Buddhist Journal 26 (2013): 96-106. 
--_. "Anarchy in the Pure Land: Tradition, modernity, and the reinvention of the cult of Maitreya in Republican China." Ph.D Dissertation, Harvard University, 2010.

-_- "Taixu: To Renew Buddhism and Save the Modern World." Thesis, Lawrence University (1999).

Robert E. Buswell ed. Encyclopedia of Buddhism. New York: Macmillan Reference USA, 2004.

Roberts, Tyler. "Between the Lines: Exceeding Historicism in the Study of Religion." Journal of the American Academy of Religion, 74, no. 3 (2006): 697-719.

Robertson, Roland. "Modernity and Religion: Towards the Comparative Genealogy of Religion in Global Perspective." Zen Buddhism Today, 6 (1988): 125-33.

Robinet, Isabella. Méditation taoïste. Paris: Dervy livres, 1979.

Rong, Xinjiang 榮新江. “Land Route or Sea Route? Commentary on the Study of the Paths of Transmission and Areas in which Buddhism Was Disseminated during the Han Period." Sino-platonic Papers, vol. 144 (2004): 1-32.

Rothschild, N. Harry. Emperor Wu Zhao and Her Pantheon of Devils, Divinities, and Dynastic Mothers. New York: Columbia University Press, 2015.

Rowe, William T. Saving the World. Chen Hongmou and Elite Consciousness in Eighteenth-Century China. Stanford: Stanford University Press, 2001.

Rubin, Vitaly A. "The Concepts of Wu-Hsing and Yin-Yang." Journal of Chinese Philosophy 9, no.2 (1982): 131-157.

Rudolph, Kurt and Alles, Gregory D. "We Learn What Religion Is from History: On the Relation between the Study of History and the Study of Religions." Historical Reflections/ Réflexions Historiques 20, no. 3 (1994): 357-76.

Rule,Paul A. "Jesuit and Confucian? Chinese Religion in the Journals of Matteo Ricci." Journal of Religious History 5 (1968). 105-24.

Rüsen, Jörn. Konfigurationen des Historismus. Studien zur deutschen Wissenschaftskultur. Frankfurt a. M: Suhrkamp, 1993.

-_- "Konfigurationen des Historismus." Geschichte des Historismus. Eine Einführung, ed. Friedrich Jaeger and Jörn Rüsen. Munich: C.H. Beck, 1992, 18-113.

Said, Edward W. Orientalism. New York: Vintage Books, 1978.

Sakae, Yamaguchi Sakae 山口栄. “Ko Teki no Chūgoku Zenshūshi ni tsuite 胡適の中國禅宗 史に就いて.”Junsei Tanki Daigaku kenkyū kiyō順正短期大學研究紀要, 3 (1973): 63- 76.

Sang, Bing 桑兵. “Minguo xueren de songdai yanjiu jiqi jiujie 民國學人的宋代研究及其糾 結.” In Xueshu jianghu: wanqing minguo de xueren yu xuefeng xueshu jianghu 學術江湖: 晚清 民國的學人與學風學術江湖.” Guilin: Guangxi shifan daxue chubanshe, 2017.

- - - “Fu Sinian 'shixue zhishi shiliao xue' zaixi 傅斯年「史學只是史料學」再析.” Jindai shi yanjiu 近代史研究, no. 5 (2007): 26-41.

- - - “Boxihe yu Zhongguo jindai xueshujie 伯希和與中國近代學術界." Lishi yanjiu 歷史研 究, no. 5 (1995): 115-38.

Sanit-Hilaire, Jules Barthélémy. The Buddha and His Religion. London: Routledge, 1914. 
Sato, Masayuki. "The Archetype of History in the Confucian Ecumene." History and Theory 46, no. 2 (2007), 218-23.

Schicketanz, Erik. "Narratives of Buddhist Decline and the Concept of the Sect (Zong) in Modern Chinese Buddhist Thought." Studies in Chinese Religions 3, no. 3 (2017): 281-300.

---. Daraku to fukkō no kindai Chūkoku Bukkyō: Nihon Bukkyō to no kaikō to so no rekishizō no kōchiku 值落と復興の近代中国仏教:日本仏教との邂逅とその歴史像の構築. Kyoto: Hozōkan, 2016.

Schleiermacher, Friedrich. Bruchstücke der unendlichen Menschheit, Fragmente, Aphorismen und Notate der frühromantischen Jahre, ed. K. Nowak. Berlin: Union Verlag Berlin, 1984.

Schmidt-Glinzer, Helwig. Die Identität der Buddhistischen Schulen und die Kompilation Buddhistischer Universal geschichten in China: Ein Beitrag zur Geistesgeschichte der Sung Zeit. Wiesbaden: Franz Steiner.1982.

Schneider, Axel. "Nation, History and Ethics: The Choices of Post-Imperial Historiography in China." In Transforming History: The Making of a Modern Academic Discipline in TwentiethCentury China, edited by Peter Zarrow Brian Moloughney. Hong Kong: The Chinese University Press, 2012.

- - - and Tanaka, Stefan. "Historical writings in China and Japan." In The Oxford History of Historical Writing: 1800-1945, edited by Stuart Macintyre, Juan Maiguashca, and Attila Pók. Oxford: University of Oxford Press, 2011.

---. "The One and the Many: A Classicist Reading and Its Role in the Modern World-An Attempt on Modern Chinese Conservatism." Procedia-Social and Behavioral Sciences 2, no. 5 (2010): 7218-7243.

- - . "Shijie lishi yu lishi xiangdui zhuyi de wenti-1919 nian yihou liangqichao de shixue 世 界歷史與歷史相對主義的問題-1919 年以后梁啟超的史學.” In Zhenli yu lishi: FuSinian, Chen Yinke de shixue sixiang yu minzu rentong 真理與歷史:傅斯年陳寅恪的史學思想與民 族認同, 238-259. Beijing: Social Sciences Documentation Publishing House, 2008.

-_- "Reconciling History With The Nation? Historicity, National Particularity, And The Question Of Universals." Historiography East and West 1 (2003): 117-36.

--- Wahrheit und Geschichte: Zwei chinesische Historiker anf der Suche nach einer modernen Identität für China. Wiesbaden: Harrassowitz Verlag, 1997.

- - . "Between Dao and History: Two Chinese Historians in Search of a Modern Identity for China." History and Theory 35, no. 4 (1996).

Schneider, Julia. Nation and Ethnicity: Chinese Discourses on History, Historiography and Nationalism (1990s-1920s). Leiden: Brill, 2017.

Schneider, Laurence A. Ku Chieh-kang and China's New History: Nationalism and the Quest for Alternative Traditions. Berkeley: University of California Press, 1971.

Schopen, Gregory. Bones, Stones, and Buddhist Monks: Collected Papers on the Archaeology, Epigraphy, and Texts of Monastic Buddhism in India. Honolulu: University of Hawai'i Press, 1997. 
- - . "Filial Piety and the Monk in the Practice of Indian Buddhism: A Question of 'Sinicization' Viewed from the Other Side." T'oung Pao 70, no. 1/3 (1984): 110-26. Schwab, Raymond. The Oriental Renaissance: Europe's Rediscovery of India and the East, 1680-1880, trans. Gene Patterson-Black. New York: Columbia University Press, 1984.

Schwarcz, Vera. The Chinese Enlightenment: Intellectuals and the Legacy of the May Fourth Movement of 1919. Berkeley: University of California Press, 1986.

Schwartz, Benjamin I. "Culture, Modernity, and Nationalism - Further Reflections.” In China in Transformation, edited by Tu Wei-ming. Cambridge, MA: Harvard University Press, 1993.

-_- "Themes in Intellectual History: May Fourth and After." In The Cambridge History of China, Republican China, 1912-1949, vol. 12, edited by John K. Fairbank. Cambridge, UK: Cambridge University Press, 1983.

-_- ed. Reflections on the May Fourth Movement: A Symposium. Cambridge, MA: East Asian Research Centre, Harvard University Press, 1972.

Schwartz, Benjamin I. The World of Thought in Ancient China. Cambridge, MA.: Harvard University Press, 1985.

- - . "History in Chinese Culture: Some Comparative Reflections." History and Theory 35, no. 4 (1996), 10.

--_. In Search of Wealth and Power. Cambridge, MA: Harvard University Press, 1983.

Scott, Gregory Adam. "Conversion by the Book: Buddhist Print Culture in Early Republican China.” Ph.D Dissertation, Columbia University, 2013.

-_- "The Publishing of Buddhist Books for Beginners in Modern China from Yang Wenhui to Master Sheng Yen.” Shengyan yanjiu 聖嚴研究 5 (2014): 51-107.

Scott, R. P. “The Boxer Indemnity in its Relation to Chinese Education." Journal of the British Institute of international Affairs 2.4 (1923): 149-67

Seager, Richard Hughes ed. The Dawn of Religious Pluralism: Voices from the World's Parliament of Religions, 1893. Illinois: Open Court Publishing, 1993.

Sébastien Billioud and Joël Thoraval. "The Contemporary Revival of Confucianism: Anshen liming or the Religious Dimension of Confucianism." China Perspectives, 3 (2008): 88-106.

Sen, Tansen. Buddhism, Diplomacy, and Trade: The Realignment of Sino-Indian Relations, 600-1400. Honolulu: University of Hawai'i Press, 2003.

Shaku, Soyen. "Sermons of A Buddhist Abbot [Zen for Americans]." In Sermons of a Buddhist Abbot, translated by D.T. Suzuki. Chicago, the Open Court Publishing Company, 1906.

Sharf, Robert H. Coming to Terms With Chinese Buddhism: A Reading of the Treasure Store Treatise. Honolulu: University of Hawai'i Press, 2002.

-_- "The Scripture in Forty-two Sections." Religions of China in Practice, ed. Donald S. Lopez, Jr. Princeton University Press, Princeton, 1996, 360-71.

-_- "Whose Zen? Zen Nationalism Revisited." Rude Awakenings: Zen, the Kyoto School and the Question of Nationalism (1995): 40-51. 
-—-. "Buddhist Modernism and the Rhetoric of Meditative Experience." Numen 42 (1995), 228-83.

-C-. “The Zen of Japanese Nationalism.” History of Religions 33, no. 1 (1993): 1-43.

Sheel, Kamal. "Hu Shih and 'The Indianisation of China': Some Comments on Modern Chinese Discourses on India." China Report, 50, no.3 (2014): 177-188.

Shen, Sung-Chiao 沈松僑. Xueheng Pai yu Wusi Shiqi de Fan Xinwenhua Yundong 學衡派與五四 時期的反新文化運動. Taipei: National Taiwan University, 1984.

Shi Zhiru. "Contextualizing Buddhist Approaches to Religious Diversity." In Religious Diversity in Chinese Thought, edited by Perry Schmidt-Leukel and Joachim Gentz. New York: Palgrave Macmillan, 2013.

Shi, Dongchu 釋東初. “Jindai fojiao zhi chengjiu 近代中國佛教之成就.” In Zhongguo fojiao jindai shi 中國佛教近代史. Taipei: Zhongguo fojiao wenhua guan, 1974.

Shi, Fachuang 釋法幢. “Mingqing zhiji jiaxingzang diaoyin de shimo yinyuan 明清之際嘉興 藏雕印的始末因緣.” Zhongguo foxue 中國佛學 1 (2014): 23-40.

Shi, Jingan 釋敬安. Bazhi toutuo shiwenji 八指頭陀詩文集. Changsha: Yuelu shushe, 1984. Shi, Jun 石峻. Lixue, Foxue, Xuanxue 理學·佛學•玄學. Beijing: Beijing daxue chubanshe, 1991. Shi, Lijun 史麗君. Chen Yuan de shiyuan xue lilun yu shijian 陳垣的史源學理論與實踐. Beijing: Renmin chubanshe, 2016.

Shi, Miaozhou 妙舟. Meng Zang Fojiao shi 蒙藏佛教史. Yangzhou: Jiangsu guangling guji keyinshe, 1997.

Shi, Yinshun 印順. Taixu Dashi nianpu 太虛大師年譜. Taipei: Zhengwen, 2003.

Shields, James Mark. Critical Buddhism: Engaging with Modern Japanese Buddhist Thought. Burlington: Ashgate, 2011.

Shih, Heng-qing. The Syncretism of Ch'an and Pure Land Buddhism. New York: Peter Lang, 1992. Shinohara, Koichi. "Rethinking the Category of Chinese Buddhist Apocrypha." Studies in Chinese Religions 1, no. 1 (2015): 70-81.

Sinha, Braj M. Time and Temporality in Sāmkhya Yoga and Abhidharma Buddhism. New Delhi: Munshiram Manoharlal Publishers Pvt. Ltd, 1983.

Smith, Barbara Herrstein. Contingencies of Value: Alternative Perspectives for Critical Theory. Cambridge, MA: Harvard University Press, 1988.

Smith, Jonathan Z. "Religion, Religions, Religious." In Critical Terms for Religious Studies, edited by Mark C. Taylored. Chicago: University of Chicago Press, 1998.

--- Imagining Religion: from Babylon to Jonestown. Chicago: University of Chicago Press, 1982.

Smith, Robert. J. Japanese Society. Tradition, Self and the Social Order. Cambridge, Cambridge University Press, 1983.

Smith, Steven. A. "Introduction: The Religion of Fools? Superstition Past and Present." Past \& Present 199, 3 (2008): 7-55.

Smith, Wilfrid Cantwell. The Meaning and End of Religion. Minneapolis: Fortress Press, 1991. 
Song, Daofa 宋道發. Fojiao shiguan yanjiu 佛教史觀研究. Beijing: Zongjiao wenhua chubenshe, 2009.

Soothill, William E. The Three Religions of China: Lectures Delivered at Oxford. London: Oxford University Press, H. Milford, 1923.

Soulen, R. Kendall. "The Believer and the Historian: Theological Interpretation and Historical Investigation." Interpretation 53.2 (2003): 174-186.

Spohn, Willfried. "Multiple Modernity, Nationalism and Religion: A Global Perspective." Current Sociology 51 (2003): 265-86.

Stache-Rosen, Velentina. German Indologists: Biographies of Scholars in Indian Studies Writing in German: With a Summary on Indology in German Speaking Countries. New Delhi: Max Müller Bhavan, 1990.

Starn, Randolph. "Historians and 'Crisis'." Past and Present 52 (1971): 3-22.

Stcherbatsky, Theodor. The Conception of Buddhist Nirvana. London: Mouton \& Co, 1965.

Stefania Travagnin. "Concepts and Institutions for a new Buddhist Education: Reforming the Samgha Between and within State Agencies." East Asian History 39 (2014).

Stein, Rolf A. "The Guardian of the Gate: An Example of Buddhist Mythology, from India to Japan." In Asian Mythologies, edited by Yves Bonnefoy ans Wendy Doniger, 122-36. Chicago: University of Chicago Press, 1991.

- - - Tibetan Civilization. Stanford: Stanford University Press, 1972.

Stewart, Charles and Shaw, Rosalind eds. Syncretism/Anti-Syncretism: The Politics of Religious Synthesis. New York: Routledge, 1994.

Storch, Tanya. The History of Chinese Buddhist Bibliography: Censorship and Transformation of the Tripitaka. Cambridge: Cambridge University Press, 2014.

Strickmann, Michel. "The Tao Among the Yao: Taoism and the Sinification of South China." In Rekishi ni okeru minshū to bunka-Sakai Tadao Sensei koki shukuga kinen ronshū 歷史におけ る民眾と文化一酒井忠夫先生古稀祝賀紀念論集, 23-30. Tokyo: Kokusho Kankokai, 1982.

--C. Mantras et mandarins: Le bouddhisme tantrique en Chine. Paris: Gallimard, 1996.

Stroumas, Guy G. A New Science: The Discovery of Religion in the Age of Reason. Cambridge, MA: Harvard University Press, 2010.

Sutton, Donald S. "From Credulity to Scorn: Confucians Confront the Spirit Mediums in Late Imperial China." Late Imperial China 21, no. 2 (2000): 23-24

Suzuki, D.T. Essays in Zen Buddhism. London: Rider and Company, 1949-1953.

-_-. "Zen: A Reply to Hu Shih." Philosophy East and West 3, no. 1 (1953): 25-46.

Swyngedouw, Jan. “Japanese Religiosity in an Age of Internationalization.” Japanese Journal of Religious Studies, 5 (1978): 87-106.

Tairyō, Matita 牧田諦亮. “Seimotsu irai ni okeru byōsan kōgaku 清末认來に於ける廟產興 學.” Chūgoku bukkyōshi kenkyu 中國佛教史研究. vol.2. Tokyo, Taito shuppansha, 1984, 290-318. 
Takanishi, Kenshō 高西賢正 ed. Higashi Honganji Shanghai kaikyō rokujūnen shi 東本願寺上海 開教六十年史. Shanghai: Higashi Honganji Shanghai Betsuin, 1937.

Takatoshi, Itō. 'The Formation of Chinese Buddhism and 'Matching the Meaning [geyi]',' in Memoirs of the Research Department of the Toyo Bunko, translated by Rolf W. Giebel. The Oriental Library, no. 54 (1996): 65-91.

Takeshi, Kobayashi 小林武. Shō Heirin to Meiji shichō mō hitotsu no kindai 章炳麟と明治思潮: も う一つの近代. Tokyo: Kenbun Shuppan, 2006.

Tan, Siting. An Exposition of Benevolence: the Jen-hseuh of Tan Ssu-t'ung, translated by Chan Sinwai. Hong Kong: The Chinese University of Hong Kong Press, 1984.

Tan, Sitong 譚嗣同. Renxue 仁學. Beijing: Huaxia chubanshe, 2002 [1896].

Tan, Zhihui. "Daoxuan's Vision of Jetavana: Imaging a Utopian Monastery in Early Tang." Ph.D dissertation, University of Arizona, 2002.

Tanaka, Stefan and Schneider, Axel. "Chinese and Japanese Historiography." In Oxford History of Historical Writing, edited by Stuart MacIntyre Daniel Woolf. Oxford: Oxford University Press, 2011.

-- . Japan's Orient: Rendering Pasts into History. Berkeley: University of California Press, 1995.

Tang, Xiaobing. Global Space and the Nationalist Discourse of Modernity: The Historical Thinking of Liang Qichao. Stanford: Stanford University Press, 1996.

Tang, Zhijun 湯志鈞. Zhang Taiyan nianpu changbian 章太炎年譜長編. Beijing: Zhonghua, 1979.

Tang, Zhongmao 唐忠毛. Zhongguo fojiao jindai zhuanxing de shehui zhi wei: minguo Shanghai jushi fojiao zuzhi yu cishan yanjiu 中國佛教近代轉型的社會之維: 民國上海居士佛教組織 與慈善研究. Guilin: Guangxi shifan daxue chubanshe, 2013.

Tao, Fanbing 陶惁炳. Zhongguo gudai shixueshi lue 中國古代史學史略. Changsha: Hunan renmin chubanshe, 1987.

Tarocco, Francesca. "Lost in Translation? The 'Treatise on the Mahāyāna Awakening of Faith (Dasheng qixin lun)' and Its Modern Readings." Bulletin of the School of Oriental and African Studies, University of London 71, no.2 Scripture and Modernity: A Tribute to Professor John Wansbrough (2008): 323-343.

Taylor, Charles. "Comparison, History, Truth." Myth and Philosophy, ed. David Tracy and Frank Reynolds. Albany: State University of New York Press, 1991.

-- - Sources of the Self: The Making of the Modern Identity. Cambridge: Harvard University Press, 1989.

Taylor, Rodney L. The Religious Dimensions of Confucianism. Albany: SUNY Press, 1990.

Teiser, Stephen F. “Popular Religion.” The Journal of Asian Studies 54, no. 2 (1995): 387-95.

Teng, Wei-jen 鄧偉仁. “Jige pipan 'fojiao Zhongguohua' lilun de zai shenshi 幾個批判 “佛教 中國化”理論的再審視.” Qiufa yu Hongfa 求法與弘法, ed., Shi Guojing 釋果鏡, Liao Zhaoheng 廖肇亭. Taipei: Fagu Wenhua, 2015, 79-104.

Ter Haar, Barend. The White Lotus Teachings in Chinese Religious History. Leiden: Brill, 1992. 
Thomas Kuhn, "Second thoughts on Paradigm." The Essential Tension: Selected Studies in Scientific Tradition and Change. Chicago: Chicago University Press, 1977, 293-319. Thurman, Robert. Inner Revolution. New York: Riverhead Books, 1998.

Tim H. Barrett and Francesca Tarocco. "Terminology and Religious Identity: Buddhism and the Genealogy of the Term Zongjiao." In Dynamics in the History of Religions between Asia and Europe, edited by Volkhard Krech and Marion Steinicke. Leiden: Brill, 2012.

Tokuno, Kyoko. "The Evaluation of Indigenous Scriptures in Chinese Buddhist Bibliographical Catalogues." In Chinese Buddhist Apocrypha, edited by Robert E Buswell. Honolulu: University of Hawaii Press, 1990.

Tong, Te-kong ed. Reminiscences of Shih Hu : Oral History. Taipei: Yuanliu 遠流, 2010.

Townsend, James. "Chinese Nationalism." The Australian Journal of Chinese Affairs, no. 27 (1992): 97-130.

Toyohachi, Fujita 藤田丰八. Zhongguo nanhai gudai jiaotong congkao 中國南海古代交通叢考, trans. He Jianmin 何健民. Shanghai: Shangwu yinshuguan, 1936.

Tsukamoto, Zenryū 塚本善隆. “The Dates of Kumārajīva and Seng-chao Reexamined.” In Zinbun Kagaku Kenkyūjo Silver Jubilee Volume, translated by Leon Hurvitz. Kyoto: Kyōto daigaku jinbun kagaku kenkyūjo, 1954.

--_. A History of Early Chinese Buddhism, translated by Leon Hurvitz. Tokyo: Kodansha International Ltd., 1985.

Tsukamoto, Zenryū 塚本善隆. Shina Bukkyō shi kenkyū 支那仏教史研究. Tokyo: Kōbundō shobō, 1924.

-—-C Chūgoku kinseibukkyōshi no shomondai 中国近世仏教史の諸問題. Tsukamoto Zenryū chosakushū 塚本善隆著作集, vol.5. Tokyo: Daitō shuppansha, 1975.

Tu Weiming. Neo-Confucian Thought in Action: Wang Yang-Ming's Youth. Berkeley: University of California Press, 1976.

Twitchett, Denis. The Writing of Official History Under the T'ang. New York: Cambridge University Press, 1992).

van Ess, Hans. "The Apocryphal Texts of the Han Dynasty and the Old Text/New Text Controversy." T'oung Pao, 85, no. 1-3 (1999), 29-64.

Verter, Bradford. "Spiritual capital: theorizing religion with Bourdieu against Bourdieu." Sociological Theory 21 no. 2 (2003): 150-74.

Vierhaus, Rudolf. “Zum Problem historischer Krisen.” In Historische Prozesse, Beiträge zur Historik, edited by Karl-Georg Faber and Christian Meier. Munich: dtv, 1978.

von Hendy, Andrew. The Modern Construction of Myth. Bloomington: Indiana University Press, 2002.

Wach Joachim. Types of Religious Experience. Christian and Non-Christian. Chicago: University of Chicago Press, 1972.

Waley, Authur. "History and Religion.” Philosophy East and West, 5, (1955): 75-78. 
Walton, Matthew J. "Buddhism, Nationalism, and Governance." In The Oxford Handbook of Contemporary Buddhism. Oxford: Oxford University Press, 2017.

Wan, Shengnan 萬繩楠 ed. Chen Yinke Wei Jin Nanbeichao shi jiangyan lu 陳寅恪魏晉南北朝史 講演錄. Hefei: Huangshan Shushe, 2007.

Wang, Ermin 王爾敏. “Zhongguo mingcheng suyuan jiqi jindai chanshi 中國名稱溯源及其現 代闡釋.” In Zhongguo jindai sixiang shilun 中國近代思想史論, 441-80. Taipei: Huashi chubanshe, 1977.

Wang, Fansen 王汎森. “Jindai Zhongguo de xianxing lishiguan: yi shehui jinhualun wei zhongxin de taolun 近代中國的線型歷史觀: 以社會進化論為中心的討論.”Xin shixue 新史學 19, no. 2 (2008): 1-46.

- “Wan Qing de zhengzhi gainian yu 'Xinshi xue”” 晚清的政治概念與 “新史學”, in Ershi shiji de Zhongguo: xueshu yu shehui - shixuejuan 20 世紀的中國: 學術與社會-史學卷, edited by Luo Zhitian 羅志田, 1-30. Jinan: Shandong renmin chubanshe, 2001.

- - . " 'Zhuyi chongbai' yu jindai Zhongguo xueshu shehui de mingyun -- yi Chen Yinke wei zhongxin de kaocha '主義崇拜”與近代中國學術社會的命運一以陳寅恪為中心的考 察.” In Zhongguo Jindai Sixiang Yu Xueshu De Xipu 中國近代思想與學術的系譜. Taipei: Lianjing, 2003, 463-88.

- - - Gushi bian yundong de xingqi 古史辩運動的興起. Taipei: Yunchen, 1987.

- - . “Cong chuantong dao Fan chuantong-Liangge sixiang mailuo de fenxi 從傳統到反傳統 一兩個思想脈絡的分析.” In Zhongguo jindai sixiang yu xueshu dexipu 中國近代思想與學 術的系譜, 111-32. Taipei: Linking, 2003.

- - . "The Impact of the Linear Model of History on Modern Chinese Historiography." In Transforming History: the Making of a Modern Academic Discipline in Twentieth-Century China, edited by Brain Moloughney and Peter Zarrow, 135-68. Hongkong: The Chinese University Press, 2012.

--_. Fu Ssu-nien: A Life in History and Politics. Cambridge: Cambridge University Press, 2010. Wang, Guowei 王國維. “Shen Yian xiansheng qishi shouxu 沈乙庵先生七十壽序.” In Guantang jilin 觀堂集林 in Wang Guowei yishu 王國維遺書. Shanghai: Shanghai guji chubanshe, 1983.

Wang, Hao 王皓. “Chen Yuan shixue yu jiaohui yinyuan 陳垣史學與教會因緣.” Zhongyang yanjiu yuan jindaishi yanjiu suo jikan 中央研究院近代史研究所集刊 97 (2017): 87-121.

Wang, Hui 汪暉. Xianzai Zhongguo sixiang de xingqi 現代中國思想的興起. Beijing: Sanlian shudian, 2002.

- - China's New Order: Society, Politics, and Economy in Transition, ed. Theodore Huters. Cambridge, MA: Harvard University Press, 2006.

Wang, Jianchuan 王見川. “Jindai Zhongguo fuji cishan: yi Yinguang wenchao wei kaocha xiansuo 近代中國扶乩慈善與「迷信」一以印光文鈔為考查線索.” In Disijie guoji hanxue huiyi lunwenji: Xinyang, shijian, yu wenhua tiaoshi 第四屆國際漢學會議論文集: 信 仰, 實践, 與文化調適. Taipei: Academia Sinica, June 2013. 
Wang, Juchang 王遽常. Qingmo Shen Meisou xiangsheng nianpu 清末沈㻗舅先生年譜. Taipei: Shangwu yinshuguan, 1982.

Wang, Q. Edward. Inventing China through History: The May Fourth Approach to Historiography. Albany: State University of New York Press, 2001.

-_-. "Time Perception in Ancient Chinese Historiography." Storia della Storiografia 28 (1995): 69-86.

Wang, Qilong 王啟龍. Ganghetai xueshu nianpu jianbian 鋼和泰學術年譜簡編. Beijing: Zhonghua shuju, 2008.

-_- "A Brief Review of Alexander von Stael-Holstein: A Great Scholar in Asian Studies." Chinese Tibetology 1 (2008): 80-93.

Wang, Rongzu 汪榮祖. Shijia Chen Yinke zhuan 史家陳寅恪傳. Taipei: Linking, 1988.

Wang, Wenyan 王文顏. Fojing yiweijing yanjiu yu kaoju 佛教疑偽經研究與考錄. Taipei:

Wenjing chubanshe, 1997.

Wang, Y. C. Chinese Intellectuals and the West 1872-1949. Chapel Hill: University of North Carolina Press, 1966.

Wang, Yinian 汪詒年. Wang Rangqing yizhu 汪稿卿遺著. Taipei: Chaohua chubanshe, 2017. Watson, Burton. Sima Qian: Records of the Grand Historian: Han dynasty. New York: Columbia University Press, 1963.

Weber, Max. Economy and Society. Berkeley: University of California Press 1978.

- - . The Protestant Ethic and the Spirit of Capitalism. New York: Routledge Classics 2001.

Weigelin-Schwiedrzik, Susanne. "On Shi and Lun: Toward a Typology of Historiography in the PRC." History and Theory, 35, 4 (1996): 74-95.

Welch, Holmes. Taoism: The Parting of the Way. Boston: Beacon Press. 1957.

- - . The Buddhist Revival in China. Cambridge: Harvard University Press, 1965.

-_- The Practice of Chinese Buddhism, 1900-1950. Cambridge, MA: Harvard University Press, 1967.

Weller, Robert P. “Worship, Teaching and State Power in China and Taiwan." In Realms and Freedom in Modern China, edited by William Kirby, 285-314. Stanford: Stanford University Press, 2001.

- - Alternate Civilities: Democracy and Culture in China and Taiwan. Boulder: Westview Press, 1999.

White, Hayden. Metahistory: The Historical Imagination in Nineteenth-Century Europe. Baltimore: Johns Hopkins University Press, 1975.

-—- Tropics of Discourse: Essays in Cultural Criticism. Baltimore: Johns Hopkins University Press. 1978.

Wilkinson, Endymion Porter. Chinese History: A Manual. Harvard Yenching Institute Monograph Series, 52. Cambridge, MA: Harvard University Asian Centre, 2000.

William, G. Boltz. “Kung Kung and the Flood: Reverse Euhemerism in the 'Yao Tian'.” T'oung Pao, 67 (1981): 141-53. 
Wing-tsit Chan. Religious Trends in Modern China. New York: Columbia University Press, 1953. Wong, Young-tsu. “The Ideal of Universality in Late Ch'ing Reformism." In Reform in Nineteenth-Century China, edited by Paul A. Cohen and John E. Schrecker, 150-54. Cambridge: East Asian Research Center, Harvard University, 1976.

---. Search for modern nationalism: Zhang Binglin and revolutionary China, 1869-1936. Hong Kong: Oxford University Press, 1989.

Wright, Arthur F. Buddhism in Chinese History. Stanford, Stanford University Press 1959. $\mathrm{Wu}$, Hong. The Wu Liang Shrine: The Ideology of Early Chinese Pictorial Art. Stanford: Stanford University Press, 1986.

Wu, Jiang and Chia, Lucille. Spreading Buddha's Word in East Asia. New York: Columbia University Press, 2015.

Wu, Jiang. Living for the Rising Sun: Chinese Zen Master Yinyuan \& the Authenticity Crisis in Early Modern East China. Oxford: Oxford University Press, 2015.

$\mathrm{Wu}, \mathrm{Ze}$ 吳澤. “Kang Youwei gongyang sanshi shuo de lishi jinhua guandian yanjiu: Kang Youwei shixue yanjiu zhiyi 康有為公羊三世說的歷史進化觀點研究：康有為史學研究 之一.” Zhonghua wenshi luncong 中華文史論叢 1. Shanghai: Zhonghua shuju (1962): 22974.

--_. "Kang Youwei gongyang sanshi shuo de lishi jinhua guandian yanjiu: Kang Youwei shixue yanjiu zhiyi.” Zhonghua wenshi luncong 中華文史論叢, 1 (1962): 229-74.

Wu, Zhanliang 吴展良. “Liang Shuming de shengsheng sixiang jiqi dui xifang lixing zhuyi de pipan (1915-1923) 梁漱溟的生生思想及其對西方理性主義的批判.” In Dangdai ruxue lunji: chuantong yu chuangxin 當代儒學論集: 傳統與創新. Taipei: Academia Sinica, 1995.

Xiao Ping 蕭平. Jindai Zhongguo fojiao de fuxing - Yu riben fojiaojie de jiaowanglu 近代中國佛教的 復興一與日本佛教界的交往錄. Guangzhou: Guangdong renmin chubanshe, 2003.

Xiao, Jiefu 蕭筆父 “Guanyu Dasheng Qixinlun de lishi dingwei 關於大乘起信論的歷史定位.” In Xiao Jiefu Wenxuan 蕭筆父文選. Wuhan: Wuhan University Press, 1998.

Xiao, Wanyuan 蕭萬源. Zhongguo jindai sixiangjia de zongjiaoguan yu guishenguan 中國近代思想 家的宗教觀與鬼神觀. Hefei: Anhui renmin chubanshe, 1991.

Xu Guansan 許冠三. “Chen Yuan: tufa weiben yangfa weijian 陳垣: 土法為本洋法為鑒.” In

Xin shixue jiushi nisn 新史學九十年, 118-146. Changsha: Yuelu shushe, 2003.

Xu, Qingxiang 徐清翔. Ouyang Jingwu pingzhuan 歐陽竟無評傳. Changsha: Baihua wenyi chubanshe, 2010.

Yanagida, Seizan 柳田聖山. “Hu Shih boshi yu Zhongguo chuqi chanzong shi zhi yanjiu 胡適 博士與中國初期禪宗史之研究.” In Hu Shih Chan xue an 胡適禪學案. Taipei:

Zhongzheng shuju, 1975.

-- - Shoki zenshū shisho no kenkyū 初期禅宗史書の研究. Kyoto: Hōzōkan, 1967.

-—- “Goroku no rekishi - Zen bunken no seiritsu-teki kenkyū 語錄の歷史一禪文獻の成 立的研究.” Tōbō gakubō 東方學報 Kyoto 57 (1985): 211-663.

-——. “Shinzoku tōshi no keifu 新続灯史の系譜.” Zengaku kenkyū 禪學研究 59 (1978). 
Yang Chao, Buwei. Autobiography of a Chinese Woman, Buwei Yang Chao. Westport: Greenwood Press, 1970 [1948].

Yang, C.K. Religion in Chinese Society: A Study of Contemporary Social Functions of Religion and Some of Their Historical Factors. Berkeley: University of California Press, 1961.

Yang, Lien-sheng 楊聯陡. “The Organization of Chinese of Chinese Official Historiography: Principles and Methods of the Standard Histories from T'ang through the Ming Dynasty." In Historians of China and Japan, edited by W. G. Beasley and E. G. Pulleyblank, 44-59. London: Oxford University Press, 1961.

Yang, Mayfair Mei-hui. Chinese Religiosities, Afflictions of Modernity and State Formation. Berkeley: University of California Press, 2008.

Yang, Wenhui 楊文會. Yang Renshan jushi yizhu 楊仁山居士遺著. Nanjing: Jinling kejingchu, 1998.

Yao, Binbin 姚涁彬. “Xiandai foxue sixiang xipu zhi fenye - yi ‘Dasheng Qixinlun’ zhenwei zhizheng wei qiji 現代佛學思想系譜之分野-- 以《大乘起信論》真偽之爭為契機.” Chung-Hwa Buddhist Studies 中華佛學研究, no. 12 (2011), 85-114.

Yeh, Wen-hsin. The Alienated Academy: Culture and Politics in Republican China, 1919-1937. Cambridge, MA: Harvard Univ Asia Center, 1990.

Yoshito, Hakeda. The Awakening of Faith. New York and London: Columbia University Press, 1967 [Reprinted in 2006 with a preface by Ryuichi Abe].

Yü, Chun-fang 于君方. “Weijing yu Guanyin Xinyang 偽經與觀音信仰.” Chung-Hwa Buddhist Journal 中華佛學學報, 8, (1995): 97-135.

-- . Kuanyin: The Chinese Transformation of Avalokiteśvara. New York: Columbia University Press, 2001.

Yu, Dawei 俞大維. “Huainian Chen Yinke xiansheng 懷念陳寅恪先生.” Lishi yuyan yanjiusuo jikan 歷史語言研究所集刊, 41, 1 (1969).

Yu, Jiaxi 余嘉錫. Muluxue fawei 目錄學發微. Beijing: Zhonghua shuju, 2007.

Yü, Lingbo 于凌波 ed. Xiandai fojiao renwu cidian 現代佛教人物辭典, 2 vols. Taipei: Foguang, 2004.

Yü, Ying-shih 余英時. “Chen Yinke shixue sanbian 陳寅恪史學三變.” In Chen Yinke wannian shiwen shizheng 陳寅恪晚年詩文釋證. Taipei: Dongda chuban gongsi, 1998.

- - . “Chen Yinke de xueshu jingshen yu wannian xinjing." In Xiandai weiji yu sixiang renwu 現代危機與思想人物, 61-73. Beijing: Sanlian shudian, 2005.

-—- "Zhongguo jindai sixiangshi shang de Hu Shih - “Hu Shizhi xiansheng nianpu changbian xu" 中國近代思想史上的胡適-- 《胡適之先生年譜長編初稿》序.”In Chongxun Hu Shih licheng 重寻胡適歷程. Taipei: Linking, 2004.

- - . “Qingdai sixiang shi de yige xinjie shi 清代思想史的一個新解釋.” In Lishi yu sixiang 歷 史與思想, 121-156. Taipei: Lianjing, 1976.

-_- "Some Preliminary Observations on the Rise of Ch'ing Confucian Intellectualism." TsingHua Journal of Chinese Studies, no. 11 (1975), 105-136. 
- - - “Wusi yundong yu Zhongguo chuantong 五四運動與中國傳統.” In Zhongguo sixiang chuantong jiqi xiandai bianqian 中國思想傳統及其現代變遷. Guilin: Guangxi shifan daxue chubanshe, 2014.

--_. "Zhang Xuecheng vesus Dai Zheng." In Chinese History and Culture: Seventeenth Century Through Twentieth Century, 85-112. New York: Columbia University Press, 2016.

-—-.Fang Yizhi wanjie kao 方以智晚節考. Beijing: Sanlian shudian, 2004.

-—- Lun Dai Zhen yu Zhang Xuecheng: Qingdai zhongqi xueshu xixiang shi yanjiu 論戴震與章學 誠:清代中期學術思想史研究. Hong Kong: Longmen shudian 龍門書店, 1976.

- - . "Changing Conceptions of National History in Twentieth-Century China." In Chinese History and Culture: Seventeenth Century Through Twentieth Century, 275-293. Columbia University Press, 2016.

Zarrow, Peter. “Old Myth into New History: The Building Blocks of Liang Qichao's 'New History'." Historiography East and West 1, no. 2 (2003): 204-41.

--C. China in War and Revolution, 1895-1949. New York: Routledge, 2005.

Zhang, Gang. "Reinventing China: Imperial Qing Ideology and the Rise of Modern Chinese National Identity in the Early Twentieth Century." Modern China 32, no. 1 (2006): 3-30. Zhang Yinlin 張蔭麟. “Ping jinren duiyu gushi zhi taolun (Gushi jueyilu zhiyi) 評近人對於古 史之討論(古史決疑錄之一).” Xueheng, 40 (1925).

Zhang, Pengyuan 張朋園. “Shehui daerwen zhuyi yu xiandaihua: Yan Fu and Liang Qichao de Jinhua guan 社會達爾文主義-一嚴復、梁啟超的進化觀.” In Tao Xisheng xiansheng bazhi rongqing lunwenji 陶希聖先生入秩榮慶論文集, 187-230. Taipei: Shihuo chubanshe 1979. Zhang, Rulun 張汝倫. "Handan xuebu, shiqi gubu - yetan Zhongguo zhexue yanjiu zhong de ‘fanxiang geyi' wenti 邯鄲學步,失其故步--也談中國哲學研究中的 “反向格義”問題.” Nanjing daxue xuebao 南京大學學報. 4 (2007): 60-76.

Zhang, Yuxin 張羽新. Qing zhengfu yu Lama jiao 清政府與喇嘛教. Lhasa: Xizang renmin chubanshe, 1988.

Zhao, Jianyong 趙建永. Tang Yongtong biannian shiji 湯用粀編年事輯. Beijing: Zhonghua shuju, 2019.

-—- “ “Tang Yongtong liuxue hanmulin daxue shiqi zhexue wengao tanwei 湯用粀留學漢姆 林大學時期哲學文稿探微.” Shijie zhexue 世界哲學 3 (2008): 105-112.

- - - “Tang Yongtong hafo daxue shiqi zhexue wengao bianxi 湯用觓哈佛大學時期哲學文 稿辨析.” Zhexue dongtai 哲學動態, 4 (2006): 33-39.

Zheng, Zhenduo 鄭振鐸.“Dunhuang de suwenxue 敦煌的俗文學.” Xiaoshuo yuebao 小說月報, 20, no.3 (1929).

Zhongguo shixuehui 中國史學會. Zhongguojindaishi ziliao congkan.Wuxu bianfa 中國近代史資 料丵刊·戊戌變法, vol.2. Shanghai: Shanghai renmin chubanshe, 2000.

Zhou, Xia 周霞. Zhongguo jindai fojiao shixue mingjia pingshu 中國近代佛教史學名家評述. Shanghai: Shanghai shehui kexueyuan chubanshe, 2006. 
Zhu, Weizheng 朱維鋝, ed. Zhou Yutong jingxueshi lunzhu xuanji 周予同經學史論著選集. Shanghai: Shanghai renmin chubanshe, 1983.

Zhuang, Meifang 莊美芳. “Hu Shih yu Linmu dazhuo lun Chan xuean - Cong Taiwan xuejie de huiying tanqi 胡適與鈴木論禪學案--從台灣學界的回應談起.” unpublished, 1998.

Zürcher, Erik. “A New Look at the Earliest Chinese Buddhist Texts.” In From Benares to Beijing: Essays on Buddhism and Chinese Religion in Honour of Prof. Jan Yün-Hua, edited by Shinohara Koichi and Gregory Schopen. 277-304. Oakville: Mosaic, 1991.

- - . "Prince Moonlight: Messianism and Eschatology in Early Medieval Chinese Buddhism." T'oung Pao 68, no. 1-3 (1982): 1-75.

--_. "Perspectives in the Study of Chinese Buddhism." Journal of the Royal Asiatic Society (1982): 161-176.

-_- The Buddhist Conquest of China. Leiden, Brill, 1959. 


\section{Declaration}

I hereby affirm in lieu of an oath that I have written the written scientific paper (dissertation) independently and have not used any sources and aids other than those indicated and that no corresponding doctorate has been applied for elsewhere and that the submitted dissertation or parts thereof have not been presented in this connection.

Furthermore, I hereby declare that this digital version corresponds to the written scientific paper (dissertation).

Göttingen, 30.06.2021

Signature: 